\title{
AUDU FUNKCIONĀLĀ MORFOLOĢIJA BĒRNIEM AR ABPUSĒJU CAUREJOŠU LŪPAS, ALVEOLĀRĀ IZAUGUMA UN AUKSLĒJU ŠĶELTNI ONTOĢENĒTISKĀ ASPEKTĀ
}

Promocijas darbs medicinas doktora zinātniskā grāda iegūšanai Specialitāte - morfoloǵija 


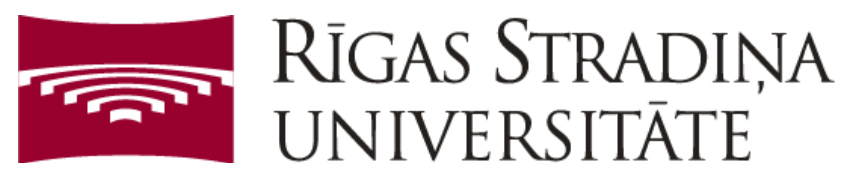

Liene Smane-Filipova

\title{
AUDU FUNKCIONĀLĀ MORFOLOĢIJA BĒRNIEM AR ABPUSĒJU CAUREJOŠU LŪPAS, ALVEOLĀRĀ IZAUGUMA UN AUKSLĒJU ŠKSELTNI ONTOĢENĒTISKĀ ASPEKTĀ
}

\author{
Promocijas darbs \\ medicīnas doktora zinātniskā grāda iegūšanai
}

Specialitāte - morfologija

Darba zinātniskā vadītāja

Dr. med., Dr. habil. med. profesore Māra Pilmane

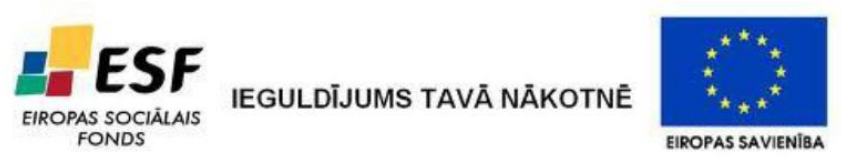

Promocijas darbs veikts ar ESF projekta "Atbalsts doktorantiem studiju programmas apguvei un zinātniskā grāda ieguvei Rīgas Stradiña universitātē” finansiālu atbalstu, vienošanās Nr. 2009/0147/1DP/1.1.2.1.2/09/IPIA/VIAA/009 
Lūpu un aukslēju šķeltnes ir viena no izplatītākajām iedzimtajām anomālijām, kas bērnam izraisa estētiskus un funkcionālus traucējumus. Abpusēja caurejoša škseltne ir smaga patologija, tās ārstēšanai tiek lietotas daudzetapu plastiskas ķirurǵiskas korekcijas, brūces slēdzas un veidojas rētaudi, kas var negatīvi ietekmēt sejas un mutes dobuma audu augšanu. Mūsdienās morfopatoǵenētiskai sejas škseltņu skarto audu izpētei ir būtiska nozīme, lai izprastu šīs embrionāli determinētās patoloğijas etiomorfopatoǵenēzi un pēcoperācijas audu remodelācijas potenciālu. Sejas un mutes dobuma attīstības pamatā ir vairāki precīzi koordinēti procesi - šūnu proliferācija, diferenciācija, migrācija, programmēta šūnu nāve, ekstracelulārās matrices sintēze un degradācija, vietējās audu aizsardzības faktoru bāzes veidošanās. Minētos procesus embrija audos koordinē dažādas signālmolekulas un augšanas faktori. Noteikti gēni, ārvides un teratogēnie faktori var izraisīt kādas noteiktas signālmolekulas un/vai augšanas faktoru trūkumu vai pārlieku lielu to esamību, kā rezultātā var attīstīties sejas škseltnes.

Pētījuma mērķis bija specifisku signālmolekulu un šūnu nāves noteikšana šķeltņu skartajos audos, kā arī to faktoru noteikšana, kuri visbūtiskāk raksturo abpusējas caurejošas škseltnes morfopatoǵenēzi ontoǵenētiskajā aspektā.

Pētījumā tika iekḷauti 46 pacienti: 22 bērniem bija abpusēja caurejoša lūpas, alveolārā izauguma un aukslēju šķeltne, 24 bērniem - vienpusēja caurejoša lūpas, alveolārā izauguma un aukslēju šķeltne.

Ar imūnhistoķīmisko metodi tika izpētīts un analizēts matrices metaloproteināzes-2 (MMP-2), matrices metaloproteināzes-8 (MMP-8), matrices metaloproteināzes-9 (MMP-9), matrices metaloproteināzes-2 audu inhibitora (TIMP-2), matrices metaloproteināzes-4 audu inhibitora (TIMP-4), gēnu proteīnu MSX1, IRF6, PAX9, RYK, vaskulārā endotēlija augšanas faktora $(V E G F)$, transformējošā augšanas faktora beta-3 (TGFß3), transmembranozā glikoproteīna CD34 (CD34), proteīngēnvielas 9.5 (PGP 9.5), nestīna, proliferācijas marķiera $K i-67$ (Ki-67), osteokalcīna $(O C)$, osteopontīna $(O P)$, osteoprotegerīna $(O P G)$ un kaula morfoǵenētiskā proteīna 2/4 (BMP2/4) imūnreaktīvo šūnu un nervšķiedru relatīvais daudzums. Izmantojot TUNEL metodi, tika izpētîta apoptotisko šūnu klātbūtne un sadalījums.

Kopumā smagākajam škseltnes veidam - abpusējai caurejošai lūpas, alveolārā izauguma un aukslēju šķeltnei - tika konstatēta samazināta transkripcijas faktora IRF6, MSX1 un PAX9, augšanas faktora $T G F \beta 3$ un $V E G F$ klātbūtne, kā arī samazināta šūnu proliferācija un apoptoze mīkstajos audos, bet balstaudos samazināta $O P N, O P G, M M P-2$, TIMP-2, BMP2/4 un TGFß3 klātbūtne. Pārliecinoši identificējām, ka morfoloğiskās audu izmaiṇas ir 
smagākas pacientiem ar abpusēju škseltni. Atkārtotu operāciju laikā vieniem un tiem pašiem pacientiem darbā novērojām palielinātu MSX1, MMP-9, TIMP-4, TGFß3, Ki-67 un samazinātu $V E G F$ ekspresiju. 


\begin{abstract}
ANNOTATION
Cleft lip and palate is one of the most common congenital pathologies, causing esthetic and functional disorders in a child. Complete bilateral cleft lip and palate is a grave pathology, in its treatment multigrade plastic surgical corrections are needed, resulting in the closure of the wound and formation of scar tissue, which can negatively affect the growth of the facial and oral tissues. Nowadays the morphogenetic study of facial cleft-affected tissues is of great significance, in order to understand the etiomorphogenesis of this embrionally determined pathology and post-operation tissue remodeling potential. The development of the face and oral cavity contains the following specifically coordinated processes - tissue proliferation, differentiation, migration, programmed tissue death, synthesis and degradation of extracellular matrix, development of the basis of local protection factors. The processes mentioned in embryonic tissues are coordinated by different signal molecules and growth factors. Specific genes, external and teratogenic factors can cause the lack or excessive presence of a certain signal molecule and/or growth factor, resulting in the development of the facial cleft.
\end{abstract}

The aim of the research was to study specific signaling molecules and tissue death determination in the cleft-affected tissues, as well as determination of those factors, which most essentially characterize morphopathogenesis of bilateral cleft lip and palate in the ontogenetic aspect.

46 patients were included in the research: 22 children had bilateral complete cleft lip, alveolar process and palate, 24 children - unilateral complete cleft lip, alveolar process and palate.

By means of immunohistochemical method there were studied and analyzed matrix metalloproteinase-2 (MMP-2), matrix metalloproteinase-8 $(M M P-8)$, matrix metalloproteinase-9 (MMP-9), tissue inhibitor of matrix metalloproteinase-2 (TIMP-2), tissue inhibitor of matrix metalloproteinase-4 (TIMP-4), gene protein MSX1, IRF6, PAX9, RYK, vascular endothelial growth factor $(V E G F)$, transformating growth factor beta-3 (TGFB3), transmembranous glycoprotein $C D 34$ (CD34), protein gene product 9.5 (PGP 9.5), nestin, proliferation marker $\mathrm{Ki}-67$ (Ki-67), osteocalcin $(O C)$, osteopontin $(O P)$, osteoprotegerin $(O P G)$ and relative amount of bone morphogenetic protein 2/4 (BMP2/4) immunoreactive structures. By TUNEL method was studied the presence and distribution of apoptotic cells.

All in all, in the most severe type of the cleft - bilateral cleft lip and palate there was found the presence of decreased transcription factor IRF6, MSX1 and PAX9, the growth factor $T G F \beta 3$ and $V E G F$, as well as the decreased cell proliferation and apoptosis in the soft 
tissues, but in the supporting tissues - the decreased $O P N, O P G, M M P-2, T I M P-2, B M P 2 / 4$ and TGF 33 presence. It was conclusively proved, that morphological tissue changes were more severe in patients with bilateral clefts. During repeated operations, one and the same patients we were identified an increased MSX1, MMP-9, TIMP-4, TGF $3, K i-67$ and decreased $V E G F$ expression. 


\section{SATURS}

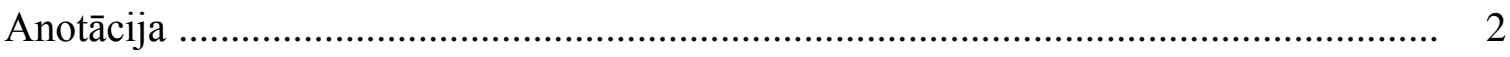

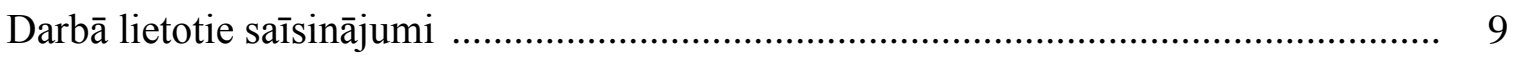

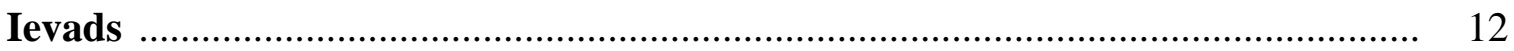

Darba aktualitāte ....................................................................................... 12

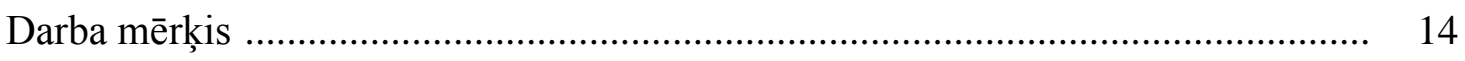

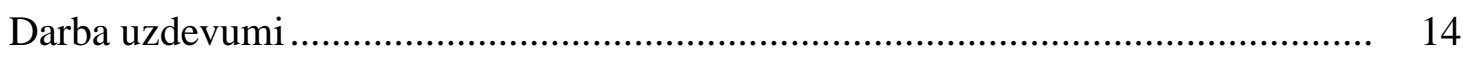

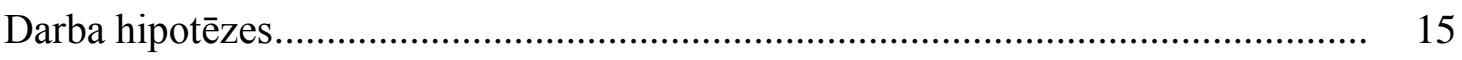

Darba novitāte........................................................................................ 15

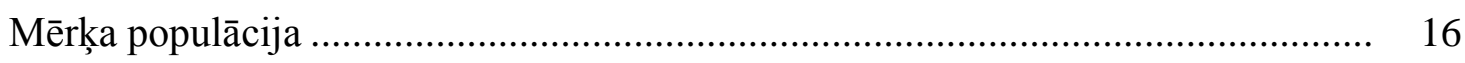

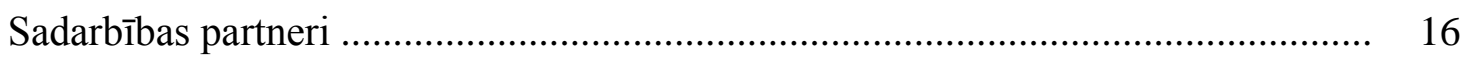

Materiāli tehniskais nodrošinājums ............................................................ 16

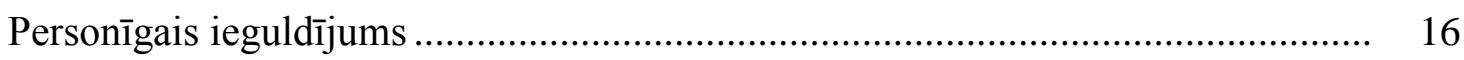

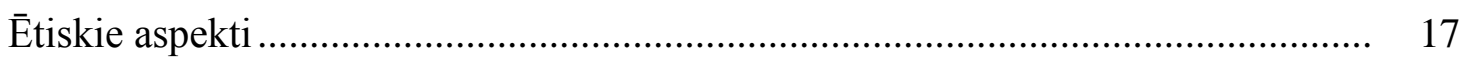

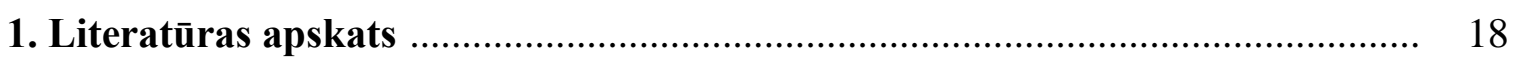

1.1. Lūpas un aukslēju šķeltnes vispārīgs raksturojums ....................................... 18

1.2. Sejas un mutes dobuma attīstības raksturojums ........................................... 19

1.2.1. Augšlūpas morfoǵenēzes molekulārie mehānismi................................. 20

1.2.2. Sekundāro aukslēju morfoǵenēzes molekulārie mehānismi .................... 21

1.3. Audu degradācijas enzīmi $(M M P)$ un ar tām saistītie endogēnie inhibitori $($ TIMP) ................................................................ 25

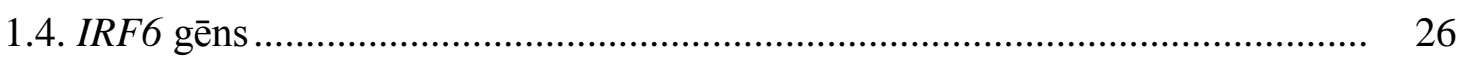

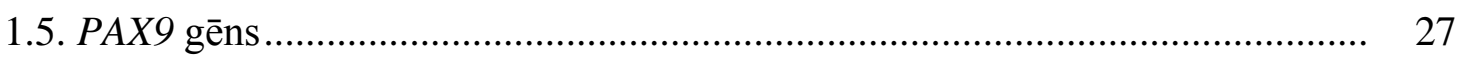

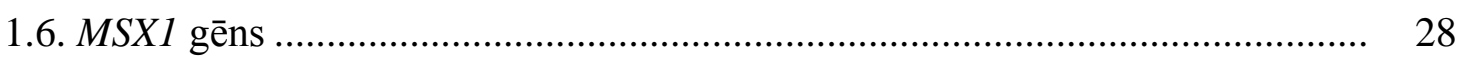

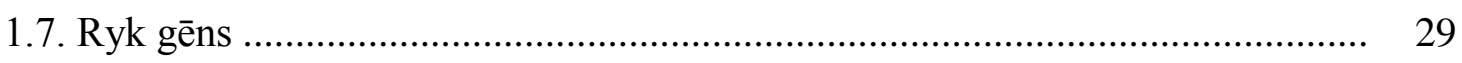

1.8. Angioǵenēzi ietekmējošie faktori .......................................................... 30

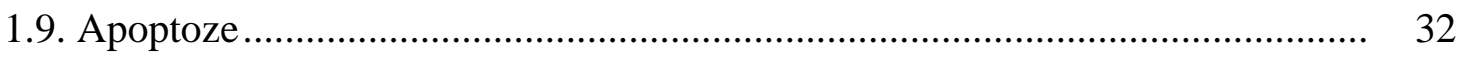

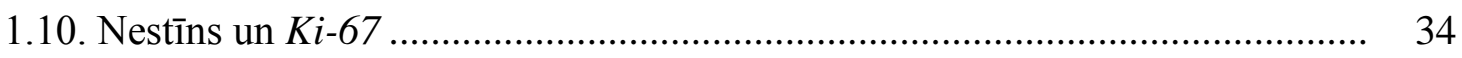

1.11. Proteīngēnviela 9.5 (PGP 9.5) .................................................................... 35

1.12. Kaula morfoǵenētiskie proteīni $(B M P)$.................................................. 36

1.13. Osteoprotegerīns $(O P G)$........................................................................ 37

1.14. Alveolārā kaula ekstracelulārās matrices $(E C M)$ nekolagēnie proteīni ........... 37

2. Materiāls un metodes ............................................................................. 39

2.1. Morfologiski pētāmais materiāls un pacientu iedalījums grupās..................... 39

2.1.1. Pirmās un otrās grupas - zīdaiṇu un bērnu ar abpusējām caurejošām lūpas, alveolārā izauguma un aukslēju šķeltnēm - raksturojums 
2.1.2. Trešās grupas - bērnu ar abpusējām caurejošām lūpas, alveolārā izauguma un aukslēju šķeltnēm - raksturojums ....

2.1.3. Ceturtās un piektās grupas - bērnu ar vienpusējām caurejošām lūpas, alveolārā izauguma un aukslēju šķeltnēm - raksturojums

2.1.4. Kontroles grupa ................................................................................ 47

2.2. Morfologiskās metodes ............................................................................. 48

2.2.1. Pētāmā audu materiāla fiksācija.............................................................. 48

2.2.2. Rutīnās histoloǵijas krāsošanas metode .................................................... 48

2.2.3. Imūnhistoķīmijas metode un reaǵenti ..................................................... 49

2.2.4. TUNEL metode .............................................................................. 51

2.3. Puskvantitatīvā skaitīšanas metode............................................................... 53

2.4. Statistiskās metodes ........................................................................................... 54

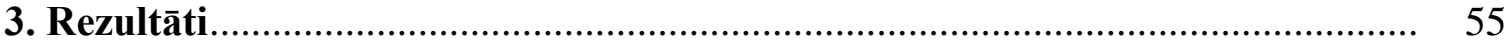

3.1. Morfologiiskā atrade kontroles grupas pacientiem un pacientiem ar šķeltni. ... 55

3.1.1. Rutīnās histoloǵijas dati kontroles grupas pacientiem............................ 55

3.1.2. Rutīnās histoloğijas dati pacientiem ar škseltni...................................... 55

3.2. Mīksto audu dažādu faktoru imūnhistoķīmisko pētîjumu un apoptozes atrade. 56

3.2.1. Audu degradācijas enzīmu (MMP) un to endogēno inhibitoru (TIMP) imūnhistoḳīmiskie dati .......................................................................... 56

3.2.2. Gēnu proteīnu imūnhistoķīmiskie dati..................................................... 57

3.2.3. Augšanas faktoru, $C D 34$, inervācijas faktora $P G P 9.5$ imūnhistoḳimiskie un statistiskie dati

3.2.4. Šūnu proliferācijas marķiera $(K i-67)$, nestīna un apoptozes atrade

3.2.5. Kaulaudu osteokalcīna $(O C)$, osteopontīna $(O P)$ un osteoprotegerīna $(O P G)$ imūnhistoḳimiskie dati

3.2.6. Kaulaudu kaula morfoǵenētiskā protē̄na $2 / 4$ (BMP2/4), matrices metaloproteināzes-2 (MMP-2), matrices metaloproteināzes-2 audu inhibitora (TIMP-2) un tranfromējošā augšanas faktora beta3 (TGFß3) imūnhistoķīmiskie dati

3.2.7. Imūnhistoķīmiski noteikto marķieru savstarpējās atbilstības ciešuma izvērtēšanas dati kontroles grupas pacientiem

3.3. Šķeltnu skartu audu faktoru atrade

3.3.1. Audu degradācijas enzīmu (MMP) un to endogēno audu inhibitoru (TIMP) imūnhistoķīmiskie un statistiskie dati

3.3.2. Gēnu proteīnu imūnhistoķīmiskie un statistiskie dati

3.3.3. Augšanas faktoru, $C D 34$, inervācijas faktora $P G P 9.5$ imūnhistoķīmiskie un statistikie dati

3.3.4. Šūnu proliferācijas mark̦iera ( $K i-67)$, nestīna un apoptozes imūnhistoķīmiskie un statistiskie dati. 
3.3.5. Osteokalcīna $(O C)$, osteopontīna $(O P N)$ un osteoprotegerīna $(O P G)$ imūnhistoķīmiskie un statistiskie dati osteoplastikas laikā iegūtajā materiālā.

3.3.6. Matrices metaloproteināzes-2 (MMP-2), matrices metaloproteināzes-2 audu inhibitora (TIMP-2), kaula morfoğenētiskā proteīna (BMP 2/4), transformējošā augšanas faktora beta3 (TGFß3) imūnhistoķīmiskie un statistiskie dati osteoplastikas laikā iegūtajā materiālā.

3.4. Imūnhistokīmisko faktoru atrade un statistiskie dati atkārtoti nemtajos audos pacientiem ar abpusēju caurejošu lūpas, alveolārā izauguma un aukslēju škseltni

3.5. Imūnhistoķīmiski noteikto marķieru savstarpējās atbilstības ciešuma izvērtēšanas dati, izmantojot Spīrmena rangu korelācijas koeficientu

4. Diskusija

5. Secinājumi

6. Literatūras saraksts

Publikācijas un prezentācijas par pētījuma tēmu

Pateicības

Pielikumi.

1. pielikums

Mikrofotogrāfijas

2. pielikums

RSU Ētikas komitejas lēmumi 


\section{DARBĀ LIETOTIE SAIISINĀJUMI}

\begin{tabular}{|c|c|c|}
\hline Saīsinājums & Nosaukums angl̦u valodā & Skaidrojums latviešu valodā \\
\hline$A A I$ & Institute of Anatomy and Anthropology & Anatomijas un antropologijas institūts \\
\hline$A D A M T S$ & $\begin{array}{l}\text { A Disintegrin And Metalloproteinase with } \\
\text { Trombospondin Motifs }\end{array}$ & $\begin{array}{l}\text { Disintegrīns un metaloproteināze ar } \\
\text { trombospondīna motīviem }\end{array}$ \\
\hline ARHGAP29 & Rho GTPase activating protein 29 gene & Rho GTPāzes aktivējošā proteīna gēns \\
\hline AXIN2 & Axis inhibition protein 2 gene & Ass inhibējošā proteīna-2 gēns \\
\hline Barxl & BarH-like homeobox 1 & BarH līdzịgais homeoboksa-1 \\
\hline$B M P 2 / 4$ & Bone morphogenetic protein $2 / 4$ & Kaula morfoǵenētiskais proteīns $2 / 4$ \\
\hline$B M P 4$ & Bone morphogenetic protein 4 & Kaula morfoğenētiskais proteīns-4 \\
\hline Bmprla & $\begin{array}{l}\text { Bone morphogenetic protein receptor, type } \\
\text { la }\end{array}$ & $\begin{array}{l}\text { Kaula morfoğenētiskā proteīna } \\
\text { receptors-1a }\end{array}$ \\
\hline Dlx5 & Distal-less homeobox 5 & Mazāk distālais homeobokss-1 \\
\hline$E$ & - & Epitēlišūnas \\
\hline$E C M$ & Extracellular matrix & Ekstracelulārā matrice \\
\hline EfnBl & Ephrin B1 & Efrīna B1 gēns \\
\hline EphB2 & Ephrin B2 & Efrīna B2 gēns \\
\hline EphB3 & Ephrin B3 & Efrīna B3 gēns \\
\hline ETM & Epithelial-mesenchymal transition & Epitēlija transformācija mezenhīmā \\
\hline$F G F$ & Fibroblast growth factor & Fibroblastu augšanas faktors \\
\hline Fgflo & Fibroblast growth factor 10 & Fibroblastu augšanas faktors- 10 \\
\hline Fgf7 & Fibroblast growth factor 7 & Fibroblastu augšanas faktors-7 \\
\hline FGFRI & Fibroblast growth factor receptor 1 & $\begin{array}{l}\text { Fibroblastu augšanas faktora receptors } \\
1\end{array}$ \\
\hline FGFR2 & Fibroblast growth factor receptor 2 & $\begin{array}{l}\text { Fibroblastu augšanas faktora receptors } \\
2\end{array}$ \\
\hline$F g f r 2 b$ & Fibroblast growth factor receptor $2 b$ & $\begin{array}{l}\text { Fibroblastu augšanas faktora receptors- } \\
2 \mathrm{~b}\end{array}$ \\
\hline Fos & FBJ osteosarcoma oncogene & FBJ osteosarkomas onkogēns \\
\hline$g$ & - & Gadi \\
\hline Hsp70 & Heat shock protein 70 & Karstumšoka proteīns 70 \\
\hline IRF6 & Interferon regulatory factor 6 & Interferona regulējošais faktors-6 \\
\hline$L E F-1$ & Lymphoid enhancer-binding factor 1 & $\begin{array}{l}\text { Limfoīdais enhansers (aktivators)- } \\
\text { saistošais faktors-1 }\end{array}$ \\
\hline$M$ & - & Meitene \\
\hline$M E E$ & Medial edge epithelium & Mediālās malas epitēlijs \\
\hline Meox2 & Mesenchyme homeobox 2 & Mezenhīmas homeoboksa-2 \\
\hline$m \bar{e} n$ & - & Mēneši \\
\hline$M M P-13$ & Matrix metalloproteinase-13 & Matrices metaloproteināze-13 \\
\hline$M M P-14$ & Matrix metalloproteinase-14 & Matrices metaloproteināze-14 \\
\hline$M M P-16$ & Matrix metalloproteinase-16 & Matrices metaloproteināze-16 \\
\hline$M M P-2$ & Matrix metalloproteinase-2 & Matrices metaloproteināze-2 \\
\hline$M M P-8$ & Matrix metalloproteinase- 8 & Matrices metaloproteināze- 8 \\
\hline$M M P-9$ & Matrix metalloproteinase-9 & Matrices metaloproteināze-9 \\
\hline$M n 1$ & Meningioma 1 & Meningioma-1 \\
\hline$M S X$ & MSX homeobox & Muskuḷu segmentācijas homeobokss \\
\hline$M S X 1$ & MSX homeobox 1 & Muskulu segmentācijas homeobokss-1 \\
\hline$M S X 2$ & MSX homeobox 2 & Muskulu segmentācijas homeobokss-2 \\
\hline$O C$ & Osteocalcin & Osteokalcīns \\
\hline$O P G$ & Osteoprotegerin & Osteoprotegerīns \\
\hline
\end{tabular}




\begin{tabular}{|c|c|c|}
\hline & & tabulas turpinājums \\
\hline Saīsinājums & Nosaukums angl̦u valodā & Skaidrojums latviešu valodā \\
\hline$O P N$ & Osteopontin & Osteopontīns \\
\hline OSRI & Odd-skipped related transciption factor & $\begin{array}{l}\text { Odd- skipped radniecīgais } \\
\text { transkripcijas faktors-1 }\end{array}$ \\
\hline Osr2 & Odd-skipped related 2 gene & $\begin{array}{l}\text { Odd- skipped radniecīgais } \\
\text { transkripcijas faktors-2 }\end{array}$ \\
\hline$P A X 7$ & Paired box 7gene & Pāra boksa transkripcijas faktors-7 \\
\hline PAX9 & Paired box 9 gene & Pāra boksa transkripcijas faktors-9 \\
\hline$P D G F C$ & Platelet derived growth factor $c$ & Trombocitārais augšanas faktors c \\
\hline PDGFRa & Platelet derived growth factor receptor alpha & $\begin{array}{l}\text { Trombocitārais augšanas faktora } \\
\text { receptors alfa }\end{array}$ \\
\hline$P G P 9.5$ & Proteine gene product 9.5 & Proteīngēnviela 9.5 \\
\hline PTC (RET) & Ret proto-oncogene & Ret protoonkogēns \\
\hline$R A N K$ & Receptor activator of NF-kappaB & NF-kappa B receptora aktivators \\
\hline RANKL & Receptor activator of NF-kappaB ligand & $\begin{array}{l}\text { NF-kappa B liganda receptora } \\
\text { aktivators }\end{array}$ \\
\hline RFC1 & Replication factor $C$ (activator 1 ) 1 & Replikācijas faktors C (aktivators-1) 1 \\
\hline$R S U$ & Rīga Stradiņš University & Rīgas Stradin̦a universitāte \\
\hline$R Y K$ & Receptor-like tyrosine kinase & Tirozīnkināzes receptoram līdzīgais \\
\hline$S$ & - & Saistaudu šūnas \\
\hline Shh & Sonic hedgehog & Shh gēns \\
\hline Shox2 & Short stature homeobox 2 & $\begin{array}{l}\text { Īsā auguma homeoboksa (mājturības)- } \\
2 \text { gēns }\end{array}$ \\
\hline SIP1 & Siplp & Sip1p gēns \\
\hline Smo & Smoothened, frizzled class receptor & $\begin{array}{l}\text { Smothened klases receptors (G } \\
\text { olbaltumvielas saistītajjreceptors) }\end{array}$ \\
\hline SNAII & Snail family zinc finger 1 & $\begin{array}{l}\text { SNAI saimes cinka pirkstinu } \\
\text { transkripcijas faktors-1 }\end{array}$ \\
\hline $\begin{array}{l}\text { SNAI2 } \\
\text { (Slug) }\end{array}$ & Snail family zinc finger 2 & $\begin{array}{l}\text { SNAI saimes cinka pirkstinuu } \\
\text { transkripcijas faktors-2 }\end{array}$ \\
\hline$T b \times 22$ & $T-b o x 22$ & T-box 22 gēns \\
\hline$T G F \alpha$ & Transforming growth factor alpha & Transformējošais augšanas faktors alfa \\
\hline$T G F \beta$ & Transforming growth factor beta & Transformējošais augšanas faktors beta \\
\hline$T G F \beta 1$ & Transforming growth factor beta 1 & $\begin{array}{l}\text { Transformējošais augšanas faktors } \\
\text { beta-1 }\end{array}$ \\
\hline$T G F \beta 2$ & Transforming growth factor beta 2 & $\begin{array}{l}\text { Transformējošais augšanas faktors } \\
\text { beta- } 2\end{array}$ \\
\hline$T G F \beta 3$ & Transforming growth factor beta 3 & $\begin{array}{l}\text { Transformējošais augšanas faktors } \\
\text { beta-3 }\end{array}$ \\
\hline TIMP-2 & Tissue inhibitor of metalloproteinase-2 & $\begin{array}{l}\text { Matrices metaloproteināzes- } 2 \text { audu } \\
\text { inhibitors }\end{array}$ \\
\hline TIMP-4 & Tissue inhibitor of metalloproteinase-4 & $\begin{array}{l}\text { Matrices metaloproteināze- } 4 \text { audu } \\
\text { inhibitors }\end{array}$ \\
\hline$T N F-\alpha$ & Tumor necrosis factor alpha & Tumora nekrozes faktors alfa \\
\hline TRAIL & $\begin{array}{l}\text { Tumor necrosis factor-related apoptosis- } \\
\text { inducing ligand }\end{array}$ & $\begin{array}{l}\text { Tumora nekrozes faktora saistìtais } \\
\text { apoptozi inducējošais ligands }\end{array}$ \\
\hline TUNEL & $\begin{array}{l}\text { Terminal deoxynucleotidyl transferase dUTP } \\
\text { nick end labeling }\end{array}$ & $\begin{array}{l}\text { Deoksinukleotidiltransferāzes mediēta } \\
\text { DNS 3'-galu mark̦ěšana ar } \\
\text { deoksiuridinfosfâtu }\end{array}$ \\
\hline Twist & $\begin{array}{l}\text { Twist basic helix-loop-helix transcription } \\
\text { factor } 1\end{array}$ & $\begin{array}{l}\text { Spirāles-cilpas-spirāle vijuma pamata } \\
\text { transkripcijas faktors-1 }\end{array}$ \\
\hline$V A X 1$ & Ventral anterior homeobox 1 & $\begin{array}{l}\text { Priekšejēās un centrālās ass } \\
\text { homeobokss-1 }\end{array}$ \\
\hline$V E G F$ & Vascular endothelial growth factor & Vaskulārā endotēlija augšanas faktors \\
\hline
\end{tabular}




\begin{tabular}{|l|l|l|}
\hline \multicolumn{2}{|c|}{ tabulas nobeigums } \\
\hline Saīsinājums & Nosaukums angḷu valodā & Skaidrojums latviešu valodā \\
\hline VWS & Van der Woude syndrome & Van der Woude sindroms \\
\hline WNT & Protein Wnt-2 & Proteīna Wnt-2 gēns \\
\hline Wnt11 & $\begin{array}{l}\text { Wingless-type MMTV integration site family, } \\
\text { member 11 }\end{array}$ & $\begin{array}{l}\text { Bezspārnu tipa MMTV integrācijas } \\
\text { saita 11 olbaltumviela }\end{array}$ \\
\hline WNT3A & $\begin{array}{l}\text { Wingless-type MMTV integration site family, } \\
\text { member 3A }\end{array}$ & $\begin{array}{l}\text { Bezspārnu tipa MMTV integrācijas } \\
\text { saita 3a olbaltumviela }\end{array}$ \\
\hline WNT5 & Wnt oncogene analog 5 & Wnt onkogēna analogs 5 \\
\hline$Z$ & - & Zēns \\
\hline
\end{tabular}




\section{IEVADS}

\section{Darba aktualitāte}

Sejas šķeltnes ir viena no izplatītākajām iedzimtajām kraniofaciālajām displāzijām, kas bērnam izraisa estētiskus un funkcionālus traucējumus (Maclean et al., 2009). N̦emot vērā anatomisko un genētisko komponentu, tās iedala šādās kategorijās: nesindromāla lūpas šķeltne un/vai aukslēju šķeltne, nesindromāla izolēta aukslēju šķeltne, sindromāla lūpas šķeltne un/vai aukslēju šķeltne un sindromāla izolēta aukslēju šķeltne. No visiem šķeltņu gadījumiem nesindromālas šķeltnes ir 70-90\%, savukārt sindromālas - 10-30\% šķeltņu gadījumu (Jugessur et al., 2009; Ray and Niswander, 2012). Šķeltnes, kas skar lūpu, alveolāro kaulu un aukslējas, var būt vienpusējas un abpusējas. Prevalence ir vidēji vienam bērnam no 1000 jaundzimušajiem pasaulē (Mossey et al., 2009; Kim et al., 2013). Latvijā dzimst vidēji viens bērns ar šķeltni uz 700-800 jaundzimušajiem vai vidēji 1,2 - 1,4 uz 1000 dzīvi dzimušajiem (Akota et al., 2001).

Lūpas un aukslēju šķeltnes etioloǵiju nosaka daudzu ǵenētisko faktoru mijiedarbība ar teratogēniem faktoriem sejas embrioǵenēzes laikā. Sejas attīstība sākas ceturtajā embrioǵenēzes nedēlāâ, kad notiek nervu kores šūnu migrācija un to kombinēšanās ar mezodermas šūnām (Bush and Jiang, 2012). Augšlūpas un sekundāro aukslēju saplūšanas morfopatoǵenēzē ir ietverti vairāki precīzi koordinēti procesi: šūnu proliferācija, diferenciācija, migrācija, programmēta šūnu nāve, ekstracelulārās matrices (ECM) sintēze, vietējās audu aizsardzības faktoru bāzes veidošanās, kurus regulē dažādas signālmolekulas, un augšanas faktori. Ir zināms, ka augšlūpas saplūšana veicina sekundāro aukslēju saplūšanu, tāpēc nepareiza lūpas saplūšana var ietekmēt aukslēju saplūšanas molekulāro kompleksu. Noteikti gēni un ārvides faktori var izraisīt kādas noteiktas signālmolekulas un/vai augšanas faktora trūkumu vai pārlieku lielu to esamību, kā rezultātā var attīstīties sejas šķeltnes (Meng et al., 2009).

Ir zināms, ka teratogēnie faktori var izraisīt izmaiņas ekstracelulālās matrices sintēzē, kā arī pārlieku lielu tās komponentu uzkrāšanos audos. Salīdzinoši nesenos pētījumos atklāta matrices metaloproteināžu $(M M P s)$ un matrices metaloproteināžu audu inhibitoru (TIMPs) iesaiste sejas šķeltņu attīstībā (Letra et al., 2007, Nikopensius et al., 2011, Letra et al., 2012, Letra et al., 2014), tomēr šo proteīnu darbības molekulārie aspekti šķeltņu skartajos audos bērniem joprojām pilnībā nav skaidri.

Būtiska loma sejas un mutes dobuma attīstībā ir angioǵenēzi veicinošajiem faktoriem. Pētījumos atklāja tādu augšanas faktoru un to receptoru kā transformējošā augšanas faktora 
beta-3 (TGF 33$)$, transformējošā augšanas faktora alfa $(T G F \alpha)$, fibroblastu augšanas faktora $(F G F)$, fibroblastu augšanas faktora receptora-1 (FGFRl), fibroblastu augšanas faktora receptora-2 $(F G F R 2)$, trombocītu augšanas faktora c $(P D G F c)$, trombocītu augšanas faktora receptora alfa (PDGFRa) iesaisti sejas šķeltņu attīstībā (Zhu et al., 2012; Vieira et al., 2003; Reutter et al., 2008; Choi et al., 2009; Stanier and Pauws, 2012; Riley and Murray, 2007; Rafigdoost et al., 2014; Webber et al., 2015; Lu et al., 2014). Vaskulārā endotēlija augšanas faktora $(V E G F)$ kā būtiska angioǵenēzi veicinošā signālproteīna loma sejas šķeltņu attīstībā joprojām nav precīzi noteikta, kaut gan divu pētījumu dati pieļauj diskusiju par šo faktoru kā potenciālo kandidātgēnu nozīmi sejas šķeltņu attīstībā (Stalmans et al., 2003; Patyna et al., 2009).

Arvien aktuālāki kḷūst pētījumi par interferona regulējošā faktora-6 (IRF6), muskulu segmentācijas homeoboksa-1 (Msxl), tirozīnkināzes receptoram līdzīgā $(R Y K)$, priekšējās un centrālās ass homeoboksa-1 (VAX1), replikācijas faktora C (aktivators-1) 1 (RFC1), kaula morfoǵenētiskā proteīna-4 (BMP4), proteīna Wnt-2 (WNT), Rho GTPāzes aktivējošā proteīna (ARHGAP29), ass inhibējošā proteīna-2 (AXIN2), transformējošā augšanas faktora beta-3 (TGFß3), pāra boksa transkripcijas faktora-9 (PAX9) un pāra boksa transkripcijas faktora-7 (PAX7) gēnu iesaisti lūpas un aukslēju šķeltnes etiologijāā. Minētajiem gēniem ir būtiska nozīme sejas un mutes dobuma attīstībā, jo tie iesaistās daudzos nozīmīgos biologiskos procesos, t. i., šūnu proliferācijā, diferenciācijāa, migrācijā un apoptozē (Halford et al., 2000; Letra et al., 2012; Song et al., 2013; Tang et al., 2013; Krasone et al., 2014; Zawiślak et al., 2014; Letra et al., 2014; Girardi et al., 2014; Nouri et al., 2015; Leslie et al., 2015; Li et al., 2015).

Joprojām tiek diskutēts par pēdējo gadu publikācijās atzīto koordinētu šūnu proliferācijas un apoptozes klātbūtni augšlūpas un sekundāro aukslēju aizmetņu saplūšanas laikā. Literatūrā ir atrodami dati, ka pilnīgs vai daļējs apoptozes trūkums var būt sejas šķeltņu attīstības cēlonis (Cuervo and Covarrubias, 2004; Dudas et al., 2007).

Sejas šķeltnes ir viena no tām iedzimtajām patoloǵijām, kuras ārstēšana vienmēr ir bijusi aktuāla. Tā ir kompleksa, ilgstoša un dārga. Pēc daudzetapu operācijām audi var sadzīt ar paliekošu defektu, kas var negatīvi ietekmēt kraniofaciālā reǵiona audu augšanu. Brūces dzī̌sanu un audu remodelāciju ietekmē augšanas faktori, transkripcijas faktori un to attiecīgie receptori, gēnu proteīni, angioǵenēzi ietekmējošie faktori, MMPs, TIMPs un citas signālmolekulas.

Mūsdienās aktuālāki kḷūst pētījumi par lokālu minēto faktoru ekspresiju, kā arī apoptozes relatīvā daudzuma noteikšanu sejas šķeltņu skartajos audos. Rīgas Stradiņa universitātes (RSU) Anatomijas un antropolog̣ijas institūta (AAI) docētāja, tagadējā docente 
Benita Krivicka-Užkurele savulaik veikusi nopietnus pētījumus par dažādu audu faktoru sadalījumu dažādu šķeltņu audos korelācijā ar piena un patstāvīgo zobu izšķilšanās vecumu (Krivicka-Uzkurele et al., 2008; Krivicka et al., 2013), un AAI kopā ar Latvijas Lūpu, aukslēju un sejas šķeltņu centru ir bijis nopietns Latvijas Zinātnes padomes finansēts projekts, kura izstrādes laikā atklājies, ka vissmagākais šķeltnes veids ir kompleksā caurejošā šķeltne. Jāpiebilst, ka, projektam beidzoties, turpināta unikālā šķeltņu operāciju materiāla vākšana. Tas ir būtiski, jo pasaulē joprojām nav pilnībā skaidru, kompleksu datu par dažādu specifisku proteolītisku enzīmu, angioǵenēzi ietekmējošo faktoru, gēnu proteīnu un citu signālmolekulu, kā arī apoptozes daudzumu un atradi bērniem ar smagāko šķeltnes veidu - abpusēju caurejošu šķeltni - ontoǵenētiskajā aspektā, proti, visā bērna ārstēšanas laikā. Mūsdienās, izmantojot morfoloǵiskās un imūnhistoķīmiskās metodes, ir iespējams šūnu līmenī izpētīt morfopatoǵenēzes procesus šīs embrionālās patoloğijas gadījumā.

\section{Darba mērḳis}

Specifisku signālmolekulu un šūnu nāves noteikšana šķeltnes skartajos audos, kā arī to faktoru noteikšana, kuri visbūtiskāk raksturo abpusējas caurejošas šķeltnes morfopatoǵenēzi ontoǵenētiskā aspektā.

\section{Darba uzdevumi}

Mērķa sasniegšanai tika izvirzīti šādi uzdevumi:

1. Izpētīt audu šķēlējenzīmu - matrices metaloproteināzes $M M P-2, M M P-8, M M P-9$ un ar tām saistīto endogēno audu inhibitoru TIMP-2, TIMP-4 relatīvo daudzumu un sadalījumu šķeltnes skartajos audos bērniem ar caurejošu škseltni, pielietojot imūnhistoķīmijas metodi.

2. Noteikt gēnu proteīnu MSX1, IRF6, PAX9 un RYK relatīvo daudzumu un sadalījumu šķeltnes skartajos audos bērniem ar caurejošu šķeltni, pielietojot imūnhistoķīmijas metodi.

3. Izvērtēt augšanas faktoru $V E G F, T G F \beta 3, C D 34$ un inervācijas faktora $P G P 9.5$ relatīvo daudzumu un sadalījumu šķeltnes skartajos audos.

4. Izpētīt nestīna un šūnu proliferācijas marķiera $K i-67$ relatīvo daudzumu un sadalījumu šķeltnes skartajos audos bērniem ar caurejošu šķeltni, pielietojot imūnhistoķīmijas metodi.

5. Noteikt apoptotisko šūnu relatīvo daudzumu un sadalījumu caurejošu šķeltņu skartajos audos, lietojot TUNEL metodi. 
6. Noteikt alveolārā kaula remodelāciju ietekmējošo faktoru $O C, O P, O P G, M M P-2, T I M P-2$, $B M P 2 / 4, T G F \beta 3$ sadalījumu un relatīvo daudzumu šķeltnes skartajos audos bērniem ar caurejošu šķeltni, pielietojot imūnhistoķīmijas metodi.

7. Izpētīt audu šksēēejenzīmu un ar tām saistīto endogēno audu inhibitoru, gēnu proteīnu, augšanas faktoru, angioǵenēzi ietekmējošo faktoru, alveolārā kaula remodelāciju ietekmējošo faktoru, šūnu proliferācijas marķieru, inervācijas un apoptozes sadalījumu un relatīivo daudzumu kontroles grupas pacientu materiālā.

8. Veikt datu statistisko analīzi un noteikt to iespējamo savstarpējo korelāciju.

\section{Darba hipotēzes}

1. Abpusēju caurejošu šķeltņu attīstības procesā raksturīga noteiktu atsevišķu faktoru lokāla ekspresijas mainība.

2. Abpusēju caurejošu šķeltņu skarto audu lokālo atbildes reakciju reǵenerācijas un deǵenerācijas procesos nosaka specifisko signālmolekulu relatīvais daudzums un ekspresija.

\section{Darba novitāte}

Kaut arī pasaulē ir daudz pētîjumu ar dzīvnieku modeḷiem un atsevišķi pētījumi izmantojot cilvēka audus, joprojām nav pilnībā skaidru datu par lokālu dažādu proteolītisku enzīmu, augšanas faktoru, transkripcijas faktoru, gēnu proteīnu, angioǵenēzi ietekmējošo faktoru, inervācijas, šūnu proliferācijas marķieru un apoptotisko šūnu sadalījumu un izvietojumu bērniem ar smagāko šķeltnes veidu - abpusēju caurejošu šķeltni - ontoǵenētiskā aspektā.

Pirmo reizi tika veikts abpusējas caurejošas lūpas, alveolārā izauguma un aukslēju šķeltnes skarto audu komplekss dažādu specifisku signālmolekulu morfologisks pētījums ontoǵenētiskā aspektā, kurā bērniem ar abpusēju caurejošu šķeltni mīkstajos audos tika atklāta transkripcijas faktora IRF6, MSX1 un PAX9, augšanas faktora TGF 33 un VEGF samazināta klātbūtne, kā arī samazināta šūnu proliferācija un apoptoze mīkstajos audos, bet balstaudos samazināta $O P N, O P G, M M P-2, T I M P-2, B M P 2 / 4$ un $T G F \beta 3$ klātbūtne. Pārliecinoši identificējām, ka morfologiskās audu izmaiņas ir smagākas pacientiem ar abpusēju šḳeltni. Atkārtotu operāciju laikā vieniem un tiem pašiem pacientiem novērojām palielinātu MSX1, MMP-9, TIMP-4, TGFß3, Ki-67 un samazinātu VEGF ekspresiju. 


\section{Mērḳa populācija}

Mērķa populācija ir Latvijas Lūpu, aukslēju un sejas šķeltṇu centrā uzskaitē esošie pacienti ar abpusējām un vienpusējām caurejošām lūpas, alveolārā izauguma un aukslēju šķeltnēm. Izmantojot morfologiskās metodes, tika izanalizēti audu paraugi no 22 pacientiem ar abpusēju caurejošu lūpas, alveolārā izauguma un aukslēju šķeltni ontoǵenētiskā aspektā, kā arī audu paraugi no 24 pacientiem ar vienpusēju caurejošu lūpas, alveolārā izauguma un aukslēju šķeltni.

\section{Sadarbības partneri}

Pētījums tika veikts sadarbībā ar SIA "RSU Stomatologiijas institūts” Lūpu, aukslēju un sejas šķeltnu centru, kur tika savākti audu paraugi morfologiskiem izmeklējumiem. Rutīnās histolog̣ijas krāsošanas metode un imūnhistoķīmiskās reakcijas tika veiktas RSU AAI Morfologijas laboratorijā.

\section{Materiāli tehniskais nodrošinājums}

RSU AAI Morfolog̣ijas katedrā un Morfolog̣ijas laboratorijā bija darba veikšanai viss nepieciešamais ekipējums - pusautomātiskās rotācijas mikrotoms (Leica RM2245, Leica Biosystems Richmond Inc., Amerikas Savienotās Valstis), gaismas mikroskops (Leica DM500RB, Leica Biosystems Richmond Inc., Amerikas Savienotās Valstis), digitālā kamera 300F (Leica, Wetzlar,Vācija), datori ar attēlu apstrādes programmu Image Pro Plus 6.0 versiju (Media Cybernetics, Silver Spring, MD, Amerikas Savienotās Valstis).

\section{Personīgais ieguldījums}

Autore piedalījās visās pētījuma stadijās: pētījuma plānošanu, imūnhistoķīmisko marķieru izvēli, pētāmā materiāla vākšanu (t. sk. redzēja šķeltṇu operācijas), zinātnisko datu ieguvi, un to statistisko analīzi, veica imūnhistoķīmiskās reakcijas un TUNEL metodi, veica imūnhistoķīmisko vizualizāciju, analizējot katru audu paraugu gaismas mikroskopā. Autore sarakstīja šo darbu un ir arī visu darbā iekļauto mikrofotogrāfiju autore. 


\section{Ētiskie aspekti}

Pētījums ir veikts saskaņā ar Helsinku deklarāciju un RSU Ētikas komitejas atḷauju: RSU Ētikas komitejas lēmumi 2003. gada 22. maijā un 2013. gada 17. janvārī (sk. 2. pielikumu). 


\section{LITERATŪRAS APSKATS}

\subsection{Lūpas un aukslēju šķeltnes vispārīgs raksturojums}

Lūpu un aukslēju šķeltnes ir audu attīstības traucējumu rezultāts, kad tiek skarti dažādu audu veidi, piemēram, epitēlijaudi, saistaudi, skrimšļaudi un kaulaudi. Pasaulē sejas šķeltnes ir atrodamas vidēji 1-2 no 1000 dzīvi dzimušajiem. Izšķir izolētas aukslēju šķeltnes, kas $42-54 \%$ gadījumos ir saistītas ar citām ǵenētiski determinētām anomālijām, un lūpas un/vai aukslēju šķeltnes, kas 14-30\% ir sindromiskas. Šķeltnes, kas skar lūpu, 68-86\% gadījumos kombinējas ar aukslēju šķeltni. Visbiežāk šķeltnes skar tieši lūpas un/vai aukslējas. Zēniem lūpas šķeltne ar vai bez aukslēju šķeltnes ir sastopama biežāk nekā meitenēm. Lūpas un/vai aukslēju šķeltnes sīkāk iedala apakštipos: slēpta lūpas vai aukslēju šķeltne, lūpas un alveolārā kaula šķeltne, vienpusēja necaurejoša lūpas un aukslēju šķeltne, vienpusēja caurejoša lūpas, alveolārā izauguma un aukslēju šķeltne (1.1. attēls), abpusēja caurejoša lūpas, alveolārā izauguma un aukslēju šķeltne (1.2. attēls). Lūpu un aukslēju šķeltņu biežums ir atkarīgs no rases, kā arī geogrāfiskā reǵiona, tomēr arī vienai - baltajai rasei - dažādās valstīs tas nav vienāds. Tieši dzeltenās rases pārstāvjiem šī patolog̣ija ir sastopama visbiežāk, retāk baltajai rasei (Arosarena, 2007; Mossey et al., 2009; Dixon et al., 2011).

Šīs patologiijas ārstēšanai tiek pielietotas dažādas operāciju metodes noteiktā laikā un secībā. Lūpas plastika tiek veikta 3 līdz 5 mēnešu vecumā, mīksto aukslēju plastika -8 līdz 12 mēnešu vecumā, cieto aukslēju plastika - 3 līdz 4 gadu vecumā, alveolārā izauguma osteoplastika ar kaula autotransplantāciju - 7 līdz 10 gadu vecumā. Tiek veiktas arī dažādas koriǵējošas plastikas, piemēram, deguna korekcija, runas korekcijai - velofaringoplastika u.c. (Farronato et al., 2015).

Izolēta lūpu un aukslēju šķeltne ir multifaktoriāla patoloǵija, kad teratogēnie faktori mijiedarbojas ar ġenētiskajiem faktoriem. Šīs sejas apvidus slimības etiologijas izprašanai ir jāzina sejas un mutes dobuma attīstības molekulārie mehānismi. 


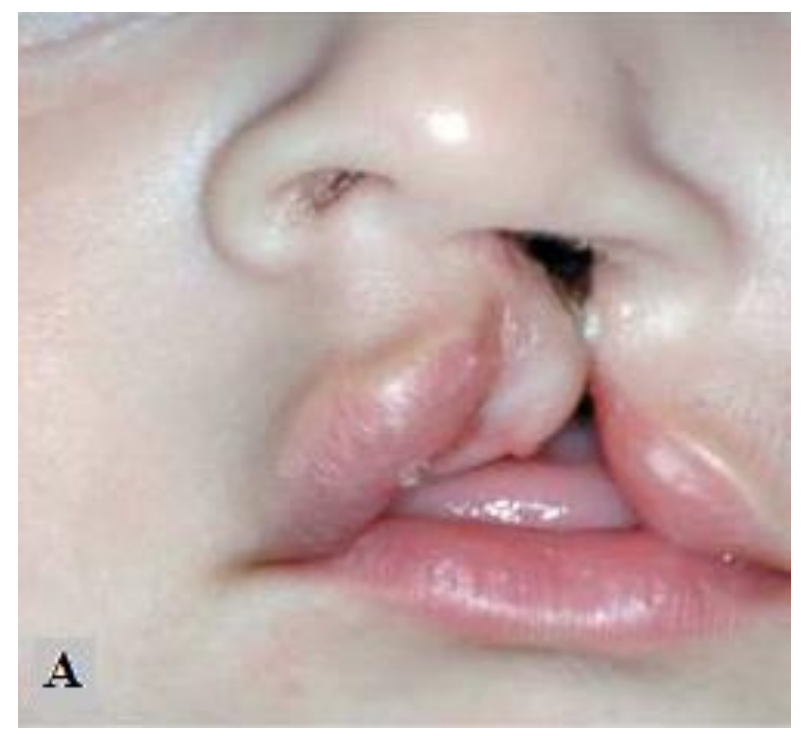

1.1. attēls. Vienpusēja caurejoša lūpas, alveolārā izauguma un aukslēju šķ̧eltne (adaptēts no Alberto de Souza FREITAS, 2012)

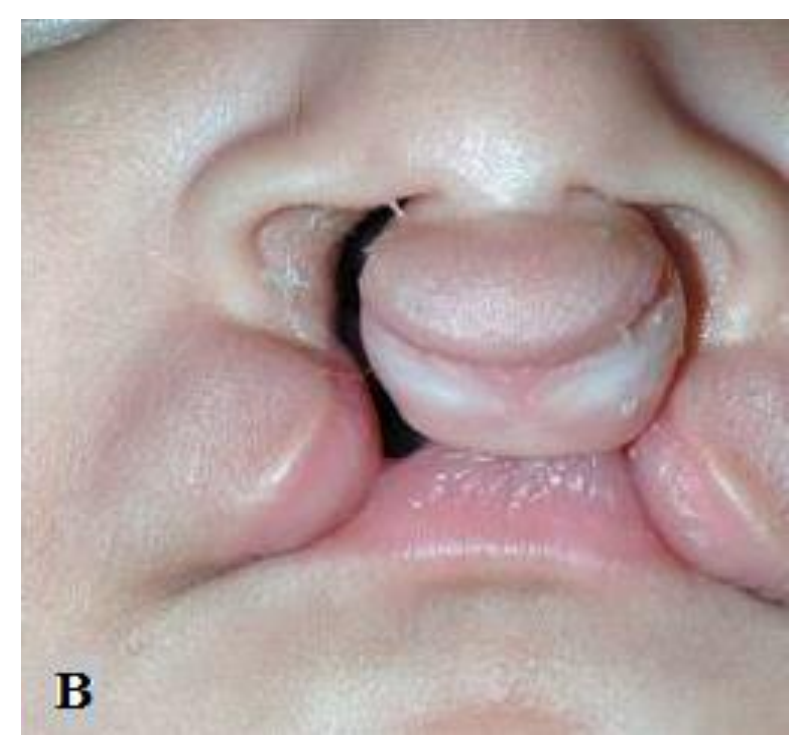

1. 2. attēls. Abpusēja caurejoša lūpas, alveolārā izauguma un aukslēju šḳeltne (adaptēts no Alberto de Souza FREITAS, 2012)

\subsection{Sejas un mutes dobuma attīstības raksturojums}

Sejas attīstība sākas 24. attīstības dienā, kad, proliferējot nervu kores šūnām, veidojas aizmetņi. Audu saplūšanai embrionālās attīstības laikā ir izšķiroša loma sirds, nervu caurules, acu, sejas un mutes dobuma formēšanas procesā. Sejas un mutes dobuma attīstība sākas ar priekšējo smadzeṇu paplašināšanos, attīstoties pirmajam žaunu lokam, kā arī sirds valnītim. Pirmais žaunu loks satur mezodermālas izcelsmes mezenhīmas šūnas, nervu kores šūnas, skrimšla aizmetni, kā arī to caurauž trijzaru nervs un aortas loks. Sejas un mutes dobuma attīstība ir cieši saistīta ar funkcionāli nozīmīgām multipotentām nervu kores šūnām, kas 
embrionālās attīstības laikā migrē uz žaunu lokiem un kombinējas ar mezodermas šūnām (Graham et al., 2004). Tālākā attīstības gaitā izveidojas ektodermāls mutes padziļinājums, kas pārtop primārajā mutes dobumā un, mijiedarbojoties nervu korei, sejas mezodermai, kā arī apkārt esošai endodermai un ektodermai, attīstās piecas sejas krokas. Ceturtajā nedēẹā sejas rajons primāri attīstās no pieres un deguna krokas, pāra augšžokḷa krokas un pāra apakšžokḷa krokas. No pieres un deguna krokas attīstās piere, virslūpas vidusdaḷa, padegunes rieva, starpžoklis un primārās aukslējas. Savukārt no augšžokḷa krokas attīstās virslūpas un augšžokḷa sānu daḷas, augšējie vaigu kauli, arī sekundāro aukslēju lielākā daḷa (Pilmane un Šūmahers, 2006). Lūpas un aukslēju šķeltne izpaužas, ja notiek primāro aukslēju nepareiza formēšanās, savukārt traucējumi, kas rodas, saplūstot sekundāro aukslēju aizmetņiem, izpaužas kā aukslēju šķeltne (Ray and Niswander, 2012).

\subsubsection{Augšlūpas morfoǵenēzes molekulārie mehānismi}

Sejas izaugumu saplūšana noris hronologiskā secībā: augšžokḷa kroka un mediālais deguna aizmetnis, mediālais un laterālais deguna aizmetnis, augšžokļa kroka un laterālais deguna aizmetnis, kā arī augšžokḷa un apakšžokļa krokas. Tieši mediālā un laterālā deguna aizmetṇa saplūšana ir svarīgs posms augšlūpas attīstībai. Aizmetņu pamatu veido mezenhīma, bet klāj epitēlijs. Traucējumi šo aizmetņu saplūšanas laikā rada laterālo lūpas šķeltni, kas var izveidoties gan vienā, gan abās pusēs (Pilmane un Šūmahers, 2006). Augšlūpas attīstība beidzas 48. gestācijas dienā, kad notiek piln̄̄ga deguna mediālā un augšžokḷa krokas epitēlija - mezenhīmas saplūšana, kā arī no starpžokḷa segmenta, kas attīstījies no distālās mediālā deguna aizmetņa daļas un formē virslūpas vidusdaļu (Jiang et al., 2006). Lūpu aizmetņu saplūšana ir komplekss process, kas ietver nozīmīgas epitēlijšūnu, mezenhimocītu morfoloǵiskās izmaiņas deguna mediālās, laterālās un augšžokḷa krokas rajonos.

Interesanti, kā lūpu aizmetņu saplūšanas molekulāro mehānismu interpretē, proti, daži zinātnieki uzskata, ka lūpas aizmeţ̦u saplūšanas laikā notiek bazālo epitēlijšūnu transformācija mezenhīmā (ETM), pamatojoties uz eksperimentiem ar vistas embrijiem (Sun et al., 2000). Morfologiski epitēlijšūnas transformācijas laikā zaudē polaritāti, izzūd šūnu savienojumi, notiek citoskeleta reorganizācija un izmaiņas organō̄du izveitojumā (Thiery et al., 2009).

20. gadsimta 50. gados tika izteikta hipotēze par programmētās šūnu nāves nozīmi aizmetņu saplūšanas laikā (Shuler, 1995; Iseki at al., 2011). Daži zinātnieki uzskata, ka augšlūpas aizmetņu saplūšanas laikā notiek peridermas šūnu apoptoze (Jiang et al., 2006). Cilvēka embrija audos ar skenējošā elektronu mikroskopa palīdzību tika vizualizētas apaļas, 
iespējams, apoptotiskas šūnas starp augšžokḷla un laterālo deguna aizmetni, kā arī starp mediālo un laterālo deguna aizmetni. Tika izvirzīta hipotēze, ka apoptoze peridermas šūnās veicina bazālo epitēlijšūnu saskarsmi ar pretējās puses šūnām un inducē katherīnu meditētu desmosomu attīstību starp aizmetņiem. Šajā gadījumā desmosomu funkcija nav nodrošināt kontaktus starp epitēlijšūnām, bet gan inducēt ETM. Turklāt arī sindekāns un E-kadherīns kalpo par trigeri ETM. Sākotnēji epitēlijšūnu morfoloǵijā redzamas filopodijas, kuras iesniedzas caur bazālās membrānas pātraukumiem mezenhīmas šūnu virzienā, bet tālākā pārveides procesā filopodijas attīstās par pseidopodijām, un notiek ETM (Sun et al., 2000). Bazālās membrānas degradāciju saplūšanas laikā nodrošina šūnu sintezētās MMPs (Blavier et al., 2001). Limfoīdais enhansera (aktivatora)-saistošais faktors-1 (LEF-1), beta-katenīns, integrīni, augšanas faktori, proto-onkogēna tirozīna kināze, FBJ osteosarkomas onkogēns (Fos), SNAI saimes cinka pirkstiņu transkripcijas faktors-1 (SNAI1), spirāles-cilpas-spirāle vijuma pamata transkripcijas faktors-1 (Twist), SNAI saimes cinka pirkstinu transkripcijas faktors-2 (Slug), sonic hedgehog (Shh) gēni un citas specifiskas signālmolekulas ir iesaistītas ETM (Cano et al., 2000; Eger et al., 2000; Yang et al., 2004; Kang and Massagué, 2004; Del Barrio and Nieto, 2004; Thiery et al., 2009).

\subsubsection{Sekundāro aukslēju morfoğenēzes molekulārie mehānismi}

Sekundāro aukslēju attīstība sākas sestajā nedēḷā, turklāt lielākā aukslēju daḷa attīstās no pirmā žaunu loka augšžokḷa krokas. Tā ir saistīta ar epitēlijšūnu un neiromezenhīmas mijiedarbību, kuru kontrolē dažādu signālmolekulu, augšanas faktoru, augšanas faktoru receptoru un transkripcijas faktoru ekspresijas dinamiskās izmaiņas. Aukslēju aizmetņu priekšpusē gḷotādas epitēlijs ekspresē Shh gēnu, kas, saistoties ar Shh gēna receptoru Patč (PTC) aktivē Smo receptora ekspresiju mezenhīmā. Savukārt Smothened klases receptors (G olbaltumvielas saistītājreceptors) (Smo) aktivē fibroblastu augšanas faktora-10 (Fgf10) sintēzi. Fgf10 saistās ar fibroblastu augšanas faktora receptoru-2b $(F g f r 2 b)$, un tiek regulēta šūnu proliferācija. Kaula morfoǵenētiskais proteīns $(B m p)$ saistās ar kaula morfoǵenētiskā proteīna receptoru-1a (Bmprla) un regulē gēnu Msxl, Shh un īsā auguma homeoboksa (mājturības)-2 (Shox2) ekspresiju. Aizmetnuu augšanu kontrolē arī efrīns B1 (EfnB1) caur efrīna B2 (EfnB2) un efrīna B3 (EfnB3) receptoriem. Gēni meningiomas 1 (Mn1), T-box 22 (Tbx22), mezenhīmas homeoboksa-2 (Meox2) un BarH līdzīgais homeobokss-1 (Barx1) kontrolē mugurējās daļas aukslēju aizmetņu augšanu. Tieši Odd-skipped radniecīgā transkripcijas faktora-1 (Osr1), Odd-skipped radniecīgā transkripcijas faktora-2 (Osr2) gēni nodrošina aukslēju aizmetņu mediolaterālo augšanu. Šo gēnu ekspresija ir no Shh signālceļa 
atkarīga. Mazāk distālais homeobokss-1 - fibroblastu augšanas faktora-7 (Dlx5-Fgf7) signālcel̦š var inhibēt Shh ekspresiju (1. 3. attēls) (Chai and Maxson, 2006; Bush and Jiang, 2012). Tas ir komplekss process, kuru regulē šūnu proliferācija, diferenciācija, migrācija, apoptoze un ETM.
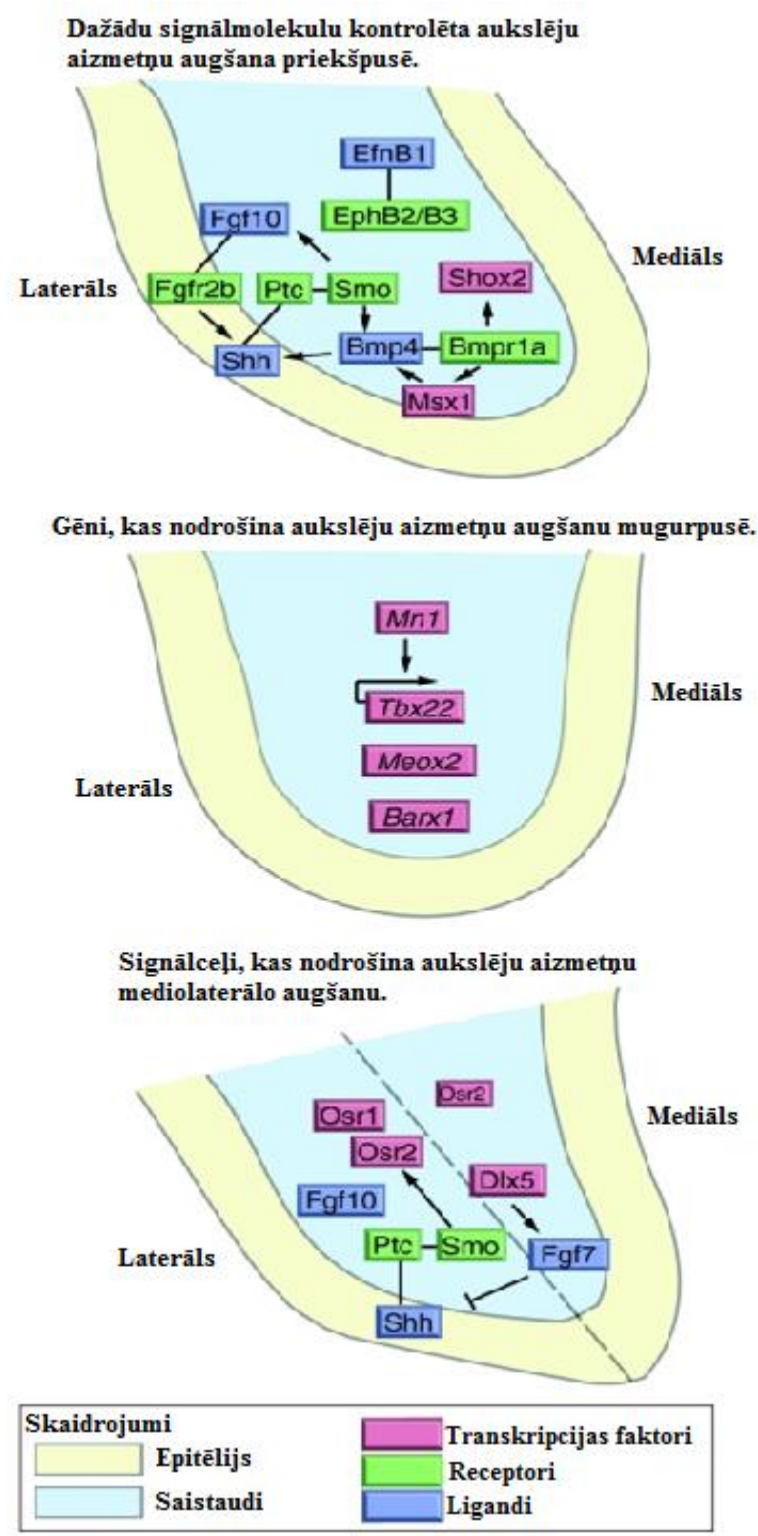

\section{3. attēls. Gēnu, augšanas un transkripcijas faktoru un to receptoru kontrolēta aukslēju attīstība un augšana (adaptēts no Bush and Jiang, 2012)}

Saīsinājumi attēlā: $E f n B 1$ - efrīna B1 gēns; $F g f 10$ - fibroblastu augšanas faktors-10; $E p h B 2 / B 3$ - efrīna B1/B3 gēns; Fgfr2b - fibroblastu augšanas faktora receptors-2b; Ptc - ret protoonkogēns; Smo - Smothened klases receptors (G olbaltumvielas saistîtājreceptors); Shox2 - īsā auguma homeoboksa (mājturības)-2 gēns; Shn - sonic hedgehog gēns; Bmp4 - kaula morfoğenētiskais proteīns-4; Bmprla - kaula morfoǵenētiskā proteīna receptors-1a; Msxl - muskuḷ segmentācijas homeobokss-1; Mn1 - meningiomas-1 gēns; Tbx22 - T-box 22 gēns; Barxl - BarH līdzīgais homeobokss-1 gēns; Osrl - Odd-skipped radniecīgais transkripcijas faktors-1; Osr2 - Odd-skipped radniecīgais transkripcijas faktors-2; Fgf7 - fibroblastu augšanas faktors-7; Dlx5 - mazāk distālais homeobokss-5. 
Nervu kores izcelsmes mezenhīma, ektodermas izcelsmes epitēlijs, apikāli novietotas peridermas šūnas un kraniāli novietotās paraaksiālās mezodermas izcelsmes miogēnās šūnas veido morfoloǵisko bāzi aukslējām (Lane and Kaartinen, 2014). Sekundāro aukslēju attīstības procesā izdala vairākas fāzes (1. 4. attēls) (Dudas et al., 2007). Vispirms aukslēju aizmetņi aug vertikāli, un starp tiem veidojas mēles aizmetnis, seko pacēlums, tad septītajā nedēḷā notiek aizmetnu pagriešanās aptuveni par $90^{\circ}$ horizontālā virzienā, tie aug viens pret otru. Aptuveni 9. nedēlāa notiek aukslēju saplūšana pa viduslīniju priekšpusē, bet līdz 12. nedēlai epitēlija saplūšana turpinās virzienā uz mugurpusi (Pilmane un Šūmahers, 2006).
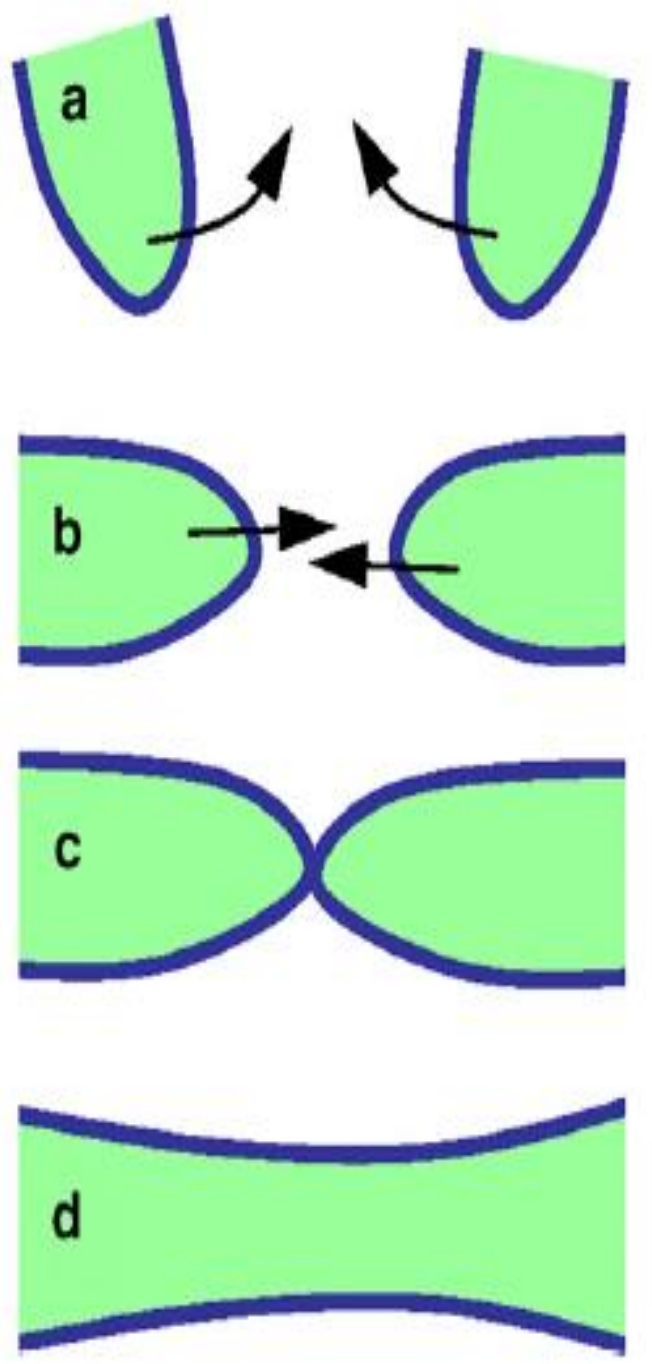

1. 4. attēls. Sekundāro aukslēju attīstības galvenie etapi (adaptēts no Dudas et al., 2007)

Attēla skaidrojums: a. Aukslēju aizmetņi aug vertikāli un izvietojas abās pusēs mēles aizmetnim, tad seko aizmetņu elevācija. b. Vēlāk tie pagriežas un izvietojas horizontāli. c. Aukslēju aizmetņi aug virzienā viens pret otru. d. Notiek aukslēju aizmetņu saplūšana.

Pēdējo gadu laikā tiek intensīvi pētīts sekundāro aukslēju aizmetņu epitēlijs. Literatūrā, pamatojoties uz eksperimentiem ar dzīvniekiem, šis jautājums tiek skaidrots vairākās teorijās. Daži autori uzskata, ka aukslēju aizmetņu epitēlija bazālās šūnas iet bojā 
apoptozes ceḷā, citi uzskata, ka notiek ETM, un trešās teorijas pārstāvji uzskata, ka epitēlijšūnas migrē mutes un deguna dobuma virzienā (Sun et al., 2000; Martinez-Alvarez et al., 2000; Dudas et al., 2007; Nawshad, 2008; Iseki, 2011). Apkopojot literatūru, jāatzīmē, ka sekundāro aukslēju saplūšanas molekulārie mehānismi ir līdzīgi lūpu aizmetņu saplūšanai, kaut gan tieši aukslēju saplūšana ir intensīvāk pêtīta, salīdzinot ar lūpu aizmetņu saplūšanu.

Sekundāro aukslēju aizmetņi sastāv no kraniālās nervu kores izcelsmes mezenhīmas šūnām, ektomezenhīmas šūnām un kraniofaringeālās ektodermas epitēlija, kas sastāv no diviem līdz četriem epitēlija slāņiem, kurus veido plakanas peridermas šūnas un bazālas kubiskas šūnas. Peridermas šūnas aizsargā zemāk esošo bazālo epitēliju, kas veido mediālās malas epitēliju (MME). $M M E$ no zemāk esošās neiromezenhīmas atdala funkcionāli nozīmīga bazālā membrāna. Literatūras dati liecina, ka ETM aukslēju aizmetņu saplūšana morfoloǵiski ir līdzịga lūpas aizmetņu saplūšanai. Līdzīgi kā lūpu aizmetņu, arī aukslēju aizmetņu epitlēlijšūnas transformācijas laikā zaudē apikāli-bazālo polaritāti, starp tām izzūd šūnu kontakti, notiek citoskeleta reorganizācija un izmaiņas organoīdu izvietojumā, kā arī notiek izmaiņas gēnu proteīnu ekspresijā (Thiery et al., 2009). Pēc sekundāro aukslēju aizmetņu reorientācijas, peridermas šūnas morfoloǵiski izmainās, un notiek saplūšanas process, izzūdot mediālās malas epitēlijam.

ETM celulārā programmā morfologiiski izšķir vairākas stadijas. Pirmkārt, virspusējās peridermas šūnas morfologiski mainās, jo uzskata, ka tās iet bojā apoptozes ceḷā. Pēc peridermas šūnu izzušanas zemāk esošās bazālās šūnas sāk producēt desmosomas komponentus. Otrkārt, vidusšuves epitēlijs zaudē šūnu-šūnu kontaktus un transformējas par mezenhīmas šūnām. Tiek samazināta E-kadherīna, sindekāna-1, klaudīna un okludīna ekspresija. ETM laikā šūnas neekspresē keratīna starpdiedziņus, bet gan vimentīna starpdiedziņus. Treškārt, šūnas sākt sintezēt MMPs un ar tām saistītos TIMPs, un vienlaikus notiek arī ekstracelulārās matrices remodelācija, bazālās membrānas degradācija un palielinās mezenhīmas šūnu mobilitātes potenciāls (Kang et al., 2005; Lamouille et al., 2013; Lamouille et al., 2014; Gonzalez and Medici, 2014). ETM process ir MMP, TIMP, TGF , p63, IRF6 un citu specifisku signālmolekulu atkarīgs (Jalali et al., 2012; Iwata et al., 2014; Nakajima et al., 2014; Lane et al., 2015; Hu et al., 2015).

Pasaulē tiek plaši diskutēts par programmētās šūnu nāves teorijas nozīmi sekundāro aukslēju saplūšanas laikā. Ir zinātnieki, kas uzskata, ka bazālā slāņa epitēlija šūnas iet bojā apoptozes cel̦ā, tādējādi nodrošinot ne tikai primāro, bet arī sekundāro aukslēju saplūšanu (Cuervo and Covarrubias, 2004; Dudas et al., 2007; Nawshad et al., 2008; Lee et al., 2008; Vukojevic et al., 2012; Sohn et al., 2012; Hirata et al., 2013; Serrano et al., 2015). Interesanti, ka 2004. gadā veiktais pētījums ar pelēm in vitro norāda, ka programmēta šūnu nāve nav 
nozīmīga aukslēju saplūšanas laikā, kaut gan dažās aukslēju attīstības stadijās atsevišķas apoptotiskas šūnas tika novērotas (Takahara et al., 2004). Savukārt nesenā pētījumā ar cilvēka embrijiem tika novērota ne tikai nozīmīga šūnu apoptoze, bet arī šūnu proliferācijas esamība aukslēju attīstības laikā. Turklāt šūnu proliferācijas aktivitāte noris paralēli šūnu apoptozei, un abi procesi ir precīzi koordinēti (Vukojevic et al., 2012). Uz jautājumu, kurš no iepriekš minētiem procesiem aukslēju attīstības laikā ir dominējošais, vēl nav atbildes. Citi pētnieki uzskata, ka nevar noteikt, kurš no šiem fenomeniem ir vadošais. Ahmeda zinātnieku kolektīvs no ASV domā, ka ETM un apoptoze viens otru papildina, tādējādi ieņem būtisku lomu primāro un sekundāro aukslēju attīstības laikā (Ahmed et al., 2007).

Trešās teorijas pārstāvji domā, ka vidusšuves epitēlija šūnas migrē deguna vai mutes dobuma virzienā. No šīm šūnām var diferencēties gan mutes dobuma, gan deguna dobuma epitēlijs (Shin et al., 2012).

Neskatoties uz daudzajiem pētîjumiem, joprojām šis jautājums rada interesi zinātnieku vidū. Nav skaidras atbildes uz jautājumu, kas notiek ar vidusšuves epitēliju. Skaidrs ir viens, sekundāro aukslēju attīstība ir fundamentāls, molekulāri sarežǵīts process, kuru ietekmē dažādi proteolītiski enzīmi, augšanas faktori, augšanas faktoru receptori, transkripcijas faktori un gēni. Viennozīmīgi, traucējumi kaut vienā no šiem molekulāriem mehānismiem var izpausties kraniofaciālās displāzijās, proti, sejas šķeltnēs.

\subsection{Audu degradācijas enzīmi (MMP) un ar tām saistītie endogēnie inhibitori (TIMP)}

Audu degradācijas enzīmi un ar tiem saistītie endogēnie inhibitori piedalās audu remodelācijā un $E C M$ degradācijā mutes dobuma attīstības laikā. Literatūrā ir aprakstītas trīs metaloproteināžu grupas, kas uztur ECM homeostāzi: MMPs, disintegrīna un metaloproteināzes ar trombospondīna motīviem (ADAMTS) proteināzes un astacīni. Pašlaik ir zināmas aptuveni 200 cinka atkarīgas metaloproteināzes zīdītājiem (Puente et al., 2003; Apte et al., 2015). Dažas proteāzes, piemēram, MMP un ar tām saistītie TIMP, nodrošina un uztur ECM homeostāzi embrionālās attīstības laikā (Buckley and Jessen, 2015). MMPs, ADAMTS, kā arī TIMPs piedalās morfoǵenēzes, šūnu migrācijas, apoptozes, angioǵenēzes procesos, kā arī augšanas faktoru, to receptoru un citokīnu biologiskās aktivitātes regulēšanā. Šiem procesiem ir svarīga loma orgānu attīstībā, audu remodelācijā, brūču dzīšanā, iekaisuma un metastazēšanās procesā (Gaffney et al., 2015; Arpino et al., 2015; Rohani and Parks, 2015). $M M P$ s proteolītiskais spektrs ietekmē šūnu virsmas proteīnu, ne-ECM atkarīgo pericelulāro molekulu, citu proteināžu, intracelulāro vielu, proteināžu inhibitoru, hemotakses molekulu, latento augšanas faktoru, šūnas-šūnas un šūnas-ECM adhēziju molekulu funkcionālo 
aktivitāti. Ir pierādīta $M M P$ aktivitāte kaulaudu attīstībā un reǵenerācijā. Eksperimentu rezultāti uz knockout peḷu modeliem norāda $M M P-2, M M P-9, M M P 13, M M P-14$ un $M M P-16$ nozīmi skeleta attīstībā (Paiva and Granjeiro, 2014).

Turklāt šiem enzīmiem ir svarīga loma daudzu patologiisku stāvokḷu attīstībā, piemēram, sejas škseltnes, zobu erozijas, reimatoīdā artrīta, osteoartrīta, glaukomas, neirodeǵeneratīvo, nieru, plaušu, kardiovaskulāro slimību, kā arī malignitātes un fibrozes attīstībā (Lu et al., 2011; Letra et al., 2014; Zarella et al., 2015; Singh et al., 2015; Musiat et al., 2015).

MMP un TIMP izdala dažādas epitēlija, saistaudu un iekaisuma veicinošas šūnas, piemēram, fibroblasti, makrofāgi, tuklās šūnas, plazmocīti, limfocīti, neitrofilie leikocīti, monocīti, endoteliālās šūnas, epiteliocīti, osteoblasti, osteocīti, hondroblasti, hondrocīti, hepatocīti, kardiomiocīti u.c. (Nagase et al., 2006).

Sejas un mutes attīstības laikā $M M P$ un TIMP ekspresija šūnu līmen̄i ir stingri kontrolēta. Būtiska nozīme aukslēju attīstības laikā ir ECM remodelācijai, kuru regulē iepriekš minētie enzīmi. Traucējumi ECM remodelācijas laikā var izpausties lūpas un aukslēju šķeltnēs. To pierāda aukslēju morfoǵenēzes laikā novērota $M M P$ un TIMP ekspresijas klātbūtne (Morris-Wiman et al., 2000; Blavier et al., 2001).

N̦emot vērā daudzos pêtījumus, joprojām MMP un TIMP funkciju molekulārie mehāniski iedzimu slimību skarto audu remodelācijā, šķeltņu pēcoperācijas brūču dzīšanā nav zināmi.

\subsection{IRF6 gēns}

Nervu kores šūnas, kraniofaciālā ektoderma, prehordālā mezoderma sekmē kraniofaciālā reǵiona attīstību, un precīzi regulēta šūnu proliferācija, migrācija un diferenciācija ir vadoši notikumi sejas un mutes dobuma morfologijā. Daudzi gēni, ieskaitot transkripcijas faktorus, augšanas faktorus un to receptorus, iesaistās šajos procesos, un mutācijas šajos gēnos var izraisīt lūpas un/vai aukslēju šķeltnes (Dai et al., 2014).

IRF6 pieder pie IRF gēnu saimes, kas satur desmit eksonus un ir būtisks imūnās sistēmas šūnu aktivētājs. IRF6 pavisam nesen tika identificēts zivīm, pelēm un arī cilvēkam (Kondo et al., 2002; Ben et al., 2005). Pašlaik ir aprakstīti deviņi IRF gēni, kam ir nozīme ne tikai imūnās sistēmas regulēšanā, bet arī šūnu proliferācijā un diferenciācijā. Irf6 ekspresija tika novērota acu, plaušu, ādas, liesas, aknu, placentas un dzimumorgānu šūnās (Kondo et al., 2002). Interesanti, ka Liu ar kolēgiem 2012. gadā publicē pētījuma rezultātus, kuros apraksta IRF6 ekspresiju plaušās, aknās, limfmezglos, smadzenēs, nierēs, skeleta muskulatūrā, tīmusā, 
sirdī, bet ne liesā (Liu et al., 2012), un Flemings izpēta IRF6 ekspresiju dzemdes epitēlijšūnās (Fleming et al., 2009). Veiktajos eksperimentos ar knockout peļu modeļiem tika atklāta Irf6 gēna nozīme skeleta, sejas un mutes dobuma attīstībā. Interesanti, ka tomēr Irf6 pelēm primāri regulē epiteliocītu proliferāciju un diferenciāciju, kā arī mutes dobuma peridermas šūnu formēšanos embrionālās attīstības laikā (Ingraham et al., 2006; Richardson et al., 2006). Bez tam Irf6 gēna nozīme tika atklāta incisīvu epitēlija invaginācijas laikā (Blackburn et al., 2012). Vashborne un Koks 2006. gadā atklāja, ka sejas aizmetņi ekspresē Irf6 (Washbourne and Cox, 2006). Mutācijas IRF6 gēnā var izraisīt Van der Woude (VWS) un poplyteal pterigium sindromu. VWS ir autosomāli dominanta saslimšana, kas klīniski raksturojas ar lūpas un aukslēju šķeltni un ir biežākais iemesls sejas šķeltnei, kuras pamatā ir noteikta gēna defekts (Malik et al., 2010). Analizējot daudzas populācijas, IRF6 gēna ietekme nesindromālo lūpas un aukslēju šķeltņu gadījumos ir pierādīta (Birnbaum et al., 2009; Shi et al., 2011; Letra et al., 2012; Miller et al., 2014; Ibarra-Arce et al., 2015; Mijiti et al., 2015). Tikmēr pavisam nesenā pētījumā tika pierādīta šī gēna cieša saistība ar smagāko šķeltnes veidu, proti, abpusēju caurejošu lūpas un aukslēju šķeltni (Kerameddin et al., 2015).

\subsection{PAX9 gēns}

$P A X 9$ gēns pieder pie $P A X$ gēnu saimes un ir atbildīgs par transkripcijas faktoru kodēšanu. Pavisam izšksir $9 P A X$ gēnus. Experimentos ar peḷu model̦iem tika novērota $\operatorname{Pax} 9$ ekspresija tīmusa, epitēlijķermen̄ī̌su, barības vada, zemžokḷa siekalu dziedzeru, mēles diegveida kārpiņu, aukslēju, vaigu gḷotādas epitēlijšūnās, kā arī deguna un aukslēju mezenhīmas šūnās, aukslēju mugurējā epitēlijā (Jaskoll et al., 2002; Jonker et al., 2004; Kist et al., 2007; Nakatomi et al., 2010; Zhou et al., 2013). Pasaulē tiek pētīta šī gēna nozīme nesindromālo šķeltņu attīstībā, jo Pax9 ir atbildīgs par lūpu, aukslēju un zobu attīstîbu (Nakatomi et al., 2010; Zhou et al., 2011). Tika novērots, ka Pax9 proteīns inducē mezenhīmas šūnu, epitēlijšūnu proliferāciju un ir svarīgs faktors mediālās malas epitēlija mijiedarbībā ar zemāk esošo mezenhīmu, ietekmējot Shh proteīna ekspresiju sekundāro aukslēju attīstības laikā (Chi and Epstein, 2002; Nakatomi et al., 2010; Zhou et al., 2013). Arī pētījumā ar Pax9 mutācijām pelēm Zhou ar kolēgiem novēroja samazinātu Bmp4, Fgf10, Msxl un Osr2 gēnu ekspresiju mezenhīmā, kas liecina par šī transkripcijas faktora nozīmi šo gēnu molekulārās darbības regulēšanā (Zhou et al., 2013). Pax9 regulē arī TGFß3 funkcijas, kas ir vadošais faktors sekundāro aukslēju aizmetņu saplūšanas laikā. Analizējot peļu aukslēju attīstību, $\operatorname{Pax} 9$ ekspresija tika novērota tieši primāro aukslēju audos, kā arī sekundāro aukslēju sānu un mugurējā rajonā. Savukārt vāja ekspresija tika saskatīta mediālās malas epitēlijā 
(Sasaki et al., 2007). Ir pierādīts, ka mutācijas $P A X 9$ gēnā izraisa iedzimtu oligodontiju, kā arī arvien aktuālāki kḷūst pētījumi par $P A X 9$ iesaisti nesindromālās lūpas un aukslēju šķeltnes attīstībā (Lee et al., 2012; Song et al., 2013; Küchler et al., 2014). Vēl joprojām PAX9 proteīna funkcijas nav izpētītas līdz galam, kaut arī bijuši gan šie, gan arī vēl citi pētījumi. Literatūrā atrodami tikai atsevišķi ziņojumi par š̄i gēna nozīmi abpusēju caurejošu šķeltņu attīstībā.

\section{6. $M S X 1$ gēns}

Homebox transkripcijas faktoriem ir svarīga loma šūnu proliferācijāa migrācijā un diferenciācijā embrija attīstības laikā. Tieši $M S X 1$ ir viens no vadošajiem gēniem sejas kaulu, aukslēju, skeleta, acu un nervu sistēmas attīstībā (Allapat et al., 2003; Berdal et al., 2009; Lopes et al., 2012). Literatūrā ir aprakstīti trīs MSX saimes gēni. MSX1 un MSX2 ir vislielākā funkcionālā loma sejas struktūru attīstībā. Visu trīs gēnu ekspresija tika novērota sejas un mutes dobuma attīstības laikā tajos rajonos, kur visintensīvāk notiek epitēlija un mezenhīmas mijiedarbība (Finnerty et al., 2009). Pelēm Msx1, Msx2 ekspresija tika novērota galvaskausa, dura mater šūnās, kā arī sejas aizmetņos, redzes un dzirdes orgānā, zobu attīstības laikā. Izteikti $M s x 1, M s x 2$ ekspresē struktūras nervu kores šūnu migrācijas laikā. Interesanti, ka izteikta $M S X 1$ ekspresija tika novērota galvaskausa morfoǵenēzē postnatāli, savukārt MSX2 ekspresija samazinājās pēc dzimšanas. Aukslēju attīstības laikā Msxl regulē Bmp funkcijas. Traucējumi $M S X$ gēna funkcijās var radīt kraniofaciālā rajona, ekstremitāšu un zobu anomālijas (Allapat et al., 2003; Levi et al., 2006). Ar knockout dzīvnieku modeļiem ir veikti arī Msxl pētījumi, kuru rezultātā tiek uzskatīts, ka nulles mutācijas rada aukslēju šķeltnes, ekstremitāšu anomālijas, zobu aǵenēziju un dažādas iekšējās auss malformācijas (Lallemand et al., 2005; Nassif et al., 2014). Savukārt Msx2 mutācijas rada zobu un smadzenīšu attīstības anomālijas pelēm, kā ar̄̄ MSX2 mutācijas sekas ir kraniosinostozes (Satokata et al., 2000; De Coster et al., 2007). Ir svarīgi minēt, ka mutācijas Msxl gēnā izraisa defektus šūnu proliferācijas līmenī tieši aukslēju priekšējās daļas mezenhīmā (Meng et al., 2009). Cilvēkam mutācijas šajā gēnā ir asociētas ar nesondromālām lūpas un aukslēju šķeltnēm, autosomāli dominanti pārmantoto hipodontiju un divu veidu sindromiskām sejas šķeltnēm: Vitkopa sindromu un Volf-Hiršhorna sindromu (Cardoso et al., 2013; Souza et al., 2013; Ma et al., 2014). MSX1 gēna polimorfisms ir vadošais dažādu populāciju nesindromālo šķeltņu attīstībā (Jezewski et al., 2003; Kim et al., 2013; Gurramkonda et al., 2015) 


\subsection{Ryk gēns}

Wnt signālcel̦am ir noteicoša loma skeleta ass attīstībā, šūnu augšanas, proliferācijas un diferenciācijas procesos embrionālās attīstības laikā, kā arī neironu attīstībā. Tam ir būtiska nozīme audu homeostāzē, reǵenerācijā un cilmes šūnu, cilmšūnu funkciju ietekmēšanā. Wnt ekspresija audos tika novērota sejas un aukslēju attīstības laikā. Tieši bezspārnu tipa MMTV integrācijas saita 11 olbaltumvielu (Wnt11) tipu ekspresēja aukslēju aizmetņu mediālās malas epitēlija šūnas. Lī ar kolēǵiem novēroja, ka Wnt11 gēna proteīns ierosināja mediālās malas epitēlija šūna apoptozi, kas ir svarīgs molekulārais mehānisms aukslēju saplūšanas laikā (Lee et al., 2008). Traucējumi WNT signālcel̦a funkcijās var radīt iedzimtas sejas un mutes dobuma malformācijas, deǵeneratīvas saslimšanas vai malignitātes cilvēkam. Mūsdienās, pateicoties genētiskajiem skrīningiem, bezspārnu tipa MMTV integrācijas saita 3a olbaltumviela (WNT3A), Wnt onkogēna analogs 5 (WNT5) un WNT11 tiek uzskatīti kā iespējamie kandidātgēni nesindromālās sejas šķeltnes attīstībā (Chiquet et al., 2008; Menezes et al., 2010; Mostowska et al., 2012). RYK pieder pie tirozīnkināzes receptoru saimes un ir šūnu virsmas proteīni, kas darbojas kā receptori Wnt gan bezmugurkaulniekiem, gan mugurkaulniekiem (Logan and Nusse, 2004; Berndt et al., 2011; Macheda et al., 2012). Tikai 2000. gadā, analizējot knockout peļu audus, tika aprakstītas Ryk gēna funkcijas zìdītājiem. Šis proteīns pirmo reizi tika klonēts pelēs 1992. gadā, un tas sastāv no ekstracelulārā Wnt inhibējošā faktora domēna un intracelulārās atipiskās kināzes domēna. $R Y K$ regulē šūnu polaritāti, šūnu diferenciāciju, šūnu migrāciju, šūnu selekciju, skeleta attīstību, nervu šūnu izaugumu augšanu (Halford and Stacker, 2001; Halford et al., 2013). Tika pierādīts, ka Ryk gēna zudums pelēm rada perinatālu mirstību iespējamas kardiovaskulāras patoloǵijas dēl, kā arī kraniofaciālas un skeleta anomālijas, piemēram, caurejošas aukslēju šķeltnes, īpatnēju kraniofaciālo fenotipu, saīsinātas ekstremitātes (Halford et al., 2000; Halford and Stacker, 2001). Analizējot embrija un pieaugušas peles audus, Ryk proteīna lokalizācija tika novērota krūšu dziedzeru, nieru, plaušu, zarnu epitēlijšūnās un mezodermālas izcelsmes audos (Keeble et al., 2006; Keeble and Cooper, 2006). Dažu pētījumu dati liecina par iespējamu $R Y K$ gēna asociāciju ar nesindromālām sejas šķeltnēm (Watanabe et al., 2006; Carter et al., 2010). Jāatzīmē, ka joprojām nav zināmi š̄ proteīna molekulārie darbības mehānismi audos sejas šķeltņu attīstībā un vēl jo vairāk, šķeltņu skartos audos to korekcijas laikā. 


\subsection{Angioğenēzi ietekmējošie faktori}

Angioǵenēze pirmo reizi tika aprakstīta 1935. gadā placentas audos. Mūsdienās jaunu asinsvadu veidošanās no iepriekš esošajiem aktīvi tiek pêtīta embrioǵenēzē un postnatālajā periodā, kā arī dažādu patoloğisku stāvokḷu attīstībā. Angioǵenēzi ietekmējošo gēnu izpēte lūpu un aukslēju šķeltņu attīstībā ir nenoliedzami aktuāla (François-Fiquet et al., 2014). Jaunu asinsvadu veidošanos kontrolē angiogēni augšanas faktori un to inhibitori. Vadošo lomu šajā procesā ieņem vaskulārais endotēlija augšanas faktors (VEGF), kuru sintezēe keratinocīti, makrofāgi, audzēju šūnas u.c., kamēr endotēlija šūnas, keratinocīti, melanocīti, audzēju, mata ārējās epitēlija maksts, mutes dobuma gḷotādas šūnas sintezē $V E G F$ receptorus (Li et al., 2012; Pianka et al., 2015). VEGF regulē asinsvadu veidošanos embrioǵenēzes, mutes dobuma gḷotādas brūču dz̄īšanas un reǵenerācijas laikā, kā arī uztur asinsvadu homeostāzi un piedalās endohondrālās osifikācijas procesā, stimulējot ne tikai šūnu proliferāciju un migrāciju, bet arī inhibējot šūnu apoptozi (Andisheh-Tadbir et al., 2014). $V E G F$ gēna polimorfismi ir asociēti bērniem ar retinopātijas attīstību, autoimūnām slimībām, hronisku periodontītu, kā arī mutes dobuma vēzi (Ku et al., 2005; Tian et al., 2013; Ali et al., 2015; Che et al., 2015). Haigs ar kolēgiem atklāja, ka traucējumi VEGF gēnā rada letālu iznākumu pel̦u embrijiem dažādu orgānu sistēmu skarto attīstības anomāliju dēl (Haigh et al., 2000). Pēdējo gadu laikā publicētie pētījumi liek diskutēt par iespējamu VEGF gēna nozīmi aukslēju aizmetņu saplūšanas laikā. Pelēm tika konstatētas minētā faktora novietojuma izmaiņas aukslēju gḷotādas brūču dzī̌sanas laikā un atklājās, ka samazināts VEGF līmenis siekalās ietekmē brūces slēgšanos, kā arī izmaina asinsvadu veidošanos sejas šķeltņu patoǵenēzes laikā (Stalmans, 2005; Patyna et al., 2009). Pasaulē nav pētījumu, kas pārliecinoši pierādītu š̄ faktora nozīmi sejas šķeltņu attīstībā. Nav arī pētīta šī faktora ekspresija aukslēju aizmetņu saplūšanas laikā (Keswani et al., 2013).

CD34 ir 110-kDa transmembranozs virsmas glikoproteīns, kuru sintezē hematopoētiskās cilmes šūnas, endotēlija šūnas, embrionālie fibroblasti, intersticiālās Kajal (Cajal) šūnas, dendrītiskās un tuklās šūnas. Šo transmembranozo virsmas glikoproteīnu var izmantot, lai identificētu jaunu asinsvadu veidošanos no esošiem asinsvadiem. Tas ir svarīgs angioǵenēzi regulējošais marķieris un raksturo normālas vai patoloǵiskas mutes dobuma glotādas mikroasisnvadu blīvumu. Asinsvadu veidošanās ir būtiski nozīmīga audu reǵenerācijā (Desai et al., 2010; Stănescu et al., 2012).

Literatūrā ir aprakstīta virkne augšanas faktoru, gēnu, kas ietekmē angioǵenēzi un korelē ar lūpu un aukslēju šķeltni. Jaunu asinsvadu veidošanos ietekmē ne tikai $V E G F, C D 34$, 
bet ar̄̄ $T G F \beta$, fibroblastu augšanas faktors $(F G F)$, fibroblastu augšanas faktora receptors (FGFR) u.c. (1.5. attēls) (François-Fiquet et al., 2014).

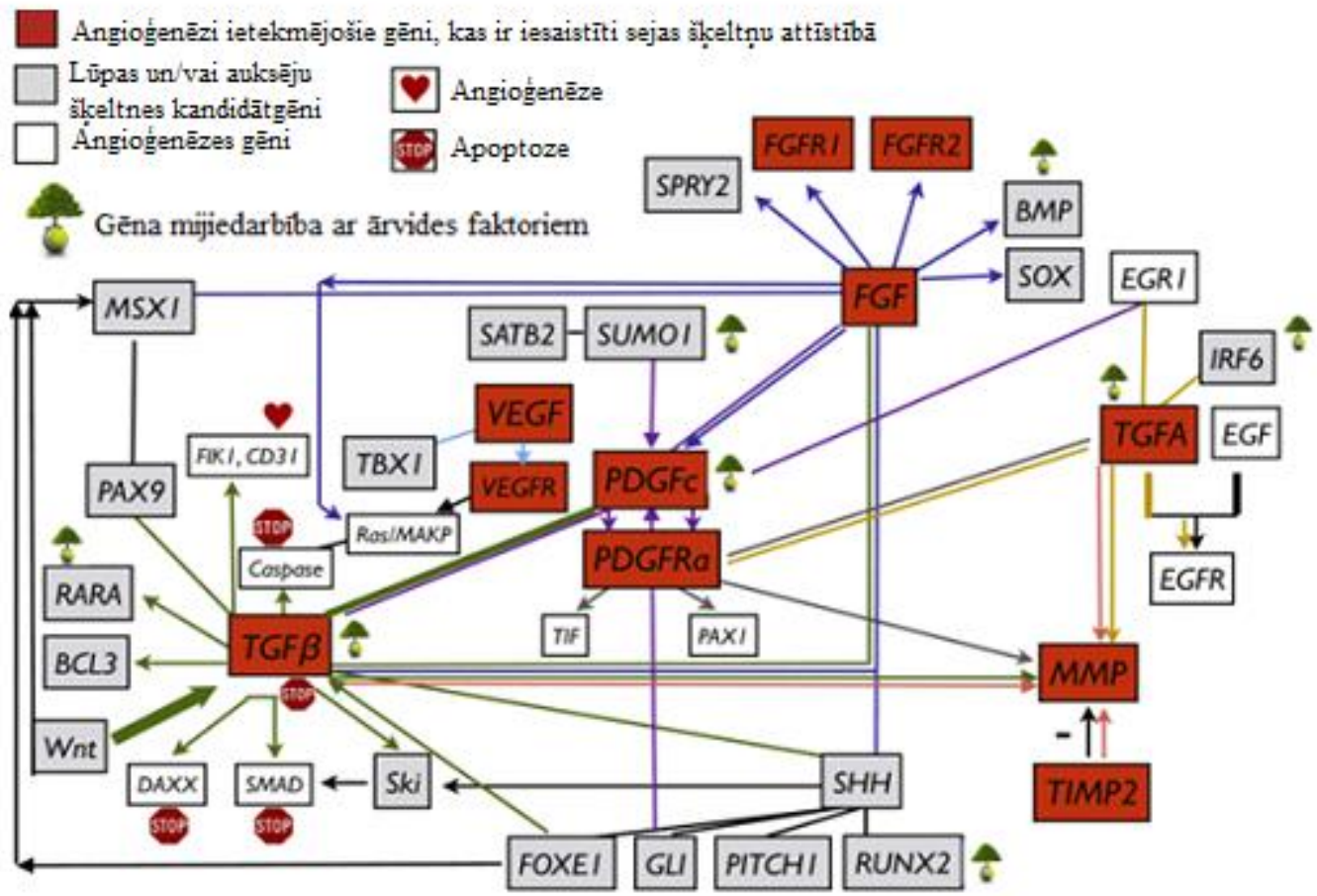

\section{5. attēls. Šķeltṇu etiopatoǵenēzē iesaistītie angioğenēzi ietekmējošie gēni (adaptēts no François-Fiquet et al., 2014)}

Saīsinājumi: $F G F R 1$ - fibroblastu augšanas faktora receptors-1; FGFR2 - fibroblastu augšanas faktora receptors-2; $F G F$ - fibroblastu augšanas faktors; $B M P$ - kaula morfoǵenētiskais proteīns; SPRY2 - sprouty RTK signālcel̦a antagonists-2; SOX - SOX proteīns; EGRI - cinka pirkstiņu proteīns 225; IRF6 - interferona regulējošais faktors-6; TGFA - transformējošais augšanas faktors alfa; $E G F$ - epidermālais augšanas faktors; $E G F R$ - epidermālā augšanas faktora receptors; $M M P$ - matrices metaloproteināzes; TIMP2 - matrices metaloproteināzes-2 audu inhibitors; MSX1 - muskuļu segmentācijas homeobokss-1; SATB2 - SATB homeobokss-2; SUMO1 - mazais ubikvitīnam līdzīgais modifikators-1; VEGF - vaskulārā endotēlija augšanas faktors; VEGFR - vaskulārā endotēlija augšanas faktora receptors; $P D G F c$ - trombocītu atvasinātais augšanas faktors c; $P D G F R a$ - trombocītu atvasinātā augšanas faktora receptors alfa; $P A X 1$ - pāra boksa transkripcijas faktors-1; TIF - tulkošanas uzsākšanas faktors; TBXI - T-boksa-1 gēns; Ras/MAKP - Ras proteīns/mitogēnaktivētā proteīnkināze; $C D 31$ - trombocītu/endotēlijšūnu adhēzijas molekula; $P A X 9$ - pāra boksa transkripcijas faktors-9; $R A R A$ - retīnskābes receptors alfa; $B C L 3$ - B šūnu CLL/limfoma-3; Wnt - proteīna Wnt-2 gēns; caspase - kaspāze; $T G F \beta$ - transformējošais augšanas faktors beta; $D A X X$ - nāves-domēna asociētais proteīns; SMAD - SMAD saimes loceklis; Ski - ski protoonkogēns; FOXE1 - forkhead bokss E1; GLI - GLI saimes cinka pirkstinu transkripcijas faktors-1; SHH - sonic hedgehog; PITCH1 - ret protoonkogēns; RUNX2 - runt radniecīgais transkripcijas faktors-2.

Transformējošais augšanas faktors $(T G F)$ un tā receptori nosaka normālu sejas un mutes dobuma struktūru attīstību. Multifunkcionāls $T G F \beta$ citokīns ir būtiski nozīmīgs nervu kores šūnu proliferāciju regulējošais faktors aukslēju attīstības laikā (Iwata et al., 2012). Interesanti, ka šis faktors regulē embrionālo cilmes šūnu diferenciāciju, kā arī epitēlija šūnu transformāciju mezenhīmas šūnās, un otrādi, kas ir svarīgi molekulārie mehānismi lūpu un aukslēju saplūšanas laikā (François-Fiquet et al., 2014). Ir zināmas trīs TGF $\beta$ izoformas: transformējošais augšanas faktors beta-1 (TGF $\beta 1)$, transformējošais augšanas faktors beta-2 (TGFß2), TGFß3. Šīm izoformām ir fundamentālas spējas regulēt dažādus biologískos 
procesus, piemēram, šūnu proliferāciju, šūnu diferenciāciju, šūnu migrāciju, šūnu izdzīvošanu un adhēziju, inducēt apoptozi, ietekmēt angioǵenēzi, ekstracelulārās matrices sintēzi, asinsvadu homeostāzi, kā arī audu dzī̌sanu un reǵenerāciju. Analizējot visu trīs izoformu un to receptoru ekspresiju aukslēju attīstības laikā, tika pierādīta to nozīme aukslēju mediālās malas epitēlija un neiromezenhīmas saplūšanas laikā (Iwata et al., 2012; Yumoto et al., 2013; Nakajima et al., 2014; Lane et al., 2015; Poniatowski et al., 2015). Eksperimentā ar pel̦u modeliem tika pierādīta arī TGFß3 loma šūnu proliferācijas un angioǵenēzes veicināšanā lūpas attīstības laikā. Tika atklāta ši proteīna funkcija inducēt endotēlija šūnu diferenciāciju un mezenhīmas šūnu proliferāciju (Muraoka et al., 2005). Pelēm Tgfß3 gēna trūkums izraisa defektīvu aukslēju aizmetņu saplūšanu (Mankarious and Goudy, 2010). Loejs ar kolēgiem secināja, ka mutācijas gēnos, kuri kodē $T G F \beta R 1$ un $T G F \beta R 2$ receptorus, izraisa cilvēkam multiplas iedzimtas malformācijas, piemēram, mentālu retardāciju, aneirismas, kraniosinostozes un arī aukslēju škseltnes (Loeys et al., 2005).

Izpētot visu TGF $\beta$ izoformu ekspresiju embrija attīstības laikā, tika secināts, ka tieši $T G F \beta 3$ ir vadošais faktors lūpu un aukslēju aizmetņu saplūšanas laikā. Interesanti, ka, ārstējot TGFß3-knockout peles ar eksogēni pievadītu TGFß, notika sekundāro aukslēju aizmetņu saplūšana, un pavisam nesen tika atklāts, ka $T G F \beta 3$ veicina epitēlija transformāciju mezenhīmā, aktivējot š̄ procesa divus nozīmīgākos transkripcijas faktorus: Snail un SIP1 (Jalali et al., 2012). Tiesa arī TGFß1 un TGFß2 aukslēju attīstības laikā regulē epitēlija tranformāciju mezenhīmā, mezenhīmas šūnu proliferāciju un ektracelulārās matrices sintēzi, bet šo faktoru ietekme aizmetnuu saplūšanas laikā ir neliela. Interesanti, ka TGFß mediētā IRF6 faktora ekspresijas traucējumu rezultātā nenotiek mediālās malas epitēlija šūnu apoptoze (Meng et al., 2009).

\subsection{Apoptoze}

Apoptoze ir iepriekš ǵenētiski programmēta vai kaitīgu faktoru izraisīta šūnas bojāeja, kas norit ne tikai embrionālās attīstība laikā, bet arī pieauguša cilvēka organismā, nodrošinot audu homeostāzi. Embrionālās attīstības laikā apoptozi var novērot morfologisko formu veidošanās, audu un orgānu diferenciācijas un filoǵenēzes laikā. 1972. gadā Kers un viņa līdzautori aprakstīja apoptozi, veicot aknu audu eksperimentālos pētījumus, kad tika pierādītas apoptozei raksturīgas molekulārās, bioķīmiskās un morfologiskās pārmaiņas šūnā (Ouyang et al., 2012). 2002. gadā apoptozes pētniecības jomā tika piešķirta Nobela prēmija S. Breneram, R. Horvicam un Dž. Salstonam. Mūsdienās apoptoze tiek pētīta saistībā ar dažādu malformāciju attīstîbu, bet īpaši sejas šķeltņu attīstību. 
Izmantojot gaismas mikroskopiju un caurstarojošo elektronmikroskopiju, tika novērotas šādas morfologiskās pārmaiņas šūnā apoptozes laikā: šūnas formas un izmēra izmaiņas, šūnas citoplazmas un kodola kondensācija, šūnas citoskeleta elementu sablīvēšanās, kodola piknoze, kodoliṇa izzušana, kurai seko kariorekse jeb šūnas kodola un hromatīna fragmentācija. Turklāt piknoze ir visraksturīgākā apoptozes morfoloǵiskā iezīme, kas rodas, kondensējoties kodola hromatīnam, savukārt apoptotisko ķermenīšu veidošanās ir vēlīna programmētās šūnu nāves pazīme. Apoptozi aktivē gan signāli no ārpuses caur Fas receptoriem, gan no iekšpuses caur mitohondriālo citohromu un endoplazmatiskā tīkla signālceļu (Arya and White, 2015). Tā ir raksturīga praktiski visām normālām šūnām, kas nepārtraukti atjaunojas. Apoptozes molekulārā mehānisma pamatā ir kaspāžu aktivizēšana no prokaspāzēm, kas atrodas šūnas citoplazmā. Pēc prokaspāžu aktivizēšanas šūnas destruktīvais process kḷūst neatgriezenisks (Elmore, 2007; Tower, 2015; Teng et al., 2015).

Apoptoze pieauguša cilvēka un embrija šūnās ir normāla fizioloǵiskos apstākḷlos noritoša parādība, kaut gan mūsdienās aktuāla ir šūnu bojāejas pētīšana dažādu slimību gadījumos. Izmainīta šūnu apoptoze var būt par iemeslu neirodeǵeneratīvu, išēmisku bojājumu, autoimūnu un hronisku iekaisuma slimību, audzēju, kā arī, iespējams, iedzimtu embrionāli determinētu malformāciju, piemēram, sejas šķeltņu attīstībā (Vukojevic et al., 2012; Yang et al., 2015; Mohammad et al., 2015). Apoptozes nozīmes izprašanai tieši sejas šķeltņu attīstībā tika pētīts šis process lūpu un aukslēju aizmetņu saplūšanas laikā, izmantojot dzīvnieku model̦us. 2006. gadā tika izteikta hipotēze, ka pilnīgs vai daļējs apoptozes trūkums augšlūpas un aukslēju aizmetņu saplūšanas laikā var būt par iemeslu šķeltņu izveidē (Burdi, 2006). Lots ar līdzautoriem izpētīja apoptozes nozīmīgumu vaigu, apakšžokḷa un nazolakrimālā izvada attīstībā (Lotz et al., 2006). Bosnijas un Hercegovinas pētnieki, pielietojot imūnhistoķīmijas un TUNEL metodi, pierādīja apoptozes klātbūtni cilvēka aukslēju attīstības laikā (Vukojevic et al., 2012).

Apoptotisko procesu regulē daudzi ǵenētiskie un un molekulārie mehānismi, kas vēl joprojām nav izzināti. Ir izpētīts, ka apoptozi regulē audzēja nekrozes faktors alfa (TNF- $\alpha$ ), interleikīns-1, TGFß, Fas ligands, CD40 ligands, onkogēni, piemēram, c-myc, kā arī audzēju gēnu supresori, piemēram, p53 (Elmore, 2007).

Apoptozi var izvērtēt, izmantojot dažādas bioķīmijas, morfoloǵijas un molekulārās biologijas metodes, kas palīdz atpazīt un raksturot šo procesu audos. Jau gaismas mikroskopijas preparātos, kas krāsoti ar hematoksilīnu un eozīnu, var novērot raksturīgo apoptozei morfoloǵisko iezīmju kopumu. Agrīnu apoptozes pazīmju noteikšanai pētījumos izmanto specifiskākas metodes. Tā, piemēram, viena no agrīnākajām apoptozes pazīmēm ir fosfatidilserīna pārvietošanās no plazmatiskās membrānas iekšèjā lipīdu slāņa uz tā ārpusi. 
Aktuāli šīs pazīmes noteikšanai ir izmantot apoptozes Annexin V FITC kitu (Rieger et al., 2011; Hankins et al., 2015). Mikroskopijas līmen̄̄ apoptozes noteikšanai tiek izmantots arī $\operatorname{CasPASE}^{T M}$ kits kaspāzes-3 un kaspāzes-7 noteikšanai kvantitatīvi, mitohondriju potenciāla noteikšanas kits izmantojams dzīvu šūnu pētīšanai, kā arī augstas sensitivitātes un specificitātes biežāk izmantotā TUNEL (TdT-mediated Dutp Nick End Labeling) metode, kas ietver DNS fragmentēšanas noteikšanu. Tiek pielietota arī plūsmas citometrija apoptozes noteikšanai. No kaspāzēm tieši kaspāze-3 ir labs marķieris šūnu apoptozes noteikšanā. Karstumšoka proteīns 70 (Hsp70) ekspresējas šūnas diferenciācijas un morfoǵenēzes laikā un inhibē apoptozi, tādējādi kontrolē šūnas dzīves ciklu. Vukojevics ar līdzautoriem pierādīja Hsp70 ekspresiju mediālās malas epitēlija šūnās (Vukojevic et al., 2012). Makroskopijas līmen̄̄ apoptozi var noteikt, pielietojot radionukleotīdu vizualizācijas metodi un optiskās vizualizācijas metodes: marķējot ar fluoroforu, bioluminiscences izmantošanu, magnētisko rezonansi un multimodālās vizualizācijas metodes (Zeng et al., 2015).

Arī pēdējo gadu publikācijās ir akcentēta šūnu proliferācijas nozīme lūpu un aukslēju aizmetņu attīstības laikā. Līdzsvarotai šūnu proliferācijai un šūnu nāvei ir nozīme normālu sejas un mutes dobuma struktūru attīstībā (Kalibović et al., 2010).

\subsection{Nestīns un $K i-67$}

Mutes dobuma gḷotādas epitēlijs ir pakḷauts pastāvīgai iekšējo un ārējo faktoru iedarbībai, kas izraisa šūnu bojāeju, līdz ar to epitēlijam piemīt fizioloǵiskā reǵenerācija. Lūpas gḷotādas daļu veido daudzkārtains, plakans, nepārragots epitēlijs un lamina propria, savukārt cietās aukslējas sedz parakeratinizēts daudzkārtu plakanais epitēlijs. Mīkstās aukslējas ir cieto aukslēju turpinājums, un tās sedz atkal nepārragots daudzkārtu plakanais epitēlijs. Jāsaka, ka mutes dobuma gl̦otādas uzbūve ir līdzīga ādas uzbūvei un satur mitotiski aktīvas šūnas. Tā ir bagātīgi apasiņota un labi inervēta. To pierāda imūnhistoķ̄imijas pētījumi par PGP 9.5 un VEGF lokalizāciju dažādos mutes dobuma rajonos (Watanabe et al., 2013; Anura et al., 2014). Nakamura 2007. gadā izolēja un aprakstīja cilmes šūnas mutes dobuma glotādas epitēlijā, izmantojot p75 marķieri. Dongs ar līdzautoriem izolēja nestīna - pozitīvas cilmšūnas žurkas - lamina propria (Dong et al., 2010). Cilmšūnas tiek raksturotas ar spēju uz savas virsmas ekspresēt specifiskus marķierus (Loeffler and Roeder, 2002).

Nestīns ir selektīvs VI tipa starpdiedziņu filaments, kas pēc struktūras ir līdzīgs vimentīnam, desmīnam un neirofilamentam. Šo proteīnu ekspresē dažādos cilvēka embrija, aug̣̦a un pieauguša cilvēka audos. Pēc reaktivācijas nestīnu ekspresējošām šūnām ir nozīme šūnu proliferācijas, diferenciācijas un migrācijas uzturēšanā, kā arī apoptozes regulēšanā. Bez 
tam nestīnam ir svarīga funkcija audu reǵenerācijā. Pēc audu ievainojuma palielinās lokāla nestīna ekspresija, kuru ietekmē augšanas faktori, transkripcijas faktori un starpdiedziņu remodelācija (Wiese et al., 2004; Chen et al., 2010; Liu et al., 2015). Nestīna ekspresija tika aprakstīta žurkas un cilvēka mutes dobuma gḷotādas lamina propria, deguna gḷotādā, sviedru dziedzeros, mēles sēņveida kārpiņās, mata folikulās, ādā, jaunizveidotajos asinsvados un audzēju gadījumos, piemēram, ādas, siekalu dziedzeru audzējos (Amoh et al., 2009; Amoh et al., 2012; Nagel et al., 2013; Yanai et al., 2013; Liu et al., 2014; Mii et al., 2014; Sabet et al., 2014).

Šūnu proliferācija ir svarīgs fizioloǵisks process aukslēju, arī augšžokļa attīstībai un augšanai. Ki-67 ir labs marķieris šūnu proliferācijas noteikšanai audos. Ki-67 ir kodola proteīns, kas ekspresējas gandrīz visu šūnas cikla făžu laikā, izṇemot miera jeb $\mathrm{G}_{0}$ fāzi (Kim and Sederstrom, 2015). Literatūrā ir atrodami tikai daži pētījumi par Ki-67 proteīna lomu cilvēka sejas un mutes dobuma struktūru attīstībā (Kalibović Govorko et al., 2010; Novakovic et al., 2011; Vukojevic et al., 2012).

Audu homeostāzes pamatā ir šūnu proliferācijas, diferenciācijas un apoptozes mijiedarbība. Minētos procesus embrija audos kontrolē gēni un koordinē dažādas signālmolekulas. Kādas noteiktas signālmolekulas trūkums vai pārlieku lielā esamība un mutācijas kādā noteiktā gēnā var izsaukt traucējumus iepriekš minētos audu homeostāzes nodrošinātāja fizioloǵiskos procesos. Rezultātā rodas disbalanss, kas var radīt sejas un mutes dobuma attīstības malformācijas, piemēram, lūpas un aukslēju šķeltnes.

\section{11. Proteīngēnviela 9.5 (PGP 9.5)}

Proteīngēnviela 9.5 (PGP 9.5) pirmo reizi tika izolēta pirms 34 gadiem no smadzeņu audiem. $P G P 9.5$ sintezē perifērās un centrālās nervu sistēmas šūnas, visu tipu nervu šķiedras, kā arī difūzās neiroendokrīnās sistēmas (DNES) šūnas (Day and Thompson, 2010). Minēto proteīnu ekspresē arī nieru tubulǐšu šūnas, spermatagoniji, Leidiga šūnas, corpus luteum, mutes dobuma gḷtādas un ādas šūnas (Genç et al., 2015). PGP 9.5 ekspresija tika identificēta peḷu embriju ektodermas šūnās agrīnā attīstības stadijā, tas liecina par šī faktora nozīmi ektodermas šūnu diferenciācijā (Sekiguchi et al., 2003). Lūpas, mutes dobuma gl̦otādas epitēlija un epidermas uzbūve ir sarežğìita un satur dažādas specializētas struktūras (matu folikulus, sviedru un tauku dziedzerus) un dažādas šūnas (epiteliocītus, keratinocītus, melanocītus, Langerhasna šūnas, neiroendokrīnās un Merkela šūnas), kā arī dažādus receptoru veidus (sāpju, taustes u.c.). Turklāt lielakā daļa no šīm morfoloǵiskām struktūrām ir labi inervētas (Boulais and Misery, 2008). 2000. gadā japāṇu pētnieku kolektīvs pētīja žurku cieto 
aukslēju inervāciju. PGP 9.5 intraepiteliālās nervu šķiedras tika vizualizētas visos cieto aukslēju rajonos. $P G P 9.5$ saturošas nervu šķiedras tika atrastas arī subepitēlijā. Tādēķ tika secināts, ka cieto aukslēju gļotāda ir bagātīgi inervēta (Mitsui et al., 2000). Ir pētīta cilvēka vaigu gḷotādas inervācija, un $P G P 9.5$ pozitīvas nervu šķiedras, nervu šķiedru kūlīši tika vizualizēti ap asinsvadiem, dziedzeriem un arī muskuļiem. Zviedru zinātnieku grupa identificēja arī PGP 9.5 pozitīvas Merkeḷa šūnas (Hilliges et al., 1994).

Interesanti, ka imūnhistoķīmiski tika pierādīta $P G P 9.5$ ekspresija ādas fibroblastos brūces dzīšanas laikā (Day and Thompson, 2010). 2014. gada pētījumā tika atklāta palielienāta PGP 9.5 ekspresija hipertrofiku rētu epidermā (Kwak et al., 2014).

\subsection{Kaula morfoǵenētiskie proteīni $(B M P)$}

$B M P$ ir multifunkcionāli augšanas faktori un pieder pie $T G F \beta$ klases. Pirmo reizi $B M P$ tika aprakstīti 1960. gadā, veidojoties ektopiskajiem kaulaudiem (Nie et al., 2006). Literatūrā ir aprakstīti vairāk kā 20 dažādi $B M P$ veidi. $B M P$ ir nozīmīgi gastrulācijas, organoǵenēzes, embrioǵenēzes laikā, kā arī skeleta attīstībā, neiroǵenēzē un hematopoēzē, tie regulē endohondrālo un tiešo kaulaudu veidošanos. Embrionālās attīstības laikā $B M P$ signālcel̦am ir svarīga nozīme šūnu determinācijā, kondensācijā, augšanā, diferenciācijā, migrācijā un apoptozē (Bragdon et al., 2011). Līdzīgi kā TGFß, arī BMP nodrošina šūnu augšanu, migrāciju un diferenciāciju sekundāro aukslēju attīstības laikā (Chen et al., 2004). Pētījumos tika pierādīta $B m p 2, B m p 4, B m p 7$ un Bmprla receptora ekspresija peḷu lūpu un aukslēju aizmetņu saplūšanas laikā (Liu et al., 2005; Levi et al., 2006; Baek et al., 2011; Kouskoura et al., 2013). Eksperimentā ar knockout peļu modeļiem tika apstiprināta Bmp2 un Bmp4 iesaiste kaula remodelācijā un homeostāzē. Turklāt kopā ar Bmp7 tiem ir izšķiroša loma kaula dzīšanā, inducējot mezenhimālo šūnu diferenciāciju par osteoblastiem un hondroblastiem (Bonilla-Claudio et al., 2012; Wang et al., 2014).

Bmp2, Bmp4 ekspresē nervu kores šūnas, agrīni sejas aizmetņu epitēlijs un mezehnīma, kā arī zoba attīstības laikā - odontoblasti, hipertrofēti hondrocīti, aukslēju aizmetņu un mēles aizmetņa šūnas (Nie et al., 2006). Tieši Bmp4 ir spēcīgs apoptozes induktors. ASV zinātnieku kolektīvs demonstrēja TUNEL - pozitīvas šūnas aukslēju aizmetņu peridermas šūnās. Iespējams, Bmp4 regulē lūpu un aukslēju aizmetņu peridermas šūnu apoptozi (Sun et al., 2000; Gong and Guo, 2003). Kaut arī ir nopublicēti daudzi pētījumi par $B M P$ proteīnu lomu skeleta malformāciju attīstībā, joprojām pastāv nozīmīgas pretrunas morfoloǵiskajā un imūnhistoķīmiskajā izpētē. 


\subsection{Osteoprotegerīns $(O P G)$}

Osteoklasti ir lielas (līdz 100 mikrometri) daudzkodolu monocītu-makrofāgu līnijas šūnas, kas atbildīgas par kaula rezorbciju. Šīs šūnas sintezē $O P G$ jeb osteoklastus inhibējošo faktoru, kas ir galvenais osteoklastu attīstības modulators un pieder tumora nekrozes faktora $(T N F)$ receptoru klasei. Tas ir sekretors glikoproteīns, kuru aprakstīja divas neatkarīgas pētnieku grupas 1997. gadā (Baud'huin et al., 2013). OPG savienojas ar nukleāro kappa B faktora ligandu (RANKL), tādējādi nel̦auj nukleārā faktora kappa $\mathrm{B}$ ligandam $(R A N K L)$ savienoties ar receptoru. RANKL sintezē un producē osteoblasti, tas saistās ar RANK un tiek ierosināta osteoklastu diferenciāciju. Kopumā tiek inducēta osteoklastu attīstība un regulēta šo šūnu aktivācija. In vivo pētījumi atklāja, ka $O P G$ trūkums palielina kaula remodelācijas spējas un veicina osteoporozes attīstību, kamēr palielinātas $O P G$ ekspresijas rezultātā pelēm attīstās osteopetroze (Kang et al., 2014).

$O P G / R A N K / R A N K L$ triāde regulē osteoklastu funkcijas, tajā skaitā arī kaulu rezorbciju. Šai triādei ir būtiska loma alveolārā kaula remodelācijā (Koide et al., 2013).

Osteoklastu apoptozes regulācija ir molekulāri sarežgīits process, kas tika intensīvi pētīts, izmantojot grauzēju model̦us, bet par osteoklastu apoptozes molekulāro mehānismu cilvēkiem ir zināms maz. Zauli ar kolēgiem pierādīja to, ka osteoklastu priekšteči ekspresē tumora nekrozes faktora saistītā apoptozi inducējošā liganda (TRAIL) receptorus (Zauli et al., 2004). TRAIL, saistoties ar TRAIL receptoriem, inducē osteoklastu apoptozi (Brunetti et al., 2007). Tātad $O P G$ regulē ne tikai $R A N K / R A N K L$, bet arī TRAIL/TRAIL receptora sistēmu (Chamoux et al., 2008).

$O P G$ sintezē dažādas šūnas, piemēram, osteoblasti, osteocīti, endotēlija šūnas, gludie miocīti, fibroblasti, kā arī asinsrades un imūnās sistēmas šūnas (Udagawa et al., 2000; Aoki et al., 2010).

Pētījumu rezultāti norāda, ka šim glikoproteīnam ir nozīme kaula remodelācijā, tomēr tā klātbūtne un loma alveolārā kaula šķeltnes audos nav plaši pētīta.

\subsection{Alveolārā kaula ekstracelulārās matrices $(E C M)$ nekolagēnie proteīni}

Alveolārā kaula ECM sastāv no organiskās un minerālās komponentes. Kolagēns mineralizētos kaulaudos veido aptuveni $80-90 \%$ organisko komponenti. I tipa kolagēns veido vairāk nekā $95 \%$, bet $5 \%$ organiskās matrices sastāvā ir V tipa kolagēns. Otro lielāko ECM komponentu grupu veido alveolārā kaula nekolagēnie proteīni, kuriem ir svarīga loma 
kaulaudu homeostāzes un remodelācijas regulācijā. Pie alveolārā kaula nekolagēniem proteīniem pieder osteopontīns (OPN) un osteokalcīns (OC) (Sodek and McKee, 2000).

$O P N$ ir fosforilēts mineralizētas kaula ECM sialoproteīns, kuru ekspresē dažādu audu šūnās: kaulaudos, cementā, dentīnā, skrimšḷaudos, smadzenēs, nierēs, asinsvados un epitēlijaudos (Sodek et al., 2000). Alveolārā kaulā tieši diferenciēti osteoblasti, osteocīti un arī osteoklasti sintezē šo proteīnu. $O P N$ regulē osteoklastu attīstību, migrāciju un piesaisti kaula matricei kaula rezorbcijas laikā (Sodek et al., 2006). Kaulu veidojošās šūnas sintezē $O P N$ fizioloǵiski kaulaudu remodelācijas laikā. Literatūrā ir dati par $O P N$ iesaistīšanos mutes dobuma iekaisuma regulēšanā un brūču dzī̌sanas procesā (Lao et al., 2006; Miragliotta et al., 2014). $O P N$ ekspresija tika novērota arī audos embrionālās attīstības laikā, attīstoties sekundārajām aukslējām (Jakobsen et al., 2009).

$O C$ ir nekolagēns kaula matrices gamma-karboksiglutamāta proteīns, kas ir cieši saistīts ar kaula ECM mineralizāciju. $O C$ sintezē osteoblasti, osteocīti, cementoblasti, odontoblasti un hondrocīti. Ja osteoblasti ekspresē $O C$, tad tā ir vēlīna šo šūnu diferenciācijas pazīme (Ferron and Lacombe, 2014). OC ekspresiju kaulaudu šūnās regulē vairāki faktori kaula morfoǵenēzes proteīns (BMP 2) (Jang et al., 2012), transformējošais augšanas faktors beta $(T G F \beta)$, fibroblastu augšanas faktors $(F G F)$ u.c. (Shiba et al., 2001).

$O C$ ir nozīme kaula rezorbcijas un mineralizācijas procesos ne tikai postnatāli, bet arī embrionālās attīstības laikā. Tas stimulē angiogenēzi, līdz ar to $O C$ piemīt kaula remodelācijas funkcija (Cantatore et al., 2005).

Neskatoties uz daudzajiem pētījumiem par $O C$, vēl joprojām nav precīzi definēti tā molekulārie darbības mehāniski un bioloǵiskā nozīme šķeltnes skartajā alveolārā kaula remodelācijas laikā. 


\section{MATERIĀLS UN METODES}

\subsection{Morfolog̣iski pētāmais materiāls un pacientu iedalījums grupās}

Morfologiskajiem pētījumiem materiāls tika vākts RSU Stomatologijas institūta Lūpu, aukslēju un sejas škseltņu centrā laika posmā no 2003. līdz 2015. gadam. Lūpas, alveolārā izauguma un aukslēju šķeltņu skartie audi tika savākti primārās lūpas, mīksto un cieto aukslēju plastikas laikā, kā arī veicot alveolārā izauguma osteoplastiku ar kaula autotransplantāciju. Lūpas plastika vienpusējām caurejošām lūpas, alveolārā izauguma un aukslēju šķeltnēm tika veikta pēc Millarda metodes (Millard, 1964). Lūpas plastika abpusējām caurejošām lūpas, alveolārā izauguma un aukslēju šķeltnēm tika veikta pēc Veau metodes modifikācijas (Lehman et al., 1990). Mīksto aukslēju plastikas metode - izmantojot mugurējā vomer lēvera metodi, osteoplastikas laikā kaula autotransplanātcija veikta no tibia vai crista iliaca anterior superior rajona (Robin et al., 2006).

Rutīnās histologiskās un imūnhistoķīmiskās metodes veikšanai pētāmais materiāls tika apstrādāts RSU AAI Morfologijas laboratorijā.

Pētījumā ar caurejošām lūpas, alveolārā izauguma un aukslēju šķeltnēm tika iekḷauti 46 pacienti: 22 bērniem bija abpusēja caurejoša lūpas, alveolārā izauguma un aukslēju šķeltne, 24 bērniem - vienpusēja caurejoša lūpas, alveolārā izauguma un aukslēju šķeltne. Kopējais morfologíiskā materiāla vienību skaits, kas tika iegūts no pacientiem abpusējas šķeltņes lūpas primārās plastikas laikā, bija 16, mīksto aukslēju plastikas laikāa - 10, cieto aukslēju plastikas laikā - 9, osteoplastikas laikā - 11. Morfologiskā materiāla vienību skaits no pacientiem ar vienpusēju šķeltni bija 24 audu paraugi, kas tika iegūti lūpas primārās plastikas laikā, un 12 audu paraugi, kas tika iegūti osteoplastikas laikā.

\section{Pacientu grupas, no kurām tika iegūts izmeklējamais materiāls:}

1. grupa - zīdaiņi un bērni ar abpusēju caurejošu lūpas, alveolārā izauguma un aukslēju šķeltni pēc lūpas plastikas;

2. grupa - bērni ar abpusēju caurejošu lūpas, alveolārā izauguma un aukslēju šķeltni pēc mīksto un cieto aukslēju plastikas;

3. grupa - zīdaiṇi un bērni ar abpusēju caurejošu lūpas, alveolārā izauguma un aukslēju šķeltni pēc osteoplastikas;

4. grupa - zīdaiņi ar vienpusēju caurejošu lūpas, alveolārā izauguma un aukslēju Šķeltni pēc lūpas plastikas;

5. grupa - bērni ar vienpusēju caurejošu lūpas, alveolārā izauguma un aukslēju šķeltni pēc osteoplastikas; 
6. grupa - kontroles grupa, no kuras tika iegūti mīkstie un cietie audi operācijās, kuras nav saistītas ar šķeltnēm.

\subsubsection{Pirmās un otrās grupas - zīdaiṇu un bērnu ar abpusēju caurejošu lūpas, alveolārā izauguma un aukslēju škseltni - raksturojums}

Pirmajā grupā tika iekḷauti 12 zīdaiṇi vecumā no trīs līdz septiņiem mēnešiem. Vienam bērnam lūpas plastika tika veikta astoņu gadu un piecu mēnešu vecumā. Kopumā 13 bērniem vecumā no 0,3 līdz 8,5 gadiem tika paņemts mîksto audu materiāls lūpas plastikas laikā. Otrajā grupā tika iekl̦auti 10 zīdaiņi un bērni vecumā no deviņiem mēnešiem līdz pieciem gadiem un diviem mēnešiem; šiem pacientiem tika paņemts audu materiāls mīksto aukslēju plastikas laikā. Cieto aukslēju plastika tika veikta astoņiem pacientiem vecumā no trīs gadiem un diviem mēnešiem līdz pieciem gadiem un diviem mēnešiem.

Pavisam pirmajā un otrajā grupā tika iekḷauti 22 pacienti. No tiem 17 bija zēni un 5 meitenes, septiniem no šiem bērniem tika veiktas atkārtotas operācijas, proti, lūpas un mīksto aukslēju plastika tika veikta četriem pacientiem, lūpas un cieto aukslēju plastika - vienam pacientam, mīksto un cieto aukslēju plastika - vienam pacientam. Vienam bērnam tika veiktas trīs secīgas operācijas: lūpas plastika, mīksto un cieto aukslēju plastika, kā arī visu operāciju laikā tika savākts mīksto audu materiāls no šķeltnes malām. Trīs bērniem audu materiāls tika savākts mīksto aukslēju plastikas laikā, un trīs bērniem - tikai cieto aukslēju plastikas laikā. Šiem bērniem nebija savākts audu materiāls no lūpas plastikas.

Kopējais pētāmā materiāla vienību skaits mīkstajiem audiem bija 35 (no 22 bērniem): 16 audu paraugi savākti lūpas plastikas laikā, 10 - mīksto aukslēju plastikas laikā un 9 - cieto aukslēju plastikas laikā. Informācija par pacientiem redzama 2.1. tabulā. 
Informācija par 1. un 2. grupas pacientiem

\begin{tabular}{|c|c|c|c|c|c|c|}
\hline \multirow[t]{3}{*}{ Nr. } & \multirow[t]{3}{*}{ Šifrs } & \multirow{3}{*}{$\begin{array}{l}\text { Pacienta } \\
\text { dzimums }\end{array}$} & \multirow[t]{3}{*}{ Klīniskā diagnoze } & 1. op. & \multirow{3}{*}{$\begin{array}{l}\text { Bērna vecums } \\
\text { materiāla } \\
\text { ņemšanas laikā } \\
\text { (gados, } \\
\text { mēnešos) }\end{array}$} & \multirow{3}{*}{$\begin{array}{c}\text { Operācijas veids, } \\
\text { kuras laikā ņemts } \\
\text { audu materiāls }\end{array}$} \\
\hline & & & & 2. op. & & \\
\hline & & & & 3. op. & & \\
\hline 1. & 180 & $\mathrm{Z}$ & $\begin{array}{l}\text { Abpusēja caurejoša } \\
\text { lūpas, alveolārā } \\
\text { izauguma un } \\
\text { aukslēju šķeltne }\end{array}$ & 28.02 .2006 & 3 g. 5 mēn. & $\begin{array}{l}\text { Cieto aukslēju } \\
\text { plastika }\end{array}$ \\
\hline 2. & 79 & $\mathrm{M}$ & $\begin{array}{l}\text { Abpusēja caurejoša } \\
\text { lūpas, alveolārā } \\
\text { izauguma un } \\
\text { aukslēju šķeltne }\end{array}$ & 31.03 .2004 & 5 g. 2 mēn. & $\begin{array}{l}\text { Mīksto un cieto } \\
\text { aukslēju plastika }\end{array}$ \\
\hline 3. & 81 & $\mathrm{Z}$ & $\begin{array}{l}\text { Abpusēja caurejoša } \\
\text { lūpas, alveolārā } \\
\text { izauguma un } \\
\text { aukslēju škseltne }\end{array}$ & 27.04 .2004 & 5 g. 0 mēn. & $\begin{array}{l}\text { Cieto aukslēju } \\
\text { plastika }\end{array}$ \\
\hline 4. & 134 & Z & $\begin{array}{l}\text { Abpusēja caurejoša } \\
\text { lūpas, alveolārā } \\
\text { izauguma un } \\
\text { aukslēju škseltne }\end{array}$ & 24.05 .2005 & 3 g. 6 mēn. & $\begin{array}{l}\text { Cieto aukslēju } \\
\text { plastika }\end{array}$ \\
\hline 5. & 150 & Z & $\begin{array}{l}\text { Abpusēja caurejoša } \\
\text { lūpas, alveolārā } \\
\text { izauguma un } \\
\text { aukslēju škseltne }\end{array}$ & 24.08 .2005 & 3 g. 5 mēn. & $\begin{array}{l}\text { Cieto aukslēju } \\
\text { plastika }\end{array}$ \\
\hline \multirow[t]{3}{*}{6.} & 168 & \multirow[t]{3}{*}{$\mathrm{Z}$} & \multirow{3}{*}{$\begin{array}{l}\text { Abpusēja caurejoša } \\
\text { lūpas, alveolārā } \\
\text { izauguma un } \\
\text { aukslēju šķeltne }\end{array}$} & 20.12 .2005 & 0 g. 6 mēn. & Lūpas plastika \\
\hline & 187 & & & 25.04 .2006 & 0 g. 10 mēn. & $\begin{array}{c}\text { Mīksto aukslēju } \\
\text { plastika }\end{array}$ \\
\hline & 232 & & & 07.10 .2008 & 3 g. 3 mēn. & $\begin{array}{c}\text { Cieto aukslēju } \\
\text { plastika }\end{array}$ \\
\hline 7. & 177 & $\mathrm{Z}$ & $\begin{array}{l}\text { Abpusēja caurejoša } \\
\text { lūpas, alveolārā } \\
\text { izauguma un } \\
\text { aukslēju škseltne }\end{array}$ & 31.01 .2006 & 0 g. 6 mēn. & Lūpas plastika \\
\hline \multirow[t]{2}{*}{8.} & 194 & \multirow[t]{2}{*}{$\mathrm{M}$} & \multirow{2}{*}{$\begin{array}{l}\text { Abpusēja caurejoša } \\
\text { lūpas, alveolārā } \\
\text { izauguma un } \\
\text { aukslēju škseltne }\end{array}$} & 23.01 .2007 & 0 g. 5 mēn. & Lūpas plastika \\
\hline & 207 & & & 14.08 .2007 & 1 g. 0 mēn. & $\begin{array}{l}\text { Mīksto aukslēju } \\
\text { plastika }\end{array}$ \\
\hline \multirow[t]{2}{*}{9.} & 196 & \multirow[t]{2}{*}{$\mathrm{M}$} & \multirow{2}{*}{$\begin{array}{l}\text { Abpusēja caurejoša } \\
\text { lūpas, alveolārā } \\
\text { izauguma un } \\
\text { aukslēju šķeltne }\end{array}$} & 10.04 .2007 & 0 g. 11 mēn. & $\begin{array}{c}\text { Mīksto aukslēju } \\
\text { plastika }\end{array}$ \\
\hline & 253 & & & 30.06 .2009 & 3 g. 2 mēn. & $\begin{array}{l}\text { Cieto aukslēju } \\
\text { plastika }\end{array}$ \\
\hline \multirow[t]{2}{*}{10.} & 204 & \multirow[t]{2}{*}{$\mathrm{Z}$} & \multirow{2}{*}{$\begin{array}{l}\text { Abpusēja caurejoša } \\
\text { lūpas, alveolārā } \\
\text { izauguma un } \\
\text { aukslēju škeltne }\end{array}$} & 12.06 .2007 & 0 g. 7 mēn. & Lūpas plastika \\
\hline & 265 & & & 23.03 .2010 & 3 g. 4 mēn. & $\begin{array}{l}\text { Cieto aukslēju } \\
\text { plastika }\end{array}$ \\
\hline 11. & 206 & $\mathrm{Z}$ & $\begin{array}{l}\text { Abpusēja caurejoša } \\
\text { lūpas, alveolārā } \\
\text { izauguma un } \\
\text { aukslēju škseltne }\end{array}$ & 14.08 .2007 & 0 g. 7 mēn. & Lūpas plastika \\
\hline
\end{tabular}




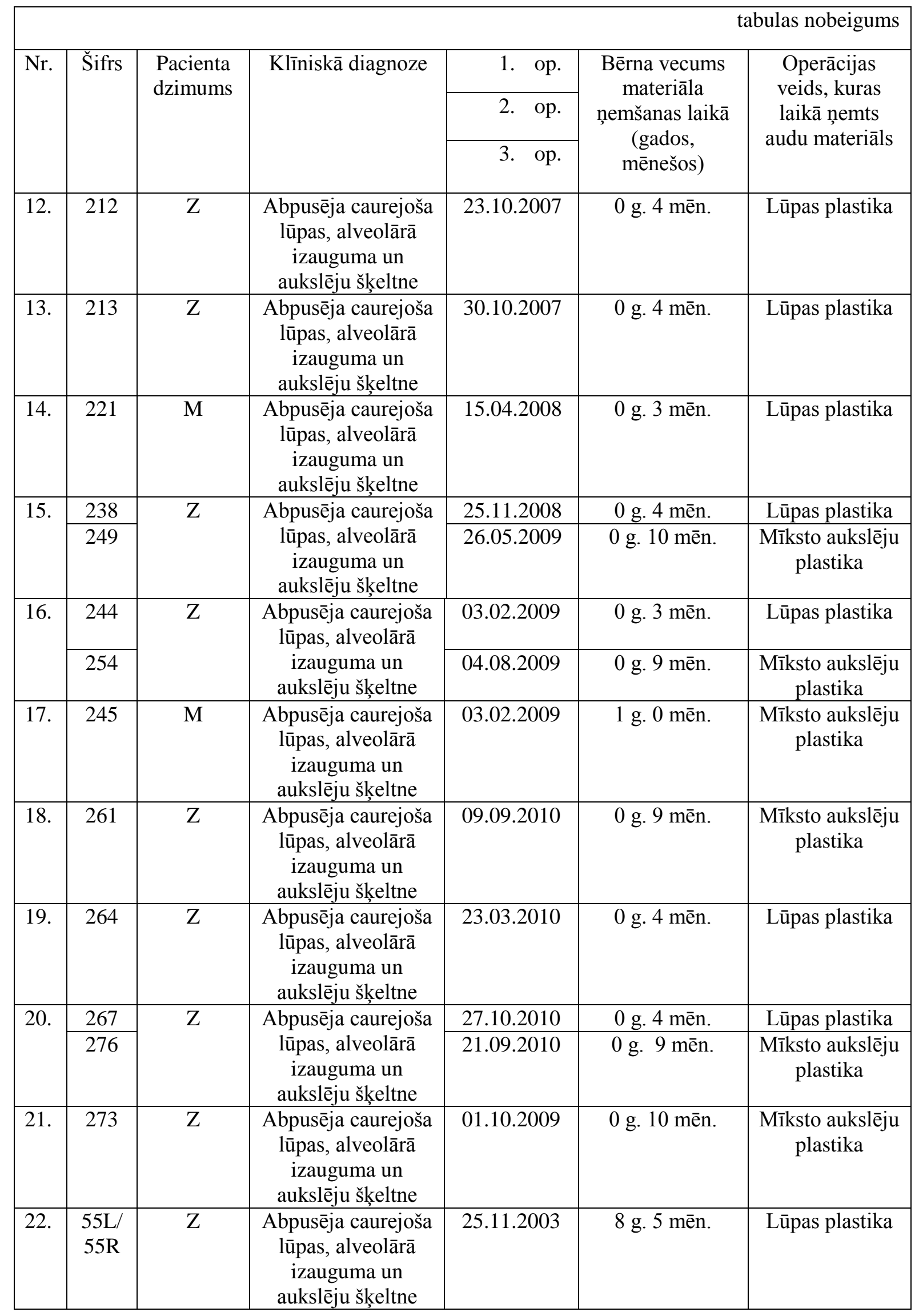

Saīsinājumi tabulā: $M$ - meitene; $Z$ - zēns; g - gadi; mēn - mēneši. 


\subsubsection{Trešās grupas - bērnu ar abpusēju caurejošu lūpas, alveolārā izauguma un aukslēju škseltni - raksturojums}

Trešajā grupā tika iekḷauti 10 bērni vecumā no sešiem gadiem līdz divpadsmit gadiem un diviem mēnešiem ar abpusējām škseltnēm. No tiem bija 9 zēni un viena meitene. Četriem pacientiem tika veiktas atkārtotas alveolārā izauguma osteoplastikas ar kaula autotransplantāciju. Diviem pacieniem tika veiktas gan cieto aukslēju plastikas, gan secīgas osteoplastikas, kuru laikā tika savākts pētāmais materiāls. Informācija par pacientiem 2.2. tabulā.

2.2. tabula

Informācija par 3. grupas pacientiem

\begin{tabular}{|c|c|c|c|c|c|}
\hline Nr. & Šifrs & $\begin{array}{c}\text { Bērna } \\
\text { dzimums }\end{array}$ & Klīniskā diagnoze & Bērna vecums & $\begin{array}{l}\text { Operācijas veids, kuras } \\
\text { laikā nnemts materiāls }\end{array}$ \\
\hline 1. & 210 & $\mathrm{Z}$ & $\begin{array}{l}\text { Abpusēja caurejoša lūpas, } \\
\text { alveolārā izauguma un } \\
\text { aukslēju šķeltne }\end{array}$ & 8 g. 6 mēn. & $\begin{array}{l}\text { Osteoplastika labajā } \\
\text { pusē }\end{array}$ \\
\hline 2. & 286 & $\mathrm{Z}$ & $\begin{array}{l}\text { Abpusēja caurejoša lūpas, } \\
\text { alveolārā izauguma un } \\
\text { aukslēju šḳeltne }\end{array}$ & 8 g. 11 mēn. & Osteoplastika \\
\hline 3. & 292 & $\mathrm{Z}$ & $\begin{array}{l}\text { Abpusēja caurejoša lūpas, } \\
\text { alveolārā izauguma un } \\
\text { aukslēju šḳeltne }\end{array}$ & 8 g. 11 mēn. & Osteoplastika \\
\hline 4. & 185 & $\mathrm{Z}$ & $\begin{array}{l}\text { Abpusēja caurejoša lūpas, } \\
\text { alveolārā izauguma un } \\
\text { aukslēju škkeltne }\end{array}$ & 9 g. 2 mēn. & Osteoplastika \\
\hline 5. & 35 & $\mathrm{Z}$ & $\begin{array}{c}\text { Abpusēja caurejoša lūpas, } \\
\text { alveolārā izauguma un } \\
\text { aukslēju šḳeltne }\end{array}$ & 9 g. 6 mēn. & Osteoplastika \\
\hline 6. & 145 & $\mathrm{Z}$ & $\begin{array}{l}\text { Abpusēja caurejoša lūpas, } \\
\text { alveolārā izauguma un } \\
\text { aukslēju šķeltne }\end{array}$ & 9 g. 6 mēn. & Osteoplastika \\
\hline 7. & 235 & $\mathrm{Z}$ & $\begin{array}{l}\text { Abpusēja caurejoša lūpas, } \\
\text { alveolārā izauguma un } \\
\text { aukslēju šķeltne }\end{array}$ & 9 g. 6 mēn. & $\begin{array}{c}\text { Osteoplastika kreisajā } \\
\text { pusē }\end{array}$ \\
\hline 8. & 214 & $\mathrm{Z}$ & $\begin{array}{l}\text { Abpusēja caurejoša lūpas, } \\
\text { alveolārā izauguma un } \\
\text { aukslēju šķeltne }\end{array}$ & 11 g. 1 mēn. & Osteoplastika \\
\hline 9. & 266 & $\mathrm{Z}$ & $\begin{array}{c}\text { Abpusēja caurejoša lūpas, } \\
\text { alveolārā izauguma un } \\
\text { aukslēju šḳeltne }\end{array}$ & 11 g. 1 mēn. & Osteoplastika \\
\hline 10. & 125 & M & $\begin{array}{l}\text { Abpusēja caurejoša lūpas, } \\
\text { alveolārā izauguma un } \\
\text { aukslēju šķeltne }\end{array}$ & 12 g. 2 mēn. & Osteoplastika \\
\hline
\end{tabular}

Saīsinājumi tabulā: $M$ - meitene; $\mathrm{Z}$ - zēns; g - gadi; mēn - mēneši. 


\subsubsection{Ceturtās un piektās grupas - bērnu ar vienpusēju caurejošu lūpas, alveolārā izauguma un aukslēju škşeltni - raksturojums}

Ceturtajā grupā tika iekḷauti 24 zīdaiṇi vecumā no trīs mēnešiem līdz septiṇiem mēnešiem ar vienpusēju caurejošu lūpas, alveolārā izauguma un aukslēju šķeltni. No tiem bija 6 meitenes un 18 zēni. 8 zīdaiņiem bija labās puses caurejoša šķeltne, bet 16 - kreisās puses caurejoša šķeltne. Visiem zīdaiņiem pētāmais materiāls tika paņemts lūpas plastikas laikā.

Piektajā grupā tika iekļauti 12 bērni vecumā no sešiem gadiem un astoņiem mēnešiem līdz deviņiem gadiem un pieciem mēnešiem ar vienpusēju caurejošu lūpas, alveolārā izauguma un aukslēju šķeltni. No tiem bija 7 zēni un 5 meitenes. 9 bērniem bija kreisās puses šķeltne, un 3 - labās puses. Visiem bērniem audu materiāls tika paņemts osteoplastikas laikā. Informācija par pacientiem 2.3. un 2.4. tabulās.

2.3. tabula

\section{Informācija par 4. grupas pacientiem}

\begin{tabular}{|c|c|c|c|c|c|}
\hline Nr. & Šifrs & $\begin{array}{c}\text { Bērna } \\
\text { dzimums }\end{array}$ & Klīniskā diagnoze & $\begin{array}{c}\text { Bērna } \\
\text { vecums }\end{array}$ & $\begin{array}{c}\text { Operācijas } \\
\text { veids, kuras } \\
\text { laikā ņemts } \\
\text { materiāls }\end{array}$ \\
\hline 1. & 195 & $\mathrm{Z}$ & $\begin{array}{c}\text { Kreisās puses caurejoša lūpas, } \\
\text { alveolārā izauguma un aukslēju šķeltne }\end{array}$ & 3 mēn. & Lūpas plastika \\
\hline 2. & 205 & $\mathrm{Z}$ & $\begin{array}{l}\text { Kreisās puses caurejoša lūpas, } \\
\text { alveolārā izauguma un aukslēju šḳeltne }\end{array}$ & 4 mēn. & Lūpas plastika \\
\hline 3. & 217 & $\mathrm{Z}$ & $\begin{array}{l}\text { Kreisās puses caurejoša lūpas, } \\
\text { alveolārā izauguma un aukslēju šḳeltne }\end{array}$ & 7 mēn. & Lūpas plastika \\
\hline 4. & 220 & $\mathrm{Z}$ & $\begin{array}{l}\text { Labās puses caurejoša lūpas, alveolārā } \\
\text { izauguma un aukslēju šķeltne }\end{array}$ & 3 mēn. & Lūpas plastika \\
\hline 5. & 223 & $\mathrm{Z}$ & $\begin{array}{c}\text { Kreisās puses caurejoša lūpas, } \\
\text { alveolārā izauguma un aukslēju šḳeltne }\end{array}$ & 1 g. 5 mēn. & Lūpas plastika \\
\hline 6. & 224 & $\mathrm{Z}$ & $\begin{array}{l}\text { Kreisās puses caurejoša lūpas, } \\
\text { alveolārā izauguma un aukslēju šķeltne }\end{array}$ & 3 mēn. & Lūpas plastika \\
\hline 7. & 227 & $\mathrm{Z}$ & $\begin{array}{l}\text { Labās puses caurejoša lūpas, alveolārā } \\
\text { izauguma un aukslēju škseltne }\end{array}$ & 5 mēn. & Lūpas plastika \\
\hline 8. & 247 & $\mathrm{Z}$ & $\begin{array}{c}\text { Kreisās puses caurejoša lūpas, } \\
\text { alveolārā izauguma un aukslēju šķeltne }\end{array}$ & 3 mēn. & Lūpas plastika \\
\hline 9 . & 258 & $\mathrm{Z}$ & $\begin{array}{c}\text { Kreisās puses caurejoša lūpas, } \\
\text { alveolārā izauguma un aukslēju šķeltne }\end{array}$ & 3 mēn. & Lūpas plastika \\
\hline 10. & 259 & $\mathrm{Z}$ & $\begin{array}{c}\text { Kreisās puses caurejoša lūpas, } \\
\text { alveolārā izauguma un aukslēju šķeltne }\end{array}$ & 4 mēn. & Lūpas plastika \\
\hline 11. & 262 & $\mathrm{Z}$ & $\begin{array}{l}\text { Kreisās puses caurejoša lūpas, } \\
\text { alveolārā izauguma un aukslēju šḳeltne }\end{array}$ & 4 mēn. & Lūpas plastika \\
\hline 12. & 277 & $\mathrm{M}$ & $\begin{array}{c}\text { Kreisās puses caurejoša lūpas, } \\
\text { alveolārā izauguma un aukslēju šķeltne }\end{array}$ & 3 mēn. & Lūpas plastika \\
\hline
\end{tabular}




\begin{tabular}{|c|c|c|c|c|c|}
\hline $\mathrm{Nr}$. & Šifrs & $\begin{array}{c}\text { Bērna } \\
\text { dzimums }\end{array}$ & Klīniskā diagnoze & $\begin{array}{c}\text { Bērna } \\
\text { vecums }\end{array}$ & $\begin{array}{c}\text { Operācijas } \\
\text { veids, kuras } \\
\text { laikā ņemts } \\
\text { materiāls }\end{array}$ \\
\hline 13. & 279 & $\mathrm{M}$ & $\begin{array}{l}\text { Labās puses caurejoša lūpas, alveolārā } \\
\text { izauguma un aukslēju škseltne }\end{array}$ & 4 mēn. & Lūpas plastika \\
\hline 14. & 282 & $\bar{Z}$ & $\begin{array}{l}\text { Labās puses caurejoša lūpas, alveolārā } \\
\text { izauguma un aukslēju šķeltne }\end{array}$ & 4 mēn. & Lūpas plastika \\
\hline 15. & 283 & $\mathrm{Z}$ & $\begin{array}{l}\text { Labās puses caurejoša lūpas, alveolārā } \\
\text { izauguma un aukslēju šķeltne }\end{array}$ & 4 mēn. & Lūpas plastika \\
\hline 16. & 284 & $\mathrm{M}$ & $\begin{array}{l}\text { Kreisās puses caurejoša lūpas, } \\
\text { alveolārā izauguma un aukslēju škseltne }\end{array}$ & 4 mēn. & Lūpas plastika \\
\hline 17. & 288 & $\mathrm{M}$ & $\begin{array}{l}\text { Kreisās puses caurejoša lūpas, } \\
\text { alveolārā izauguma un aukslēju šḳeltne }\end{array}$ & 4 mēn. & Lūpas plastika \\
\hline 18. & 289 & $\mathrm{Z}$ & $\begin{array}{c}\text { Labās puses caurejoša lūpas, alveolārā } \\
\text { izauguma un aukslēju škseltne }\end{array}$ & 4 mēn. & Lūpas plastika \\
\hline 19. & 299 & $\mathrm{Z}$ & $\begin{array}{l}\text { Labās puses caurejoša lūpas, alveolārā } \\
\text { izauguma un aukslēju šķeltne }\end{array}$ & 3 mēn. & Lūpas plastika \\
\hline 20. & 300 & $\mathrm{Z}$ & $\begin{array}{c}\text { Kreisās puses caurejoša lūpas, } \\
\text { alveolārā izauguma un aukslēju šķeltne }\end{array}$ & 4 mēn. & Lūpas plastika \\
\hline 21. & 302 & $\mathrm{M}$ & $\begin{array}{l}\text { Labās puses caurejoša lūpas, alveolārā } \\
\text { izauguma un aukslēju škseltne }\end{array}$ & 7 mēn. & Lūpas plastika \\
\hline 22. & 303 & $\mathrm{Z}$ & $\begin{array}{l}\text { Kreisās puses caurejoša lūpas, } \\
\text { alveolārā izauguma un aukslēju šķeltne }\end{array}$ & 4 mēn. & Lūpas plastika \\
\hline 23. & 306 & M & $\begin{array}{c}\text { Kreisās puses caurejoša lūpas, } \\
\text { alveolārā izauguma un aukslēju šḳeltne }\end{array}$ & 3 mēn. & Lūpas plastika \\
\hline 24. & 307 & $\mathrm{Z}$ & $\begin{array}{l}\text { Kreisās puses caurejoša lūpas, } \\
\text { alveolārā izauguma un aukslēju šķeltne }\end{array}$ & 3 mēn. & Lūpas plastika \\
\hline
\end{tabular}

Saīsinājumi tabulā: $M$ - meitene; $Z$ - zēns; g - gadi; mēn - mēneši. 
Informācija par 5. grupas pacientiem

\begin{tabular}{|c|c|c|c|c|c|}
\hline Nr. & Šifrs & $\begin{array}{c}\text { Bērna } \\
\text { dzimums }\end{array}$ & Klīniskā diagnoze & $\begin{array}{l}\text { Bērna vecums } \\
\text { materiāla } \\
\text { ņemšanas laikā }\end{array}$ & $\begin{array}{l}\text { Operācijas veids, kuras } \\
\text { laikā n̦emts materiāls }\end{array}$ \\
\hline 1. & $176 / 3$ & $\mathrm{Z}$ & $\begin{array}{l}\text { Labās puses caurejoša } \\
\text { lūpas, alveolārā izauguma } \\
\text { un aukslēju šḳeltne }\end{array}$ & 6 g. 10 mēn. & Osteoplastika \\
\hline 2. & $190 / 2$ & $\mathrm{Z}$ & $\begin{array}{l}\text { Kreisās puses caurejoša } \\
\text { lūpas, alveolārā izauguma } \\
\text { un aukslēju škseltne }\end{array}$ & 14 g. 6 mēn. & Osteoplastika \\
\hline 3. & $225 / 2$ & $\mathrm{Z}$ & $\begin{array}{l}\text { Kreisās puses caurejoša } \\
\text { lūpas, alveolāāā izauguma } \\
\text { un aukslēju škeltne }\end{array}$ & 7 g. 1 mēn. & Osteoplastika \\
\hline 4. & $228 / 2$ & $\mathrm{M}$ & $\begin{array}{l}\text { Kreisās puses caurejoša } \\
\text { lūpas, alveolāarā izauguma } \\
\text { un aukslēju škeltne }\end{array}$ & 7 g. 8 mēn. & Osteoplastika \\
\hline 5. & $248 / 2$ & $\mathrm{M}$ & $\begin{array}{l}\text { Kreisās puses caurejoša } \\
\text { lūpas, alveolārā izauguma } \\
\text { un aukslēju šḳeltne }\end{array}$ & 7 g. 2 mēn. & Osteoplastika \\
\hline 6. & $263 / 2$ & $\mathrm{M}$ & $\begin{array}{l}\text { Labās puses caurejoša } \\
\text { lūpas, alveolārā izauguma } \\
\text { un aukslēju šḳeltne }\end{array}$ & 6 g. 8 mēn. & Osteoplastika \\
\hline 7. & 268 & $\mathrm{Z}$ & $\begin{array}{l}\text { Kreisās puses caurejoša } \\
\text { lūpas, alveolārā izauguma } \\
\text { un aukslēju škseltne }\end{array}$ & 8 g. 5 mēn. & Osteoplastika \\
\hline 8. & 269 & $\bar{Z}$ & $\begin{array}{l}\text { Kreisās puses caurejoša } \\
\text { lūpas, alveolārā izauguma } \\
\text { un aukslēju šḳeltne }\end{array}$ & 9 g. 1 mēn. & Osteoplastika \\
\hline 9. & $278 / 2$ & $\mathrm{M}$ & $\begin{array}{l}\text { Kreisās puses caurejoša } \\
\text { lūpas, alveolārā izauguma } \\
\text { un aukslēju škseltne }\end{array}$ & 9 g. 5 mēn. & Osteoplastika \\
\hline 10. & $295 / 2$ & $\mathrm{Z}$ & $\begin{array}{l}\text { Labās puses caurejoša } \\
\text { lūpas, alveolārā izauguma } \\
\text { un aukslēju šķeltne }\end{array}$ & 8 g. 5 mēn. & Osteoplastika \\
\hline 11. & $296 / 2$ & $\mathrm{Z}$ & $\begin{array}{l}\text { Kreisās puses caurejoša } \\
\text { lūpas, alveolārā izauguma } \\
\text { un aukslēju šḳeltne }\end{array}$ & 7 g. 5 mēn. & Osteoplastika \\
\hline 12. & 246 & $\mathrm{M}$ & $\begin{array}{l}\text { Kreisās puses caurejoša } \\
\text { lūpas, alveolārā izauguma } \\
\text { un aukslēju škseltne }\end{array}$ & 7 g. 10 mēn. & Osteoplastika \\
\hline
\end{tabular}

Saīsinājumi tabulā: $M$ - meitene; $Z$ - zēns; g - gadi; mēn - mēneši. 


\subsubsection{Kontroles grupa}

Kontroles materiāls tika iegūts augšlūpas saitītes plastikas laikā un zobu ekstrakcijas laikā. Mīksto audu materiāls tika ievākts SIA "RSU Stomatoloǵijas institūtā" 2013. gadā no bērniem ar augšlūpas saitītes hipertrofiju. Cietajiem audiem tika izmantots RSU AAI arhīvā esošais alveolārā kaula materiāls. Kontroles grupas pacienti - 3 meitenes un 4 zēni mīksto audu materiāla paņemšanas laikā bija vecumā no pieciem līdz 14 gadiem. Kontroles grupas pacienti - 4 meitenes un 3 zēni cieto audu materiāla paņemšanas laikā bija vecumā no sešiem gadiem un deviņiem mēnešiem līdz 14 gadiem un pieciem mēnešiem.

Informācija par kontroles grupas pacientiem aplūkojama 2.5. un 2.6. tabulās.

2.5. tabula

\section{Informācija par mīksto audu kontroles grupas pacientiem}

\begin{tabular}{|c|c|c|c|c|c|}
\hline Nr. & Šifrs & $\begin{array}{c}\text { Bērna } \\
\text { dzimums }\end{array}$ & Klīniskā diagnoze & $\begin{array}{l}\text { Bērna vecums } \\
\text { materiāla } \\
\text { nemšanas laikā }\end{array}$ & $\begin{array}{c}\text { Operācijas veids, kuras } \\
\text { laikā n̦emts materiāls }\end{array}$ \\
\hline 1. & $1 / 1$ & $\mathrm{M}$ & $\begin{array}{l}\text { Hipertrofēta augšlūpas } \\
\text { saitîte }\end{array}$ & $5 \mathrm{~g}$. & $\begin{array}{c}\text { Augšlūpas saitītes } \\
\text { plastika }\end{array}$ \\
\hline 2. & $1 / 2(1)$ & $\mathrm{Z}$ & $\begin{array}{l}\text { Hipertrofêta augšlūpas } \\
\text { saitīte }\end{array}$ & $7 \mathrm{~g}$. & $\begin{array}{l}\text { Augšlūpas saitītes } \\
\text { plastika }\end{array}$ \\
\hline 3. & $1 / 2(2)$ & $\mathrm{Z}$ & $\begin{array}{l}\text { Hipertrofêta augšlūpas } \\
\text { saitîte }\end{array}$ & $9 \mathrm{~g}$. & $\begin{array}{c}\text { Augšlūpas saitītes } \\
\text { plastika }\end{array}$ \\
\hline 4. & $2 / 1$ & $\bar{Z}$ & $\begin{array}{l}\text { Hipertrofēta augšlūpas } \\
\text { saitīte }\end{array}$ & $8 \mathrm{~g}$. & $\begin{array}{l}\text { Augšlūpas saitītes } \\
\text { plastika }\end{array}$ \\
\hline 5. & 5 & $\mathrm{Z}$ & $\begin{array}{l}\text { Hipertrofēta augšlūpas } \\
\text { saitīte }\end{array}$ & $10 \mathrm{~g}$. & $\begin{array}{l}\text { Augšlūpas saitītes } \\
\text { plastika }\end{array}$ \\
\hline 6. & 11 & $\bar{M}$ & $\begin{array}{l}\text { Hipertrofēta augšlūpas } \\
\text { saitīte }\end{array}$ & $14 \mathrm{~g}$. & $\begin{array}{l}\text { Augšlūpas saitītes } \\
\text { plastika }\end{array}$ \\
\hline 7. & 18 & $\mathrm{M}$ & $\begin{array}{l}\text { Hipertrofêta augšlūpas } \\
\text { saitīte }\end{array}$ & $13 \mathrm{~g}$. & $\begin{array}{l}\text { Augšlūpas saitītes } \\
\text { plastika }\end{array}$ \\
\hline
\end{tabular}

Saīsinājumi tabulā: $M$ - meitene; $Z$ - zēns; g - gadi; mēn - mēneši.

2.6. tabula

Informācija par cieto audu kontroles grupas pacientiem

\begin{tabular}{|l|c|c|c|c|}
\hline Nr. & Šifrs & $\begin{array}{c}\text { Bērna } \\
\text { dzimums }\end{array}$ & $\begin{array}{c}\text { Bērna vecums materiāla } \\
\text { ņemšanas laikā }\end{array}$ & $\begin{array}{c}\text { Operācijas veids, kuras laikā ņemts } \\
\text { materiāls }\end{array}$ \\
\hline 1. & 1. & M & 10 g. 5 mēn. & Zoba ekstrakcija \\
\hline 2. & 2. & Z & 9 g. 9 mēn. & Zoba ekstrakcija \\
\hline 3. & 3. & M & 10 g. 2 mēn. & Zoba ekstrakcija \\
\hline 4. & 5. & Z & 11 g. 7 mēn. & Zoba ekstrakcija \\
\hline 5. & 8. & Z & 14 g. 5 mēn. & Zoba ekstrakcija \\
\hline 6. & 9 & M & 12 g. 8 mēn. & Zoba ekstrakcija \\
\hline 7. & 10. & M & 6 g. 9 mēn. & \\
\hline
\end{tabular}

Saīsinājumi tabulā: $M$ - meitene; $\mathrm{Z}$ - zēns; g - gadi; mēn - mēneši. 


\subsection{Morfologiskās metodes}

\subsubsection{Pētēmā audu materiāla fiksācija}

Audu fiksācija 24 stundas tika veikta RSU Stomatologijas institūta Lūpu, aukslēju un sejas šķeltņu centrā pēc lūpas plastikas, mīksto aukslēju plastikas, cieto aukslēju plastikas un osteoplastikas veikšanas. Minēto operāciju laikā iegūtais audu materiāls nekavējoties tika ievietots tālāk minētajā fiksatorā. Jāpiemin, ka fiksējošie šķ̄īumi var būt dažādi, bet pētījumā audu materiāls tika fiksēts Stefanini (Zamboni) šķ̄idumā, kuru Stefanini ar līdzautoriem 1967. gadā pirmo reizi izmantoja spermatozoīdu fiksācijai (Stefanini et al., 1967). Šì fiksējošāa šķ̄īuma pagatavošanai ir nepieciešami šādi reaǵenti: $20 \mathrm{~g}$ paraformaldehīds, $150 \mathrm{ml}$ pikrīnskābe, $425 \mathrm{ml}$ Sorensena buferis (pH 7.2) un $425 \mathrm{ml}$ destilēts ūdens. Pēc fiksācijas pētāmais materiāls tika nogādāts RSU AAI Morfolog̣ijas laboratorijā skalošanai ar Tyrode (sastāvs: $\mathrm{NaCl}, \mathrm{KCl}, \mathrm{CaCl}_{2} \cdot 2 \mathrm{H}_{2} \mathrm{O}, \mathrm{MgCl}_{2} \cdot 6 \mathrm{H}_{2} \mathrm{O}, \mathrm{NaHCO}_{3}, \mathrm{NaH}_{2} \mathrm{PO}_{4} \cdot \mathrm{H}_{2} \mathrm{O}$, glukoze, sukroze) šķ̄īdumu 24 stundas, atūdeņošanai pieaugošas koncentrācijas spirta šķ̄īdumos $\left(50^{\circ}\right.$, $70^{\circ}, 90^{\circ}, 95^{\circ}$ un absolūtais spirts), attaukošanai ksilolā $30 \mathrm{~min}$, tad vienu stundu ilgi izturēšanai parafīnā I un divas stundas ilgi parafīnā II, ieguldīšanai izkausētā parafīnā, sacietināšanai un tālākai apstrādei rutīnās un imūnhistoķīmijas metodes veikšanai.

\subsubsection{Rutīnās histoloğijas krāsošanas metode}

No katra zīdaiņa vai bērna operāciju laikā iegūtā audu materiāla bloka tika sagatavoti 3 mikrometri plāni audu griezumi ar pusautomātiskā rotācijas mikrotoma (Leica RM2245, Leica Biosystems Richmond Inc., Amerikas Savienotās Valstis) palīdzību. Griezumi tika pārnesti uz priekšmetstikliņiem (code-6130603; Histobond ${ }^{\circledR+}$, Paul Marienfeld GmbH \& Co. $K G$, Vācija), ievietoti žāvēšanai termostatā, pēc tam deparafinizēti ksilolā, atūdeņoti, izmantojot dažāâdas koncentrācijas spirtus, nokrāsoti ar hematoksilīnu un eozīnu, uzpilināta histoloǵiskā līme un pārklāti ar ḷoti plāniem 0,13-0,16 mm segstikliņiem (code-H875.2; Carl Roth GmbH + Co, Vācija) (Lillie et al., 1976). Hematoksilīna un eozīna krāsojums bija nepieciešams, lai iegūtu pārskata morfoloǵisko ainu. Nokrāsotie preparāti tika analizēti ar gaismas mikroskopu (Leica DM500RB, Leica Biosystems Richmond Inc., Amerikas Savienotās Valstis). 


\subsubsection{Imūnhistoḳīmijas metode un reaǵenti}

Specifisku proteolītisku enzīmu, transkripcijas faktoru, gēnu proteīnu, augšanas faktoru, šūnu proliferācijas marķieru, kaula morfoǵenēzes proteīnu, nekolagēno kaula proteīnu un osteoprotegerīna noteikšanai tika pielietota imūnhistoķīmijas metodi (Hsu et al., 1981).

Informācija par imūnhistoķīmijā pielietotām primārām antivielām apkopota 2.7 . tabulā.

Imūnhistoḳīmijas krāsošanas protokolam, lai vizualizētu antigēna-antivielas reakciju, tika pielietoti sekojoši reaǵenti:

1. EDTA (pH 9.0) buferis (code-T0103; Diapath, Martinengo BG, Itālija);

2. TRIS buferis (code-15-M106; Bio-Optica, Milano, Itālija);

3. BIODEC R dekalcifikācijas šķīdums (code-05-M03009; Bio-Optica, Milano, Itālija);

4. Antivielu atšķaidītājs Antibody Diluent (code-ab64211; Abcam, Burlingame, CA, Amerikas Savienotās Valstis);

5. HiDef Detection ${ }^{\mathrm{TM}}$ reakcijas amplifikators (code-954D-31; Sigma-Aldrich, Rocklin, $C A$, Amerikas Savienotās Valstis);

6. HiDef Detection ${ }^{\mathrm{TM}}$ HRP polimēra iezīmētājs (code-954D-32; Sigma-Aldrich, Rocklin, CA, Amerikas Savienotās Valstis);

7. Kazas ImmunoCruz ${ }^{T M} A B C$ krāsošanas sistēma (code-sc-2023; Santa Cruz Biotechnology, Inc., Santa Cruz, CA, Amerikas Savienotās Valstis), tā ietver biotīnu saturošas sekundāras un terciālas antivielas, kas satur avidīnu un biotīna-mārrutku peroksidāzes šķīdumu;

8. DAB Substrate Kit (code-957D-30; Cell Marque, Rocklin, CA, Amerikas Savienotās Valstis);

9. Hematoksilīns (code-ab143166; Abcam, Burlingame, CA, Amerikas Savienotās Valstis);

10. Histologiskā līme Pertex ${ }^{\circledR}$ (code-00811; HistoLab ${ }^{\circledR}$, Gothenburg, Zviedrija).

Kaulaudi pirms talāk minētās apstrādes tika izturēti vienu diennakti BIODEC $R$ dekalcifikācijas šķīdumā.

No katra bloka tika griezti 3 mikrometri plāni audu griezumi, kas tika pārnesti uz adhezīviem ar silānu pārklātiem priekšmetstikliņiem, deparafinizēti ksilolā un hidratēti spirta šķīiumos ar dilstošu koncentrāciju. Tika veikta skalošana 2 reizes pa piecām minūtēm ar TRIS bufera šķīiumu, vārīšanu EDTA buferī 5 min mikrovilņnu krāsnī. Pēc tam 10 min tika 
bloķēta endogēnās peroksidāzes aktivitāte ar 3\% peroksidāzi. Visas pêtījumā pielietotās antivielas tika atšksaidītas ar Antibody Diluent.

Peles vai truša izcelsmes antivielām tika lietota HiDef Detection ${ }^{T M} H R P$ polimēra sistēma. Šīs sistēmas pielietošanas gadījumā pēc primāro antivielu inkubācijas un trīsreizējas skalošanas ar TRIS bufera šķīdumu tika izmantota HiDef Detection ${ }^{T M}$ reakcijas amplifikators 10 min istabas temperatūrā. Pēc šīs apstrādes preparāti tika skaloti ar TRIS bufera šķ̄īumu trīs reizes pa piecām minūtēm. Tālāk 10 min istabas temperatūrā tika izmantots HiDef Detection ${ }^{T M} H R P$ polimēra iezīmētājs, un atkal tika veikta skalošana ar TRIS bufera šks̄îumu. Pēc skalošanas, pielietojot šo polimēra sistēmu, 5 min tika izmantots $H R P$ hromogēns.

Kazas izcelsmes antivielām tika izmantota ImmunoCruz ${ }^{T M} A B C$ krāsošanas sistēma. $A B C$ krāsošanas sistēmas pielietošanas gadījumā mikropreparāti inkubēti ar 1,5 \% bloķēěanas serumu TRIS bufera šksīdumā līdz vienai stundai istabas temperatūrā. Tad sekoja preparātu inkubācija ar primāro antivielu vienu stundu istabas temperatūrā. Pēc trīsreizējas piecu minūšu skalošanas TRIS bufera šķ̄îumā griezumi inkubēti $30 \mathrm{~min}$ ar biotīnu saturošu sekundāru antivielu (biotinylated goat Ig). Pēc tam sekoja atkārtoti trīsreizēja pa piecām minūtēm paraugu skalošana TRIS bufera šķīdumā un inkubācija ar terciālo antivielu 30 min istabas temperatūrā. Tad tika veikta skalošana ar TRIS bufera šksīdumu. Turpmāk tika lietots DAB Substrate Kit 10 min.

Pēc hromogēna, lietojot gan kazas ImmunoCruzTM ABC krāsošanas sistēmu, gan HiDef DetectionTM HRP polimēra sistēmu, tika izmantots šūnu kodolu krāsviela hematoksilīns. Pēc krāsošanas ar hematoksilīnu mikropreparāti skaloti destilētā ūden̄̄ un dehidratēti augošas koncentrācijas spirtos, caurspīdināti ksilolā un pārklāti ar līmi Pertex ${ }^{\circledR}$.

Minēto preparātu paralēliem griezumiem primārā antiviela tika aizstāta ar antivielu atšķaidītāju Antibody Diluent. Šie griezumi tika lietoti kā negatīvā kontrole. Katrai preparātu sērijai tika pagatavotas arī pozitīvās kontroles (audos, kuros vienmēr ir pozitīva reakcija). 


\subsubsection{TUNEL metode}

Programmēta šūnu nāve jeb apoptoze operāciju laikā iegūtajos mīksto audu paraugos tika izvērtēta, pielietojot augstas sensitivitātes un specificitātes TUNEL (code: 11684817 910, In Situ Cell Death Detection Kit, Roche Diagnostics, Vācija) kita standartizētu komplektu.

Komplektā ietilps šādi svarīgi reaǵenti: gala deoksilnukleotidil-transferāze, kas iegūta no tel̦a aizkrūts dziedzera, nukleotidu maisījums buferī, anti-fluorescīna antivielas un no aitām iegūts $F a b$ fragments, kas konjugēts ar mārrutku peroksidāzi.

Pirmkārt, TUNEL reakcijas veikšanai audu paraugi tika deparafinizēti, izmantojot ksilolu un dilstošas koncentrācijas etanola šķīdumos (absolūts, 95\%, 90\%, 80\%, 70\% etanols), tad aptuveni 10 min skaloti destilētā ūden̄̄ un pēc tam TRIS šķīdumā. Otrkārt, tika bloķēta endogenās peroksidāzes aktivitāte ar 3\% ūdeņraža peroksīdu un audu paraugi tika skaloti TRIS šķīdumā trīs reizes pa 5 min. Treškārt, audu paraugi tika ievietoti EDTA buferškīdumā uz 10 min un ielikti mikrovil̦nu krāsnī uz 5 min, pēc tam atdzesēti istabas temperatūrā. Tam sekoja preparātu skalošana TRIS šķīdumā. Ceturtkārt, preparāti tika mazgāti TRIS buferšķīdumā un atstāti $0,1 \%$ govs seruma albumīna fosfāta buferšksīumā. Nākamā darba gaitas etapā vienu stundu $37^{\circ} \mathrm{C}$ temperatūrā audu paraugi tika pārklāti ar TUNEL mix (TUNEL Enzyme solution). Pēc skalošanas TRIS bufera šķīdumā divas reizes pa piecām minūtēm griezumi inkubēti ar mārrutku peoksidāzi saturošu reaǵentu Converte-POD solution $30 \mathrm{~min}$ $37^{0} \mathrm{C}$ temperatūrā. Atkārtoti paraugi pa piecām minūtēm tika skaloti ar TRIS buferi, tad griezumi pārklāti ar $D A B$ (10 min) šksīdumu peroksidāzes noteikšanai un skaloti destilētā ūdenī.

Pēdējā protokola etapā šūnu kodolu kontrastēšana veikta ar Meijera hematoksilīnu, audu paraugi dehidratēti pieaugošas koncentrācijas spirta šķīdumos, caurspīdināti ksilolā un ieslēgti histologískā Pertex ${ }^{\circledR}$ līmē, pārklāti ar plānu segstikliṇu. 
Informācija par imūnhistoḳīmijā pielietotām primārām antivielām

\begin{tabular}{|c|c|c|c|c|c|c|}
\hline Nr. & Antiviela & Kods & Klons & $\begin{array}{l}\text { No kā } \\
\text { iegūts }\end{array}$ & $\begin{array}{c}\text { Darba } \\
\text { atšķaidījums }\end{array}$ & Ražotājs \\
\hline 1. & $M M P-2$ & sc-53630 & $4 D 3$ & Peles & $1: 100$ & $\begin{array}{lr}\text { Santa } & \text { Cruz } \\
\text { Biotechnology, } & \text { Inc., } \\
\text { Santa Cruz, } & \text { CA, } \\
\text { Amerikas } & \text { Savienotās } \\
\text { Valstis } & \end{array}$ \\
\hline 2. & $M M P-8$ & sc-80206 & $6-19 Z$ & Peles & $1: 50$ & $\begin{array}{lr}\text { Santa } & \text { Cruz } \\
\text { Biotechnology, } & \text { Inc., } \\
\text { Santa Cruz, } & \text { CA, } \\
\text { Amerikas } & \text { Savienotās } \\
\text { Valstis } & \end{array}$ \\
\hline 3. & $M M P-9$ & sc-10737 & $H-129$ & Truša & $1: 100$ & $\begin{array}{lr}\text { Santa } & \text { Cruz } \\
\text { Biotechnology, } & \text { Inc., } \\
\text { Santa Cruz, } & \text { CA, } \\
\text { Amerikas } & \text { Savienotās } \\
\text { Valstis } & \end{array}$ \\
\hline 4. & TIMP-2 & sc-21735 & $3 A 4$ & Peles & $1: 100$ & $\begin{array}{lr}\text { Santa } & \text { Cruz } \\
\text { Biotechnology, } & \text { Inc., } \\
\text { Santa Cruz, } & \text { CA, } \\
\text { Amerikas } & \text { Savienotās } \\
\text { Valstis } & \end{array}$ \\
\hline 5. & TIMP-4 & sc-30076 & $H-60$ & Truša & $1: 100$ & $\begin{array}{lr}\text { Santa } & \text { Cruz } \\
\text { Biotechnology, } & \text { Inc., } \\
\text { Santa Cruz, } & \text { CA, } \\
\text { Amerikas } & \text { Savienotās } \\
\text { Valstis } & \\
\end{array}$ \\
\hline 6. & $M S X 1$ & orb18823 & - & Kazas & $1: 100$ & $\begin{array}{l}\text { Biorbyt Ltd., Cambridge, } \\
\text { Anglija }\end{array}$ \\
\hline 7. & IRF6 & ab167403 & $\begin{array}{c}\text { EPR634 } \\
8\end{array}$ & Truša & $1: 100$ & $\begin{array}{l}\text { Abcam, Burlingame, } C A, \\
\text { Amerikas } \\
\text { Valstis }\end{array}$ \\
\hline 8. & PAX9 & sc-56823 & $7 C 2$ & Peles & $1: 100$ & $\begin{array}{lr}\text { Santa } & \text { Cruz } \\
\text { Biotechnology, } & \text { Inc., } \\
\text { Santa Cruz, } & \text { CA, } \\
\text { Amerikas } & \text { Savienotās } \\
\text { Valstis } & \end{array}$ \\
\hline 9. & $R Y K$ & orb38371 & - & Truša & $1: 50$ & $\begin{array}{l}\text { Biorbyt Ltd, Cambridge, } \\
\text { Anglija }\end{array}$ \\
\hline 10. & $T G F \beta 3$ & sc- 82 & $V$ & Truša & $1: 200$ & $\begin{array}{lr}\text { Santa } & \text { Cruz } \\
\text { Biotechnology, } & \text { Inc., } \\
\text { Santa Cruz, } & \text { CA, } \\
\text { Amerikas } & \text { Savienotās } \\
\text { Valstis } & \end{array}$ \\
\hline 11. & Nestin & ab22035 & $10 C 2$ & Peles & $1: 200$ & $\begin{array}{l}\text { Abcam, Burlingame, } C A, \\
\text { Amerikas } \\
\text { Valstis }\end{array}$ \\
\hline 12. & CD34 & sc-19621 & $B I-3 C 5$ & Peles & $1: 200$ & $\begin{array}{lr}\text { Santa } & \text { Cruz } \\
\text { Biotechnology, } & \text { Inc., } \\
\text { Santa Cruz, } & \text { CA, } \\
\text { Amerikas } & \text { Savienotās } \\
\text { Valstis } & \\
\end{array}$ \\
\hline
\end{tabular}




\begin{tabular}{|c|c|c|c|c|c|c|}
\hline & & & & & & tabulas nobeigums \\
\hline $\mathrm{Nr}$. & Antiviela & Kods & Klons & $\begin{array}{l}\text { No kā } \\
\text { iegūts }\end{array}$ & $\begin{array}{c}\text { Darba } \\
\text { atšķaidījums }\end{array}$ & Ražotājs \\
\hline 13. & $V E G F$ & sc-7269 & $C-1$ & Peles & $1: 50$ & $\begin{array}{lr}\text { Santa } & \text { Cruz } \\
\text { Biotechnology, } & \text { Inc., } \\
\text { Santa Cruz, } & \text { CA, } \\
\text { Amerikas } & \text { Savienotās } \\
\text { Valstis } & \\
\end{array}$ \\
\hline 14. & $P G P 9.5$ & ab10404 & - & Truša & $1: 50$ & $\begin{array}{l}\text { Abcam, Burlingame, CA, } \\
\text { Amerikas } \\
\text { Valstis }\end{array}$ \\
\hline 15. & $O C$ & sc-30044 & $F L-100$ & Truša & $1: 100$ & $\begin{array}{lr}\text { Santa } & \text { Cruz } \\
\text { Biotechnology, } & \text { Inc., } \\
\text { Santa Cruz, } & \text { CA, } \\
\text { Amerikas } & \text { Savienotās } \\
\text { Valstis } & \\
\end{array}$ \\
\hline 16. & $O P N$ & sc-73631 & $\begin{array}{c}\text { LFMb- } \\
14\end{array}$ & Peles & $1: 100$ & $\begin{array}{lr}\text { Santa } & \text { Cruz } \\
\text { Biotechnology, } & \text { Inc., } \\
\text { Santa Cruz, } & \text { CA, } \\
\text { Amerikas } \quad \text { Savienotās } \\
\text { Valstis }\end{array}$ \\
\hline 17. & $O P G$ & sc- 8468 & $N-20$ & Kazas & $1: 50$ & $\begin{array}{lr}\text { Santa } & \text { Cruz } \\
\text { Biotechnology, } & \text { Inc., } \\
\text { Santa Cruz, } & \text { CA, } \\
\text { Amerikas } & \text { Savienotās } \\
\text { Valstis } & \end{array}$ \\
\hline 18. & $B M P 2 / 4$ & AF355 & - & Kazas & $1: 100$ & $\begin{array}{l}\text { R\&D Systems, Inc., } \\
\text { Minneapolis, Amerikas } \\
\text { Savienotās Valstis }\end{array}$ \\
\hline 19. & Ki-67 & ab16667 & SP6 & Truša & $1: 100$ & $\begin{array}{l}\text { Abcam, Burlingame, } C A, \\
\text { Amerikas } \\
\text { Valstis }\end{array}$ \\
\hline
\end{tabular}

Saīsinājumi tabulā: $M M P-2$ - matrices metaloproteināze-2; $M M P-8$ - matrices metaloproteināze-8; $M M P-9$ matrices metaloproteināze-9; TIMP-2 - matrices metaloproteināzes-2 audu inhibitors; TIMP-4 - matrices metaloproteināzes-4 audu inhibitors; MSX1 - transkripcijas faktors MSX1; IRF6 - transkripcijas faktors IRF6; $P A X 9$ - transkripcijas faktors $P A X 9 ; R Y K-R Y K$ gēns; $T G F \beta 3$ - trandformējošais augšanas faktors beta3; Nestin - VI tipa starpdziedziṇu proteīns nestīns; $C D 34$ - transmembranozs glikoproteīns $C D 34$; VEGF - vaskulārais endotēlija augšanas faktors; $P G P 9.5$ - proteīngēnviela 9.5; $O C$ - osteokalcīns; $O P N$ - osteopontīns; $B M P 2 / 4$ kaula morfoğenētiskais proteīns $2 / 4 ; K i-67$ - šūnu proliferācijas marḳieris $K i-67$.

\subsection{Puskvantitatīvā skaitīšanas metode}

Imūnhistoķīmiski noteikto struktūru relatīvais daudzums tika izvērtēts gaismas mikroskopā, izmantojot 40x objektīvu un 10x okulārās lēcas. Imūnhistoķīmisko marķieru klātbūtne audos tika izvērtēta atbilstoši puskvantitatīvai skaitīšanas metodei (Pilmane et al., 1998). Pozitīvo struktūru relatīvais daudzums tika analizēts desmit nejauši izvēlētos redzes laukos katram sagatavotajam audu griezumam (sk. 2.8. tabulu). 
Imūnhistoķīmiski noteikto struktūru relatīvā biežuma vērtēšanas kritēriji (Pilmane et al., 1998)

\begin{tabular}{|c|c|}
\hline Lietotie apzīmējumi & Paskaidrojumi \\
\hline 0 & Redzes laukā netika konstatēta neviena pozitīva struktūra \\
\hline $0 /+$ & Redzes laukā retas pozitīvās struktūras \\
\hline+ & Redzes laukā maz pozitīvo struktūru \\
\hline$+/++$ & Redzes laukā maz līdz vidēji daudz pozitīvo struktūru \\
\hline++ & Redzes laukā vidēji daudz pozitīvo struktūru \\
\hline$++/+++$ & Redzes laukā vidēji daudz līdz daudz pozitīvo struktūru \\
\hline+++ & Redzes laukā daudz pozitīvo struktūru \\
\hline$+++/++++$ & Redzes laukā daudz līdz ḷoti daudz pozitīvo struktūru \\
\hline++++ & Redzes laukā l̦oti daudz pozitîvo struktūru \\
\hline
\end{tabular}

\subsection{Statistiskās metodes}

Pētījuma grupu vispārīgai raksturošanai tika izmantotas vispārpien̦emtās aprakstošās statistikas metodes (Teibe, 2007). Pētījuma datu izvērtēšanai izmantotas neparametriskās statistikas metodes. Vairāku nesaistītu grupu salīdzināšanai - Kraskela-Vollisa (KruskalWallis) rangu dispersijas analīze, kas ir Manna-Vitnija testa paplašinājums. Piecu grupu salīdzināšanai pa pāriem pielietots Bonferoni (Bonferroni) labojums p vērtības būtiskuma līmeņa noteikšanai. Pēc rangu skalas lielumiem tika aprēķināts arī Spīrmena (Spearman) korelācijas koeficients $|r|$, kuru pirmo reizi sāka lietot Č. Spīrmens 1904. gadā, pētot jautājumu, kas ir intelekts (Deary et al., 2004). Iegūtie rezultāti tika interpretēti: $|r| \leq 0,25$ vāja korelācija, $0,25<|r|<0,75$ - vidēja korelācija, $|r| \geq 0,75$ - cieša korelācija. Rezultāti uzskatīti par statistiski ticamiem, ja $\mathrm{p}<0,05$. Statistiskā analīze veikta ar SPSS 22. versiju (IBM Corp., Armonk, NY, Amerikas Savienotās Valstis). 


\section{REZULTĀTI}

\subsection{Morfoloğiskā atrade kontroles grupas pacientiem un pacientiem ar šķeltni}

\subsubsection{Rutīnās histoloğijas dati kontroles grupas pacientiem}

No pētījumā izmantotajiem kontroles grupas pacientu pārskata preparātiem septiņu pacientu mutes dobuma audu paraugos, kas tika iegūti augšlūpas saitītes plastikas laikā, tika konstatēta vispārpieņemtajai normai atbilstoša histologiskāa atrade (3.1. mikrofotogrāfija pielikumā). Visos preparātos tika fiksēta segg̣̦otāda un košḷā̌sanas funkciju nodrošinātājgḷotāda, kā arī gḷotādas saistaudi jeb lamina propria bez izmaiṇām. Trīs pacientiem tika vizualizēti mazie siekalu dziedzeri, matu folikuli un tauku dziedzeri. Visu kontroles grupas pacientu zobu ekstrakciju laikā iegūtajos kaulaudos tika konstatēta vispārpieņemtajai normai atbilstoša balstaudu morfoloǵiskā aina (3.2. mikrofotogrāfija pielikumā).

\subsubsection{Rutīnās histoloǵijas dati pacientiem ar škseltni}

Audu paraugos, kas tika iegūti lūpas primārās plastikas laikā, bija labi redzama mutes dobuma gļotāda. Pacientu audu materiālā tika atrasta lūpas ārējās virsmas āda ar matiem, tauku dziedzeriem, kā arī matu folikuli un neliela perivaskulāra iekaisuma šūnu infiltrācija (3.3. mikrofotogrāfija pielikumā). Atsevišķos paraugos bija lūpas pārejas daḷas gḷotādas daudzkārtainais plakanais epitēlijs ar pārragošanās pazīmēm (ortokeratinizāciju). Lūpas glotādā tika vizualizēti ar̄̄ mazie siekalu dziedzeri. Mīksto un cieto aukslēju audu paraugos bija vispārpieņemtajai normai atbilstošas uzbūves mutes dobuma gḷotāda. Cieto aukslēju audu materiālu veidoja parakeratinizēts daudzkārtainais plakanais epitēlijs, zemāk esoša lamina propria, zemgḷotādā tika konstatēti jauktie siekalu dziedzeri. Tādus atradām arī mīkstajās aukslējās, un šeit nereti to izvadus veidoja hiperplazētas šūnas (3.4. mikrofotogrāfija pielikumā).

Visizteiktākās morfologiskās pārmaiņas atradām epitēlijā. Tā biezums dažiem pacientiem bija atšķirīgs, proti, dažiem pacientiem redzējām plānu, atrofisku, bet citiem novērojām biezu epitēliju ar izteiktu bazālā slāṇa šūnu hiperplāziju, proliferāciju un epitēlija polimorfo šūnu vakuolizāciju (3.5. mikrofotogrāfija pielikumā). Turklāt, daļai bērnu ar šķeltni epitēlijaudi garu izaugumu veidā iestiepās zemāk novietotajā lamina propria (3.6. mikrofotogrāfija pielikumā). 
Pacientiem ar šķeltni nereti vizualizējām lamina propria ar blīvi un dažkārt haotiski novietotiem kolagēno šķiedru kūlīšiem, starp kuriem bija atsevišķas saistaudu šūnas, galvenokārt, fibroblasti (3.7. mikrofotogrāfija pielikumā). Redzējām daudz sīku asinsvadu un neizmainītu matu folikulu, tauku dziedzeru, kā arī mazo siekalu dziedzeru sekretorās daļas un izvadus. Mutes dobuma gḷotādas epitēlijā un saistaudos redzējām arī iekaisuma šūnu infiltrāciju, bet ne visu pacientu audu paraugos.

Pacientu audu materiālā, kas tika iegūts osteoplastikas laikā, nereti redzējām deǵeneratīvu alveolārā kaula izaugumu. To raksturoja niecīgs osteonu daudzums un neregulārs to izvietojums, kā arī mazs osteocītu daudzums. Dažiem pacientiem bija vispārpieņemtajai normai atbilstoša kaula uzbūve, kā arī izteikts periosts (3.8. mikrofotogrāfija pielikumā).

\subsection{Mīksto audu dažādu faktoru imūnhistoḳīmisko pētījumu un apoptozes atrade kontroles grupas pacientiem}

\subsubsection{Audu degradācijas enzīmu (MMP) un to endogēno inhibitoru (TIMP) imūnhistoķīmiskie dati}

Matrices metaloproteināzes-2 (MMP-2) klātbūtne tika analizēta atsevišķi epitēlijā un zemāk esošajos saistaudos. Visu kontroles grupas pacientu epitēlijā bija MMP-2 pozitīvas šūnas. $M M P-2$ pozitīvas epitēlijšūnas variēja robežās no maz $(+)$ līdz vidēji daudz $(++)$ redzes laukā (3.1. tabula; 3.9. mikrofotogrāfija pielikumā). Kopumā MMP-2 pozitīvas epitēlijšūnas bija maz līdz vidēji daudz (+/++). Tikai vienam no septinsiem pacientiem tika konstatēts vidēji daudz (++) MMP-2 saturošu saistaudu šūnu (3.1. tabula).

Matrices metaloproteināzes-8 $(M M P-8)$ atrade kontroles grupas pacientu mutes dobuma glotādā arī tika vizualizēta epitēlijā un saistaudos. Pacientiem epitēlijā bija sastopamas retas $(0 /+)$ līdz vidēji daudz $(++) M M P-8$ pozitīvas šūnas, un arī saistaudos atrade bija līdzīga, $M M P-8$ pozitîvas šūnas bija robežās no retām $(0 /+)$ līdz maz $(+)$ redzes laukā (3.10. mikrofotogrāfija pielikumā). Vienam pacientam netika atklātas $M M P-8$ saturošas struktūras (3.1. tabula).

Matrices metaloproteināzes-9 (MMP-9) klātbūtne arī tika analizēta visos mutes dobuma gḷotādas slāņos. Lielākajai daḷai pacientu $M M P-9$ pozitīvas epitēlijšūnas bija robežās no retām $(0 /+)$ līdz vidēji daudz $(++)$ šūnām redzes laukā. Viena pacienta audos tika novērots daudz (+++) MMP-9 pozitīvu epitēlijšūnu. Saistaudos konstatētas $M M P-9$ pozitīvas šūnas bija robežās no retām $(0 /+)$ līdz vidēji daudz $(++)$ (3.11. mikrofotogrāfija pielikumā), kaut gan vienam pacientam saistaudos netika redzētas $M M P-9$ pozitīvas šūnas (3.1. tabula). 
Matrices metaloproteināzes-2 audu inhibitora (TIMP-2) klātbūtne tika atrasta epitēlijā un saistaudos. TIMP-2 saturošas epitēlijšūnas bija robežās no retām $(0 /+)$ līdz vidēji daudz (++) šūnām (3.1. tabula; 3.12. mikrofotogrāfija pielikumā). Vienam pacientam epitēlijā netika konstatētas TIMP-2 saturošas šūnas. Diviem pacientiem atradām retas (0/+) TIMP-2 pozitīvas saistaudu šūnas (3.1. tabula).

Visiem kontroles grupas pacientiem epitēlijā un saistaudos tika vizualizēta matrices metaloproteināzes-4 audu inhibitora (TIMP-4) klātbūtne. Epitēlijā TIMP-4 klātbūtne variēja no retām $(0 /+)$ līdz vidēji daudz $(++)$ pozitīvām šūnām redzes laukā (3.1. tabula; 3.13. mikrofotogrāfija pielikumā), savukārt saistaudos TIMP-4 pozitīvu šūnu relatīvais daudzums redzes laukā bija robežās no retām (0/+) līdz maz (+) (3.1. tabula).

3.1. tabula

Audu degradācijas enzīmu (MMP), to endogēno inhibitoru (TIMP) pozitīvu struktūru relatīvais daudzums kontroles grupas pacientu audos

\begin{tabular}{|l|c|c|c|c|c|c|c|c|c|c|c|}
\hline \multirow{2}{*}{ Nr. } & \multirow{2}{*}{ Sifrs } & \multicolumn{2}{|c|}{$M M P-2$} & \multicolumn{2}{c|}{$M M P-8$} & \multicolumn{2}{c|}{$M M P-9$} & \multicolumn{2}{c|}{ TIMP-2 } & \multicolumn{2}{c|}{ TIMP-4 } \\
\cline { 3 - 14 } & & $\mathrm{E}$ & $\mathrm{S}$ & $\mathrm{E}$ & $\mathrm{S}$ & $\mathrm{E}$ & $\mathrm{S}$ & $\mathrm{E}$ & $\mathrm{S}$ & $\mathrm{E}$ & $\mathrm{S}$ \\
\hline 1. & $1 / 1$ & ++ & 0 & $+/++$ & $0 /+$ & +++ & $+/++$ & ++ & 0 & ++ & + \\
\hline 2. & $1 / 2(1)$ & + & 0 & $0 /+$ & + & $+/++$ & ++ & $0 /+$ & 0 & $+/++$ & $0 /+$ \\
\hline 3. & $1 / 2(2)$ & + & 0 & + & + & + & ++ & + & 0 & + & + \\
\hline 4. & $2 / 1$ & ++ & 0 & + & $0 /+$ & + & $0 /+$ & ++ & 0 & $0 /+$ & $0 /+$ \\
\hline 5. & 5 & + & 0 & $0 /+$ & + & ++ & + & + & 0 & ++ & $+/++$ \\
\hline 6. & 11 & ++ & ++ & 0 & 0 & + & ++ & ++ & ++ & + & + \\
\hline 7. & 18 & $+/++$ & 0 & + & + & $0 /+$ & 0 & $+/++$ & 0 & $0 /+$ & + \\
\hline
\end{tabular}

Apzīmējumi tabulā: 0 - redzes laukā nav konstatēta neviena pozitīva struktūra; 0/+ - redzes laukā ir retas pozitīvas struktūras; + - redzes laukā ir maz pozitīivu struktūru; +/++ - redzes laukā ir maz līdz vidēji daudz pozitīivu struktūru; ++ - redzes laukā ir vidēji daudz pozitīivu struktūru; ++/+++ - redzes laukā ir vidēji daudz līdz daudz pozitīvu struktūru; +++ - redzes laukā ir daudz pozit̄̄vu struktūru; +++/++++ - redzes laukā ir daudz līdz l’oti daudz pozitīvu struktūru; ++++ - redzes laukā ir l̦oti daudz pozitīvu struktūru.

Saīsinājumi tabulā: E - epitēlijšūnas; S - saistaudu šūnas; $M M P-2$ - matrices metaloproteināze-2; $M M P-8$ matrices metaloproteināze-8; MMP-9 - matrices metaloproteināze-9; TIMP-2 - matrices metaloproteināzes-2 audu inhibitors; TIMP-4 - matrices metaloproteināzes-4 audu inhibitors.

\subsubsection{Gēnu proteīnu imūnhistoķīmiskie dati}

Transkripcijas faktora MSX1 atrade kontroles grupas pacientu mutes dobuma glotādā bija pārliecinoša. Epitēlijā tika konstatētas maz (+) līdz daudz (+++) MSX1 pozitīvas šūnas redzes laukā (3.2. tabula; 3.14. mikrofotogrāfija pielikumā). Tāpat tika konstatēti arī MSX1 pozitīvi fibroblasti un makrofāgi lamina propria. MSX1 saistaudos variēja no maz (+) līdz vidēji daudz (++) pozitīiām šūnām redzes laukā (3.2. tabula).

Transkripcijas faktors IRF6 tika konstatēts gan epitēlijā, gan saistaudos visos kontroles grupas pacientu audu griezumos. Epitēlijā IRF6 pozitīvas šūnas tika redzētas 
robežās no maz (+) līdz vidēji daudz $(++)$, bet saistaudos - no retām $(0 /+)$ līdz daudz (+++) redzes laukā (3.2. tabula; 3.15. mikrofotogrāfija pielikumā).

Transkripcijas faktora PAX9 klātbūtne arī tika analizēta visos mutes dobuma glotādas epitēlija slāņos un zemāk esošajos saistaudos. Kopumā epitēlijā pārliecinoši tika konstatēts vidēji daudz (++) PAX9 pozitīvu šūnu. Vidēji daudz (++) PAX9 pozitīvu bazālā un dzeloņainā slāņa epitēlijšūnu tika konstatēts pieciem kontroles grupas pacientiem (3.16. mikrofotogrāfija pielikumā) un vidēji daudz līdz daudz (++/+++) diviem pacientiem. Trīs kontroles grupas pacientiem tika konstatētas retas (0/+) PAX9 saturošas saistaudu šūnas (3.2. tabula).

RYK gēna proteīna klātbūtne tika novērota gandrīz visiem kontroles grupas pacientiem. Epitēlijā un saistaudos bija atrodamas RYK saturošas šūnas robežās no retām $(0 /+)$ līdz vidēji daudz (++) redzes laukā (3.17. mikrofotogrāfija pielikumā). Vienam pacientam netika vizualizētas RYK pozitīvas šūnas epitēlijāa, citam pacientam - RYK pozitīvas šūnas saistaudos (3.2. tabula).

3.2. tabula

\section{Gēnu proteīnu pozitīvu struktūru relatīvais daudzums kontroles grupas pacientu audos}

\begin{tabular}{|l|c|c|c|c|c|c|c|c|c|}
\hline \multirow{2}{*}{ Nr. } & \multirow{2}{*}{ Sifrs } & \multicolumn{2}{|c|}{ MSX1 } & \multicolumn{2}{|c|}{ IRF6 } & \multicolumn{2}{c|}{ PAX9 } & \multicolumn{2}{c|}{ RYK } \\
\cline { 3 - 10 } & & $\mathrm{E}$ & $\mathrm{S}$ & $\mathrm{E}$ & $\mathrm{S}$ & $\mathrm{E}$ & $\mathrm{S}$ & $\mathrm{E}$ & $\mathrm{S}$ \\
\hline 1. & $1 / 1$ & ++ & $+/++$ & + & + & ++ & $0 /+$ & $0 /+$ & $0 /+$ \\
\hline 2. & $1 / 2(1)$ & $++/+++$ & + & + & + & ++ & 0 & $0 /+$ & 0 \\
\hline 3. & $1 / 2(2)$ & +++ & + & + & $0 /+$ & $++/+++$ & 0 & $0 /+$ & + \\
\hline 4. & $2 / 1$ & ++ & ++ & ++ & + & ++ & 0 & + & + \\
\hline 5. & 5 & ++ & + & ++ & ++ & ++ & 0 & 0 & + \\
\hline 6. & 11 & ++ & ++ & ++ & $++/+++$ & ++ & $0 /+$ & ++ & ++ \\
\hline 7. & 18 & $+/++$ & ++ & + & ++ & $++/+++$ & $0 /+$ & + & + \\
\hline
\end{tabular}

Apzīmējumi tabulā: 0 - redzes laukā nav konstatēta neviena pozitīva struktūra; 0/+ - redzes laukā ir retas pozitīvas struktūras; + - redzes laukā ir maz pozitīvu struktūru; +/++ - redzes laukā ir maz līdz vidēji daudz pozitīvu struktūru; ++ - redzes laukā ir vidēji daudz pozitīvu struktūru; ++/+++ - redzes laukā ir vidēji daudz līdz daudz pozit̄̄vu struktūru; +++ - redzes laukā ir daudz pozit̄ivu struktūru; +++/++++ - redzes laukā ir daudz līdz loti daudz pozit̄̄vu struktūru; ++++ - redzes laukā ir ļoti daudz pozitīvu struktūru.

Sā̄sinājumi tabulā: E - epitēlijšūnas; S - saistaudu šūnas; MSX1 - transkripcijas faktors MSX1; IRF6 transkripcijas faktors IRF6; PAX9 - transkripcijas faktors PAX9; RYK - RYK gēna proteīns. 


\subsubsection{Augšanas faktoru, $C D 34$ un inervācijas faktora $P G P 9.5$ imūnhistoķīmiskie dati}

Transformējošā augšanas faktora beta-3 (TGFß3) saturošas struktūras tika novērotas visu kontroles grupas pacientu audos. Četriem pacientiem tika atrasts daudz (+++) $T G F \beta 3$ pozitīvu epitēlijšūnu, diviem pacientiem - vidēji daudz $(++)$ un vienam pacientam daudz līdz ļoti daudz (+++/++++) pozitīvu epitēlijšūnu (3.18. mikrofotogrāfija pielikumā), kamēr imūnhistoķīmiski noteikto saistaudu šūnu relatīvais daudzums variēja no vidēji daudz $(++)$ līdz daudz $(+++)$ redzes laukā (3.3. tabula). Četriem pacientiem tika konstatētas $T G F \beta 3$ saturošas šūnas asinsvadu sieniṇās.

Vaskulārā endotēlija augšanas faktora $(V E G F)$ saturošo šūnu klātbūtne tika konstatēta visu kontroles grupas pacientu audu paraugos asinsvadu sieniṇā, kur tas iezīmēja maz (+) līdz vidēji daudz (++) endoteliocītus (3.3. tabula; 3.19. mikrofotogrāfija pielikumā).

CD34 klātbūtne tika konstatēta visos kontroles grupas pacientu audu paraugos asinsvadu sieniņās. Imūnhistoķīmiski noteikto $C D 34$ pozitīvo šūnu relatīvais daudzums variēja no vidēji daudz $(++)$ līdz daudz $(+++)$ redzes laukā (3.3. tabula; 3.20. mikrofotogrāfija pielikumā).

Proteīngēnvielas 9.5 ( $P G P$ 9.5) pozitīvas nervšķiedras tika konstatētas visiem audu paraugiem, pārsvarā starp epiteliocītiem. Dažos gadījumos tika novērotas $P G P 9.5$ pozitīvas struktūras asinsvadu sieniņās un to tuvumā. Tika atrasti arī $P G P 9.5$ saturoši nervu šķiedru kūlīši. Kopumā $P G P 9.5$ saturošas struktūras bija retas $(0 /+)$ līdz daudz $(+++)$ redzes laukā (3.3. tabula; 3.21. mikrofotogrāfija pielikumā). 


\section{TGFß3, VEGF, CD34 un PGP 9.5 pozitīvu struktūru relatīvais daudzums kontroles grupas pacientu audos}

\begin{tabular}{|l|c|c|c|c|c|c|}
\hline \multirow{2}{*}{ Nr. } & \multirow{2}{*}{ Šifrs } & \multicolumn{2}{|c|}{ TGFß3 } & \multirow{2}{*}{ VEGF } & CD34 & PGP 9.5 \\
\cline { 3 - 5 } & & $\mathrm{E}$ & $\mathrm{S}$ & & & \\
\hline 1. & $1 / 1$ & ++ & ++ & ++ & +++ & + \\
\hline 2. & $1 / 2(1)$ & +++ & +++ & ++ & ++ & $0 /+$ \\
\hline 3. & $1 / 2(2)$ & +++ & ++ & ++ & ++ & +++ \\
\hline 4. & $2 / 1$ & +++ & +++ & + & +++ & + \\
\hline 5. & 5 & ++ & ++ & $+/++$ & +++ & + \\
\hline 6. & 11 & $+++/+++$ & +++ & + & +++ & $+/++$ \\
\hline 7. & 18 & +++ & +++ & $+/++$ & +++ & + \\
\hline
\end{tabular}

Apzīmējumi tabulā: 0 - redzes laukā nav konstatēta neviena pozitīva struktūra; 0/+ - redzes laukā ir retas pozitīvas struktūras; + - redzes laukā ir maz pozitīvu struktūru; +/++ - redzes laukā ir maz līdz vidēji daudz pozitīvu struktūru; ++ - redzes laukā ir vidēji daudz pozit̄̄vu struktūru; ++/+++ - redzes laukā ir vidēji daudz līdz daudz pozitīvu struktūru; +++ - redzes laukā ir daudz pozitīvu struktūru; +++/++++ - redzes laukā ir daudz līdz loti daudz pozitīvu struktūru; ++++ - redzes laukā ir ḷoti daudz pozitīvu struktūru.

Saīsinājumi tabulā: E - epitēlijšūnas; $\mathrm{S}$ - saistaudu šūnas; $T G F \beta 3$ - transformējošais augšanas faktors beta3; $V E G F$ - vaskulārais endotēlija augšanas faktors; CD34 - transmembranozais glikoproteīns CD34; PGP 9.5 proteīngēnviela 9.5 .

\subsection{4. Šūnu proliferācijas marķiera $K i-67$, nestīna un apoptozes atrade}

Ki-67 pozitīvi epitēlijšūnu kodoli tika konstatēti piecu kontroles grupas pacientu audu paraugos. Vienam pacientam nebija redzama neviena $K i-67$ pozitīva šūna. Vienam pacientam pētījumā bija maz (+) Ki-67 pozitīvas šūnas epitēlijā (3.22. mikrofotogrāfija pielikumā), un piecu pacientu audu paraugos tika vizualizētas retas $(0 /+) K i-67$ pozitīvas šūnas redzes laukā (3.4. tabula).

Nestīns bagātīgi iezīmēja epitēlijšūnas četriem pacientiem. Vienam pacientam bija vidēji daudz līdz daudz $(++/+++)$ pozitīvu epitēlijšūnu, diviem pacientiem - daudz līdz ļoti daudz $(+++/++++)$ pozitīivu epitēlijšūnu (3.4. tabula; 3.23. mikrofotogrāfija pielikumā). Jāatzīmē, ka kontroles grupas pacientiem nestīnu bagātīgi saturēja epitēlija bazālā slāņa šūnas, bet tika novērotas arī nestīna saturošas saistaudu šūnas.

Apoptotiskās šūnas tika novērotas pieciem pacientiem. Šiem pacientiem maz (+) līdz vidēji daudz (++) epiteliocītu bija apoptotiski (3.4. tabula; 3.24. mikrofotogrāfija pielikumā). Apoptotiskas šūnas saistaudos netika vizualizētas. Diviem pacientiem netika atrasta neviena apoptotiska šūna (3.4. tabula). 
Ki-67, nestīna un apoptotisko šūnu relatīvais daudzums kontroles grupas pacientu audos

\begin{tabular}{|l|c|c|c|c|}
\hline Nr. & Šifrs & $K i-67$ & Nestīns & Apoptoze \\
\hline 1. & $1 / 1$ & $0 /+$ & $++/+++$ & $+/++$ \\
\hline 2. & $1 / 2(1)$ & 0 & ++++ & 0 \\
\hline 3. & $1 / 2(2)$ & + & ++++ & $+/++$ \\
\hline 4. & $2 / 1$ & $0 /+$ & ++++ & 0 \\
\hline 5. & 5 & $0 /+$ & ++++ & + \\
\hline 6. & 11 & $0 /+$ & $+++/++++$ & $+/++$ \\
\hline 7. & 18 & $0 /+$ & $+++/++++$ & + \\
\hline
\end{tabular}

Apzīmējumi tabulā: 0 - redzes laukā nav konstatēta neviena pozitīva struktūra; 0/+ - redzes laukā ir retas pozitīvas struktūras; + - redzes laukā ir maz pozitīvu struktūru; +/++ - redzes laukā ir maz līdz vidēji daudz pozitīvu struktūru; ++ - redzes laukā ir vidēji daudz pozitīvu struktūru; ++/+++ - redzes laukā ir vidēji daudz līdz daudz pozit̄̄vu struktūru; +++ - redzes laukā ir daudz pozit̄ivu struktūru; +++/++++ - redzes laukā ir daudz līdz loti daudz pozit̄̄vu struktūru; ++++ - redzes laukā ir l̦oti daudz pozitīvu struktūru.

Saīsinājums tabulā: Ki-67 - šūnu proliferācijas marķieris Ki-67.

\subsubsection{Kaulaudu osteokalcīna $(O C)$, osteopontīna $(O P)$ un osteoprotegerīna $(O P G)$ imūnhistoķīmiskie dati}

Osteokalcīna $(O C)$ klātbūtne kontroles grupas pacientu audos tika konstatēta osteocītos un osteoblastos visos audu paraugos. Imūnhistoķīmiski noteikto kaulaudu šūnu relatīvais daudzums variēja no vidēji daudz un daudz (++/+++) līdz ļoti daudz (++++) redzes laukā (3.5. tabula; 3.25. mikrofotogrāfija pielikumā).

Osteopontīnu $(O P N)$ saturēja galvenokārt osteocīti. Pieciem pacientiem tika novēroti reti $(0 /+)$ pozitīvi osteocīti, vienam pacientam - vidēji daudz līdz daudz $(++/+++)$ pozitīvu osteocītu (3.26. mikrofotogrāfija pielikumā), bet vienam pacientam imūnreaktīvas šūnas netika vizualizētas (3.5. tabula).

Osteoprotegerīna $(O P G)$ klātbūtne cietajos audos tika novērota visu kontroles grupas pacientu osteoblastos un osteocītos. $O P G$ pozitīvas šūnas variēja no retām $(0 /+)$ līdz loti daudz $(++++)$ redzes laukā (3.5. tabula; 3.27. mikrofotogrāfija pielikumā). 
$O C, O P$ un $O P G$ pozitīvu struktūru relatīvais daudzums kontroles grupas pacientu kaulaudos

\begin{tabular}{|l|c|c|c|c|}
\hline Nr. & Šifrs & $O C$ & $O P N$ & $O P G$ \\
\hline 1. & 1 & +++ & $0 /+$ & $+/++$ \\
\hline 2. & 2 & +++ & $0 /+$ & $0 /+$ \\
\hline 3. & 3 & +++ & $0 /+$ & ++ \\
\hline 4. & 5 & $++/+++$ & 0 & $+/++$ \\
\hline 5. & 8 & ++++ & $0 /+$ & $+++/+++$ \\
\hline 6. & 9 & $++/+++$ & $++/+++$ & $+++/++++$ \\
\hline 7. & 10 & ++++ & $0 /+$ & +++ \\
\hline 8. & 11 & $++/+++$ & $0 /+$ & $+++/++++$ \\
\hline
\end{tabular}

Apzīmējumi tabulā: 0 - redzes laukā nav konstatēta neviena pozitīva struktūra; 0/+ - redzes laukā ir retas pozitīvas struktūras; + - redzes laukā ir maz pozitīvu struktūru; +/++ - redzes laukā ir maz līdz vidēji daudz pozitīvu struktūru; ++ - redzes laukā ir vidēji daudz pozitīvu struktūru; ++/+++ - redzes laukā ir vidēji daudz līdz daudz pozit̄̄vu struktūru; +++ - redzes laukā ir daudz pozitīvu struktūru; +++/++++ - redzes laukā ir daudz līdz loti daudz pozitīvu struktūru; ++++ - redzes laukā ir ļoti daudz pozitīvu struktūru.

Saīsinājumi tabulā: $O C$ - ostekalcīns; $O P$ - osteopontīns; $O P G$ - osteoprotegerīns.

\subsubsection{Kaulaudu kaula morfoğenētiskā proteīna 2/4 (BMP2/4), matrices} metaloproteināzes-2 (MMP-2), matrices metaloproteināzes-2 audu inhibitora (TIMP-2) un tranfromējošā augšanas faktora beta-3 (TGFß3) imūnhistoķīmiskie dati

Kaula morfogenenētiskais proteīns $2 / 4(B M P 2 / 4)$ tika konstatēts visiem kontroles grupas pacientiem. BMP2/4 saturošo osteoblastu un osteocītu skaits variēja no maz $(+)$ līdz daudz $(+++)$ redzes laukā (3.6. tabula; 3.28. mikrofotogrāfija pielikumā).

Matrices metaloproteināze-2 (MMP-2) un tās endogēnais audu inhibitors (TIMP2) tika novērots visos cieto audu griezumos. $M M P-2, T I M P-2$ variēja no reti sastopamām (0/+) līdz daudz (+++) pozitīvām šūnām redzes laukā (3.6. tabula; 3.29. un 3.30. mikrofotogrāfija pielikumā).

Transformējošā augšanas faktora beta-3 (TGFß3) klātbūtne kaulaudu šūnās tika konstatēta visiem pacientiem. TGFß3 saturošas šūnas variēja robežās no maz (+) līdz daudz (+++) redzes laukā (3.6. tabula; 3.31. mikrofotogrāfija pielikumā). 
BMP 2/4, MMP-2, TIMP-2 un TGFß3 pozitīvu struktūru relatīvais daudzums kontroles grupas pacientu kaulaudos

\begin{tabular}{|c|c|c|c|c|c|}
\hline $\mathrm{Nr}$. & Šifrs & $B M P 2 / 4$ & $M M P-2$ & TIMP-2 & $T G F \beta 3$ \\
\hline 1. & 1 & $+/++$ & $0 /+$ & ++ & + \\
\hline 2. & 2 & $+/++$ & $0 /+$ & $0 /+$ & + \\
\hline 3. & 3 & + & + & $0 /+$ & ++ \\
\hline 4. & 5 & $++/+++$ & $++/+++$ & $0 /+$ & ++ \\
\hline 5. & 8 & + & + & + & ++ \\
\hline 6. & 9 & + & + & $+/++$ & ++ \\
\hline 7. & 10 & ++ & + & $+/++$ & ++ \\
\hline 8. & 11 & ++ & $0 /+$ & $0 /+$ & +++ \\
\hline
\end{tabular}

Apzīmējumi tabulā: 0 - redzes laukā nav konstatēta neviena pozitīva struktūra; 0/+ - redzes laukā ir retas pozitīvas struktūras; + - redzes laukā ir maz pozitīvu struktūru; +/++ - redzes laukā ir maz līdz vidēji daudz pozitīvu struktūru; ++ - redzes laukā ir vidēji daudz pozitīvu struktūru; ++/+++ - redzes laukā ir vidēji daudz līdz daudz pozitīvu struktūru; +++ - redzes laukā ir daudz pozit̄̄vu struktūru; +++/++++ - redzes laukā ir daudz līdz ḷoti daudz pozit̄̄vu struktūru; ++++ - redzes laukā ir ḷoti daudz pozitīvu struktūru.

Sā̄sinājumi tabulā: $B M P 2 / 4$ - kaula morfogenenētiskais protē̄ns $2 / 4 ; M M P-2$ - matrices metaloproteināze-2; $T I M P$-2 - matrices metaloproteināzes-2 audu inhibitors; TGF 3 - transformējošais augšanas faktors beta-3.

\subsubsection{Imūnhistoḳīmiski noteikto marķieru savstarpējās atbilstības ciešuma izvērtēšanas dati kontroles grupas pacientiem}

Kontroles grupas audu paraugos noteikto faktoru savstarpējās atbilstības ciešuma izvērtēšanai tika izmantots Spīrmena rangu korelācijas koeficients.

Statistiski nozīmīga cieša, pozitīva $(|r| \geq 0,75)$ korelācija tika konstatēta:

$\mathrm{r}_{\mathrm{s}}=0,938 ; \mathrm{p}<0,01-\operatorname{starp}$ TIMP-2 un TIMP-4 pozitīvām epitēlijšūnām;

$\mathrm{r}_{\mathrm{s}}=-0,933 ; \mathrm{p}<0,01-\operatorname{starp}$ MMP-9 pozitīvām saistaudu šūnām un MMP-2 pozitīvām epitēlijš̄ūnām;

$\mathrm{r}_{\mathrm{s}}=0,889 ; \mathrm{p}<0,01$ - starp MSX1 pozitīvām saistaudu šūnām un RYK pozitīvām epitēlijšūnām. 


\section{3. Škseltṇu skartu audu faktoru atrade}

\subsubsection{Audu degradācijas enzīmu (MMP) un to endogēno audu inhibitoru (TIMP) imūnhistoḳīmiskie un statistiskie dati}

\section{Matrices metaloproteināzes-2 (MMP-2) atrade lūpas primārās plastikas laikā iegūtajā materiālā zīdaiņiem un bērniem ar lūpas, alveolārā izauguma un aukslēju škseltnēm}

MMP-2 klātbūtne pacientiem abpusēju caurejošu šķeltņu audos tika redzēta gan epitēlijā, gan lamina propria. Dažiem pacientiem pētījumā tika vizualizētas vidēji daudz līdz daudz (++/+++) MMP-2 pozitīvas šūnas mazo siekalu dziedzeru izvados un sekretorajās daļās. $M M P-2$ pozitīvas šūnas redzējām arī tauku dziedzeros. Visos audu paraugos tika konstatēts vidēji daudz (++) līdz ļoti daudz (++++) pozitīvu epitēlijšūnu (3.7. tabula). MMP-2 pozitīvas saistaudu šūnas variēja no retām $(0 /+)$ līdz daudz $(+++)$ redzes laukā (3.7. tabula; 3.32. mikrofotogrāfija pielikumā).

\section{7. tabula}

MMP un TIMP pozitīvu struktūru relatīvais daudzums abpusēju caurejošu lūpas, alveolārā izauguma un aukslēju šķeltņu skartajos audos, kas iegūti lūpas plastikas laikā

\begin{tabular}{|l|c|c|c|c|c|c|c|c|c|c|c|}
\hline \multirow{2}{*}{ Nr. } & \multirow{2}{*}{ Sifrs } & \multicolumn{2}{|c|}{$M M P-2$} & \multicolumn{2}{c|}{$M M P-8$} & \multicolumn{2}{c|}{$M M P-9$} & \multicolumn{2}{c|}{ TIMP-2 } & \multicolumn{2}{c|}{ TIMP-4 } \\
\cline { 3 - 13 } & & $\mathrm{E}$ & $\mathrm{S}$ & $\mathrm{E}$ & $\mathrm{S}$ & $\mathrm{E}$ & $\mathrm{S}$ & $\mathrm{E}$ & $\mathrm{S}$ & $\mathrm{E}$ & $\mathrm{S}$ \\
\hline 1. & $55 \mathrm{~L}$ & ++ & ++ & ++ & + & $0 /+$ & $0 /+$ & + & $+/++$ & + & $0 /+$ \\
\hline 2. & $55 \mathrm{R}$ & ++ & $++/+++$ & + & + & $0 /+$ & $0 /+$ & $+/++$ & ++ & $0 /+$ & $0 /+$ \\
\hline 3. & 168 & ++ & $+/++$ & $0 /+$ & $0 /+$ & 0 & 0 & $+/++$ & $+/++$ & 0 & 0 \\
\hline 4. & 177 & ++ & $0 /+$ & + & $0 /+$ & 0 & $0 /+$ & ++ & $0 /+$ & 0 & 0 \\
\hline 5. & 194 & $++/+++$ & $+/++$ & ++ & $0 /+$ & + & $0 /+$ & ++ & $+/++$ & $0 /+$ & $0 /+$ \\
\hline 6. & 204 & ++ & $+/++$ & + & $0 /+$ & $0 /+$ & 0 & + & + & 0 & 0 \\
\hline 8. & 206 & $++/+++$ & ++ & $0 /+$ & $0 /+$ & 0 & 0 & $+/++$ & $+/++$ & 0 & 0 \\
\hline 9. & 212 & ++ & ++ & 0 & $0 /+$ & $0 /+$ & $0 /+$ & $+/++$ & + & 0 & 0 \\
\hline 10. & 213 & $++/+++$ & + & + & $0 /+$ & $0 /+$ & 0 & $+/++$ & $+/++$ & 0 & 0 \\
\hline 11. & 221 & $+++/+++$ & +++ & +++ & $0 /+$ & ++ & $+/++$ & $++/+++$ & ++ & $+/++$ & + \\
\hline 12. & 238 & $+++/++++$ & ++ & $+/++$ & $0 /+$ & $0 /+$ & $0 /+$ & ++ & ++ & + & $0 /+$ \\
\hline 13. & 244 & $++/+++$ & ++ & +++ & $0 /+$ & + & $0 /+$ & + & + & ++ & $0 /+$ \\
\hline 14. & 264 & $++/+++$ & ++ & ++ & $0 /+$ & $0 /+$ & $0 /+$ & ++ & ++ & + & $0 /+$ \\
\hline 15. & 267 & ++ & ++ & ++ & + & $0 /+$ & 0 & + & ++ & $0 /+$ & + \\
\hline 16. & 197 & ++ & + & ++ & $0 /+$ & + & 0 & ++ & + & $0 /+$ & 0 \\
\hline
\end{tabular}

Apzīmējumi tabulā: 0 - redzes laukā nav konstatēta neviena pozitīva struktūra; 0/+ - redzes laukā ir retas pozitīvas struktūras; + - redzes laukā ir maz pozitīvu struktūru; +/++ - redzes laukā ir maz līdz vidēji daudz pozitīvu struktūru; ++ - redzes laukā ir vidēji daudz pozitīvu struktūru; $++/+++$ - redzes laukā ir vidēji daudz

līdz daudz pozitīvu struktūru; +++ - redzes laukā ir daudz pozitīvu struktūru; +++/++++ - redzes laukā ir daudz līdz lıti daudz pozitīvu struktūru; ++++ - redzes laukā ir l̦oti daudz pozitīvu struktūru.

Saīsinājumi tabulā: E - epitēlijšūnas; S - saistaudu šūnas; $M M P-2$ - matrices metaloproteināze-2; MMP-8 matrices metaloproteināze-8; MMP-9 - matrices metaloproteināze-9; TIMP-2 - matrices metaloproteināzes-2 audu inhibitors; TIMP-4 - matrices metaloproteināzes-4 audu inhibitors. 
Epitēlijā un saistaudos visiem vienpusēju caurejošu lūpas, alveolārā izauguma un aukslēju šķeltņu skartajiem audu paraugiem tika konstatētas $M M P-2$ saturošas šūnas. Epitēlijā MMP-2 pozitīvas šūnas bija redzamas robežās no retām $(0 /+)$ līdz vidēji daudz $(++)$ redzes laukā. Lamina propria tika fiksēti galvenokārt MMP-2 pozitīvi makrofāgi un fibroblasti. Kopumā saistaudos atrade variēja robežās no reti (0/+) līdz ļoti daudz (++++) MMP-2 saturošām šūnām redzes laukā (3.8. tabula; 3.33. mikrofotogrāfija pielikumā).

3.8. tabula

MMP un TIMP pozitīvu struktūru relatīvais daudzums vienpusēju caurejošu lūpas, alveolārā izauguma un aukslēju šḳeltṇu skartajos audos, kas iegūti lūpas plastikas laikā

\begin{tabular}{|c|c|c|c|c|c|c|c|c|c|c|c|}
\hline \multirow[t]{2}{*}{$\mathrm{Nr}$. } & \multirow[t]{2}{*}{ Šifrs } & \multicolumn{2}{|c|}{$M M P-2$} & \multicolumn{2}{|c|}{$M M P-8$} & \multicolumn{2}{|c|}{$M M P-9$} & \multicolumn{2}{|c|}{ TIMP-2 } & \multicolumn{2}{|c|}{ TIMP-4 } \\
\hline & & $E$ & $S$ & $E$ & $S$ & $E$ & $S$ & $E$ & $S$ & $E$ & $S$ \\
\hline 1. & 195. & $+/++$ & + & + & $0 /+$ & ++ & $0 /+$ & + & $0 /+$ & ++ & + \\
\hline 2. & 205 & $+/++$ & + & ++ & $0 /+$ & ++ & $0 /+$ & ++ & $+/++$ & $++/+++$ & + \\
\hline 3. & 217. & $+/++$ & $0 /+$ & $+/++$ & $0 /+$ & ++ & $+/++$ & $0 /+$ & $0 /+$ & ++ & ++ \\
\hline 4. & 220 & $0 /+$ & $0 /+$ & ++ & + & ++ & ++ & $\begin{array}{c}+/+ \\
+\end{array}$ & $+/++$ & $++/+++$ & +++ \\
\hline 5. & 223. & + & $0 /+$ & + & $0 /+$ & $+/++$ & ++ & $\begin{array}{c}+/+ \\
+\end{array}$ & $0 /+$ & ++ & $\begin{array}{c}++/++ \\
+\end{array}$ \\
\hline 6. & 224 & $0 /+$ & $0 /+$ & $+/++$ & $0 /+$ & ++ & + & $\begin{array}{c}+/+ \\
+\end{array}$ & $0 /+$ & ++ & ++ \\
\hline 7. & 227 & + & $0 /+$ & +++ & 0 & +++ & $+/++$ & +++ & + & +++ & ++ \\
\hline 8. & 247. & $0 /+$ & 0 & 0 & 0 & $+/++$ & $0 /+$ & 0 & 0 & $0 /+$ & $0 /+$ \\
\hline 9. & 258 & ++ & +++ & $0 /+$ & $0 /+$ & ++ & $+/++$ & $\begin{array}{c}+/+ \\
+\end{array}$ & +++ & $++/+++$ & $\begin{array}{c}++/++ \\
+\end{array}$ \\
\hline 10. & 259. & ++ & +++ & ++ & $0 /+$ & $+/++$ & $+/++$ & $\begin{array}{c}+/+ \\
+\end{array}$ & +++ & +++ & $\begin{array}{c}++/++ \\
+\end{array}$ \\
\hline 11. & 262. & $0 /+$ & +++ & $\begin{array}{c}++/+ \\
++\end{array}$ & ++ & ++ & $+/++$ & +++ & +++ & +++ & +++ \\
\hline 12. & 277. & $0 /+$ & $0 /+$ & $+/++$ & + & ++ & ++ & +++ & +++ & + & + \\
\hline 13. & 279. & $0 /+$ & $0 /+$ & 0 & 0 & ++ & ++ & ++ & ++ & +++ & $\begin{array}{c}++/++ \\
+ \\
\end{array}$ \\
\hline 14. & 282. & ++ & +++ & $+/++$ & $0 /+$ & $+/++$ & +++ & + & + & $\begin{array}{c}+++/+++ \\
+\end{array}$ & ++++ \\
\hline 15. & 283 & ++ & +++ & $+/++$ & $0 /+$ & ++ & ++ & $\begin{array}{c}+/+ \\
+\end{array}$ & $+/++$ & $++/+++$ & +++ \\
\hline 16. & 284. & ++ & +++ & ++ & $\begin{array}{c}+/+ \\
+ \\
\end{array}$ & +++ & ++ & $\begin{array}{l}++/ \\
+++ \\
\end{array}$ & ++ & +++ & ++++ \\
\hline 17. & 288. & $0 /+$ & $0 /+$ & $0 /+$ & $0 /+$ & $+/++$ & $0 /+$ & + & + & ++ & ++ \\
\hline 18. & 289. & ++ & +++ & 0 & 0 & ++ & ++ & $\begin{array}{c}+/+ \\
+ \\
\end{array}$ & +++ & $++/+++$ & ++++ \\
\hline 19. & 299. & ++ & $+/++$ & $+/++$ & + & ++ & ++ & $\begin{array}{c}+/+ \\
+ \\
\end{array}$ & ++ & +++ & ++++ \\
\hline 20 & 300 & $\begin{array}{c}++/+ \\
++\end{array}$ & $\begin{array}{c}+++ \\
+\end{array}$ & ++ & $0 /+$ & $+/++$ & $0 /+$ & ++ & +++ & ++ & ++ \\
\hline
\end{tabular}




\begin{tabular}{|c|c|c|c|c|c|c|c|c|c|c|c|}
\hline \multicolumn{10}{|c|}{ Nr. } & \multirow{2}{*}{ Šifrs } & \multicolumn{2}{|c|}{$M M P-2$} & \multicolumn{1}{c|}{$M M P-8$} & \multicolumn{2}{c|}{$M M P-9$} & \multicolumn{2}{c|}{$T I M P-2$} & \multicolumn{2}{c|}{ TIMP-4 } \\
\cline { 3 - 11 } & & $\mathrm{E}$ & $\mathrm{S}$ & $\mathrm{E}$ & $\mathrm{S}$ & $\mathrm{E}$ & $\mathrm{S}$ & $\mathrm{E}$ & $\mathrm{S}$ & $\mathrm{E}$ & $\mathrm{S}$ \\
\hline 21. & 302. & ++ & +++ & ++ & $0 /+$ & +++ & $+/++$ & +++ & $\begin{array}{c}++++ \\
+\end{array}$ & +++ & +++ \\
\hline 22. & 303. & $+/++$ & $\begin{array}{c}++/+ \\
++\end{array}$ & ++ & $0 /+$ & $\begin{array}{c}++/++ \\
+\end{array}$ & ++ & $0 /+$ & $0 /+$ & +++ & +++ \\
\hline 23. & 306. & $0 /+$ & $0 /+$ & $+/++$ & $0 /+$ & ++ & + & + & + & $++/+++$ & ++ \\
\hline 24. & 307. & $0 /+$ & +++ & $+/++$ & $0 /+$ & $\begin{array}{c}++/+ \\
+\end{array}$ & +++ & $\begin{array}{c}+/+ \\
+\end{array}$ & +++ & $\begin{array}{c}++++++ \\
+\end{array}$ & ++++ \\
\hline
\end{tabular}

Apzīmējumi tabulā: 0 - redzes laukā nav konstatēta neviena pozitīva struktūra; 0/+ - redzes laukā ir retas pozitīvas struktūras; + - redzes laukā ir maz pozit̄ivu struktūru; +/++ - redzes laukā ir maz līdz vidēji daudz pozitīvu struktūru; ++ - redzes laukā ir vidēji daudz pozitīvu struktūru; ++/+++ - redzes laukā ir vidēji daudz līdz daudz pozitīvu struktūru; +++ - redzes laukā ir daudz pozitīvu struktūru; +++/++++ - redzes laukā ir daudz līdz loti daudz pozitīivu struktūru; ++++ - redzes laukā ir l̦oti daudz pozitīvu struktūru.

Saīsinājumi tabulā: E - epitēlijšūnas; $\mathrm{S}$ - saistaudu šūnas; $M M P-2$ - matrices metaloproteināze-2; $M M P-8-$ matrices metaloproteināze-8; MMP-9 - matrices metaloproteināze-9; TIMP-2 - matrices metaloproteināzes-2 audu inhibitors; TIMP-4 - matrices metaloproteināzes-4 audu inhibitors.

Statistiskie dati. Tika atklāta tendence uz imūnhistoķīmiski noteikto epitēlijšūnu relatīvā daudzuma vidējo rangu atšķirību starp vienpusējām un abpusējām caurejošām lūpas, alveolārā izauguma un aukslēju šķeltnēm. Pacientiem ar abpusēju caurejošu šķeltni $\underline{M M P-2}$ pozitīvo epitēlijšūnu relatīvais daudzums bija statistiski ticami lielāks, salīdzinot ar pacientiem, kuriem bija vienpusēja caurejoša šķeltne $(\mathrm{p}<0,001)$ (3.1. attēls). Imūnhistoķīmiski noteikto $M M P-2$ pozitīvo saistaudu šūnu vidējais relatīvais daudzums gan vienpusēju, gan abpusēju caurejošu šķeltṇu skartajos audos bija statistiski ticami lielāks nekā kontroles grupas pacientiem $(\mathrm{p}<0,05)$ (3.2. attēls). 


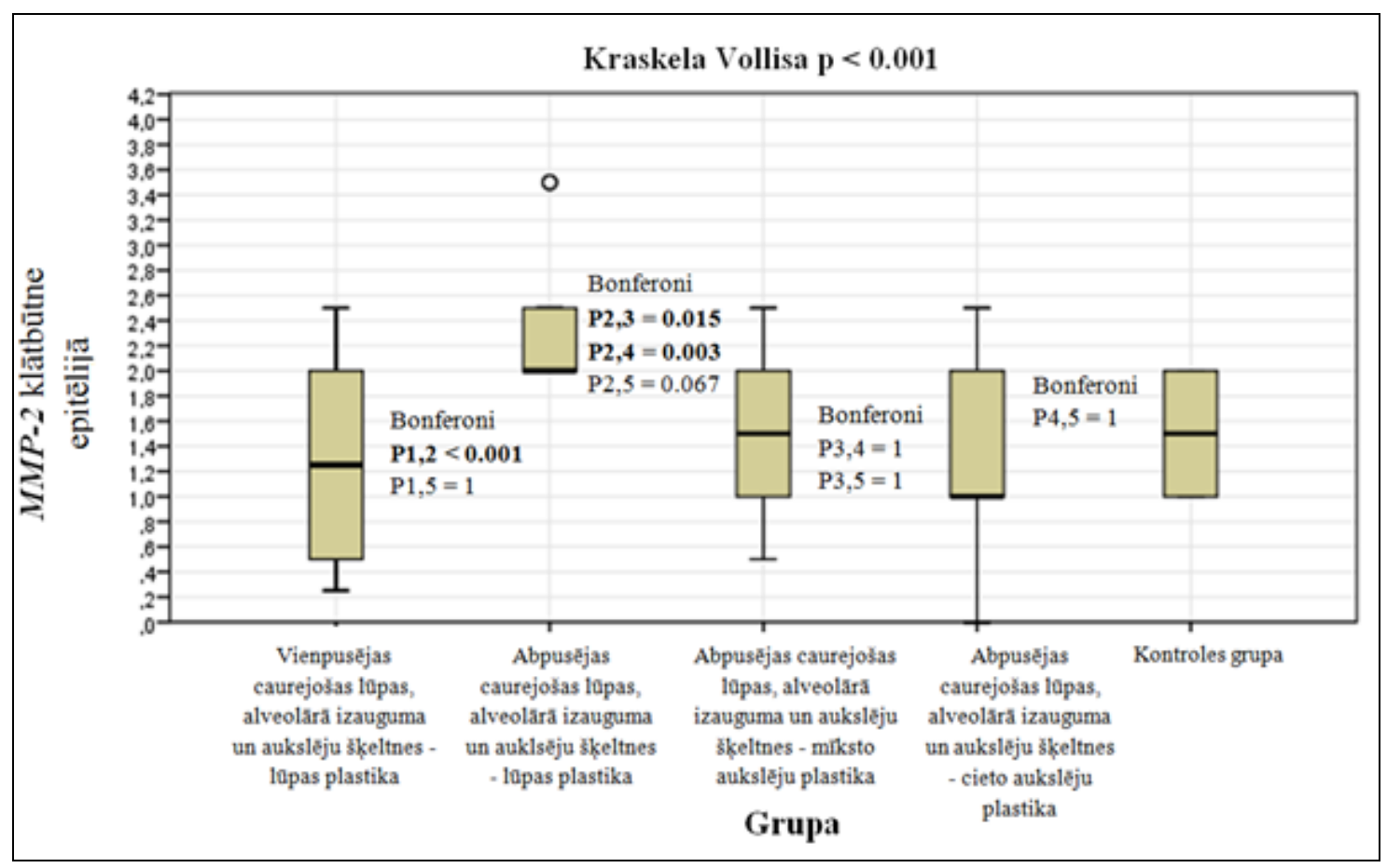

3.1. attēls. Matrices metaloproteināzi-2 (MMP-2) saturošo imūnhistoḳīmiski noteikto epitēlijšūnu relatīvā daudzuma vidējo rangu atšķirības starp dažādām izmeklējamā materiāla grupām

Saīsinājumi attēlā: $M M P-2$ - matrices metaloproteināze-2; P1 - vienpusējas caurejošas lūpas un aukslēju šḳeltnes grupa pēc lūpas plastikas; P2 - abpusējas caurejošas lūpas un aukslēju šķeltnes grupa pēc lūpas plastikas; P3 - abpusējas caurejošas lūpas un aukslēju šķeltnes grupa pēc mīksto aukslēju plastikas; P4 abpusējas caurejošas lūpas un aukslēju šķeltnes grupa pēc cieto aukslēju plastikas; P5 kontroles grupa.

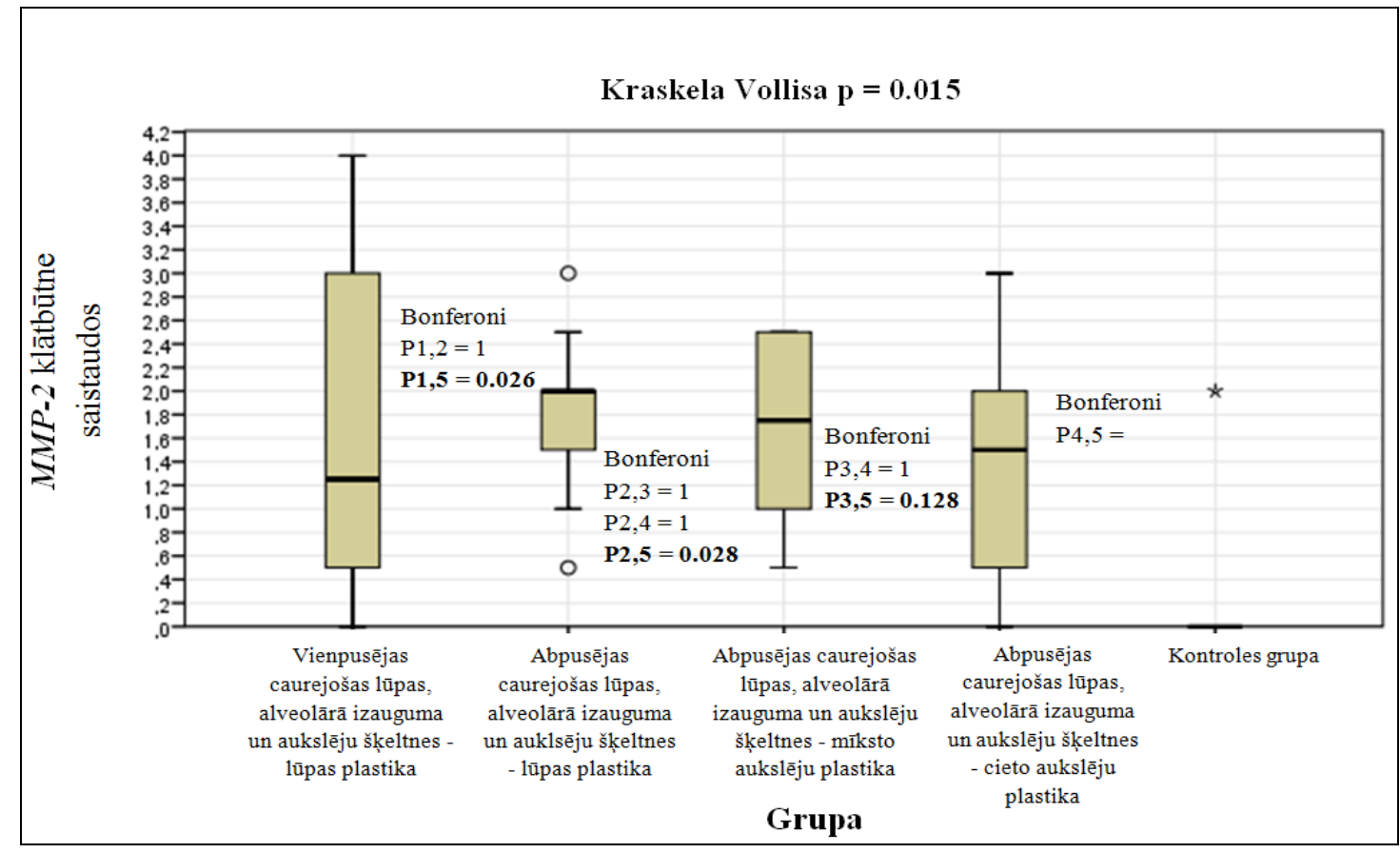

3.2. attēls. Matrices metaloproteināzi-2 (MMP-2) saturošo imūnhistoķīmiski noteikto saistaudu šūnu relatīvā daudzuma vidējo rangu atšķirības starp dažādām izmeklējamā materiāla grupām

Saīsinājumi attēlā: $M M P-2$ - matrices metaloproteināze-2; P1 - vienpusējas caurejošas lūpas un aukslēju šḳeltnes grupa pēc lūpas plastikas; P2 - abpusējas caurejošas lūpas un aukslēju šķeltnes grupa pēc lūpas plastikas; P3 - abpusējas caurejošas lūpas un aukslēju šķeltnes grupa pēc mīksto aukslēju plastikas; P4 abpusējas caurejošas lūpas un aukslēju šķeltnes grupa pēc cieto aukslēju plastikas; P5 - kontroles grupa 
Matrices metaloproteināzes-2 (MMP-2) atrade mīksto un cieto aukslēju plastikas laikā iegūtajā materiālā bērniem ar abpusēju caurejošu lūpas, alveolārā izauguma un aukslēju šķeltni

Visiem audu paraugiem mīksto aukslēju plastikas laikā iegūtajā materiālā tika novērotas $M M P-2$ pozitīvas epitēlijšūnas un saistaudu šūnas. Mīksto aukslēju epitēlijā bija reti $(0 /+)$ līdz vidēji daudz (++) MMP-2 saturošu šūnu redzes laukā (3.9. tabula). Saistaudu $M M P$ 2 pozitīvās šūnas variēja no retām $(0 /+)$ līdz daudz $(+++)$ redzes laukā (3.9. tabula; 3.34 . mikrofotogrāfija pielikumā).

3.9. tabula

$M M P$ un TIMP pozitīvu struktūru relatīvais daudzums abpusēju caurejošu lūpas, alveolārā izauguma un aukslēju šķ̧eltņu skartajos audos, kas iegūti mīksto aukslēju plastikas laikā

\begin{tabular}{|l|c|c|c|c|c|c|c|c|c|c|c|}
\hline \multirow{2}{*}{ Nr. } & \multirow{2}{*}{ Sifrs } & \multicolumn{2}{|c|}{$M M P-2$} & \multicolumn{2}{c|}{$M M P-8$} & \multicolumn{2}{c|}{$M M P-9$} & \multicolumn{2}{c|}{ TIMP-2 } & \multicolumn{2}{c|}{ TIMP-4 } \\
\cline { 3 - 13 } & & $\mathrm{E}$ & $\mathrm{S}$ & $\mathrm{E}$ & $\mathrm{S}$ & $\mathrm{E}$ & $\mathrm{S}$ & $\mathrm{E}$ & $\mathrm{S}$ & $\mathrm{E}$ & $\mathrm{S}$ \\
\hline 1. & 79 & $+/++$ & $++/+++$ & $0 /+$ & $0 /+$ & ++ & +++ & $0 /+$ & ++ & +++ & ++ \\
\hline 2. & 187 & ++ & ++ & 0 & 0 & 0 & 0 & 0 & 0 & 0 & 0 \\
\hline 3. & 196 & $+/++$ & $0 /+$ & $0 /+$ & 0 & $+/++$ & $+/++$ & $0 /+$ & $0 /+$ & $+/++$ & +++ \\
\hline 4. & 207 & $0 /+$ & $+/++$ & 0 & 0 & + & + & $0 /+$ & $0 /+$ & ++ & ++ \\
\hline 5. & 245 & $0 /+$ & + & 0 & 0 & $+/++$ & +++ & 0 & 0 & $+/++$ & +++ \\
\hline 6. & 249 & + & + & $0 /+$ & + & + & + & $0 /+$ & 0 & + & ++ \\
\hline 7. & 254 & $+/++$ & $0 /+$ & $0 /+$ & $0 /+$ & ++ & ++ & $0 /+$ & $0 /+$ & $+/++$ & $+/++$ \\
\hline 8. & 261 & $++/+++$ & $++/+++$ & + & $0 /+$ & ++ & +++ & $+/++$ & $0 /+$ & $++/+++$ & ++ \\
\hline 9. & 273 & ++ & $++/+++$ & $+/+$ & $0 /+$ & $++/++$ & +++ & $+/++$ & + & $++/+++$ & $+++/$ \\
& & & & + & & + & & & & & ++++ \\
\hline 10. & 276 & $+/++$ & ++ & ++ & +++ & +++ & +++ & $+/++$ & ++ & +++ & +++ \\
\hline
\end{tabular}

Apzīmējumi tabulā: 0 - redzes laukā nav konstatēta neviena pozitīva struktūra; 0/+ - redzes laukā ir retas pozitīvas struktūras; + - redzes laukā ir maz pozitīvu struktūru; +/++ - redzes laukā ir maz līdz vidēji daudz pozitīvu struktūru; ++ - redzes laukā ir vidēji daudz pozitīvu struktūru; ++/+++ - redzes laukā ir vidēji daudz līdz daudz pozitīvu struktūru; +++ - redzes laukā ir daudz pozitīvu struktūru; +++/++++ - redzes laukā ir daudz līdz ļoti daudz pozitīvu struktūru; ++++ - redzes laukā ir l̦oti daudz pozitīvu struktūru.

Saīsinājumi tabulā: E - epitēlijšūnas; S - saistaudu šūnas; $M M P-2$ - matrices metaloproteināze-2; $M M P-8$ matrices metaloproteināze-8; MMP-9 - matrices metaloproteināze-9; TIMP-2 - matrices metaloproteināzes-2 audu inhibitors; TIMP-4 - matrices metaloproteināzes-4 audu inhibitors.

Cieto aukslēju audos $M M P$-2 saturošas morfologiskās struktūras variēja no retām (0/+) līdz daudz $(+++)$ redzes laukā (3.10. tabula; 3.35. mikrofotogrāfija pielikumā). Diviem pacientiem netika novērota šì enzīma ekspresija.

3.10. tabula

MMP un TIMP pozitīvu struktūru relatīvais daudzums abpusēju caurejošu lūpas, alveolārā izauguma un aukslēju šḳeltṇu skartajos audos, kas iegūti cieto aukslēju plastikas laikā

\begin{tabular}{|l|c|c|c|c|c|c|c|c|c|c|c|}
\hline \multirow{2}{*}{ Nr. } & \multirow{2}{*}{ Sifrs } & \multicolumn{2}{|c|}{$M M P-2$} & \multicolumn{2}{c|}{$M M P-8$} & \multicolumn{2}{c|}{$M M P-9$} & \multicolumn{2}{c|}{ TIMP-2 } & \multicolumn{2}{c|}{ TIMP-4 } \\
\cline { 3 - 12 } & & $\mathrm{E}$ & $\mathrm{S}$ & $\mathrm{E}$ & $\mathrm{S}$ & $\mathrm{E}$ & $\mathrm{S}$ & $\mathrm{E}$ & $\mathrm{S}$ & $\mathrm{E}$ & $\mathrm{S}$ \\
\hline 1. & $79 / 1$ & $+/++$ & $++/+++$ & $0 /+$ & $0 /+$ & ++ & +++ & $+/++$ & ++ & +++ & ++ \\
\hline 2. & 81 & 0 & 0 & 0 & 0 & 0 & 0 & 0 & 0 & ++ & +++ \\
\hline 3. & $134 / 1$ & $0 /+$ & 0 & 0 & $0 /+$ & 0 & + & 0 & 0 & ++ & ++ \\
\hline 4. & $134 / 2$ & + & $0 /+$ & $0 /+$ & $0 /+$ & + & +++ & 0 & 0 & ++ & ++ \\
\hline
\end{tabular}




\begin{tabular}{|c|c|c|c|c|c|c|c|c|c|c|c|}
\hline & & & & & & & & & & \multicolumn{2}{|c|}{ tabulas nobeigums } \\
\hline \multirow[t]{2}{*}{$\mathrm{Nr}$. } & \multirow[t]{2}{*}{ Šifrs } & \multicolumn{2}{|c|}{$M M P-2$} & \multicolumn{2}{|c|}{$M M P-8$} & \multicolumn{2}{|c|}{$M M P-9$} & \multicolumn{2}{|c|}{ TIMP-2 } & \multicolumn{2}{|c|}{$T I M P-4$} \\
\hline & & $\mathrm{E}$ & $S$ & $\mathrm{E}$ & $S$ & $\mathrm{E}$ & $S$ & $\mathrm{E}$ & $\mathrm{S}$ & $\mathrm{E}$ & $\mathrm{S}$ \\
\hline 5. & 150 & ++ & + & 0 & 0 & 0 & 0 & ++ & ++ & ++ & ++ \\
\hline 6. & 180 & + & ++ & $0 /+$ & + & $+/++$ & +++ & $0 /+$ & + & ++ & +++ \\
\hline 7. & 232 & ++ & ++ & $+/++$ & $0 /+$ & +++ & +++ & + & + & $++/+++$ & $++/+++$ \\
\hline 8. & 253 & + & $+/++$ & $0 /+$ & $0 /+$ & $+/++$ & ++ & + & $0 /+$ & ++ & +++ \\
\hline 9. & 265 & $\begin{array}{c}++/++ \\
+\end{array}$ & +++ & + & $0 /+$ & +++ & +++ & + & $0 /+$ & +++ & +++ \\
\hline
\end{tabular}

Apzīmējumi tabulā: 0 - redzes laukā nav konstatēta neviena pozitīva struktūra; 0/+ - redzes laukā ir retas pozitīvas struktūras; + - redzes laukā ir maz pozitīivu struktūru; +/++ - redzes laukā ir maz līdz vidēji daudz pozitīvu struktūru; ++ - redzes laukā ir vidēji daudz pozitīvu struktūru; ++/+++ - redzes laukā ir vidēji daudz līdz daudz pozitīvu struktūru; +++ - redzes laukā ir daudz pozitīvu struktūru; +++/++++ - redzes laukā ir daudz līdz loti daudz pozitīivu struktūru; ++++ - redzes laukā ir l̦oti daudz pozitīvu struktūru.

Saīsinājumi tabulā: E - epitēlijšūnas; S - saistaudu šūnas; $M M P-2$ - matrices metaloproteināze-2; $M M P-8-$ matrices metaloproteināze-8; MMP-9 - matrices metaloproteināze-9; TIMP-2 - matrices metaloproteināzes-2 audu inhibitors; TIMP-4 - matrices metaloproteināzes-4 audu inhibitors.

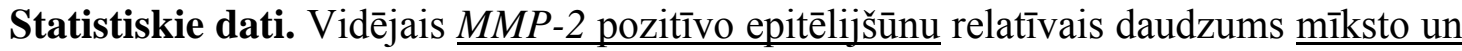
cieto aukslēju plastikas laikā iegūtajos audos bija statistiski ticami mazāks nekā lūpas plastikas laikā iegūtos audos no bērniem ar abpusēju caurejošu lūpas, alveolārā izauguma un aukslēju škseltni $(\mathrm{p}<0,05)$ (3.2. attēls). Statistiski ticamas atšķirības ar kontroles grupas pacientiem netika konstatētas. 
Matrices metaloproteināzes-8 (MMP-8) atrade lūpas primārās plastikas laikā iegūtajā materiālā zīdaiņiem un bērniem ar caurejošu lūpas, alveolārā izauguma un aukslēju šḳeltni

MMP-8 klātbūtne tika konstatēta pacientiem ar abpusēju škseltni - 13 pacientu epitēlijā un visu 15 pacientu saistaudos - fibroblastos un makrofāgos. Epitēlijā bija retas (0/+) $M M P-8$ pozitīvas šūnas diviem pacientiem, maz $(+)$ - pieciem pacientiem, vidēji daudz $(++)-$ pieciem pacientiem, bet vienam pacientam - daudz (+++) pozitīvu struktūru redzes laukā. Divpadsmit pacientiem lamina propria bija atsevišksas $(0 /+) M M P-8$ pozitīvas un trīs pacientiem - maz $(+)$ pozitīvas šūnas (3.7. tabula; 3.36. mikrofotogrāfija pielikumā).

MMP-8 saturēja arī 21 pacienta ar vienpusēju šķeltni šūnas epitēlijā. Trīs pacientu paraugos netika fiksētas $M M P-8$ saturošas šūnas. Pētījumā novērots no retām $(0 /+)$ līdz daudz (+++) MMP-8 pozitīvām šūnām epitēlijā (3.8. tabula). Lamina propria saturēja retas $(0 /+)$ līiz maz (+) MMP-8 pozitīvas saistaudu šūnas (3.8. tabula; 3.37. mikrofotogrāfija pielikumā). Kopumā tika konstatēts maz līdz vidēji daudz (+/++) MMP-8 pozitīvu šūnu epitēlijā, kamēr saistaudos tikai atsevišksas $(0 /+)$ pozitīvas šūnas.

Statistiskie dati. Salīdzinot imūnhistoķīmiski noteikto epitēlijšūnu un saistaudu šūnu vidējos rangus, netika novērota statistiski ticama atškirība starp vienpusēju un abpusēju caurejošu škseltni, kā arī kontroles grupas pacientiem $(p>0,05)$ (3.3. attēls).

\section{Matrices metaloproteināzes-8 (MMP-8) atrade mīksto un cieto aukslēju plastikas laikā iegūtajā materiālā bērniem ar abpusējām caurejošām lūpas, alveolārā izauguma un aukslēju škseltnēm}

Trim pacientiem ar abpusēju šķeltni netika fiksētas $M M P-8$ pozitīvas šūnas mīkstajās aukslējās. Vienam pacientam bija vidēji daudz $(++) M M P-8$ saturošas šūnas epitēlijā un daudz $(+++)$ pozitīvas šūnas saistaudos (3.9. tabula; 3.38. mikrofotogrāfija pielikumā). Citos audu paraugos $M M P-8$ pozitīvo šūnu relatīvais daudzums bija no retām $(0 /+)$ līdz maz $(+)$ šūnām gan mutes dobuma gḷotādas epitēlijā, gan saistaudos (3.9. tabula).

Kopumā cieto aukslēju glototāā $M M P-8$ pozitīvo epitēlijšūnu un saistaudu šūnu relatīvais daudzums variēja no retām $(0 /+)$ līdz vidēji daudz (++) redzes laukā (3.10. tabula; 3.39. mikrofotogrāfija pielikumā).

Statistiskie dati. Imūnhistoķīmiski noteikto $M M P-8$ pozitīvo epitēlijšūnu vidējais relatīvais daudzums cieto aukslēju plastikas laikā paņemtajos audos bija statistiski ticami mazāks nekā lūpas plastikas laikā paņemtajā materiālā $(\mathrm{p}<0,05)$ (3.3. attēls). Salīdzinot imūnhistoķīmiski noteiktas saistaudu šūnu vidējos rangus, netika novērota statistiski ticama atšķirība starp izmeklējamā materiāla grupām $(\mathrm{p}>0,05)$. Statistiski ticamas atšķirības starp 
pacientiem ar abpusēju caurejošu šķeltni pēc mīksto un cieto aukslēju plastikas un kontroles grupas pacientiem netika konstatētas.

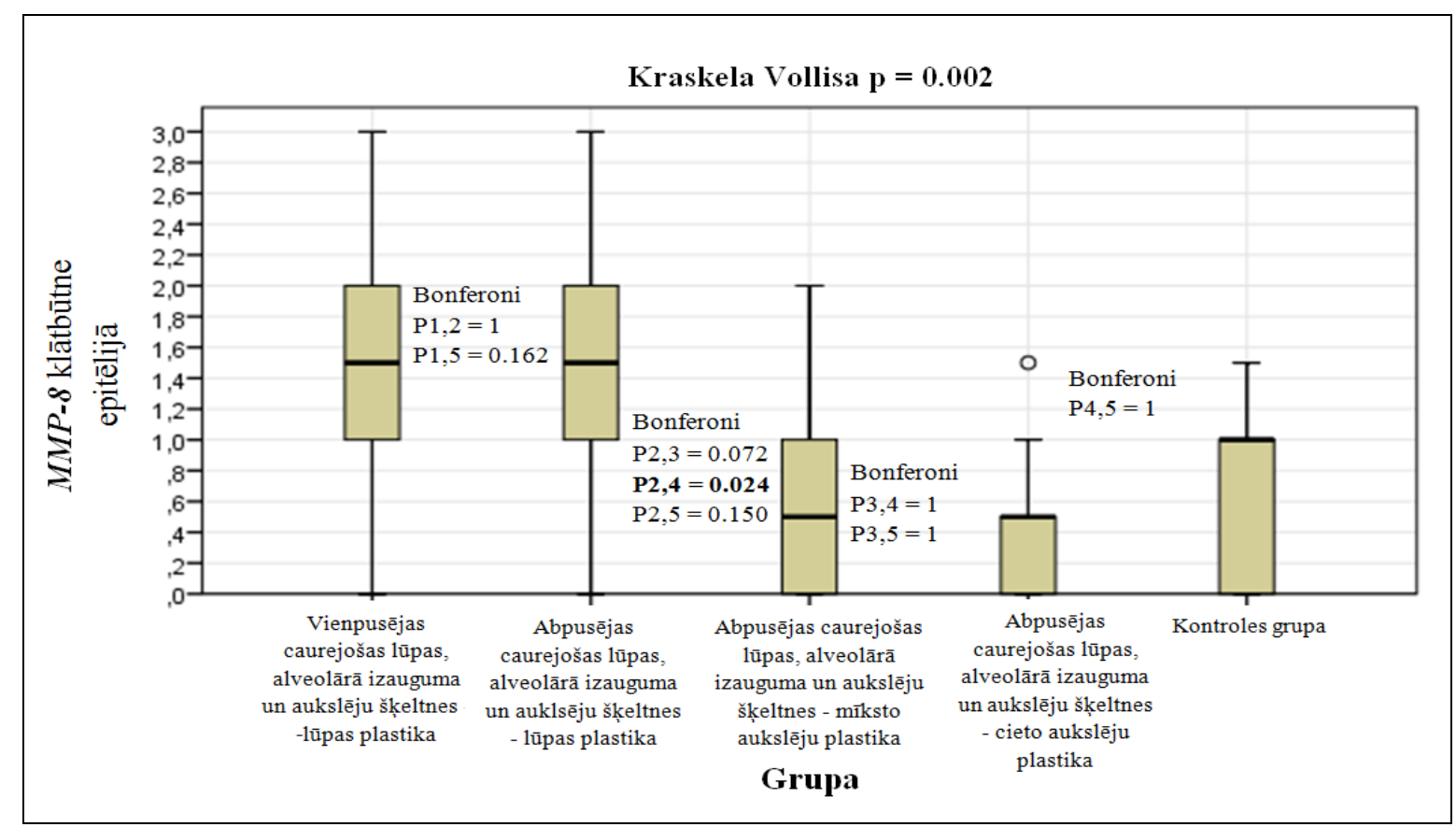

3.3. attēls. Matrices metaloproteināzi-8 $(M M P-8)$ saturošo imūnhistoḳīmiski noteikto epitēlijšūnu relatīvā daudzuma vidējo rangu atšķirības starp dažādām izmeklējamā materiāla grupām

Saīsinājumi attēlā: $M M P-8$ - matrices metaloproteināze-8; P1 - vienpusējas caurejošas lūpas un aukslēju šķeltnes grupa pēc lūpas plastikas; P2 - abpusējas caurejošas lūpas un aukslēju šķeltnes grupa pēc lūpas plastikas; P3 - abpusējas caurejošas lūpas un aukslēju šķeltnes grupa pēc mīksto aukslēju plastikas; P4 abpusējas caurejošas lūpas un aukslēju šķeltnes grupa pēc cieto aukslēju plastikas; P5 - kontroles grupa.

\section{Matrices metaloproteināzes-9 (MMP-9) atrade lūpas primārās plastikas laikā iegūtajā materiālā no zīdaiṇiem un bērniem ar caurejošu lūpas, alveolārā izauguma un aukslēju škseltni}

Lūpas plastikas laikā iegūtajā materiālā no pacientiem ar abpusēju škseltni tika konstatēta $M M P-9$ ekspresija epitēlijā, saistaudos, matu folikulos un tauku dziedzeros. Augšlūpas gḷotādā $M M P-9$ pozitīvas šūnas netika saskatītas divu pacientu audu paraugos. Pacientiem ar abpusēju caurejošu lūpas, alveolārā izauguma un aukslēju škseltni tika fiksētas tikai retas (0/+) MMP-9 pozitīvas epitēlijšūnas un saistaudu šūnas (3.7. tabula; 3.40. mikrofotogrāfija pielikumā).

Interesanti, ka visiem pacientiem ar vienpusēju šķeltni $M M P-9$ pozitīvu epitēlijšūnu bija robežās no maz (+) līdz daudz (+++) redzes laukā (3.8. tabula). Turklāt šo enzīmu ekspresēja bazālā slāņa šūnas un arī saistaudu šūnas (3.41. mikrofotogrāfija pielikumā). Šāda atrade netika manīta pacientiem abpusēju šķelțu materiālā. Kopumā konstatējām vidēji daudz (++) MMP-9 pozitīvas epitēlijšūnas. Mutes dobuma glotādas lamina propria šūnas arī saturēja $M M P-9$. Saistaudos $M M P-9$ klātbūtne variēja no atsevišķām (0/+) līdz daudz (+++) pozitīiām šūnām redzes laukā (3.8. tabula). 
Statistiskie dati. Imūnhistoķīmiski noteikto $M M P-9$ pozitīvo epitēlijšūnu vidējais relatīvais daudzums vienpusēju šķeltņu skartajos audos bija statistiski ticami lielāks nekā kontroles grupas pacientiem $(\mathrm{p}<0,001)$ (3.4. attēls). Vidējais imūnhistoķīmiski noteiktais MMP-9 pozitīvo šūnu relatīvais daudzums saistaudos abpusējas caurejošas lūpas un aukslēju šķeltnes pacientu audos bija statistiski ticami mazāks nekā vienpusējas caurejošas lūpas un aukslēju šķeltnes pacientu audos ( $<<0,001)$ (3.5. attēls).

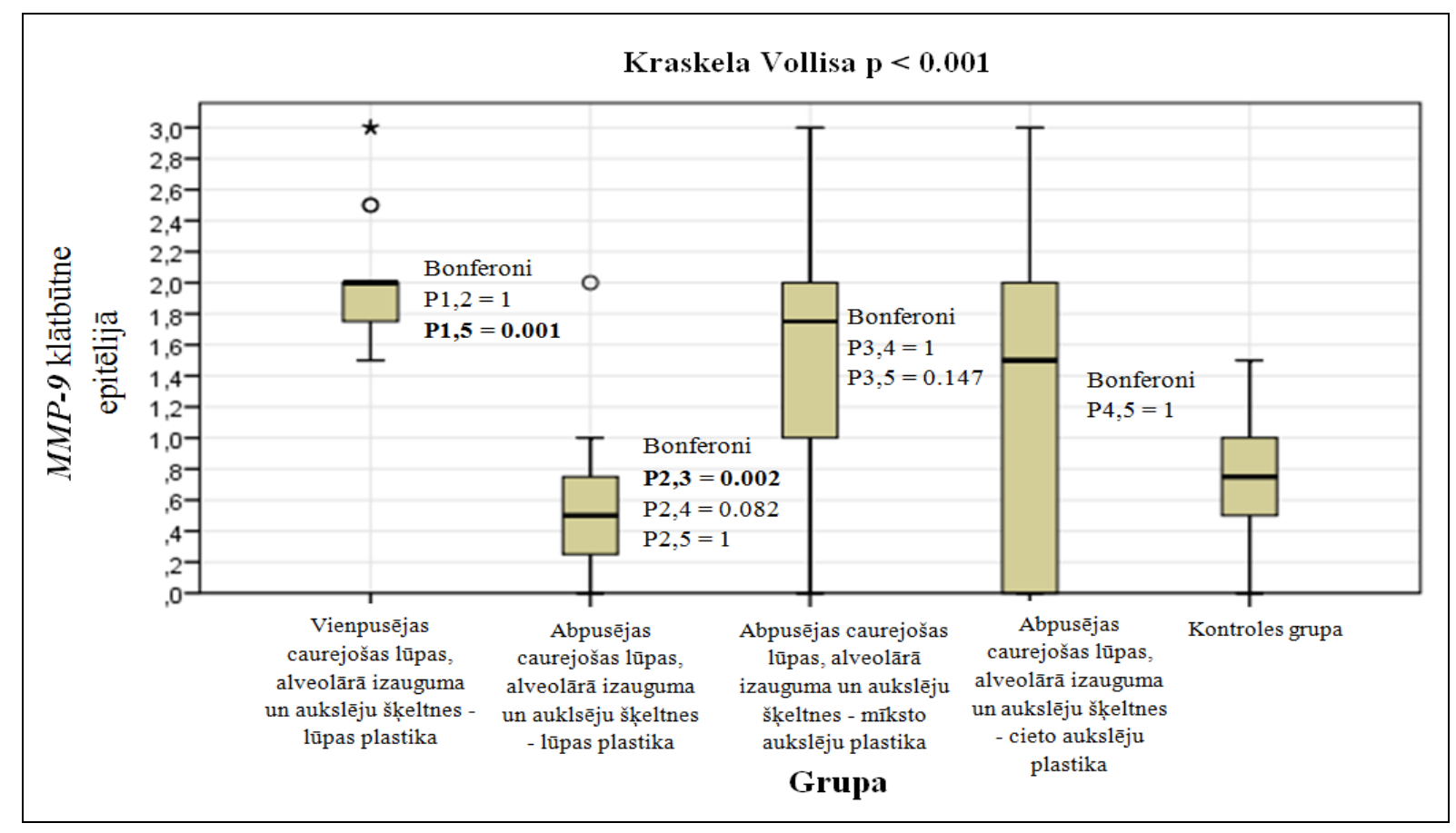

3.4. attēls. Matrices metaloproteināzi-9 (MMP-9) saturošo imūnhistoķīmiski noteikto epitēlijšūnu relatīvā daudzuma vidējo rangu atšksirības starp dažādām izmeklējamā materiāla grupām

Saīsinājumi attēlā: $M M P$-9 - matrices metaloproteināze-9; P1 - vienpusējas caurejošas lūpas un aukslēju šķeltnes grupa pēc lūpas plastikas; P2 - abpusējas caurejošas lūpas un aukslēju šķeltnes grupa pēc lūpas plastikas; P3 - abpusējas caurejošas lūpas un aukslēju šķeltnes grupa pēc mīksto aukslēju plastikas; P4 abpusējas caurejošas lūpas un aukslēju šķeltnes grupa pēc cieto aukslēju plastikas; P5 - kontroles grupa. 


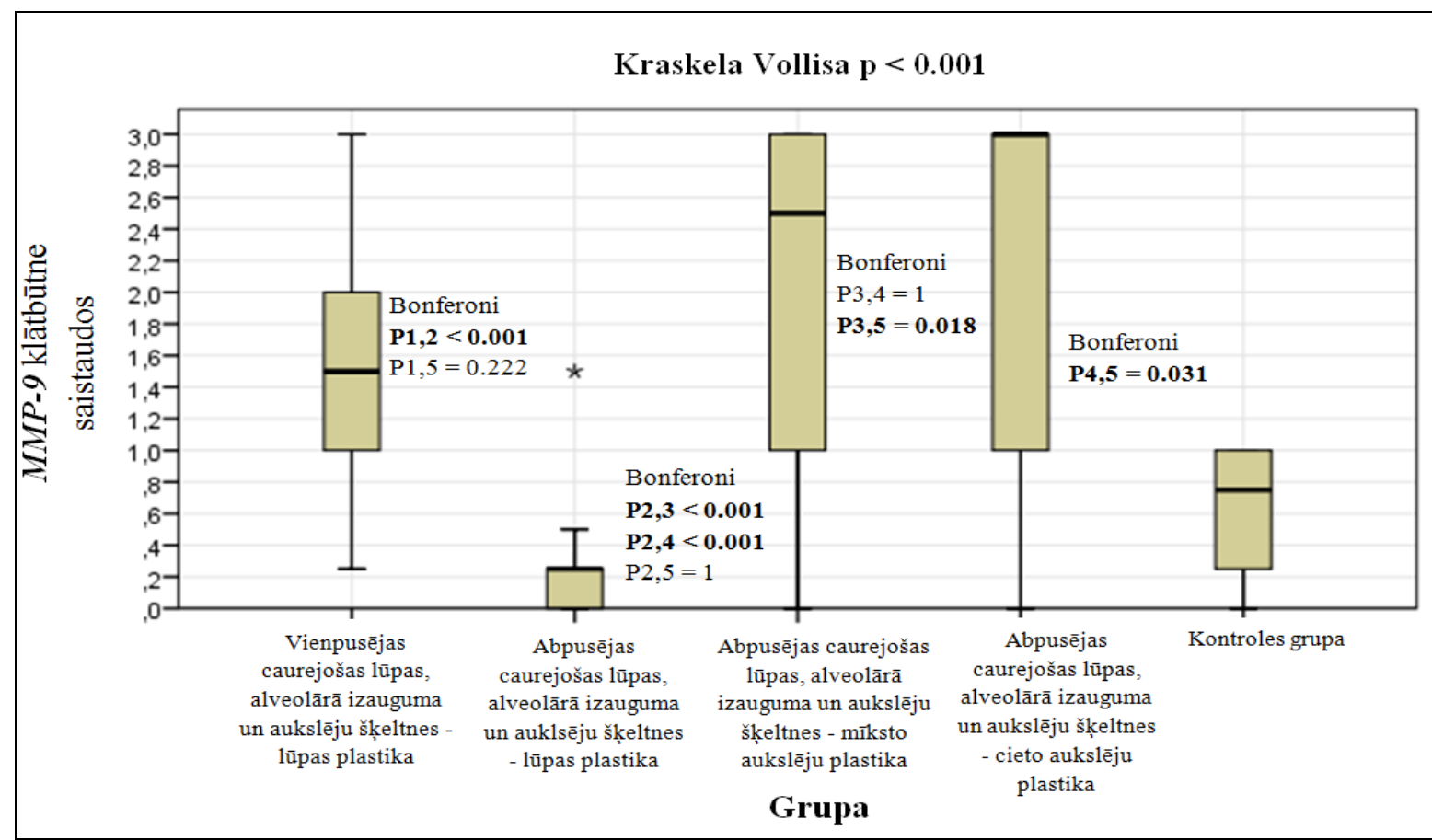

3.5. attēls. Matrices metaloproteināzi-9 (MMP-9) saturošo imūnhistoķīmiski noteikto saistaudu šūnu relatīvā daudzuma vidējo rangu atšķirības starp dažādām izmeklējamā materiāla grupām Saīsinājumi attēlā: $M M P-9$ - matrices metaloproteināze-9; P1 - vienpusējas caurejošas lūpas un aukslēju šķeltnes grupa pēc lūpas plastikas; P2 - abpusējas caurejošas lūpas un aukslēju šķeltnes grupa pēc lūpas plastikas; P3 - abpusējas caurejošas lūpas un aukslēju šķeltnes grupa pēc mīksto aukslēju plastikas; P4 abpusējas caurejošas lūpas un aukslēju šķeltnes grupa pēc cieto aukslēju plastikas; P5 - kontroles grupa.

\section{Matrices metaloproteināzes-9 (MMP-9) atrade mīksto un cieto aukslēju plastikas laikāa iegūtajā materiālā bērniem ar abpusējām caurejošām lūpas, alveolārā izauguma un aukslēju škseltnēm}

Mīksto aukslēju plastikas laikā iegūtajā materiālā $M M P-9$ pozitīvie epiteliocīti variēja no maz $(+)$ līdz daudz $(+++)$ redzes laukā (3.9. tabula). MMP-9 pozitīvo saistaudu šūnu atrade bija līdzīga, kaut gan vidējais imūnreaktīvo struktūru daudzums saistaudos bija lielāks (3.9. tabula; 3.42. mikrofotogrāfija pielikumā). Pieciem pacientiem konstatējām daudz (+++) $M M P-9$ pozitīvas saistaudu šūnas (3.9. tabula).

Cieto aukslēju plastikas laikā iegūtajā materiālā $M M P-9$ pozitīvas epitēlijšūnas sešiem pacientiem variēja no maz $(+)$ līdz daudz $(+++)$, trīs pacietiem MMP-9 ekspresija netika konstatēta (3.10. tabula). MMP-9 pozitīvas saistaudu šūnas septiņiem pacientiem tika konstatētas robežās no maz $(+)$ līdz daudz $(+++)$, diviem pacientiem MMP-9 saistaudu šūnās netika vizualizētas.

Statistiskie dati. Mīksto aukslēju plastikas laikā iegūtajā materiālā vidējais $\underline{M M P-9}$ pozitīvo struktūru relatīvais daudzums epitēlijā bija statistiski ticami lielāks nekā lūpas plastikas laikā iegūtajā materiālā $(\mathrm{p}<0,002)$ (3.4. attēls). Saistaudos tika novērots statistiski ticami lielāks $M M P-9$ saturošo šūnu relatīvais daudzums mīksto un cieto aukslēju plastikas laikā iegūtajā materiālā nekā lūpas plastikas laikā iegūtajos audos ( $<$ 0,001) (3.5. attēls). 
Matrices metaloproteināzes-2 audu inhibitora (TIMP-2) atrade lūpas primārās plastikas laikā iegūtajā materiālā zīdaiņiem un bērniem ar caurejošu lūpas, alveolārā izauguma un aukslēju škseltni

Epitēlijā visos audu paraugos, kas tika iegūti no pacientiem ar abpusēju šķeltni, TIMP2 klātbūtne variēja no maz $(+)$ līdz daudz $(+++)$ pozitīvām šūnām redzes laukā (3.7. tabula; 3.43. mikrofotogrāfija pielikumā). Lamina propria TIMP-2 klātbūtne tika novērota vienlaikus fibroblastos un iekaisuma šūnās, galvenokārt makrofāgos un atsevišķos limfocītos. TIMP-2 saturošas saistaudu šūnas variēja robežās no atsevišksām $(0 /+)$ līdz vidēji daudz (++) redzes laukā.

Izvērtējot vienpusēju škseltņu lūpas audus, tika novērota TIMP-2 ekspresija epitēlijā, saistaudos un matu folikulos. Interesanti, ka tika vizualizētas TIMP-2 saturošas bazālā slāņa šūnas, lai gan pacientiem abpusēju šķeltņu audu paraugos bazālās šūnas nesaturēja TIMP-2 (3.44. mikrofotogrāfija pielikumā). TIMP-2 saturošas šūnas tika konstatētas 23 no 24 pacientiem ar vienpusēju caurejošu lūpas, alveolārā izauguma un aukslēju šķeltni. TIMP-2 pozitīvas šūnas epitēlijā variēja robežās no retām $(0 /+)$ līdz daudz (+++) redzes laukā. Tieši tāda pati atrade tika konstatēta lamina propria audos (3.8. tabula).

Statistiskie dati. Izvērtējot imūnhistoķīmiski noteikto struktūru relatīvā daudzuma vidējos rangus, statistiska ticamība starp grupām pētījumā netika novērota.

Matrices metaloproteināzes-2 audu inhibitora (TIMP-2) atrade mīksto un cieto aukslēju plastikas laikā iegūtajā materiālā bērniem ar abpusēju caurejošu lūpas, alveolārā izauguma un aukslēju škseltni

Mīksto aukslēju plastikas laikā iegūtos audos, respektīvi, epitēlijā un saistaudos, arī tika konstatēta TIMP-2 ekspresija. Trīs pacientu audu paraugos TIMP-2 saturošas šūnas netika vizualizētas. Citu pacientu audu paraugos tika konstatētas atsevišķas $(0 /+)$ līdz vidēji daudz (++) pozitīvas epitēlijšūnas un saistaudu šūnas redzes laukā (3.9. tabula; 3.45. mikrofotogrāfija pielikumā).

Cieto aukslēju plastikas laikā iegūtajos audos tika iegūti tādi paši rezultāti kā mīksto aukslēju materiālā (3.10. tabula).

Statistiskie dati. Vidējais $\underline{T I M P-2}$ pozitīvo šūnu relatīvais daudzums epitēlijā

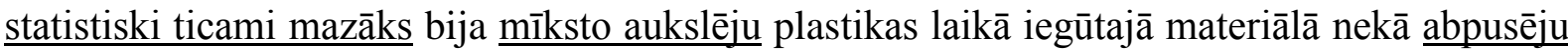
šķeltņu pacientu lūpas plastikas laikā iegūtajos audos ( $<$ < 0,05) (3.6. attēls). Imūnhistoķīmiski izvērtējot noteikto saistaudu šūnu relatīvo daudzumu, atšksirības netika konstatētas. 


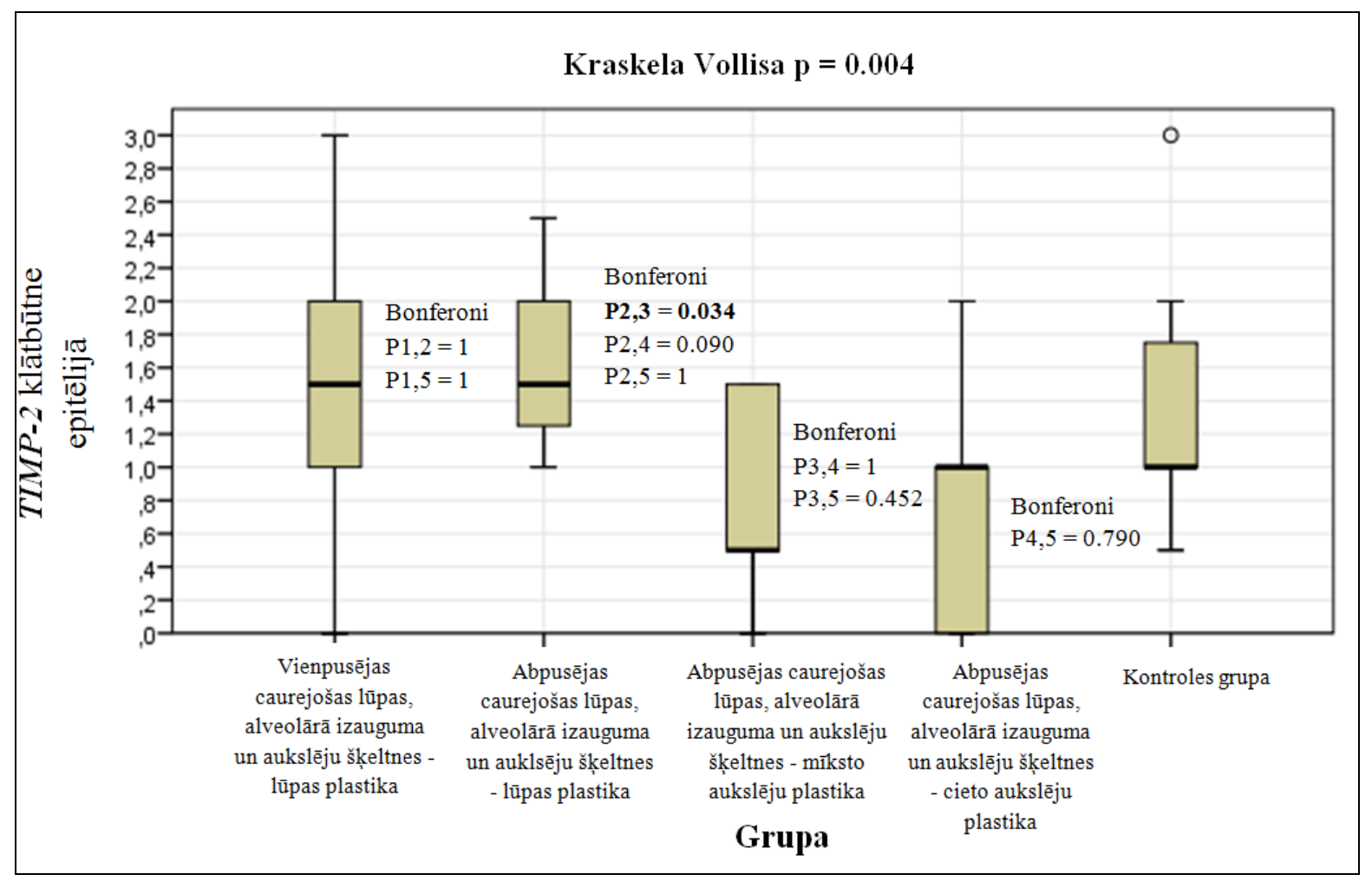

3.6. attēls. Matrices metaloproteināzes-2 audu inhibitora (TIMP-2) saturošo imūnhistoḳīmiski noteikto epitēlijšūnu relatīvā daudzuma vidējo rangu atšksirības starp dažādām izmeklējamā materiāla grupām Saīsinājumi attēlā: TIMP-2 - matrices metaloproteināzes-2 audu inhibitors; P1 - vienpusējas caurejošas lūpas un aukslēju šķeltnes grupa pēc lūpas plastikas; P2 - abpusējas caurejošas lūpas un aukslēju šķeltnes grupa pēc lūpas plastikas; P3 - abpusējas caurejošas lūpas un aukslēju šķeltnes grupa pēc mīksto aukslēju plastikas; P4 abpusējas caurejošas lūpas un aukslēju šķeltnes grupa pēc cieto aukslēju plastikas; P5 - kontroles grupa.

\section{Matrices metaloproteināzes-4 audu inhibitora (TIMP-4) atrade lūpas primārās plastikas laikā iegūtajā materiālā zīdaiņiem un bērniem ar caurejošu lūpas, alveolārā izauguma un aukslēju šķeltni}

Sešiem pacientiem ar abpusēju škseltni netika novērota TIMP-4 klātbūtne ne epitēlijā, ne saistaudos. Kopumā mutes dobuma gḷotādā maz (+) epiteliocītu saturēja TIMP-4. Četriem pacientiem tika fiksēti reti (0/+) TIMP-4 saturoši epiteliocīti, kamēr pārējiem četriem tika atrasts maz (+) līdz vidēji daudz (++) TIMP-4 saturošu epiteliocītu (3.7. tabula). Septingos audu paraugos lamina propria netika konstatēta neviena TIMP-4 saturoša šūna. Astoņiem šķeltņu pacientiem TIMP-4 pozitīvas saistaudu šūnas tika konstatētas robežās no retām $(0 /+)$ līdz maz (+) redzes laukā (3.7. tabula; 3.46. mikrofotogrāfija pielikumā).

TIMP-4 ekspresija vienpusējas šķeltnes lūpu plastikas laikā iegūtajā materiālā bija gan epitēlijāa, gan saistaudos. Matu folikulu un tauku dziedzeru šūnas arī saturēja TIMP-4. Epitēlijā kopumā TIMP-4 saturēja vidēji daudz līdz daudz (++/+++) šūnu. Visvairāk bija pacientu (16) ar vidēji līdz vidēji daudz $(++/+++)$ un daudz $(+++)$ TIMP-4 saturošu epiteliocītu, kamēr astoņiem pacientiem tika redzētas vidēji daudz (++) TIMP-4 saturošas epitēlijšūnas (3.8. tabula). Pētîjumā konstatējām interesantu faktu, ka TIMP-4 pozitīvas šūnas tika novērotas bazālajā slānī, kaut gan pacientu abpusēju šķeltņu audu paraugos TIMP-4 
saturošas šūnas šajā slānī netika fiksētas, savukārt saistaudos TIMP-4 klātbūtne variēja no maz $(+)$ līdz ļoti daudz $(++++)$ pozitīiām šūnām redzes laukā (3.8. tabula; 3.47. mikrofotogrāfija pielikumā).

Statistiskie dati. Izvērtējot imūnreaktīvo epiteliocītu un saistaudu šūnu vidējo relatīvo daudzumu, tika novērotas statistiski ticamas atšķirības starp pētījuma grupām. $\underline{\text { TIMP-4}}$

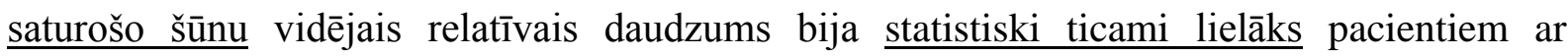
vienpusēju caurejošas lūpas un aukslēju šķeltni, nekā pacientiem ar abpusēju caurejošu lūpas un aukslēju škseltni un kontroles grupas pacientiem (p < 0,05) (3.7. un 3.8. attēls).

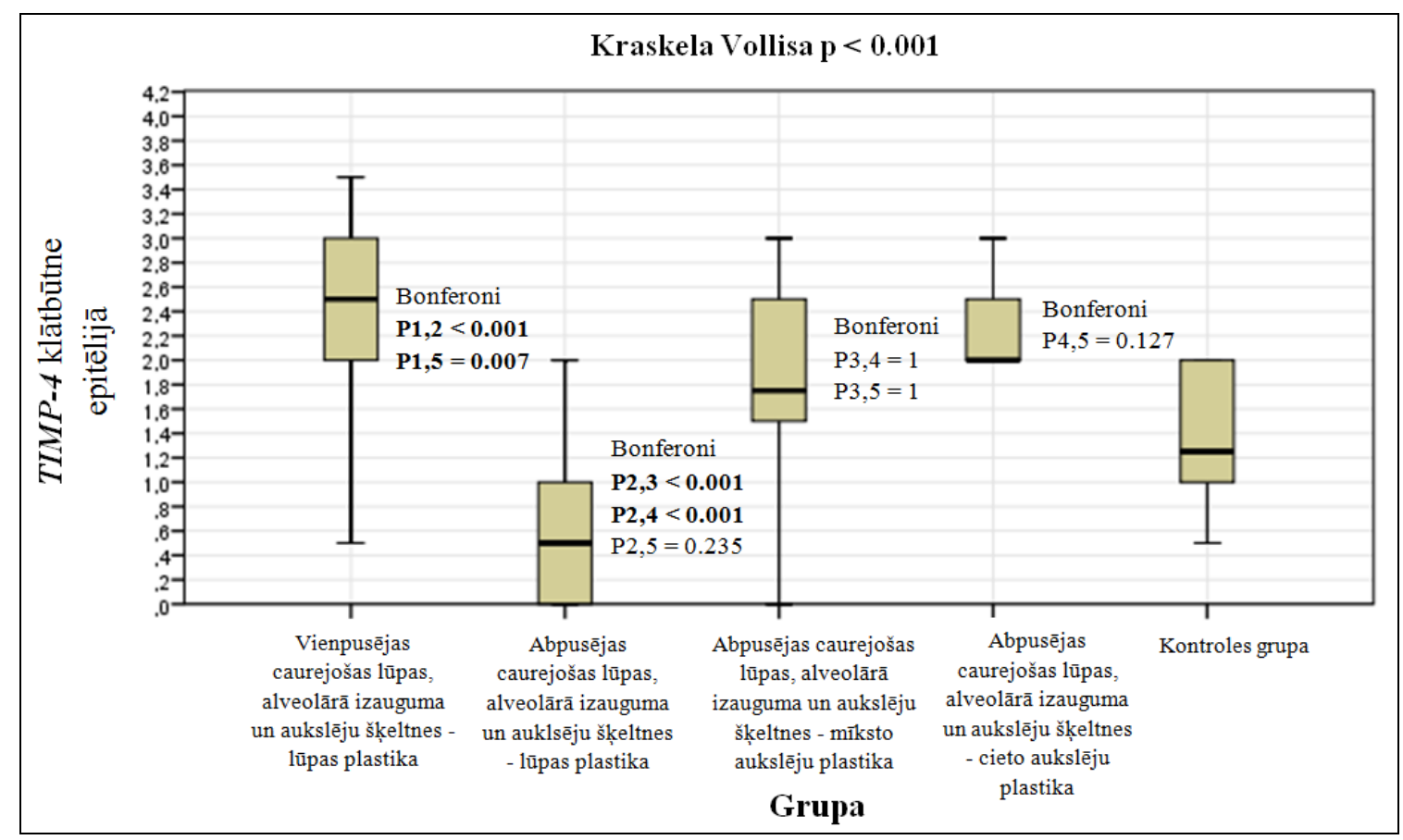

3.7. attēls. Matrices metaloproteināzes-4 audu inhibitora (TIMP-4) saturošo imūnhistoķīmiski noteikto epitēlijšūnu relatīiā daudzuma vidējo rangu atšķirī̄bas starp dažādām izmeklējamā materiāla grupām Saīsinājumi attēlā: TIMP-4 - matrices metaloproteināzes-4 audu inhibitors; P1 - vienpusējas caurejošas lūpas un aukslēju šķeltnes grupa pēc lūpas plastikas; P2 - abpusējas caurejošas lūpas un aukslēju šķeltnes grupa pēc lūpas plastikas; P3 - abpusējas caurejošas lūpas un aukslēju šķeltnes grupa pēc mīksto aukslēju plastikas; P4 abpusējas caurejošas lūpas un aukslēju šķeltnes grupa pēc cieto aukslēju plastikas; P5 - kontroles grupa. 


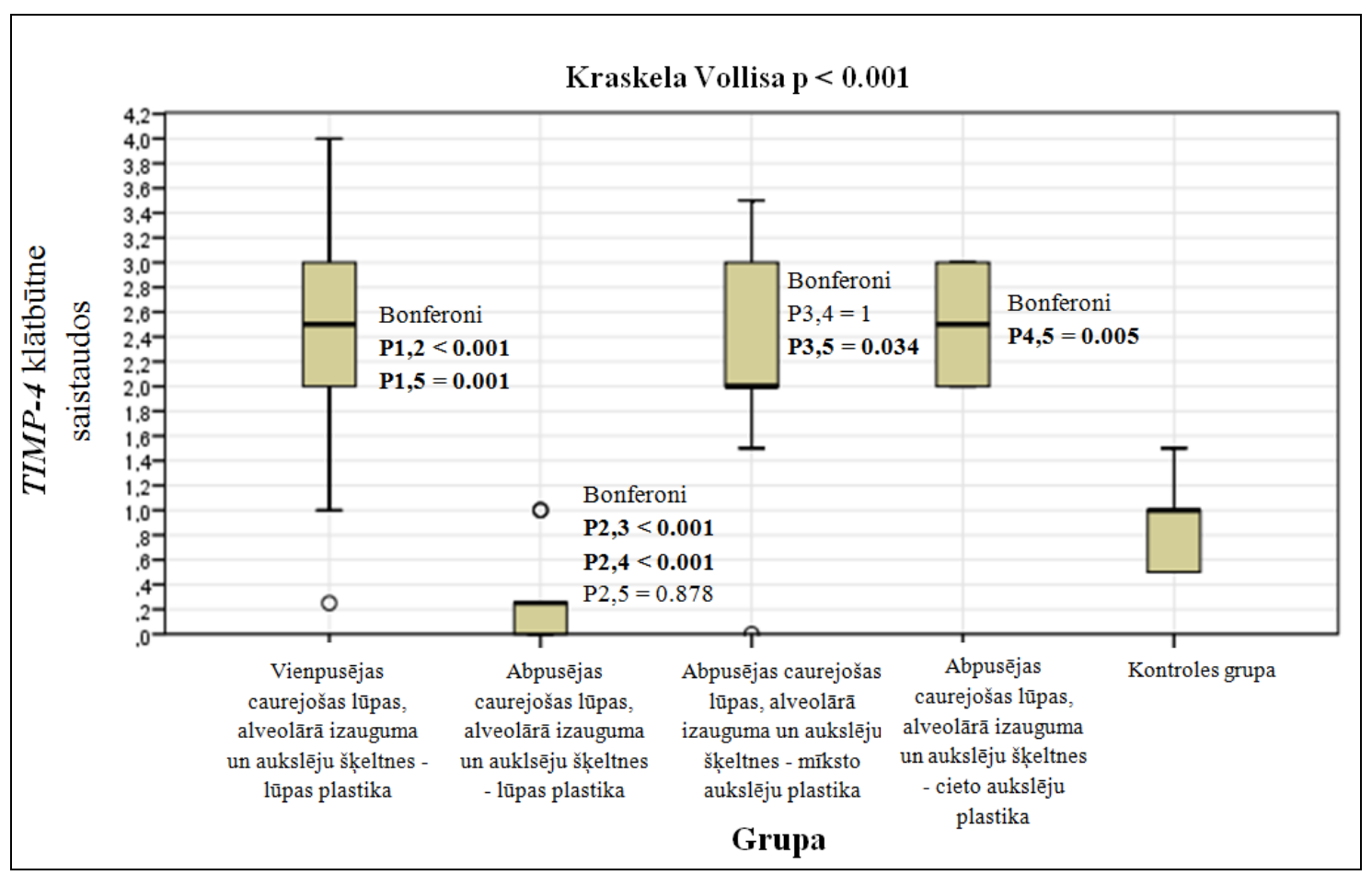

3.8. attēls. Matrices metaloproteināzes-4 audu inhibitora (TIMP-4) saturošo imūnhistoḳīmiski noteikto saistaudu šūnu relatīvā daudzuma vidējo rangu atšķirības starp dažādām izmeklējamā materiāla grupām Saīsinājumi attēlā: TIMP-4 - matrices metaloproteināzes-4 audu inhibitors; P1 - vienpusējas caurejošas lūpas un aukslēju šķeltnes grupa pēc lūpas plastikas; P2 - abpusējas caurejošas lūpas un aukslēju šķeltnes grupa pēc lūpas plastikas; P3 - abpusējas caurejošas lūpas un aukslēju šḳeltnes grupa pēc mīksto aukslēju plastikas; P4 abpusējas caurejošas lūpas un aukslēju šķeltnes grupa pēc cieto aukslēju plastikas; P5 - kontroles grupa.

Matrices metaloproteināzes-4 audu inhibitora (TIMP-4) atrade mīksto un cieto aukslēju plastikas laikā iegūtajā materiālā bērniem ar abpusēju caurejošu lūpas, alveolārā izauguma un aukslēju škseltni

Vienā mīksto aukslēju plastikas laikā iegūtajā audu paraugā netika vizualizēta neviena TIMP-4 saturoša šūna. Pārējos audu paraugos TIMP-4 pozitīvas epitēlijšūnas redzes laukā variēja no maz $(+)$ līdz daudz (+++). Vienlaikus zemāk esošos saistaudos kopumā vidēji daudz (++) fibroblasti, makrofāgi un atsevišķi polimorfonukleārie leikocīti saturēja TIMP-4 (3.9. tabula; 3.48. mikrofotogrāfija pielikumā).

Visos cieto aukslēju plastikas laikā iegūtajos audu paraugos tika konstatētas TIMP-4 pozitīvas šūnas gan epitēlijā, gan saistaudos, kas redzes laukā variēja no vidēji daudz $(++)$ līdz daudz (+++) (3.10. tabula; 3.49. mikrofotogrāfija pielikumā).

Statistiskie dati. Vidējais imūnhistoķīmiski noteikto struktūru relatīvais daudzums gan epitēlijā, gan saistaudos bija statistiski ticami lielāks mīksto un cieto aukslēju plastikas laikā iegūtajā materiālā, nekā lūpas plastikas laikā iegūtajos audos $(\mathrm{p}<0,001)$ (3.7. un 3.8. attēls). Kontroles grupas pacientu audos TIMP-4 pozitīvas saistaudu šūnas bija statistiski ticami mazāk, salīdzinot ar abpusēju caurejošu škseltņu mīksto un cieto aukslēju plastikas laikā iegūtajiem audu paraugiem $(\mathrm{p}<0,05)(3.8$. attēls $)$. 


\subsubsection{Gēnu proteīnu imūnhistoķīmiskie un statistiskie dati}

Transkripcijas faktora MSX1 atrade lūpas primārās plastikas laikā iegūtajā materiālā zīdaiņiem un bērniem ar lūpas, alveolārā izauguma un aukslēju šḳeltni

MSX1 gēna proteīna klātbūtne pacientiem ar abpusēju caurejošu šķeltni tika novērota gandrīz visos lūpas primārās plastikas laikā paņemtajos audu paraugos, izņemot divus pacientus. Minēto transkripcijas faktoru saturēja mutes dobuma gḷotādas epiteliocīti, un vienam pacientam tika fiksētas atsevišķas pozitīvas saistaudu šūnas. MSX1 saturēja retas $(0 /+)$ līdz vidēji daudz (++) šūnas segglotādas epitēlijā (3.11. tabula; 3.50. mikrofotogrāfija pielikumā). Imūnreaktīvas struktūras tika konstatētas arī matu folikulu ārējā epiteliālajā makstī un tauku dziedzeros.

3.11. tabula

Gēnu proteīnu pozitīvu struktūru relatīvais daudzums abpusēju caurejošu lūpas, alveolārā izauguma un aukslēju škseltņu skartajos audos, kas iegūti lūpas plastikas laikā

\begin{tabular}{|l|c|c|c|c|c|c|c|c|c|}
\hline \multirow{2}{*}{ Nr. } & \multirow{2}{*}{ Sifrs } & \multicolumn{2}{|c|}{ MSX1 } & \multicolumn{2}{c|}{ IRF6 } & \multicolumn{2}{c|}{ PAX9 } & \multicolumn{2}{c|}{ RYK } \\
\cline { 3 - 10 } & & $\mathrm{E}$ & $\mathrm{S}$ & $\mathrm{E}$ & $\mathrm{S}$ & $\mathrm{E}$ & $\mathrm{S}$ & $\mathrm{E}$ & $\mathrm{S}$ \\
\hline 1. & $55 \mathrm{~L}$ & $0 /+$ & 0 & + & ++ & $+/++$ & 0 & 0 & 0 \\
\hline 2. & $55 \mathrm{R}$ & $0 /+$ & 0 & $0 /+$ & $+/++$ & $0 /+$ & 0 & 0 & 0 \\
\hline 3. & 168 & $0 /+$ & 0 & $0 /+$ & ++ & $0 /+$ & 0 & $0 /+$ & 0 \\
\hline 4. & 177 & + & 0 & $0 /+$ & + & $0 /+$ & 0 & 0 & 0 \\
\hline 5. & 194 & $+/++$ & $0 /+$ & + & $+/++$ & + & 0 & 0 & 0 \\
\hline 6. & 204 & $0 /+$ & 0 & 0 & $0 /+$ & 0 & 0 & 0 & 0 \\
\hline 8. & 206 & $0 /+$ & 0 & 0 & $0 /+$ & $0 /+$ & 0 & 0 & 0 \\
\hline 9. & 212 & 0 & 0 & 0 & 0 & 0 & 0 & 0 & 0 \\
\hline 10. & 213 & + & 0 & $0 /+$ & + & + & 0 & $0 /+$ & 0 \\
\hline 11. & 221 & $0 /+$ & 0 & $0 /+$ & ++ & + & 0 & $0 /+$ & 0 \\
\hline 12. & 238 & $0 /+$ & 0 & 0 & ++ & + & 0 & $0 /+$ & 0 \\
\hline 13. & 244 & $+/++$ & 0 & + & $0 /+$ & $+/++$ & 0 & $0 /+$ & 0 \\
\hline 14. & 264 & + & 0 & 0 & ++ & + & 0 & $0 /+$ & 0 \\
\hline 15. & 267 & 0 & 0 & + & + & + & 0 & 0 & 0 \\
\hline 16. & 197 & + & 0 & $0 /+$ & $0 /+$ & + & 0 & $0 /+$ & 0 \\
\hline
\end{tabular}

Apzīmējumi tabulā: 0 - redzes laukā nav konstatēta neviena pozitīva struktūra; 0/+ - redzes laukā ir retas pozitīvas struktūras; + - redzes laukā ir maz pozit̄ivu struktūru; +/++ - redzes laukā ir maz līdz vidēji daudz pozitīvu struktūru; ++ - redzes laukā ir vidēji daudz pozitīvu struktūru; ++/+++ - redzes laukā ir vidēji daudz līdz daudz pozit̄̄vu struktūru; +++ - redzes laukā ir daudz pozitīvu struktūru; +++/++++ - redzes laukā ir daudz līdz ļoti daudz pozitīivu struktūru; ++++ - redzes laukā ir l̦oti daudz pozitīvu struktūru.

Saīsinājumi tabulā: E - epitēlijšūnas; S - saistaudu šūnas; MSX1 - transkripcijas faktors MSX1; IRF6 transkripcijas faktors IRF6; PAX9 - transkripcijas faktors PAX9; RYK - RYK gēna proteīns.

Pacientiem ar vienpusēju caurejošu lūpas un aukslēju šķeltni šķeltnes epitēlijā tika atrastas maz (+) līdz ļoti daudz (++++) MSX1 pozitīvas šūnas redzes laukā, saistaudos - no retām $(0 /+)$ līdz daudz $(+++)$ pozitīvām šūnām redzes laukā (3.12. tabula; 3.51. mikrofotogrāfija pielikumā). 
Gēnu proteīnu pozitīvu struktūru relatīvais daudzums vienpusēju caurejošu lūpas, alveolārā izauguma un aukslēju škseltņu skartajos audos, kas iegūti lūpas plastikas laikā

\begin{tabular}{|l|c|c|c|c|c|c|c|c|c|}
\hline \multirow{2}{*}{ Nr. } & \multirow{2}{*}{ Sifrs } & \multicolumn{2}{|c|}{ MSX1 } & \multicolumn{2}{c|}{ IRF6 } & \multicolumn{2}{c|}{ PAX9 } & \multicolumn{2}{c|}{ RYK } \\
\cline { 3 - 10 } & & $\mathrm{E}$ & $\mathrm{S}$ & $\mathrm{E}$ & $\mathrm{S}$ & $\mathrm{E}$ & $\mathrm{S}$ & $\mathrm{E}$ & $\mathrm{S}$ \\
\hline 1. & 195. & $+/++$ & 0 & ++ & $0 /+$ & + & 0 & $0 /+$ & 0 \\
\hline 2. & 205. & ++ & + & $0 /+$ & ++ & ++ & $0 /+$ & $0 /+$ & 0 \\
\hline 3. & 217. & ++ & $0 /+$ & ++ & ++ & +++ & + & + & 0 \\
\hline 4. & 220. & $+/++$ & $0 /+$ & ++ & ++ & $+++/++++$ & ++ & 0 & 0 \\
\hline 5. & 223. & $+/++$ & $+/++$ & + & +++ & $++/+++$ & $0 /+$ & + & 0 \\
\hline 6. & 224. & + & + & ++ & $++/+++$ & ++ & + & $0 /+$ & 0 \\
\hline 7. & 227. & ++++ & $+/++$ & ++++ & ++ & ++++ & + & ++ & 0 \\
\hline 8. & 247. & + & $0 /+$ & $0 /+$ & $0 /+$ & ++ & $0 /+$ & 0 & 0 \\
\hline 9. & 258. & + & $+/++$ & ++ & ++ & ++ & ++ & $0 /+$ & 0 \\
\hline 10. & 259. & +++ & ++ & +++ & $++/+++$ & $++/+++$ & + & $0 /+$ & 0 \\
\hline 11. & 262. & +++ & +++ & +++ & $++/+++$ & ++++ & ++ & $0 /+$ & 0 \\
\hline 12. & 277. & ++ & ++ & ++ & +++ & +++ & $++/+++$ & $0 /+$ & 0 \\
\hline 13. & 279. & + & ++ & ++ & ++ & +++ & $++/+++$ & $0 /+$ & 0 \\
\hline 14. & 282. & ++ & + & ++ & +++ & $+++/++++$ & +++ & $0 /+$ & 0 \\
\hline 15. & 283. & ++ & ++ & ++ & ++ & $++/+++$ & ++ & + & 0 \\
\hline 16. & 284. & ++ & ++ & $++/+++$ & ++ & $++/+++$ & + & ++ & 0 \\
\hline 17. & 288. & + & $0 /+$ & $++/+++$ & $+/++$ & $+/++$ & $0 /+$ & 0 & 0 \\
\hline 18. & 289. & + & $0 /+$ & ++ & +++ & +++ & $0 /+$ & 0 & 0 \\
\hline 19. & 299. & +++ & + & $+/++$ & ++ & +++ & $0 /+$ & $0 /+$ & 0 \\
\hline 20. & 300. & ++ & ++ & +++ & +++ & $++/+++$ & $+/++$ & $0 /+$ & 0 \\
\hline 21. & 302. & ++ & $+/++$ & $++/+++$ & +++ & ++ & $0 /+$ & $0 /+$ & 0 \\
\hline 22. & 303. & $++/+++$ & + & ++ & ++ & +++ & $0 /+$ & $0 /+$ & 0 \\
\hline 23. & 306. & ++ & $0 /+$ & $+/++$ & ++ & +++ & $0 /+$ & $0 /+$ & 0 \\
\hline 24. & 307. & ++ & ++ & $+/++$ & +++ & +++ & ++ & $0 /+$ & 0 \\
\hline
\end{tabular}

Apzīmējumi tabulā: 0 - redzes laukā nav konstatēta neviena pozitīva struktūra; 0/+ - redzes laukā ir retas pozitīvas struktūras; + - redzes laukā ir maz pozitīivu struktūru; +/++ - redzes laukā ir maz līdz vidēji daudz pozitīvu struktūru; ++ - redzes laukā ir vidēji daudz pozitīivu struktūru; ++/+++ - redzes laukā ir vidēji daudz līdz daudz pozitīvu struktūru; +++ - redzes laukā ir daudz pozitīvu struktūru; +++/++++ - redzes laukā ir daudz līdz loti daudz pozitīvu struktūru; ++++ - redzes laukā ir l̦oti daudz pozitīvu struktūru.

Saīsinājumi tabulā: E - epitēlijšūnas; S - saistaudu šūnas; MSX1 - transkripcijas faktors MSX1; IRF6 transkripcijas faktors IRF6; PAX9 - transkripcijas faktors PAX9; RYK - RYK gēna proteīns.

Statistiskie dati. Tika secināts, ka vidējais imūnhistoḳimiski noteikto struktūru relatīvais daudzums gan epitēlijā, gan saistaudos bija statistiski ticami mazāks pacientiem ar abpusēju caurejošu lūpas, alveolārā izauguma un aukslēju šķeltni nekā pacientiem ar vienpusēju caurejošu lūpas, alveolārā izauguma un aukslēju šķeltni, kā arī kontroles grupas pacientiem $(\mathrm{p}<0,001 ; \mathrm{p}<0,001)$ (3.9. un 3.10. attēls). 


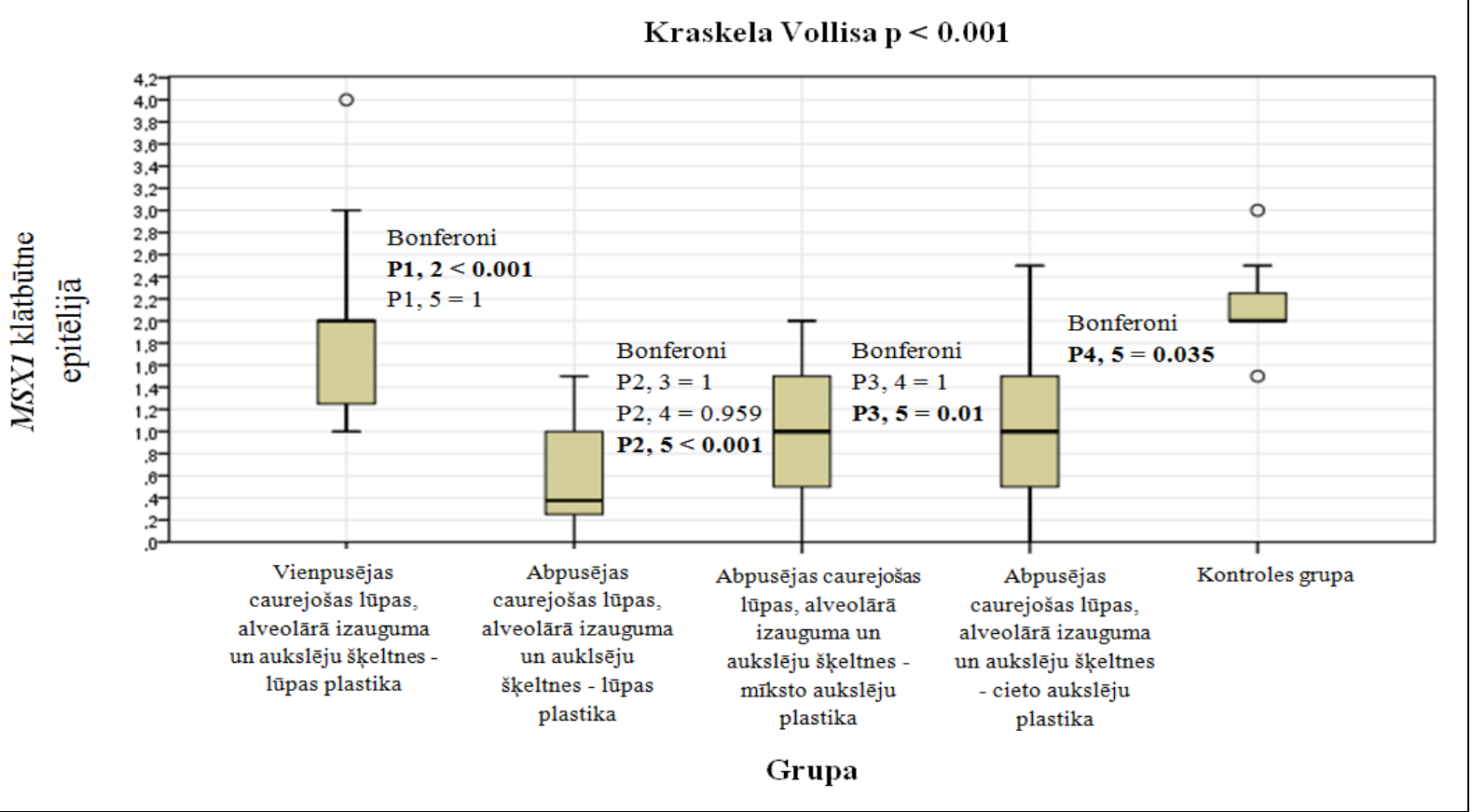

3.9. attēls. MSX1 saturošo imūnhistoḳīmiski noteikto epitēlijšūnu relatīvā daudzuma vidējo rangu atšķirības starp dažādām izmeklējamā materiāla grupām

Saīsinājumi attēlā: MSX1 - transkripcijas faktors MSX1; P1 - vienpusējas caurejošas lūpas un aukslēju šķeltnes grupa pēc lūpas plastikas; P2 - abpusējas caurejošas lūpas un aukslēju šķeltnes grupa pēc lūpas plastikas; P3 abpusējas caurejošas lūpas un aukslēju šķeltnes grupa pēc mīksto aukslēju plastikas; P4 - abpusējas caurejošas lūpas un aukslēju šķeltnes grupa pēc cieto aukslēju plastikas; P5 - kontroles grupa.

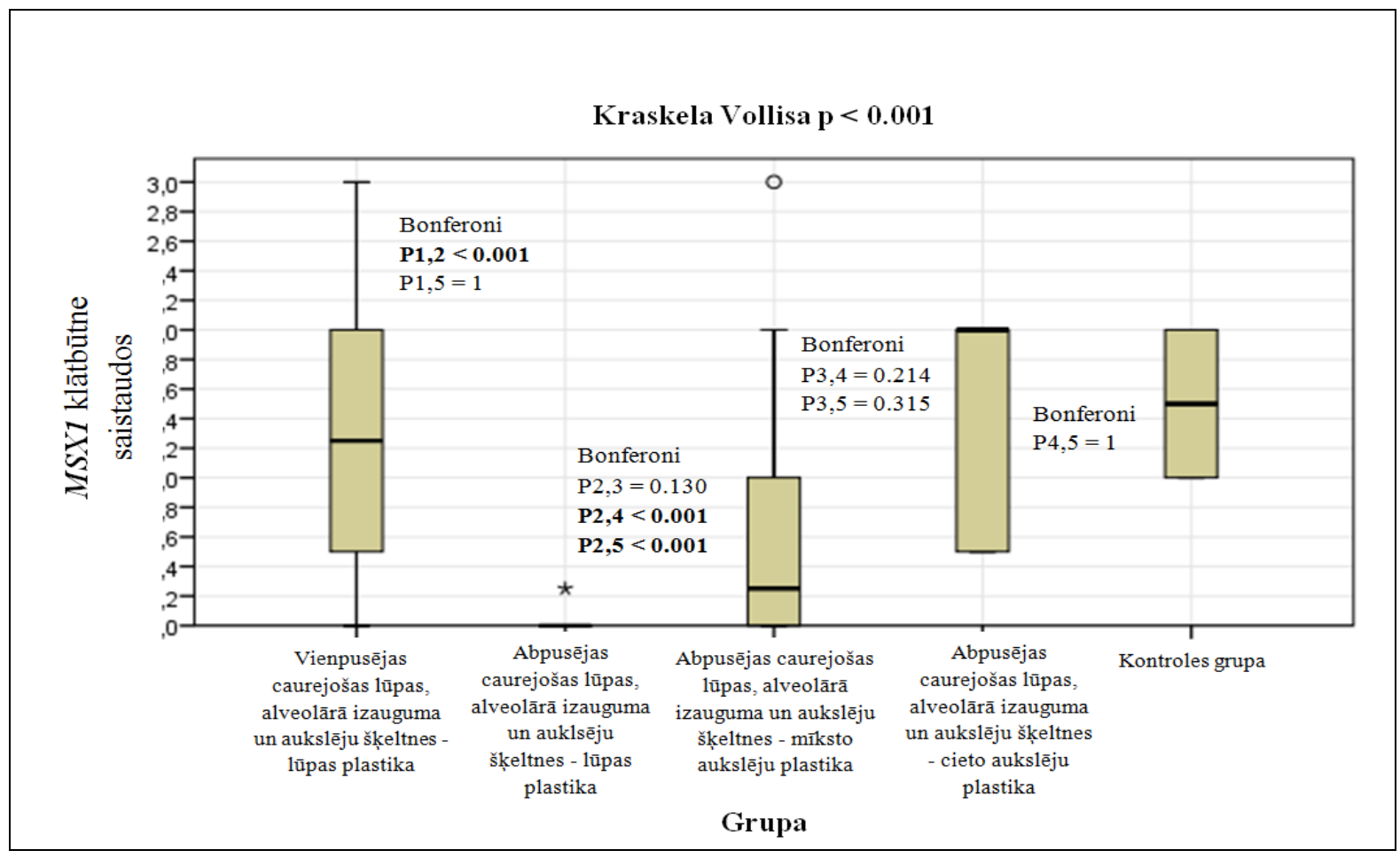

3.10. attēls. MSX1 saturošo imūnhistok̦īmiski noteikto saistaudu šūnu relatīvā daudzuma vidējo rangu atšksirības starp dažādām izmeklējamā materiāla grupām

Saīsinājumi attēlā: MSX1 - transkripcijas faktors MSX1; P1 - vienpusējas caurejošas lūpas un aukslēju šķeltnes grupa pēc lūpas plastikas; P2 - abpusējas caurejošas lūpas un aukslēju šḳeltnes grupa pēc lūpas plastikas; P3 - abpusējas caurejošas lūpas un aukslēju šḳeltnes grupa pēc mīksto aukslēju plastikas; P4 abpusējas caurejošas lūpas un aukslēju šķeltnes grupa pēc cieto aukslēju plastikas; P5 - kontroles grupa. 
Transkripcijas faktora MSX1 atrade mīksto un cieto aukslēju plastikas laikā iegūtajāā materiālā bērniem ar abpusēju caurejošu lūpas, alveolārā izauguma un aukslēju šķ̧eltni

Visos mīksto aukslēju plastikas laikā iegūtajos audu paraugos tika redzētas MSX1 saturošas šūnas. Mīksto aukslēju plastikas laikā iegūtajos paraugos tika konstatētas retas $(0 /+)$ līdz vidēji daudz (++) MSX1 pozitīvas epitēlijšūnas, savukārt MSX1 saistaudos variēja no retām (0/+) MSX1 līdz daudz (+++) pozitīvām šūnām redzes laukā (3.13. tabula).

3. 13. tabula

Gēnu proteīnu pozitīvu struktūru relatīvais daudzums abpusēju caurejošu lūpas, alveolārā izauguma un aukslēju šķeltņu skartajos audos, kas iegūti mīksto aukslēju plastikas laik̄ā

\begin{tabular}{|l|c|c|c|c|c|c|c|c|c|}
\hline \multirow{2}{*}{ Nr. } & \multirow{2}{*}{ Sifrs } & \multicolumn{2}{|c|}{ MSX1 } & \multicolumn{2}{|c|}{ IRF6 } & \multicolumn{2}{c|}{ PAX9 } & \multicolumn{2}{c|}{ RYK } \\
\cline { 3 - 10 } & & E & S & E & S & E & S & E & S \\
\hline 1. & 79 & $0 /+$ & ++ & +++ & +++ & +++ & 0 & 0 & $0 /+$ \\
\hline 2. & 187 & 0 & 0 & 0 & 0 & +++ & 0 & 0 & + \\
\hline 3. & 196 & + & 0 & ++ & ++ & +++ & 0 & 0 & 0 \\
\hline 4. & 207 & + & 0 & + & + & $0 /+$ & 0 & 0 & 0 \\
\hline 5. & 245 & $0 /+$ & 0 & ++ & +++ & +++ & 0 & $0 /+$ & + \\
\hline 6. & 249 & + & + & $0 /+$ & ++ & + & 0 & 0 & $0 /+$ \\
\hline 7. & 254 & $+/++$ & 0 & $0 /+$ & ++ & $+/++$ & 0 & $0 /+$ & + \\
\hline 8. & 261 & + & $0 /+$ & $++/+++$ & +++ & +++ & 0 & 0 & $0 /+$ \\
\hline 9. & 273 & ++ & +++ & $++/+++$ & ++ & ++ & 0 & $0 /+$ & 0 \\
\hline 10. & 276 & $+/++$ & + & +++ & ++++ & +++ & 0 & $0 /+$ & + \\
\hline
\end{tabular}

Apzīmējumi tabulā: 0 - redzes laukā nav konstatēta neviena pozitīva struktūra; 0/+ - redzes laukā ir retas pozitīvas struktūras; + - redzes laukā ir maz pozitīvu struktūru; +/++ - redzes laukā ir maz līdz vidēji daudz pozitīvu struktūru; ++ - redzes laukā ir vidēji daudz pozitīvu struktūru; ++/+++ - redzes laukā ir vidēji daudz līdz daudz pozit̄̄vu struktūru; +++ - redzes laukā ir daudz pozit̄̄vu struktūru; +++/++++ - redzes laukā ir daudz līdz loti daudz pozit̄̄vu struktūru; ++++ - redzes laukā ir ļoti daudz pozitīvu struktūru.

Saīsinājumi tabulā: E - epitēlijšūnas; S - saistaudu šūnas; MSX1 - transkripcijas faktors MSX1; IRF6 transkripcijas faktors IRF6; PAX9 - transkripcijas faktors PAX9; RYK - RYK gēna proteīns.

Cieto aukslēju materiālā MSX1 saturoši epiteliocīti variēja no retām (0/+) līdz daudz $(+++)$ pozitīvām šūnām redzes laukā (3.52. mikrofotogrāfija pielikumā), bet MSX1 pozitīvas saistaudu šūnas - no retām $(0 /+)$ līdz vidēji daudz $(++)$ redzes laukā (3.14. tabula). 
Gēnu proteīnu pozitīvu struktūru relatīvais daudzums abpusēju caurejošu lūpas, alveolārā izauguma un aukslēju šķeltņu skartajos audos, kas iegūti cieto aukslēju plastikas laikā

\begin{tabular}{|l|c|c|c|c|c|c|c|c|c|}
\hline \multirow{2}{*}{ Nr. } & \multirow{2}{*}{ Sifrs } & \multicolumn{2}{|c|}{ MSX1 } & \multicolumn{2}{|c|}{ IRF6 } & \multicolumn{2}{c|}{ PAX9 } & \multicolumn{2}{c|}{ RYK } \\
\cline { 3 - 10 } & & $\mathrm{E}$ & $\mathrm{S}$ & $\mathrm{E}$ & $\mathrm{S}$ & $\mathrm{E}$ & $\mathrm{S}$ & $\mathrm{E}$ & $\mathrm{S}$ \\
\hline 1. & $79(1)$ & $0 /+$ & ++ & +++ & +++ & +++ & 0 & 0 & 0 \\
\hline 2. & 81 & 0 & ++ & +++ & +++ & +++ & 0 & $0 /+$ & 0 \\
\hline 3. & $134(1)$ & + & $0 /+$ & $++/+++$ & $++/+++$ & +++ & 0 & +++ & + \\
\hline 4. & $134(2)$ & + & $0 /+$ & +++ & $++/+++$ & +++ & 0 & ++ & + \\
\hline 5. & 150 & ++ & ++ & ++ & $+/++$ & ++++ & ++ & ++++ & ++ \\
\hline 6. & 180 & $0 /+$ & ++ & +++ & +++ & +++ & 0 & $0 /+$ & 0 \\
\hline 7. & 232 & + & ++ & +++ & +++ & ++ & 0 & $0 /+$ & 0 \\
\hline 8. & 253 & $+/++$ & $0 /+$ & +++ & +++ & +++ & 0 & $0 /+$ & 0 \\
\hline 9. & 265 & $+++/+$ & ++ & +++ & +++ & +++ & 0 & $0 /+$ & 0 \\
& & ++ & & & & & & & \\
\hline
\end{tabular}

Apzīmējumi tabulā: 0 - redzes laukā nav konstatēta neviena pozitīva struktūra; 0/+ - redzes laukā ir retas pozitīvas struktūras; + - redzes laukā ir maz pozitīvu struktūru; +/++ - redzes laukā ir maz līdz vidēji daudz pozitīvu struktūru; ++ - redzes laukā ir vidēji daudz pozitīvu struktūru; ++/+++ - redzes laukā ir vidēji daudz līdz daudz pozit̄̄vu struktūru; +++ - redzes laukā ir daudz pozitīvu struktūru; +++/++++ - redzes laukā ir daudz līdz loti daudz pozit̄̄vu struktūru; ++++ - redzes laukā ir ḷoti daudz pozitīvu struktūru.

Saīsinājumi tabulā: E - epitēlijšūnas; S - saistaudu šūnas; MSX1 - transkripcijas faktors MSX1; IRF6 transkripcijas faktors IRF6; PAX9 - transkripcijas faktors PAX9; RYK - RYK gēna proteīns.

Statistiskie dati. Netika konstatēta statistiski ticama atšķirība MSX1 saturošu epitēlijšūnu relatīvā daudzumā mīksto un cieto aukslēju plastikas laikā iegūtajos audos, tomēr vidējais relatīvais struktūru daudzums bija statistiski ticami mazāks, salīdzinot ar kontroles grupu (attiecīgi $\mathrm{p}<0,01$ un $\mathrm{p}<0,03$ ) (3.9. attēls). Statistiski ticama atšķkirība starp MSX1 saturošām saistaudu šūnām mīksto un cieto aukslēju, kā arī kontroles grupas pacientu audiem netika konstatēta. Taču MSX1 pozitīvo saistaudu šunu vidējais relatīvais daudzums bija $\underline{\text { statistiski ticami lielāks cieto aukslēju plastikas laikā iegūtajos audu paraugos, salīdzinot ar }}$ lūpas plastikas laikā iegūtajiem audu paraugiem ( $<<0,001)$ (3.10. attēls).

\section{Transkripcijas faktora IRF6 atrade lūpas primārās plastikas laikā iegūtajā materiālā zīdaiṇiem un bērniem ar lūpas, alveolārā izauguma un aukslēju šķeltni}

IRF6 klātbūtne abpusējas caurejošas šķeltnes skartā mutes dobuma gḷotādā tika konstatēta gan epitēlijā, gan saistaudos. Atsevišşu pacientu lūpu materiālā tika novērota IRF6 ekspresija mazo siekalu dziedzeru šūnās. No 16 pacientiem ar abpusēju caurejošu lūpas, alveolārā izauguma un aukslēju šķeltni IRF6 daudzkārtainajā plakanajā epitēlijā tika konstatēts 11 pacientiem robežās no retām $(0 /+)$ līdz maz (+) pozitīvām šūnām redzes laukā. IRF6 pozitīvas saistaudu šūnas tika konstatētas visiem pacientiem, izṇemot vienu, un to daudzums bija robežās no retām (0/+) līdz vidēji daudz (++) redzes laukā (3.53. mikrofotogrāfija pielikumā) (3.11. tabula). 
Visiem 24 pacientiem ar vienpusēju caurejošu lūpas, alveolārā izauguma un aukslēju šķeltni IRF6 ekspresija tika fiksēta gan epitēlijā, gan saistaudos. Lūpas gḷotādas epitēlijā IRF6 variēja no retām $(0 /+)$ līdz loti daudz $(++++)$ pozitīvām šūnām redzes laukā. Saistaudos IRF6 saturošas šūnas tika redzētas robežās no retām $(0 /+)$ līdz daudz $(+++)$ redzes laukā (3.12. tabula; 3.54. mikrofotogrāfija pielikumā).

Statistiskie dati. Vidējais IRF6 saturošo šunu daudzums epitēlijā un saistaudos $\underline{\text { statistiski ticami mazāks bija pacientiem ar abpusēju škseltni, salīdzinot ar pacientiem, kuriem }}$ bija vienpusēja caurejoša šķeltne, un kontroles grupas pacientiem $(p<0,05)$ (3.11. attēls). $\underline{\text { IRF6 saturošo saistaudu šūnu relatīvais daudzums statistiski ticami mazāks bija abpusējas }}$ caurejošas šķeltnes skartajos audos, salīdzinot ar vienpusējas caurejošas šk̦eltnes audiem (p < 0,001) (3.12. attēls).

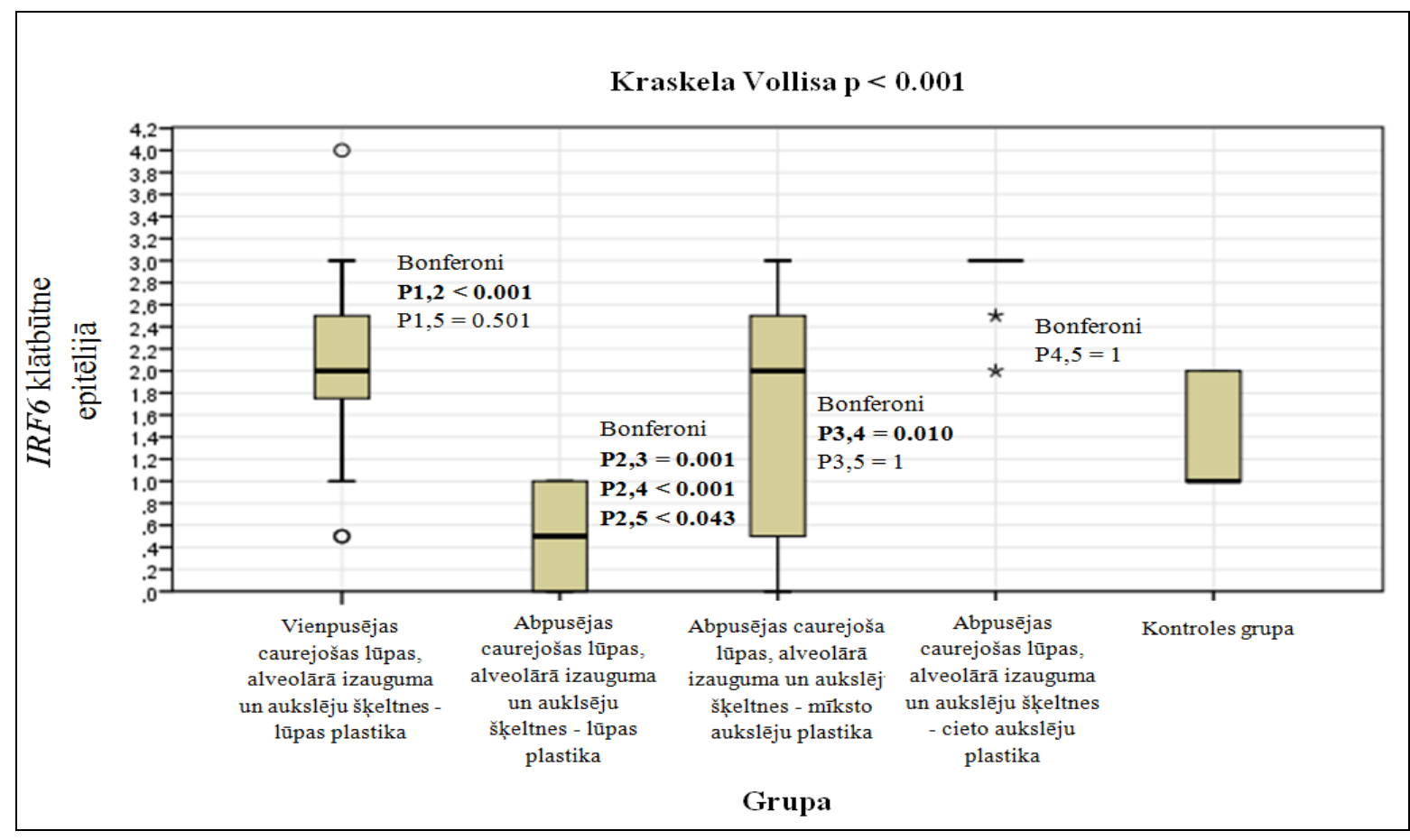

\subsection{1. attēls. IRF6 saturošo imūnhistoḳīmiski noteikto epitēlijšūnu relatīiā daudzuma vidējo rangu atšķiīības starp dažādām izmeklējamā materiāla grupām}

Saīsinājumi attēlā: IRF6 - transkripcijas faktors IRF6; P1 - vienpusējas caurejošas lūpas un aukslēju šķeltnes grupa pēc lūpas plastikas; P2 - abpusējas caurejošas lūpas un aukslēju šķeltnes grupa pēc lūpas plastikas; P3 abpusējas caurejošas lūpas un aukslēju šķeltnes grupa pēc mīksto aukslēju plastikas; P4 - abpusējas caurejošas lūpas un aukslēju škseltnes grupa pēc cieto aukslēju plastikas; P5 - kontroles grupa. 


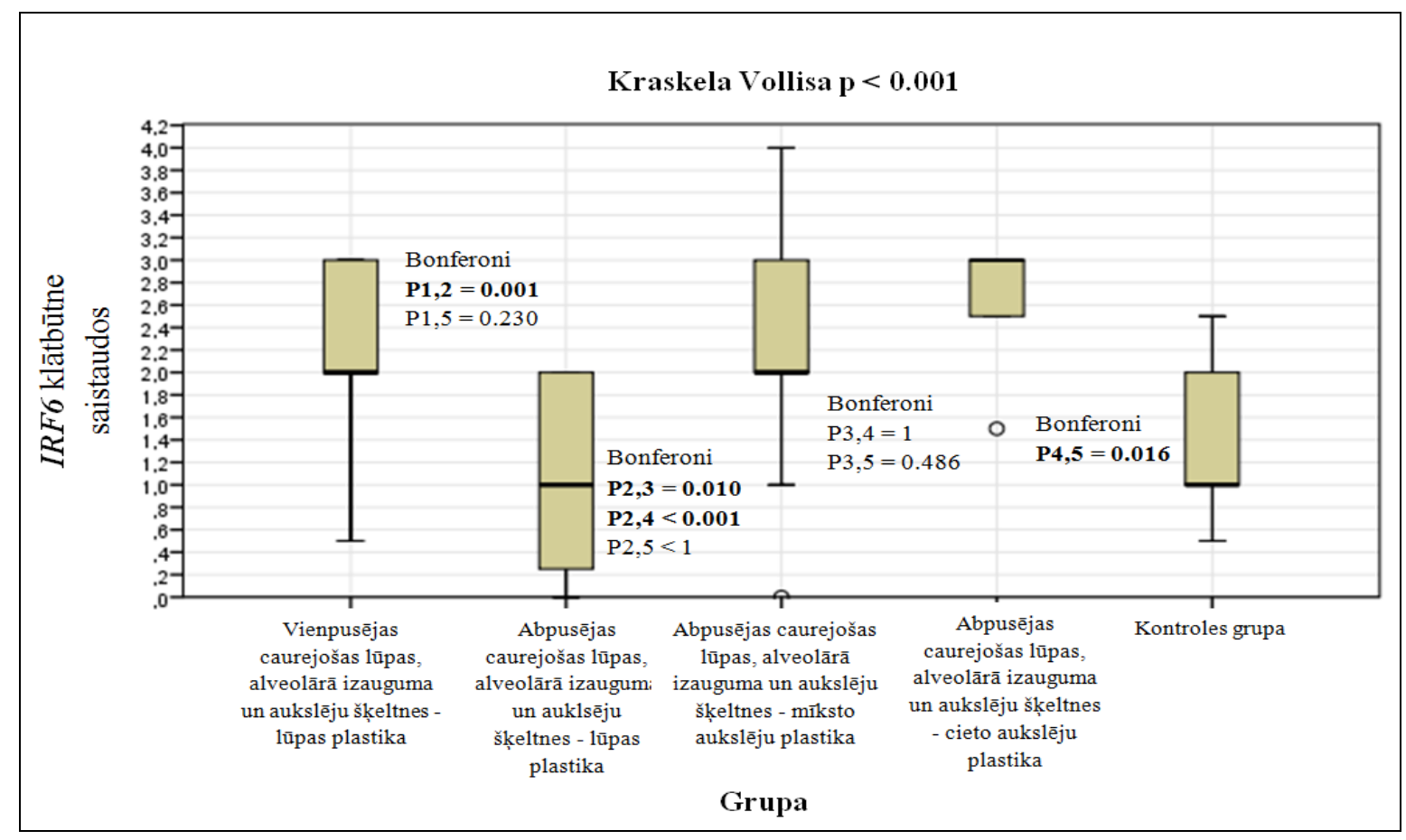

3.12. attēls. IRF6 saturošo imūnhistoķīmiski noteikto saistaudu šūnu relatīvā daudzuma vidējo rangu atšķiīibas starp dažādām izmeklējamā materiāla grupām

Saīsinājumi attēlā: IRF6 - transkripcijas faktors IRF6; P1 - vienpusējas caurejošas lūpas un aukslēju šķeltnes grupa pēc lūpas plastikas; P2 - abpusējas caurejošas lūpas un aukslēju šķeltnes grupa pēc lūpas plastikas; P3 abpusējas caurejošas lūpas un aukslēju šķeltnes grupa pēc mīksto aukslēju plastikas; P4 - abpusējas caurejošas lūpas un aukslēju škseltnes grupa pēc cieto aukslēju plastikas; P5 - kontroles grupa.

\section{Transkripcijas faktora IRF6 atrade mīksto un cieto aukslēju plastikas laikā iegūtajā materiālā bērniem ar abpusēju caurejošu lūpas, alveolārā izauguma un aukslēju šķeltni}

IRF6 atrade abpusēju škseltṇu pacientu mīksto aukslēju gḷotādā dominēja tieši saistaudos. IRF6 saturoši epiteliocīti, fibroblasti un makrofāgi tika atrasti deviņiem no desmit šķeltṇu pacientiem. Epitēlijā tika redzētas retas $(0 /+)$ līdz daudz (+++), savukārt saistaudos maz (+) līdz ļoti daudz $(++++)$ pozitīvas šūnas redzes laukā (3.13. tabula; 3.55. mikrofotogrāfija pielikumā).

IRF6 gēna proteīna klātbūtne cieto aukslēju plastikas laikā iegūtajā materiālā arī tika novērota epitēlijā un saistaudos, abos audu veidos tika konstatētas IRF6 saturošas šūnas robežās no vidēji daudz $(++)$ līdz daudz $(+++)$ (3.14. tabula; 3.56. mikrofotogrāfija pielikumā).

Statistiskie dati. Kopumā tika fiksēta būtiska statistiski ticama pieaugoša IRF6

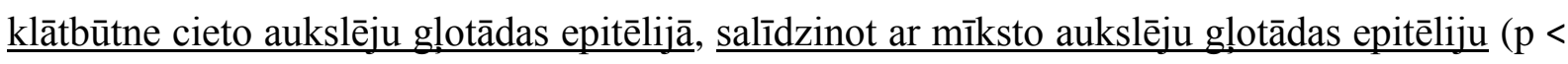
0,05). Mīksto un cieto aukslēju glotādā IRF6 pozitīvo epitēlijšūnu un saistaudu šūnu relatīvais daudzums bija statistiski ticami lielāks, salīdzinot ar lūpas glotādā esošo IRF6 pozitīvo šūnu relatīvo daudzumu $(\mathrm{p}<0,05)$. Salīdzinot ar kontroles grupas pacientiem, pētījumā tika 
konstatēts, ka tikai cieto aukslēju glototādas vidējais imūnhistoķīmiski noteikto saistaudu šūnu relatīvais daudzums bija statistiski ticami lielāks $(\mathrm{p}<0,05)$ (3.11. un 3.12. attēls).

Transkripcijas faktora PAX9 atrade lūpas primārās plastikas laikā iegūtajā materiālā zīdaiņiem un bērniem ar lūpas, alveolārā izauguma un aukslēju šķ̧eltni

PAX9 saturošas struktūras tika novērotas visu 16 abpusēju šķeltņu pacientu epitēlijāa, bet saistaudos PAX9 klātbūtne netika novērota. Tika redzēti reti (0/+) PAX9 saturoši siekalu dziedzeru glandulocīti, bet daudz PAX9 pozitīvas šūnas to izvados (3.57. mikrofotogrāfija pielikumā). Kopumā epitēlijā bija maz (+) epiteliocītu, kas saturēja PAX9 (3.58. mikrofotogrāfija pielikumā), taču trīs šķeltņu pacientu epitēlijā tika fiksēti reti (0/+) PAX9 saturoši epiteliocīti. Vienam pacientam netika novērota neviena PAX9 pozitīva šūna. Interesanti, ka nevienā no lūpas primārās plastikas laikā iegūtajiem audu paraugiem netika redzētas PAX9 pozitīvas saistaudu šūnas (3.11. tabula).

PAX9 saturēja arī visu 24 vienpusējas lūpu, alveolārā izauguma un aukslēju šķeltnes pacientu mutes dobuma gḷotādas audu paraugi, epitēlijā tika konstatēti vidēji daudz $(+++)$ PAX9 saturoši epiteliocīti. Turklāt 23 pacientu lūpas gl̦otādā tika atrastas PAX9 saturošas saistaudu šūnas. Lamina propria bija redzamas retas $(0 /+)$ līdz daudz (+++) PAX9 pozitīvas šūnas redzes laukā (3.12. tabula; 3.59. mikrofotogrāfija pielikumā).

Statistiskie dati. Vidējais imūnhistoķīmiski noteikto epitēlijšūnu un saistaudu šūnu relatîvais daudzums bija statistiski ticami mazāks pacientiem ar abpusēju šḳeltni nekā pacientiem ar vienpusēju šḳeltni $(p<0,001)$ (3.13. un 3.14. attēls). Kontroles grupas pacientiem vidējais PAX9 pozitīvo epitēlijšūnu relatīvais daudzums bija būtiski lielāks nekā pacientiem ar abpusēju šķeltni $(\mathrm{p}<0,001)$. 


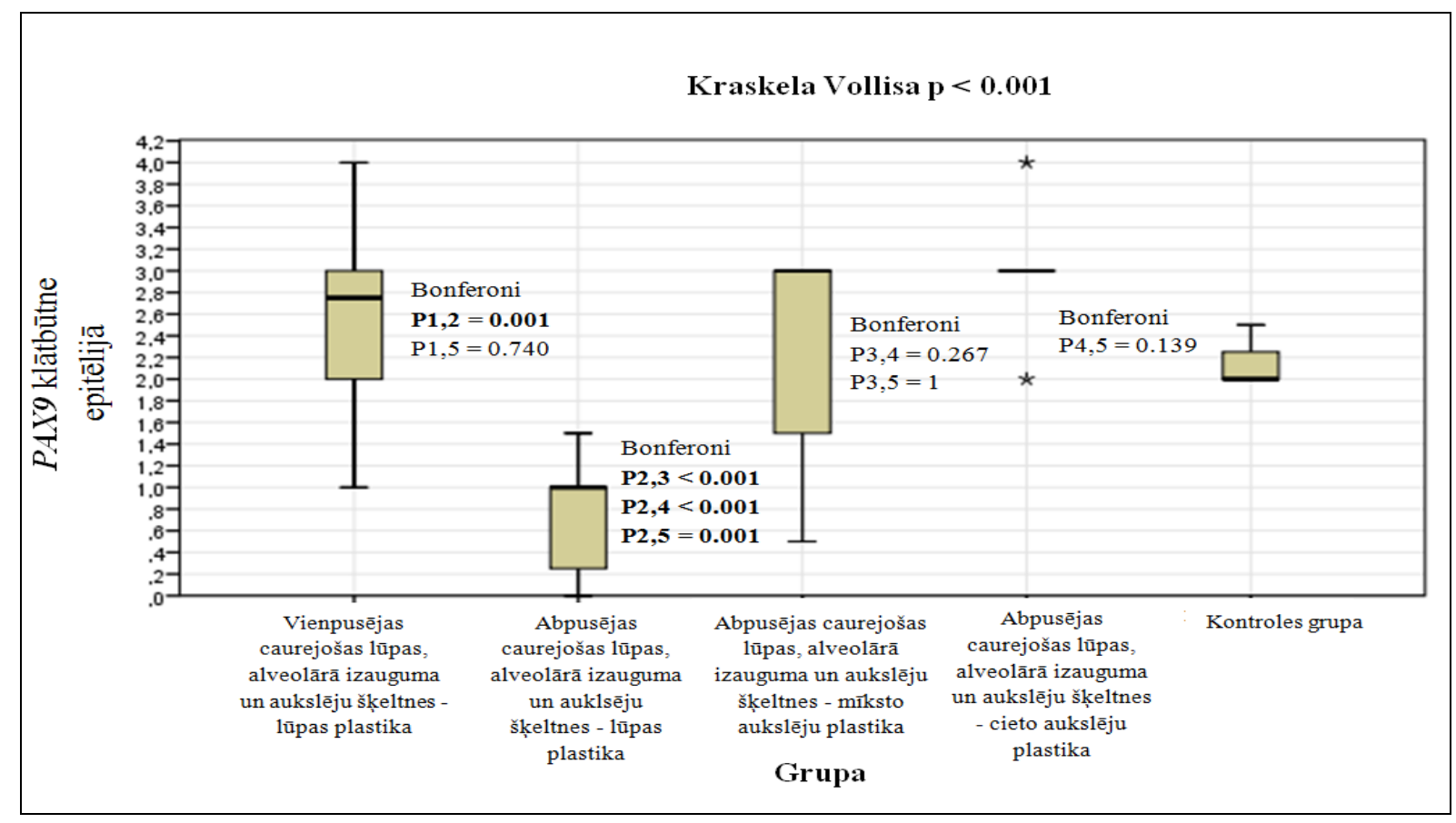

\subsection{3. attēls. PAX9 saturošo imūnhistoḳīmiski noteikto epitēlijšūnu relatīvā daudzuma vidējo rangu atškirīības starp dažādām izmeklējamā materiāla grupām}

Saīsinājumi attēlā: PAX9 - transkripcijas faktors PAX9; P1 - vienpusējas caurejošas lūpas un aukslēju šķeltnes grupa pēc lūpas plastikas; P2 - abpusējas caurejošas lūpas un aukslēju šķeltnes grupa pēc lūpas plastikas; P3 abpusējas caurejošas lūpas un aukslēju šķeltnes grupa pēc mīksto aukslēju plastikas; P4 - abpusējas caurejošas

lūpas un aukslēju šķeltnes grupa pēc cieto aukslēju plastikas; P5 - kontroles grupa

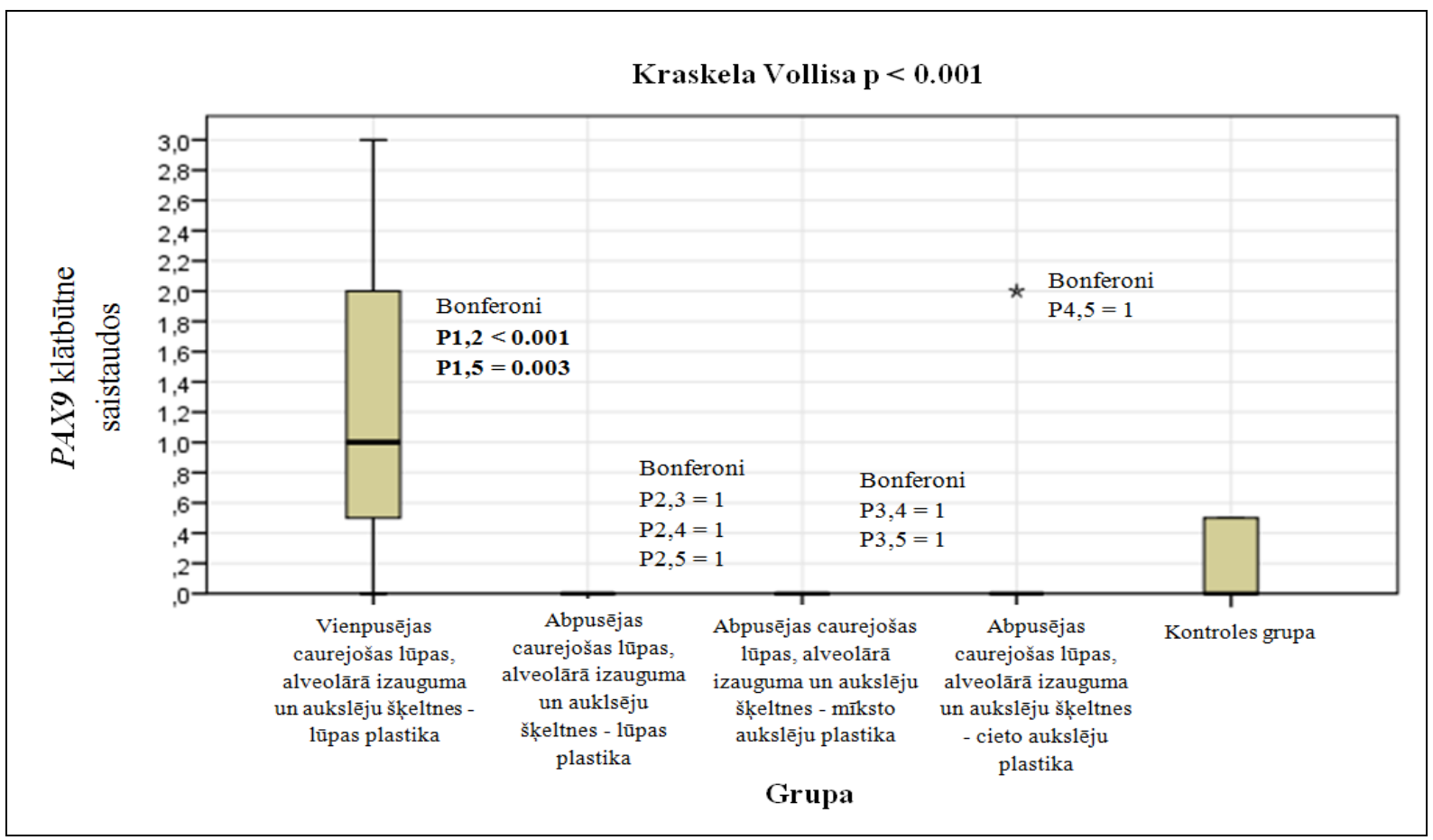

3.14. attēls. PAX9 saturošo imūnhistoḳīmiski noteikto saistaudu šūnu relatīvā daudzuma vidējo rangu atšķirības starp dažādām izmeklējamā materiāla grupām

Saīsinājumi attēlā: PAX9 - transkripcijas faktors PAX9; P1 - vienpusējas caurejošas lūpas un aukslēju šķeltnes grupa pēc lūpas plastikas; P2 - abpusējas caurejošas lūpas un aukslēju šķeltnes grupa pēc lūpas plastikas; P3 abpusējas caurejošas lūpas un aukslēju šķeltnes grupa pēc mīksto aukslēju plastikas; P4 - abpusējas caurejošas lūpas un aukslēju šķeltnes grupa pēc cieto aukslēju plastikas; P5 - kontroles grupa 
Transkripcijas faktora PAX9 atrade mīksto un cieto aukslēju plastikas laikā iegūtajā materiālā bērniem ar abpusēju caurejošu lūpas, alveolārā izauguma un aukslēju šķeltni

Mīksto aukslēju gḷotādā tika novērotas retas (0/+) līdz daudz (+++) PAX9 pozitīvas epitēlijšūnas. Deviņiem pacientiem bija daudz (+++) PAX9 pozitīvas epitēlijšūnas, savukārt tikai vienam pacientam bija retas (0/+) PAX9 pozitivvas šūnas (3.12. tabula). Saistaudos netika vizualizētas PAX9 pozitīvas šūnas (3.13. tabula).

Cieto aukslēju gḷotādas epitēlijā tika konstatētas vidēji daudz (++) līdz ļoti daudz (++++) PAX9 pozitīvas šūnas redzes laukā (3.14. tabula; 3.60. mikrofotogrāfija pielikumā). Cieto aukslēju lamina propria vienam pacientam saturēja daudz $(++)$ PAX9 pozitīvas saistaudu šūnas.

Statistiskie dati. Tika konstatēts, ka mīksto un cieto plastikas laikā ñemtajos audos

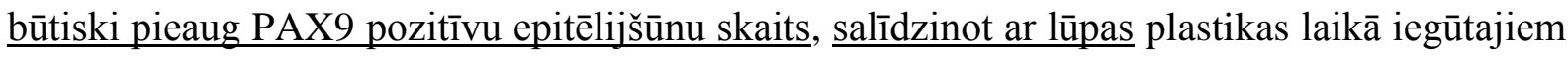
audu paraugiem $(\mathrm{p}<0,001)$ (3.13. attēls).

\section{RYK gēna proteīna atrade lūpas primārās plastikas laikā iegūtajā materiālā zīdaiņiem un bērniem ar caurejošu lūpas, alveolārā izauguma un aukslēju šķeltni}

RYK klātbūtne epitēlijā tika konstatēta tikai sešiem pacientiem ar abpusēju caurejošu lūpas, alveolārā izauguma un aukslēju škseltni, turklāt nevienam pacientam netika redzēta RYK ekspresija lūpas lamina propria. Interesanti, ka visiem sešiem pacientiem tika atrasti reti (0/+) RYK saturoši epiteliocīti (3.11. tabula; 3.61. mikrofotogrāfija pielikumā).

RYK ekspresija tika fiksēta 22 pacientiem ar vienpusēju caurejošu šķeltni. Pacientiem ar vienpusēju caurejošu šķeltni tika atrastas retas (0/+) (3.62. mikrofotogrāfija pielikumā) līdz vidēji daudz (++) RYK pozitīvas epitēlijšūnas. Tomēr arī šai pacientu grupai netika konstatēta RYK ekspresija saistaudu šūnās (3.12. tabula).

Statistiskie dati. Analizējot vidējo RYK pozitīvo epitēlijšūnu relatīvo daudzumu, netika novērota statistiski ticama atšķirība starp pacientiem ar abpusēju šķeltni, pacientiem ar vienpusēju šķeltni un arī kontroles grupas pacientiem (3.15. attēls). Tomēr saistaudos tika $\underline{\text { novērots statistiki ticami lielāks RYK pozitīvo šūnu relatīvais daudzums kontroles grupas }}$ pacientiem, salīdzinot ar škeltṇu pacientiem (p <0,001) (3.16. attēls). 


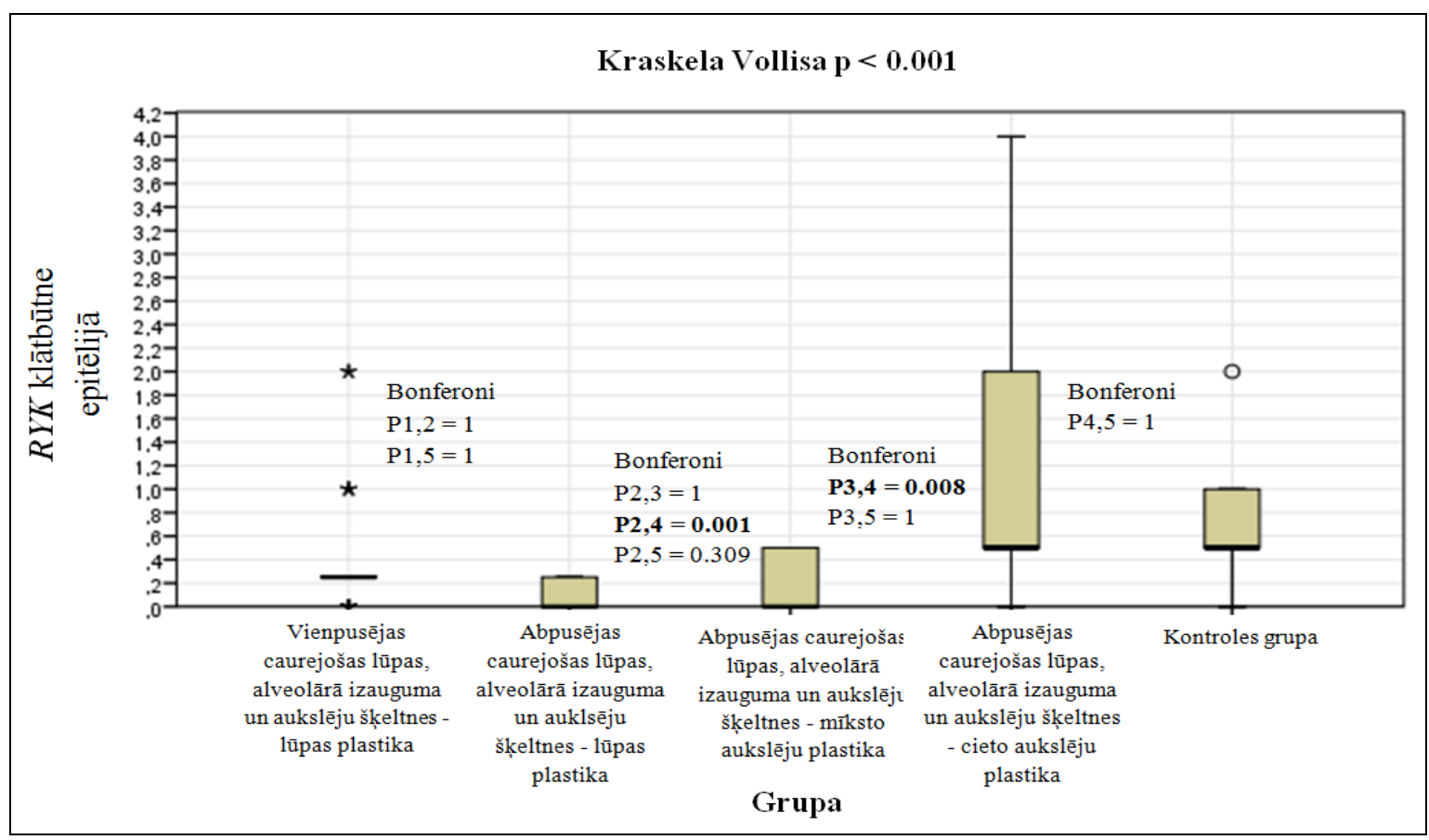

\subsection{5. attēls. RYK saturošo imūnhistoķīmiski noteikto epitēlijšūnu relatīvā daudzuma vidējo rangu atšķirības starp dažādām izmeklējamā materiāla grupām}

Saīsinājumi attēlā: RYK - RYK gēna proteīns; P1 - vienpusējas caurejošas lūpas un aukslēju šķeltnes grupa pēc lūpas plastikas; P2 - abpusējas caurejošas lūpas un aukslēju škeltnes grupa pēc lūpas plastikas; P3 - abpusējas caurejošas lūpas un aukslēju šḳeltnes grupa pēc mīksto aukslēju plastikas; P4 - abpusējas caurejošas lūpas un aukslēju šķeltnes grupa pēc cieto aukslēju plastikas; P5 - kontroles grupa.

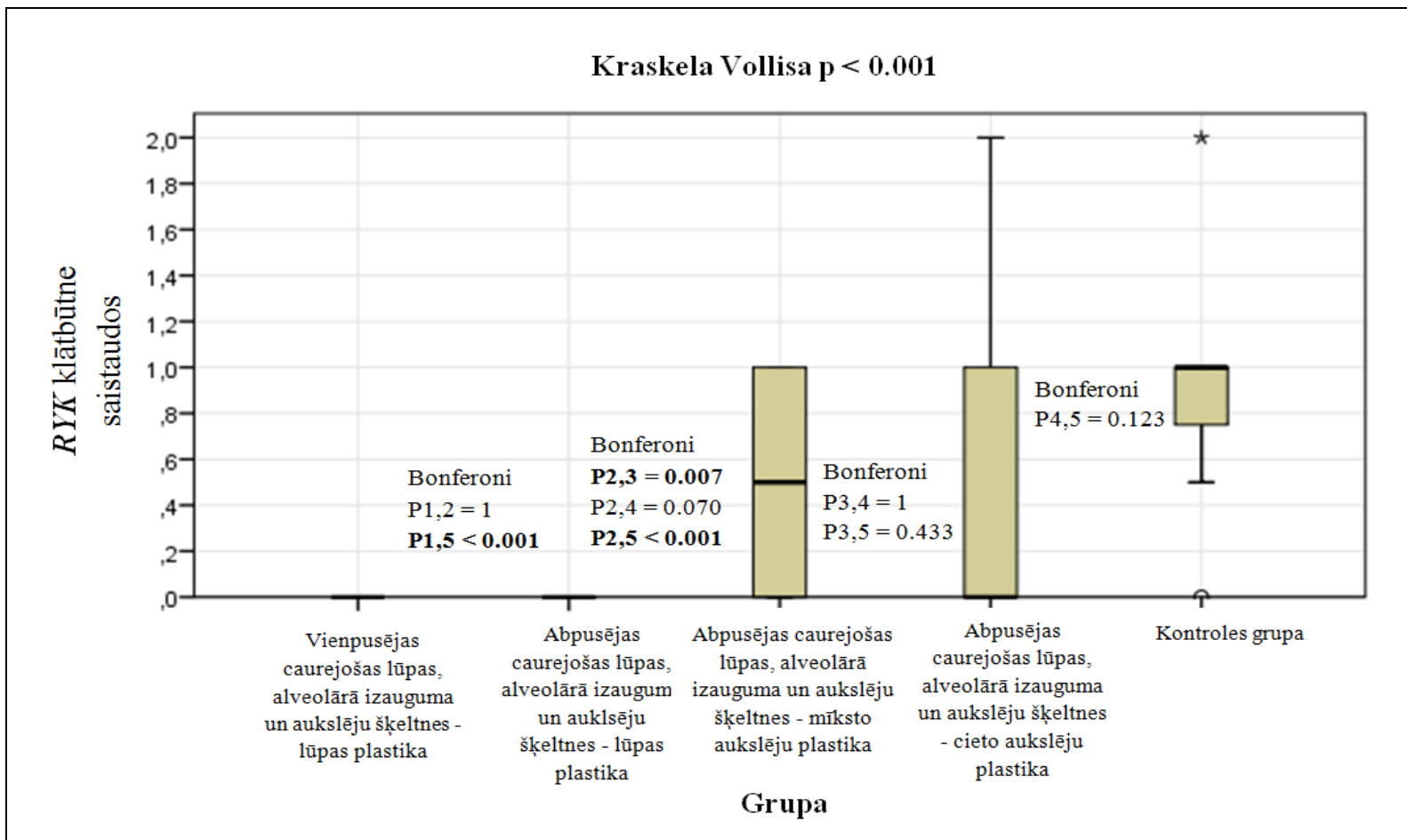

\subsection{6. attēls. RYK saturošo imūnhistoḳīmiski noteikto saistaudu šūnu relatīvā daudzuma vidējo} rangu atšķiīības starp dažādām izmeklējamā materiāla grupām

Saīsinājumi attēlā: RYK - RYK gēna proteīns; P1 - vienpusējas caurejošas lūpas un aukslēju šḳeltnes grupa pēc lūpas plastikas; P2 - abpusējas caurejošas lūpas un aukslēju šķeltnes grupa pēc lūpas plastikas; P3 - abpusējas caurejošas lūpas un aukslēju šķeltnes grupa pēc mīksto aukslēju plastikas; P4 - abpusējas caurejošas lūpas un aukslēju šķeltnes grupa pēc cieto aukslēju plastikas; P5 - kontroles grupa. 
RYK gēna proteīna atrade mīksto un cieto aukslēju plastikas laikā iegūtajā materiālā bērniem ar abpusēju caurejošu lūpas, alveolārā izauguma un aukslēju škseltni

RYK gēna proteīns tika atrasts četru pacientu mīksto aukslēju glotādas epitēlijā. Retas (0/+) mīksto aukslēju epitēlijšūnas saturēja RYK proteīnu. Mīksto aukslēju plastikas laikā iegūtajā materiālā RYK ekspresējošu saistaudu šūnu relatīvais daudzums variēja no retām (0/+) līdz vidēji daudz (++) šūnām (3.13. tabula).

RYK ekspresija tika redzēta astoṇu pacientu cieto aukslēju gḷotādas epitēlijā. Tika novērotas retas $(0 /+)$ līdz ļoti daudz $(++++)$ RYK pozitīvas epitēlijšūnas (3.14. tabula; 3.63. mikrofotogrāfija pielikumā). Cieto aukslēju plastikas laikā iegūtajā materiālā RYK ekspresējošu saistaudu šūnu relatīvais daudzums variēja no retām $(0 /+)$ līdz vidēji daudz $(++)$.

Statistiskie dati. Pētījumā tika novērota pieaugoša RYK ekspresija cieto aukslēju epitēlijāā, salīdzinot ar mīksto aukslēju un lūpas glotāâs epitēliju $(\mathrm{p}<0,05)$ (3.15. attēls). RYK saturošo saistaudu šūnu skaits mīkstajās aukslējās bija statistiski ticami lielāks nekā tāds lūpas glotādas saistaudos $(\mathrm{p}<0,05)$ (3.16. attēls). Salīdzinot RYK pozitīvo vidējo struktūru daudzumu atkārtoti ņemtajos audos ar kontroles grupu, būtiskas atšksirības netika konstatētas.

\subsubsection{Augšanas faktoru, $C D 34$, inervācijas faktora $P G P 9.5$ imūnhistoḳīmiskie un statistiskie dati}

Transformējošā augšanas faktora beta-3 (TGFß3) atrade lūpas primārās plastikas laikā iegūtajā materiālā zīdaiņiem un bērniem ar caurejošām lūpas, alveolārā izauguma un aukslēju škseltnēm

Kopumā pacientiem ar abpusēju caurejošu škseltni epitēlijā retas $(0 /+)$ šūnas saturēja $T G F \beta 3$. Sešiem pacientiem $T G F \beta 3$ saturošas šūnas mutes dobuma gḷotādā netika konstatētas. Saistaudos $T G F \beta 3$ pozitīvas šūnas variēja robežās no retām $(0 /+)$ l̄idz maz $(+)$ redzes laukā (3.64. mikrofotogrāfija pielikumā), izņemot vienu pacientu - zīdaini (3.15. tabula), kuram tika redzētas maz līdz vidēji daudz $(+/++)$ TGF 33 pozitīvas šūnas. Pacientiem tika konstatēti arī TGFB3 saturoši glandulocīti, matu folikulu šūnas, mazo siekalu dziedzeru izvadu šūnas un asinsvadu endoteliocīti. 
TGFß3, VEGF, CD34 un PGP 9.5 pozitīvu struktūru relatīvais daudzums abpusēju caurejošu lūpas, alveolārā izauguma un aukslēju šḳeltṇu skartajos audos, kas iegūti lūpas plastikas laikā

\begin{tabular}{|l|c|c|c|c|c|c|}
\hline \multirow{2}{*}{ Nr. } & \multirow{2}{*}{ Sifrs } & \multicolumn{2}{|c|}{$T G F \beta 3$} & VEGF & CD34 & $P G P 9.5$ \\
\cline { 3 - 7 } & & $\mathrm{E}$ & $\mathrm{S}$ & & & \\
\hline 1. & $55 \mathrm{~L}$ & 0 & + & 0 & ++++ & ++ \\
\hline 2. & $55 \mathrm{R}$ & 0 & + & 0 & ++++ & $0 /+$ \\
\hline 3. & 168 & 0 & + & + & ++++ & ++ \\
\hline 4. & 177 & $0 /+$ & + & + & ++++ & $+/++$ \\
\hline 5. & 194 & 0 & $0 /+$ & ++ & ++++ & ++ \\
\hline 6. & 204 & 0 & + & ++ & ++++ & ++ \\
\hline 8. & 206 & $0 /+$ & + & ++ & ++++ & + \\
\hline 9. & 212 & $0 /+$ & $0 /+$ & 0 & ++++ & + \\
\hline 10. & 213 & + & $0 /+$ & + & ++++ & + \\
\hline 11. & 221 & 0 & $0 /+$ & $++/+++$ & ++++ & + \\
\hline 12. & 238 & $0 /+$ & $+/++$ & ++ & ++++ & + \\
\hline 13. & 244 & $0 /+$ & $0 /+$ & ++ & ++++ & ++ \\
\hline 14. & 264 & $0 /+$ & $0 /+$ & + & ++++ & ++ \\
\hline 15. & 267 & $0 /+$ & $0 /+$ & ++ & ++++ & ++ \\
\hline 16. & 197 & $0 /+$ & $0 /+$ & + & ++++ & ++ \\
\hline
\end{tabular}

Apzīmējumi tabulā: 0 - redzes laukā nav konstatēta neviena pozitīva struktūra; 0/+ - redzes laukā ir retas pozitīvas struktūras; + - redzes laukā ir maz pozitīvu struktūru; +/++ - redzes laukā ir maz līdz vidēji daudz pozitīvu struktūru; ++ - redzes laukā ir vidēji daudz pozitīvu struktūru; ++/+++ - redzes laukā ir vidēji daudz līdz daudz pozit̄ivu struktūru; +++ - redzes laukā ir daudz pozitīvu struktūru; +++/++++ - redzes laukā ir daudz līdz loti daudz pozit̄̄vu struktūru; ++++ - redzes laukā ir ḷoti daudz pozitīvu struktūru.

Saīsinājumi tabulā: E - epitēlijšūnas; $\mathrm{S}$ - saistaudu šūnas; $T G F \beta 3$ - transformējošais augšanas faktors beta-3; $V E G F$ - vaskulārais endotēlija augšanas faktors; $C D$-34 - transmembranozais glikoproteīns $C D$-34; $P G P 9.5$ proteīngēnviela 9.5 .

TGFß3 klātbūtne tika novērota visu 24 pacientu, kuriem bija vienpusēja caurejoša šķeltne, audu paraugos. Ļoti daudz $(++++)$ pozitīvu epitēlijšūnu redzes laukā tika fiksēts deviņiem pacientiem, daudz līdz loti daudz $(+++/++++)$ - pieciem pacientiem (3.65. mikrofotogrāfija pielikumā), daudz (+++) - deviņiem pacientiem un vidēji daudz $(++)$ vienam pacientam. Vienpusēju caurejošu šķeltņu skartajos audos tika konstatēti arī TGFß3 saturoši glandulocīti, matu folikulu šūnas, mazo siekalu dziedzeru izvadu šūnas un asinsvadu endoteliocīti. TGFß3 saturošas saistaudu šūnas tika novērotas asinsvadu un nervu šķiedru tuvumā. TGFß3 saturošus fibroblastus un makrofāgus konstatējām visos audu paraugos. Vienpusēju caurejošu šķeltņu pacientu saistaudos $T G F \beta 3$ relatīvais šūnu daudzums variēja no retām $(0 /+)$ līdz ļoti daudz $(++++)$ redzes laukā (3.16. tabula). 
$T G F \beta 3, V E G F, C D 34$ un PGP 9.5 pozitīvu struktūru relatīvais daudzums vienpusēju caurejošu lūpas, alveolārā izauguma un aukslēju šķeltņu skartajos audos, kas iegūti lūpas plastikas laikā

\begin{tabular}{|l|c|c|c|c|c|c|}
\hline \multirow{2}{*}{ Nr. } & \multirow{2}{*}{ Sifrs } & \multicolumn{2}{|c|}{$T G F \beta 3$} & $V E G F$ & $C D 34$ & PGP 9.5 \\
\cline { 3 - 7 } & & $\mathrm{E}$ & $\mathrm{S}$ & & & \\
\hline 1. & 195. & ++ & $0 /+$ & + & ++++ & + \\
\hline 2. & 205. & +++ & $0 /+$ & ++ & ++++ & + \\
\hline 3. & 217. & ++++ & +++ & ++ & ++++ & + \\
\hline 4. & 220. & $+++/+++$ & ++ & +++ & ++++ & $0 /+$ \\
\hline 5. & 223. & ++++ & ++ & + & ++++ & ++ \\
\hline 6. & 224. & $+++/+++$ & $+/++$ & $++/+++$ & ++++ & ++ \\
\hline 7. & 227. & ++++ & + & $+++/++++$ & ++++ & ++ \\
\hline 8. & 247. & +++ & $0 /+$ & ++ & ++++ & 0 \\
\hline 9. & 258. & ++++ & ++ & $+/++$ & ++++ & + \\
\hline 10. & 259. & ++++ & +++ & $++/+++$ & ++++ & + \\
\hline 11. & 262. & ++++ & ++++ & $+++/++++$ & ++++ & +++ \\
\hline 12. & 277. & +++ & $++/+++$ & $+++/++++$ & ++++ & +++ \\
\hline 13. & 279. & ++++ & $+++/++++$ & +++ & ++++ & $+/++$ \\
\hline 14. & 282. & ++++ & +++ & $+/++$ & ++++ & + \\
\hline 15. & 283. & ++++ & +++ & $+/++$ & ++++ & + \\
\hline 16. & 284. & $+++/++++$ & $++/+++$ & ++ & ++++ & + \\
\hline 17. & 288. & +++ & $0 /+$ & + & ++++ & $+/++$ \\
\hline 18. & 289. & $+++/++++$ & $++/+++$ & $0 /+$ & ++++ & $+/++$ \\
\hline 19. & 299. & +++ & +++ & $++/+++$ & ++++ & $0 /+$ \\
\hline 20. & 300. & +++ & $+++/++++$ & ++ & ++++ & $+/++$ \\
\hline 21. & 302. & +++ & ++ & $++/+++$ & ++++ & + \\
\hline 22. & 303. & $+++/++++$ & ++ & + & ++++ & + \\
\hline 23. & 306. & +++ & + & + & ++++ & $0 /+$ \\
\hline 24. & 307. & +++ & +++ & ++ & ++++ & + \\
\hline & & & & & & \\
\hline & & & + & + & + & + \\
\hline
\end{tabular}

Apzīmējumi tabulā: 0 - redzes laukā nav konstatēta neviena pozitīva struktūra; 0/+ - redzes laukā ir retas pozitīvas struktūras; +- redzes laukā ir maz pozitīvu struktūru; +/++ - redzes laukā ir maz līdz vidēji daudz pozitīvu struktūru; ++ - redzes laukā ir vidēji daudz pozitīvu struktūru; ++/+++ - redzes laukā ir vidēji daudz līdz daudz pozit̄ivu struktūru; +++ - redzes laukā ir daudz pozitīvu struktūru; +++/++++ - redzes laukā ir daudz līdz loti daudz pozit̄̄vu struktūru; ++++ - redzes laukā ir ḷoti daudz pozitīvu struktūru.

Saīsinājumi tabulā: E - epitēlijšūnas; $\mathrm{S}$ - saistaudu šūnas; $T G F \beta 3$ - transformējošais augšanas faktors beta-3; $V E G F$ - vaskulārais endotēlija augšanas faktors; $C D$-34 - transmembranozais glikoproteīns $C D$-34; $P G P 9.5$ proteīngēnviela 9.5 .

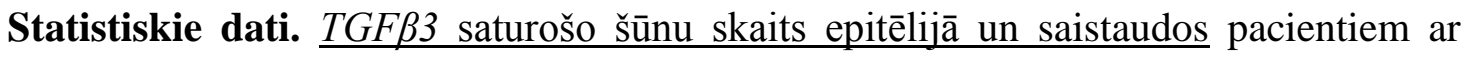
vienpusēju lūpas, alveolārā izauguma un aukslēju šķeltni bija statistiski ticami lielāks nekā pacientiem ar abpusēju lūpas, alveolārā izauguma un aukslēju šķeltni ( $\mathrm{p}<0,001)$. Pacientiem

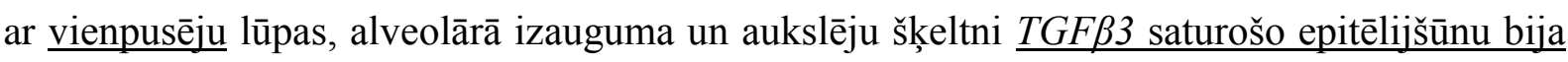

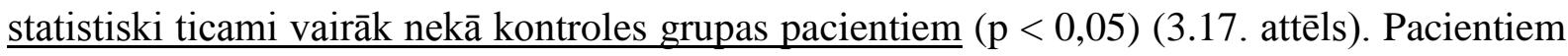

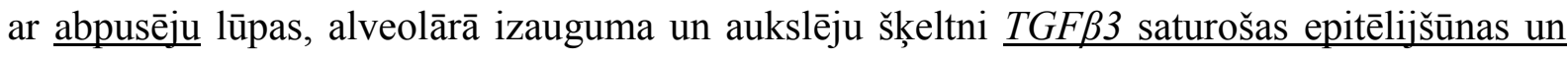

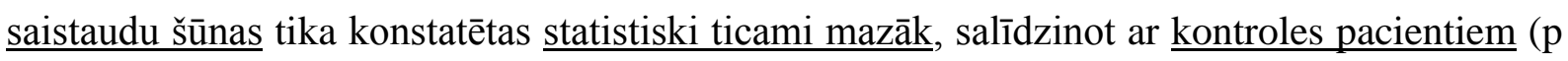
$<0,001$ ) (3.17. un 3.18. attēls). 


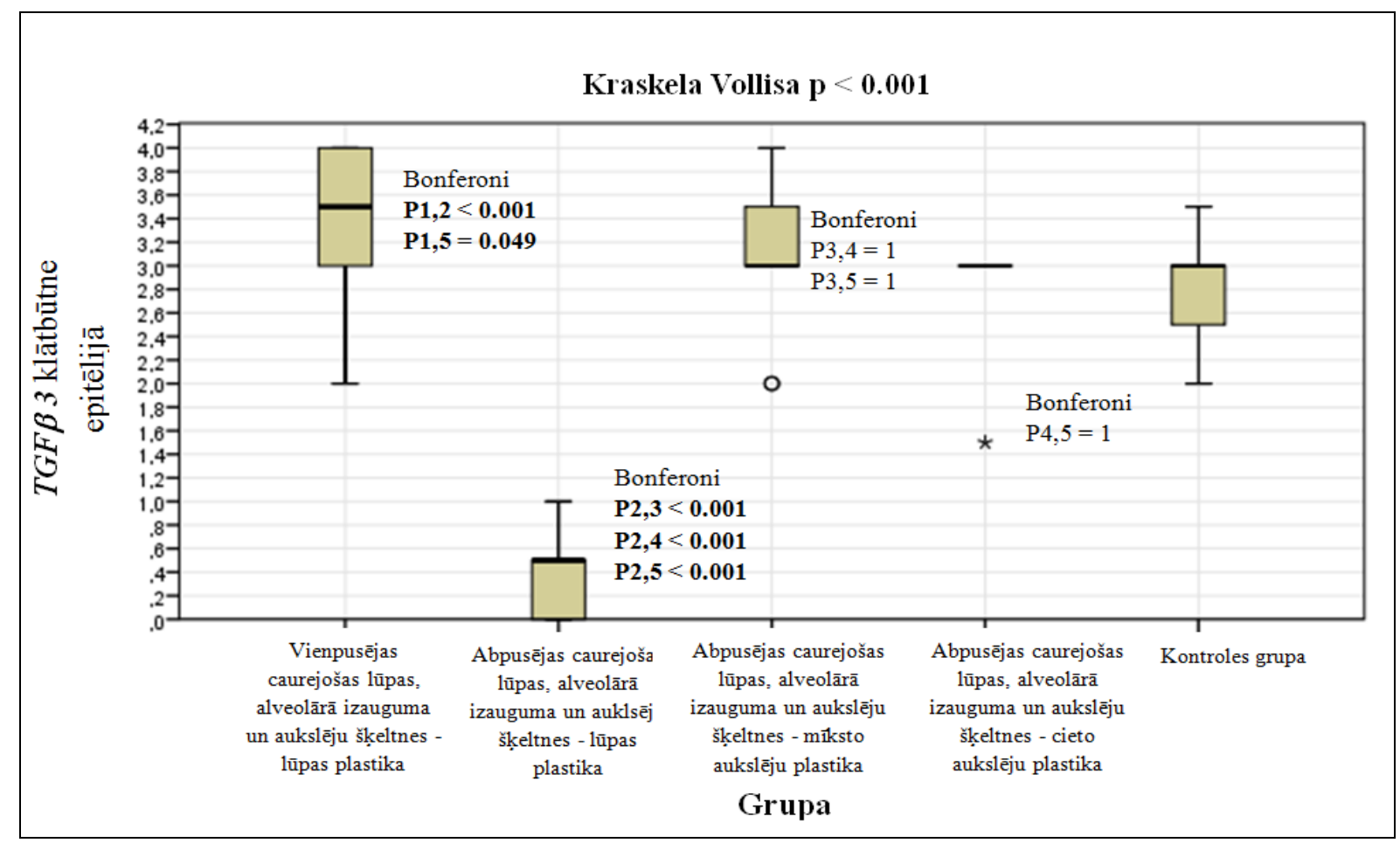

3.17. attēls. TGFß3 saturošo imūnhistoḳīmiski noteikto epitēlijšūnu relatīvā daudzuma vidējo rangu atšķirības starp dažādām izmeklējamā materiāla grupām

Saīsinājumi attēlā: TGF 3 - transformējošais augšanas faktors beta-3; P1 - vienpusējas caurejošas lūpas un aukslēju šķeltnes grupa pēc lūpas plastikas; P2 - abpusējas caurejošas lūpas un aukslēju šķeltnes grupa pēc lūpas plastikas; P3 - abpusējas caurejošas lūpas un aukslēju šķeltnes grupa pēc mīksto aukslēju plastikas; P4 abpusējas caurejošas lūpas un aukslēju škseltnes grupa pēc cieto aukslēju plastikas; P5 - kontroles grupa.

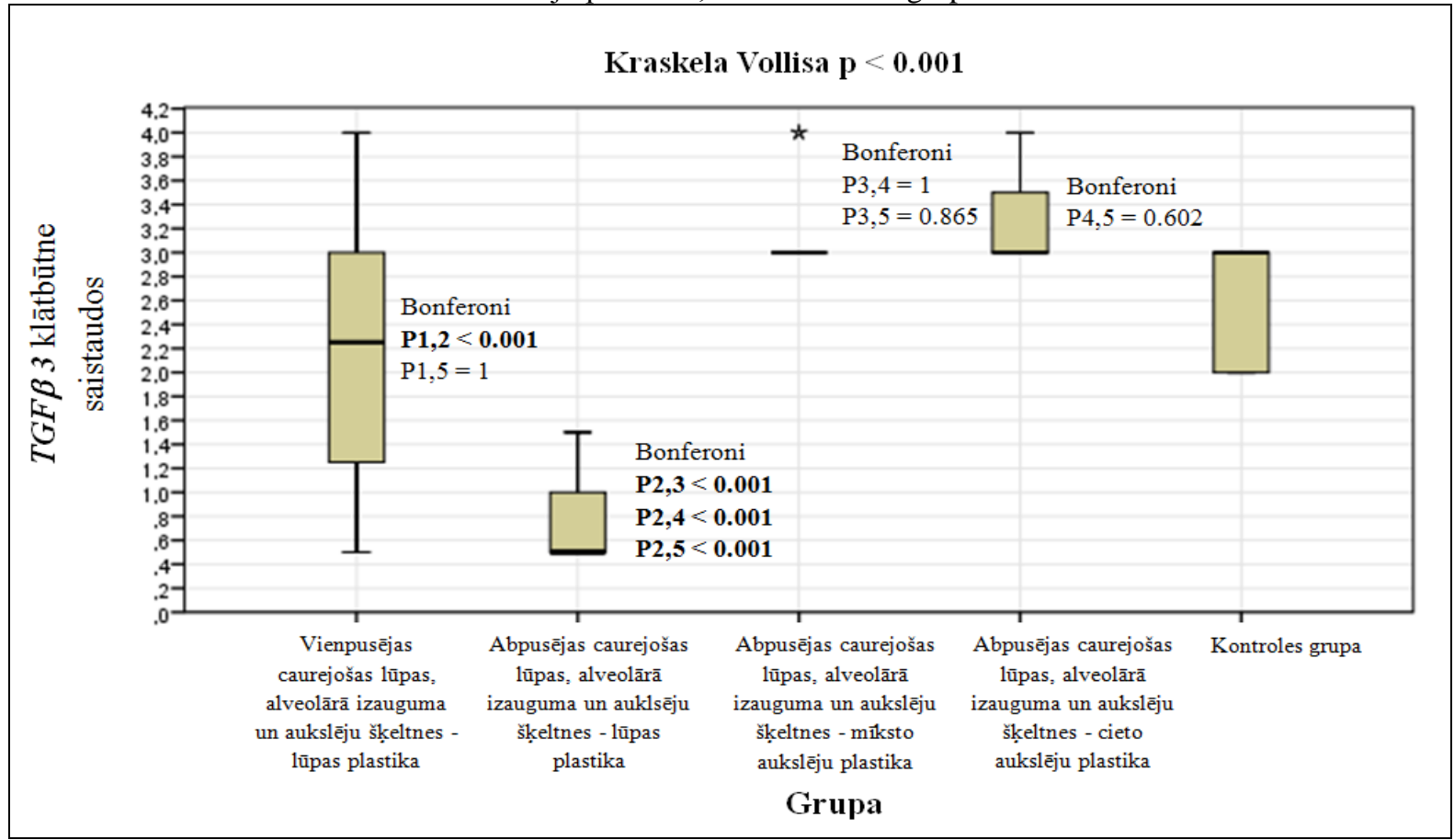

\subsection{8. attēls. $T G F \beta 3$ saturošo imūnhistoḳīmiski noteikto saistaudu šūnu relatīvā daudzuma vidējo rangu} atšḳirības starp dažādām izmeklējamā materiāla grupām

Saīsinājumi attēlā: TGFß3 - transformējošais augšanas faktors beta-3; P1 - vienpusējas caurejošas lūpas un aukslēju šķeltnes grupa pēc lūpas plastikas; P2 - abpusējas caurejošas lūpas un aukslēju šķeltnes grupa pēc lūpas plastikas; P3 - abpusējas caurejošas lūpas un aukslēju šķeltnes grupa pēc mīksto aukslēju plastikas; P4 - abpusējas caurejošas lūpas un aukslēju šķeltnes grupa pēc cieto aukslēju plastikas; P5 - kontroles grupa. 
Transformējošā augšanas faktora beta-3 (TGFß3) atrade mīksto un cieto aukslēju plastikas laikā iegūtajā materiālā bērniem ar abpusēju caurejošu lūpas, alveolārā izauguma un aukslēju škseltni

Mīksto aukslēju plastikas laikā iegūtajā materiālā tika novērotas vidēji daudz (++) līdz ļoti daudz (++++) TGFß3 saturošas epitēlijšūnas un saistaudu šūnas (3.17. tabula; 3.66. mikrofotogrāfija pielikumā).

TGFß3, VEGF, CD34 un PGP 9.5 pozitīvu struktūru relatīvais daudzums abpusēju caurejošu lūpas, alveolārā izauguma un aukslēju šķeltṇu skartajos audos, kas iegūti mīksto aukslēju plastikas laikāa

\begin{tabular}{|l|c|c|c|c|c|c|}
\hline \multirow{2}{*}{ Nr. } & \multirow{2}{*}{ Sifrs } & \multicolumn{2}{|c|}{$T G F \beta 3$} & VEGF & CD34 & PGP 9.5 \\
\cline { 3 - 7 } & & $\mathrm{E}$ & $\mathrm{S}$ & & & \\
\hline 1. & 79 & ++++ & ++++ & + & ++ & $0 /+$ \\
\hline 2. & 187 & +++ & ++++ & + & ++ & $0 /+$ \\
\hline 3. & 196 & ++ & +++ & + & ++ & $0 /+$ \\
\hline 4. & 207 & +++ & +++ & + & ++ & $0 /+$ \\
\hline 5. & 245 & +++ & +++ & $0 /+$ & ++ & 0 \\
\hline 6. & 249 & ++ & +++ & + & ++ & 0 \\
\hline 7. & 254 & +++ & +++ & $0 /+$ & ++++ & 0 \\
\hline 8. & 261 & ++++ & +++ & + & ++ & + \\
\hline 9. & 273 & +++++++ & +++ & + & ++ & + \\
\hline 10. & 276 & +++ & +++ & $0 /+$ & +++ & 0 \\
\hline
\end{tabular}

Apzīmējumi tabulā: 0 - redzes laukā nav konstatēta neviena pozitīva struktūra; 0/+ - redzes laukā ir retas pozitīvas struktūras; + - redzes laukā ir maz pozit̄̄vu struktūru; +/++ - redzes laukā ir maz līdz vidēji daudz pozitīivu struktūru; ++ - redzes laukā ir vidēji daudz pozitīivu struktūru; ++/+++ - redzes laukā ir vidēji daudz līdz daudz pozitīvu struktūru; +++ - redzes laukā ir daudz pozitīvu struktūru; +++/++++ - redzes laukā ir daudz līdz loti daudz pozitīivu struktūru; ++++ - redzes laukā ir l̦oti daudz pozitīvu struktūru.

Saīsinājumi tabulā: E - epitēlijšūnas; $\mathrm{S}$ - saistaudu šūnas; TGF 33 - transformējošais augšanas faktors beta-3; $V E G F$ - vaskulārais endotēlija augšanas faktors; $C D$-34 - transmembranozais glikoproteīns $C D$-34; $P G P 9.5$ proteīngēnviela 9.5 .

Cieto aukslēju plastikas laikā iegūtajā materiālā atrade bija līdzīga, tika vizualizētas maz līdz vidēji daudz (+/++) līdz ḷoti daudz (++++) TGFß3 pozitīvas šūnas (3.18. tabula). 
TGFß3, VEGF, CD34 un PGP 9.5 relatīvais daudzums abpusēju caurejošu lūpas, alveolārā izauguma un aukslēju šķeltṇu skartajos audos, kas iegūti cieto aukslēju plastikas laikā

\begin{tabular}{|l|c|c|c|c|c|c|}
\hline \multirow{2}{*}{ Nr. } & \multirow{2}{*}{ Šfrs } & \multicolumn{2}{|c|}{$T G F \beta 3$} & VEGF & CD34 & PGP 9.5 \\
\cline { 3 - 7 } & & $\mathrm{E}$ & $\mathrm{S}$ & & & \\
\hline 1. & $79(1)$ & +++ & +++ & + & ++ & +++ \\
\hline 2. & 81 & +++ & +++ & + & +++ & ++ \\
\hline 3. & $134(1)$ & +++ & +++ & + & ++ & + \\
\hline 4. & $134(2)$ & +++ & +++ & + & ++ & $0 /+$ \\
\hline 5. & 150 & +++ & +++ & + & +++ & + \\
\hline 6. & 180 & $+/++$ & ++++ & $0 /+$ & + & ++ \\
\hline 7. & 232 & +++ & ++++ & + & ++++ & $0 /+$ \\
\hline 8. & 253 & +++ & +++ & $+/++$ & +++ & $0 /+$ \\
\hline 9. & 265 & +++ & $+++/++++$ & ++ & ++++ & ++ \\
\hline
\end{tabular}

Apzīmējumi tabulā: 0 - redzes laukā nav konstatēta neviena pozitīva struktūra; 0/+ - redzes laukā ir retas pozitīvas struktūras; + - redzes laukā ir maz pozitīvu struktūru; +/++ - redzes laukā ir maz līdz vidēji daudz pozitīvu struktūru; ++ - redzes laukā ir vidēji daudz pozitīvu struktūru; ++/+++ - redzes laukā ir vidēji daudz līdz daudz pozit̄ivu struktūru; +++ - redzes laukā ir daudz pozitīvu struktūru; +++/++++ - redzes laukā ir daudz līdz loti daudz pozit̄̄vu struktūru; ++++ - redzes laukā ir ḷoti daudz pozitīvu struktūru.

Saīsinājumi tabulā: E - epitēlijšūnas; S - saistaudu šūnas; $T G F \beta 3$ - transformējošais augšanas faktors beta-3; $V E G F$ - vaskulārais endotēlija augšanas faktors; $C D$-34 - transmembranozais glikoproteīns $C D$-34; $P G P 9.5$ proteīngēnviela 9.5 .

Statistiskie dati. Analizējot datus, tika secināts, ka TGFß3 pozitīvo struktūru vidējais relatīvais daudzums bija statistiski ticami lielāks mīksto un cieto aukslēju plastikas laikā iegūtajos audos nekā lūpas materiālā $(\mathrm{p}<0,001)$ (3.17. un 3.18. attēls).

\section{Vaskulārā endotēlija augšanas faktora (VEGF) atrade lūpas primārās plastikas laikā iegūtajā materiālā zīdaiņiem un bērniem ar caurejošu lūpas, alveolārā izauguma un aukslēju škseltni}

Triju pacientu abpusējas škseltnes audu paraugos netika konstatēti VEGF saturoši endoteliocīti. Divpadsmit bērnu audu paraugi saturēja maz (+) līdz daudz $(+++)$ pozitīvus endoteliocītus redzes laukā (3.15. tabula; 3.67. mikrofotogrāfija pielikumā).

Taču VEGF saturēja visu 24 pacientu, kuriem bija vienpusēja caurejoša lūpas, alveolārā izauguma un aukslēju škseltne, audu paraugi. VEGF pozitīvas endotēlijšūnas variēja no retām $(0 /+)$ līdz ļoti daudz (++++) redzes laukā (3.16. tabula; 3.68. mikrofotogrāfija pielikumā).

Statistiskie dati. $\underline{V E G F}$ pozitīvo struktūru vidējais relatīvais daudzums vienpusēju caurejošu lūpas, alveolārā izauguma un aukslēju šķeltņu audos tika vizualizēts vairāk nekā abpusēju caurejošu lūpas, alveolārā izauguma un aukslēju šķeltu skartajos audos $(p<0,05)$ (3.19. attēls). 


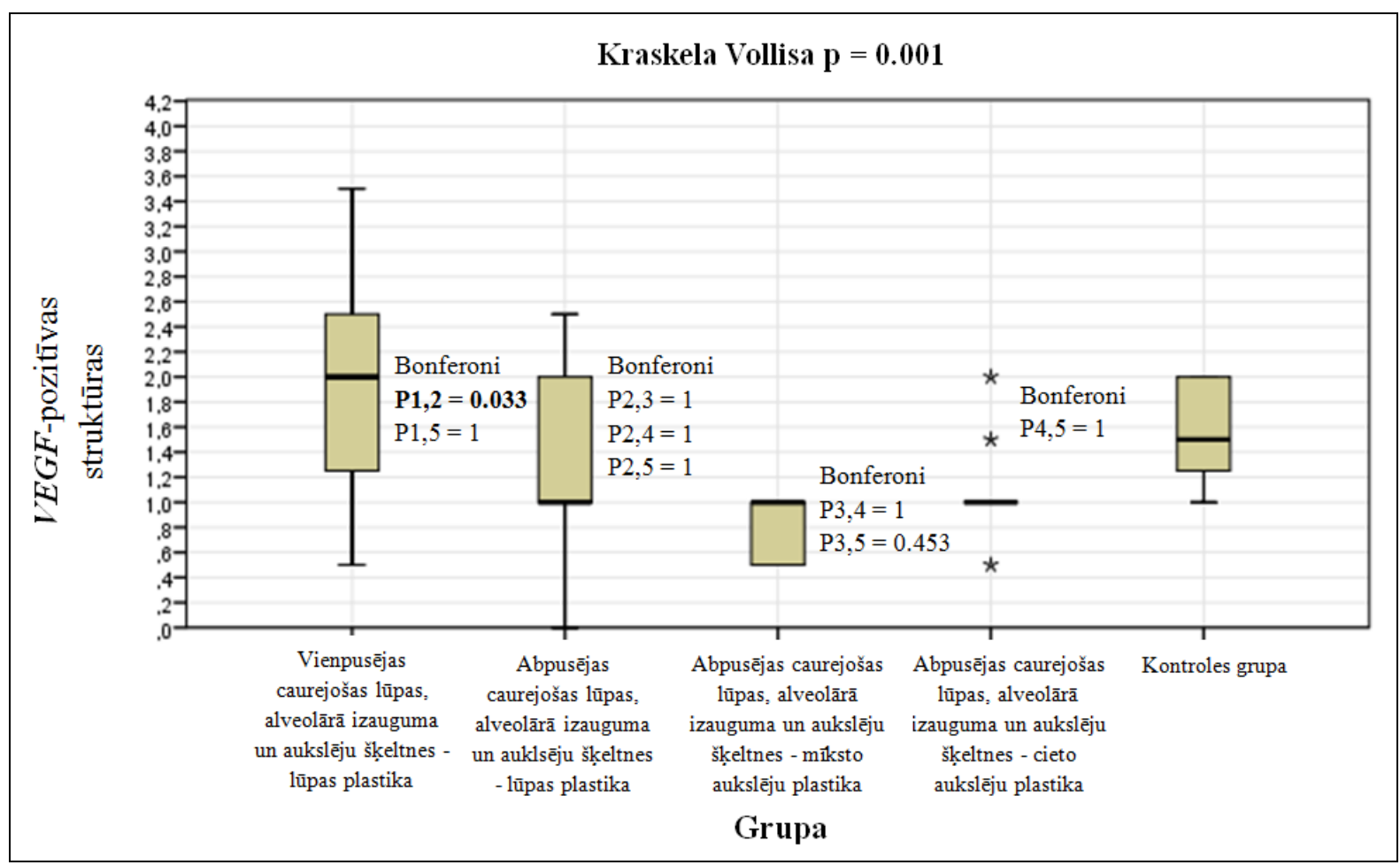

3.19. attēls. VEGF saturošo imūnhistoḳīmiski noteikto struktūru relatīvā daudzuma vidējo rangu atšķirības starp dažādām izmeklējamā materiāla grupām

Saīsinājumi attēlā: $V E G F$ - vaskulārais endotēlija augšanas faktors; P1 - vienpusējas caurejošas lūpas un aukslēju šķeltnes grupa pēc lūpas plastikas; P2 - abpusējas caurejošas lūpas un aukslēju šķeltnes grupa pēc lūpas plastikas; P3 - abpusējas caurejošas lūpas un aukslēju šķeltnes grupa pēc mīksto aukslēju plastikas; P4 abpusējas caurejošas lūpas un aukslēju šķeltnes grupa pēc cieto aukslēju plastikas; P5 - kontroles grupa.

Vaskulārā endotēlija augšanas faktora (VEGF) atrade mīksto un cieto aukslēju plastikas laikā iegūtajā materiālā bērniem ar abpusēju caurejošu lūpas, alveolārā izauguma un aukslēju škseltni

Mīksto aukslēju plastikas laikā iegūtajos audu paraugos tika konstatētas retas (0/+) līdz maz (+) VEGF saturošas endotēlijšūnas (3.17. tabula; 3.69. mikrofotogrāfija pielikumā).

Visos cieto aukslēju plastikas laikā iegūtajos audu paraugos novērotas VEGF pozitīvas endotēlijšūnas; to skaits variēja no retām (0/+) līdz vidēji daudz (++) redzes laukā (3.18. tabula).

Statistiskie dati. Šajās pētījuma grupās statistiski ticamas atšksirības netika konstatētas $(\mathrm{p}>0,05)$.

Transmembranozā glikoproteīna $C D 34$ (CD34) atrade lūpas primārās plastikas laikā iegūtajā materiālā zīdaiņiem un bērniem ar caurejošu lūpas, alveolārā izauguma un aukslēju škseltni

Visos (16) abpusējas caurejošas šķeltnes gadījumos tika novērota bagātīga CD34 ekspresija asinsvadu sieniņās. Kopumā CD34 pozitīvo šūnu relatīvais daudzums bija ļoti daudz (++++) redzes laukā (3.15. tabula). 
Divdesmit četriem pacientiem ar vienpusēju caurejošu šķeltni arī tika konstatēta bagātīga CD34 klatbūtne asinsvadu sieniņās. CD34 pozitīvo endoteliocītu relatīvais daudzums bija l̦oti daudz (++++) redzes laukā (3.16. tabula; 3.70. mikrofotogrāfija pielikumā).

Statistiskie dati. Salīdzinot ar kontroles grupu, novērojām statistiski ticami vairāk $\underline{C D 34}$ pozitīvo struktūru škeltṇu pacientu audos ( $\mathrm{p}<0,001)$ (3.20. attēls).

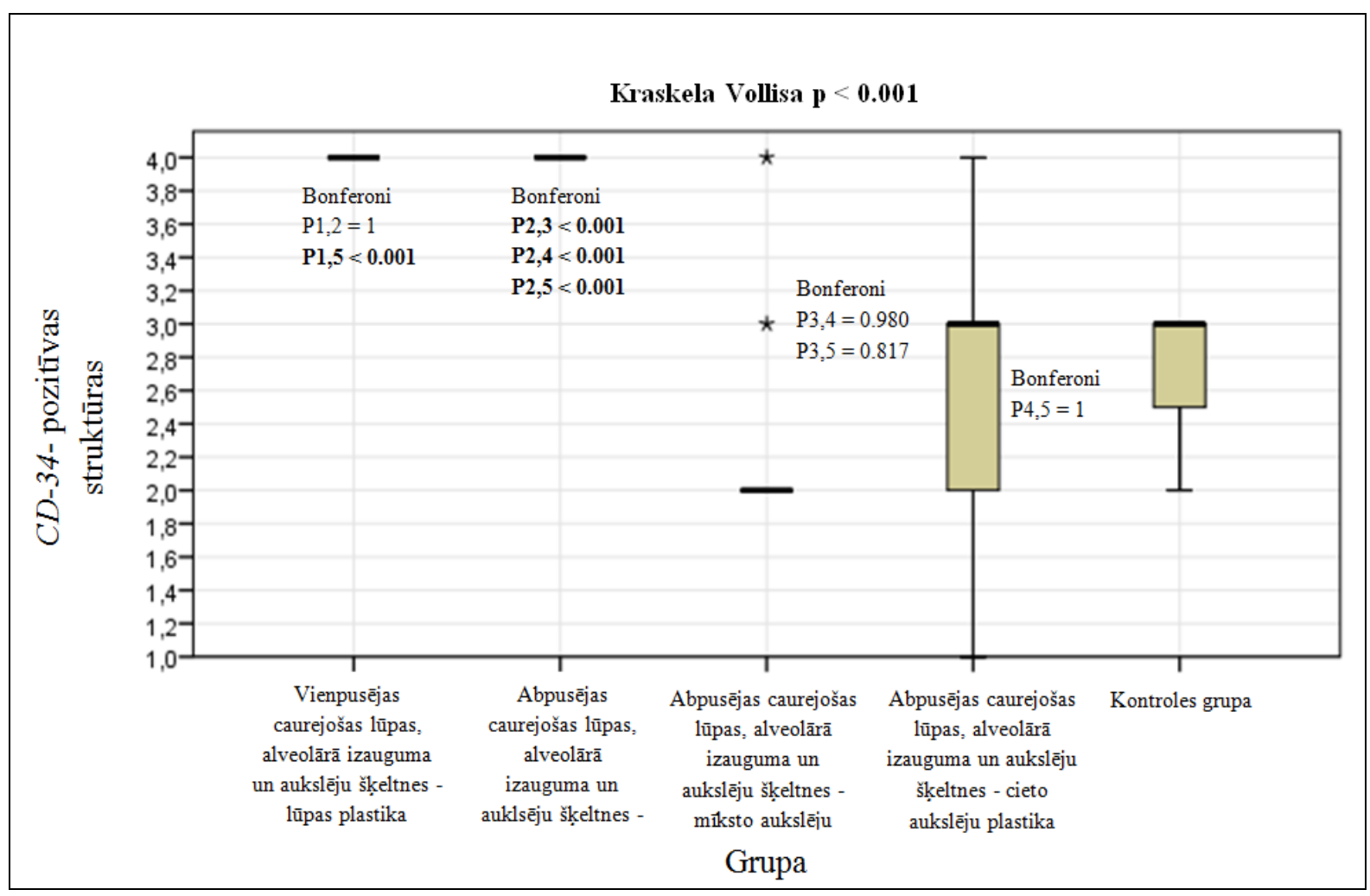

3.20. attēls. $C D 34$ saturošo imūnhistoḳīmiski noteikto struktūru relatīvā daudzuma vidējo rangu atšķiīības starp dažādām izmeklējamā materiāla grupām

Saīsinājumi attēlā: $C D 34$ - transmembranozais glikoproteīns $C D 34 ; \mathrm{P} 1$ - vienpusējas caurejošas lūpas un aukslēju šķeltņes grupa pēc lūpas plastikas; P2 - abpusējas caurejošas lūpas un aukslēju šķeltnes grupa pēc lūpas plastikas; P3 - abpusējas caurejošas lūpas un aukslēju šķeltnes grupa pēc mīksto aukslēju plastikas; P4 abpusējas caurejošas lūpas un aukslēju šķeltnes grupa pēc cieto aukslēju plastikas; P5 - kontroles grupa.

Transmembranozā glikoproteīna $C D 34$ (CD34) atrade mīksto un cieto aukslēju plastikas laikā iegūtajā materiālā bērniem ar abpusēju caurejošu lūpas, alveolārā izauguma un aukslēju škseltni

Visos (10) mīksto aukslēju plastikas laikā iegūtajos audu paraugos tika vizualizētas CD34 saturošas šūnas asinsvadu sieniņās. Mīksto aukslēju plastikas laikā iegūtajos audu paraugos CD34 pozitīvas šūnas variēja no vidēji daudz $(++)$ līdz ļoti daudz $(++++)$ redzes laukā (3.17. tabula).

Visos (9) cieto aukslēju plastikas laikā iegūtajos audu paraugos tika konstatētas CD34 pozitīvas šūnas asinsvadu sieniņās. Cieto aukslēju plastikas laikā iegūtajos audu paraugos CD34 pozitīvas šūnas bija robežās no vidēji daudz $(++)$ līdz ļoti daudz $(++++)$ redzes laukā (3.18. tabula; 3.71. mikrofotogrāfija pielikumā). 
Statistiskie dati. Minētā proteīna klātbūtne abpusējas lūpas škseltnes materiālā bija statistiski ticami izteiktāka nekā mīksto un cieto aukslēju audos (p < 0,001) (3.20. attēls).

\section{Proteīngēnvielas 9.5 (PGP 9.5) atrade lūpas primārās plastikas laikā iegūtajā materiālā zīdaiņiem un bērniem ar caurejošu lūpas, alveolārā izauguma un aukslēju škşeltni}

PGP 9.5 saturošas struktūras mūsu pētījumā tika novērotas visu 16 pacientu ar abpusēju škseltni operāciju laikā paņemtajos audos. Vidēji tika konstatētas maz līdz vidēji daudz (+/++) PGP 9.5 saturošas DNES struktūras, no retām $(0 /+)$ līdz vidēji daudz (++) redzes laukā (3.15. tabula). Dažos paraugos tika fiksētas $P G P 9.5$ saturošas neiroendokrīnās šūnas epitēlijāa $P G P 9.5$ lūpas plastikas iegūtajos audos bagātīgi saturēja nervu šķiedras ap tauku dziedzeriem, matu folikuliem, asinsvadiem, kā arī atsevišķas nervu šķiedras epitēlijā (3.72. mikrofotogrāfija pielikumā). Tika redzētas sīkas $P G P 9.5$ saturošas nervu šķiedras subepitēlijā.

PGP 9.5 iekrāsoja DNES struktūras gandrīz visu vienpusējas šķeltnes pacientu audus, kas tika iegūti lūpas plastikas laikā. Redzes laukā bija retas (0/+) līdz daudz (+++) PGP 9.5 pozitīvas struktūras (3.16. tabula). PGP 9.5 bagātīgi iekrāsoja nervu šķiedras ap asinsvadiem un asinsvadu sieniņās (3.73. mikrofotogrāfija pielikumā), ap matu folikuliem (3.74. mikrofotogrāfija pielikumā), tauku un mazajiem siekalu dziedzeriem (3.75. mikrofotogrāfija pielikumā), kā arī nervu šķiedru kūlīšus (3.76. mikrofotogrāfija pielikumā). Jāatzīmē, ka $P G P$ 9.5 iekrāsoja arī sīkas nervu šķiedras subepitēlijā un epitēlijā. Tika novērotas arī PGP 9.5 saturošas neiroendokrīnās šūnas epitēlijā (3.77. mikrofotogrāfija pielikumā).

Statistiskie dati. $\underline{P G P} 9.5$ pozitīvo struktūru vidējais relatīvais daudzums šo šķeltņu pacientu grupās bija variabls un neatškīīās no kontroles grupas vidējā relatīiā rādītāja (3.21. attēls). 


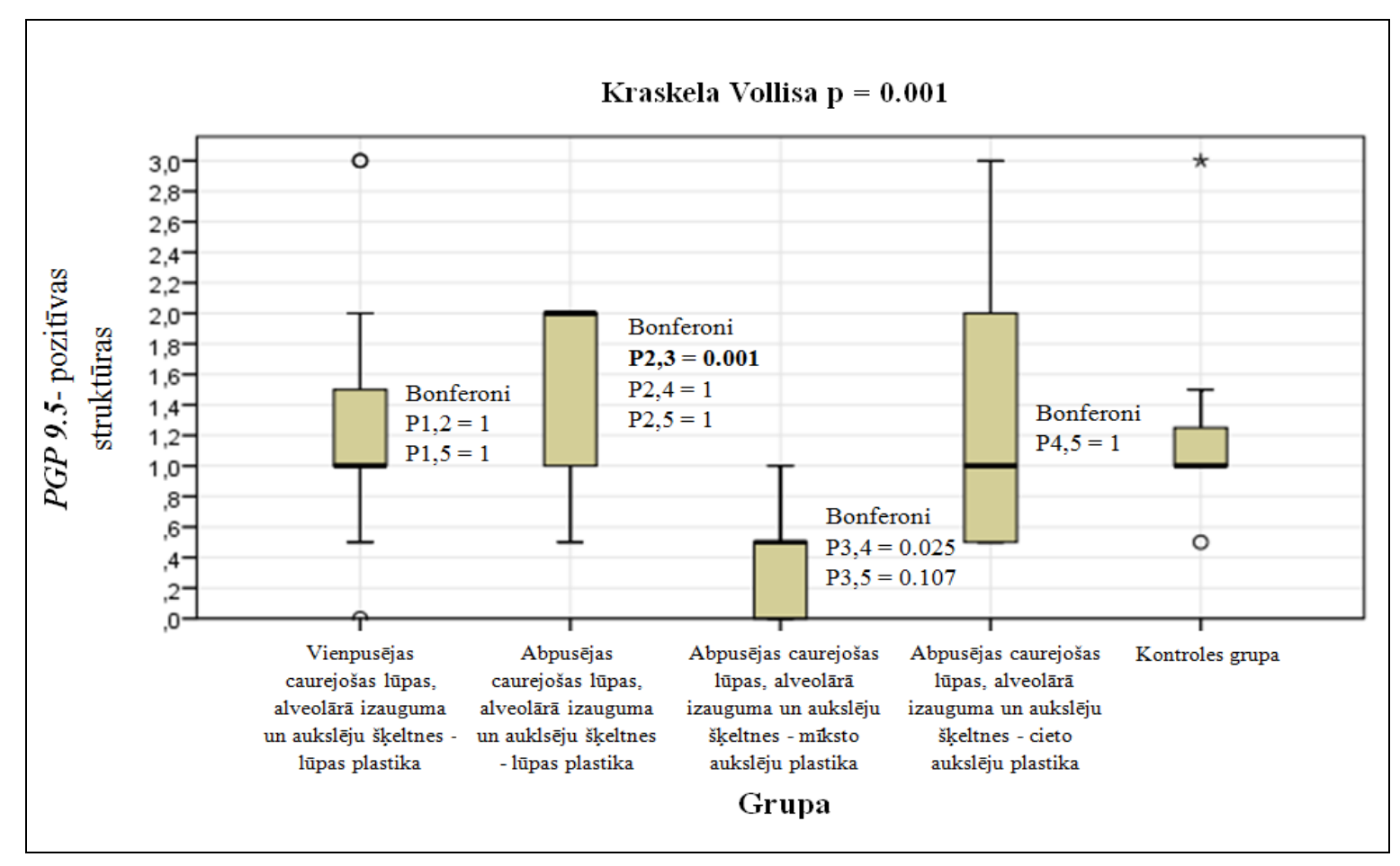

3.21. attēls. PGP 9.5 saturošo imūnhistoḳīmiski noteikto struktūru relatīvā daudzuma vidējo rangu atšksirības starp dažādām izmeklējamā materiāla grupām

Saīsinājumi attēlā: PGP 9.5 - proteīngēnviela 9.5; P1 - vienpusējas caurejošas lūpas un aukslēju šķeltnes grupa pēc lūpas plastikas; P2 - abpusējas caurejošas lūpas un aukslēju šķeltnes grupa pēc lūpas plastikas; P3 - abpusējas caurejošas lūpas un aukslēju šķeltnes grupa pēc mīksto aukslēju plastikas; P4 abpusējas caurejošas lūpas un aukslēju šķeltnes grupa pēc cieto aukslēju plastikas; P5 - kontroles grupa.

\section{Proteīngēnvielas 9.5 (PGP 9.5) atrade mīksto un cieto aukslēju plastikas laikā iegūtajā} materiālā bērniem ar abpusēju caurejošu lūpas, alveolārā izauguma un aukslēju šķeltni

Mīksto aukslēju plastikas laikā iegūtajos audu paraugos četriem pacientiem netika saskatīta neviena $P G P 9.5$ pozitīva struktūra. Četru pacientu audos tika redzētas retas $(0 /+)$ nervu šķiedras saistaudos un divu pacientu audos tādu bija maz - (+) (3.17. tabula; 3.78. mikrofotogrāfija pielikumā).

Cieto aukslēju plastikas laikā iegūtajos audu paraugos tika fiksētas retas $(0 /+)$ lìdz daudz (+++) PGP 9.5 saturošas nervu šķiedras epitēlijā un subepitēlijā (3.18. tabula; 3.79. mikrofotogrāfija pielikumā).

Statistiskie dati. $\underline{P G P} 9.5$ klātbūtne abpusēju caurejošu lūpas, alveolārā izauguma un aukslēju šķeltņu lūpas plastikas laikā iegūtajā materiālā bija statistiski ticami lielāka nekā

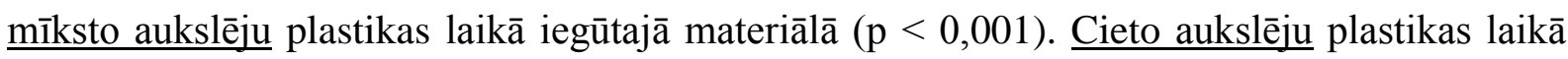
iegūtajos audu paraugos $\underline{P G P 9.5 \text { saturošo struktūru relatīvais daudzums bija statistiski ticami }}$ lielāks nekā mīksto aukslēju plastikas laikā iegūtajos audu paraugos $(\mathrm{p}<0,05)$ (3.21. attēls). 

statistiskie dati

\section{Ki-67 atrade lūpas plastikas laikā iegūtajā materiālā zīdaiņiem un bērniem ar caurejošu lūpas, alveolārā izauguma un aukslēju šḳeltni}

Tikai vienam pacientam ar abpusēju caurejošu lūpas, alveolārā izauguma un aukslēju šķeltni tika konstatēta šūnu proliferācijas marķiera Ki-67 ekspresija epitēlijšūnu kodolos. Jāatzīmēe ka š̄ pacienta audos tika redzēti tikai reti (0/+) Ki-67 pozitīvi mutes dobuma gḷotādas epiteliocīti (3.19. tabula) (3.80. mikrofotogrāfija pielikumā).

3.19. tabula

Ki-67, nestīna un apoptozes relatīvais daudzums abpusēju caurejošu lūpas, alveolārā izauguma un aukslēju šķeltṇu skartajos audos, kas iegūti lūpas plastikas laikāa

\begin{tabular}{|l|c|c|c|c|}
\hline Nr. & Šifrs & $K i-67$ & Nestīns & Apoptoze \\
\hline 1. & $55 \mathrm{~L}$ & 0 & ++ & ++ \\
\hline 2. & $55 \mathrm{R}$ & 0 & + & $0 /+$ \\
\hline 3. & 168 & 0 & ++ & $0 /+$ \\
\hline 4. & 177 & 0 & + & + \\
\hline 5. & 194 & 0 & +++ & + \\
\hline 6. & 197 & 0 & $+/++$ & + \\
\hline 7. & 204 & 0 & ++ & + \\
\hline 8. & 206 & 0 & ++ & $0 /+$ \\
\hline 9. & 212 & 0 & 0 & + \\
\hline 10. & 213 & 0 & $+/++$ & + \\
\hline 11. & 221 & 0 & +++ & $+/+$ \\
\hline 12. & 238 & 0 & ++ & $+/++$ \\
\hline 13. & 244 & 0 & ++ & + \\
\hline 14. & 264 & $0 /+$ & +++ & + \\
\hline 15. & 267 & 0 & ++ & $0 /+$ \\
\hline
\end{tabular}

Apzīmējumi tabulā: 0 - redzes laukā nav konstatēta neviena pozitīva struktūra; 0/+ - redzes laukā ir retas pozitīvas struktūras; + - redzes laukā ir maz pozitīvu struktūru; +/++ - redzes laukā ir maz līdz vidēji daudz pozitīvu struktūru; ++ - redzes laukā ir vidēji daudz pozitīvu struktūru; ++/+++ - redzes laukā ir vidēji daudz līdz daudz pozitīvu struktūru; +++ - redzes laukā ir daudz pozitīvu struktūru; +++/++++ - redzes laukā ir daudz līdz ļoti daudz pozitīvu struktūru; ++++ - redzes laukā ir l̦oti daudz pozitīvu struktūru.

Sāisinājums tabulā: Ki-67 - šūnu proliferācijas marķieris Ki-67.

Divdesmit trijiem no 24 pacientiem ar vienpusēju caurejošu lūpas, alveolārā izauguma un aukslēju škseltni pacientiem epitēlijā tika konstatētas retas $(0 /+)$ līdz maz (+) Ki-67 pozitīvas struktūras redzes laukā (3.20. tabula; 3.81. mikrofotogrāfija pielikumā). 
Ki-67 un nestīna pozitīvu struktūru relatīvais daudzums vienpusēju caurejošu lūpas, alveolārā izauguma un aukslēju šķeltņu skartajos audos, kas iegūti lūpas plastikas laikā

\begin{tabular}{|c|c|c|c|c|}
\hline $\mathrm{Nr}$. & Šifrs & $K i-67$ & Nestīns & Apoptoze \\
\hline 1. & 195 & $0 /+$ & +++ & + \\
\hline 2. & 205 & $0 /+$ & +++ & ++ \\
\hline 3. & 217 & $0 /+$ & $++/+++$ & +++ \\
\hline 4. & 220 & $0 /+$ & +++ & $+++/++++$ \\
\hline 5. & 223 & 0 & ++ & ++ \\
\hline 6. & 224 & $0 /+$ & $++/+++$ & ++ \\
\hline 7. & 227 & $0 /+$ & $+++/++++$ & +++ \\
\hline 8. & 247 & $0 /+$ & ++ & $0 /+$ \\
\hline 9. & 258 & $0 /+$ & +++ & $+/++$ \\
\hline 10. & 259 & $0 /+$ & ++ & ++ \\
\hline 11. & 262 & $0 /+$ & $+++/++++$ & ++ \\
\hline 12. & 277 & $0 /+$ & ++ & $++/+++$ \\
\hline 13. & 279 & $0 /+$ & $++/+++$ & ++ \\
\hline 14. & 282 & $0 /+$ & ++ & $+/++$ \\
\hline 15. & 283 & $0 /+$ & +++ & + \\
\hline 16. & 284 & + & +++ & $+/++$ \\
\hline 17. & 288 & $0 /+$ & ++ & + \\
\hline 18. & 289 & $0 /+$ & +/++ & + \\
\hline 19. & 299 & + & ++ & $0 /+$ \\
\hline 20. & 300 & $0 /+$ & $++/+++$ & $+/++$ \\
\hline 21. & 302 & $0 /+$ & +++ & $0 /+$ \\
\hline 22. & 303 & + & +++ & ++ \\
\hline 23. & 306 & $0 /+$ & $++/+++$ & $+/++$ \\
\hline 24. & 307 & $0 /+$ & +++ & $+/++$ \\
\hline
\end{tabular}

Apzīmējumi tabulā: 0 - redzes laukā nav konstatēta neviena pozitīva struktūra; 0/+ - redzes laukā ir retas pozitīvas struktūras; + - redzes laukā ir maz pozitīvu struktūru; +/++ - redzes laukā ir maz līdz vidēji daudz pozit̄̄vu struktūru; ++ - redzes laukā ir vidēji daudz pozitīvu struktūru; ++/+++ - redzes laukā ir vidēji daudz līdz daudz pozitīvu struktūru; +++ - redzes laukā ir daudz pozit̄ivu struktūru; +++/++++ - redzes laukā ir daudz līdz loti daudz pozit̄̄vu struktūru; ++++ - redzes laukā ir ḷoti daudz pozitīvu struktūru.

Saīsinājums tabulā: Ki-67 - šūnu proliferācijas marḳieris Ki-67.

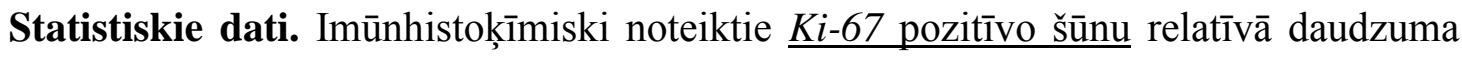
vidējie rangi audos bija statistiski ticami lielāki pacientiem ar vienpusēju caurejošu lūpas, alveolārā izauguma un aukslēju šķeltni nekā pacientiem ar abpusēju caurejošu škseltni (p < 0,05) (3.22. attēls). 


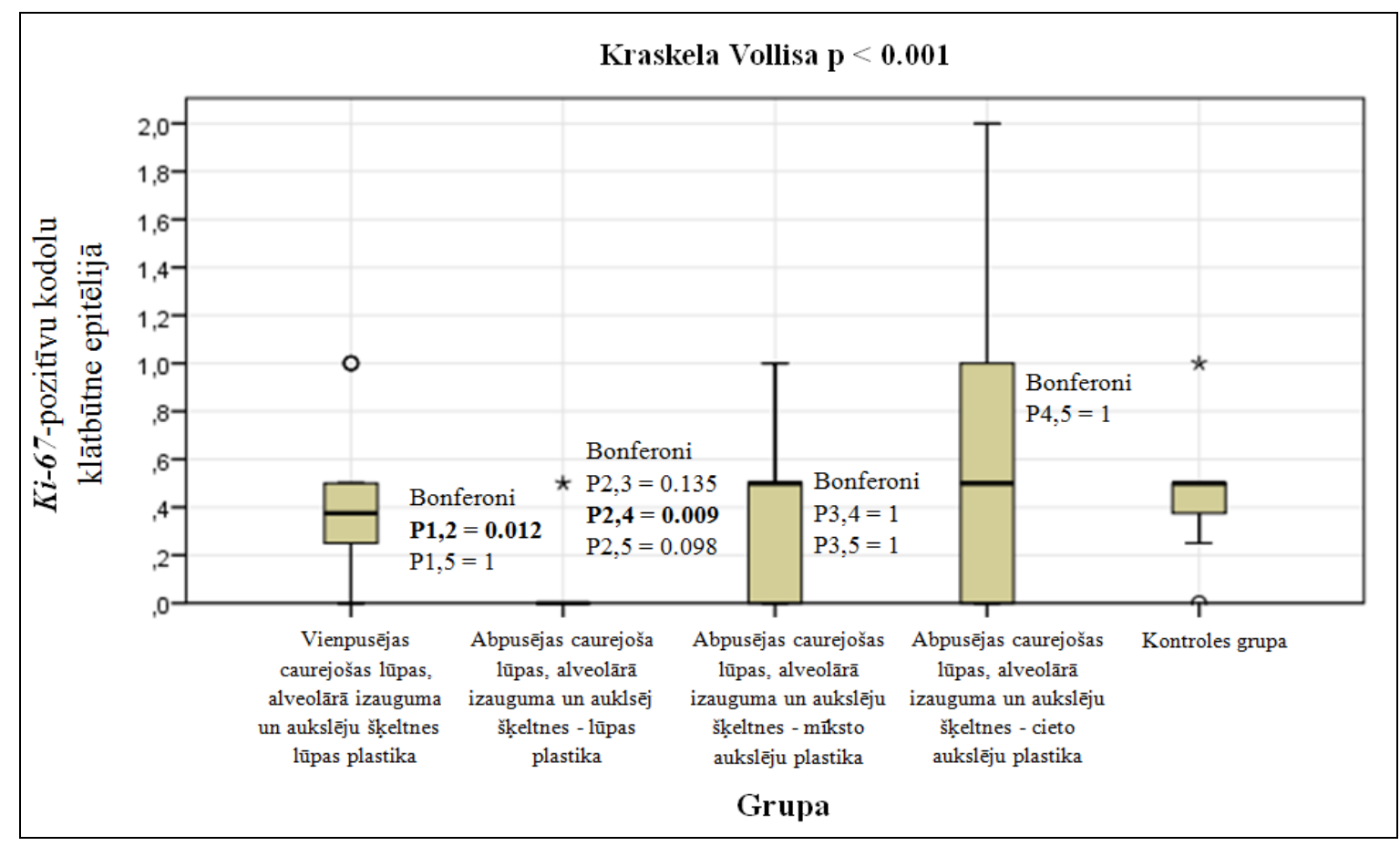

3. 22. attēls. Ki-67 saturošo imūnhistoķīmiski noteikto struktūru relatīvā daudzuma vidējo rangu atšksirības starp dažādām izmeklējamā materiāla grupām

Saīsinājumi attēlā: Ki-67 - proliferācijas marķieris Ki-67; P1 - vienpusējas caurejošas lūpas un aukslēju šķeltnes grupa pēc lūpas plastikas; P2 - abpusējas caurejošas lūpas un aukslēju šķeltnes grupa pēc lūpas plastikas; P3 - abpusējas caurejošas lūpas un aukslēju šķeltnes grupa pēc mīksto aukslēju plastikas; P4 abpusējas caurejošas lūpas un aukslēju šķeltnes grupa pēc cieto aukslēju plastikas; P5 - kontroles grupa.

Ki-67 atrade mīksto un cieto aukslēju plastikas laikā iegūtajā materiālā bērniem ar abpusēju caurejošu lūpas, alveolārā izauguma un aukslēju šķeltni

Mīksto aukslēju plastikas laikā iegūtajos audu paraugos tika novēroti reti (0/+) līdz maz (+) Ki-67 pozitīvi epitēlijšūnu kodoli (3.21. tabula; 3.82. mikrofotogrāfija pielikumā). Četriem pacientiem netika redzēts neviens pozitīvs kodols. 
Ki-67 un nestīna pozitīvu struktūru relatīvais daudzums abpusēju caurejošu lūpas, alveolārā izauguma un aukslēju šķeltņu skartajos audos, kas iegūti mīksto aukslēju plastikas laikā

\begin{tabular}{|l|c|c|c|}
\hline Nr. & Šifrs & Ki-67 & Nestīns \\
\hline 1. & 79 & + & $++/+++$ \\
\hline 2. & 187 & 0 & $++/+++$ \\
\hline 3. & 196 & 0 & + \\
\hline 4. & 207 & 0 & $+/++$ \\
\hline 5. & 245 & 0 & ++ \\
\hline 6. & 249 & $0 /+$ & + \\
\hline 7. & 254 & $0 /+$ & ++ \\
\hline 8. & 261 & $0 /+$ & $++/+++$ \\
\hline 9. & 273 & $0 /+$ & +++ \\
\hline 10. & 276 & + & ++ \\
\hline
\end{tabular}

Apzīmējumi tabulā: 0 - redzes laukā nav konstatēta neviena pozitīva struktūra; 0/+ - redzes laukā ir retas pozitīvas struktūras; + - redzes laukā ir maz pozitīvu struktūru; +/++ - redzes laukā ir maz līdz vidēji daudz pozitīvu struktūru; ++ - redzes laukā ir vidēji daudz pozitīvu struktūru; ++/+++ - redzes laukā ir vidēji daudz līdz daudz pozit̄̄vu struktūru; +++ - redzes laukā ir daudz pozitīvu struktūru; +++/++++ - redzes laukā ir daudz līdz ļoti daudz pozitīvu struktūru; ++++ - redzes laukā ir ļoti daudz pozitīvu struktūru.

Saīsinājums tabulā: $K i-67$ - šūnu proliferācijas marķieris $K i-67$.

Cieto aukslēju plastikas laikā iegūtajā materiālā vienam pacientam epitēlijā tika fiksēts vidēji daudz (++), diviem pacientiem - maz (+), diviem pacientiem - retas (0/+) Ki-67 saturošas šūnas redzes laukā (3.22. tabula).

3. 22. tabula

Ki-67 un nestīna pozitīvu struktūru relatīvais daudzums abpusēju caurejošu lūpas, alveolārā izauguma un aukslēju šķeltņu skartajos audos, kas iegūti cieto aukslēju plastikas laikā

\begin{tabular}{|l|c|c|c|}
\hline Nr. & Šifrs & Ki-67 & Nestīns \\
\hline 1. & $79 / 1$ & + & $++/+++$ \\
\hline 2. & 81 & 0 & ++ \\
\hline 3. & $134 / 1$ & 0 & +++ \\
\hline 4. & $134 / 2$ & 0 & ++ \\
\hline 5. & 150 & $0 /+$ & +++ \\
\hline 6. & 180 & $0 /+$ & $++/+++$ \\
\hline 7. & 232 & ++ & +++ \\
\hline 8. & 253 & 0 & ++ \\
\hline 9. & 265 & + & +++ \\
\hline
\end{tabular}

Apzīmējumi tabulā: 0 - redzes laukā nav konstatēta neviena pozitīiva struktūra; 0/+ - redzes laukā ir retas pozitīvas struktūras; + - redzes laukā ir maz pozit̄ivu struktūru; +/++ - redzes laukā ir maz līdz vidēji daudz pozitīvu struktūru; ++ - redzes laukā ir vidēji daudz pozitīvu struktūru; ++/+++ - redzes laukā ir vidēji daudz līdz daudz pozitīvu struktūru; +++ - redzes laukā ir daudz pozitīvu struktūru; +++/++++ - redzes laukā ir daudz līdz ļoti daudz pozitīivu struktūru; ++++ - redzes laukā ir ļoti daudz pozitīvu struktūru.

Saīsinājums tabulā: $K i-67$ - šūnu proliferācijas marķieris $K i-67$. 
Statistiskie dati. Relatīvais pozit̄̄vo struktūru daudzums cieto aukslēju plastikas laikā iegūtajā materiālā bija statistiski ticami lielāks, salīdzinot ar lūpu plastikas laikā iegūto materiālu $(\mathrm{p}<0,05)(3.22$. attēls $)$.

\section{Nestīna atrade lūpas plastikas laikā iegūtajā materiālā zīdaiṇiem un bērniem ar caurejošu lūpas, alveolārā izauguma un aukslēju šḳeltni}

Visiem abpusējas škseltnes lūpas plastikas laikā iegūtajiem audu paraugiem tika novērotas nestīnu saturošas šūnas. Kopumā tika konstatēts vidēji daudz (++) nestīna pozitīvu epitēlijšūnu. Septiņiem pacientiem tika vizualizētas vidēji daudz $(++)$ nestīnu saturošas šūnas, trīs pacientiem tādu bija daudz (+++) (3.19. tabula). Mutes dobuma gḷotādas epitēlijā tika konstatēts daudz līdz ļoti daudz $(+++/++++)$ faktora pozitīvu bazālā slāṇa šūnu (3.83. mikrofotogrāfija pielikumā). Šo pacientu audu paraugos tika redzētas ne tikai nestīnu saturošas epitēlijšūnas, bet arī endotēlijšūnas, mazo siekalu dziedzeru, matu folikula ārējās epiteliālās maksts un saistaudu šūnas.

Vienpusējas lūpas primārās plastikas laikā iegūtajos mīksto audu paraugos tika novērots arī nestīnu saturošas epitēlijšūnas. Nestīna pozitīvās šūnas variēja no vidēji daudz (++) līdz l’oti daudz (++++) redzes laukā (3.20. tabula; 3.84. mikrofotogrāfija pielikumā). Kopumā desmit pacientiem tika novērots daudz $(+++)$ nestīnu saturošu šūnu epitēlijā. Minēto proteīnu saturēja arī glandulocīti tauku dziedzeros un mazos siekalu dziedzeros, kā arī saistaudu šūnas. Jāatzīmēe, ka arī šai pacientu grupai nestīnu bagātīgi saturēja bazālā slāņa šūnas.

Statistiskie dati. Pacientiem ar vienpusēju caurejošu lūpas, alveolārā izauguma un aukslēju šķeltni audu materiālā tika konstatēts statistiski ticams nestīna pozitīvo šūnu vidējā relatīvā daudzuma pieaugums nekā pacientiem ar abpusēju škseltni ( $\mathrm{p}<0,05)$. Kontroles grupas pacientu audu materiālā tika fiksētas statistiski ticami vairāk nestīna saturošu šūnu nekā škeltṇu pacientu audu materiālā $(\mathrm{p}<0,05)$ (3.23. attēls). 


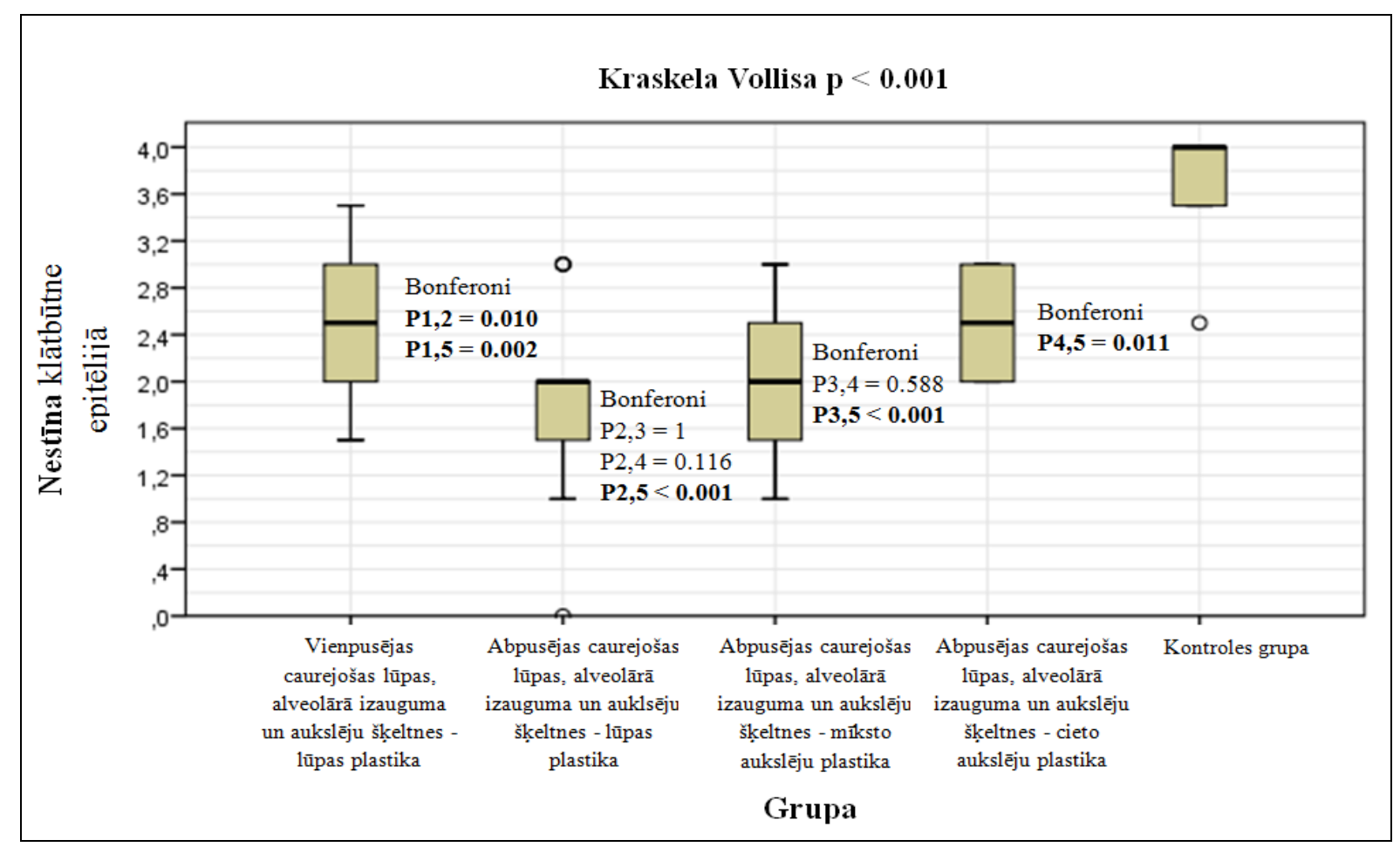

3.23. attēls. Nestīna saturošo imūnhistoḳīmiski noteikto struktūru relatīvā daudzuma vidējo rangu atšḳirības starp dažādām izmeklējamā materiāla grupām

Saīsinājumi attēlā: P1 - vienpusējas caurejošas lūpas un aukslēju šķeltnes grupa pēc lūpas plastikas; P2 - abpusējas caurejošas lūpas un aukslēju šķeltnes grupa pēc lūpas plastikas; P3 - abpusējas caurejošas lūpas un aukslēju šķeltnes grupa pēc mīksto aukslēju plastikas; P4 - abpusējas caurejošas lūpas un aukslēju šķeltnes grupa pēc cieto aukslēju plastikas; P5 - kontroles grupa.

Nestīna atrade mīksto un cieto aukslēju plastikas laikā iegūtajā materiālā bērniem ar abpusēju caurejošu lūpas, alveolārā izauguma un aukslēju šķeltni

Nestīnu saturošas šūnas tika novērotas visos mīksto aukslēju audu paraugos. Tajos bija maz $(+)$ līdz daudz $(+++)$ pozitīvas šūnas redzes laukā (3.21. tabula). Nestīnu saturošas šūnas tika redzētas arī augšanas slānī un asinsvadu sieniņās, un saistaudos.

Cieto aukslēju plastikas laikā iegūtajos audu paraugos nestīnu saturēja arī epitēlija, asinsvadu un saistaudu šūnas. Nestīnu saturošas šūnas tika redzētas robežās no vidēji daudz $(++)$ līdz daudz (+++) redzes laukā (3.22. tabula; 3.85. mikrofotogrāfija pielikumāa).

Statistiskie dati. Nestīna klātbūtnes vidējie rangi kontroles grupas pacientu audu materiālā bija statistiski ticami lielāki nekā mīksto un cieto aukslēju plastikas laikā iegūtajos audu paraugos $(\mathrm{p}<0,05)(3.23$. attēls).

\section{Apoptozes izvērtējums lūpas plastikas laikā iegūtajā materiālā zīdaiṇiem un bērniem ar abpusēju caurejošu lūpas, alveolārā izauguma un aukslēju šķeltni}

Pacientiem ar abpusēju šķeltni visos audu paraugos vizualizējām variablu epitēlija un siekalu dziedzeru apoptotisko šūnu relatīvo daudzumu; šūnas variēja no retām (0/+) līdz vidēji daudz (++) redzes laukā (3.19. tabula; 3.86. mikrofotogrāfija pielikumā). 
Apoptozes izvērtējums lūpas plastikas laikā iegūtajā materiālā zīdaiņiem un bērniem ar vienpusēju caurejošu lūpas, alveolārā izauguma un aukslēju šķeltni

Apoptotisko šūnu klātbūtne tika novērota visos audu paraugos, kas tika iegūti lūpas plastikas laikā, bet pozitīvo struktūru relatīvais daudzums bija variabls. Apoptotiskās šūnas variēja robežās no retām $(0 /+)$ līdz ļoti daudz $(++++)$ redzes laukā (3.20. tabula; 3.87. mikrofotogrāfija pielikumā). Pārsvarā šūnu apoptoze tika novērota epitēlijā. Vienam pacientam redzējām apoptotiskas šūnas matu folikulos un tauku dziedzeros.

Statistiskie dati. Apoptotisko šūnu vidējais relatīvais daudzums bija statistiski ticami lielāks bērniem ar vienpusēju caurejošu lūpas, alveolārā izauguma un aukslēju šķeltni, salīdzinot ar bērniem, kuriem bija abpusēja caurejoša lūpas, alveolārā izauguma un aukslēju šķeltne ( $\mathrm{p}<0,001)$. Salīdzinot audos esošo apoptotisko šūnu vidējo relatīvo daudzumu pacientiem ar škeltnēm un kontroles grupas pacientiem, novērojām statistiski ticami palielinātu TUNEL pozitīvo šūnu relatīvo daudzumu pacientiem ar vienpusēju caurejošu lūpas, alveolārā izauguma un aukslēju šķeltni ( $<$ <,05) (3.24. attēls).

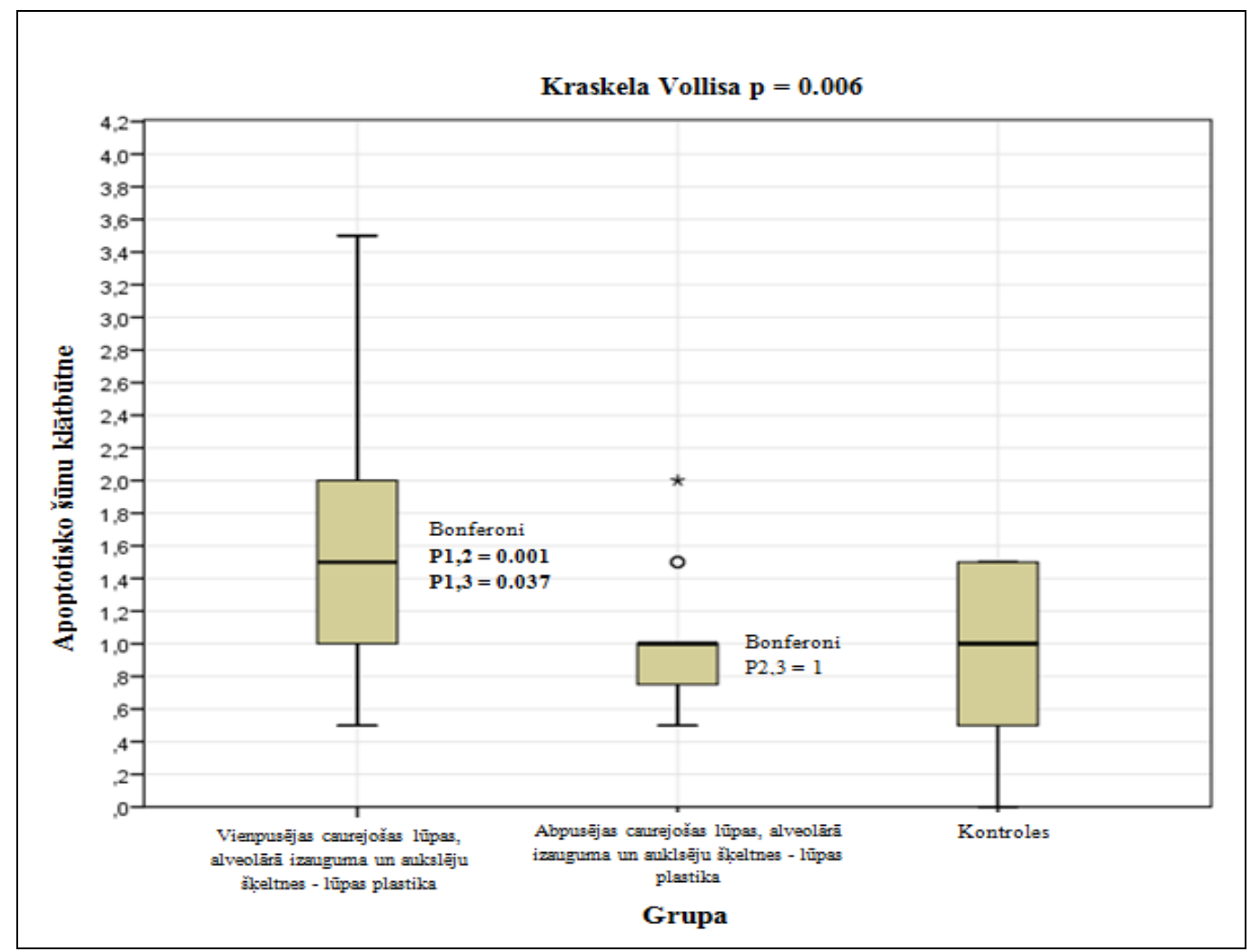

3.24. attēls. Apoptotisko šūnu relatīvā daudzuma vidējo rangu atšķirības starp dažādām izmeklējamā materiāla grupām

Saīsinājumi attēlā: P1 - vienpusējas caurejošas lūpas un aukslēju šķeltnes grupa pēc lūpas plastikas; P2 abpusējas caurejošas lūpas un aukslēju šķeltnes grupa pēc lūpas plastikas; P3 - kontroles grupa. 
3.3.5. Osteokalcīna $(O C)$, osteopontīna $(O P N)$ un osteoprotegerīna $(O P G)$ imūnhistoḳīmiskie un statistiskie dati osteoplastikas laikā iegūtajā materiālā

$O C$ pozitīvie osteocīti abpusēju caurejošu lūpas, alveolārā izauguma un aukslēju šķeltņu skartajos audos variēja no maz (+) līdz daudz (+++) redzes laukā (3.23. tabula; 3.88. mikrofotogrāfija pielikumā).

3.23. tabula

$O C, O P$ un $O P G$ pozitīvu struktūru relatīvais daudzums abpusēju caurejošu lūpas, alveolārā izauguma un aukslēju šķeltņu pacientu audos, kas iegūti osteoplastikas laikā

\begin{tabular}{|l|c|c|c|c|}
\hline Nr. & Šifrs & $O C$ & $O P N$ & $O P G$ \\
\hline 1. & $100 / 1$ & +++ & + & $++/+++$ \\
\hline 2. & 145 & +++++ & 0 & $0 /+$ \\
\hline 3. & 172 & +++ & $0 /+$ & ++ \\
\hline 4. & 185 & +++ & 0 & $0 /+$ \\
\hline 5. & 214 & +++ & 0 & + \\
\hline 6. & 235 & +++ & 0 & $0 /+$ \\
\hline 7. & 241 & +++ & 0 & $++/+++$ \\
\hline 8. & 266 & +++ & $0 /+$ & $++/+++$ \\
\hline 9. & 280 & ++++ & 0 & $0 /+$ \\
\hline 10. & 286 & ++ & 0 & $0 /+$ \\
\hline 11. & 292 & $+/++$ & 0 & $0 /+$ \\
\hline
\end{tabular}

Apzīmējumi tabulā: 0 - redzes laukā nav konstatēta neviena pozitīva struktūra; 0/+ - redzes laukā ir retas pozitīvas struktūras; + - redzes laukā ir maz pozit̄̄vu struktūru; +/++ - redzes laukā ir maz līdz vidēji daudz pozitīvu struktūru; ++ - redzes laukā ir vidēji daudz pozitīvu struktūru; ++/+++ - redzes laukā ir vidēji daudz līdz daudz pozitīvu struktūru; +++ - redzes laukā ir daudz pozitīvu struktūru; +++/++++ - redzes laukā ir daudz līdz ļoti daudz pozitīvu struktūru; ++++ - redzes laukā ir l̦oti daudz pozitīvu struktūru.

Sāisinājumi tabulā: $O C$ - osteokalcīns; $O P$ - osteopontīns; $O P G$ - osteoprotegerīns.

Bērniem ar vienpusēju caurejošu lūpas, alveolārā izauguma un aukslēju šķeltni tika konstatēts vidēji daudz (++) līdz ļoti daudz $(++++)$ pozitīvu struktūru redzes laukā (3.24. tabula).

3. 24. tabula

$O C, O P$ un $O P G$ pozitīvu struktūru relatīvais daudzums vienpusēju caurejošu lūpas, alveolārā izauguma un aukslēju šķeltņu pacientu audos, kas iegūti osteoplastikas laikā

\begin{tabular}{|l|c|c|c|c|}
\hline Nr. & Šifrs & $O C$ & $O P N$ & $O P G$ \\
\hline 1. & $176 / 3$ & ++ & ++ & $++/+++$ \\
\hline 2. & $190 / 2$ & ++ & + & ++ \\
\hline 3. & $225 / 2$ & +++ & +++ & $+++/++++$ \\
\hline 4. & $229 / 2$ & +++ & $++/+++$ & ++++ \\
\hline 5. & $246 / 2$ & ++ & ++ & $++/+++$ \\
\hline 6. & $248 / 2$ & ++++ & ++++ & ++++ \\
\hline 7. & $263 / 2$ & ++++ & ++++ & ++++ \\
\hline
\end{tabular}




\begin{tabular}{|l|c|c|c|c|}
\hline \multicolumn{4}{|c}{} & \multicolumn{2}{c|}{ tabulas nobeigums } \\
\hline Nr. & Šifrs & $O C$ & $O P N$ & $O P G$ \\
\hline 8. & $268 / 2$ & +++ & ++ & $+++/++++$ \\
\hline 9. & $270 / 2$ & ++++ & +++ & ++++ \\
\hline 10. & $278 / 2$ & +++ & +++ & $+++/++++$ \\
\hline 11. & $295 / 2$ & $+++/++++$ & $+++/++++$ & ++++ \\
\hline 12. & $296 / 2$ & +++ & +++ & $+++/++++$ \\
\hline 13. & $305 / 1$ & ++ & ++ & +++ \\
\hline
\end{tabular}

Apzīmējumi tabulā: 0 - redzes laukā nav konstatēta neviena pozitīva struktūra; 0/+ - redzes laukā ir retas pozitīvas struktūras; + - redzes laukā ir maz pozit̄ivu struktūru; +/++ - redzes laukā ir maz līdz vidēji daudz pozitīvu struktūru; ++ - redzes laukā ir vidēji daudz pozitīvu struktūru; ++/+++ - redzes laukā ir vidēji daudz līdz daudz pozitīvu struktūru; +++ - redzes laukā ir daudz pozitīvu struktūru; +++/++++ - redzes laukā ir daudz līdz l̦oti daudz pozitīvu struktūru; ++++ - redzes laukā ir l̦oti daudz pozitīvu struktūru.

Saīsinājumi tabulā: $O C$ - osteokalcīns; $O P$ - osteopontīns; $O P G$ - osteoprotegerīns.

Statistiskie dati. $O C$ klātbūtne pacientiem ar vienpusēju un abpusēju šķeltni statistiski

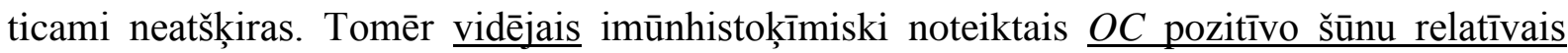
daudzums statistiski ticami mazāks bija pacientiem ar abpusēju caurejošu lūpas, alveolārā izauguma un aukslēju škşeltni nekā kontroles grupas pacientiem $(\mathrm{p}<0,05)(3.25$. attēls).

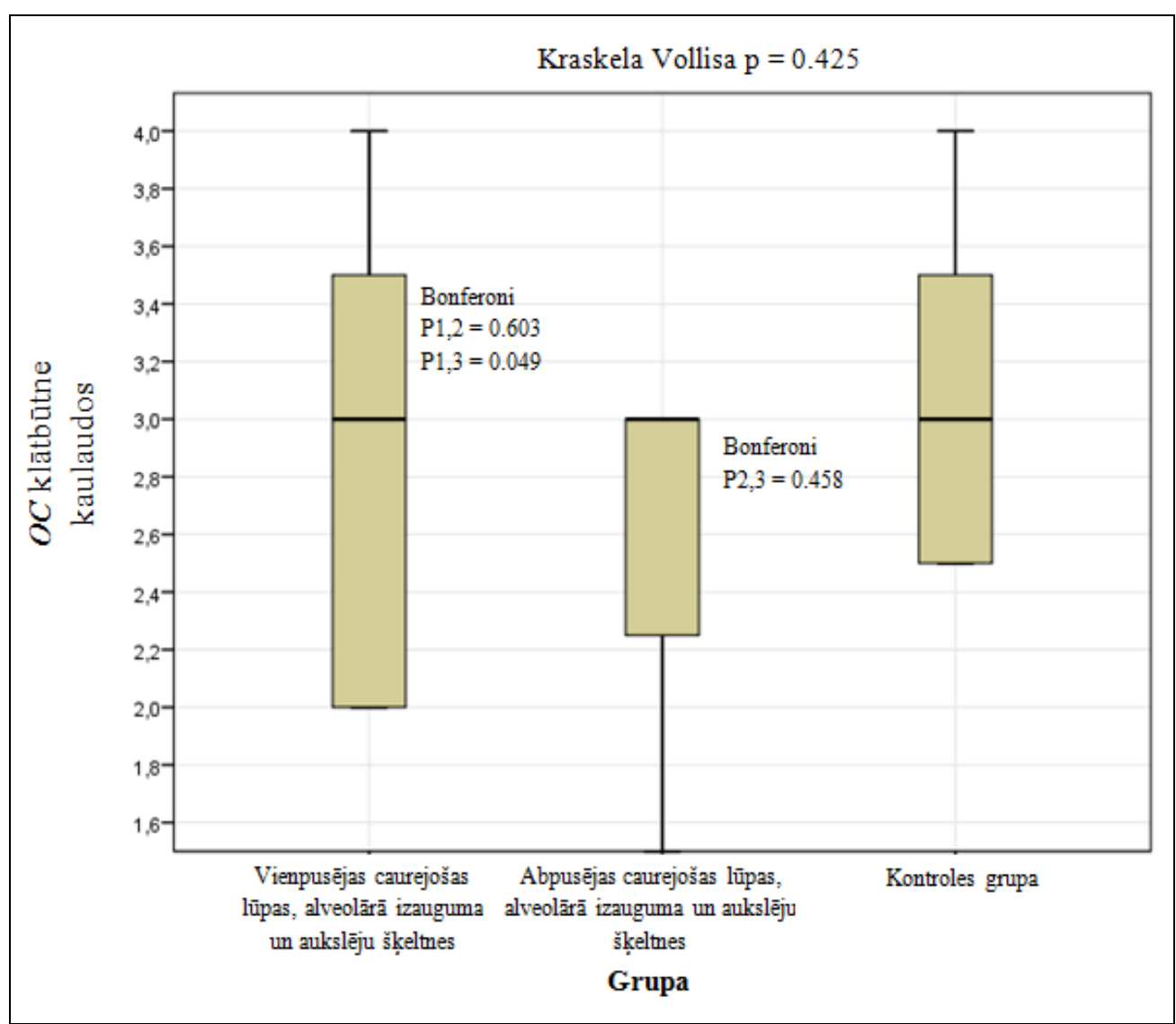

\subsection{5. attēls. Osteokalcīna $(O C)$ saturošo imūnhistoķīmiski noteikto struktūru relatīvā daudzuma vidējo rangu atšḳirības starp dažādām izmeklējamā materiāla grupām}

Saīsinājumi attēlā: $O C$ - osteokalcīns; P1 - vienpusējas caurejošas lūpas un aukslēju šķeltnes grupa pēc osteoplastikas; P2 - abpusējas caurejošas lūpas un aukslēju šķeltnes grupa pēc osteoplastikas; P3 - kontroles grupa. 
$O P N$ saturošas šūnas tika vizualizētas trijiem pacientiem ar abpusēju caurejošu lūpas, alveolārā izauguma un aukslēju šķeltni. $O P N$ pozitīvi osteocīti un osteoblasti variēja robežās no retiem $(0 /+)$ līdz maz (+) redzes laukā (3.23. tabula; 3.89. mikrofotogrāfija pielikumā).

Pacientiem ar vienpusēju škseltni tika novērots maz (+) līdz ļoti daudz (++++) OPN pozitīvu šūnu redzes laukā (3.24. tabula; 3.90. mikrofotogrāfija pielikumā).

Statistiskie dati. Pacientiem ar vienpusēju caurejošu škseltni $\underline{O P N \text { pozitīvo šūnu }}$ daudzums bija statistiski ticami lielāks nekā pacientiem ar abpusēju caurejošu šķeltni (p < 0,001). $O P N$ pozitīvo struktūru relatīvais daudzums abpusēju škseltņu pacientu audos un

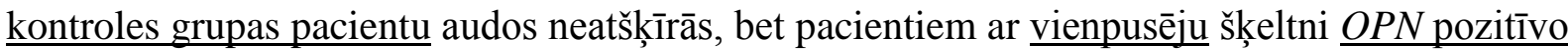
šūnu vidējais relatīvais daudzums bija statistiski ticami lielāks, salīdzinot ar kontroles grupu $(\mathrm{p}<0,001)(3.26$. attēls $)$.

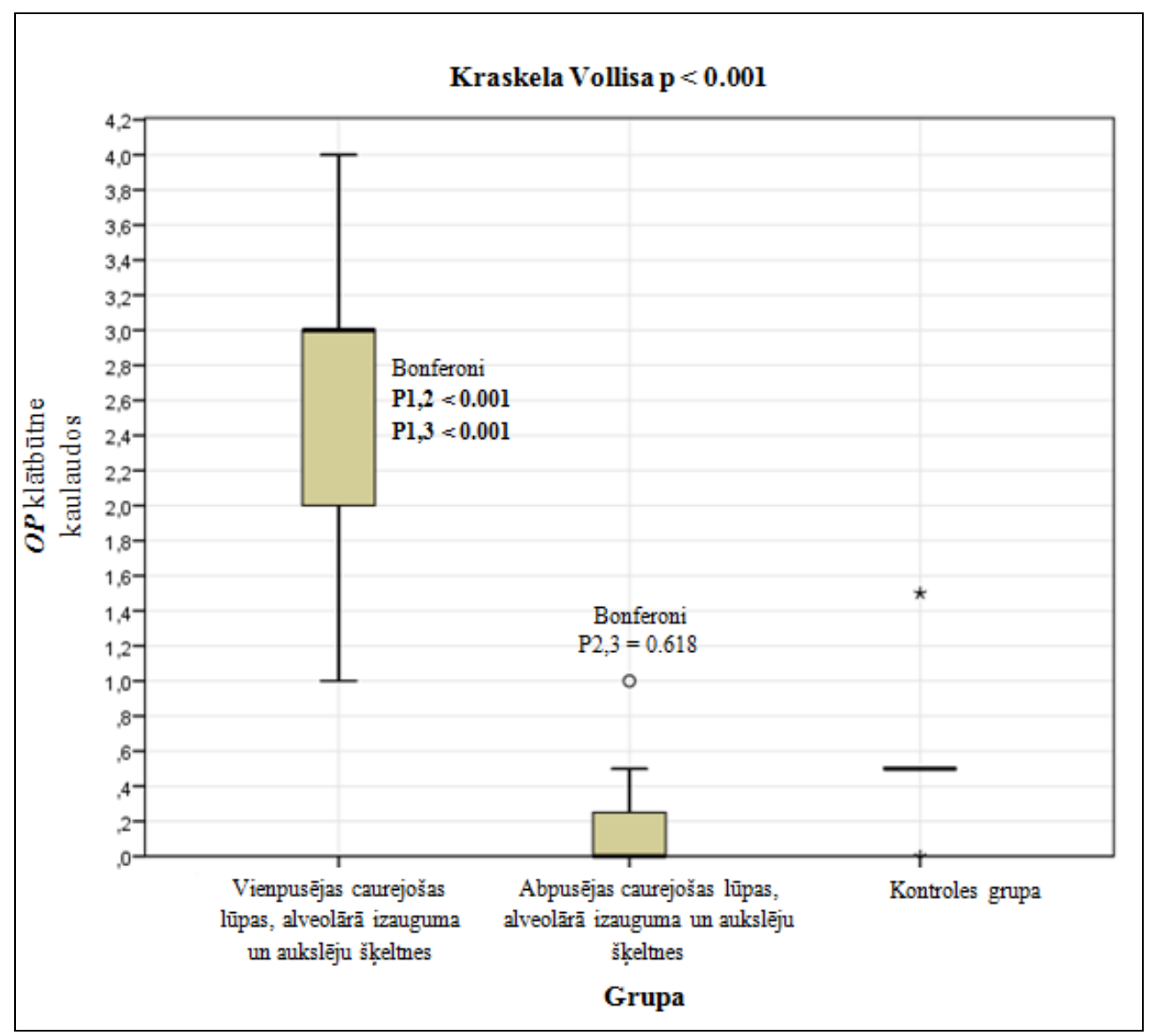

3.26. attēls. Osteopontīnu $(O P N)$ saturošo imūnhistoḳīmiski noteikto struktūru relatīvā daudzuma vidējo rangu atšķiīības starp dažādām izmeklējamā materiāla grupām

Saīsinājumi attēlā: $O P N$ - osteopontīns; P1 - vienpusējas caurejošas lūpas un aukslēju škeltnes grupa pēc osteoplastikas; P2 - abpusējas caurejošas lūpas un aukslēju šķeltnes grupa pēc osteoplastikas; P3 - kontroles grupa.

Pacientiem ar abpusēju šķeltni audos $O P G$ pozitīvās šūnas variēja no retām $(0 /+)$ līdz daudz $(+++)$ redzes laukā (3.23. tabula; 3.91. mikrofotogrāfija pielikumā). 
Izvērtējot $O P G$ klātbūtni osteoplastikas laikā iegūtajos audos, tika konstatēts, ka pacientiem ar vienpusēju šķeltni audos $O P G$ pozitīvās šūnas variēja no vidēji daudz $(++)$ līdz ļoti daudz $(++++)$ redzes laukā (3.24. tabula).

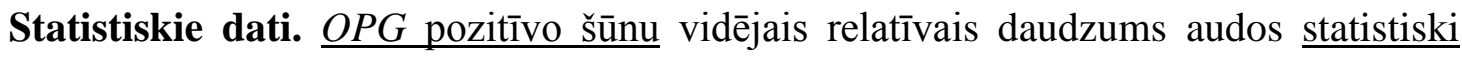

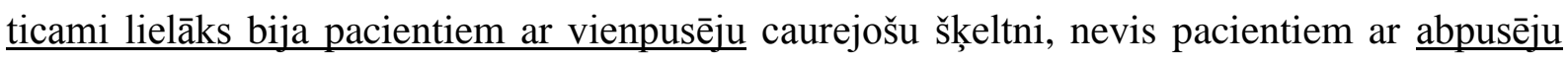
šķeltni ( $\mathrm{p}<0,001)$. Abpusēju šķeltņu skartajos audos $O P G$ pozitīvo šūnu vidējais relatīvais daudzums bija statistiski ticami mazāks nekā kontroles grupas pacientiem $(\mathrm{p}<0,05)$ (3.27. attēls).

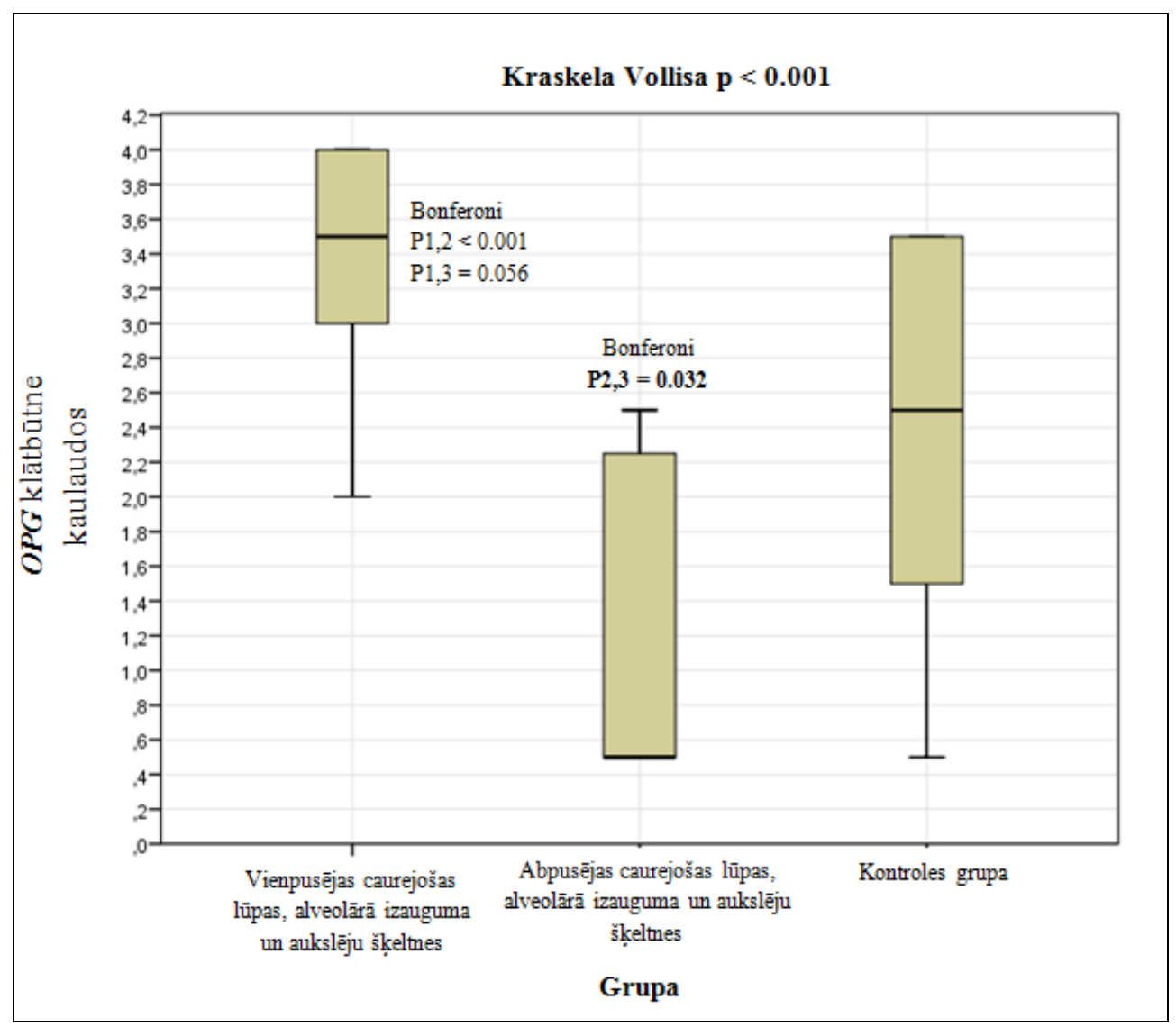

3.27. attēls. Osteoprotegerīna $(O P G)$ saturošo imūnhistoḳīmiski noteikto struktūru relatīvā daudzuma vidējo rangu atšķirības starp dažādām izmeklējamā materiāla grupām

Saīsinājumi attēlā: $O P G$ - osteoprotegerīns; P1 - vienpusējas caurejošas lūpas un aukslēju šķeltnes grupa pēc osteoplastikas; P2 - abpusējas caurejošas lūpas un aukslēju šķeltnes grupa pēc osteoplastikas; P3 - kontroles grupa.

3.3.6. Matrices metaloproteināzes-2 (MMP-2), matrices metaloproteināzes-2 audu inhibitora (TIMP-2), kaula morfoğenētiskā proteīna (BMP2/4), transformējošā augšanas faktora beta-3 (TGFß3) imūnhistoķīmiskie un statistiskie dati osteoplastikas laikā iegūtajā materiālā

Bērniem ar abpusēju škseltni $M M P-2$ pozitīvās šūnas variēja no retām (0/+) līdz daudz $(+++)$ redzes laukā (3.25. tabula; 3.92. mikrofotogrāfija pielikumā). 
Bērniem ar vienpusēju šķeltni $M M P-2$ pozitīvie osteocīti variēja no maz (+) līdz ļoti daudz (++++) redzes laukā (3.26. tabula; 3.93. mikrofotogrāfija pielikumā).

3. 25. tabula

MMP-2, TIMP-2, BMP2/4 un TGFß3 pozitīvu struktūru relatīvais daudzums abpusēju caurejošu lūpas, alveolārā izauguma un aukslēju šķeltṇu pacientu audos, kas iegūti osteoplastikas laikā

\begin{tabular}{|l|c|c|c|c|c|}
\hline Nr. & Šifrs & $M M P-2$ & $T I M P-2$ & $B M P 2 / 4$ & $T G F \beta 3$ \\
\hline 1. & $100 / 1$ & + & $0 /+$ & $+/++$ & +++ \\
\hline 2. & 145 & + & $0 /+$ & $0 /+$ & ++ \\
\hline 3. & 172 & + & $0 /+$ & ++ & ++ \\
\hline 4. & 185 & $0 /+$ & $0 /+$ & $0 /+$ & ++ \\
\hline 5. & 214 & ++ & + & $++/+++$ & +++ \\
\hline 6. & 235 & + & $0 /+$ & + & ++ \\
\hline 7. & 241 & + & $0 /+$ & $+/++$ & $++/++$ \\
\hline 8. & 266 & $+/++$ & $0 /+$ & ++ & ++ \\
\hline 9. & 280 & + & $0 /+$ & $+/++$ & ++ \\
\hline 10. & 286 & $0 /+$ & $0 /+$ & + & ++ \\
\hline 11. & 292 & +++ & +++ & $++/+++$ & +++ \\
\hline
\end{tabular}

Apzīmējumi tabulā: 0 - redzes laukā nav konstatēta neviena pozitīva struktūra; 0/+ - redzes laukā ir retas pozitīvas struktūras; + - redzes laukā ir maz pozitīvu struktūru; +/++ - redzes laukā ir maz līdz vidēji daudz pozitīvu struktūru; ++ - redzes laukā ir vidēji daudz pozitīvu struktūru; ++/+++ - redzes laukā ir vidēji daudz līdz daudz pozit̄̄vu struktūru; +++ - redzes laukā ir daudz pozit̄ivu struktūru; +++/++++ - redzes laukā ir daudz līdz loti daudz pozit̄̄vu struktūru; ++++ - redzes laukā ir ḷoti daudz pozitīvu struktūru.

Sā̄sinājums tabulā: $M M P-2$ - matrices metaloproteināze-2; TIMP-2 - matrices metaloproteināzes-2 audu inhibitors; $B M P$ 2/4 - kaula morfoǵenētiskais proteīns 2/4; TGFB3 - transformējošais augšanas faktors beta-3.

3. 26. tabula

MMP-2, TIMP-2, BMP 2/4 un TGFß3 pozitīyu struktūru relatīvais daudzums vienpusēju caurejošu lūpas, alveolārā izauguma un aukslēju šķeltņu pacientu audos, kas iegūti osteoplastikas laik $\overline{\mathbf{a}}$

\begin{tabular}{|c|c|c|c|c|c|}
\hline Nr. & Šifrs & $M M P-2$ & TIMP-2 & $B M P 2 / 4$ & $T G F \beta 3$ \\
\hline 1. & $176 / 3$ & ++ & + & ++ & +++ \\
\hline 2. & $190 / 2$ & + & + & ++ & $++/+++$ \\
\hline 3. & $225 / 2$ & ++++ & ++++ & ++++ & ++++ \\
\hline 4. & $229 / 2$ & +++ & ++++ & $+++/++++$ & $+++/++++$ \\
\hline 5. & $246 / 2$ & +++ & +++ & +++ & ++++ \\
\hline 6. & $248 / 2$ & ++++ & +++ & ++++ & ++++ \\
\hline 7. & $263 / 2$ & ++++ & $++/+++$ & ++++ & ++++ \\
\hline 8. & $268 / 2$ & ++++ & $+/++$ & ++++ & ++++ \\
\hline 9. & $270 / 2$ & ++++ & + & ++++ & ++++ \\
\hline 10. & $278 / 2$ & +++ & ++ & ++++ & ++++ \\
\hline 11. & $295 / 2$ & $+++/++++$ & +++ & ++++ & ++++ \\
\hline 12. & $296 / 2$ & +++ & ++ & +++ & +++ \\
\hline 13. & $305 / 1$ & ++ & $+/++$ & +++ & ++ \\
\hline
\end{tabular}

Apzīmējumi tabulā: 0 - redzes laukā nav konstatēta neviena pozitīva struktūra; 0/+ - redzes laukā ir retas pozitīvas struktūras; + - redzes laukā ir maz pozitīivu struktūru; +/++ - redzes laukā ir maz līdz vidēji daudz pozitīvu struktūru; ++ - redzes laukā ir vidēji daudz pozitīvu struktūru; ++/+++ - redzes laukā ir vidēji daudz līdz daudz pozitīvu struktūru; +++ - redzes laukā ir daudz pozitīvu struktūru; +++/++++ - redzes laukā ir daudz līdz ļoti daudz pozitīivu struktūru; ++++ - redzes laukā ir l̦oti daudz pozitīvu struktūru.

Saīsinājumi tabulā: $M M P-2$ - matrices metaloproteināze-2; TIMP-2 - matrices metaloproteināzes-2 audu inhibitors; BMP 2/4 - kaula morfoǵenētiskais proteīns 2/4; TGFß3 - transformējošais augšanas faktors beta-3. 
Statistiskie dati. Izvērtējot imūnhistoķīmiski noteiktos šūnu relatīvā daudzuma vidējos rangus, tika konstatēts statistiski ticami lielāks $M M P-2$ pozitīvo šūnu daudzums bērniem ar vienpusēju šķeltni nekā bērniem ar abpusēju šķeltni $(\mathrm{p}<0,001)$. Pacientiem ar vienpusēju šķeltni $\underline{M M P-2}$ pozitīvo šūnu vidējais relatīvais daudzums bija statistiski ticami lielāks, salīdzinot ar kontroles grupu ( $\mathrm{p}<0,001)$ (3.28. attēls).

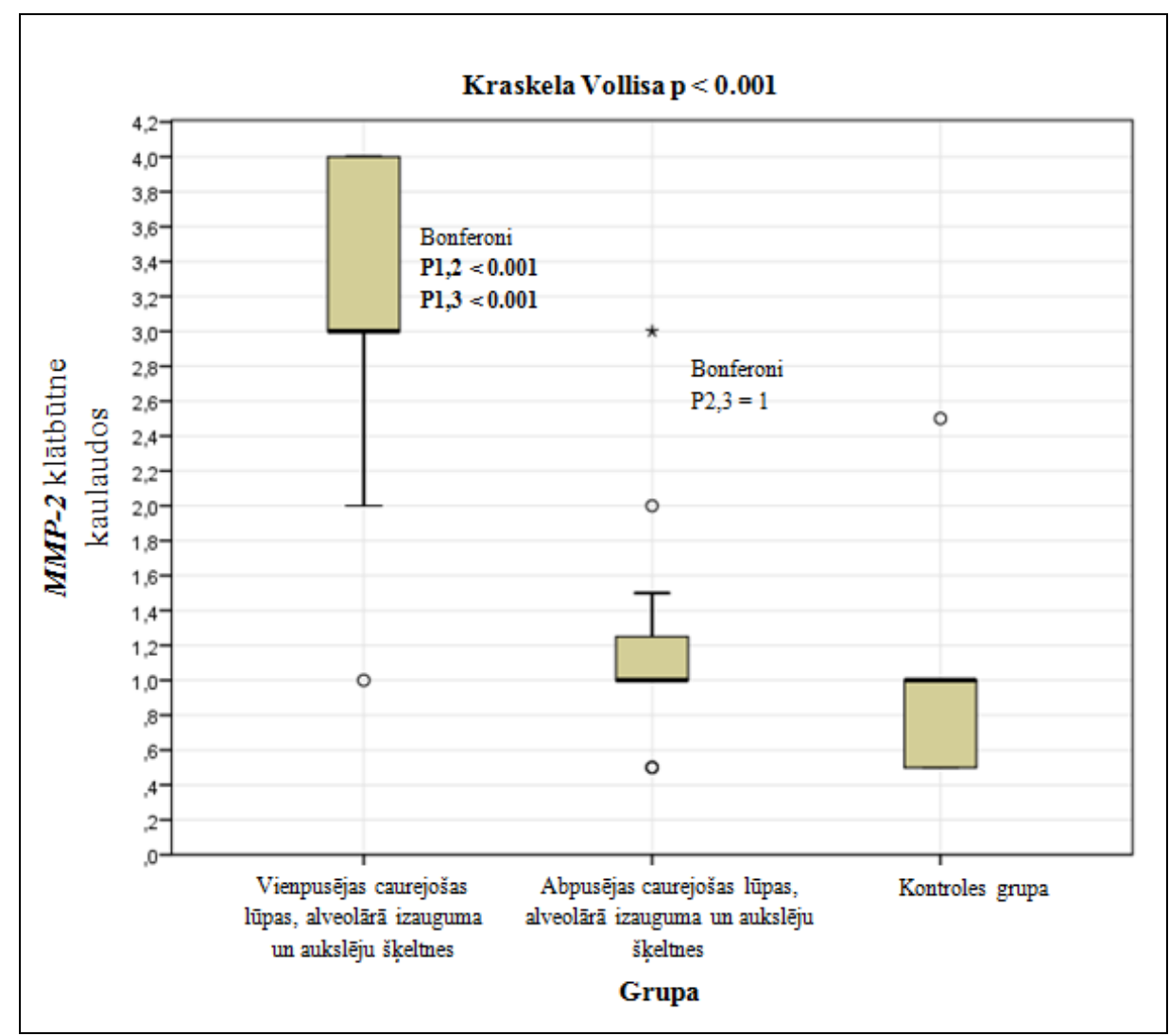

3.28. attēls. Matrices metaloproteināzi-2 (MMP-2) saturošo imūnhistoḳīmiski noteikto struktūru relatīvā daudzuma vidējo rangu atšksirības starp dažādām izmeklējamā materiāla grupām

Saīsinājumi attēlā: $M M P-2$ - matrices metaloproteināze-2; P1 - vienpusējas caurejošas lūpas un aukslēju šķeltnes grupa pēc osteoplastikas; P2 - abpusējas caurejošas lūpas un aukslēju šķeltnes grupa pēc osteoplastikas; P3 - kontroles grupa.

Abpusēju šķeltņu pacientiem TIMP-2 pozitīvas kaulaudu šūnas variēja robežās no retām $(0 /+)$ līdz daudz $(+++)$ redzes laukā (3.25. tabula; 3.94. mikrofotogrāfija pielikumā).

Vienpusēju caurejošu lūpas, alveolārā izauguma un aukslēju šķeltņu pacientu audos tika atrastas maz (+) līiz ļoti daudz $(++++)$ TIMP-2 pozitīvas kaulaudu šūnas redzes laukā (3.26. tabula).

Statistiskie dati. Pacientiem ar abpusēju caurejošu lūpas, alveolārā izauguma un aukslēju škseltni audos TIMP-2 pozitīvas struktūras bija statistiski ticami mazāk, salīdzinot ar pacientiem, kuriem bija vienpusēja caurejoša lūpas, alveolārā izauguma un aukslēju šķeltne (p

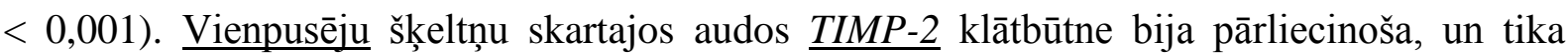


fiksēts statistiski ticami vairāk imūnreaktīvo šūnu nekā abpusēju škşeltņu skartajos un kontroles pacientu audos $(\mathrm{p}<0,001)$ (3.29. attēls).

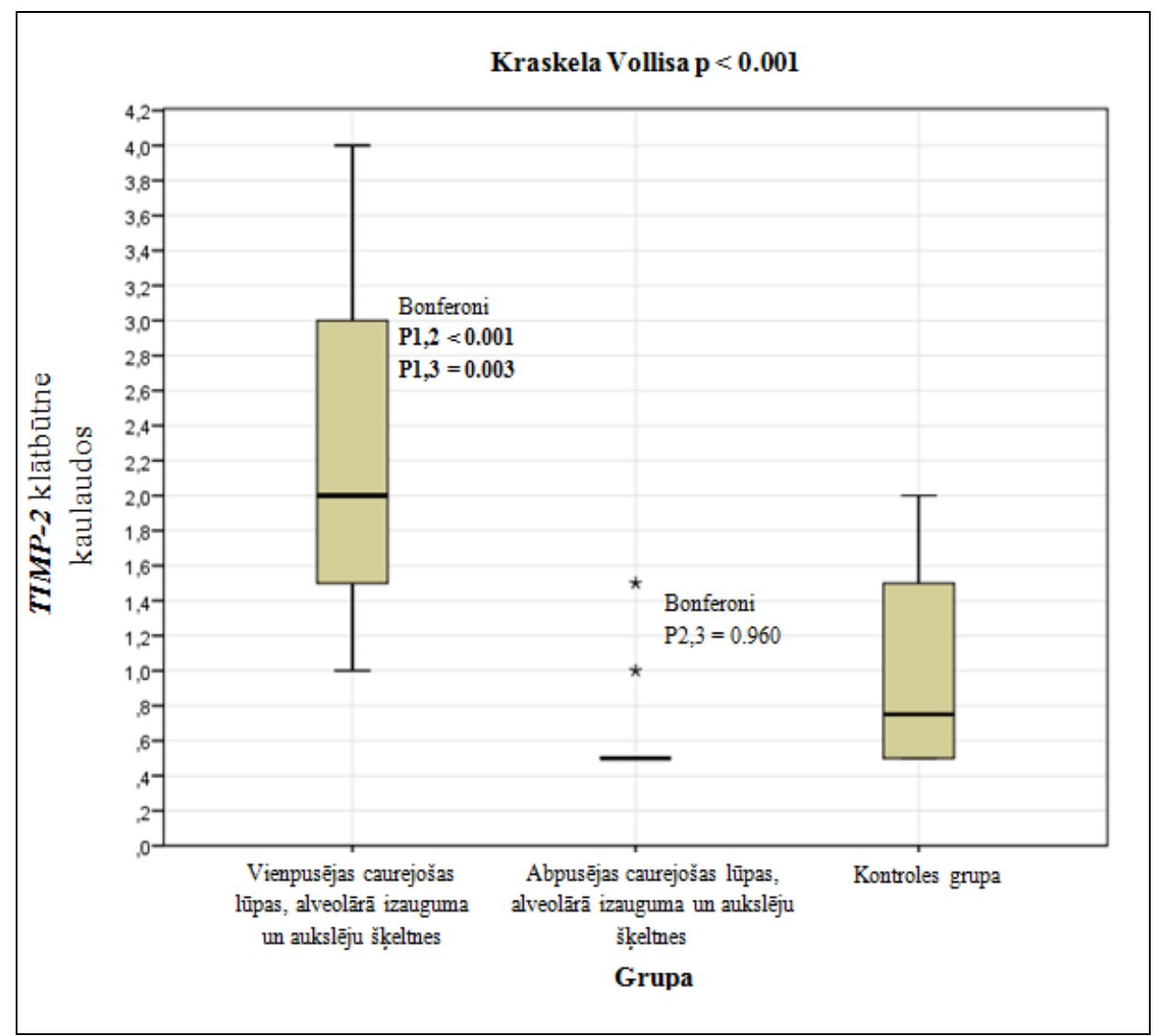

3.29. attēls. Matrices metaloproteināzes-2 audu inhibitora (TIMP-2) saturošo imūnhistoķīmiski noteikto struktūru relatīvā daudzuma vidējo rangu atšksirības starp dažādām izmeklējamā materiāla grupām Saīsinājumi attēlā: TIMP-2 - matrices metaloproteināzes-2 audu inhibitors; P1 - vienpusējas caurejošas lūpas un aukslēju šķeltnes grupa pēc osteoplastikas; P2 - abpusējas caurejošas lūpas un aukslēju šķeltnes grupa pēc osteoplastikas; P3 - kontroles grupa.

Pacientiem ar abpusēju šķeltni audos tika atrastas retas $(0 /+)$ līdz daudz (+++) pozitīvas šūnas redzes laukā (3.95. mikrofotogrāfija pielikumā).

Bērniem ar vienpusēju škseltni $B M P 2 / 4$ pozitīvas struktūras variēja no vidēji daudz $(++)$ līdz ļoti daudz $(++++)$ redzes laukā (3.96. mikrofotogrāfija pielikumā). Lielākam pacientu skaitam (7) tika novērots ļoti daudz $(++++) B M B 2 / 4$ pozitīvu šūnu.

Statistiskie dati. Bērniem ar abpusēju šķeltni $\underline{B M P 2 / 4}$ pozitīvo šūnu relatīvais daudzums bija statistiski ticami mazāks nekā bērniem ar vienpusēju šķeltni (p < 0,001) (3.30. attēls). 


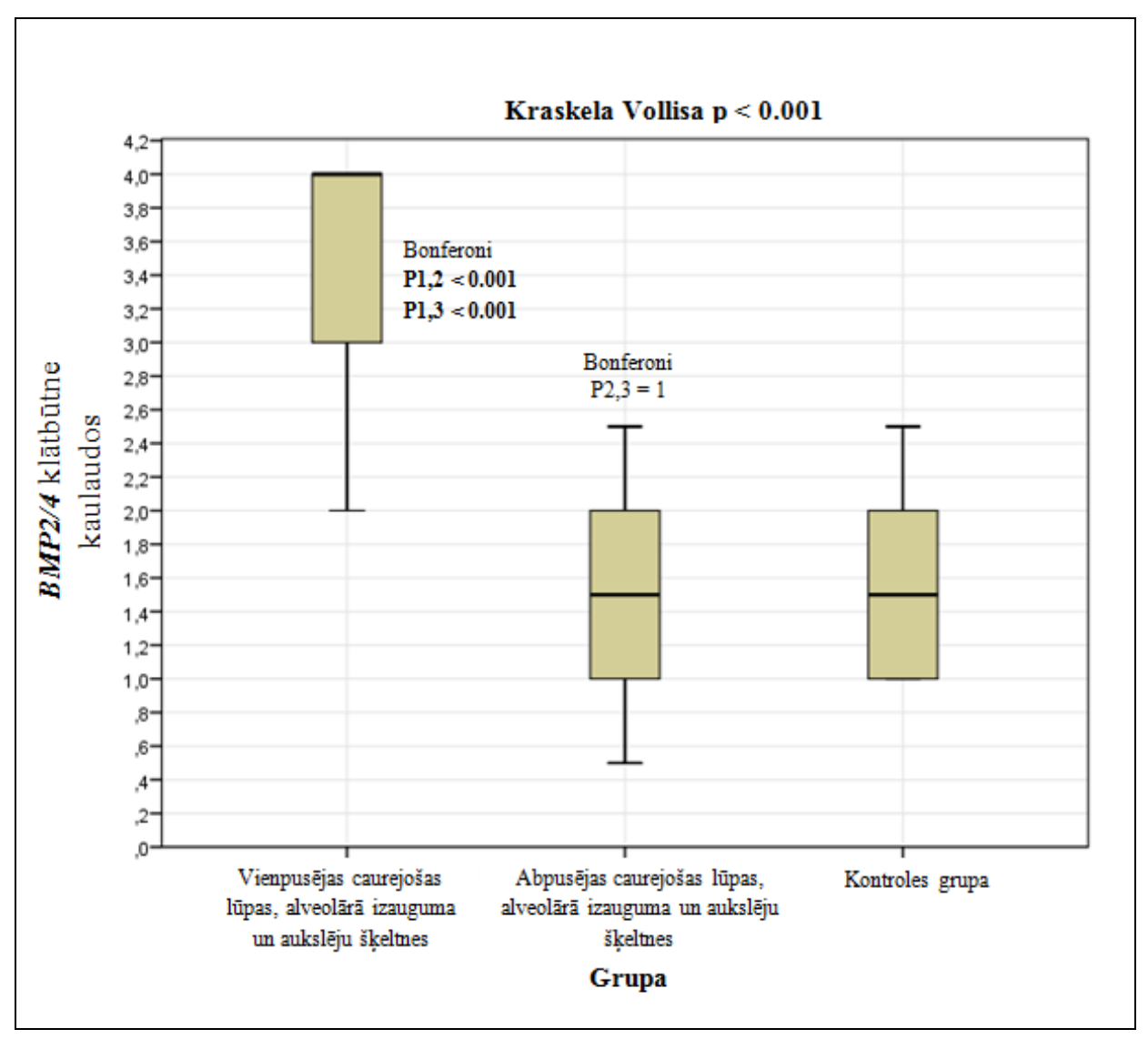

3.30. attēls. Kaula morfoǵenētiskā protē̄nu (BMP2/4) saturošo imūnhistoḳīmiski noteikto struktūru relatīvā daudzuma vidējo rangu atšķirības starp dažādām izmeklējamā materiāla grupām

Saīsinājumi attēlā: BMP2/4 - kaula morfoğenētiskais proteīns; P1 - vienpusējas caurejošas lūpas un aukslēju šķeltnes grupa pēc osteoplastikas; P2 - abpusējas caurejošas lūpas un aukslēju šķeltnes grupa pēc osteoplastikas; P3 - kontroles grupa.

Kopumā tika konstatēti daudz līdz ļoti daudz (+++/++++) TGFß3 pozitīvi osteocīti bērniem ar vienpusēju lūpas, alveolārā izauguma un aukslēju šķeltni (3.97. mikrofotogrāfija pielikumā), bet bērniem ar abpusēju škseltni kopumā tika konstatēti vidēji daudz $(++)$ pozitīvi osteocīti redzes laukā (3.98. mikrofotogrāfija pielikumā).

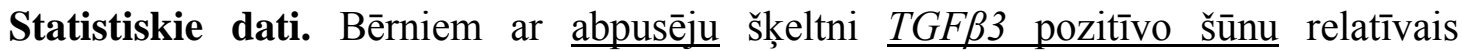
daudzums bija statistiski ticami mazāks nekā bērniem ar vienpusēju škseltni $(\mathrm{p}<0,001)$.

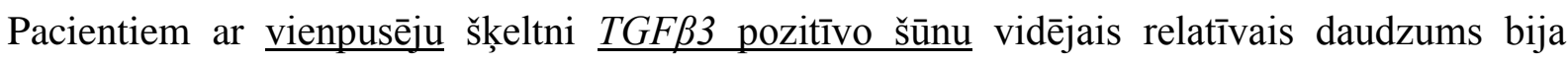

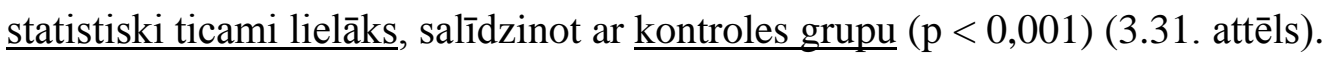




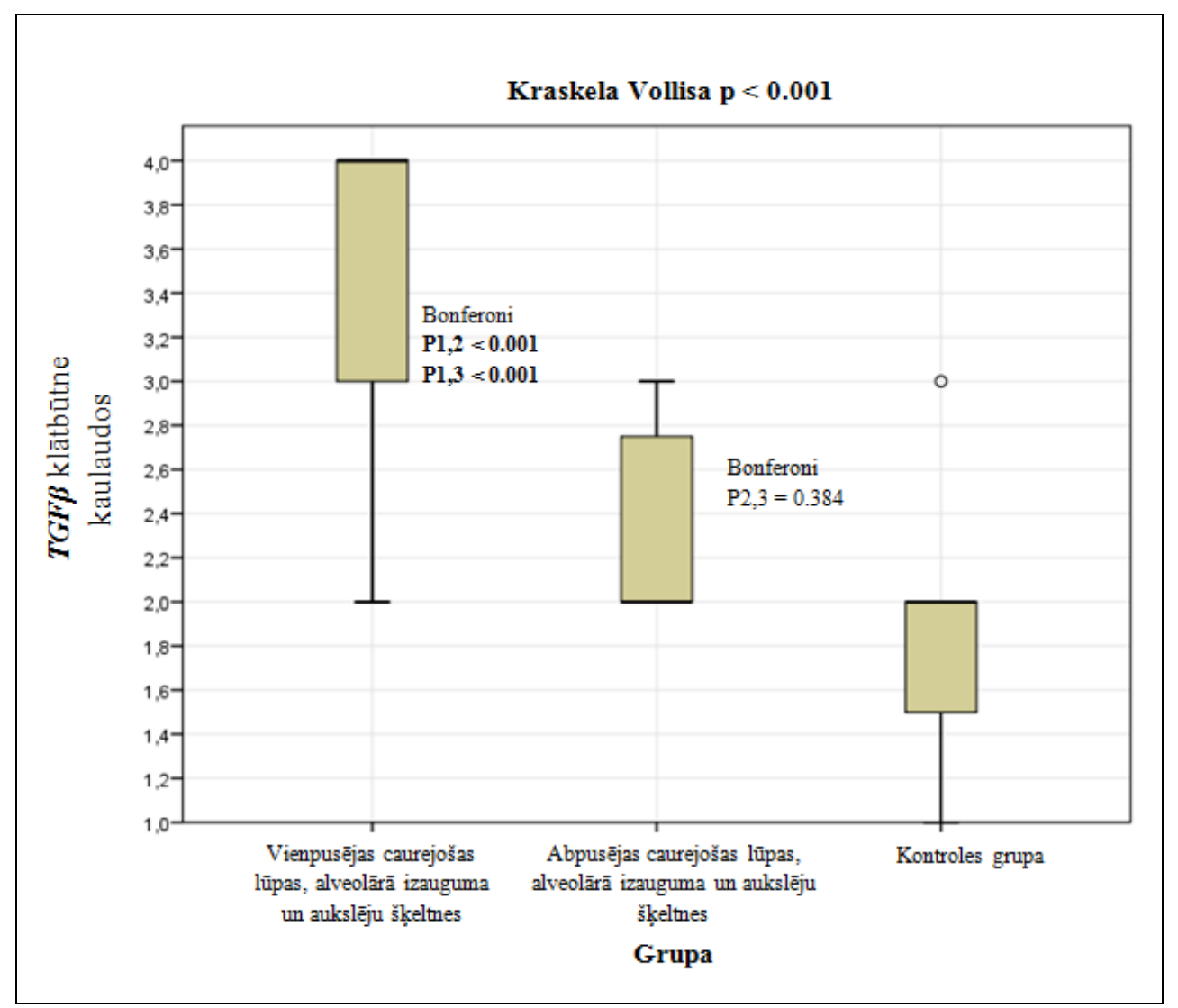

3.31. attēls. Transfromējošais augšanas faktors beta-3 (TGF $\beta 3)$ saturošo imūnhistoḳīmiski noteikto struktūru relatīvā daudzuma vidējo rangu atšksirības starp dažādām izmeklējamā materiāla grupām Saīsinājumi attēlā: TGF 33 - transformējošais augšanas faktors beta-3; P1 - vienpusējas caurejošas lūpas un aukslēju šķeltnes grupa pēc osteoplastikas; P2 - abpusējas caurejošas lūpas un aukslēju šķeltnes grupa pēc osteoplastikas; P3 - kontroles grupa.

\subsection{Imūnhistoķīmisko faktoru atrade un statistiskie dati atkārtoti ņemtajos audos pacientiem ar abpusēju caurejošu lūpas, alveolārā izauguma un aukslēju šķeltni}

Septiniiem pacientiem tika veiktas atkārtotas secīgas šķeltnes korekcijas operācijas, kuru laikā tika savākts unikāls audu materiāls no šķeltnes malām un imūnhistoķīmiski izanalizētas visas primārās antivielas.

Atkārtoti paņemtajos audos tika novērotas MSX1, MMP-9, TIMP-4, TGFß3, Ki-67 un VEGF ekspresiju savstarpējās atšksirības.

Pārējiem 10 marķieriem (nestīnam, MMP-2, MMP-8, TIMP-2, IRF6, PAX9, RYK, CD34, $P G P$ 9.5) statistiski ticamas atšķirības starp pirmo un atkārtoto operācija netika konstatētas.

Transkripcijas faktora MSX1 pozitīvas retas (0/+) saistaudu šūnas tika vizualizētas vienam pacientam lūpas plastikas laikā paņemtajā audu paraugā. Pārējiem pieciem pacientiem nekonstatējām MSX1 pozitīvas saistaudu šūnas. Šiem pašiem pacientiem tika veikta mīksto aukslēju plastika, kuras laikā iegūtajā materiālā - mīksto aukslēju audu paraugos - redzējām

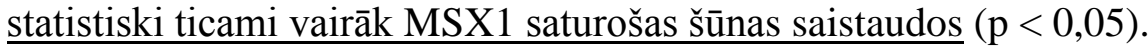

Matrices metaloproteināzes-9 (MMP-9) klātbūtne saistaudos tika konstatēta trīs pacientu lūpas plastikas laikā iegūtajos audu paraugos, diviem pacientiem netika konstatētas 
imūnreaktīvas struktūras saistaudos. Trim pacientiem tika novērotas retas (0/+) MMP-9 pozitīvas saistaudu šūnas. Šo triju pacientu mīksto aukslēju plastikas laikā iegūtajos paraugos tika fiksētas maz $(+)$ līdz daudz $(+++)$ pozitīvas saistaudu šūnas redzes laukā. Atkārtotu operāciju laikā paņemtajos mīksto audu paraugos tika novērota statistiski ticami lielāka $M M P$ 9 klātbūtne saistaudos $(\mathrm{p}<0,05)$.

Matrices metaloproteināzes-4 audu inhibitora (TIMP-4) klātbūtne bija četru pacientu lūpas plastikas laikā iegūtajos audos, vienam pacientam netika konstatētas TIMP-4 imūnreaktīvas saistaudu šūnas. TIMP-4 saturošas saistaudu šūnas variēja no retām $(0 /+)$ līdz maz $(+)$ redzes laukā, bet mīksto aukslēju plastikas laikā iegūtajos audos tika fiksēts maz (+) un vidēji daudz $(+/++)$, līdz daudz (+++) šūnu redzes laukā. Analizējot iegūtos datus, tika konstatēts, ka

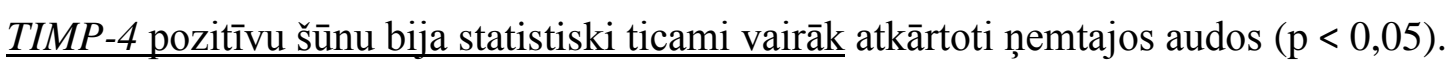

Transformējošā augšanas faktora beta-3 (TGFß3) klātbūtne epitēlijā tika atrasta trīs pacientu audos pēc lūpas primārās plastikas. TGFß3 pozitīvas šūnas bija reti $(0 /+)$ vizualizējamas. Visiem pacientiem saistaudos tika novērotas $T G F \beta 3$ pozitīvas struktūras. Tās variēja no retām $(0 /+)$ līdz maz un vidēji daudz $(+/++)$ redzes laukā. Visiem pacientiem mīksto aukslēju plastikas laikā iegūtajos audu paraugos tika konstatētas $T G F \beta 3$ saturošas šūnas epitēlijā un saistaudos. Epitēlijā $T G F \beta 3$ pozitīvas šūnas variēja no vidēji daudz (++) līdz daudz (+++), kamēr saistaudos - no daudz (+++) līdz ļoti daudz (++++) redzes laukā. Līdz ar to tika konstatēta statistiski ticama palielināta TGFß3 klātbūtne pētījuma audu paraugos $(\mathrm{p}<0,05)$.

Šūnu proliferācijas marķiera Ki-67 klātbūtne netika vizualizēta abpusējas caurejošas šķeltnes lūpas primārās plastikas laikā paņemtajos audu paraugos, bet atkārtotu operāciju laikā iegūtajos audos bija retas $(0 /+)$ līdz vidēji daudz $(++) K i-67$ pozitīvas šūnas epitēlijā. Tika konstatēta statistiski ticama palielināta $K i-67$ ekspresija atkārtoti paṇemtajos pētījuma audu paraugos $(\mathrm{p}<0,05)$.

Vaskulārā endotēlija augšanas faktoru (VEGF) vizualizējām epitēlijā un endotēlijā. Kopumā $V E G F$ saturošas struktūras lūpas plastikas laikā iegūtajā materiālā bija vidēji daudz $(++)$. Jāatzīmēe, ka visu pacientu lūpas plastikas laikā iegūtajos audos redzējām VEGF pozitīvas struktūras. Tomēr šo pacientu mīksto aukslēju plastikas laikā iegūtajos audos $\underline{V E G F}$ pozitīvo struktūru bija statistiski ticami mazāk $(\mathrm{p}<0,05)$. 


\subsection{Imūnhistoķ̄imiski noteikto marķieru savstarpējās atbilstības ciešuma izvērtēšanas dati, izmantojot Spīrmena rangu korelācijas koeficientu}

Audu materiālā, kas tika iegūts lūpas plastikas laikā no zīdaiņiem ar vienpusēju caurejošu lūpas, alveolārā izauguma un aukslēju šķeltni tika konstatēta statistiski nozīmīga cieša, pozitīva korelācija starp MMP-9 un TIMP-4 saistaudos (3.28. tabula), bet audu paraugos, kas tika iegūti lūpas plastikas laikā no zīdaiņiem ar abpusēju šķeltni - starp $M M P-8$ un TIMP-4 epitēlijā, kā arī starp TIMP-4 epitelijā un TIMP-4 saistaudos (3.29. tabula). Visvairāk ciešas, pozitīvas korelācijas tika konstatētas mīksto un cieto aukslēju plastikas laikā iegūtajos audu paraugos (3.30. un 3.31. tabula). Vienpusēju caurejošu lūpas, alveolārā izauguma un aukslēju šķeltņu pacientu audos, kas iegūti osteoplastikas laikā, tika konstatētas ciešas, pozitīvas korelācijas starp $O C$ un $O P G, O C$ un $O P, B M P 2 / 4$ un $T I M P-2, B M P 2 / 4$ un $T G F \beta 3, O C$ un $M M P-2, M M P-2$ un $T G F \beta 3, O P$ un $O P G, O C$ un $B M P 2 / 4$ kaulu šūnās (3.32. tabula), bet abpusēju caurejošu lūpas, alveolārā izauguma un aukslēju šķeltņu skartajos kaulaudos cieša, pozitīva korelācija tika konstatēta tikai starp $B M P 2 / 4$ un $M M P-2$ kaulu šūnās (3.33. tabula).

3. 28. tabula

Imūnhistoḳīmiski noteikto marḳieru savstarpējās korelācijas dati vienpusēju caurejošu lūpas, alveolārā izauguma un aukslēju šḳeltņu pacientu audos, kas iegūti lūpas primārās plastikas

laikā

\begin{tabular}{|l|l|l|l|l|}
\hline Marķieris 1 & Marķieris 2 & $\mathrm{r}_{\mathrm{s}}$ & $\mathrm{p}$ & $\mathrm{n}$ \\
\hline \multicolumn{5}{|c|}{ Cieša, pozitīiva $(|\boldsymbol{r}| \geq \mathbf{0 , 7 5})$ korelācija konstatēta: } \\
\hline$M M P$-9 saistaudos & TIMP-4 saistaudos & 0,772 & $<0,01$ & 24 \\
\hline
\end{tabular}

Apzīmējumi tabulā: $\mathrm{r}_{\mathrm{s}}$ - Spīrmena korelācijas koeficients; $\mathrm{p}$ - Spīrmena korelācijas $\mathrm{p}$ vērtība; $\mathrm{n}$ - morfologiskā materiāla vienību skaits

3. 29. tabula

Imūnhistoḳīmiski noteikto marķieru savstarpējās korelācijas dati abpusēju caurejošu lūpas, alveolārā izauguma un aukslēju šķeltṇu pacientu audos, kas iegūti lūpas primārās plastikas

laik̄̄a

\begin{tabular}{|l|l|l|l|l|}
\hline Marķieris 1 & Marķieris 2 & $\mathrm{r}_{\mathrm{s}}$ & $\mathrm{p}$ & $\mathrm{n}$ \\
\hline \multicolumn{7}{|c|}{ Cieša, pozitīva $(|\boldsymbol{r}| \geq \mathbf{0 , 7 5})$ korelācija konstatēta: } \\
\hline$M M P-8$ epitēlijā & TIMP-4 epitēlijā & 0,857 & $<0,01$ & 15 \\
\hline$T I M P-4$ epitēlijā & $T I M P-4$ saistaudos & 0,768 & $<0,01$ & 15 \\
\hline
\end{tabular}

Apzīmējumi tabulā: $\mathrm{r}_{\mathrm{s}}$ - Spīrmena korelācijas koeficients; $\mathrm{p}$ - Spīrmena korelācijas $\mathrm{p}$ vērtība; $\mathrm{n}$ - morfoloǵiskā materiāla vienību skaits 
Imūnhistoḳīmiski noteikto marḳieru savstarpējās korelācijas dati abpusēju caurejošu lūpas, alveolārā izauguma un aukslēju šḳeltṇu pacientu audos, kas iegūti mīksto aukslēju plastikas laik̄ā

\begin{tabular}{|c|c|c|c|c|}
\hline Marķieris 1 & Marķieris 2 & $\mathrm{r}_{\mathrm{s}}$ & $\mathrm{p}$ & $\mathrm{n}$ \\
\hline \multicolumn{5}{|c|}{ Cieša, pozitīva $(|r| \geq 0,75)$ korelācija konstatēta: } \\
\hline$M M P-8$ epitēlijā & $T I M P-2$ epitēlijā & 0,915 & $<0,01$ & 10 \\
\hline TIMP-4 epitēlijā & TIMP-2 saistaudos & 0,910 & $<0,01$ & 10 \\
\hline TIMP-2 saistaudos & $T I M P-4$ saistaudos & 0,910 & $<0,01$ & 10 \\
\hline$M M P-8$ epitēlijā & $M M P-9$ epitēlijā & 0,852 & $<0,01$ & 10 \\
\hline$T G F \beta 3$ epitēlijā & Nestīns epitēlijā & 0,857 & $<0,01$ & 10 \\
\hline$M M P-9$ epitēlijā & $M M P-9$ saistaudos & 0,846 & $<0,01$ & 10 \\
\hline$M M P-2$ saistaudos & $T G F \beta 3$ epitēlijā & 0,838 & $<0,01$ & 10 \\
\hline$M M P-9$ epitēlijā & TIMP-2 saistaudos & 0,809 & $<0,01$ & 10 \\
\hline$M M P-9$ epitēlijā & TIMP-4 epitēlijā & 0,805 & $<0,01$ & 10 \\
\hline IRF6 epitēlijā & IRF6 saistaudos & 0,802 & $<0,01$ & 10 \\
\hline$M M P-8$ epitēlijā & $M M P-8$ saistaudos & 0,781 & $<0,01$ & 10 \\
\hline$M M P-9$ saistaudos & TIMP-4 epitēlijā & 0,773 & $<0,01$ & 10 \\
\hline$M M P-9$ epitēlijā & TIMP-2 epitēlijā & 0,767 & $<0,01$ & 10 \\
\hline VEGF saistaudos & CD34 saistaudos & 0,759 & $<0,05$ & 10 \\
\hline
\end{tabular}

Apzīmējumi tabulā: $\mathrm{r}_{\mathrm{s}}$ - Spīrmena korelācijas koeficients; $\mathrm{p}$ - Spīrmena korelācijas $\mathrm{p}$ vērtība; $\mathrm{n}$ - morfologiskā materiāla vienību skaits

3. 31. tabula

Imūnhistoḳīmiski noteikto marḳieru savstarpējās korelācijas dati abpusēju caurejošu lūpas, alveolārā izauguma un aukslēju šḳeltṇu pacientu audos, kas iegūti cieto aukslēju plastikas laikā

\begin{tabular}{|c|c|c|c|c|}
\hline Marķieris 1 & Marķieris 2 & $\mathrm{r}_{\mathrm{s}}$ & $\mathrm{p}$ & $\mathrm{n}$ \\
\hline \multicolumn{5}{|c|}{ Cieša, pozitīva $(|r| \geq 0,75)$ korelācija konstatēta: } \\
\hline$M M P-8$ epitēlijā & $M M P-9$ epitēlijā & 0,955 & $<0,01$ & 9 \\
\hline IRF6 saistaudos & RYK epitēlijā & 0,917 & $<0,01$ & 9 \\
\hline RYK saistaudos & RYK epitēlijā & 0,917 & $<0,01$ & 9 \\
\hline TIMP-2 epitēlijā & TIMP-2 saistaudos & 0,898 & $<0,01$ & 9 \\
\hline$M M P-9$ epitēlijā & $M M P-2$ saistaudos & 0,897 & $<0,01$ & 9 \\
\hline$M M P-8$ epitēlijā & $M M P-9$ saistaudos & 0,849 & $<0,01$ & 9 \\
\hline$M M P-9$ epitēlijā & $M M P-9$ saistaudos & 0,819 & $<0,01$ & 9 \\
\hline IRF6 epitēlijā & IRF6 saistaudos & 0,818 & $<0,01$ & 9 \\
\hline RYK saistaudos & IRF6 epitēlijā & 0,818 & $<0,01$ & 9 \\
\hline$M M P-9$ epitēlijā & TIMP-4 epitēlijā & 0,812 & $<0,01$ & 9 \\
\hline$M M P-2$ saistaudos & TIMP-4 epitēlijā & 0,809 & $<0,01$ & 9 \\
\hline IRF6 epitēlijā & RYK epitēlijā & 0,800 & $<0,01$ & 9 \\
\hline$M M P-2$ epitēlijā & $M M P-2$ saistaudos & 0,777 & $<0,05$ & 9 \\
\hline$M M P-8$ epitēlijā & $M M P-2$ saistaudos & 0,773 & $<0,05$ & 9 \\
\hline$M M P-8$ saistaudos & $M M P-9$ saistaudos & 0,768 & $<0,05$ & 9 \\
\hline$M M P-2$ epitēlijā & $T I M P-2$ epitēlijā & 0,767 & $<0,05$ & 9 \\
\hline
\end{tabular}

Apzīmējumi tabulā: $\mathrm{r}_{\mathrm{s}}$ - Spīrmena korelācijas koeficients; $\mathrm{p}$ - Spīrrmena korelācijas $\mathrm{p}$ vērtība; $\mathrm{n}$ - morfoloğiskā materiāla vienību skaits 
Imūnhistoḳīmiski noteikto marķieru savstarpējās korelācijas dati vienpusēju caurejošu lūpas, alveolārā izauguma un aukslēju šḳeltṇu pacientu audos, kas iegūti osteoplastikas laikā

\begin{tabular}{|l|l|l|l|l|}
\hline Markieris 1 & Markieris 2 & $\mathrm{r}_{\mathrm{s}}$ & $\mathrm{p}$ & $\mathrm{n}$ \\
\hline \multicolumn{2}{|c|}{ Cieša, pozitīva $(|\boldsymbol{r}| \geq \mathbf{0 , 7 5})$ korelācija konstatēta: } \\
\hline$O C$ kaulu šūnās & $O P G$ kaulu šūnās & 0,923 & $<0,01$ & 12 \\
\hline$O C$ kaulu šūnās & $O P$ kaulu šūnās & 0,884 & $<0,01$ & 12 \\
\hline$B M P 2 / 4$ kaulu šūnās & $T I M P-2$ kaulu šūnās & 0,883 & $<0,01$ & 12 \\
\hline$B M P 2 / 4$ kaulu šūnās & $T G F \beta 3$ kaulu šūnās & 0,841 & $<0,01$ & 12 \\
\hline$O C$ kaulu šūnās & $M M P$-2 kaulu šūnās & 0,828 & $<0,01$ & 12 \\
\hline$M M P-2$ kaulu šūnās & $T G F \beta 3$ kaulu šūnās & 0,827 & $<0,01$ & 12 \\
\hline$O P$ kaulu šūnās & $O P G$ kaulu šūnās & 0,826 & $<0,01$ & 12 \\
\hline$O C$ kaulu šūnās & $B M P 2 / 4$ kaulu šūnās & 0,825 & $<0,01$ & 12 \\
\hline
\end{tabular}

Apzīmējumi tabulā: $r_{s}$ - Spīrmena korelācijas koeficients; $p$ - Spīrrmena korelācijas $p$ vērtība; $n$ - morfoloğiskā materiāla vienību skaits

3. 33. tabula

Imūnhistoķīmiski noteikto marķieru savstarpējās korelācijas dati abpusēju caurejošu lūpas, alveolārā izauguma un aukslēju šķeltņu pacientu audos, kas iegūti osteoplastikas laikā

\begin{tabular}{|l|l|l|l|l|}
\hline Marķieris 1 & Marķieris 2 & $\mathrm{r}_{\mathrm{s}}$ & $\mathrm{p}$ & $\mathrm{n}$ \\
\hline \multicolumn{4}{|c|}{ Cieša, pozitīva $(|\boldsymbol{r}| \geq \mathbf{0 , 7 5})$ korelācija konstatēta: } \\
\hline$B M P 2 / 4$ kaulu šūnās & $M M P-2$ kaulu šūnās & 0,828 & $<0,01$ & 11 \\
\hline
\end{tabular}

Apzīmējumi tabulā: $r_{s}$ - Spīrmena korelācijas koeficients; $p$ - Spīrrmena korelācijas p vērtība; $n$ - morfoloğiskā materiāla vienību skaits

Mūsu darbā tika izvērtēts arī visu imūnhistoķīmiski noteikto marķieru savstarpējās atbilstības ciešums pacientu audos saistībā ar vecumu atkārtotu operāciju laikā iegūtajos audos, izmantojot Spīrmena rangu korelācijas koeficientu.

Ja korelācijas koeficients sasniedza maksimumu 1 vai minimumu -1 , tad p vērtība netika rēksināta.

Statistiski nozīmīga cieša, pozitīva $(|r| \geq 0,75)$ korelācija tika konstatēta:

$\mathrm{r}_{\mathrm{s}}=-0,882 ; \mathrm{p}<0,05-$ starp vecumu (mēnešos) un $\boldsymbol{T I M P}-4$ pozitīvām epitēlijšūnām;

$\mathrm{r}_{\mathrm{s}}=-0,840 ; \mathrm{p}<0,05-$ starp vecumu (mēnešos) un $\boldsymbol{V E G F}$ pozitīvām struktūrām;

$\mathrm{r}_{\mathrm{s}}=0,868 ; \mathrm{p}<0,05-$ starp vecumu (mēnešos) un $\boldsymbol{M M P}-8$ pozitīiām struktūrām;

$\mathrm{r}_{\mathrm{s}}=0,939 ; \mathrm{p}<0,001-$ starp vecumu (mēnešos) un $\boldsymbol{P G P} 9.5$ pozitīvām struktūrām. 


\section{DISKUSIJA}

Kopumā pacientiem ar vienpusēju un abpusēju caurejošu lūpas, alveolārā izauguma un aukslēju šķeltni audu paraugu morfologiiskā atrade atbilda vispārpieņemtajai normai. Tomēr daļai pacientu mīksto un cieto audu paraugos gaismas mikroskopijā konstatējām tādas nespecifiskas audu pārmaiņas, kā epitēlija atrofiju, bazālā slāņa šūnu hiperplāziju un proliferāciju, dzeloṇainā slāņa šūnu vakuolizāciju, kā arī iekaisuma šūnu infiltrāciju.

Pētījumi par sejas šķeltņu iespējamajiem patoǵenēzes, pēcoperācijas brūču dzīšanas un audu remodelācijas molekulārajiem mehānismiem pārsvarā ir veikti ar eksperimenta dzīvniekiem laboratorijas apstākļos. Pasaulē plaši tiek pētītas dažādu gēnu ǵenētiskās variācijas, izmantojot dažādu populāciju bērnu audu paraugus. Nav daudz pētījumu par cilvēka sejas un mutes dobuma embrionālās attīstības morfoǵenēzes mehānismiem, kā arī nav daudz dažādu audu faktoru imūnhistoķīmisku pētījumu par postnatāli operāciju laikā iegūtu zīdaiņu un bērnu sejas šķeltņu skarto audu morfolog̣iju ontoǵenētiskā aspektā. Tādēḷ diskusiju lielākoties var balstīt uz mūsu datiem korelācijā ar literatūrā pieejamajiem pētījumu rezultātiem, kas iegūti no eksperimenta dzīvniekiem. Būtiski, ka Bodo ar kolēgiem veicis nozīmīgu pētījumu, kurā pierādīts, ka pēc dzimšanas cilvēka šşeltņu skarto audu šūnu fenotips atšķiras no normālu audu šūnu fenotipa (Bodo et al., 1999). Š̃ iemesla dēḷ pētījumi ar šķeltņu skarto audu paraugiem, kas iegūti postnatāli, var tikt uzskatīti par piemērotiem šķeltņu etiopatoǵenēzes izpētei pat tad, ja šķeltne ir embrionālas izcelsmes audu attīstības traucējums. Lūpu un aukslēju morfoǵenēze ietver šūnu proliferāciju, diferenciāciju, migrāciju, programmēto šūnu nāvi, ekstracelulārās matrices sintēzi un degradāciju, kā arī vietējās audu aizsardzības faktoru bāzes veidošanos. Minētos procesus embrija audos koordinē dažādas signālmolekulas, augšanas faktori, transkripcijas faktori un to receptori, audu degradācijas enzīmi un to endogēnie inhibitori, kā arī šūnu adhēzijas molekulas. Minēto faktoru trūkums audos vai pārlieku liels to daudzums var izraisīt bērnam sejas šķeltni (Meng et al., 2009).

\section{MMP un TIMP imūnhistoḳīmiskais profils šķeltnes skartajos mīkstajos audos.} Augšlūpas un aukslēju aizmetņu attīstības laikā ECM remodelāciju, epitēlija transformāciju mezenhīmā un postnatāli sejas audu homeostāzi regulē $M M P s$ un audu endogēnie inhibitori $T I M P s$, ko pierāda šo enzīmu ekspresijas izpēte peḷu audos. Tieši $M M P-2, M M P-3, M M P-7$, MMP-9, MMP-13, MMP-25 un TIMP-1, TIMP-2, TIMP-3 ekspresija tika izvērtēta peļu embrijiem aukslēju aizmetņu saplūšanas laikā. Nenoliedzami, ka lokālas izmaiņas šo enzīmu relatīivā daudzumā var izraisīt audu defektus lūpu un aukslēju aizmetņu saplūšanas laikā (Blavier et al., 2001; Wiman et al., 2000; Brown and Nazarali, 2010). Tiek uzskatīts, ka MMPs un TIMPs ir iespējamie nesindromālo lūpas un aukslēju šķeltņu kandidātgēni. Daudzās 
populācijās ir analizētas genētiskās variācijas MMPs un TIMPs gēnos saistībā ar sejas šķeltnēm, bet atklātie rezultāti dažādām populācijām un rasēm ir pretrun̄̄gi (Nikopensius et al., 2011; Letra et al., 2012; Letra et al., 2014). Lai gan dažu MMPs un TIMPs veidu nozīme sejas šķeltņu attīstībā ir pamatota, tomēr šo enzīmu lokāla ekspresija nav plaši pētīta audos, kas iegūti postnatāli no bērniem ar vienpusēju un abpusēju caurejošu lūpas, alveolārā izauguma un aukslēju šķeltni ontoğenētiskā aspektā. Šajā pētījumā vienpusēju un abpusēju caurejošu lūpas, alveolārā izauguma un aukslēju šķeltņu skartajos audos tika kompleksi izvērtēts $M M P-2, M M P-8, M M P-9$ un TIMP-2, TIMP-4 imūnreaktīvo struktūru relatīvais daudzums un sadalījums, tos salīdzinot ar kontroles grupas audu paraugiem.

Pētījumā konstatējām pārliecinoši palielinātu $M M P-2$ klātbūtni epitēlijāa, kas lūpas plastikas laikā iegūts no bērniem ar abpusēju caurejošu šķeltni ( $\mathrm{p}<0,001)$, kamēr mīksto un cieto aukslēju audos $M M P-2$ bija samazināta $(\mathrm{p}<0,05)$. Jāatzīmē, ka $M M P-2$ klātbūtne saistaudos kontroles grupas pacientiem bija statistiski ticami mazāka nekā pacientiem ar šķeltnēm ( $\mathrm{p}<0,05)$. Tādējādi uzskatām, ka MMP-2 šūnu membrānas asociētajam MMP (MT1-MMP)/TIMP-2 signālcel̦am nenoliedzami ir nozīme sejas šķelţ̦u skarto audu pēcoperācijas dzī̌sanas fāzēs, proti, proliferācijas un remodelēšanās, kā arī rētaudu veidošanās procesā un audu homeostāzē. Iespējams, ar palielinātu $M M P-2$ enzīma ekspresiju tiek kompensēts kāda cita enzīma funkcionālās aktivitātes trūkums. Kopumā tika novērota $M M P-2$ relatīvā daudzuma un novietojuma mainība, tādēḷ, iespējams, šiem mūsu pacientiem raksturīgas arī $M M P-2$ ǵenētiskās variācijas.

Lielbritānijas zinātnieku kolektīvs 2002. gadā pierādīja tieši MMP-2 izteiktu ekspresiju in vivo aukslēju attīstības laikā. Tika atklāts, ka, inaktivējot $M M P-2$, tika ietekmētas vēl citas - MMP-13 - MMP funkcijas (Brown et al., 2002). Cits zinātnieku kolektīvs 2009. gadā atklāja, ka heparināzes trūkums tiek kompensēts ar palielinātu MMP-2, MMP-9 un MMP-14 ekspresiju (Zcharia et al., 2009). Pētījuma rezultāti nenoliedzami apstiprina šādu faktu: ja ir piln̄̄gi vai nepiln̄̄gi traucēta viena proteolītiska enzīma funkcija, tiek ietekmēta cita audu degradācijas enzīma un ar to saistītā endogēnā inhibitora funkcionālā aktivitāte vai tiek kompensēta š̄ enzīma funkcija ar cita enzīma lokālu pieaugošu ekspresiju audos. Jāpiemin, ka $M M P$-2 izpēte sejas un mutes dobuma audos attīstības laikā ir radījusi plašu interesi vairāku gadu garumā, jo $M M P-2$ degradē arī fibronektīnu un III tipa kolagēnu, kas ir peļu aukslēju aizmetņu pamatkomponenti līdz 13. embrionālās attīstības dienai. Pēc tam, no 13. līdz 14. embrionālās attīstības dienai, peļu aukslēju audos notiek fibronektīna un III tipa kolagēna degradācija, kas saistīta tieši ar MMP-2 aktivitāti (de Oliveira Demarchi et al., 2010). Samazināta MMP-2 ekspresija žurku 
ādas brūces dzī̌sanas procesā tika pierādīta arī saistībā ar palielinātu rētaudu veidošanās risku (Dang et al., 2003).

Interesanti, ka $M M P-2$ funkcijas līdzinās $M M P-9$ funkcijām, proti, tās degradē līdzīgus ECM komponentus: želatīnu, bazālās membrānas proteīnus un elastīnu (Ravanti and Kähäri, 2000). Ir pierādīts, ka $M M P-9$ būtiski ietekmē audu dzīšanu, stimulējot epitēlija migrāciju un reǵenerāciju (Mohan et al., 2002). Mūsu pētījumā, kas tika veikts ar vienpusēju un abpusēju šķeltņu skartajiem audiem postnatāli, vieglākos šķeltnes gadījumos atradām izteiktu $M M P-9$ ekspresiju, bet smagākos gadījumos, proti, pacientiem ar abpusēju caurejošu lūpas, alveolārā izauguma un aukslēju šķeltni konstatējām nozīmīgi samazinātu $M M P-9$ klātbūtni. Tādus pašus rezultātus ieguvuši arī Čehijas zinātnieki lūpas plastikas laikā iegūtajos audos bērniem vecumā no diviem līdz četriem mēnešiem (Blaha et al., 2013). Eksperimentos ar dzīvniekiem ir atklāts, ka palielināta $M M P-9$ ekspresija samazina rētaudu veidošanos, kamēr zema vai nenosakāma $M M P-9$ aktivitāte norāda uz hipertrofiskas rētas veidošanos brūces dzīšanas laikā un pārmērīgu kolagēna produkciju kontrastā ar samazinātu tā degradāciju (Hosokawa et al., 2003; Manuel and Gawronska-Kozak, 2006). Balstoties uz iepriekš minēto, piel̦aujam, ka samazināta $M M P$-9 klātbūtne mūsu pacientu augšlūpas audos norāda uz lielāku rētaudu veidošanos risku abpusējas šķeltnes gadījumos.

Papildus jāatzīmē, ka $M M P-9$ pieaugoši ekspresējas audos peļu aukslēju aizmetņu saplūšanas laikā (Wiman et al., 2000). MMP-9 gēns ir lokalizēts 20q12.2 un atbild par ECM pamatkomponenta IV tipa kolagēna degradāciju, tādējādi nodrošinot šūnu migrāciju (Zhang et $a l ., 1999)$. Ņemot vērā MMP-9 funkcijas, iespējams, ka samazināta MMP-9 klātbūtne audos rada nepilnu bazālās membrānas degradāciju, tāpēc arī nenotiek epitēlija transformācija mezenhīmā un līdz ar to lūpu un aukslēju aizmetņu saplūšana. Lai gan ir konstatēta nozīmīga $M M P-9$ ekspresija dzīvnieku aukslēju attīstības laikā, tomēr nav pārliecinošu pētījumu par šī enzīma iesaisti nesindromālo šşeltņu etioloǵijā. Letra ar līdzautoriem pêtīja $M M P-9$ gēna nozīmi Braz̄ilijas iedzīvotāju populācijā. Pētījumā netika pārliecinoši identificēts MMP-9 - 1562 C/T polimorfisms saistībā ar nesindromālām lūpas un aukslēju šķeltnēm. Paši autori to saista ar, iespējams, nepietiekamu gadījumu skaitu, kas tika iekḷauts šajā pētījumā (Letra et al., 2007). De Oliveira Demarchi ar kolēgiem noteica MMP-9 klātbūtni aukslēju aizmetņos dzīvniekiem dažādos embrionālās attīstības laikos. Peļu aukslēju attīstības 13. embrionālās attīstības dienā MMP-9 ekspresija netika vizualizēta, bet no 14 . līdz 15 . embrionālās attīstības dienai tika atklāta $M M P-9$ ekspresija aukslēju mediālās malas epitēlijā. Šajā laikā pelēm, degradējoties bazālajai membrānai un ekstracelulārajai matricei, notiek aukslēju aizmetņu saplūšana. Līdz ar to tika izteikta doma par iespējamu $M M P-9$ nozīmi aukslēju ontoǵenēzē (de Oliveira Demarchi et al., 2010). 
Interesants pētījums saistībā ar TIMP-1 un MMP-9 lomu brūces dzī̌sanā un rētaudu veidošanos bērniem ar lūpas šķeltnēm ir veikts Čehijāa. Tiesa, šis pêtījums nebalstījās uz šķeltnes diagnozi un smaguma pakāpi. Pētījuma autori izpētīja TIMP-1 un MMP-9 koncentrāciju lūpas plastikas laikā iegūtajā materiālā: gan epitēlijā, gan saistaudos. Pacienti tika iedalīti divās grupās: pirmajā grupā audi tika paņemti no zīdaiņiem, kuriem operācija veikta septiṇu dienu vecumā, otrajā grupā audi tika paṇemti no zīdaiṇiem, kuriem operācija tika veikta divu līdz četru mēnešu vecumā. Pētnieki agrīnu operāciju laikā paņemtajos audos konstatēja samazinātu TIMP-1 daudzumu saistaudos ( $\mathrm{p}=0,018)$, bet MMP-9 daudzums gan epitēlijā, gan saistaudos bija palielināts (Blaha et al., 2013). Augsts MMP-9 līmenis apstiprina arī kolagēna produkcijas un degradācijas procesu, kā arī atšksirīgu brūces reorganizācijas kinētiku (Gawronska-Kozak, 2011). Divu līdz četru mēnešu vecu zīdaiņu operācijas laikā iegūtajos audos tika konstatēts palielināts TIMP-1 un samazināts $M M P-9$ daudzums. Iespējams, ka zems TIMP-1, TIMP-2 līmenis saistaudos kavē rētaudu veidošanos, savukārt paaugstināts rada pretēju efektu (Chen et al., 2007).

Šajā pētījumā konstatējām samazinātu $M M P-8$ klātbūtni abpusēju caurejošu šķeltņu cieto aukslēju epitēlijaudos ( $\mathrm{p}<0,05)$, kamēr lūpas plastikas laikā iegūtajos audos MMP-8 tika konstatēts pārliecinoši daudz $(\mathrm{p}<0,05)$, liecinot, ka šim enzīmam ir nozīme šķeltņu skarto audu remodelācijā. Atradām ciešu negatīvu korelāciju ar bērna vecumu mēnešos $\left(\mathrm{r}_{\mathrm{s}}=-0,868 ; \mathrm{p}<0,05\right)$.

Literatūrā netika atrasti pārliecinoši ziņojumi par š̄i enzīma nozīmi aukslēju ontoǵenēzē un saistîbā ar lūpu un aukslēju šķeltnēm, kā arī ekspresijas mainību saistībā ar bērna vecumu, un ir maz nopublicētu pētījumu par š̄ faktora lokālu ekspresiju lūpu un aukslēju šķeltņu skartajos audos saistībā ar brūces dzīšanas, audu remodelācijas un homeostāzes procesiem, lai gan $M M P-8$ ir plaši izplatîts audos un to ekspresē dažādas šūnas epitēlijšūnas, fibroblasti, makrofāgi u.c. (Van Lint and Libert, 2006). Ir zināms, ka kraniofaciālā rajona audi primāri attīstās no nervu kores šūnām, un zinātnieki ir pierādījuši MMP-8 klātbūtni dažādos embrionālos audos, tostarp nervu kores šūnās (Giambernardi et al., 2001). Turklāt Korpi ar līdzautoriem norāda, ka MMP-8 spēj modulēt iekaisuma procesu un kolagēna metabolismu alveolārā kaulā un mutes dobuma gḷotādā, tādējādi ietekmējot brūces dzī̌sanu (Korpi et al., 2008). Pētījumā ar cilvēka periodontālās saites audu paraugiem tika pierādīts, ka MMP-8 ekspresija samazinās, palielinoties cilvēka vecumam (Grzibovskis et al., 2011).

Mūsu pētījumā tika izvērtēta TIMP-2 klātbūtne trīs līdz sešus mēnešus vecu zīdaiṇu lūpas plastikas laikā iegūtajā materiālā. Tika atklāta statistiski nozīmīga TIMP-2 samazināta klātbūtne mīksto un cieto aukslēju plastikas laikā iegūtajā materiālā, salīdzinot ar lūpas 
plastikas laikā iegūtajiem audu paraugiem no bērniem ar abpusēju caurejošu lūpas, alveolārā izauguma un aukslēju šķeltni, turklāt novērotā saistība saglabājās arī, aprēķinot Bonferoni korekciju ( $\mathrm{p}<0,05)$, kas norāda uz iegūtā rezultāta būtiskumu. TIMP-2 samazināta ekspresija tika novērota epitēlijšūnās. Šo faktu varētu skaidrot ar TIMP-2 spēcīgu inhibējošo nozīmi audu deǵenerācijā mīksto un cieto aukslēju šķeltnes skartajos audos, kamēr palielināta TIMP-2 klātbūtne varētu liecināt par augšlūpas brūces dzī̌sanu ar lielāku rētaudu veidošanās risku. Šie dati atbilst uzskatam, ka TIMP-2 atkarīga, precīzi koordinēta $M M P$ aktivitāte nosaka veiksmīgu aukslēju aizmetņu saplūšanu, proti, ka izmainīta Timp-2 ekspresija un funkcionālā aktivitāte kavē aukslēju aizmetņu saplūšanu un epitēlija transformāciju mezenhīmā (Verstappen and Von den Hoff et al., 2006).

Pētījumā ar cilvēka audu paraugiem ir uzrādīta TIMP-2 gēna saistība ar nesindromālām lūpas un aukslēju šķeltnēm Eiropas populācijāâ, un nesenā 2014. gada pētījumā tika identificēts TIMP-2 promotera polimorfisms, atklājot tā saistību ar šo embrionāli determinēto patologiju (Nikopensius et al., 2011; Letra et al., 2014).

Mēs vizualizējām nozīmīgi samazinātu TIMP-4 klātbūtni bērniem ar abpusēju caurejošu lūpas, alveolārā izauguma un aukslēju šķeltni, savukârt TIMP-4 bagātīgi saturēja vienpusēju caurejošu lūpas, alveolārā izauguma šķeltņu audi $(\mathrm{p}<0,001)$. Tomēr aukslēju plastikas laikā iegūtajos audos TIMP-4 ekspresija pieauga ( $\mathrm{p}<0,001)$. Tika novērota pārliecinoši ticama TIMP-4 pieaugoša ekspresija atkārtotās operācijās iegūtajos saistaudos vieniem un tiem pašiem pacientiem ar abpusēju lūpas un aukslēju šķeltni $(\mathrm{p}<0,05)$. Šī atrade skaidrojama ar to, ka, iespējams, samazinātu TIMP-2 ekspresiju šķeltņu skartajos audos kompensē palielināta cita inhibitora, proti, TIMP-4 lokāla ekspresija. Interesanti, ka atradām TIMP-4 ciešu negatīvu korelāciju ar bērna vecumu mēnešos $\left(\mathrm{r}_{\mathrm{s}}=-0,882 ; \mathrm{p}<0,05\right)$.

TIMP-4 inhibē dažādas $M M P s$ un līdz ar to šim enzīmam, iespējams, ir nozīmīga loma sekundāro aukslēju morfoǵenēzē. Mums nav izdevies atrast publicētus datus par TIMP-4 lomu sejas un mutes dobuma attīstībā, tā funkcionālo nozīmi sejas šķeltnu skartajos audos bērniem, kā arī par ekspresijas mainību saistībā ar bērna vecumu. Interesanti, ka līizīgi kā TIMP-2, arī TIMP-4 funkcionālā aktivitāte ir saistīta ar $M M P-2$, proti, viena no šî proteīna funkcijām ir inhibēt MMP-2 un noteiktos apstākḷıs aktivēt proMMP-2 (Wang et al., 2000). Šis proteīns inhibē arī dažādas MMPs, kuru loma ir pierādīta sekundāro aukslēju attīstîbas laikā, piemēram, MMP-2, MMP-3, MMP-9 un MMP-13 (Koskivirta et al., 2010). Turklāt TIMP-4 netieši regulē MMP-2 un MMP-9 gēnu transkripcijas līmeņus (Zhang et al., 2003). Pētījumos tika analizēta TIMP-4 ekspresija augošo smaganu un periodontīta skartajos audos. Domājams, ka TIMP-4 ir būtiska nozīme periodontīta patoğenēzē (Kubota et al., 2008; 
Nakasone et al., 2009). 2006. gadā Zhang ar līdzautoriem pierādīja ciešu saistību starp TIMP ekspresiju un orgānu vecuma pārmaiṇām (Zhang et al., 2006).

Kopumā audu degradācijas enzīmu un to endogēno inhibitoru relatīvais daudzums un sadalījums atšķ̄îās, proti, pacientiem ar vienpusēju caurejošu lūpas, alveolārā izauguma un aukslēju šķeltni, kā arī kontroles gadījumos tas bija lielāks, nekā pacientiem ar abpusēju caurejošu lūpas, alveolārā izauguma un aukslēju škseltni, kas liecina par šo proteīnu nozīmi ne tikai aukslēju embrionālās attīstības laikā, kas ir pierādīts daudzos pētījumos, bet arī postnatāli, kad šķeltne jau ir attīstījusies.

Gēnu un to produktu imūnhistoķīmiskais profils šķeltnes skartajos audos. Noteikti transkripcijas faktori, augšanas faktori un gēni regulē sejas un mutes dobuma attīstību, kā arī ietekmē $M M P$ un TIMP un citu faktoru ekspresiju. Ir atklāta transkripcijas faktora IRF6 nozīme aukslēju ontoǵenēzē, un ir atrodami pārliecinoši pētījumi par transkripcijas faktora IRF6 būtisku lomu sindromisko un nesindromisko lūpas un aukslēju šķeltņu attīstībā (Beaty et al., 2010; Dougherty et al., 2013). Nesenā pētījumā tika atklāta saistība starp IRF6 gēna V274I polimorfismu un vienpusēju caurejošu kreisās puses lūpas, alveolārā izauguma un aukslēju šķeltni (Letra et al., 2012). Citu autoru rezultātu dati IRF6 saista galvenokārt ar lūpas šķeltņi, lūpas un/vai aukslēju šķeltni un izolētu aukslēju šķeltni (Mostowska et al., 2010; Nikopensius et al., 2010; Larrabee et al., 2011). Vienā no pētījumiem ir publicēti rezultāti par IRF6 kā smaguma pakāpes marķieri pacientiem ar lūpas un aukslēju škseltni (Kerameddin et al., 2015).

Mēs identificējām pārliecinoši samazinātu IRF6 klātbūtni bērniem ar smagāko šķeltnes veidu - abpusēju caurejošu lūpas, alveolārā izauguma un aukslēju šķeltni $(p<0,001)$, kas norāda uz šì faktora saistību ar šķeltnes smaguma pakāpi. Jāatzīmēe, ka tika konstatēta cieša, pozitīva korelācija starp IRF6 pozitīvām epitēlijšūnām un saistaudu šūnām mīksto un cieto aukslēju plastikas laikā iegūtos audos no bērniem ar abpusēju škseltni $\left(\mathrm{r}_{\mathrm{s}}=0,802 ; \mathrm{p}<0,05 ; \mathrm{r}_{\mathrm{s}}=0,818 ; \mathrm{p}<0,05\right)$. Atkārtoto operāciju laikā vieniem un tiem pašiem pacientiem atškşirības šì transkripcijas faktora klātbūtnē netika konstatētas. Šī atrade norāda uz vēl ciešāku šñ faktora saistîbu ar šķeltnes smaguma pakāpi neatkarīgi no šķeltnes skarto audu anatomiskās lokalizācijas un operācijas veida. Mēs konstatējām palielinātu IRF6 klātbūtni mutes dobuma epitēlijšūnās, saistaudu šūnās un mazo siekalu dziedzeru šūnās bērniem ar vienpusēju caurejošu lūpas, alveolārā izauguma un aukslēju šķeltni $(\mathrm{p}<0,001)$. Interesanti, ka nesenā pētījumā tika konstatētas svarīgas IRF6 funkcijas - epiteliocītu proliferācijas regulācija un mutes dobuma embrionālās attīstības laika peridermas veidošana (Ke et al., 2015). Tika pierādīts, ka IRF6 intensīvi ekspresējas sejas aizmetņos pirms primāro un primāro aukslēju morfoǵenēzes laikā (Washbourne and Cox, 2006). Provizoriski pelēm 
tika atklāta IRF6 ekspresija aukslēju mediālās malas epitēlijā sekundāro aukslēju aizmetņu saplūšanas laikā, zobu aizmetņos, matu folikulos un ādā (Kondo et al., 2002).

Mēs analizējām arī RYK gēna proteīna lokālu klātbūtni škseltnes skartajos audos. Kopumā nav daudz pētījumu par $R Y K$ gēna iespējamo nozīmi lūpu un aukslēju šķeltņu etiopatoǵenēzē un šķeltnēm raksturīgo fenotipisko šūnu proliferācijāa diferenciācijā un polaritātes regulēšanā postnatālajā periodā. Salīdzinot ar kontroles grupas pacientiem ( $\mathrm{p}<0,001$ ), pētījumā redzējām samazinātu RYK imūnreaktīvo struktūru daudzumu saistaudos pacientiem ar abpusēju šķeltni lūpas plastikas laikā iegūtajos audos, kas liecina par iespējamu būtisku šī faktora nozīmi sejas šķeltņu etiopatoǵenēzē. Pacientiem ar abpusēju caurejošu lūpas, alveolārā izauguma un aukslēju šķeltni pēc lūpas plastikas vizualizējām mazāk pozitīvas struktūras, kamēr mīksto un cieto aukslēju plastikas laikā iegūtajos audu paraugos ievērojām pieaugošu pozitivitāti $(\mathrm{p}<0,05)$. Šo novērojumu var skaidrot ar samazinātu šūnu diferenciācijas potenciālu lūpas audos, salīdzinot ar mīksto un cieto aukslēju plastikas laikā iegūtajiem audiem.

$R Y K$ gēns ir būtisks sejas un mutes dobuma struktūru morfoǵenēzi ietekmējošais faktors. Watanabe ar līdzautoriem norāda uz iespējamu missense mutāciju 1355G>A (Y452C) $R Y K$ gēnā un retu atsevišķu nukleotīda polimorfisma haplotipu saistību ar lūpas un/vai aukslēju šķeltnes attīstību Vjetnamas bērnu populācijā, un lūpas un/vai aukslēju, vai izolētu aukslēju šķeltņu attīstību Japānas bērnu populācijā (Watanabe et al., 2006). RYK gēna proteīna lokalizācijas un in situ hibridizācijas pētījumi pierāda šĩ faktora ekspresiju ne tikai embrija kraniofaciālā reǵiona audos, bet arī postnatāli. Turklāt tika pierādīts, ka Ryk gēna nepietiekama funkcionālā aktivitāte pel̦u embrijiem rada kraniofaciālā reǵiona defektus, proti, caurejošas šķeltnes un arī skeleta defektus (Halford et al., 2000).

Viens no svarīgiem sejas, skeleta un zobu attīstību ietekmējošiem faktoriem ir transkripcijas faktors $M S X 1$, kas plaši ekspresējas kraniofaciālā rajona audos un veicina aukslēju priekšējās daḷas attīstību (Bush and Jiang, 2012). Abi MSX saimes pārstāvji - MSX1 un MSX2 - atbild par sejas un mutes dobuma attīstību (Dai et al., 2014). Pētījumos, kuros bija izmantoti dzīvnieki, tika atklāts, ka šis gēns regulē ETM un inducē apoptozi (Hwang et al., 1998; Lallemand et al., 2009). Turklāt Nassif ar kolēgiem pierādīja MSX1 nozīmi peḷu sejas audu remodelācijā (Nassif et al., 2014). Arī nesen veiktos pētījumos tika parādīta iespējama saistība ar MSX1 gēna genētiskām variācijām un nesidromālām lūpas un/vai aukslēju šķeltnēm (Cardoso et al., 2013; Ma et al., 2014; Gurramkonda et al., 2015).

Pētījumā iegūtie rezultāti atklāja samazinātu MSX1 pozitīvu epiteliocītu klātbūtni pacientiem ar abpusēju lūpas un aukslēju šķeltni pēc lūpas, mīksto un cieto aukslēju plastikas, salīdzinot ar pacientiem, kuriem bija vienpusēja lūpas un aukslēju šķeltne. Tas pats tika 
novērots arī kontroles grupas pacientiem $(\mathrm{p}<0,05)$. Interesanti, ka arī MSX1 pozitīvo saistaudu šūnu relatīvais daudzums materiālā, kas ņemts no pacientiem ar abpusēju šķeltni bija mazāks $(\mathrm{p}<0,001)$, kamēr mīksto un cieto aukslēju plastikas laikā iegūtajos audu paraugos šūnu relatīvais daudzums pārliecinoši pieauga $(\mathrm{p}<0,001)$. Tas liecina, ka MSX1 ir būtisks abpusēju caurejošu lūpas, alveolārā izauguma un aukslēju škseltņu skarto audu morfoloǵiju raksturojošs transkripcijas faktors. Nenoliedzami, šis faktors ir iesaistīts smagākā šķeltnes veida audu remodelācijā. Izanalizējot četru gēnu proteīnu relatīvo daudzumu un sadalījumu vieniem un tiem pašiem pacientiem ontoǵenētiskā aspektā, tika konstatēta tikai MSX1 pieaugoša klātbūtne atkārtoti paņemtajos audos $(\mathrm{p}<0,05)$, kas liecina par vēl pārliecinošāku ticamību š̄ proteīna iesaistei smagākā šķeltņu veida šūnu proliferācijas, diferenciācijas un migrācijas regulēšanā.

Ģenētisko pētījumu rezultāti liecina par iespējamu PAX9 gēna saistību ar nesindromalām lūpas un/vai aukslēju šķeltnēm (Sasaki et al., 2007; Lee et al., 2012; Küchler et al., 2014).

Abpusēju šķeltņu skartajos audos, kas iegūti pēc lūpas plastikas, PAX9 saturošus epiteliocītus un saistaudu šūnas redzējām nozīmīgi mazāk nekā vienpusēju šķeltņu skartajos audos ( $\mathrm{p}<0,001)$. Tika novērota pieaugoša PAX9 klātbūtne abpusēju škseltņu mīksto un cieto aukslēju epitēlijā $(\mathrm{p}<0,001)$. Interesanti, ka šajā pētījumā tika konstatēta asociācija starp PAX9 un MSX1 saturošām epitēlijšūnām un saistaudu šūnām, PAX9 saturošām epitēlijšūnām un saistaudu šūnām bērniem ar vienpusu caurejošu lūpas, alveolārā izauguma un aukslēju šķeltni $(\mathrm{p}<0,05)$. Turklāt PAX9 saturošas epitēlijšūnas korelēja ar PAX9 saturošām saistaudu šūnām bērniem ar abpusēju škseltni cieto aukslēju plastikas laikā iegūtajā materiālā $(p<0,05)$. To varētu interpretēt kā varbūtēju apstiprinājumu Nakatomi et al. teorijai, apgalvojot, ka, savstarpēji mijiedarbojoties, $P A X 9$ un $M S X 1$ gēni regulē sejas audu morfoğenēzi, un reducēta šo gēnu proteīnu klātbūtne cilvēkam var palielināt sejas šķeltņu attīstības risku (Nakatomi et al., 2010).

Izvērtējot savstarpējās asociācijas starp PAX9 un IRF6 gēnu proteīnu klātbūtni audos, tika konstatētas nozīmīgas gan ciešas, gan vidēji ciešas pozitīvas korelācijas šķeltṇu skartajos audos. Šis fakts norāda uz Song et al. pieņēmumu, ka PAX9 un IRF6 gēnu mijiedarbībai ir potenciāli svarīga nozīme šķeltņu etioloǵijā (Song et al., 2013). Nobeigumā jāuzsver, ka šajā pētījumā kompleksi tika izvērtēts visu četru gēnu (PAX9, RYK, MSX1, IRF6) proteīnu savstarpējās korelācijas šķeltṇu skartajos audos. Mēs atradām ciešu, pozitīvu korelāciju cieto aukslēju škeltṇu skartajos audos starp IRF6 un RYK saturošām struktūrām, kas liecina par iespējamu šo gēnu mijiedarbību aukslēju morfoǵenēzē. Tā kā mums neizdevās atrast publicētus datus par šo pieņēmumu, tad šo savu atradi vērtējam kā novatorisku atklājumu. 
Apoptoze un šūnu proliferācija šķeltnes mīkstajos audos. Šķkeltnes skartos audus raksturo gan šūnu proliferācija, gan apoptoze. Apoptotisko šūnu relatīvais daudzums pacientiem ar vienpusēju šķeltni bija izteiktāks nekā pacientiem ar abpusēju škşeltni ( $\mathrm{p}<0,001$ ). Kopumā apoptotisko šūnu relatīvais daudzums audos pacientiem ar abpusēju šķeltni bija mazāks nekā kontroles pacientiem, kaut gan statistiski ticamas atšķirības nekonstatējām. Š̀i atrade ir izskaidrojama ar šķeltnes smaguma pakāpi un abpusēju šķeltņu skarto audu homeostāzes īpatnībām. Šajā pētījumā redzējām arī pārliecinoši samazinātu šūnu proliferāciju bērniem ar abpusēju caurejošu lūpas, alveolārā izauguma un aukslēju škseltni lūpas plastikas laikā iegūtajos audos, kamēr mīksto un cieto aukslēju plastikas laikā vizualizējām pieaugošu šūnu proliferāciju ( $\mathrm{p}<0,05)$. Iespējams, ka minētie rezultāti atspoguḷo smagākā škseltnes veida audu morfoloǵiskās īpatnības. Līdz ar to šūnu proliferācijai un apoptozei ir svarīga nozīme ne tikai embrionālās attīstības laikā, bet arī postnatāli šķeltņu skarto audu homeostāzē.

Ir akceptēta pēdējo gadu publikācijās uzsvērtā programmētās šūnu nāves teorija lūpu un aukslēju aizmetņu attīstības un morfoǵenēzes laikā, tomēr literatūrā ir atrodami pretrunīgi dati (Novakovic et al., 2011). Pētījumā ar pelēm Cuervo un Covarrubias pierādīja apoptotisku šūnu klātbūtni, izmantojot TUNEL metodi priekšèjā aukslēju mediālās malas epitēlija rajonā īsi pēc aukslēju aizmetņu saplūšanas, kamēr mugurējās malas epitēlija šūnu apoptoze tika saskatīta pirms aizmetņu saplūšanas. Abi zinātnieki secināja, ka mediālās malas epitēlija deǵenerāciju nodrošina šūnu apoptoze un šis process aktivē bazālās membrānas degradāciju aukslēju aizmetņu saplūšanas laikā (Cuervo and Covarrubias, 2004). Līdzīgi rezultāti tika publicēti senākā pētījumā, kurā Martínez-Alvarez ar līdzautoriem vizualizēja apoptotiskas šūnas pirms aukslēju aizmetņu saplūšanas (Martínez-Alvarez et al., 2000). Turpretī cita zinātnieku grupa no Japānas šim pētījumam oponē. Tahakara ar kolektīvu in vitro, kultivējot peḷu aukslējas un inhibējot šūnu nāvi, pierādīja, ka piln̄̄gs apoptozes trūkums neietekmē aukslēju saplūšanu. Šajā pētîjumā šūnu nāve tika inhibēta ar kaspāzes-1, kaspāzes-3 inhibitoriem vai aurintrikarboksilskābi. Pat tad, kad šūnu nāve bija pilnīgi inhibēta, aukslēju aizmetņu saplūšana notika. Histoloǵiski izmeklējot audus in vivo, pētnieki redzēja abu aukslēju aizmetņu malas epitēlija adhēziju, vidusšuves epitēlija izzušanu un mezenhīmas saplūšanu, keratīnu-pozitīvu epitēlijšūnu migrāciju uz deguna un mutes dobuma rajonu (Takahara et al., 2004). Jāuzsver, ka abi iepriekš minētie pētījumi veikti, izmantojot eksperimenta dzīvniekus - peles. Turpretī pavisam nesenā Horvātijā veiktā pētījumā (Vukojevic et al., 2012) cilvēka embrijiem un augliem tika izvērtēta ne tikai šūnu apoptozes, bet arī šūnu proliferācija aukslēju aizmetņu audos. Šajā pētījumā, tāpat kā mūsu pêtījumā, tika vizualizētas Ki-67 pozitīvas epitēlijšūnas un apoptotiskas šunas šķeltnes skartajos audos. 
Tomēr nevar nepiebilst, ka starp mūsu pētījumu un Horvātijas pētījumu ir pētāmā audu materiāla atšksirības. Primāro aukslēju aizmetņu saplūšanas laikā Vukojevic ar līdzautoriem (2012) konstatēja proporcionāli samazinātu aukslēju mediālās malas epitēlija šūnu proliferāciju (no 42\% līdz 32\%) un šūnu apoptozi (no 11\% līdz 7\%) primāro aukslēju aizmetņu saplūšanas laikā, kamēr sekundāro aukslēju aizmetņu malas epitēlijā tika vizualizētas $28 \%$ proliferējošu šūnu un $5 \%$ apoptotisku šūnu. Imūnhistoķīmiski šūnu proliferācija, tāpat kā mūsu pētījumā tika vizualizēta, lietojot šūnu proliferācijas marķieri $K i-67$, bet šūnu apoptoze tika identificēta, pielietojot TUNEL metodi. Šis pētījums ar cilvēka embrija audiem pierāda, ka šūnu proliferācijai un apoptozei ir būtiska nozīme ne tikai primāro un sekundāro aukslēju attīstībā, bet arī, iespējams, sejas šķeltņu etiopatoǵenēzē (Vukojevic et al., 2012).

\section{Nestīna un CD34 imūnhistoķīmiskais profils škseltnes mīkstajos audos. Mūsu} pētījumā vienpusēju un abpusēju šķelţ̦u, kā arī bagātīgi kontroles pacientu gḷotādā konstatējām nestīnu saturošas epitēlijšūnas un saistaudu šūnas. Salīdzinot nestīna klātbūtni materiālā, kas iegūts pēc lūpas plastikas pacientiem ar vienpusēju šķeltni un pacientiem ar abpusēju šķeltni, tika novērotas nozīmīgas atšksirības. Abpusēju šķeltņu materiālā pozitīvu šūnu bija mazāk $(\mathrm{p}<0,05)$. Kontroles pacientu audu paraugos tika konstatēta pārliecinoši bagātīga nestīna klātbūtne mutes dobuma gḷotādā $(p<0,001)$. Šo atradi var skaidrot ar audu reǵenerācijas potenciāla samazināšanos bērniem ar šķeltnēm un izteiktāk pacientiem ar abpusējām škseltnēm.

Ir atklāts, ka nestīnu ekspresējošās šūnas spēj proliferēt, diferenciēties un migrēt. Pēc ievainojuma šūnas pastiprināti ekspresē nestīnu, un šis atklājums norāda uz būtisku šī proteīna lomu audu reǵenerācijā, turklāt nestīna pieaugošu ekspresiju regulē dažādi augšanas faktori un citas signālmolekulas (Wiese et al., 2004). Izmantojot dažādus cilmes šūnu marķierus, tajā skaitā nestīnu, nesenā pētījumā tika izvērtēta mutes dobuma gl̦otādas celmšūnu/multipotento cilmes šūnu klātbūtne, jo mutes dobuma gḷotādas epitēlijā esošām celmšūnām/multipotentām cilmes šūnām ir svarīga nozīme audu homeostāzē un brūču dzī̌sanā. Šajā pētījumā, izmantojot imūnfluorescences metodi, netika identificēta nestīna klātbūtne gḷotādā. Tajā pašā laikā Jones ar kolēǵi apraksta nestīna ekspresiju vaigu un smaganu gḷotādā (Jones and Klein, 2013). Interesanti, ka nestīna ekspresija tika pētîta arī normālos un patoloǵiskos cilvēka zobu audos. Rezultāti pierādīja, ka nestīnam ir nozīme šūnu diferenciācijā ne tikai normālos, bet arī patoloǵijas skartos audos. Interesanti, ka šì proteīna ekspresiju regulē BMP-4 (About et al., 2000).

Mūsu pētījumā visos škseltņu gadījumos konstatējām bagātīgu CD34 klātbūtni lamina propria asinsvadu sieninas šūnās. Pārliecinoši vairāk CD34 pozitīvu endotēlijšūnu tika 
novērots šķeltņu pacientu lūpas plastikas laikā iegūtajos audos nekā kontroles pacientu audos ( $\mathrm{p}<0,001)$. Šì atrade vērtējama kā kompensatora reakcija audu pārmaiṇām, stimulējot jaunu asinsvadu šūnu veidošanos.

Līdzīgu pētījumu ir veicis zinātnieku kolektīvs no Indijas. Šajā pētījumā tika izvērtēta vaskuloǵenēze, kas saistīta ar mutes dobuma g̣̦otādas fibrotiskām pārmaiṇām un epitēlija atrofiju, lietojot $C D 34$ un $F G F$ marķierus. Tika pierādīts, ka $C D 34$ ir tiešs mutes dobuma gḷotādas vaskuloǵenēzi raksturojošs faktors. Patologiisku procesu skartajā mutes dobuma glotādā tika atklāts statistiski ticami samazināts $C D 34$ pozitīvo struktūru daudzums saistībā ar mutes dobuma gļotādas atrofiju (Pandiar and Shameena, 2014). Otrs zinātnieku kolektīvs pierādīja, ka patoloǵisku procesu skartajā mutes dobuma gḷotādā ir palielināts CD34 pozitīvo struktūru daudzums (Desai et al., 2010).

TGFß3 un VEGF imūnhistoķīmiskais profils škseltnes mīkstajos audos. Mūsu pētījumā konstatējām nozīmīgi samazinātu $T G F \beta 3$ pozitīivu struktūru relatīvo daudzumu abpusēju šķeltņu lūpas materiālā, salīdzinot ar vienpusēju šķeltņu un kontroles audu paraugiem ( $\mathrm{p}<0,001 ; \mathrm{p}<0,005)$. Salīdzinot osteoplastikas laikā iegūtos audu paraugus, redzējām samazinātu $T G F \beta 3$ osteoblastu un osteocītu vidējo relatīvo daudzumu pacientiem ar abpusēju škseltni un kontroles grupas pacientiem $(\mathrm{p}<0,001)$. Šo faktu varētu izskaidrot ar nepietiekamu šūnu proliferāciju, diferenciāciju un apoptozi smagākā šķeltnes veida, t. i., abpusēju caurejošu lūpas, alveolārā izauguma un aukslēju šķelțu gadījumos. Izvērtējot šī faktora klātbūtni atkārtoti paņemtos audu paraugos, vizualizējām pārliecinoši lielāku TGFß3 relatīvo struktūru daudzumu mīksto un cieto aukslēju plastikas laikā iegūtajos audu paraugos $(\mathrm{p}<0,05)$. Šo atradi var skaidrot ar saglabātu pozitīvu audu kompensatoru reakciju. Turklāt tika konstatēta vidēja, pozitīva korelācija starp TGFß3 epitēlijā un saistaudos $(\mathrm{p}<0,05)$. Ir zināms, ka TGFß3 regulē šūnu nāvi (Yu et al., 2009). Interesanti, ka šajā pētījumā atradām asociāciju starp $T G F \beta 3$ pozitīvām struktūrām un apoptotiskām šūnām bērniem ar vienpusēju caurejošu lūpas, alveolārā izauguma un aukslēju šķeltni $(\mathrm{p}<0,05)$. Tā kā TGFß3 inducē MMP-9 ekspresiju un aktivitāti (Hosokawa et al., 2003), tika pārbaudīts, vai starp šiem marķieriem pastāv saistība pacientiem ar šķeltnēm. Izvērtējot rezultātus, tika konstatēta vidēji cieša korelācija starp $T G F \beta 3$ un $M M P-9$ pozitīvām saistaudu šūnām un starp $M M P-9$ pozitīvām saistaudu šūnām un $T G F \beta 3$ epitēlijšūnām. Palielinoties viena faktora klātbūtnei, palielinās otra faktora klātbūtne audos, kas liecina par to, ka starp šiem diviem faktoriem pastāv cieša asociācija saistībā ar šķeltņu etiopatoǵenēzi.

Tiek uzskatīts, ka TGF 33 signālcel̦š mijiedarbojas ar citu augšanas faktoru, transkripcijas faktoru vai enzīmu signālcel̦iem, kuri iesaistās škşeltņu patoǵenēzēe (Galloway et al., 2013). Piemēram, $X u$ ar līdzautoriem ir secinājis, ka transkripcijas faktoru 
IRF6 kontrolē TGFß3 (Xu et al., 2006). Mūsu pētījumā bērniem ar škseltnēm atklājām korelāciju starp TGFß3 un IRF6 pozitīvām struktūrām saistaudos (p = 0,001). Tika izanalizētas arī citu gēnu proteīnu asociācijas ar TGFß3 un konstatētas vairākas gan ciešas pozitīvas, gan vidējas pozitīvas korelācijas (MSX1, PAX9, RYK), kas šķeltņu skartajos audos norāda uz TGFß3 lokālu mijiedarbību ar citiem faktoriem.

Mūsu pētījumam līdzīgi rezultāti tika iegūti 2006. gadā Itālijā. Šajā pētījumā tika izvērtēta TGFß3 ekspresija operācijas materiālā no bērniem ar izolētām aukslēju škeltnēm un lūpas, alveolārā izauguma un/vai aukslēju škseltnēm. Rullo ar kolēǵiem bērniem ar šķeltnēm konstatēja pārliecinoši samazinātu $T G F \beta 3$ ekspresiju epitēlijā, salīdzinot ar kontroles materiālu, kurš tika iegūts zoba ekstrakcijas laikā (Rullo et al., 2006). Diemžēl pētījumā netika izvērtēta $T G F \beta 3$ pozitivitāte saistaudos, bet mēs š̄ augšanas faktora klātbūtni izvērtējām saistībā ar škseltnes smaguma pakāpi.

Turklāt tika atklāts, ka TGFß3 regulē osteoblastu diferenciāciju, tādējādi TGFß3 iesaistās kaula remodelācijā (Bouletreau et al., 2000; Chen et al., 2012). Kaula resorbcijas laikā osteoklasti aktivizē latentu $T G F \beta 3$, kas stimulē kaula formēšanos. Šis atklājums parāda, ka TGFß3 ir vadošais faktors kaula dzīšanas procesa fāzē - remodelācijāa (Silva et al., 2004). N̦emot vērā pêtījuma rezultātus, tika secināts, ka TGFß3 ir būtisks angioǵenēzi ietekmējošais augšanas faktors lūpu un aukslēju attīstības laikā tieši vēlīnās attīstības stadijās, kad notiek peridermas šūnu izzušana un aizmetņu saplūšana (Muraoka et al., 2005; Jalali et al., 2012). Ir zināms, ka $T G F \beta 3$ inducē $E T M$, regulējot šūnu proliferāciju, diferenciāciju, ECM, un, iespējams, arī MEE apoptozi (Tian and Schiemann, 2009; Galloway et al., 2013). Pēdējo gadu publikācijās ir aprakstītas sejas aizmetņu peridermas slāņa šūnas, jo to izzušana nodrošina veiksmīgu lūpu un aukslēju aizmetņu saplūšanu. Izpētot peļu aukslēju aizmetņu audus, 2015. gada pētījumā ir pierādīts, ka TGFß3 regulē peridermas šūnu izzušanu, veicinot veiksmīgu aukslēju aizmetņu saplūšanu (Hu et al., 2015). Japānas pētnieku grupa atklāja TGFß3 ekspresiju peḷu lūpu aizmetņu epitēlijšūnās, savukārt TGFß3 trūkumu novēroja pelēm ar lūpas šķeltni. Tika atklāts interesants fakts, ka pelēm eksogēni ievadīts $T G F \beta 3$ veicina lūpas aizmetņu saplūšanu, inducējot endotēlijšūnu diferenciāciju un veicinot mezenhīmas šūnu proliferāciju. TGF 33 inducē divu svarīgu angioǵenēzi veicinošo faktoru - Flk-1 un CD31 ekspresiju (Muraoka et al., 2005). Līdzīgi secinājumi bija publicēti 1998. gada pētījumā, kad tika novērots, ka eksogēni ievadīts $T G F \beta 3$ vistām ar šķeltni veicina normālu aukslēju aizmetņu saplūšanu (Sun et al., 1998). Ohno ar kolēǵiem injicēja žurkām $0.5 \mathrm{ml} T G F \beta 3$ vaigu zemgḷotādā un secināja, ka šis faktors veicina epitelizāciju un tādējādi samazina rētaudu veidošanos (Ohno et al., 2011). Šì pētījuma rezultāti apstiprina faktu, ka TGFß3 veicina mutes dobuma gḷtādas reǵenerāciju. Izvērtējot TGFß3 funkcijas, daudzās populācijās tika 
analizētas arī genētiskās variācijas šajā gēnā saistībā ar lūpas un aukslēju šķeltnes attīstību (Reutter et al., 2008; Suazo et al., 2010; Saleem et al., 2012; Tang et al., 2013; Mehrotra, 2015).

Mūsu iepriekšējā pētījumā (Smane et al., 2012) tika izvērtēta IL-6 klātbūtne vienpusēju caurejošu lūpas, alveolārā izauguma un aukslēju šķeltņu mīkstajos un cietajos audos. Rezultātā tika saskatītas atsevišksas $I L-6$ pozitīvas epitēlijšūnas un saistaudu šūnas, kā arī maz līdz vidēji daudz tika vizualizēti $I L-6$ pozitīvi osteocīti un hondrocīti. Šì atrade, iespējams, parāda, ka IL-6 ekspresiju šķeltnes skartajos audos regulē citi augšanas faktori vai signālmolekulas, kā norāda, piemēram, Baroni et al. TGFß3 pētījums (Baroni et al., 2003).

Baroni ar kolēgiem pētīja TGFß3 ietekmi uz IL-6 ekspresiju sejas šķeltņu fibroblastos. Šī pētījuma rezultāti rāda, ka $I L-6$ inhibē šķeltṇu fibroblastu funkciju sintezēt kolagēnu un glikozoaminoglikānus, kā arī samazina tieši hialuronskābes un dermatānsulfāta sintēzi. TGF 33 pārliecinoši samazina fibroblastu funkciju sintezēt IL-6. Tātad TGFß3 un IL-6 funkcionālā mijiedarbība ir iesaistīta aukslēju škseltnes indukcijā (Baroni et al., 2003).

Savukārt Kohama ar kolēǵiem demonstrēja, ka $T G F \beta 3$ ir vadošs faktors brūces dzišanā pēc lūpas plastikas, inducējot mezenhīmas šūnu proliferāciju un migrāciju ievainoto audu virzienā (Kohama et al., 2002). Eksperimentā ar pelēm, tika pierādīts, ka TGFß3 reducē rētaudu veidošanos in vivo. Pētījuma autori ķirurğiski izveidoja lūpas šķeltni, tad veica šķeltnes korekciju un analizēja iegūto materiālu. Trīsdesmit minūtes pēc lūpas plastikas audos tika identificēta palielināta $T G F \beta 3$ klātbūtne, kas inducēja enzīma $M M P-9$ ekspresiju un aktivitāti, kas savukārt reducēja pirmā tipa kolagēna akumulāciju un inhibēja gludo miocītu $\alpha$ aktīna ekspresiju šūnās. Pirmā tipa kolagēna akumulācija nenotiek, jo tiek inhibēta miofibroblastu diferenciācija un tādējādi arī attiecīgā kolagēna sintēze (Hosokawa et al., 2003).

Salīdzinot vienpusēju caurejošu lūpas, alveolārā izauguma un aukslēju šķeltņu audu paraugus, kas tika iegūti no pacientiem lūpas plastikas laikā, ar abpusēju šķeltņu audu paraugiem, atklājām, ka VEGF imūnreaktīvo struktūru vidējais relatīvais daudzums smagāko šķeltņu gadījumos bija samazināts ( $<$ < 0,05). Cieto aukslēju plastikas laikā iegūtajā materiālā $V E G F$ pozitīvo struktūru daudzums bija mazāks nekā kontroles pacientiem $(\mathrm{p}<0,005)$. Salīdzinot Sundeeps un viņa kolēǵu veiktā pētījuma rezultātus, šì darba atradi var skaidrot ar, iespējams, traucētu neovaskularizāciju un reepitelizāciju lūpu un aukslēju gļotādas brūces dzī̌sanas procesā bērniem ar smagāko šķeltnes veidu, t.i., ar abpusēju caurejošu lūpas, alveolārā izauguma un aukslēju šķeltni. Tomēr atkārtotu operāciju laikā iegūtajos audu paraugos redzējām pieaugošu $V E G F$ saturošo struktūru daudzumu, kas liecina par vēlīnu audu išēmiju, kas, acīmredzot, parādās ilgstošā reǵenerācijas laikā. 
Vaskulārais endotēlija augšanas faktors (VEGF) pieder pie signālmolekulu saimes, kas veido asinsvadus embrionālās attīstības un brūču dzīšanas laikā, kā arī nodrošina asinsvadu homeostāzi cilvēka organismā un spēj inhibēt apoptozi (Ferrara et al., 2003; Roy et al., 2006; Andisheh-Tadbir et al., 2014). Pētījumos tika atklāts, ka VEGF un tā receptors VEGFR-2 ekspresējas veselā cilvēka epidermā, matu folikulu ārējā epiteliālajā makstī, regulējot epiteliocītu proliferāciju un migrāciju, kā arī samazina šo šūnu adhēzijas kapacitāti (Man et al., 2006; Li et al., 2012). Literatūrā nav tiešu pêtījumu datu par šì faktora nozīmi sejas šķeltņu attīstībā, tomēr dažu pētījumu rezultāti liek diskutēt par iespējamu šī faktora iesaistīšanos sejas šķeltṇu patoǵenēzē. Piemēram, Patyna ar kolēgiem savā pētījumā, ārstējot žurkas un trušus ar $V E G F$ inhibitoru $S U T E N T \circledR \geq 1 \mathrm{mg} / \mathrm{kg} /$ dienā, aprakstīja lūpas un aukslēju šķeltnes attīstību trušiem (Patyna et al., 2009). Savukārt citā pētījumā tika pierādīta iespējamā TBX1 proteīna, kam ir nozīme sejas un kakla rajona asinsvadu attīstībā, loma mazo asinsvadu patologijāa embrija audos. Mikrodelēcijas š̄i gēna noteiktos lokusos izraisa $D i$ Džordža sindromu, kam klīniski raksturīga aukslēju šķeltne. Interesanti, ka TBX1 proteīna ekspresija ir atkarīga no VEGF izoformas (Yagi et al., 2003). Reducēts VEGF daudzums samazina TBX1 funkciju, tāpēc var attīstīties asinsvadu malformācijas (Stalmans et al., 2003). Asinsvadu veidošanās traucējumi lūpu un aukslēju aizmetņu mezenhīmā, iespējams, negatīvi ietekmē audu remodelāciju, tāpēc tiek izmainīta citu signālmolekulu ekspresija un audu saplūšana (François-Fiquet et al., 2014). Sundeep pētījuma ietvaros tika analizēta siekalu VEGF saistība ar aukslēju gḷotādas dzī̌sanas un neovaskularizācijas potenciālu pēc ievainojumiem. Tika atklāts, ka zems VEGF līmenis siekalās korelē ar traucētu neovaskularizāciju, reepitelizāciju un kolagēna akumulāciju, kas liecina par šĩ faktora nozīmi aukslēju gḷotādas brūces dzīšanas procesā (Keswani et al., 2013).

PGP 9.5 imūnhistoķīmiskais profils šķeltnes mīkstajos audos. Mūsu pētījumā $P G P$ 9.5 saturošas nervu šķiedras novērojām visos vienpusēju un abpusēju šķeltņu gadījumos. $P G P$ 9.5 saturēja atsevišķas nervu šķiedras epitēlijā un subepitēlijā, kā arī nervu šķiedras ap tauku dziedzeriem, matu folikuliem un asinsvadiem. Sīkas nervšķiedras tika vizualizētas tuvāk bazālajai membrānai. Arī asinsvadu sieniṇās novērojām PGP 9.5 pozitīvas nervu šķiedras. Dažos paraugos epitēlijā - stratum basale un stratum spinosum slāņos - tika konstatētas PGP 9.5 saturošas neiroendokrīnās šūnas. Mūsu pētījuma rezultāti ir līdzīgi, tomēr nesakrīt ar pētījuma rezultātiem, kurus ieguva zinātnieki no Brazīlijas. Pēdējie izvērtēja mēles, vaigu un aukslēju gļotādas inervāciju žurkām, pielietojot imūnhistoķīmijas metodi un caurstarojošo elketronmikroskopijas analīzi. Līdzīgi mūsu pētījumam, arī Watanabe et al. atrada daudz PGP 9.5 pozitīvas nervu šķiedras žurkas mutes dobuma gḷotādas saistaudos (Watanabe et al., 2013), lai gan kopumā tika atrasts maz līdz vidēji daudz (+/++) pozitīvu nervšķiedru. Līdzīgs, 
bet senāks pētījums tika veikts 2000. gadā, analizējot žurkas cieto aukslēju glotādas inervāciju ar PGP 9.5. Rezultātā tika secināts, ka cieto aukslēju gḷotāda ir labi inervēta (Mitsui et al., 2000). Šis fakts, iespējams, jāsaista ar atšķirībām izmeklējamajā materiālā. Abpusēju šķeltņu skartu audu materiālā saskatījām $P G P 9.5$ sadalījuma atšķirības, proti, abpusēju šķeltņu materiālā $P G P 9.5$ saturošo struktūru relatīvais daudzums bija samazināts, salīdzinot ar audu paraugiem no pacientiem ar vienpusēju šķeltni $(\mathrm{p}<0,05)$, kas, iespējams, ir saistīts ar šķeltnes smaguma veidu. Turklāt ievērojām, ka mīksto aukslēju plastikas laikā iegūtajos audos PGP 9.5 pozitīvo struktūru bija mazāk nekā lūpas un cieto aukslēju plastikas laikā iegūtajos audu paraugos $(\mathrm{p}<0,05)$. Iespējams, mīksto aukslēju glotāda šķeltņu pacietiem ir mazāk inervēta. Kato et al. veiktajā pētîjumā ar dzīvnieku modeļiem tika secināts, ka cieto un mīksto aukslēju pārejas zona ir labi inervēta (Kato et al., 1998), pie kam cita autora kolektīva pētījuma rezultāti liecina, ka ne tikai pārejas zona, bet arī mīksto aukslēju gḷotādas rajons ir pietiekami labi inervēts (Shimokawa et al., 2005). Iespējams, šie rezultāti ir saistāmi ar sugu atšķirībām.

MMP un TIMP imūnhistoķīmiskais profils škşeltnes skartajos audos. Izvērtējot MMP-2 un TIMP-2 klātbūtni osteoplastikas laikā iegūtajā materiālā, pētījumā tika novērotas samazinātas šo proteīnu saturošas struktūras bērniem ar smagāko šķeltnes veidu, t.i., abpusēju caurejošu lūpas, alveolārā izauguma un aukslēju šķeltni $(p<0,001)$. Šì atrade, iespējams, skaidrojama ar to, ka pacientiem ar abpusēju škseltni alveolārā kaula remodelācijas potenciāls ir mazāk izteikts nekā pacientiem ar vienpusēju šķeltni.

Alveolārā kaula remodelācijas molekulārie mehānismi saistībā ar sejas šķeltnēm un to ārstēšanā pielietoto osteoplastiku nav plaši pētīti. Nesenā pētījumā tika pierādīta $M M P-2$ ekspresija un tā loma alveolārā kaula deǵenerācijā žurkām pēc zoba ekstrakcijas (Accorsi-Mendonça et al., 2008). Zinātnieki no Braz̄ilijas ziņoja, ka, stimulējot MMP-2 ekspresiju, tiek sekmēta kaula remodelācija un veiksmīga brūces dz̄īšna (Rocha et al., 2014). Turklāt tika atklāts, ka samazināta $M M P-2$ funkcionālā aktivitāte negatīvi ietekmē kaula kvalitāti (Nyman et al., 2011). Kramer ar līdzautoriem izpētīja, ka, injicējot TIMP-2 galvaskausa kaulu defektu rajonos, tiek stimulēts dzī̌sanas process (Kramer et al., 2008).

Alveolārā kaula šķeltne osteoplastikas laikā tiek koriǵēta ar autotransplantētiem kaulaudiem no tibia vai crista iliaca superior rajona, kas mūsdienās tiek uzskatîts par zelta standartu caurejošu šķeltņu alveolārā kaula defekta ārstēšanai bērniem maiņas sakodiena vecumā (Herford et al., 2007). Galvenais osteoplastikas mērķis ir piepildīt defekta vietu, stabilizēt augšžokli, aizvērt oronazālo fistulu, nodrošināt zoba erupciju un uzlabot deguna simetriju (Bajaj et al., 2003). N̦emot vērā, ka alveolārā kaula dzīšana un remodelācija ir komplekss process, kuru koordinē šūnas, bioaktīvie faktori un ECM, stimulējot preosteoblastu 
proliferāciju, diferenciāciju un migrāciju, tiek pētītas dažādu faktoru spējas ietekmēt kaula reǵenerāciju. Reǵenerācijas laikā tiek inducēta dažādu signālceḷu kaskāde, tāpēc palielinās iekaisumu veicinošo citokīnu, angioǵenēzi un osteoǵenēzi ietekmējošo augšanas faktoru ekspresija. Turklāt šiem faktoriem ir būtiska nozīme sejas kaulu un aukslēju attīstībā, kā arī skeletu veidojošo kaulu homeostāzē (Vo et al., 2012).

BMP2/4 imūnhistoķīmiskais profils šķeltnes skartajos cietajos audos. Mūsu pētījumā saskatījām nozīmīgi samazinātu BMP2/4 klātbūtni bērniem ar abpusēju škseltni ( $\mathrm{p}<$ 0,001). Samazinātu BMP2/4 klātbūtni novērojām arī kontroles pacientu materiālā, salīdzinot ar materiālu, kas ņemts no pacientiem ar vienpusēju šķeltni $(\mathrm{p}<0,001)$. Kopumā bērniem ar vienpusēju caurejošu lūpas, alveolārā izauguma un aukslēju šķeltni tika vizualizēta bagātīga $B M P 2 / 4$ klātbūtne kaulaudu šūnās. Tātad pacientiem ar vienpusēju škseltni kaula dzī̌šnas un reǵenerācijas spējas pat pēc ķirurğiskas operācijas izraisītas traumas kaulā ir izteiktākas nekā pacientiem ar smagāko šķeltnes veidu un smagākos šķeltnes gadījumos kaula dzī̌sanas un augšanas potenciāls ir būtiski samazināts. Atrade kontroles pacientu materiālā liecina par BMP2/4 nozīmi normālu audu funkciju regulēšanā. Šajā pētījumā veiktais atklājums parāda, ka bērniem ar abpusēju šķeltni ir samazināts kaula reǵenerācijas potenciāls, tāpēc ir lielāka varbūtība, ka šiem bērniem brūce sadzīs ar paliekošu defektu. Līdzīgus rezultātus ieguva Alarmo un Torrecillas-Martínez ar kolēgiem (Alarmo et al., 2013; Torrecillas-Martínez et al., 2015).

Pamatojoties uz pētījumu rezultātiem, $A S V$ ir apstiprināta cilvēka rekombinantā kaula morfoǵenētiskāa proteīna-2 (rhBMP-2) lietošana alveolārā kaula šķeltnes ārstēšanai (Woo, 2013). Š̄i augšanas faktora izmantošanai alveolārā kaula šķeltnes korekcijai ir vairākas priekšrocības: samazinās operācijas ilgums un stacionārā pavadīto dienu skaits, kā arī tiek reducēta rētaudu veidošanās. $A S V$ pētnieki pierādīja, ka $r h B M P-2$ lietošanas laikā kaula šķeltne tiek pilnīgi slēgta, un pieņēma, ka $r h B M P-2$ var būt kā alternatīva kaula autotransplantācijai. Jāatzīmē gan, ka šajā pētījumā tika iekḷauti tikai 12 bērni ar vienpusēju alveolārā izauguma šķeltni, kas ir neliels pacientu skaits tik nopietnam secinājumam (Herford et al., 2007).

Nesenos pētījumos ar dz̄ivnieku modeļiem tika pierādīts, ka arī BMP-4 inducē cieto audu reǵenerāciju (Shi et al., 2013; Shiozaki et al., 2013). Torrecillas-Martínez savā pētījumā uzsver, ka BMP-4 veic būtisku nozīmi kaula homeostāzē un reǵenerācijā pēc ķirurǵiskas augšžokḷa dobuma paplašināšanas (Torrecillas-Martínez et al., 2015). Ir atrodami arī vairāki neseni pētījumi, kas liecina par BMP-4 gēna pozitīvu saistību ar lūpas ar/bez aukslējas šķeltnēm dažādās populācijās (Kempa et al., 2014; Chen et al., 2014; Hu et al., 2015). Suzuki et al., pielietojot imūnhistoķīmijas metodi, identificēja BMP-2 ekspresiju zoba 
aizmetņos un žokḷa rajona audos cilvēka embrijiem, kas liecina par šī proteīna nozīmi sejas un mutes dobuma audu morfoǵenēzē (Suzuki et al., 2001).

\section{Alveolārā kaula pamatvielas nekolagēno proteīnu un $O P G$ imūnhistoķīmiskais}

profils. Kopumā $O C$ saturošas šūnas pacientiem ar vienpusēju un abpusēju alveolārā kaula šķeltni tika konstatētas visos audu paraugos. Gan pacientiem ar škseltni, gan kontroles pacientiem atrade bija līdzīga, kaut gan kontroles grupas pacientiem tika konstatēts statistiski ticami lielāks $O C$ saturošo struktūru relatīvais daudzums ( $<<0,05)$. Izvērtējot šo atradi, secinājām, ka pacientiem ar šķeltni alveoloārā kaula mineralizācija noris aktīvi.

Ir pierādīta $O C$ nozīme kaula mineralizācijā, kaula formēšanās un resorbcijas procesā (Murshed et al., 2004). Jau kopš 1996. gada pētījumos ar pelēm pierādīts, ka $O C$ trūkums palielina kaulaudu masu un ietekmē tā kvalitāti (Ducy et al., 1996). Turklāt tika atklāts, ka $O C$ stimulē angioǵenēzi, kas vēl vairāk apstiprina tā nozīmi kaula dzīšanā un remodelācijā (Cantatore et al., 2005). OC ekspresija tika izvērtēta peļu alveolārā kaula dzī̌sanas periodā, kur tika atklāta tā pieaugoša ekspresija periodā, kad notiek intensīva kaula mineralizācija (Rodrigues Luvizuto et al., 2010).

Mēs izvērtējām $O P N$ klātbūtni tieši audos, kas tika iegūti no alveolārā kaula šķeltnes rajona, un identificējām nozīmīgi samazinātu $O P N$ klātbūtni kontroles grupas pacientiem un bērniem ar abpusēju alveolārā izauguma šķeltni, salīdzinot ar pacientiem, kuriem bija vienpusēja šķeltne ( $\mathrm{p}<0,001 ; \mathrm{p}<0,003)$. Mēs konstatējām, ka šie rezultāti, pirmkārt, parāda, kāda ir škseltnes smaguma pakāpe. Otrkārt, izvērtējot šī faktora funkcijas audos, iespējams, $O P N$ samazina šūnu mobilizāciju, migrāciju, rezistenci pret apoptozi, kā arī kavē angioǵenēzi alveolārā kaula dzīšanas un remodelācijas laikā.

$O P N$ ir potenciāls aukslēju un alveolārā kaula attīstību veicinošs faktors (Jono et al., 2000). Turklāt divos nesenos pētījumos tika uzsvērta $O P N$ loma peḷu aukslēju attīstībā un tika konstatētas nozīmīgas $O P N$ ekspresijas izmaiņas kraniofaciālā reǵiona attīstības laikā (Mukhopadhyay et al., 2004). Jakobsena ar līdzautoriem savā pētījumā publicēja interesantus rezultātus par $O P N$ jeb sekretorā fosfoproteīna nozīmi cilvēka aukslēju attīstībā, kā arī lūpas un aukslēju šķeltnes iespējamajā etiopatoğenēzē (Jakobsen et al., 2009). Šajā pētījumā tika pielietota Gene Chip analīzes un kvantitatīva reversās transkripcijas un polimerāzes ķēdes reakcijas analīze $(R T-P C R)$. Tika analizēti audu paraugi no pacientiem izolētu lūpas, aukslēju šķeltnes un lūpas un aukslēju šķeltņu gadījumos, kā arī imūnhistoķīmiski izanalizēta $O P N$ ekspresija cilvēka embriju kraniofaciālā reǵiona audos. Izmantojot Gene Chip un RT-PCR analīzi, tika konstatēta statistiski ticami palielināta $O P N$ ekspresija aukslēju materiālā no pacientiem ar lūpas un aukslēju šķeltni. Turklāt, lietojot imūnhistoķīmijas metodi, $O P N$ tika identificēts cilvēka embrija aukslēju audos, lai gan pētījumā ar pelēm tika atklāts, ka $O P N$ 
trūkums nav saistīts ne ar lūpas un/vai aukslēju šķeltnes attīstību, ne ar kaula attīstības defektiem. OPN deficīts ietekmē osteklastoǵenēzi in vitro (Rittling et al., 1998). OPN regulē šūnu adhēziju, migrāciju un kaula remodelāciju, kā arī ir iekaisumu veicinošais citokīns, kas kontrolē imūnās sistēmas funkcijas (Standal et al., 2004). Izmantojot dzīvniekus eksperimentos, tika atklāts, ka izmainīta $O P N$ ekspresija kavē agrīnu vaskularizāciju, pārmaina ECM organizāciju, kā arī kaula remodelāciju (Duvall et al., 2008). Interesants pētījums tika veikts 2002. gadā. Š̀ pētījuma ietvaros tika pierādīts, ka imūnās sistēmas stimulācija grūsnām pelēm pēc teratogēno faktoru ekspozīcijas samazina sejas škseltņu incidenci (Holladay et al., 2002). 2015. gada pêtījumā tika atklāts, ka kaula sialoproteīna trūkums pelēm rada smagus alveolārā kaula un apakšžokḷa mineralizācijas traucējumus, bet citu kraniofaciālā rajona kaulu mineralizāciju ietekmē maz (Foster et al., 2015). Šie pētījumi atklāj iespējamu imūnās sistēmas un kaula metabolisma mijiedarbības lomu lūpas un aukslēju šķeltnes attīstībā.

$O P G$ šajā pētījumā tika izvērtēts kā spēcīgs kaula remodelāciju inhibējošais faktors. Kopumā bērniem ar abpusēju alveolārā kaula šķeltni $O P G$ klātbūtne bija pārliecinoši mazāka, salīdzinot ar pacientiem, kuriem bija vienpusēja šķeltne, un kontroles grupas pacientiem $(\mathrm{p}<0,001 ; \mathrm{p}<0,05)$.

Pētījumos ar pelēm tika atklāts, ka lokāla $O P G$ nepietiekamības rezultātā tiek inhibēta kaula modelācija (Dunn et al., 2007; Meijome et al., 2015). In vivo pētījumā tika atklāts, ka $O P G$ gēna terapija aizsargā alveolāro kaulu no pārmērīgas resorbcijas, kuru ierosina periodontīts (Tang et al., 2015). Izvērtējot veiktā darba rezultātus, $O P G$ atrade rāda, ka bērniem ar abpusēju alveolārā izauguma šķeltni ir samazinātas kaula aizsargspējas, kas var negatīvi ietekmēt alveolārā kaula pēcoperācijas reǵenerācijas procesu.

Analizējot iegūto rezultātu korelācijas, tika konstatēts, ka pastāv statistiski ticama cieša korelācija starp $O C, O P$ un, $O P G$ kaulaudos, kas iegūti no pacientiem ar vienpusēju šķeltni. Proti, palielinoties $O C$ ekspresijai, pieaug arī $O P$ un $O P G$ ekspresija, kā arī, palielinoties $O P$ ekspresijai, pieaug $O P G$ ekspresija. Tas liecina par līdzsvarotu alveolārāa kaula remodelācijas procesu. Pacientiem ar smagākas pakāpes šķeltni, t.i., abpusēju alveolārā kaula šķeltni, šì korelācija bija vājāk izteikta.

Diskusijas nobeigumā jāmin, ka šī darba pētījumā pirmo reizi ar imūnhistoķ̄imijas metodi kompleksi ir izvērtētas smagākā šķeltņu veida - abpusējas caurejošas lūpas, alveolārā izauguma un aukslēju šķ̧eltnes audu morfoloǵiskās pārmaiņas ontoǵenētiskajā aspektā. Izvērtējot MMP un TIMP klātbūtni caurejošu lūpas, alveolārā izauguma un aukslēju šķeltņu skartajos audos, skaidri redzams, ka no audu deǵenerācijas faktoriem abpusēju šķeltņu pacietu audos dominē $M M P-2$, bet kā inhibējošais faktors - TIMP-2. Interesanti, ka pacientiem ar 
vienpusēju šķeltni pārliecinoši tika vizualizēta $M M P-9$ un TIMP-4 dominējoša klātbūtne. Tā kā ir pierādīts, ka paaugstināts $M M P-9$ līmenis reducē rētaudu veidošanos, tad tiek secināts, ka pacientiem ar abpusēju šķeltni ir lielāka varbūtība, ka operācijas radītas gl̦otādas dzīšanas fāzes tiks negatīvi ietekmētas un brūce dzīs ar palielinātu rētaudu veidošanās risku. $M M P-2$ loma rētaudu veidošanās procesā joprojām ir neskaidra. Bērniem ar abpusēju šķeltni mīksto un cieto aukslēju audos tika konstatēta palielināta MMP-9 un TIMP-4 klātbūtne, bet MMP-2 un $M M P-8$ klātbūtne bija samazināta. Tika atrastas arī nozīmīgas korelācijas starp $M M P$ un TIMP pozitīvām šūnām kā epitēlijā, tā saistaudos. Identificētās korelācijas parāda $M M P$ un TIMP savstarpējo kompensatoro mijiedarbību, proti, ja ir traucēta viena faktora funkcija, tiek ietekmēta cita enzīma funkcionālā aktivitāte.

Kopumā smagākajam šḳeltnes veidam - abpusējai caurejošai lūpas, alveolārā izauguma un aukslēju šķeltnei - tika konstatēta samazināta transkripcijas faktora IRF6, MSXI un $P A X 9$, augšanas faktora $T G F \beta 3$ un VEGF klātbūtne, kā arī samazināta šūnu proliferācija un apoptoze mīkstajos audos, bet balstaudos samazināta $O P N, O P G, M M P-2, T I M P-2$, BMP2/4 un TGFß3 klātbūtne. Pārliecinoši identificējām, ka morfologiskās audu izmaiņas ir smagākas pacientiem ar abpusēju šķeltni. Atkārtotu operāciju laikā vieniem un tiem pašiem pacientiem darbā novērojām palielinātu MSX1, MMP-9, TIMP-4, TGFß3, Ki-67 un samazinātu $V E G F$ ekspresiju. 


\section{SECINĀJUMI}

1. Abpusēju lūpas, alveolārā izauguma un aukslēju škseltņu pacientu audos raksturīgās galvenokārt nespecifiskās pārmaiņas ir mutes dobuma gḷotādas epitēlija vakuolizācija un/vai bazālā slāņa šūnu hiperplāzija, epitēlija tīklveida izaugumu veidošanās, kā arī saistaudu fibroze un izteikta neovaskularizācija lamina propria, bet kaulaudos neregulārs osteonu izvietojums kaulā ar perēkḷıeida saistaudu proliferāciju.

2. Abpusēju caurejošu lūpas, alveolārā izauguma un aukslēju šķeltņu pacientu lūpas plastikas laikā iegūtajā materiālā ir izteikta deǵenerācijas enzīma $M M P-2$ klātbūtne un tā inhibitora TIMP-2 klātbūtne, kamēr vienpusēju škseltņu materiālā dominē $M M P-8$ un $M M P-9$, un TIMP-4 ekspresija. MMP-9 palielināta ekspresija liecina par pēcoperācijas audu dzī̌sanu bez nozīmīgi paliekošiem rētaudiem bērniem ar vienpusēju caurejošu šķeltni. Abpusējas caurejošas šķeltnes skartajos audos değenerācijas enzīma $M M P-8$ ekspresija samazinās un to inhibitora TIMP-4 ekspresija palielinās, pieaugot bērna vecumam.

3. Abpusēju caurejošu lūpas, alveolārā izauguma un aukslēju šķeltņu pacientiem mazā MSX1, IRF6 un PAX9 ekspresija mutes dobuma audos saistīta ar samazinātu šūnu proliferāciju, diferenciāciju, migrāciju, atjaunošanos, kā arī programmētās šūnu nāves kavēšanu, nosakot smagu šķeltnes veidu. Toties pieaugoša IRF6, PAX9 ekspresija nosaka šūnu migrācijas funkcionālo aktivitāti un šūnu proliferāciju, diferenciāciju šķeltnes skartajos mīksto un cieto aukslēju audos. Būtiskā statistiski ticama korelācija starp PAX9 un IRF6, kā arī starp PAX9 un MSX1, IRF6 un RYK ekspresiju mīkstajos audos norāda uz morfoǵenētisku savstarpējo gēnu ietekmi šķeltnes gadījumos.

4. Abpusēju caurejošu šķeltņu skartos mīkstos audus raksturo izteikti nabadzīga transformējošāa augšanas faktora beta-3 (TGFß3) klātbūtne, kas liecina par nepietiekošu šūnu migrāciju, proliferāciju, diferenciāciju un apoptozi smagākam šķeltnes veidam, kamēr kaulaudus raksturo statistiski izteiktāka š̄ faktora ekspresija, liecinot par kompensatoru blakus novietoto audu reakciju un faktora būtisku nozīmi noteikta šķeltņu veida patoǵenēzē.

5. Abpusēju šķeltņu skartos mīkstos audus raksturo samazināta vaskulārā endotēlija augšanas faktora $(V E G F)$ klātbūtne, kas norāda uz sākotnēju išēmijas trūkumu audos un, iespējams, saistīta ar izmainītu neovaskularizāciju un reepitelizāciju. Vienpusēju un abpusēju caurejošu lūpas, alveolārā izauguma un aukslēju šķeltņu skartos mīkstos audus raksturo izteikta $C D 34$ ekspresija, kas norāda uz paaugstinātu asinsvadu šūnu veidošanās lokālo potenciālu. 
6. Abpusējas caurejošas lūpas, alveolāra izauguma un aukslēju škseltnes gadījumā statistiski samazināta nestīna saturošo šūnu klātbūtne lūpas plastikas laikā iegūtajos audos pamato neirālas izcelsmes šūnu diferenciācijas ierobežošanu.

7. Apoptotisko šūnu relatīvā daudzuma samazināšanās abpusēju šķeltņu pacientiem liecina par mīksto audu remodelācijas mazināšanos smagākam škseltnes veidam.

8. Statistiski ticami kaula morfoǵenētiskā proteīna 2/4 (BMP2/4), transformējošā augšanas faktora beta-3 (TGFß3), matrices metaloproteināzes-2 (MMP-2), matrices metaloproteināzes-2 audu inhibitora (TIMP-2) saturošo struktūru relatīvā daudzuma samazināšanās abpusēju caurejošu lūpas, alveolarā izauguma un aukslēju šķeltņu pacientiem liecina par alveolārā kaula reǵenerācijas un remodelācijas procesu mazināšanos.

9. Statistiski ticama osteoprotegerīna $(O P G)$ un osteopontīna $(O P N)$ relatīvā daudzuma samazināšanās abpusēju alveolārā izauguma šķeltṇu pacientiem pierāda kaulaudu šūnu funkcionālās aktivitātes, vienlaikus šūnu proliferācijas potenciāla samazināšanos un kaula rezorbcijas palielināšanos smagākam šķeltnes veidam, bet uz praktiski neizmainītas mineralizācijas fona $(O C)$.

10. Abpusēju caurejošu lūpas, alveolārā izauguma un aukslēju šķeltņu audiem raksturīga pieaugoša MSX1, MMP-9, TIMP-4, TGFß3, Ki-67 un samazināta VEGF ekspresija ontoǵenēzēe, kas norāda uz šo faktoru dominējošo lomu šķeltnes skarto audu kompensatoro iespēju regulēšanā pēc atkārtotām operācijām.

11. Abpusēju škseltņu audus un īpaši, mīkstās aukslējas, raksturo samazināta neiropeptīdu saturošā inervācija. Šī īpatnība raksturo slimības smaguma pakāpi, kas tāda izveidojas, visticamāk, audu trūkuma dēḷ un arī nestīna saturošo neirālo priekšteču deficìta dēḷ. 


\section{LITERATŪRAS SARAKSTS}

1. About I., Laurent-Maquin D., Lendahl U., Mitsiadis T. A. Nestin expression in embryonic and adult human teeth under normal and pathological conditions. Am J Pathol. 2000; 157(1): $287-$ 295.

2. Accorsi-Mendonça T., Paiva K. B., Zambuzzi W. F., Cestari T. M., et al. Expression of matrix metalloproteinases-2 and -9 and RECK during alveolar bone regeneration in rat. J Mol Histol. 2008; 39(2): 201-208.

3. Ahmed S., Liu C. C., Nawshad A. Mechanisms of palatal epithelial seam disintegration by transforming growth factor (TGF) beta3. Dev Biol. 2007; 309(2): 193-207.

4. Alappat S., Zhang Z. Y., Chen Y. P. Msx homeobox gene family and craniofacial development. Cell Res. 2003; 13(6): 429-442.

5. Alarmo E. L., Huhtala H., Korhonen T., Pylkkänen L., et al. Bone morphogenetic protein 4 expression in multiple normal and tumor tissues reveals its importance beyond development. Mod Pathol. 2013; 26(1):10-21.

6. Ali A. A., Hussien N. F., Samy R. M., Husseiny K. A. Polymorphisms of Vascular Endothelial Growth Factor and Retinopathy of Prematurity. J Pediatr Ophthalmol Strabismus. 2015; 14: 1-10.

7. Amoh Y., Aki R., Hamada Y., Niiyama S., et al. Nestin-positive hair follicle pluripotent stem cells can promote regeneration of impinged peripheral nerve injury. J Dermatol. 2012; 39(1): 33-38.

8. Amoh Y., Li L., Katsuoka K., Hoffman R. M. Multipotent nestin-expressing hair follicle stem cells. J Dermatol. 2009; 36(1): 1-9.

9. Andisheh-Tadbir A., Hamzavi M., Rezvani G., Ashraf M. J., et al. Tissue expression, serum and salivary levels of vascular endothelial growth factor in patients with HNSCC. Braz J Otorhinolaryngol. 2014; 80(6): 503-507.

10. Anura A., Das R. K., Pal M., Paul R. R., et al. Correlated analysis of semi-quantitative immunohistochemical features of E-cadherin, VEGF and CD105 in assessing malignant potentiality of oral submucous fibrosis. Pathol Res Pract. 2014; 210(12): 1054-1063.

11. Aoki S., Honma M., Kariya Y., Nakamichi Y., et al. Function of OPG as a traffic regulator for RANKL is crucial for controlled osteoclastogenesis. J Bone Miner Res. 2010; 25(9): 19071921.

12. Apte S. S., Parks W. C. Metalloproteinases: A parade of functions in matrix biology and an outlook for the future. Matrix Biol. 2015; 44-46C:1-6.

13. Arosarena O. A. Cleft lip and palate. Otolaryngol Clin North Am. 2007; 40(1): 27-60.

14. Arpino V., Brock M., Gill S. E. The role of TIMPs in regulation of extracellular matrix proteolysis. Matrix Biol. 2015; 44-46C: 247-254.

15. Arya R., White K.. Cell death in development: Signaling pathways and core mechanisms. Semin Cell Dev Biol. 2015; 39: 12-19.

16. Baek J. A., Lan Y., Liu H., Maltby K. M., et al. Bmpr1a signaling plays critical roles in palatal shelf growth and palatal bone formation. Dev Biol. 2011; 350(2): 520-531.

17. Bajaj A. K., Wongworawat A. A., Punjabi A. Management of alveolar clefts. J Craniofac Surg. 2003; 14(6): 840-6.

18. Baroni T., Carinci P., Bellucci C., Lilli C., et al. Cross-talk between interleukin-6 and transforming growth factor-beta3 regulates extracellular matrix production by human fibroblasts from subjects with non-syndromic cleft lip and palate. J Periodontol. 2003; 74(10): 1447-1453.

19. Baud'huin M., Duplomb L., Teletchea S., Lamoureux F., et al. Osteoprotegerin: multiple partners for multiple functions. Cytokine Growth Factor Rev. 2013; 24(5): 401-409.

20. Beaty T. H., Murray J. C., Marazita M. L., Munger R. G., et al., A genome-wide association study of cleft lip with and without cleft palate identifies risk variants near MAFB and ABCA4. Nat Genet. 2010; 42(6): 525-529. 
21. Ben J., Jabs E. W., Chong S. S. Genomic, cDNA and embryonic expression analysis of zebrafish IRF6, the gene mutated in the human oral clefting disorders Van der Woude and popliteal pterygium syndromes. Gene Expr Patterns. 2005; 5(5): 629-638.

22. Berdal A., Molla M., Hotton D., Aïoub M., et al. Differential impact of MSX1 and MSX2 homeogenes on mouse maxillofacial skeleton. Cells Tissues Organs. 2009; 189(1-4): 126132.

23. Berndt J. D., Aoyagi A., Yang P., Anastas J. N., et al. Mindbomb 1, an E3 ubiquitin ligase, forms a complex with RYK to activate Wnt/ $\beta$-catenin signaling. J Cell Biol. 2011; 194(5): 737-750.

24. Birnbaum S., Ludwig K. U., Reutter H., Herms S., et al. IRF6 gene variants in Central European patients with non-syndromic cleft lip with or without cleft palate. Eur J Oral Sci. 2009; 117(6): 766-769.

25. Blackburn J., Ohazama A., Kawasaki K., Otsuka-Tanaka Y., et al. The role of Irf6 in tooth epithelial invagination. Dev Biol. 2012; 365(1): 61-70.

26. Blaha K., Borsky J., Kasparova M., Steklacova A., et al. Concentrations of MMP-9 and TIMP-1 in lip tissue and their impact on cleft lip surgery healing. Biomed Pap Med Fac Univ Palacky Olomouc Czech Repub. 2013; 157(4): 363-366.

27. Blavier L., Lazaryev A., Groffen J., Heisterkamp N., et al. TGF-beta3-induced palatogenesis requires matrix metalloproteinases. Mol Biol Cell. 2001; 12(5): 1457-1466.

28. Bodo M., Baroni T., Carinci F., Becchetti E., et al. TGFbeta isoforms and decorin gene expression are modified in fibroblasts obtained from non-syndromic cleft lip and palate subjects. J Dent Res. 1999; 78(12): 1783-1790.

29. Bonilla-Claudio M., Wang J., Bai Y., Klysik E., et al. Bmp signaling regulates a dosedependent transcriptional program to control facial skeletal development. Development. 2012; 139(4): 709-719.

30. Boulais N., Misery L. The epidermis: a sensory tissue. Eur J Dermatol. 2008; 18(2): 119-127.

31. Bouletreau P. J., Steinbrech D., Spector J. A., Warren S. M., et al. Gene expression of transforming growth factor-beta 3 and tissue inhibitor of metalloproteinase type 1 during membranous bone healing in rats. J Craniofac Surg. 2000; 11(6): 521-526.

32. Bragdon B., Moseychuk O., Saldanha S., King D., et al. Bone morphogenetic proteins: a critical review. Cell Signal. 2011; 23(4): 609-620.

33. Brown G. D., Nazarali A. J. Matrix metalloproteinase- 25 has a functional role in mouse secondary palate development and is a downstream target of TGF- $\beta 3$. BMC Dev Biol. 2010; 10: 93.

34. Brown N. L., Yarram S. J., Mansell J. P., Sandy J. R. Matrix metalloproteinases have a role in palatogenesis. J Dent Res. 2002; 81(12): 826-830.

35. Brunetti G., Oranger A., Mori G., Tamma R., et al. TRAIL is involved in human osteoclast apoptosis. Ann N Y Acad Sci. 2007; 1116: 316-322.

36. Buckley J. J., Jessen J. R. Matrix metalloproteinase function in non-mammalian model organisms. Front Biosci (Schol Ed). 2015; 7: 168-183.

37. Burdi A. R. Cleft lip and palate, 2nd ed. Berlin: Springer-Verlag, 2006, , 3. - 12. pp.

38. Bush J. O., Jiang R. Palatogenesis: morphogenetic and molecular mechanisms of secondary palate development. Development. 2012; 139(2): 231-243.

39. Cano A., Pérez-Moreno M. A., Rodrigo I., Locascio A., et al. The transcription factor snail controls epithelial-mesenchymal transitions by repressing E-cadherin expression. Nat Cell Biol. 2000; 2(2): 76-83.

40. Cantatore F. P., Crivellato E., Nico B., Ribatti D. Osteocalcin is angiogenic in vivo. Cell Biol Int. $2005 ; 29(7): 583-585$.

41. Cardoso M. L., Bezerra J. F., Oliveira G. H., Soares C. D., et al. MSX1 gene polymorphisms in non-syndromic cleft lip and/or palate. Oral Dis. 2013; 19(5): 507-512.

42. Carter T. C., Molloy A. M., Pangilinan F., Troendle J. F., et al. Testing reported associations of genetic risk factors for oral clefts in a large Irish study population. Birth Defects Res A Clin Mol Teratol. 2010; 88(2): 84-93. 
43. Chai Y., Maxson R. E. Jr. Recent advances in craniofacial morphogenesis. Dev Dyn. 2006; 235(9): 2353-2375.

44. Chamoux E., Houde N., L'Eriger K., Roux S. Osteoprotegerin decreases human osteoclast apoptosis by inhibiting the TRAIL pathway. J Cell Physiol. 2008; 216(2): 536-542.

45. Che N., Li Y., Liu S., Pan W., et al. Investigation on association between five common polymorphisms in vascular endothelial growth factor and prototypes of autoimmune diseases. Immunobiology. 2015; 220(6): 722-733.

46. Chen D., Zhao M., Mundy G. R. Bone morphogenetic proteins. Growth Factors. 2004; 22(4): 233-241.

47. Chen G., Deng C., Li Y. P. TGF- $\beta$ and BMP signaling in osteoblast differentiation and bone formation. Int J Biol Sci. 2012; 8(2): 272-288.

48. Chen H. L., Yuh C. H., Wu K. K. Nestin is essential for zebrafish brain and eye development through control of progenitor cell apoptosis. PLoS One. 2010; 5(2): e9318.

49. Chen Q., Wang H., Schwender H., Zhang T., et al. Joint testing of genotypic and geneenvironment interaction identified novel association for BMP4 with non-syndromic CL/P in an Asian population using data from an International Cleft Consortium. PLoS One. 2014; 9(10): e109038.

50. Chen W., Fu X., Ge S., Sun T., et al. Differential expression of matrix metalloproteinases and tissue-derived inhibitors of metalloproteinase in fetal and adult skins. Int J Biochem Cell Biol. 2007; 39(5): 997-1005.

51. Chi N., Epstein J. A. Getting your Pax straight: Pax proteins in development and disease. Trends Genet. 2002; 18(1): 41-47.

52. Chiquet B. T., Blanton S. H., Burt A., Ma D., et al. Variation in WNT genes is associated with non-syndromic cleft lip with or without cleft palate. Hum Mol Genet. 2008; 17(14): 22122218.

53. Choi S. J., Marazita M. L., Hart P. S., Sulima P. P., et al. The PDGF-C regulatory region SNP rs28999109 decreases promoter transcriptional activity and is associated with CL/P. Eur J Hum Genet. 2009; 17(6): 774-784.

54. Cuervo R., Covarrubias L. Death is the major fate of medial edge epithelial cells and the cause of basal lamina degradation during palatogenesis. Development. 2004; 131(1): 15-24.

55. Dai J., Mou Z., Shen S., Dong Y., et al. Bioinformatic analysis of Msx1 and Msx2 involved in craniofacial development. J Craniofac Surg. 2014; 25(1): 129-134.

56. Dang C. M., Beanes S. R., Lee H., Zhang X., et al. Scarless fetal wounds are associated with an increased matrix metalloproteinase-to-tissue-derived inhibitor of metalloproteinase ratio. Plast Reconstr Surg. 2003; 111(7): 2273-2285.

57. Day I. N., Thompson R. J. UCHL1 (PGP 9.5): neuronal biomarker and ubiquitin system protein. Prog Neurobiol. 2010; 90(3): 327-362.

58. De Coster P. J., Mortier G., Marks L. A., Martens L. C. Cranial suture biology and dental development: genetic and clinical perspectives. J Oral Pathol Med. 2007; 36(8): 447-455.

59. de Oliveira Demarchi A. C., Zambuzzi W. F., Paiva K. B., da Silva-Valenzuela Md., et al. Development of secondary palate requires strict regulation of ECM remodeling: sequential distribution of RECK, MMP-2, MMP-3, and MMP-9. Cell Tissue Res. 2010; 340(1): 61-69.

60. Deary I. J., Bell P. J., Bell A. J., Campbell M. L., et al. Sensory discrimination and intelligence: testing Spearman's other hypothesis. Am J Psychol. 2004; 117(1): 1-18.

61. Del Barrio M. G., Nieto M. A. Relative expression of Slug, RhoB, and HNK-1 in the cranial neural crest of the early chicken embryo. Dev Dyn. 2004; 229(1): 136-139.

62. Desai R. S., Mamatha G. S., Khatri M. J., Shetty S. J. Immunohistochemical expression of CD34 for characterization and quantification of mucosal vasculature and its probable role in malignant transformation of atrophic epithelium in oral submucous fibrosis. Oral Oncol. 2010; 46(7): 553-558.

63. Dixon M. J., Marazita M. L., Beaty T. H., Murray J. C. Cleft lip and palate: understanding genetic and environmental influences. Nat Rev Genet. 2011; 12(3): 167-178. 
64. Dong R., Liu X., Fan M., Yang L., et al. Isolation and differentiation of nestin positive cells from rat oral mucosal lamina propria. Differentiation. 2010; 79(1): 9-14.

65. Dougherty M., Kamel G., Grimaldi M., Gfrerer L., et al. Distinct requirements for wnt9a and irf6 in extension and integration mechanisms during zebrafish palate morphogenesis. Development. 2013; 140(1): 76-81.

66. Ducy P., Desbois C., Boyce B., Pinero G., et al. Increased bone formation in osteocalcindeficient mice. Nature. 1996; 382(6590): 448-452.

67. Dudas M., Li W. Y., Kim J., Yang A., et al. Palatal fusion - where do the midline cells go? A review on cleft palate, a major human birth defect. Acta Histochem. 2007; 109(1): 1-14.

68. Dunn M. D., Park C. H., Kostenuik P. J., Kapila S., et al. Local delivery of osteoprotegerin inhibits mechanically mediated bone modeling in orthodontic tooth movement. Bone. 2007; 41(3): 446-455.

69. Duvall C. L., Weiss D., Robinson S. T., Alameddine F. M., et al. The role of osteopontin in recovery from hind limb ischemia. Arterioscler Thromb Vasc Biol. 2008; 28(2): 290-295.

70. Eger A., Stockinger A., Schaffhauser B., Beug H., et al. Epithelial mesenchymal transition by c-Fos estrogen receptor activation involves nuclear translocation of beta-catenin and upregulation of beta-catenin/lymphoid enhancer binding factor-1 transcriptional activity. J Cell Biol. 2000; 148(1): 173-188.

71. Elmore S. Apoptosis: a review of programmed cell death. Toxicol Pathol. 2007; 35(4): 495516.

72. Farronato G., Kairyte L., Giannini L., Galbiati G., et al. How various surgical protocols of the unilateral cleft lip and palate influence the facial growth and possible orthodontic problems? Which is the best timing of lip, palate and alveolus repair? literature review. Stomatologija. 2014; 16(2): 53-60.

73. Ferrara N., Gerber H. P., LeCouter J. The biology of VEGF and its receptors. Nat Med. 2003; 9(6): 669-676.

74. Ferron M., Lacombe J. Regulation of energy metabolism by the skeleton: osteocalcin and beyond. Arch Biochem Biophys. 2014; 561: 137-146.

75. Finnerty J. R., Mazza M. E., Jezewski P. A. Domain duplication, divergence, and loss events in vertebrate Msx paralogs reveal phylogenomically informed disease markers. BMC Evol Biol. 2009; 9: 18.

76. Fleming J. A., Song G., Choi Y., Spencer T. E., et al. Interferon regulatory factor 6 (IRF6) is expressed in the ovine uterus and functions as a transcriptional activator. Mol Cell Endocrinol. 2009; 299(2): 252-260.

77. Foster B. L., Ao M., Willoughby C., Soenjaya Y., et al. Mineralization defects in cementum and craniofacial bone from loss of bone sialoprotein. Bone. 2015; 78: 150-164.

78. François-Fiquet C., Poli-Merol M. L., Nguyen P., Landais E., et al. Role of angiogenesisrelated genes in cleft lip/palate: review of the literature. Int J Pediatr Otorhinolaryngol. 2014; 78(10): 1579-1585.

79. Freitas J. A., Garib D. G., Trindade-Suedam I. K., Carvalho R. M., et al. Rehabilitative treatment of cleft lip and palate: experience of the Hospital for Rehabilitation of Craniofacial Anomalies-USP (HRAC-USP)--part 3: oral and maxillofacial surgery. J Appl Oral Sci. 2012; 20(6): 673-679.

80. Gaffney J., Solomonov I., Zehorai E., Sagi I. Multilevel regulation of matrix metalloproteinases in tissue homeostasis indicates their molecular specificity in vivo. Matrix Biol. 2015; 44-46C: 191-199.

81. Galloway J. L., Jones S. J., Mossey P. A., Ellis I. R. The control and importance of hyaluronan synthase expression in palatogenesis. Front Physiol. 2013; 4: 10.

82. Gawronska-Kozak B. Scarless skin wound healing in FOXN1 deficient (nude) mice is associated with distinctive matrix metalloproteinase expression. Matrix Biol. 2011; 30(4): 290-300.

83. Genç B., Lagrimas A. K., Kuru P., Hess R., et al. Visualization of Sensory Neurons and Their Projections in an Upper Motor Neuron Reporter Line. PLoS One. 2015; 10(7): e0132815. 
84. Giambernardi T. A., Sakaguchi A. Y., Gluhak J., Pavlin D., et al. Neutrophil collagenase (MMP-8) is expressed during early development in neural crest cells as well as in adult melanoma cells. Matrix Biol. 2001; 20(8): 577-587.

85. Girardi A., Martinelli M., Cura F., Palmieri A., et al. RFC1 and non-syndromic cleft lip with or without cleft palate: an association based study in Italy. J Craniomaxillofac Surg. 2014; 42(7): 1503-1505.

86. Gong S. G., Guo C. Bmp4 gene is expressed at the putative site of fusion in the midfacial region. Differentiation. 2003; 71(3): 228-236.

87. Gonzalez D. M., Medici D. Signaling mechanisms of the epithelial-mesenchymal transition. Sci Signal. 2014; 7(344): re8.

88. Graham A., Begbie J., McGonnell I. Significance of the cranial neural crest. Dev Dyn. 2004; 229(1): 5-13.

89. Grzibovskis M., Urtane I., Pilmane M. Specific signaling molecule expression in periodontal ligaments in different age groups: pilot study. Stomatologija. 2011; 13(4): 117-122.

90. Gurramkonda V. B., Hussain Syed A., Murthy J., Lakkakula B. V. Evidence of the involvement of the polymorphisms near MSX1 gene in non-syndromic cleft lip with or without cleft palate. Int J Pediatr Otorhinolaryngol. 2015; 79(7): 1081-1084.

91. Haigh J. J., Gerber H. P., Ferrara N., Wagner E. F. Conditional inactivation of VEGF-A in areas of collagen2a1 expression results in embryonic lethality in the heterozygous state. Development. 2000; 127(7): 1445-1453.

92. Halford M. M., Armes J., Buchert M., Meskenaite V., et al. Ryk-deficient mice exhibit craniofacial defects associated with perturbed Eph receptor crosstalk. Nat Genet. 2000; 25(4): 414-418.

93. Halford M. M., Macheda M. L., Parish C. L., Takano E. A., et al. A fully human inhibitory monoclonal antibody to the Wnt receptor RYK. PLoS One. 2013; 8(9): e75447.

94. Halford M. M., Stacker S. A. Revelations of the RYK receptor. Bioessays. 2001; 23(1): 3445.

95. Hankins H. M., Baldridge R. D., Xu P., Graham T. R. Role of flippases, scramblases and transfer proteins in phosphatidylserine subcellular distribution. Traffic. 2015; 16(1): 35-47.

96. Herford A. S., Boyne P. J., Rawson R., Williams R. P. Bone morphogenetic protein-induced repair of the premaxillary cleft. J Oral Maxillofac Surg. 2007; 65(11): 2136-2141.

97. Hilliges M., Hellman M., Ahlström U., Johansson O. Immunohistochemical studies of neurochemical markers in normal human buccal mucosa. Histochemistry. 1994; 101(4): 235 244.

98. Hirata A., Katayama K., Tsuji T., Natsume N., et al. Heparanase localization during palatogenesis in mice. Biomed Res Int. 2013; 2013: 760236.

99. Holladay S. D., Sharova L. V., Punareewattana K., Hrubec T. C., et al. Maternal immune stimulation in mice decreases fetal malformations caused by teratogens. Int Immunopharmacol. 2002; 2(2-3): 325-332.

100. Hosokawa R., Nonaka K., Morifuji M., Shum L., et al. TGF-beta 3 decreases type I collagen and scarring after labioplasty. J Dent Res. 2003; 82(7): 558-564.

101. Hsu S. M., Raine L., Fanger H. The use of antiavidin antibody and avidin-biotin-peroxidase complex in immunoperoxidase technics. Am J Clin Pathol. 1981; 75(6): 816-821.

102. Hu L., Liu J., Li Z., Ozturk F., et al. TGF $\beta 3$ regulates periderm removal through $\triangle N p 63$ in the developing palate. J Cell Physiol. 2015; 230(6): 1212-1225.

103. Hwang S. J., Beaty T. H., McIntosh I., Hefferon T., et al. Association between homeoboxcontaining gene MSX1 and the occurrence of limb deficiency. Am J Med Genet. 1998; 75(4): 419-423.

104. Ibarra-Arce A., García-Álvarez M., Cortés-González D., Ortiz de Zarate-Alarcón G., et al. IRF6 polymorphisms in Mexican patients with non-syndromic cleft lip. Meta Gene. 2015; 4: $8-16$. 
105. Ingraham C. R., Kinoshita A., Kondo S., Yang B., et al. Abnormal skin, limb and craniofacial morphogenesis in mice deficient for interferon regulatory factor 6 (Irf6). Nat Genet. 2006; 38(11): 1335-1340.

106. Iseki S.. Disintegration of the medial epithelial seam: is cell death important in palatogenesis? Dev Growth Differ. 2011; 53(2): 259-268.

107. Iwata J., Hacia J. G., Suzuki A., Sanchez-Lara P. A., et al. Modulation of noncanonical TGF- $\beta$ signaling prevents cleft palate in Tgfbr2 mutant mice. J Clin Invest. 2012; 122(3): 873-885.

108. Iwata J., Suzuki A., Yokota T., Ho T. V., et al. TGF $\beta$ regulates epithelial-mesenchymal interactions through WNT signaling activity to control muscle development in the soft palate. Development. 2014; 141(4): 909-917.

109. Iwata J., Tung L., Urata M., Hacia J. G., et al. Fibroblast growth factor 9 (FGF9)-pituitary homeobox 2 (PITX2) pathway mediates transforming growth factor $\beta$ (TGF $\beta$ ) signaling to regulate cell proliferation in palatal mesenchyme during mouse palatogenesis. J Biol Chem. 2012; 287(4): 2353-2363.

110. Jakobsen L. P., Borup R., Vestergaard J., Larsen L. A., et al. Expression analyses of human cleft palate tissue suggest a role for osteopontin and immune related factors in palatal development. Exp Mol Med. 2009; 41(2): 77-85.

111. Jalali A., Zhu X., Liu C., Nawshad A. Induction of palate epithelial mesenchymal transition by transforming growth factor $\beta 3$ signaling. Dev Growth Differ. 2012; 54(6): 633-648.

112. Jang W. G., Kim E. J., Kim D. K., Ryoo H. M., et al. BMP2 protein regulates osteocalcin expression via Runx2-mediated Atf6 gene transcription. J Biol Chem. 2012; 287(2): 905-915.

113. Jaskoll T., Zhou Y. M., Chai Y., Makarenkova H. P., et al. Embryonic submandibular gland morphogenesis: stage-specific protein localization of FGFs, BMPs, Pax6 and Pax9 in normal mice and abnormal SMG phenotypes in FgfR2-IIIc(+/Delta), BMP7(-/-) and Pax6(-/-) mice. Cells Tissues Organs. 2002; 170(2-3): 83-98.

114. Jezewski P. A., Vieira A. R., Nishimura C., Ludwig B., et al. Complete sequencing shows a role for MSX1 in non-syndromic cleft lip and palate. J Med Genet. 2003; 40(6): 399-407.

115. Jiang R., Bush J. O., Lidral A. C. Development of the upper lip: morphogenetic and molecular mechanisms. Dev Dyn. 2006; 235(5): 1152-1166.

116. Jones K. B., Klein O. D. Oral epithelial stem cells in tissue maintenance and disease: the first steps in a long journey. Int J Oral Sci. 2013; 5(3): 121-129.

117. Jonker L., Kist R., Aw A., Wappler I., et al. Pax9 is required for filiform papilla development and suppresses skin-specific differentiation of the mammalian tongue epithelium. Mech Dev. 2004; 121(11): 1313-1322.

118. Jono S., Peinado C., Giachelli C. M. Phosphorylation of osteopontin is required for inhibition of vascular smooth muscle cell calcification. J Biol Chem. 2000; 275(26): 20197-20203.

119. Jugessur A., Farlie P. G., Kilpatrick N. The genetics of isolated orofacial clefts: from genotypes to subphenotypes. Oral Dis. 2009; 15(7): 437-453.

120. Kalibović Govorko D., Bečić T., Vukojević K., Mardešić-Brakus S., et al. Spatial and temporal distribution of Ki-67 proliferation marker, Bcl-2 and Bax proteins in the developing human tooth. Arch Oral Biol. 2010; 55(12): 1007-1016.

121. Kang P., Svoboda K. K. Epithelial-mesenchymal transformation during craniofacial development. J Dent Res. 2005; 84(8): 678-690.

122. Kang Y., Massagué J. Epithelial-mesenchymal transitions: twist in development and metastasis. Cell. 2004; 118(3): 277-279.

123. Kato J., Uddman R., Sundler F., Kurisu K. Immunohistochemical study of the innervation of the boundary area of the hard and soft palates of the rat. Acta Anat (Basel). 1998; 163(2): $92-$ 98.

124. Ke C. Y., Xiao W. L., Chen C. M., Lo L. J., et al. IRF6 is the mediator of TGF 33 during regulation of the epithelial mesenchymal transition and palatal fusion. Sci Rep. 2015; 5: 12791.

125. Keeble T. R., Cooper H. M. Ryk: a novel Wnt receptor regulating axon pathfinding. Int J Biochem Cell Biol. 2006; 38(12): 2011-2017. 
126. Keeble T. R., Halford M. M., Seaman C., Kee N., et al. The Wnt receptor Ryk is required for Wnt5a-mediated axon guidance on the contralateral side of the corpus callosum. J Neurosci. 2006; 26(21): 5840-5848.

127. Kempa I., Ambrozaitytė L., Stavusis J., Akota I., et al. Association of BMP4 polymorphisms with non-syndromic cleft lip with or without cleft palate and isolated cleft palate in Latvian and Lithuanian populations. Stomatologija. 2014; 16(3): 94-101.

128. Kerameddin S., Namipashaki A., Ebrahimi S., Ansari-Pour N. IRF6 Is a Marker of Severity in Nonsyndromic Cleft Lip/Palate. J Dent Res. 2015; 94(9 Suppl): 226S-232S.

129. Keswani S. G., Balaji S., Le L. D., Leung A., et al. Role of salivary vascular endothelial growth factor (VEGF) in palatal mucosal wound healing. Wound Repair Regen. 2013; 21(4): 554-562.

130. Kim K. H., Sederstrom J. M. Assaying Cell Cycle Status Using Flow Cytometry. Curr Protoc Mol Biol. 2015; 111: 28.6.1-28.6.11.

131. Kim N. Y., Kim Y. H., Park J. W., Baek S-H. Association between MSX1 SNPs and nonsyndromic cleft lip with or without cleft palate in the Korean population. J Korean Med Sci 2013; 28(4): 522-526.

132. Kist R., Greally E., Peters H. Derivation of a mouse model for conditional inactivation of Pax9. Genesis. 2007; 45(7): 460-464.

133. Kohama K., Nonaka K., Hosokawa R., Shum L., et al. TGF-beta-3 promotes scarless repair of cleft lip in mouse fetuses. J Dent Res. 2002; 81(10): 688-694.

134. Koide M., Kobayashi Y., Ninomiya T., Nakamura M., et al. Osteoprotegerin-deficient male mice as a model for severe alveolar bone loss: comparison with RANKL-overexpressing transgenic male mice. Endocrinology. 2013; 154(2): 773-782.

135. Kondo S., Schutte B. C., Richardson R. J., Bjork B. C., et al. Mutations in IRF6 cause Van der Woude and popliteal pterygium syndromes. Nat Genet. 2002; 32(2): 285-289.

136. Korpi J. T., Aström P., Lehtonen N., Tjäderhane L., et al. Healing of extraction sockets in collagenase-2 (matrix metalloproteinase-8)-deficient mice. Eur J Oral Sci. 2009; 117(3): 248254.

137. Korpi J. T., Kervinen V., Mäklin H., Väänänen A., et al. Collagenase-2 (matrix metalloproteinase-8) plays a protective role in tongue cancer. Br J Cancer. 2008; 98(4): 766775 .

138. Koskivirta I., Kassiri Z., Rahkonen O., Kiviranta R., et al. Mice with tissue inhibitor of metalloproteinases 4 (Timp4) deletion succumb to induced myocardial infarction but not to cardiac pressure overload. J Biol Chem. 2010; 285(32): 24487-24493.

139. Kouskoura T., Kozlova A., Alexiou M., Blumer S., et al. The etiology of cleft palate formation in BMP7-deficient mice. PLoS One. 2013;8(3):e59463.

140. Kramer F. J., Meyer M., Morgan D., Forssmann W. G., et al. Tissue inhibitor of metalloproteinases II (TIMP-2) is an osteoanabolic factor in vitro and in vivo. Eur J Med Res. 2008; 13(6): 292-298.

141. Krasone K., Lāce B., Akota I., Care R., et al. IRF6 AP-2a binding site promoter polymorphism is associated with oral clefts in Latvia. Stomatologija. 2014; 16(4): 132-136.

142. Krivicka B., Pilmane M., Akota I. Expression of growth factors and growth factor receptors in human cleft-affected tissue. Stomatologija. 2013; 15(4): 111-118.

143. Krivicka-Uzkurele B., Pilmane M., Akota I. Barx1, growth factors and apoptosis in facial tissue of children with clefts. Stomatologija. 2008; 10(2): 62-66.

144. Ku K. T., Wan L., Peng H. C., Tsai M. H., et al. Vascular endothelial growth factor gene-460 C/T polymorphism is a biomarker for oral cancer. Oral Oncol. 2005; 41(5): 497-502.

145. Kubota T., Itagaki M., Hoshino C., Nagata M., et al. Altered gene expression levels of matrix metalloproteinases and their inhibitors in periodontitis-affected gingival tissue. J Periodontol. 2008; 79(1): 166-173.

146. Küchler E. C., Sabóia T. M., Vieira T. C., Lips A., et al. Studies of genes involved in craniofacial development and tumorigenesis: FGF3 contributes to isolated oral clefts and may interact with PAX9. Acta Odontol Scand. 2014; 72(8): 1070-1078. 
147. Kwak I. S., Choi Y. H., Jang Y. C., Lee Y. K. Immunohistochemical analysis of neuropeptides (protein gene product 9.5, substance $\mathrm{P}$ and calcitonin gene-related peptide) in hypertrophic burn scar with pain and itching. Burns. 2014; 40(8): 1661-1667.

148. Lallemand Y., Bensoussan V., Cloment C. S., Robert B. Msx genes are important apoptosis effectors downstream of the Shh/Gli3 pathway in the limb. Dev Biol. 2009; 331(2): 189-198.

149. Lallemand Y., Nicola M. A., Ramos C., Bach A., et al. Analysis of Msx1; Msx2 double mutants reveals multiple roles for Msx genes in limb development. Development. 2005; 132(13): 3003-3014.

150. Lamouille S., Subramanyam D., Blelloch R., Derynck R. Regulation of epithelialmesenchymal and mesenchymal-epithelial transitions by microRNAs. Curr Opin Cell Biol. 2013; 25(2): 200-207.

151. Lamouille S., Xu J., Derynck R. Molecular mechanisms of epithelial-mesenchymal transition. Nat Rev Mol Cell Biol. 2014; 15(3): 178-196.

152. Lane J., Kaartinen V. Signaling networks in palate development. Wiley Interdiscip Rev Syst Biol Med. 2014; 6(3): 271-278.

153. Lane J., Yumoto K., Azhar M., Ninomiya-Tsuji J., et al. Tak1, Smad4 and Trim33 redundantly mediate TGF- $\beta 3$ signaling during palate development. Dev Biol. 2015; 398(2): 231-241.

154. Lao M., Marino V., Bartold PM. Immunohistochemical study of bone sialoprotein and osteopontin in healthy and diseased root surfaces. J Periodontol. 2006; 77(10): 1665-1673.

155. Larrabee Y. C., Birkeland A. C., Kent D. T., Flores C., et al. Association of common variants, not rare mutations, in IRF6 with nonsyndromic clefts in a Honduran population. Laryngoscope. 2011; 121(8): 1756-1759.

156. Lee J. K., Park J. W., Kim Y. H., Baek S. H. Association between PAX9 single-nucleotide polymorphisms and nonsyndromic cleft lip with or without cleft palate. J Craniofac Surg. 2012; 23(5): 1262-1266.

157. Lee J. M., Kim J. Y., Cho K. W., Lee M. J., et al. Wnt11/Fgfr1b cross-talk modulates the fate of cells in palate development. Dev Biol. 2008; 314(2): 341-350.

158. Lehman J. A. Jr., Douglas B. K., Ho W. C., Husami T. W. One-stage closure of the entire primary palate. Plast Reconstr Surg. 1990; 86(4): 675-681.

159. Leslie E. J., Taub M. A., Liu H., Steinberg K. M., et al. Identification of functional variants for cleft lip with or without cleft palate in or near PAX7, FGFR2, and NOG by targeted sequencing of GWAS loci. Am J Hum Genet. 2015; 96(3): 397-411.

160. Letra A., Bjork B., Cooper M. E., Szabo-Rogers H., et al. Association of AXIN2 with nonsyndromic oral clefts in multiple populations. J Dent Res. 2012; 91(5): 473-478.

161. Letra A., da Silva R. A., Menezes R., de Souza A. P., et al. Studies with MMP9 gene promoter polymorphism and nonsyndromic cleft lip and palate. Am J Med Genet A. 2007; 143A(1): 8991.

162. Letra A., Fakhouri W., Fonseca R. F., Menezes R., et al. Interaction between IRF6 and TGFA genes contribute to the risk of nonsyndromic cleft lip/palate. PLoS One. 2012; 7(9): e45441.

163. Letra A., Maili L., Mulliken J. B., Buchanan E., et al. Further evidence suggesting a role for variation in ARHGAP29 variants in nonsyndromic cleft lip/palate. Birth Defects Res A Clin Mol Teratol. 2014; 100(9): 679-685.

164. Letra A., Silva R. A., Menezes R., Astolfi C. M., et al. MMP gene polymorphisms as contributors for cleft lip/palate: association with MMP3 but not MMP1. Arch Oral Biol. 2007; 52(10): 954-960.

165. Letra A., Silva R. M., Motta L. G., Blanton S. H., et al. Association of MMP3 and TIMP2 promoter polymorphisms with nonsyndromic oral clefts. Birth Defects Res A Clin Mol Teratol. 2012; 94(7): 540-548.

166. Letra A., Zhao M., Silva R. M., Vieira A. R., et al. Functional Significance of MMP3 and TIMP2 Polymorphisms in Cleft Lip/Palate. J Dent Res. 2014; 93(7): 651-656. 
167. Levi G., Mantero S., Barbieri O., Cantatore D., et al. Msx1 and Dlx5 act independently in development of craniofacial skeleton, but converge on the regulation of Bmp signaling in palate formation. Mech Dev. 2006; 123(1): 3-16.

168. Li Q., Kim Y., Suktitipat B., Hetmanski J. B., et al. Gene-Gene Interaction Among WNT Genes for Oral Cleft in Trios. Genet Epidemiol. 2015; 39(5): 385-394.

169. Li W., Lu Z. F., Man X. Y., Li C. M., et al. VEGF upregulates VEGF receptor-2 on human outer root sheath cells and stimulates proliferation through ERK pathway. Mol Biol Rep. 2012; 39(9): 8687-8694.

170. Lillie R. D., Pizzolato P., Donaldson P. T. Hematoxylin substitutes: a survey of mordant dyes tested and consideration of the relation of their structure to performance as nuclear stains. Stain Technol. 1976; 51(1): 25-41.

171. Liu F., Zhang C., Hoffman R. M. Nestin-expressing stem cells from the hair follicle can differentiate into motor neurons and reduce muscle atrophy after transplantation to injured nerves. Tissue Eng Part A. 2014; 20(3-4): 656-662.

172. Liu J., Ji X., Li Z., Zheng H., et al. Nestin overexpression promotes the embryonic development of heart and brain through the regulation of cell proliferation. Brain Res. 2015; 1610: $1-11$.

173. Liu W., Sun X., Braut A., Mishina Y., et al. Distinct functions for Bmp signaling in lip and palate fusion in mice. Development. 2005; 132(6): 1453-1461.

174. Liu Y., Xu J., Fu W., Weng Z., et al. Tissues Expression, Polymorphisms of IFN Regulatory Factor 6 (IRF6) Gene and Their Associated with Immune Traits in Three Pig Populations. Asian-Australas J Anim Sci. 2012; 25(2): 163-169.

175. Loeffler M., Roeder I. Tissue stem cells: definition, plasticity, heterogeneity, self-organization and models--a conceptual approach. Cells Tissues Organs. 2002; 171(1): 8-26.

176. Loeys B. L., Chen J., Neptune E. R., Judge D. P., et al. A syndrome of altered cardiovascular, craniofacial, neurocognitive and skeletal development caused by mutations in TGFBR1 or TGFBR2. Nat Genet. 2005; 37(3): 275-281.

177. Logan C. Y., Nusse R. The Wnt signaling pathway in development and disease. Annu Rev Cell Dev Biol. 2004; 20: 781-810.

178. Lopes M., Goupille O., Saint Cloment C., Robert B. Msx1 is expressed in retina endothelial cells at artery branching sites. Biol Open. 2012; 1(4): 376-384.

179. Lotz K., Proff P., Bienengraeber V., Fanghaenel J., et al. Apoptosis as a creative agent of embryonic development of bucca, mentum and nasolacrimal duct. An in vivo study in rats. J Craniomaxillofac Surg. 2006; 34(2): 8-13.

180. Lu P., Takai K., Weaver V. M., Werb Z. Extracellular matrix degradation and remodeling in development and disease. Cold Spring Harb Perspect Biol. 2011; 3(12).

181. Lu X. C., Yu W., Tao Y., Zhao P. L., et al. Contribution of transforming growth factor $\alpha$ polymorphisms to nonsyndromic orofacial clefts: a HuGE review and meta-analysis. Am $\mathbf{J}$ Epidemiol. 2014; 179(3): 267-281.

182. Ma L., Xu M., Li D., Han Y., et al. A miRNA-binding-site SNP of MSX1 is Associated with NSOC Susceptibility. J Dent Res. 2014; 93(6): 559-564.

183. Macheda M. L., Sun W. W., Kugathasan K., Hogan B. M., et al. The Wnt receptor Ryk plays a role in mammalian planar cell polarity signaling. J Biol Chem. 2012; 287(35): 29312-29323.

184. Maclean G., Dollé P., Petkovich M. Genetic disruption of CYP26B1 severely affects development of neural crest derived head structures, but does not compromise hindbrain patterning. Dev Dyn. 2009; 238(3): 732-745.

185. Malik S., Kakar N., Hasnain S., Ahmad J., et al. Epidemiology of Van der Woude syndrome from mutational analyses in affected patients from Pakistan. Clin Genet. 2010; 78(3): 247256.

186. Man X. Y., Yang X. H., Cai S. Q., Yao Y. G., et al. Immunolocalization and expression of vascular endothelial growth factor receptors (VEGFRs) and neuropilins (NRPs) on keratinocytes in human epidermis. Mol Med. 2006; 12(7-8): 127-136. 
187. Mankarious L. A., Goudy S. L. Craniofacial and upper airway development. Paediatr Respir Rev. 2010; 11(4): 193-198.

188. Manuel J. A., Gawronska-Kozak B. Matrix metalloproteinase 9 (MMP-9) is upregulated during scarless wound healing in athymic nude mice. Matrix Biol. 2006; 25(8): 505-514.

189. Martínez-Alvarez C., Tudela C., Pérez-Miguelsanz J., O'Kane S., et al. Medial edge epithelial cell fate during palatal fusion. Dev Biol. 2000; 220(2): 343-357.

190. Mehrotra D. Genomic expression in non syndromic cleft lip and palate patients: A review. J Oral Biol Craniofac Res. 2015; 5(2): 86-91.

191. Meijome T. E., Hooker R. A., Cheng Y. H., Walker W., et al. GATA-1 deficiency rescues trabecular but not cortical bone in OPG deficient mice. J Cell Physiol. 2015; 230(4): 783-790.

192. Menezes R., Letra A., Kim A. H., Küchler E. C., et al. Studies with Wnt genes and nonsyndromic cleft lip and palate. Birth Defects Res A Clin Mol Teratol. 2010; 88(11): 9951000 .

193. Meng L., Bian Z., Torensma R., Von den Hoff J. W. Biological mechanisms in palatogenesis and cleft palate. J Dent Res. 2009; 88(1): 22-33.

194. Mii S., Amoh Y., Katsuoka K., Hoffman R. M. Comparison of nestin-expressing multipotent stem cells in the tongue fungiform papilla and vibrissa hair follicle. J Cell Biochem. 2014; 115(6): 1070-1076.

195. Mijiti A., Ling W., Guli, Moming A. Association of single-nucleotide polymorphisms in the IRF6 gene with non-syndromic cleft lip with or without cleft palate in the Xinjiang Uyghur population. Br J Oral Maxillofac Surg. 2015; 53(3): 268-274.

196. Millard D. R. Jr. Rotation-advancement principle in cleft lip closure. Cleft Palate J. 1964; 12: 246-252.

197. Miller S. F., Weinberg S. M., Nidey N. L., Defay D. K., et al. Exploratory genotypephenotype correlations of facial form and asymmetry in unaffected relatives of children with non-syndromic cleft lip and/or palate. J Anat. 2014; 224(6): 688-709.

198. Miragliotta V., Pirone A., Donadio E., Abramo F., et al. Osteopontin expression in healing wounds of horses and in human keloids. Equine Vet J. 2016; 48(1): 72-77.

199. Mitsui C., Iwanaga T., Yoshida S., Kawasaki T. Immunohistochemical demonstration of nerve terminals in the whole hard palate of rats by use of an antiserum against protein gene product 9.5 (PGP 9.5). Arch Histol Cytol. 2000; 63(5): 401-410.

200. Mohammad R. M., Muqbil I., Lowe L., Yedjou C., et al. Broad targeting of resistance to apoptosis in cancer.Semin Cancer Biol. 2015; 35: S78-103.

201. Mohan R., Chintala S. K., Jung J. C., Villar W. V., et al. Matrix metalloproteinase gelatinase B (MMP-9) coordinates and effects epithelial regeneration. J Biol Chem. 2002; 277(3): 20652072.

202. Morris-Wiman J., Burch H., Basco E. Temporospatial distribution of matrix metalloproteinase and tissue inhibitors of matrix metalloproteinases during murine secondary palate morphogenesis. Anat Embryol (Berl). 2000; 202(2): 129-141.

203. Morris-Wiman J., Burch H., Basco E. Temporospatial distribution of matrix metalloproteinase and tissue inhibitors of matrix metalloproteinases during murine secondary palate morphogenesis. Anat Embryol (Berl). 2000; 202(2): 129-141.

204. Mossey P. A., Little J., Munger R. G., Dixon M. J., et al. Cleft lip and palate. Lancet. 2009; 374(9703): 1773-1785.

205. Mostowska A., Hozyasz K. K., Biedziak B., Wojcicki P., et al. Genotype and haplotype analysis of WNT genes in non-syndromic cleft lip with or without cleft palate. Eur J Oral Sci. 2012; 120(1): $1-8$.

206. Mostowska A., Hozyasz K. K., Wojcicki P., Biedziak B., et al. Association between genetic variants of reported candidate genes or regions and risk of cleft lip with or without cleft palate in the polish population. Birth Defects Res A Clin Mol Teratol. 2010; 88(7): 538-545.

207. Mukhopadhyay P., Greene R. M., Zacharias W., Weinrich M. C., et al. Developmental gene expression profiling of mammalian, fetal orofacial tissue. Birth Defects Res A Clin Mol Teratol. 2004; 70(12): 912-926. 
208. Muraoka N., Shum L., Fukumoto S., Nomura T., et al. Transforming growth factor-beta3 promotes mesenchymal cell proliferation and angiogenesis mediated by the enhancement of cyclin D1, Flk-1, and CD31 gene expression during CL/Fr mouse lip fusion. Birth Defects Res A Clin Mol Teratol. 2005; 73(12): 956-965.

209. Murshed M., Schinke T., McKee M. D., Karsenty G. Extracellular matrix mineralization is regulated locally; different roles of two gla-containing proteins. J Cell Biol. 2004; 165(5): 625-630.

210. Musiał K., Bargenda A., Zwolińska D. Urine matrix metalloproteinases and their extracellular inducer EMMPRIN in children with chronic kidney disease. Ren Fail. 2015; 37(6): 980-984.

211. Nagase H., Visse R., Murphy G. Structure and function of matrix metalloproteinases and TIMPs. Cardiovasc Res. 2006; 69(3): 562-573.

212. Nagel S., Rohr F., Weber C., Kier J., et al. Multipotent nestin-positive stem cells reside in the stroma of human eccrine and apocrine sweat glands and can be propagated robustly in vitro. PLoS One. 2013; 8(10): e78365.

213. Nakajima A., Ito Y., Tanaka E., Sano R., et al. Functional role of TGF- $\beta$ receptors during palatal fusion in vitro. Arch Oral Biol. 2014; 59(11): 1192-1204.

214. Nakasone N., Kubota T., Hoshino C., Nohno K., et al. Differential gene and protein expression of tissue inhibitors of metalloproteinases (TIMP)-3 and TIMP-4 in gingival tissues from drug induced gingival overgrowth. Arch Oral Biol. 2009; 54(7): 634-641.

215. Nakatomi M., Wang X. P., Key D., Lund J. J., et al. Genetic interactions between Pax9 and Msx1 regulate lip development and several stages of tooth morphogenesis. Dev Biol. 2010; 340(2): 438-449.

216. Nassif A., Senussi I., Meary F., Loiodice S., et al. Msx1 role in craniofacial bone morphogenesis. Bone. 2014; 66: 96-104.

217. Nawshad A. Palatal seam disintegration: to die or not to die? that is no longer the question. Dev Dyn. 2008; 237(10): 2643-2656.

218. Nie X., Luukko K., Kettunen P. BMP signalling in craniofacial development. Int J Dev Biol. 2006; 50(6): 511-521.

219. Nikopensius T., Kempa I., Ambrozaitytė L., Jagomägi T., et al. Variation in FGF1, FOXE1, and TIMP2 genes is associated with nonsyndromic cleft lip with or without cleft palate. Birth Defects Res A Clin Mol Teratol. 2011; 91(4): 218-225.

220. Nouri N., Memarzadeh M., Carinci F., Cura F., et al. Family-based association analysis between nonsyndromic cleft lip with or without cleft palate and IRF6 polymorphism in an Iranian population. Clin Oral Investig. 2015; 19(4): 891-894.

221. Novakovic J., Mardesic-Brakus S., Vukojevic K., Saraga-Babic M. Developmental patterns of Ki-67, bcl-2 and caspase-3 proteins expression in the human upper jaw. Acta Histochem. 2011; 113(5): 519-526.

222. Nyman J. S., Lynch C. C., Perrien D. S., Thiolloy S., et al. Differential effects between the loss of MMP-2 and MMP-9 on structural and tissue-level properties of bone. J Bone Miner Res. 2011; 26(6): 1252-1260.

223. Ohno S., Hirano S., Kanemaru S., Tateya I., et al.Prevention of buccal mucosa scarring with transforming growth factor $\beta 3$. Laryngoscope. 2011; 121(7): 1404-1409.

224. Ouyang L., Shi Z., Zhao S., Wang F. T., et al. Programmed cell death pathways in cancer: a review of apoptosis, autophagy and programmed necrosis. Cell Prolif. 2012; 45(6): 487-498.

225. Paiva K. B., Granjeiro J. M. Bone tissue remodeling and development: focus on matrix metalloproteinase functions. Arch Biochem Biophys. 2014; 561: 74-87.

226. Pandiar D., Shameena P. Immunohistochemical expression of CD34 and basic fibroblast growth factor (bFGF) in oral submucous fibrosis. J Oral Maxillofac Pathol. 2014; 18(2): 155161.

227. Patyna S., Haznedar J., Morris D., Freshwater K., et al. Evaluation of the safety and pharmacokinetics of the multi-targeted receptor tyrosine kinase inhibitor sunitinib during embryo-fetal development in rats and rabbits. Birth Defects Res B Dev Reprod Toxicol. 2009; 86(3): 204-213. 
228. Pianka A., Knösel T., Probst F. A., Troeltzsch M., et al. Vascular endothelial growth factor receptor isoforms: are they present in oral squamous cell carcinoma? J Oral Maxillofac Surg. 2015; 73(5): 897-904.

229. Pilmane M., Rumba I., Sundler F., Luts A. Patterns of distribution and occurrence of neuroendocrine elements in lungs of humans with chronic lung disease. Proc Latv Acad Sci. 1998; 52: 144-152.

230. Poniatowski Ł. A., Wojdasiewicz P., Gasik R., Szukiewicz D. Transforming growth factor Beta family: insight into the role of growth factors in regulation of fracture healing biology and potential clinical applications. Mediators Inflamm. 2015; 2015: 137823.

231. Puente X. S., Sánchez L. M., Overall C. M., López-Otín C. Human and mouse proteases: a comparative genomic approach. Nat Rev Genet. 2003; 4(7): 544-558.

232. Rafiqdoost Z., Rafiqdoost A., Rafiqdoost H., Hashemi M., et al. Investigation of FGF1 and FGFR gene polymorphisms in a group of Iranian patients with nonsyndromic cleft lip with or without cleft palate. Int J Pediatr Otorhinolaryngol. 2014; 78(5): 731-736.

233. Ravanti L., Kähäri V. M. Matrix metalloproteinases in wound repair (review). Int J Mol Med. 2000; 6(4): 391-407.

234. Ray H. J., Niswander L. Mechanisms of tissue fusion during development. Development. 2012; 139(10): 1701-1711.

235. Reutter H., Birnbaum S., Mende M., Lauster C., et al. TGFB3 displays parent-of-origin effects among central Europeans with nonsyndromic cleft lip and palate. J Hum Genet. 2008; 53(7): 656-661.

236. Richardson R. J., Dixon J., Malhotra S., Hardman M. J., et al. Irf6 is a key determinant of the keratinocyte proliferation-differentiation switch. Nat Genet. 2006; 38(11): 1329-1334.

237. Rieger A. M., Nelson K. L., Konowalchuk J. D., Barreda D. R. Modified annexin V/propidium iodide apoptosis assay for accurate assessment of cell death. J Vis Exp. 2011; (50). pii: 2597.

238. Riley B. M., Murray J. C. Sequence evaluation of FGF and FGFR gene conserved non-coding elements in non-syndromic cleft lip and palate cases. Am J Med Genet A. 2007; 143A(24): $3228-3234$.

239. Rittling S. R., Matsumoto H. N., McKee M. D., Nanci A., et al. Mice lacking osteopontin show normal development and bone structure but display altered osteoclast formation in vitro. J Bone Miner Res. 1998; 13(7): 1101-1111.

240. Robin N. H., Baty H., Franklin J., Guyton F. C., et al. The multidisciplinary evaluation and management of cleft lip and palate. South Med J. 2006; 99(10): 1111-1120.

241. Rocha C. A., Cestari T. M., Vidotti H. A., de Assis G. F., et al. Sintered anorganic bone graft increases autocrine expression of VEGF, MMP-2 and MMP-9 during repair of critical-size bone defects. J Mol Histol. 2014; 45(4): 447-461.

242. Rodrigues Luvizuto E., Mônica Dias S., Chiantelli Cláudio-Coutinho C., Alves Machado L., et al. Temporal localization of osteocalcin protein during healing of tooth extraction sockets in rats. Minerva Stomatol. 2010; 59(6): 355-361.

243. Rohani M. G., Parks W. C. Matrix remodeling by MMPs during wound repair. Matrix Biol. 2015; 44-46C: 113-121.

244. Roy H., Bhardwaj S., Babu M., Kokina I., et al. VEGF-A, VEGF-D, VEGF receptor-1, VEGF receptor-2, NF-kappaB, and RAGE in atherosclerotic lesions of diabetic Watanabe heritable hyperlipidemic rabbits. FASEB J. 2006; 20(12): 2159-2161.

245. Rullo R., Gombos F., Ferraraccio F., Farina A., et al. TGFbeta3 expression in non-syndromic orofacial clefts. Int J Pediatr Otorhinolaryngol. 2006; 70(10): 1759-1764.

246. Sabet M. N., Rakhshan A., Erfani E., Madjd Z. Co-expression of putative cancer stem cell markers, CD133 and Nestin, in skin tumors. Asian Pac J Cancer Prev. 2014; 15(19): 81618169.

247. Saleem S., Rajendran R., Moinak B., Anna J., et al. Evidence for transforming growth factorbeta 3 gene polymorphism in non-syndromic cleft lip and palate patients from Indian subcontinent. Med Oral Patol Oral Cir Bucal. 2012; 17(2): e197-200. 
248. Sasaki Y., O'Kane S., Dixon J., Dixon M. J., et al. Temporal and spatial expression of Pax9 and Sonic hedgehog during development of normal mouse palates and cleft palates in TGFbeta3 null embryos. Arch Oral Biol. 2007; 52(3): 260-267.

249. Satokata I., Ma L., Ohshima H., Bei M., et al. Msx2 deficiency in mice causes pleiotropic defects in bone growth and ectodermal organ formation. Nat Genet. 2000; 24(4): 391-395.

250. Sekiguchi S., Yoshikawa Y., Tanaka S., Kwon J., et al. Immunohistochemical analysis of protein gene product 9.5, a ubiquitin carboxyl-terminal hydrolase, during placental and embryonic development in the mouse. Exp Anim. 2003; 52(4): 365-369.

251. Serrano M. J., Liu J., Svoboda K. K., Nawshad A., et al. Ephrin reverse signaling mediates palatal fusion and epithelial-to-mesenchymal transition independently of TgfB3. J Cell Physiol. 2015; 230(12): 2961-2972.

252. Shi J., Song T., Jiao X., Qin C., et al. Single-nucleotide polymorphisms (SNPs) of the IRF6 and TFAP2A in non-syndromic cleft lip with or without cleft palate (NSCLP) in a northern Chinese population. Biochem Biophys Res Commun. 2011; 410(4): 732-736.

253. Shi J., Zhang X., Zhu J., Pi Y., et al. Nanoparticle delivery of the bone morphogenetic protein 4 gene to adipose-derived stem cells promotes articular cartilage repair in vitro and in vivo. Arthroscopy. 2013; 29(12): 2001-2011.e2.

254. Shiba H., Uchida Y., Kamihagi K., Sakata M., et al. Transforming growth factor-beta1 and basic fibroblast growth factor modulate osteocalcin and osteonectin/SPARC syntheses in vitamin-D-activated pulp cells. J Dent Res. 2001; 80(7): 1653-1659.

255. Shimokawa T., Yi S., Tanaka S. Nerve supply to the soft palate muscles with special reference to the distribution of the lesser palatine nerve. Cleft Palate Craniofac J. 2005; 42(5): 495-500.

256. Shin J. O., Nakagawa E., Kim E. J., Cho K. W., et al. miR-200b regulates cell migration via Zeb family during mouse palate development. Histochem Cell Biol. 2012; 137(4): 459-470.

257. Shiozaki Y., Kitajima T., Mazaki T., Yoshida A., et al. Enhanced in vivo osteogenesis by nanocarrier-fused bone morphogenetic protein-4. Int J Nanomedicine. 2013; 8: 1349-1360.

258. Shuler C. F. Programmed cell death and cell transformation in craniofacial development. Crit Rev Oral Biol Med. 1995; 6(3): 202-217.

259. Silva T. A., Rosa A. L., Lara V. S. Dentin matrix proteins and soluble factors: intrinsic regulatory signals for healing and resorption of dental and periodontal tissues? Oral Dis. 2004; 10(2): 63-74.

260. Singh D., Srivastava S. K., Chaudhuri T. K., Upadhyay G. Multifaceted role of matrix metalloproteinases (MMPs). Front Mol Biosci. 2015; 2: 19.

261. Smane L., Pilmane M., Akota I. Apoptosis and MMP-2, TIMP-2 expression in cleft lip and palate. Stomatologija. 2013; 15(4): 129-134.

262. Sodek J., Batista Da Silva A. P., Zohar R. Osteopontin and mucosal protection. J Dent Res. 2006; 85(5): 404-415.

263. Sodek J., Ganss B., McKee M. D. Osteopontin. Crit Rev Oral Biol Med. 2000; 11(3): 279303.

264. Sodek J., McKee M. D. Molecular and cellular biology of alveolar bone. Periodontol 2000. 2000; 24: 99-126.

265. Sohn W. J., Ji Y. R., Kim H. S., Gwon G. J., et al. Rgs19 regulates mouse palatal fusion by modulating cell proliferation and apoptosis in the MEE. Mech Dev. 2012; 129(9-12): 244254.

266. Song T., Wu D., Wang Y., Li H., et al. SNPs and interaction analyses of IRF6, MSX1 and PAX9 genes in patients with non-syndromic cleft lip with or without palate. Mol Med Rep. 2013; 8(4): 1228-1234.

267. Souza L. T., Kowalski T. W., Collares M. V., Félix T. M. MSX1 gene and nonsyndromic oral clefts in a Southern Brazilian population. Braz J Med Biol Res. 2013; 46(7): 555-558.

268. Stalmans I. Role of the vascular endothelial growth factor isoforms in retinal angiogenesis and DiGeorge syndrome. Verh K Acad Geneeskd Belg. 2005; 67(4): 229-276.

269. Stalmans I., Lambrechts D., De Smet F., Jansen S., et al. VEGF: a modifier of the del22q11 (DiGeorge) syndrome? Nat Med. 2003; 9(2): 173-182. 
270. Standal T., Borset M., Sundan A. Role of osteopontin in adhesion, migration, cell survival and bone remodeling. Exp Oncol. 2004; 26(3): 179-184.

271. Stănescu R., Didilescu A. C., Jianu A. M., Rusu M. C. Angiogenesis in the reparatory mucosa of the mandibular edentulous ridge is driven by endothelial tip cells. Rom J Morphol Embryol. 2012; 53(2): 375-378.

272. Stanier P., Pauws E. Development of the lip and palate: FGF signalling. Front Oral Biol. 2012; 16: 71-80.

273. Stefanini M., De Martino C., Zamboni L. Fixation of ejaculated spermatozoa for electron microscopy. Nature. 1967; 216(5111): 173-174.

274. Suazo J., Santos J. L., Scapoli L., Jara L., et al. Association between TGFB3 and nonsyndromic cleft lip with or without cleft palate in a Chilean population. Cleft Palate Craniofac J. 2010; 47(5): 513-517.

275. Sun D., Baur S., Hay E. D. Epithelial-mesenchymal transformation is the mechanism for fusion of the craniofacial primordia involved in morphogenesis of the chicken lip. Dev Biol. 2000; 228(2): 337-349.

276. Sun D., Vanderburg C. R., Odierna G. S., Hay E. D. TGFbeta3 promotes transformation of chicken palate medial edge epithelium to mesenchyme in vitro. Development. 1998; 125(1): 95-105.

277. Suzuki T., Bessho K., Segami N., Iizuka T., et al. Immunohistochemical localization of bone morphogenetic protein-2 in the oral and maxillofacial area of the human embryo. Br J Oral Maxillofac Surg. 2001; 39(4): 289-293.

278. Takahara S., Takigawa T., Shiota K. Programmed cell death is not a necessary prerequisite for fusion of the fetal mouse palate. Int. J. Dev. Biol. 2004; 48: 39-46.

279. Tang H., Mattheos N., Yao Y., Jia Y., et al. In vivo osteoprotegerin gene therapy preventing bone loss induced by periodontitis. J Periodontal Res. 2015; 50(4): 434-443.

280. Tang M., Wang Y., Han S., Guo S., et al. Transforming growth factor-beta3 gene polymorphisms and nonsyndromic cleft lip and palate risk: a meta-analysis. Genet Test Mol Biomarkers. 2013; 17(12): 881-889.

281. Teng X., Hardwick J. M. Cell death in genome evolution. Semin Cell Dev Biol. 2015; 39: 311.

282. Thiery J. P., Acloque H., Huang R. Y., Nieto M. A. Epithelial-mesenchymal transitions in development and disease. Cell. 2009; 139(5): 871-890.

283. Tian M., Schiemann W. P. The TGF-beta paradox in human cancer: an update. Future Oncol. 2009; 5(2): 259-271.

284. Tian Y., Li J. L., Hao L., Yue Y., et al. Association of cytokines, high sensitive C-reactive protein, VEGF and beta-defensin-1 gene polymorphisms and their protein expressions with chronic periodontitis in the Chinese population. Int J Biol Markers. 2013; 28(1): 100-107.

285. Torrecillas-Martínez L., Galindo-Moreno P., Ávila-Ortiz G., Ortega-Oller I., et al. Significance of the Immunohistochemical Expression of Bone Morphogenetic Protein-4 in Bone Maturation after Maxillary Sinus Grafting in Humans. Clin Implant Dent Relat Res. 2015; May 12. [Epub ahead of print].

286. Tower J. Programmed cell death in aging. Ageing Res Rev. 2015; 23(Pt A): 90-100.

287. Udagawa N., Takahashi N., Yasuda H., Mizuno A., et al. Osteoprotegerin produced by osteoblasts is an important regulator in osteoclast development and function. Endocrinology. 2000; 141(9): 3478-3484.

288. Van Lint P., Libert C. Matrix metalloproteinase-8: cleavage can be decisive. Cytokine Growth Factor Rev. 2006; 17(4): 217-223.

289. Verstappen J., Von den Hoff J. W. Tissue inhibitors of metalloproteinases (TIMPs): their biological functions and involvement in oral disease. J Dent Res. 2006; 85(12): 1074-1084.

290. Vieira A. R., Orioli I. M., Castilla E. E., Cooper M. E., et al. MSX1 and TGFB3 contribute to clefting in South America. J Dent Res. 2003; 82(4): 289-292.

291. Vo T. N., Kasper F. K., Mikos A. G. Strategies for controlled delivery of growth factors and cells for bone regeneration. Adv Drug Deliv Rev. 2012; 64(12): 1292-1309. 
292. Vukojevic K., Kero D., Novakovic J., Kalibovic Govorko D., et al. Cell proliferation and apoptosis in the fusion of human primary and secondary palates. Eur J Oral Sci. 2012; 120(4): 283-291.

293. Wang R. N., Green J., Wang Z., Deng Y., et al. Bone Morphogenetic Protein (BMP) signaling in development and human diseases. Genes Dis. 2014; 1(1): 87-105.

294. Wang Z., Juttermann R., Soloway P. D. TIMP-2 is required for efficient activation of proMMP-2 in vivo. J Biol Chem. 2000; 275(34): 26411-26415.

295. Washbourne B. J., Cox T. C. Expression profiles of cIRF6, cLHX6 and cLHX7 in the facial primordia suggest specific roles during primary palatogenesis. BMC Dev Biol. 2006; 6: 18.

296. Watanabe A., Akita S., Tin N. T., Natsume N., et al. A mutation in RYK is a genetic factor for nonsyndromic cleft lip and palate. Cleft Palate Craniofac J. 2006; 43(3): 310-316.

297. Watanabe I. S., Dias F. J., Mardegan Issa J. P., dos Santos Haemmerle C. A., et al. Immunohistochemistry and ultrastructural characteristics of nerve endings in the oral mucosa of rat. Microscopy (Oxf). 2013; 62(2): 259-270.

298. Webber D. M., MacLeod S. L., Bamshad M. J., Shaw G. M., et al. Developments in our understanding of the genetic basis of birth defects. Birth Defects Res A Clin Mol Teratol. 2015; 103(8): 680-689.

299. Wiese C., Rolletschek A., Kania G., Blyszczuk P., et al. Nestin expression--a property of multi-lineage progenitor cells? Cell Mol Life Sci. 2004; 61(19-20): 2510-2522.

300. Woo E. J. Adverse events after recombinant human BMP2 in nonspinal orthopaedic procedures. Clin Orthop Relat Res. 2013; 471(5): 1707-1711.

301. Xu X., Han J., Ito Y., Bringas P. Jr., et al. Cell autonomous requirement for Tgfbr2 in the disappearance of medial edge epithelium during palatal fusion. Dev Biol. 2006; 297(1): 238248.

302. Yagi H., Furutani Y., Hamada H., Sasaki T., et al. Role of TBX1 in human del22q11.2 syndrome. Lancet. 2003; 362(9393): 1366-1373.

303. Yanai H., Sato Y., Nagatsuka H., Yoshino T. Nestin is a wide-spectrum abluminal cell marker of salivary gland tumors. Pathol Int. 2013; 63(10): 496-501.

304. Yang J., Mani S. A., Donaher J. L., Ramaswamy S., et al. Twist, a master regulator of morphogenesis, plays an essential role in tumor metastasis. Cell. 2004; 117(7):927-939.

305. Yang Y., Jiang G., Zhang P., Fan J. Programmed cell death and its role in inflammation. Mil Med Res. 2015; 2: 12.

306. Yu F., Chou C. W., Chen C. C. TNF-alpha suppressed TGF-beta-induced CTGF expression by switching the binding preference of p300 from Smad4 to p65. Cell Signal. 2009 Jun; 21(6): 867-872.

307. Yumoto K., Thomas P. S., Lane J., Matsuzaki K., et al. TGF- $\beta$-activated kinase 1 (Tak1) mediates agonist-induced Smad activation and linker region phosphorylation in embryonic craniofacial neural crest-derived cells. J Biol Chem. 2013; 288(19): 13467-13480.

308. Zarella B. L., Cardoso C. A., Pelá V. T., Kato M. T., et al. The role of matrix metalloproteinases and cysteine-cathepsins on the progression of dentine erosion. Arch Oral Biol. 2015; 60(9): 1340-1345.

309. Zauli G., Rimondi E., Nicolin V., Melloni E., et al. TNF-related apoptosis-inducing ligand (TRAIL) blocks osteoclastic differentiation induced by RANKL plus M-CSF. Blood. 2004; 104(7): 2044-2050.

310. Zawiślak A., Woźniak K., Jakubowska A., Lubiński J., et al. Polymorphic variants in VAX1 gene (rs7078160) and BMP4 gene (rs762642) and the risk of non-syndromic orofacial clefts in the Polish population. Dev Period Med. 2014; 18(1): 16-22.

311. Zcharia E., Jia J., Zhang X., Baraz L., et al. Newly generated heparanase knock-out mice unravel co-regulation of heparanase and matrix metalloproteinases. PLoS One. 2009; 4(4): e5181.

312. Zeng W., Wang X., Xu P., Liu G., et al. Molecular imaging of apoptosis: from micro to macro. Theranostics. 2015; 5(6): 559-582. 
313. Zhang B., Henney A., Eriksson P., Hamsten A., et al. Genetic variation at the matrix metalloproteinase-9 locus on chromosome 20q12.2-13.1. Hum Genet. 1999; 105(5): 418-423.

314. Zhang J., Zhao Y. G., Cao Y. J., Sang Q. X., et al. Expression and implications of tissue inhibitor of metalloproteinases-4 in mouse embryo. Mol Hum Reprod. 2003; 9(3): 143-149.

315. Zhang X., Chen X., Hong Q., Lin H., et al. TIMP-1 promotes age-related renal fibrosis through upregulating ICAM-1 in human TIMP-1 transgenic mice. J Gerontol A Biol Sci Med Sci. 2006; 61(11): 1130-1143.

316. Zhou J., Gao Y., Lan Y., Jia S., et al. Pax9 regulates a molecular network involving Bmp4, Fgf10, Shh signaling and the Osr2 transcription factor to control palate morphogenesis. Development. 2013; 140(23): 4709-4718.

317. Zhou J., Gao Y., Zhang Z., Zhang Y., et al. Osr2 acts downstream of Pax9 and interacts with both Msx1 and Pax9 to pattern the tooth developmental field. Dev Biol. 2011; 353(2): 344353.

318. Zhu X., Ozturk F., Pandey S., Guda C. B., et al. Implications of TGF $\beta$ on Transcriptome and Cellular Biofunctions of Palatal Mesenchyme. Front Physiol. 2012; 3: 85.

\section{Latviešu valodā}

1. Akota I., Barkāne B., Grasmane N. Iedzimto sejas šķeltņu biežuma rādītāji Latvijā no 1960. līdz 1997. gadam. // AML/RSU Zinātniskie raksti 2000. - Rīga: AML/RSU, 2001, 166.-170. lpp.

2. Pilmane M., Šūmahers G. H. Medicīniskā embriolog̣ija. Rīga: Rīgas Stradiṇa universitāte, 2006, 164.-172. lpp.

3. Teibe U. Biologískā statistika. Rīga: LU Akadēmiskais apgāds, 2007, 49.-58. lpp. 


\section{PUBLIKĀCIJAS UN PREZENTĀCIJAS PAR PĒTĪJUMA TĒMU}

\section{Zinātniskie raksti (5)}

1. Smane L., Pilmane M., Akota I. Local expression of inflammatory cytokines in the facial tissue of children with a cleft lip and palate. Papers on Anthropology XXI. 2012: 264-275.

2. Smane L., Pilmane M., Akota I. Apoptosis and MMP-2, TIMP-2 expression in cleft lip and palate. Stomatologija. 2013; 15(4): 129-134.

3. Smane L., Pilmane M. IRF6, RYK, and PAX9 expression in facial tissue of children with cleft palate. Int. J. Morphol. 2015; 33(2): 647-652.

4. Smane L., Pilmane M. Osteopontin, osteocalcin, and osteoprotegerin expression in human cleft lip and palate affected tissue. SHS Web of Conferences 30. 2016: 1-9. doi: $10.1051 /$ shsconf/20163000008.

5. Smane-Filipova L., Pilmane M., Akota I. MMPs and TIMPs expression in facial tissue of children with cleft lip and palate - pieñemts publicēšanai Biomed Pap Med Fac Univ Palacky Olomouc Czech Repub. 2016; 160: XX.

\section{Tēzes un prezentācijas starptautiskās konferencēs (13)}

1. Smane L., Pilmane M., Akota I. "Local expression of inflammatory cytokines in facial tissue of children with clefts lip and palate", 11. Joint Symposium der Universitäten Riga und Rostock tēzes, Rostoka 2012, publicēts simpozija mājaslapā. (Mutisks ziṇojums).

2. Smane L., Pilmane M., Akota I. "Immunohistochemical detection of growth factors, protein gene product 9.5 (PGP 9.5) in cleft lip and palate”, 7. Baltijas Morfologijas konferences tēzes, Rīga 2013, Tēžu grāmata 51. lpp. (Stenda referāts).

3. Smane L., Pilmane M., Akota I. "Analysis of apoptosis and expression of specific signaling proteins in facial tissue of children with clefts lip and palate”, 21st International Conference on Oral and Maxillofacial Surgery tēzes, Barselona 2013, Tēžu grāmata 183. lpp. (Stenda referāts).

4. Smane L., Pilmane M., Akota I. "IRF6, RYK and PAX9 role in facial tissue of children with clefts", 18th Congress of the International Federation of Associations of Anatomists tēzes, Beidžinga 2013, Annals of Anatomy 2014; 196(S1): 86. (Stenda referāts). 
5. Smane L., Pilmane M., Akota I. "Immunohistochemical analysis of nestin, CD34 and TGF $\beta 3$ in cleft lip and palate", XXIV European Congress of Perinatal Medicine tēzes, Florence 2014, J Matern Fetal Neonatal Med. 2014; 27(1): 275. (Stenda referāts).

6. Pilmane M., Smane L., Akota I. "Degeneration and remodelation potential in hyaline cartilage and bone of complete cleft lip palate affected facial tissue in children", International Conference REDEOR tēzes, Venēcija 2015. (Stenda referāts).

7. Smane L., Pilmane M., Akota I. "Expression of transcription factors MSX1 and PAX9 in a group of Latvian patients with complete unilateral and bilateral cleft lip and palate", Baltic Paediatric Congress tēzes, Rīga 2015, Tēžu grāmata 70. lpp. (Stenda referāts).

8. Smane L., Pilmane M., Akota I. "Association of gene proteins with cleft lip and palate in the Latvian population", 2nd World Congress on Controversies in Pediatrics tēzes, Budapešta 2015, Tēžu grāmata 64. 1pp. (Stenda referāts).

9. Smane L., Pilmane M., Akota I. "Osteopontin, osteocalcin, osteoprotegerin expression in facial tissue of children with cleft lip and palate", 5th International Interdisciplinary Scientific Conference "SOCIETY. HEALTH. WELFARE" tēzes, Rīga 2015, Tēžu grāmata 68. lpp. (Stenda referāts).

10. Smane L., Pilmane M., Akota I. "Expression of non-collagenous proteins in facial tissue of children with cleft lip and palate" Experimental Biology tēzes, Bostona 2015, FASEB J. 2015; 29: 765.2. (Stenda referāts).

11. Smane L., Pilmane M., Akota I. "Patterns of MMP-2, TIMP-2, BMP2/4, and TGF $\beta 3$ expression in alveolar bone tissue of children with orofacial clefts" 8. Baltijas Morfologijas konferences tēzes, Viḷna 2015, Tēžu grāmata 65. lpp. (Mutisks ziņojums).

12. Smane-Filipova L., Pilmane M. "Functional morphology of tissues in children with complete bilateral cleft lip and palate" 6th International Congress of UENPS tēzes, Valensija 2016. (Stenda referāts).

13. Smane-Filipova L., Pilmane M., Akota I. "Evaluation of VEGF and CD34 protein expression in facial tissue of children with cleft" 6th International Interdisciplinary Scientific Conference "SOCIETY. HEALTH. WELFARE" tēzes, Rīga 2016. (Stenda referāts).

\section{Tēzes un prezentācijas vietēja mēroga konferencēs Latvijā (7)}

1. Smane L., Pilmane M., Akota I. "Iekaisuma signālmolekulu izpēte bērniem ar lūpu un aukslēju šķeltnēm”, Rīgas Stradiņa universitātes 2012. gada Zinātniskā konference. Tēzes, 316. lpp. (Stenda referāts). 
2. Smane L., Pilmane M., Akota I. "Cilmes šūnu marķieru CD34 un nestīna izvērtējums bērniem ar abpusējām lūpas un aukslēju šķeltnēm”, Latvijas Ārstu 7. kongress, tēzes publicētas kongresa mājaslapā:

http://www.arstukongress.lv/?\&s=1361881321\&fu=read\&id=16 (Stenda referāts).

3. Smane L., Pilmane M., Akota I. "Audu faktoru un šūnu apoptozes izvērtējums bērniem ar abpusējām lūpas un aukslēju šķeltnēm”, Rīgas Stradiṇa universitātes 2013. gada Zinātniskā konference. Tēzes, 290. lpp. (Stenda referāts).

4. Smane L., Pilmane M., Akota I. "Matrices metaloproteināžu un to inhibitoru izvērtējums lūpas šķeltnes zonas audos”, Rīgas Stradiņa universitātes 2014. gada Zinātniskā konference. Tēzes, 332. lpp. (Stenda referāts).

5. Smane L., Pilmane M. "MSX1, IRF6 un PAX9 izvērtējums bērniem ar abpusējām lūpas un aukslēju škseltnēm”, Bērnu klīniskās universitātes slimnīcas 2014. gada Zinātniskā konference "Jaunas diagnostikas un ārstēšanas metodes Latvijas bērnu veselības uzlabošanai”. Tēzes, 48. lpp. (Stenda referāts).

6. Smane L., Pilmane M., Akota I. "Audu remodelāciju ietekmējošo enzīmu un ar tiem saistîto endogēno inhibitoru izvērtējums šķeltnes zonas audos”, Rīgas Stradiņa universitātes 2015. gada Zinātniskā konference. Tēzes, 294. lpp. (Stenda referāts).

7. Smane L., Pilmane M., Akota I. "Alveolārā kaula reǵenerāciju un remodelāciju ietekmējošo faktoru izvērtējums šķeltnes zonas audos”, Rīgas Stradiņa universitātes 2016. gada Zinātniskā konference. Tēzes, 222. lpp. (Stenda referāts). 


\section{PATEICĪBAS}

Vēlos pateikties mana promocijas darba vadītājai Dr. habil. med. profesorei Mārai Pilmanei par pacietību, atbalstu, ieguldīto darbu un laiku, dotajiem vērtīgiem padomiem gan doktorantūras studiju laikā, gan promocijas darba izstrādāšanas gaitā.

Pateicos DDS, Dr.med., MSc (Oslo universitāte), MRCSEd (Edinburga) profesorei Ilzei Akotai par palīdzību audu materiāla iegūšanā.

Paldies Rīgas Stradiņa universitātes Anatomijas un antropoloğijas institūta darbiniekiem, it īpaši Morfologijas laboratorijas laborantei Natālijai Morozai, par palīdzību histoloǵisko preparātu sagatavošanā un inženierim Jānim Krievam par palīdzību mikrofotogrāfiju uzṇemšanā.

Liels paldies Rīgas Stradiṇa universitātes Fizikas katedras docentam Renāram Ertam un Rīgas Stradiņa universitātes Statistiskas laboratorijas vadītājam Andrejam Ivanovam par palīdzību un konsultācijām statistisko metožu izvēlē un statistiskos aprēķinos.

Pateicos savai Alma mater Rīgas Stradiņa universitātei par doto iespēju studēt doktorantūrā, iegūstot izcilas zināšanas, un sniegto finansiālo atbalstu, piešķirot ESF stipendiju.

Vislielākais paldies manai mīḷajai mammai Tatjanai, mīḷajam tētim Mārim un mīḷajiem dēliem Robertam un Ričardam par neatsveramu mīlestību, palīdzību, atbalstu un sapratni visā darba tapšanas laikā. Vissirsnīgākais paldies manām mịlajām vecmāmiņām un vīram par sapratni, atbalstu un rūpēm, īpaši pētniecisko darbu nobeidzot. 


\section{PIELIKUMI}


Mikrofotogrāfijas

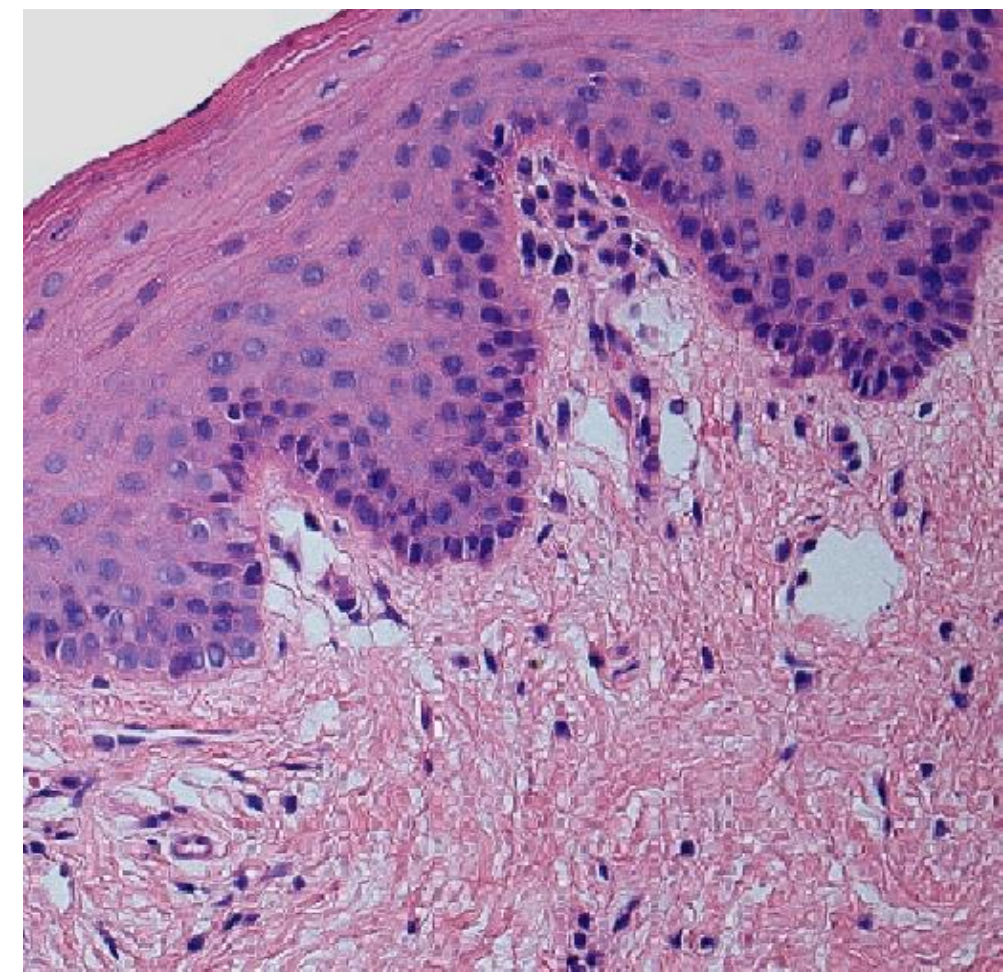

3.1. mikrofotogrāfija. Piecus gadus veca bērna mutes dobuma gḷotādas audu griezums ar neizmainītu daudzkārtainu plakanu epitēliju un lamina propria.

Hematoksilīns un eozīns, $\times 200$

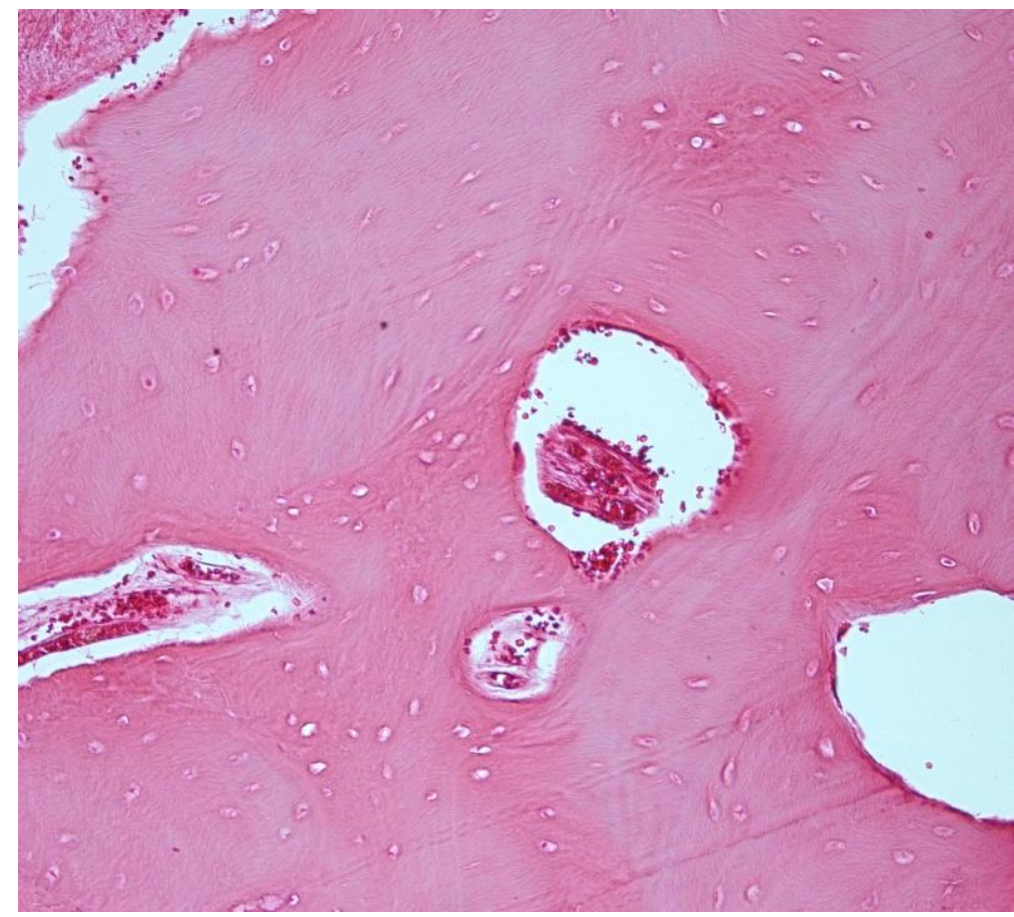

3.2. mikrofotogrāfija. Sešus gadus un 9 mēnešus veca bērna praktiski neizmainīta alveolārā kaula morfologiiskā aina. Hematoksilīnas un eozīns, $\times 200$ 


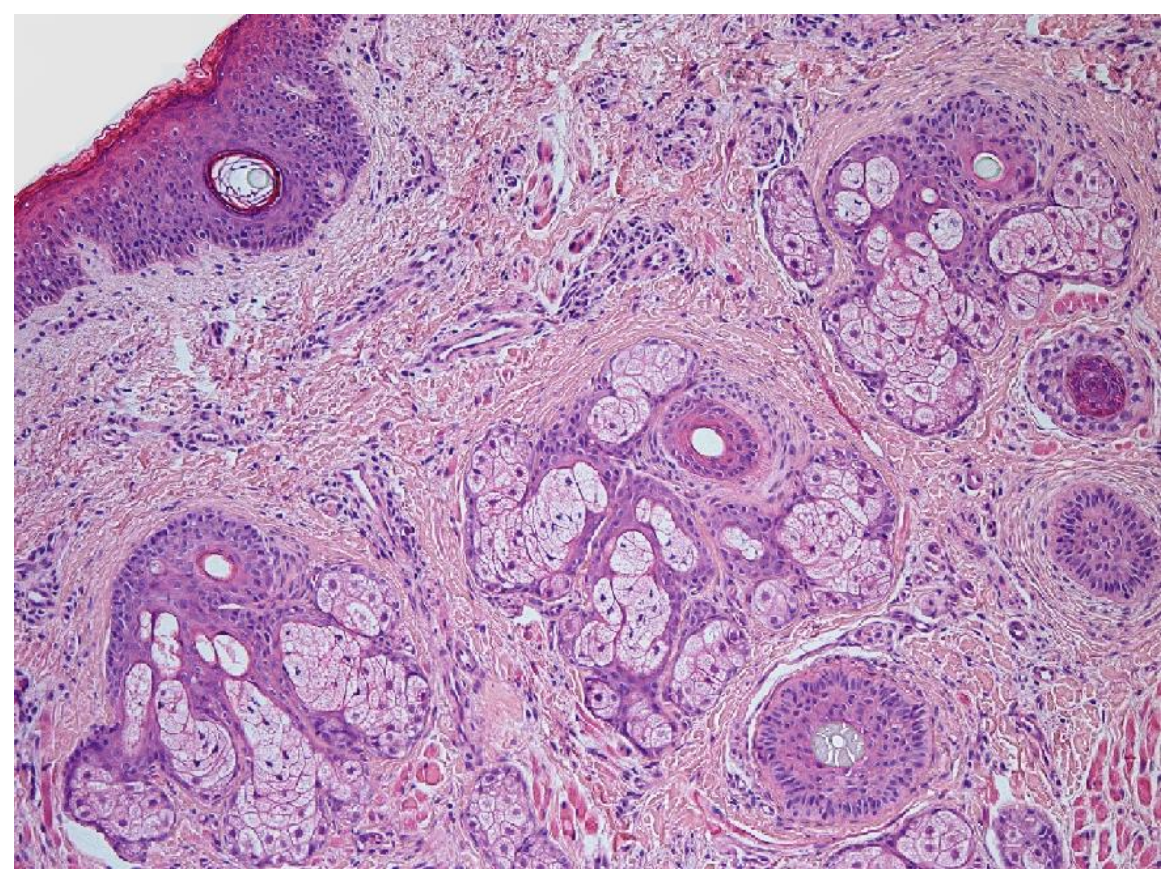

3.3. mikrofotogrāfija. Trīs mēnešus veca zīdaiṇa lūpas plastikas laikā iegūta lūpas ārējās virsmas āda ar tauku dziedzeriem, matu folikuliem un perivaskulāru šūnu infiltrāciju, iekaisuma šūnu infiltrāciju. Hematoksilīns un eozinns, $\times 100$

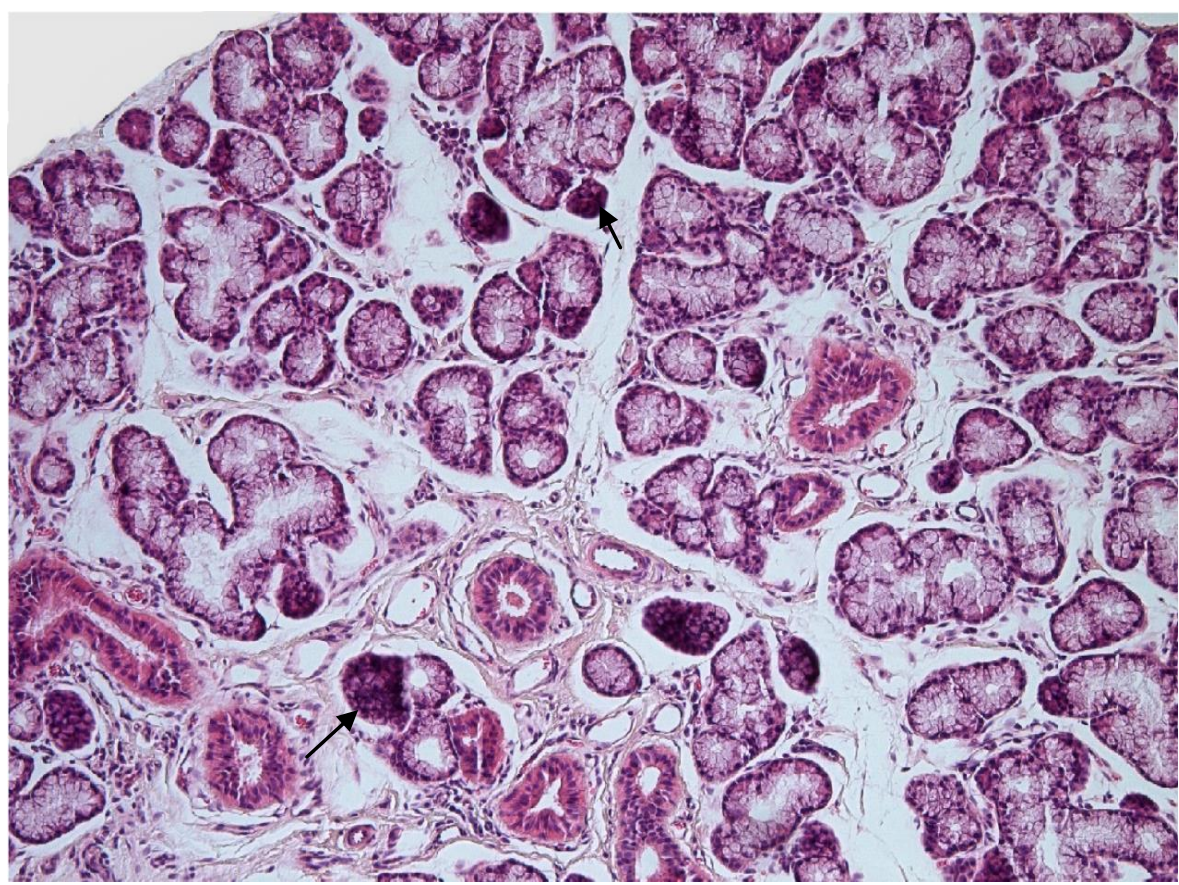

3.4. mikrofotogrāfija. Desmit mēnešus veca zīdaiṇa mīksto aukslēju audos lokalizēti jauktie siekalu dziedzeri ar izvadu epitēlija perēkḷlveida šūnu hiperplāziju (bultiṇas). Hematoksilīns un eozīns, $\times 100$ 


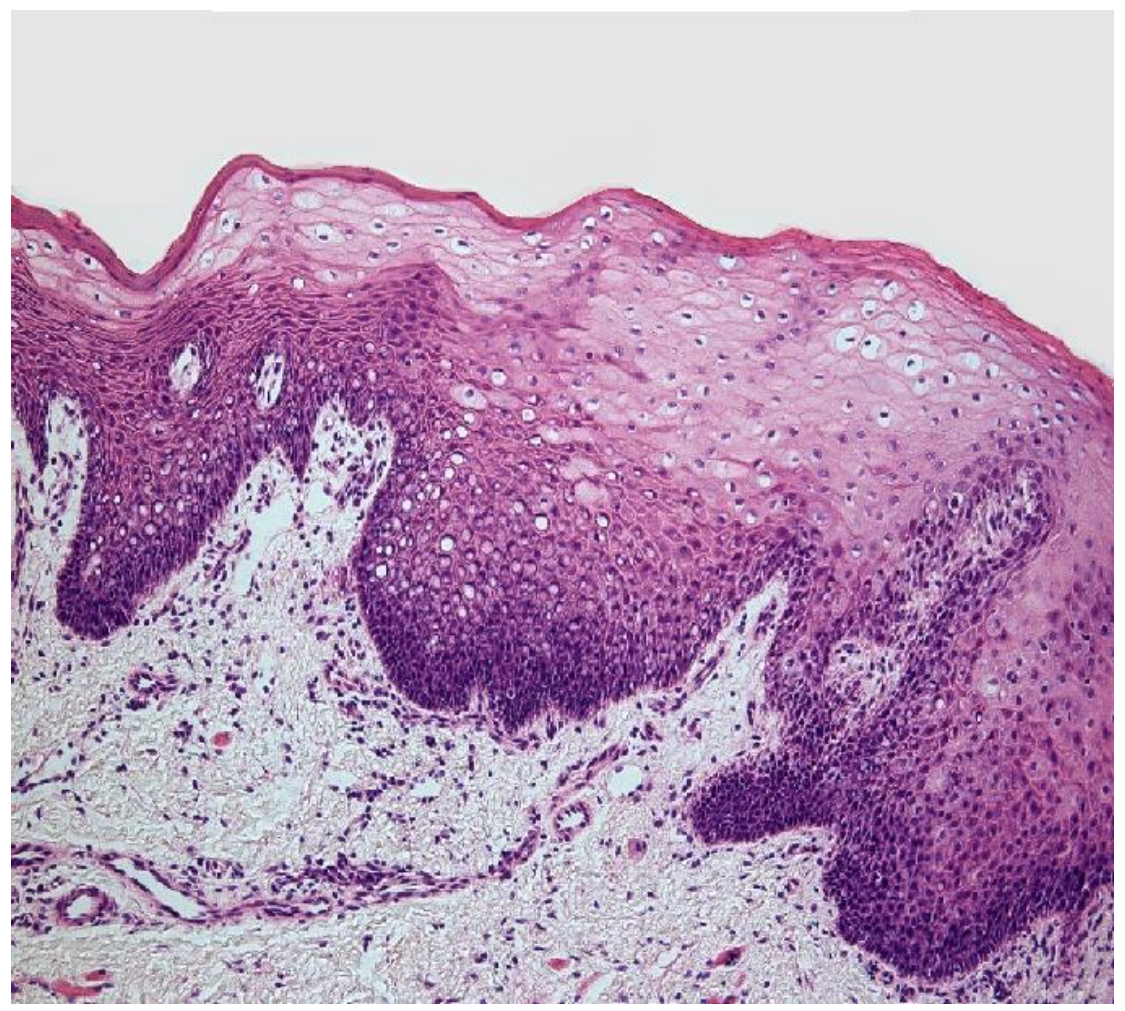

3.5. mikrofotogrāfija. Četrus mēnešus veca zīdaiṇa lūpas plastikas laikā iegūts audu materiāls, kurā redzams biezs epitēlijs ar bazālā slāṇa šūnu izteiktu hiperplāziju un polimorfo šūnu vakuolizāciju. Hematoksilīns un eozīns, $\times 100$

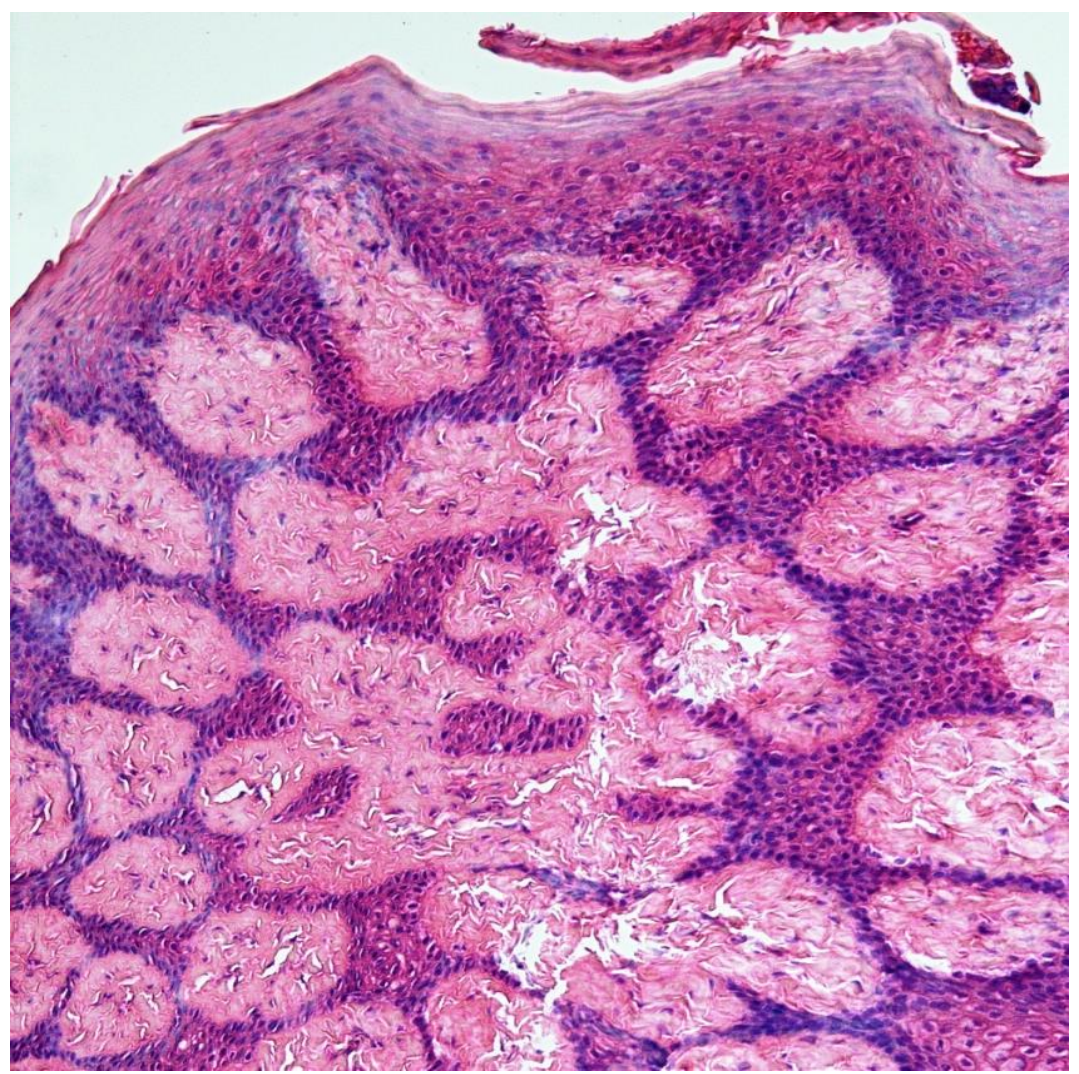

3.6. mikrofotogrāfija. Sešus mēnešus veca zīdaiņa lūpas plastikas laikā iegūts audu materiāls, kurā redzama augšanas slāṇa šūnu izaugumu iestiepšanās lamina propria. Hematoksilīns un eoz̄ins, $\times 100$ 


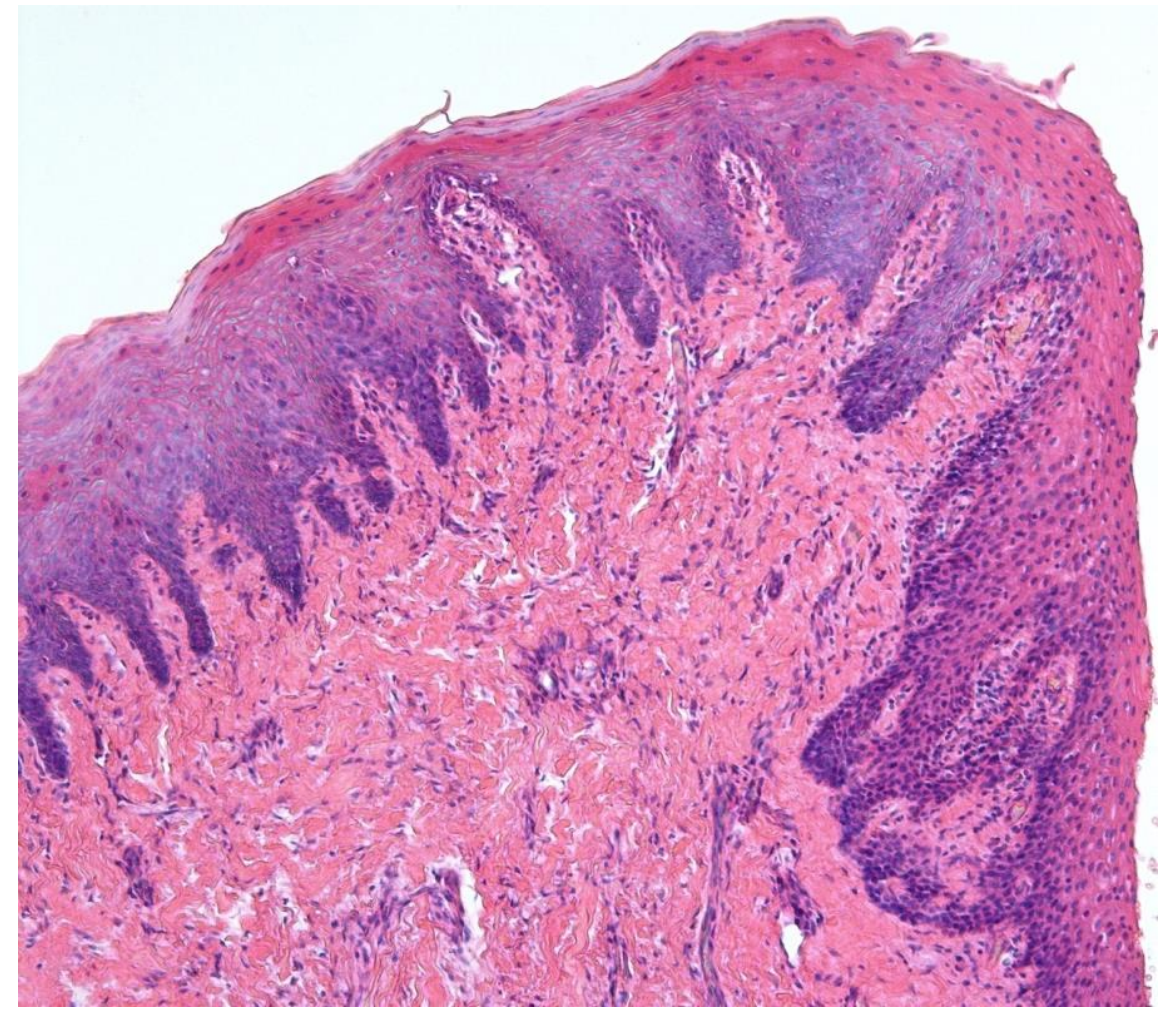

3.7. mikrofotogrāfija. Trīs gadus un 2 mēnešus veca bērna cieto aukslēju plastikas laikā iegūts audu materiāls, kurā redzama lamina propria ar blīviem haotiski novietotiem saistaudu šķiedru kūlīšiem. Hematoksilīns un eozīns, × 100

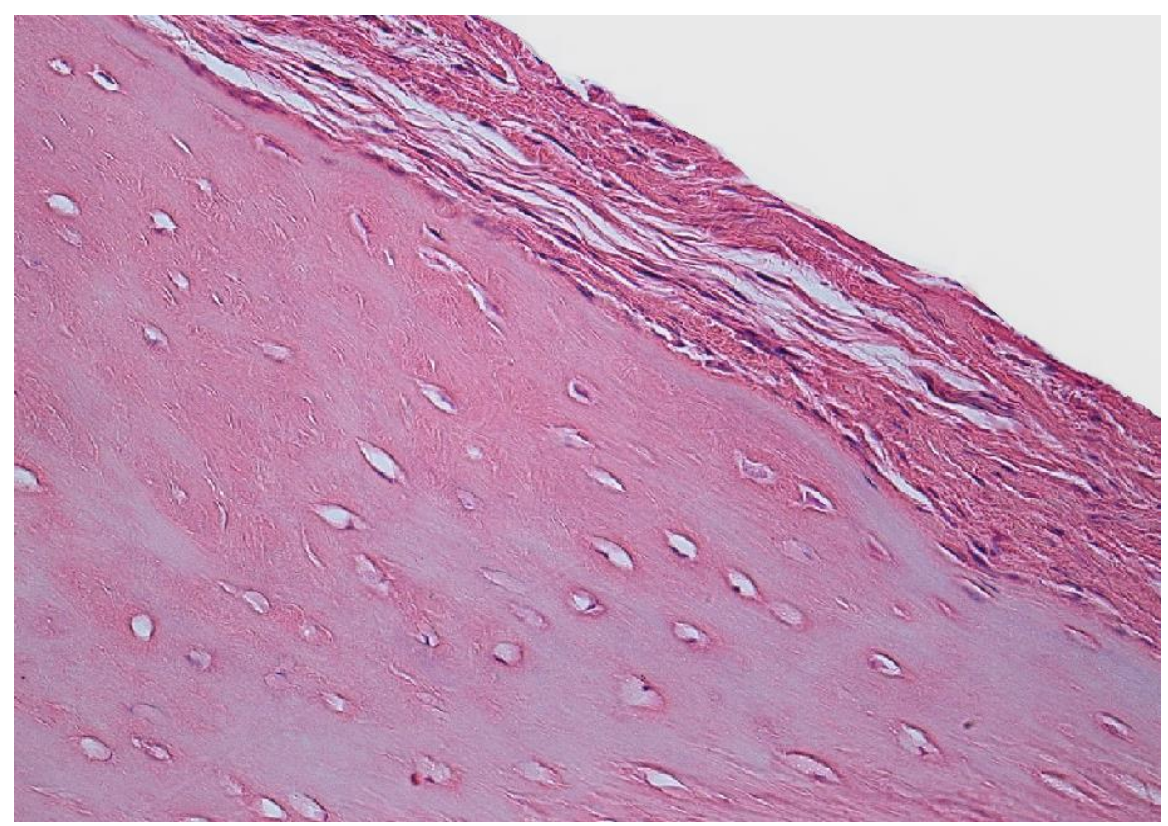

3.8. mikrofotogrāfija. Četrpadsmit gadus un 6 mēnešus veca bērna osteoplastikas laikā iegūts vispārpieņemtajai normai atbilstošs alveolārais kauls ar periostu. Hematoksilīns un eozīns, $\times 100$ 


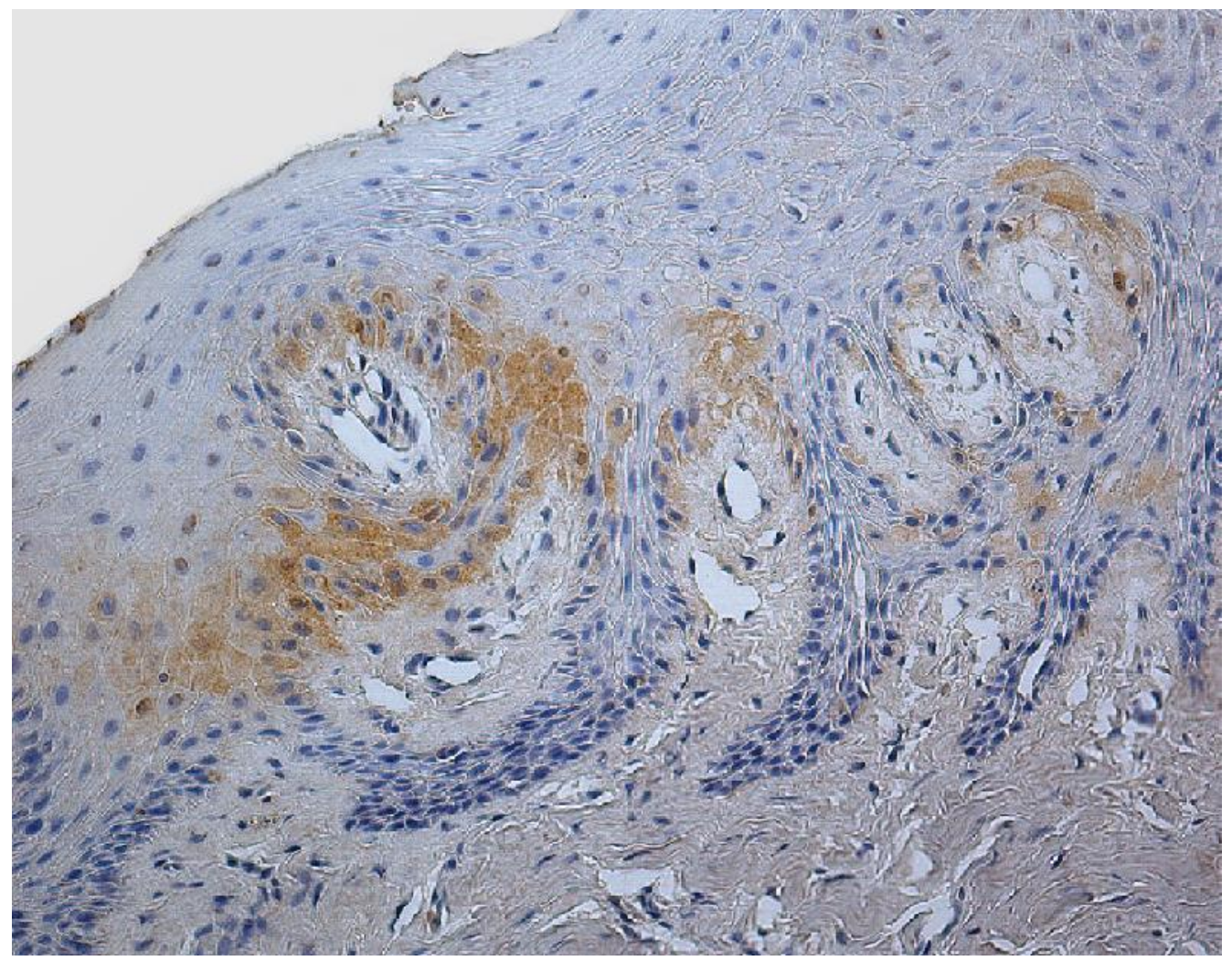

3.9. mikrofotogrāfija. Maz (+) MMP-2 pozitīvu epiteliocītu 7 gadus veca kontroles pacienta mutes dobuma gḷotādā. MMP-2 IMH, $\times 200$

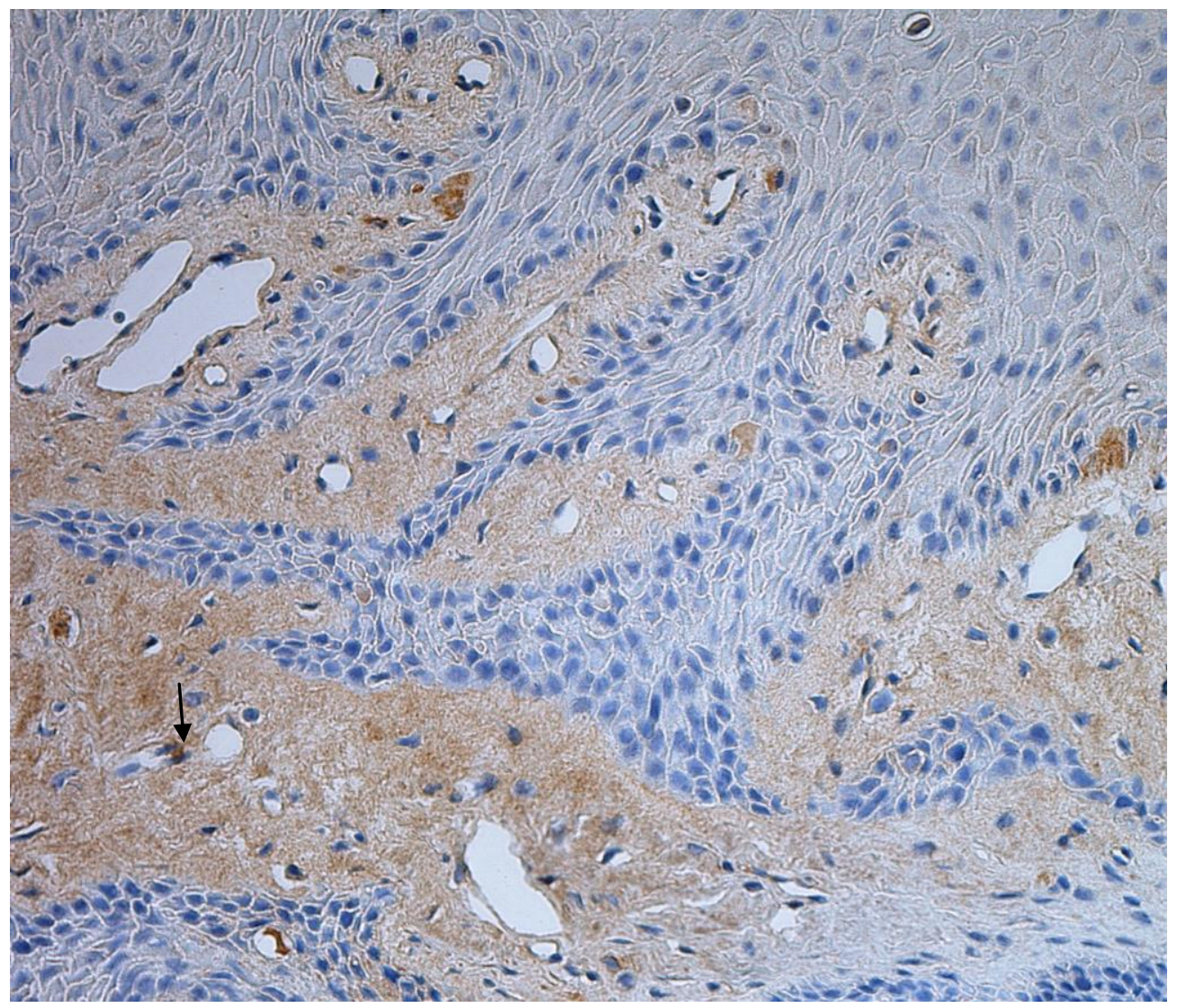

3.10. mikrofotogrāfija. Reti (0/+) MMP-8 pozitīvi epiteliocīti un saistaudu šūnas 7 gadus veca kontroles pacienta mutes dobuma gḷotādā (bultiņa). MMP-8 IMH, × 200 


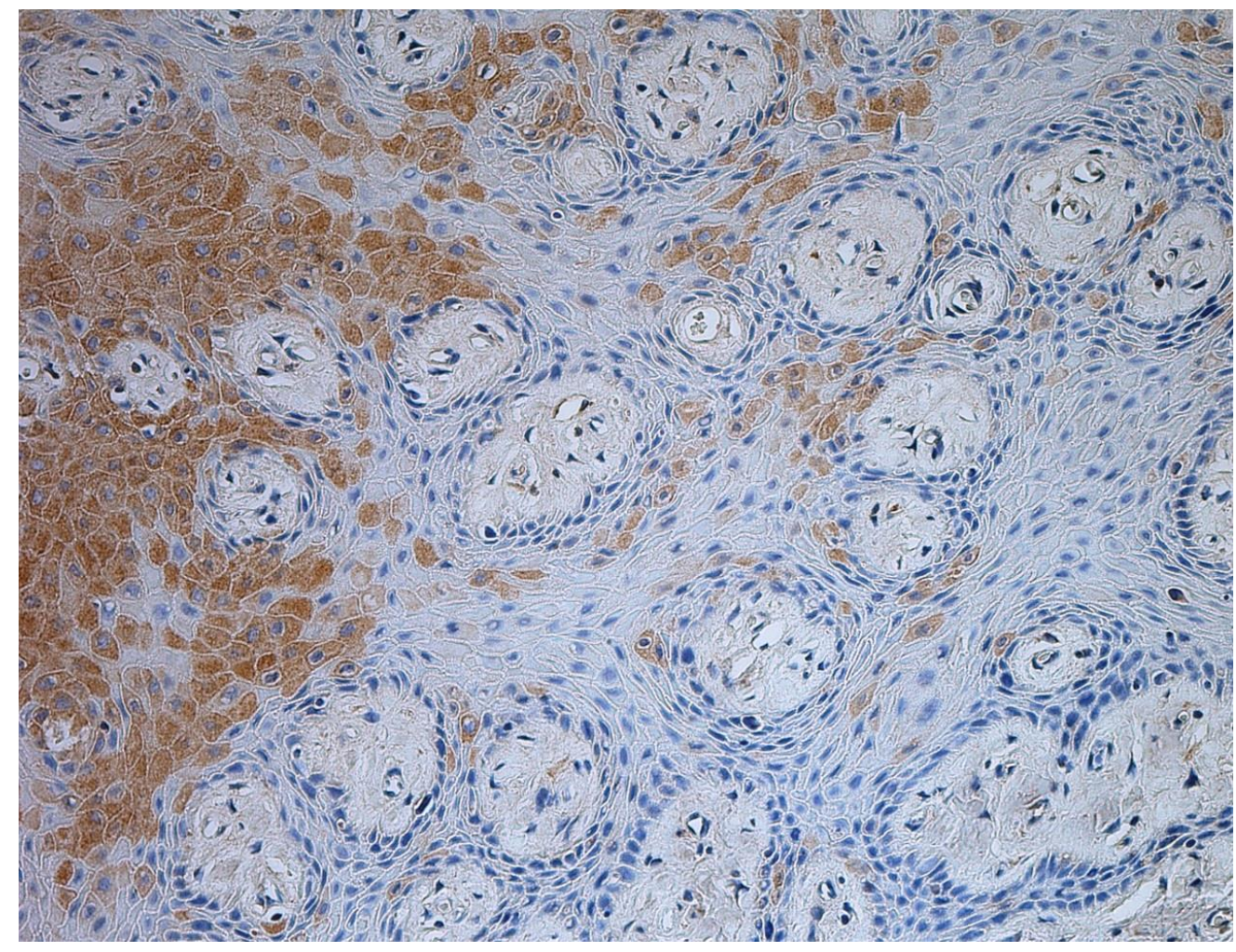

3.11. mikrofotogrāfija. Maz līdz vidēji daudz (+/++) perēkḷveidīgu novietotu MMP-9 pozitīvu epiteliocītu 5 gadus veca kontroles pacienta mutes dobuma gḷotādā. MMP-9 IMH, × 200

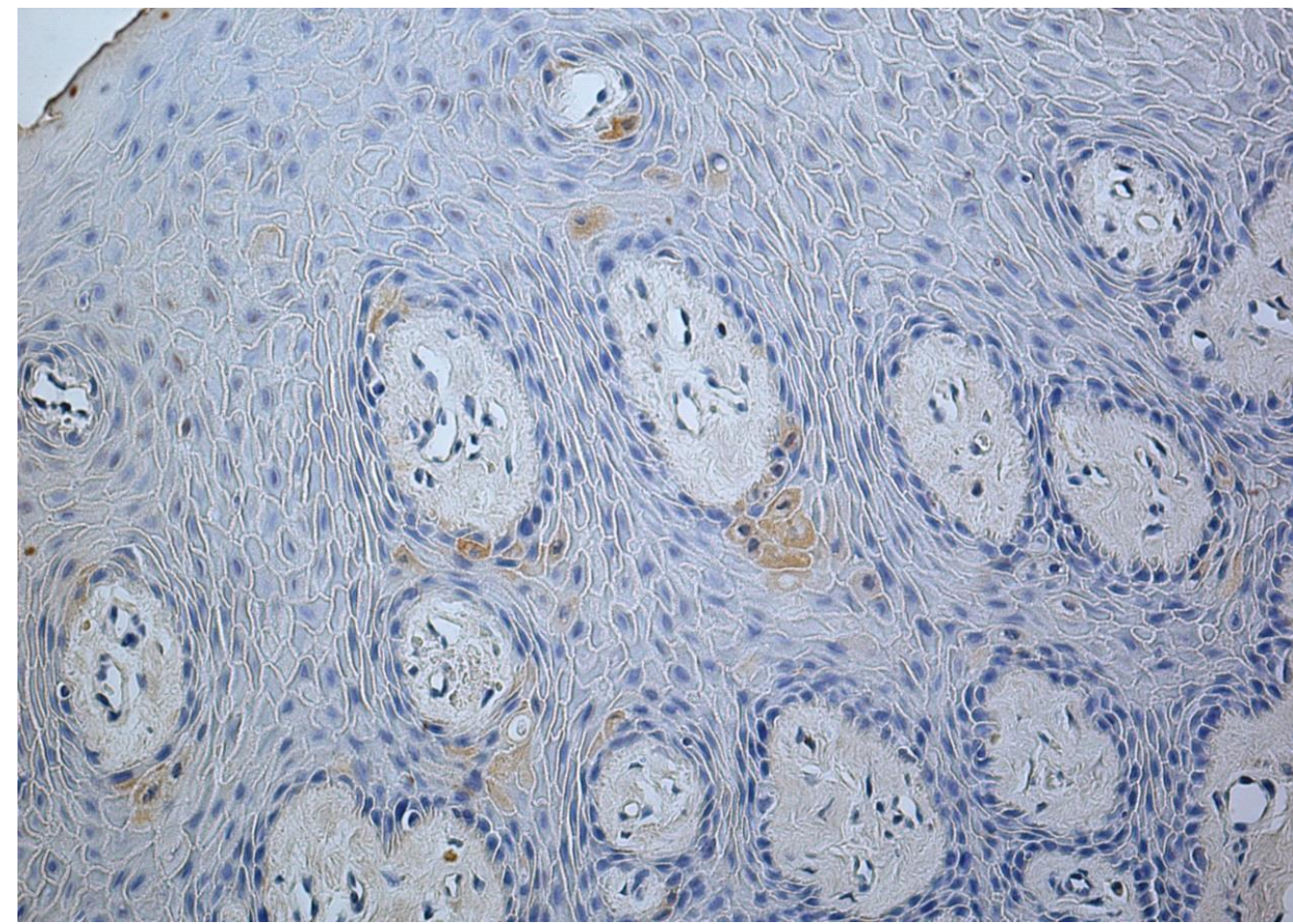

3.12. mikrofotogrāfija. Retas (0/+) TIMP-2 pozitīvas epitelijšūnas 9 gadus veca kontroles pacienta mutes dobuma gḷotādā. TIMP -2 IMH, $\times 200$ 


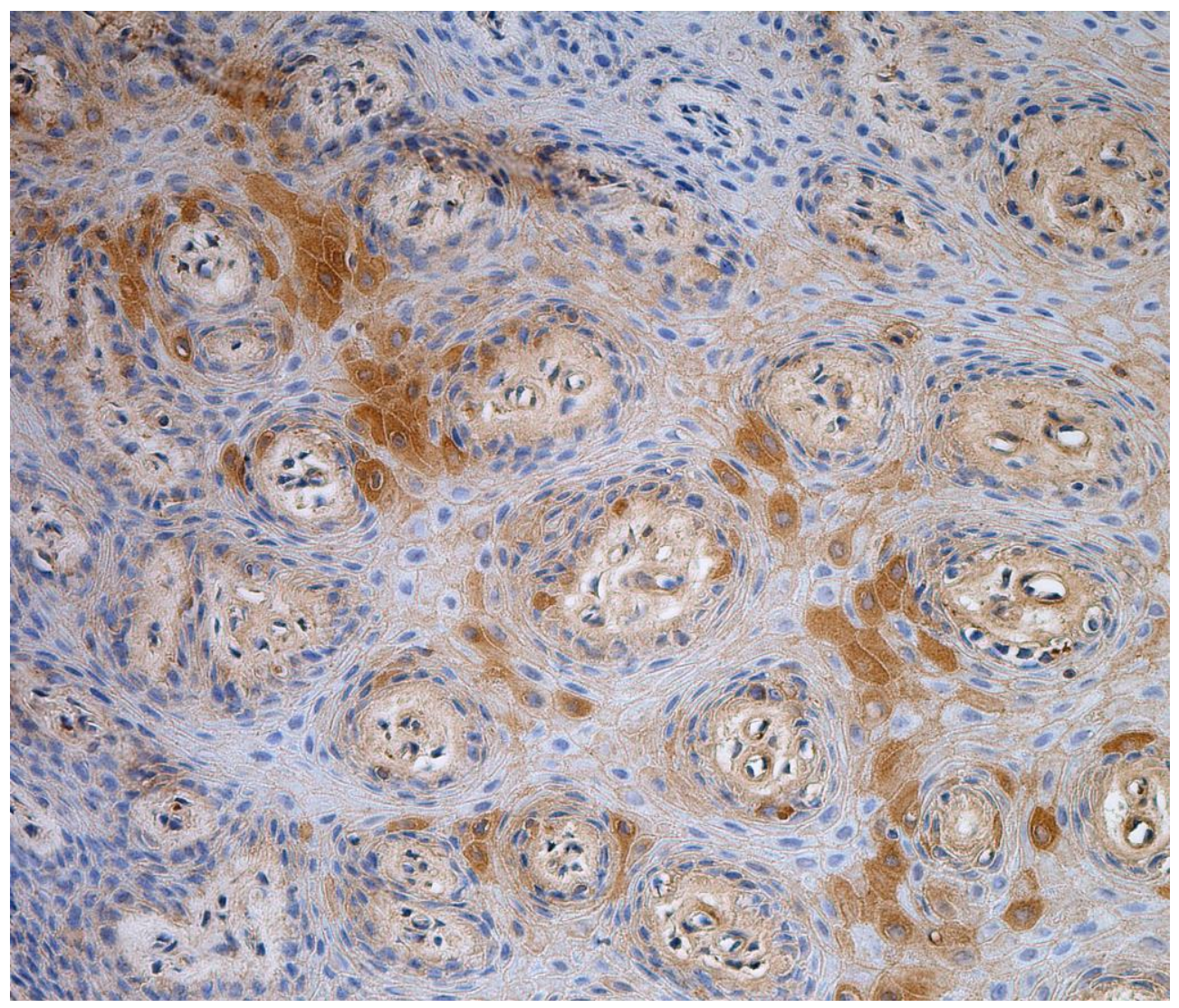

3.13. mikrofotogrāfija. Maz (+) TIMP-4 pozitīvu epitelijšūnu 9 gadus veca kontroles pacienta mutes dobuma gḷtotāē. TIMP-4 IMH, $\times 200$

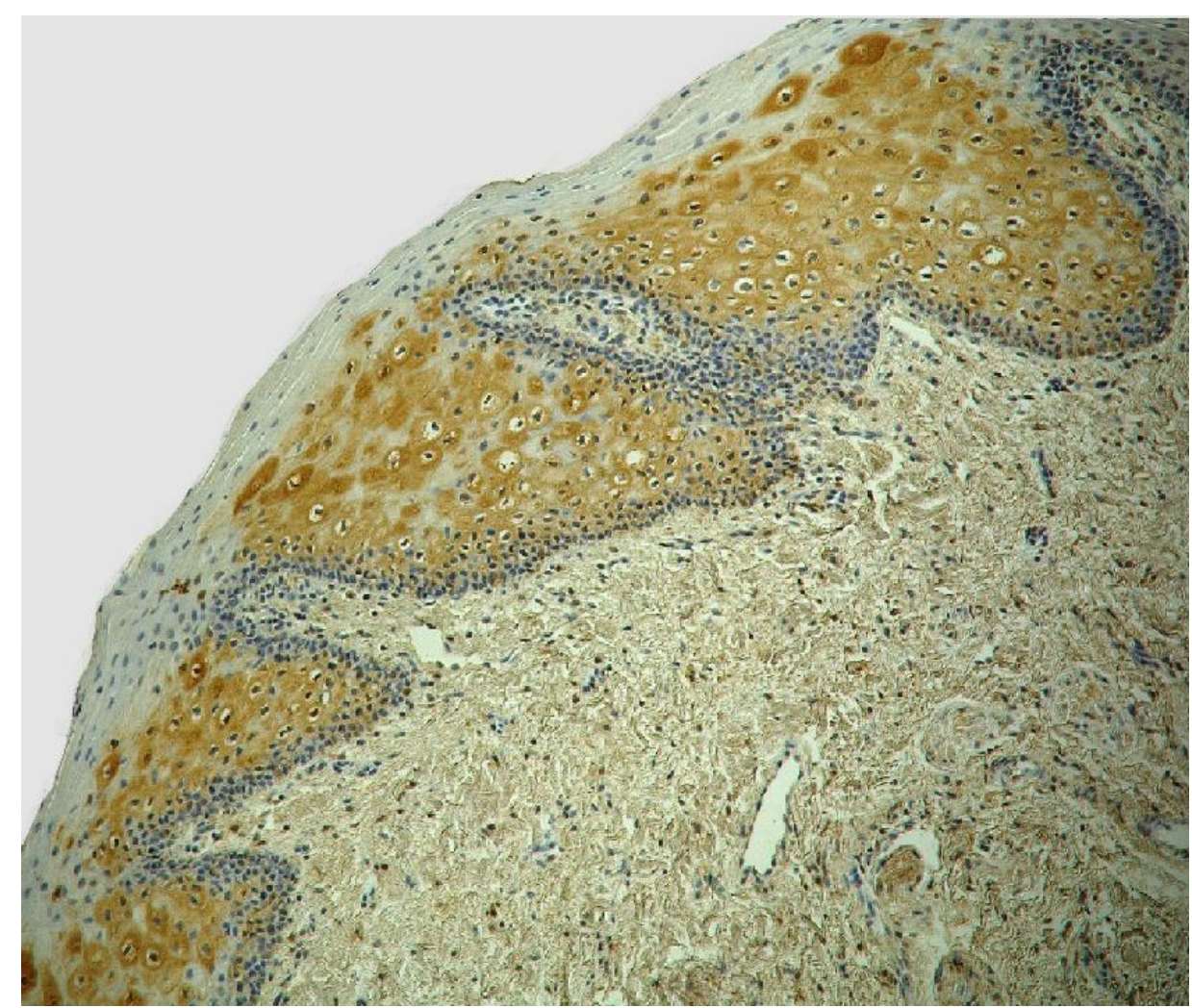

3.14. mikrofotogrāfija. Vidēji daudz (++) MSX1 pozitīvu epitēlijšūnu un saistaudu šūnu 8 gadus veca kontroles pacienta mutes dobuma gḷotādā. MSX1 IMH, × 100 


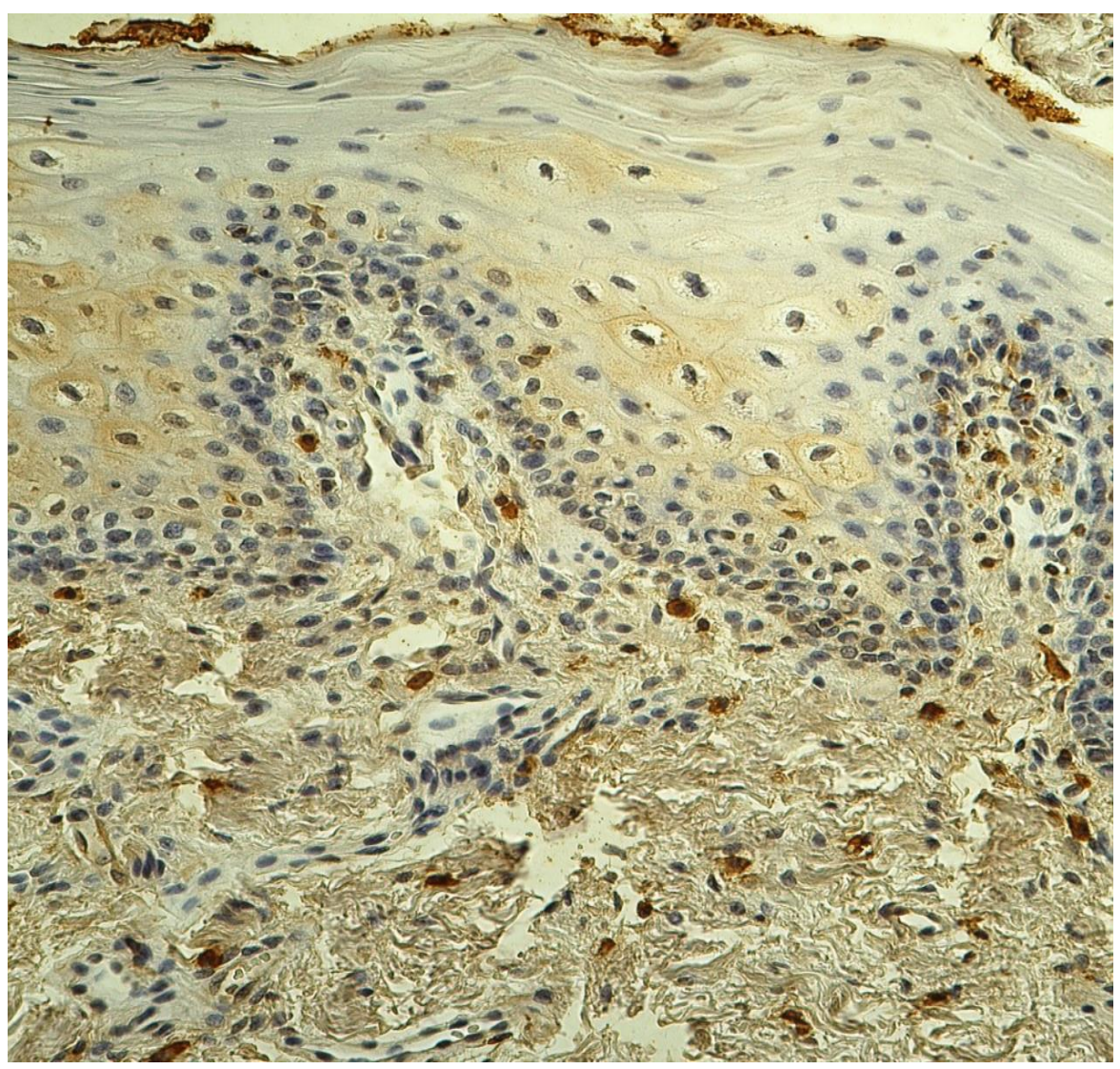

3.15. mikrofotogrāfija. Vidēji daudz (++) IRF6 vāju pozitīvu saistaudu šūnu 10 gadus veca kontroles pacienta mutes dobuma gḷotādā. IRF6 IMH, × 200

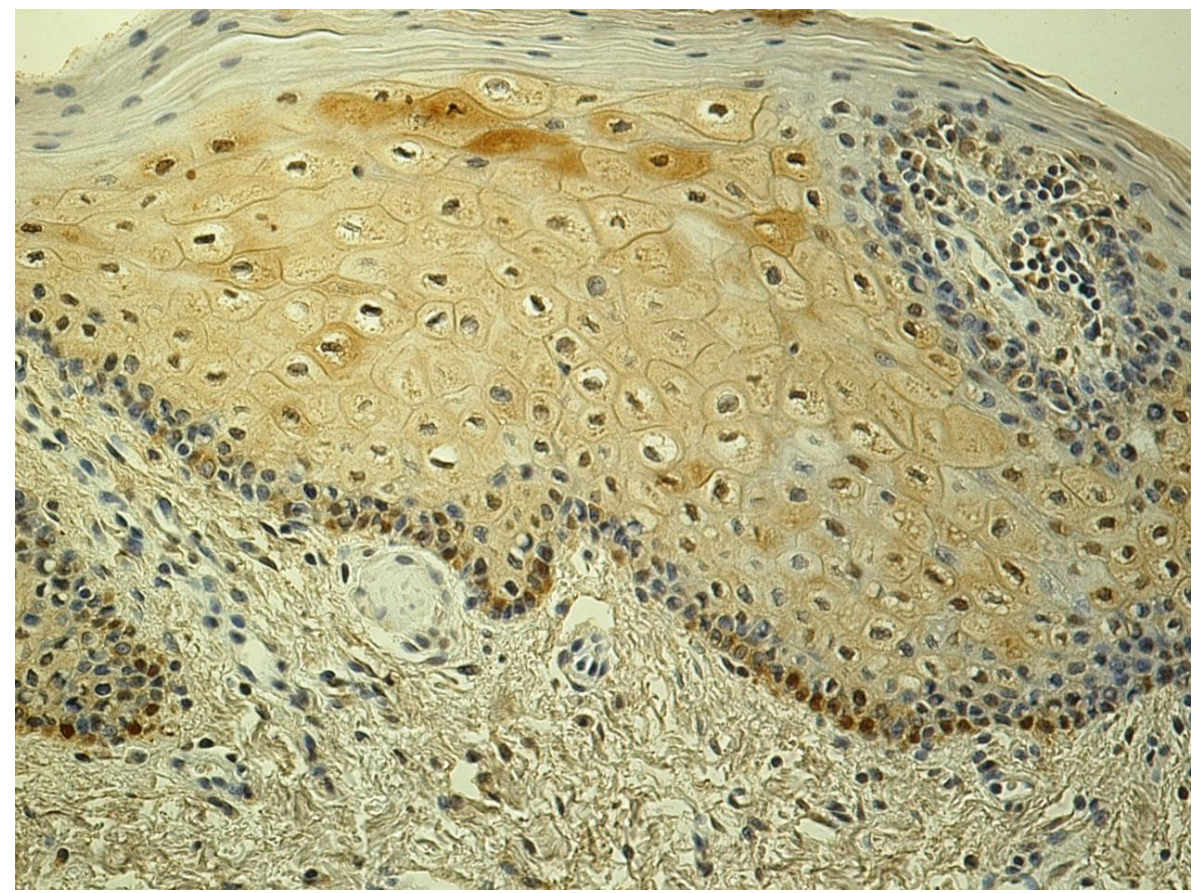

3.16. mikrofotogrāfija. Vidēji daudz (++) PAX9 saturošu bazālā un poligonālā slāņa šūnu 13 gadus veca kontroles pacienta mutes dobuma gḷotādā. PAX9 IMH, × 200 


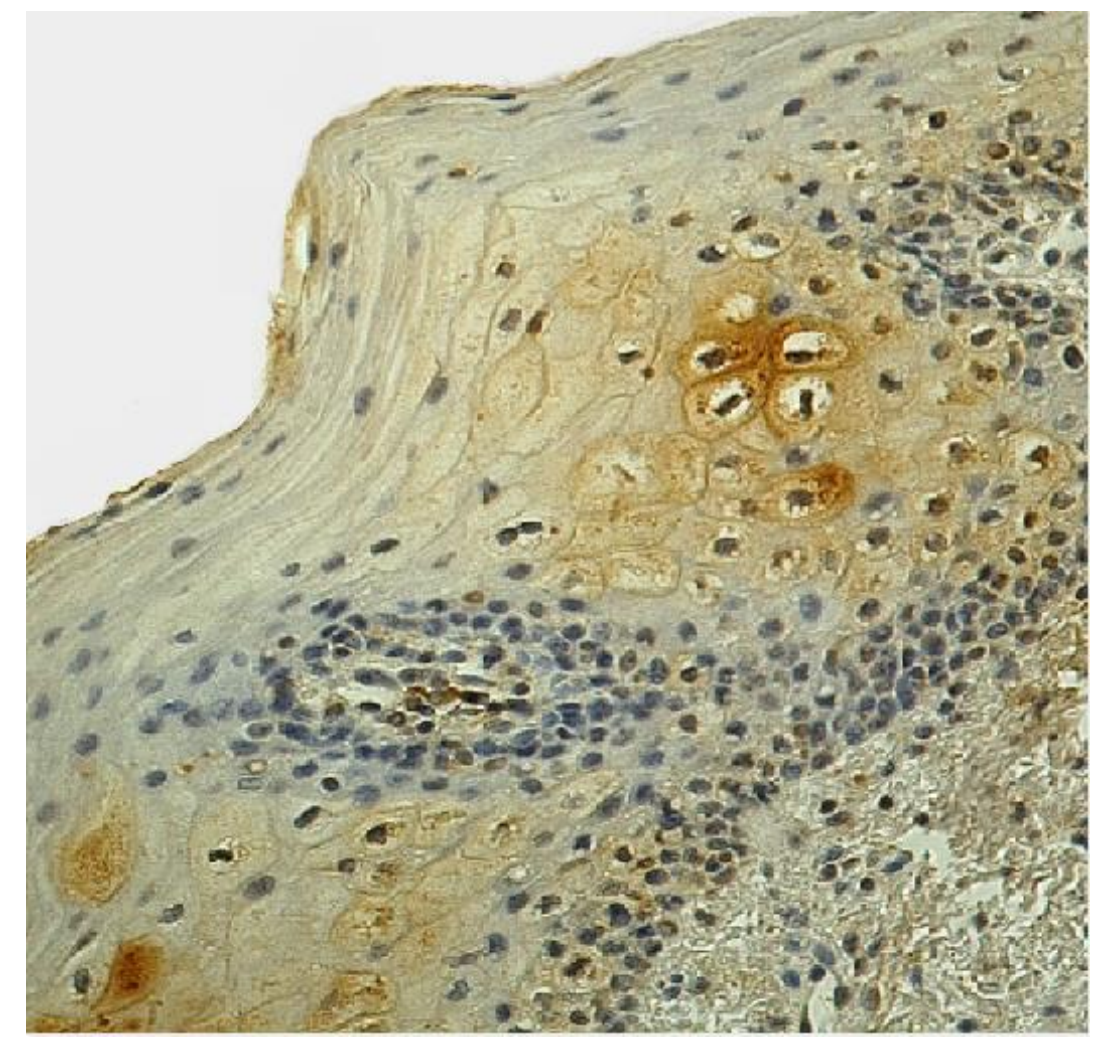

3.17. mikrofotogrāfija. Vidēji daudz (++) vāju un intensīvi krāsotu RYK saturošu epitēlijšūnu 5 gadus veca kontroles pacienta mutes dobuma gḷotādā. RYK IMH, × 200

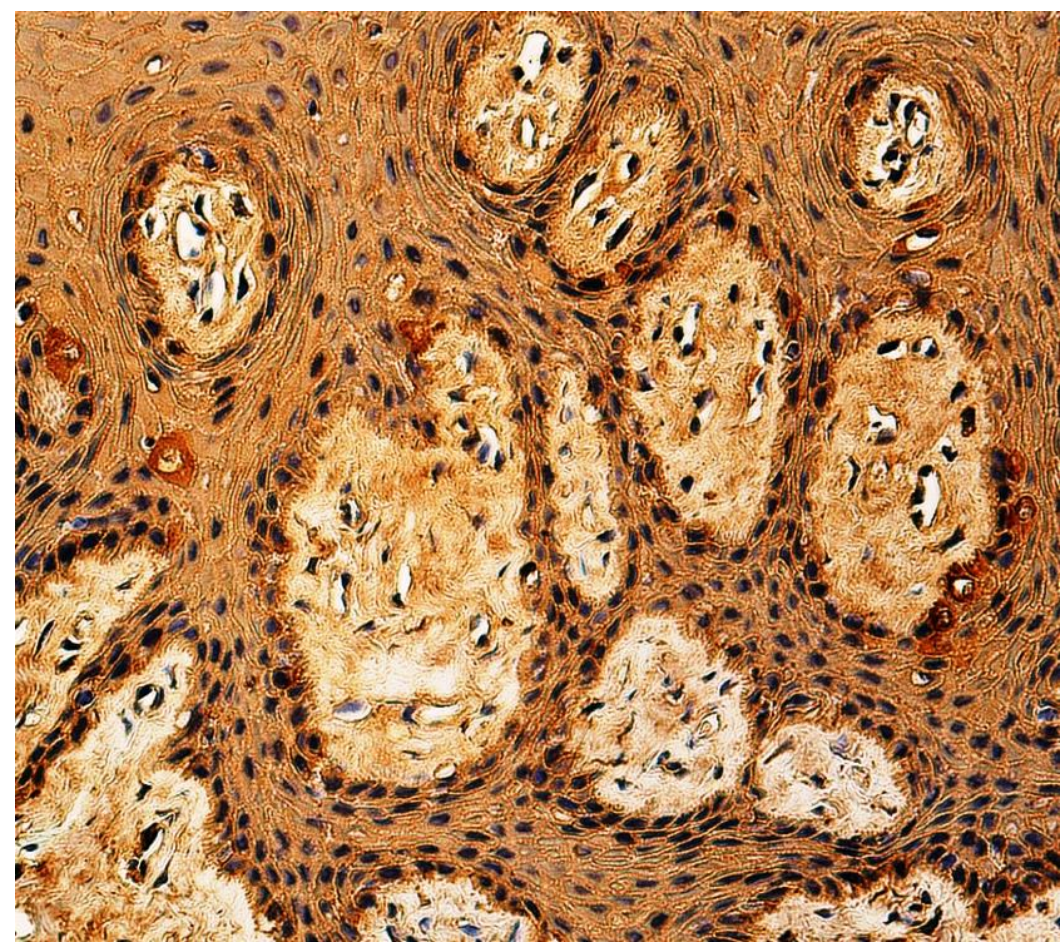

3.18. mikrofotogrāfija. Ļoti daudz (++++) TGFß3 pozitīvu epitēlijšūnu 9 gadus veca kontroles pacienta mutes dobuma gḷotādā. TGFß3 IMH, × 200 


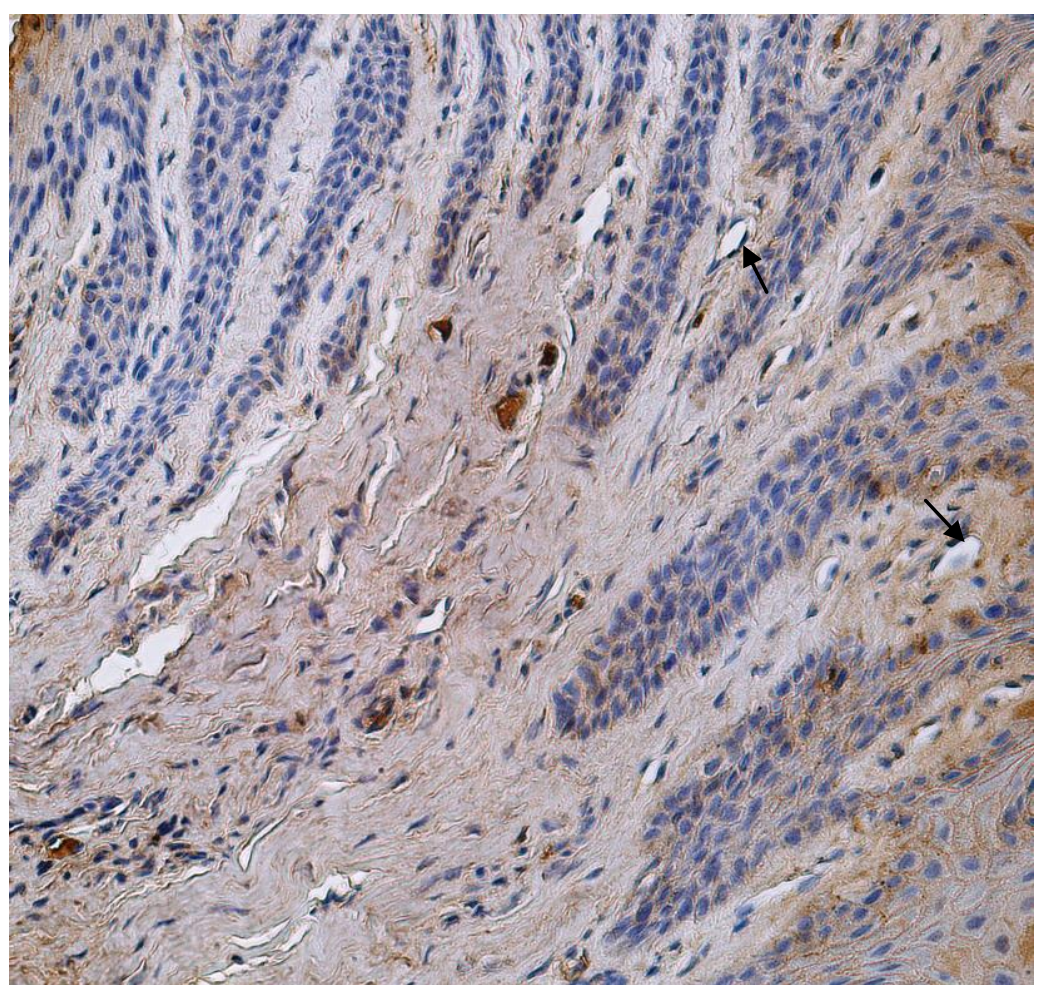

3.19. mikrofotogrāfija. Maz (+) vāju krāsotu $V E G F$ saturošu endotēlijšūnu 7 gadus veca kontroles pacienta mutes dobuma glotādā (bultiņas). VEGF IMH, × 200

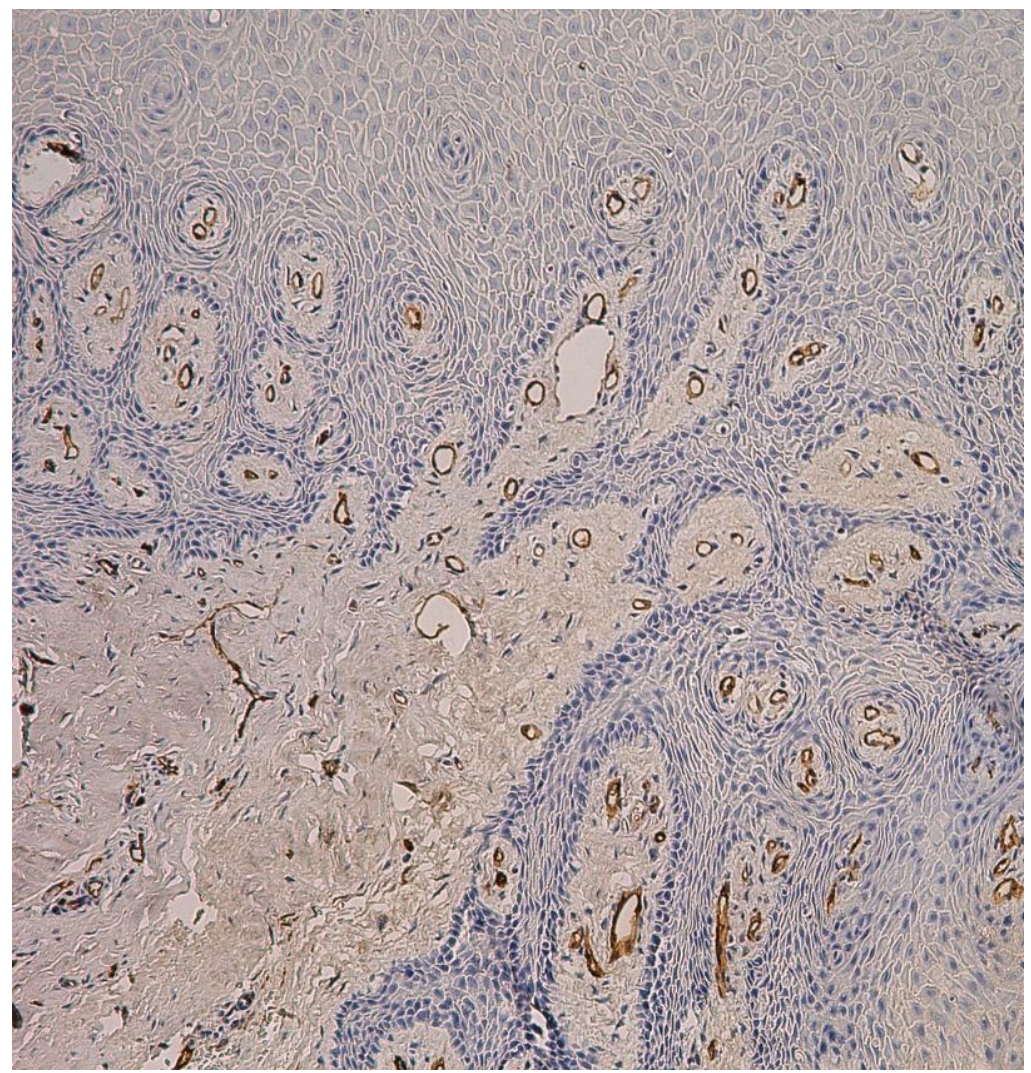

3.20. mikrofotogrāfija. Daudz (+++) CD34 pozitīvu šūnu 9 gadus veca kontroles pacienta mutes dobuma gḷotādas asinsvadu sieniñā. CD34 IMH, × 100 


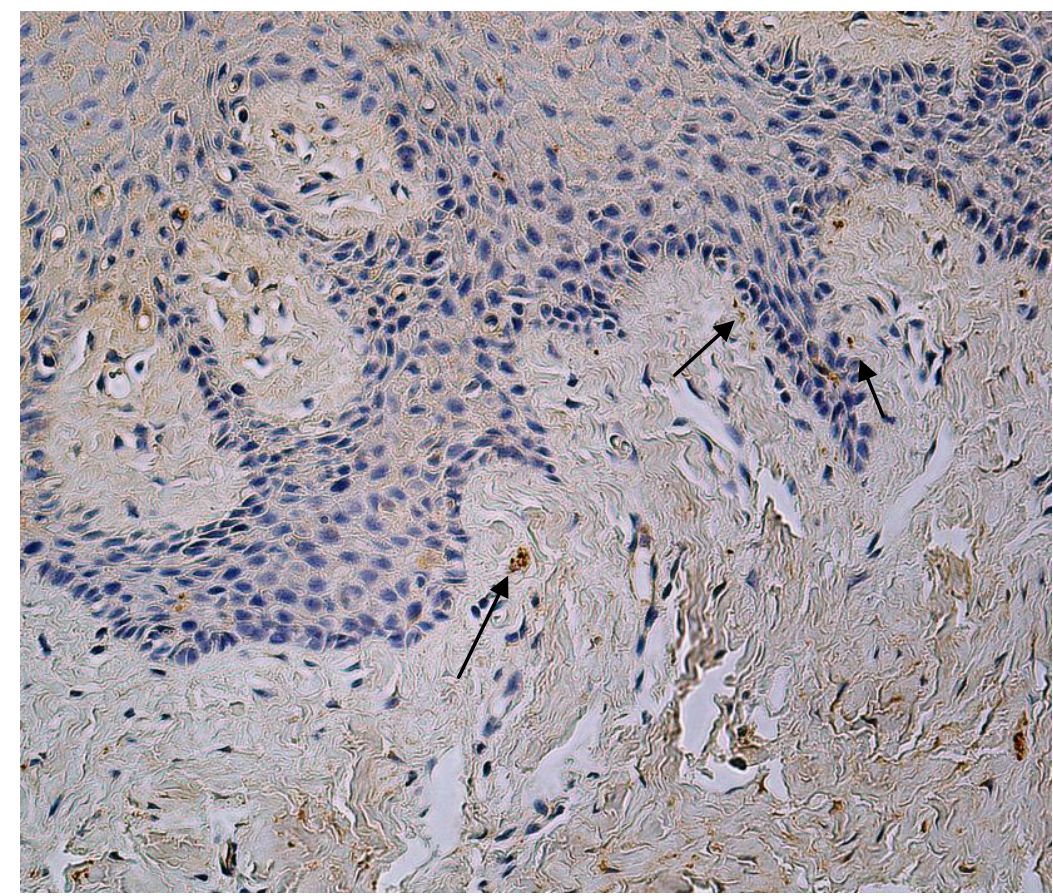

3.21. mikrofotogrāfija. Maz (+) PGP 9.5 pozitīvu nervšķiedru lamina propria 9 gadus veca kontroles pacienta mutes dobuma gḷotādā (bultiṇas). PGP 9.5 IMH, × 200

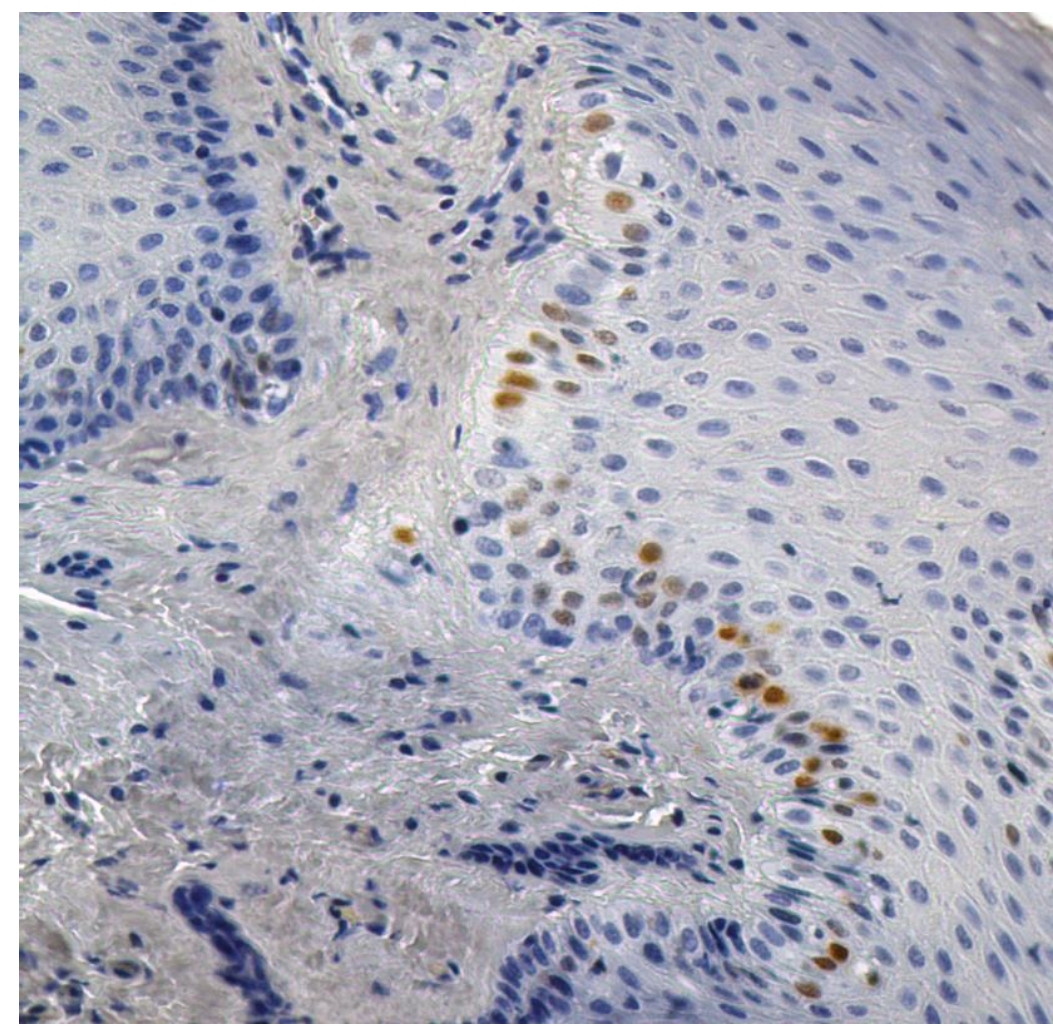

3.22. mikrofotogrāfija. Maz (+) Ki-67 pozitīvu epitēlijšūnu 14 gadus veca kontroles pacienta mutes dobuma glotādā. Ki-67 IMH, × 200 


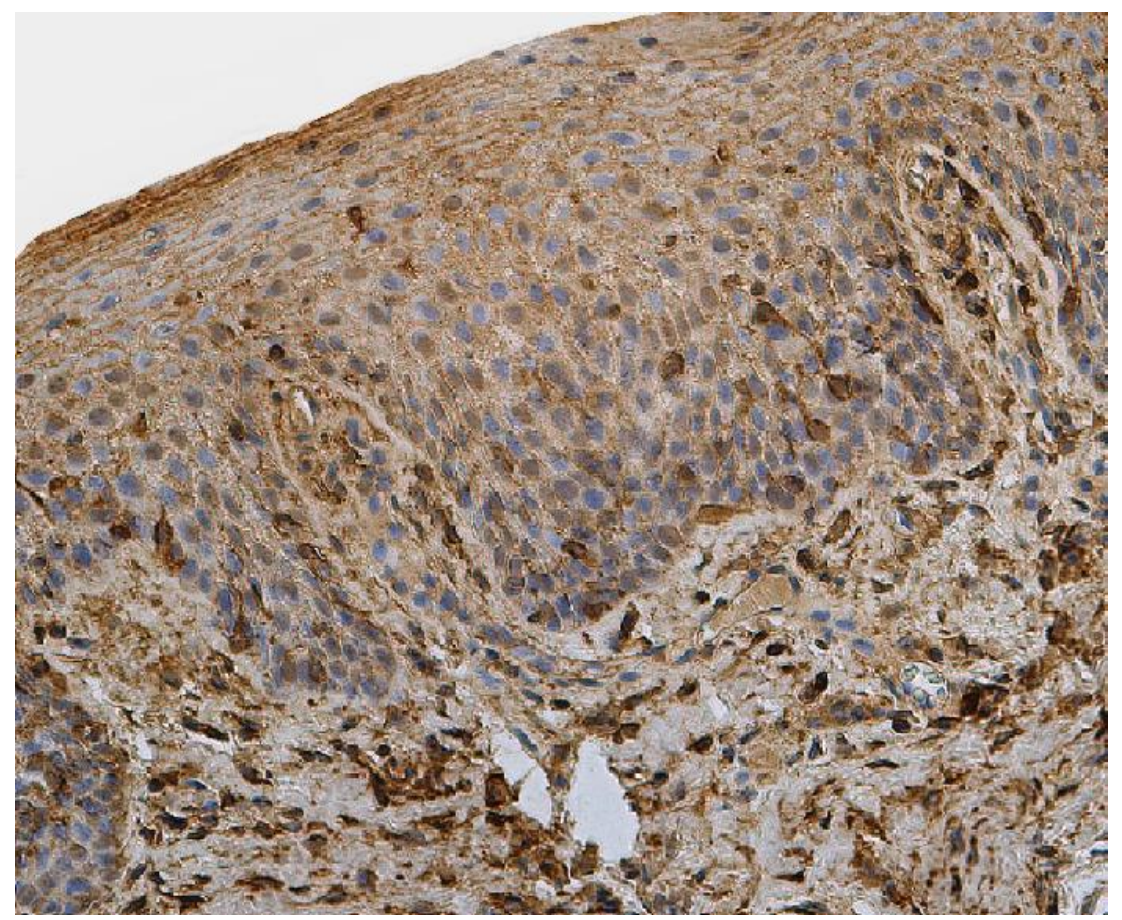

3.23. mikrofotogrāfija. Vidēji daudz $(++)$ nestīna pozitīivu epitēlijšūnu 8 gadus veca kontroles pacienta mutes dobuma gḷotādā. Nestīns $I M H, \times 200$

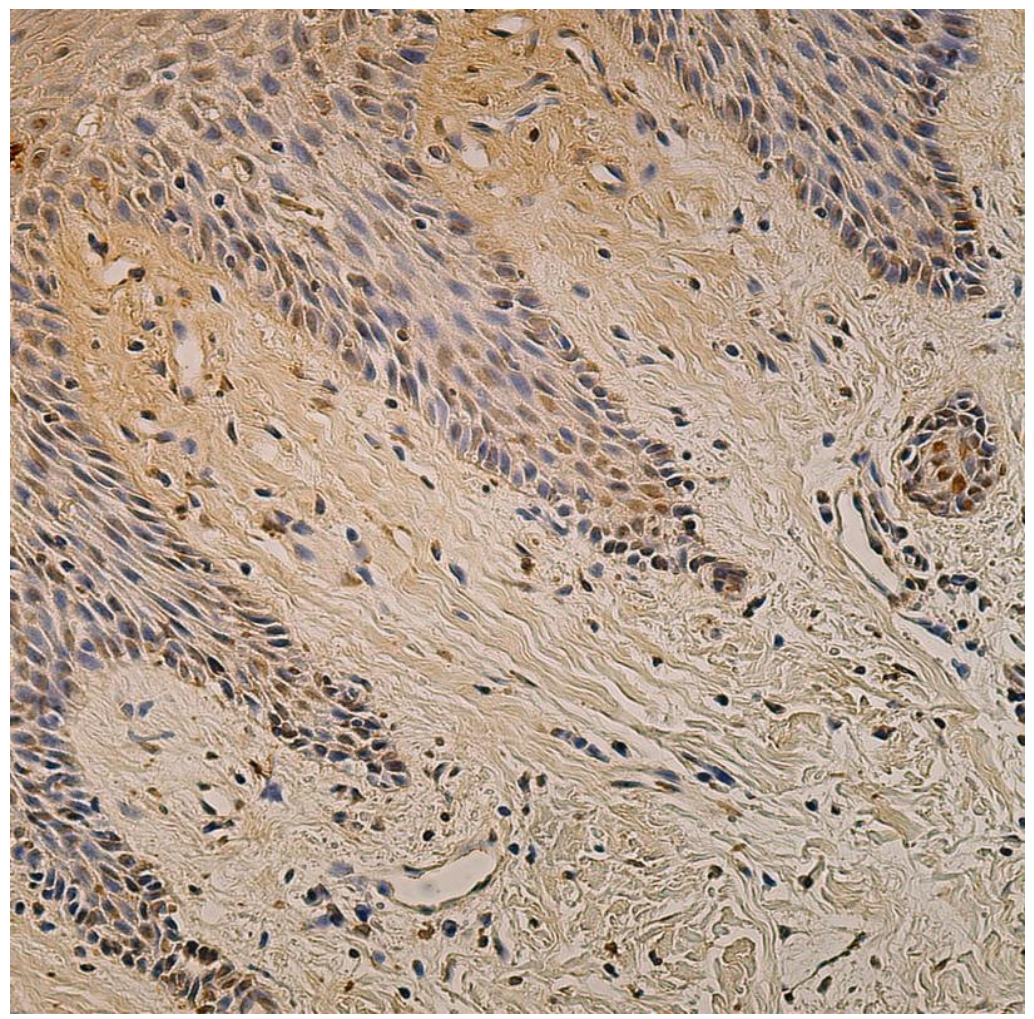

3.24. mikrofotogrāfija. Maz līdz vidēji daudz (+/++) apoptotisku šūnu 9 gadus veca kontroles pacienta mutes dobuma gḷotādas epitēlijā. TUNEL, × 200 


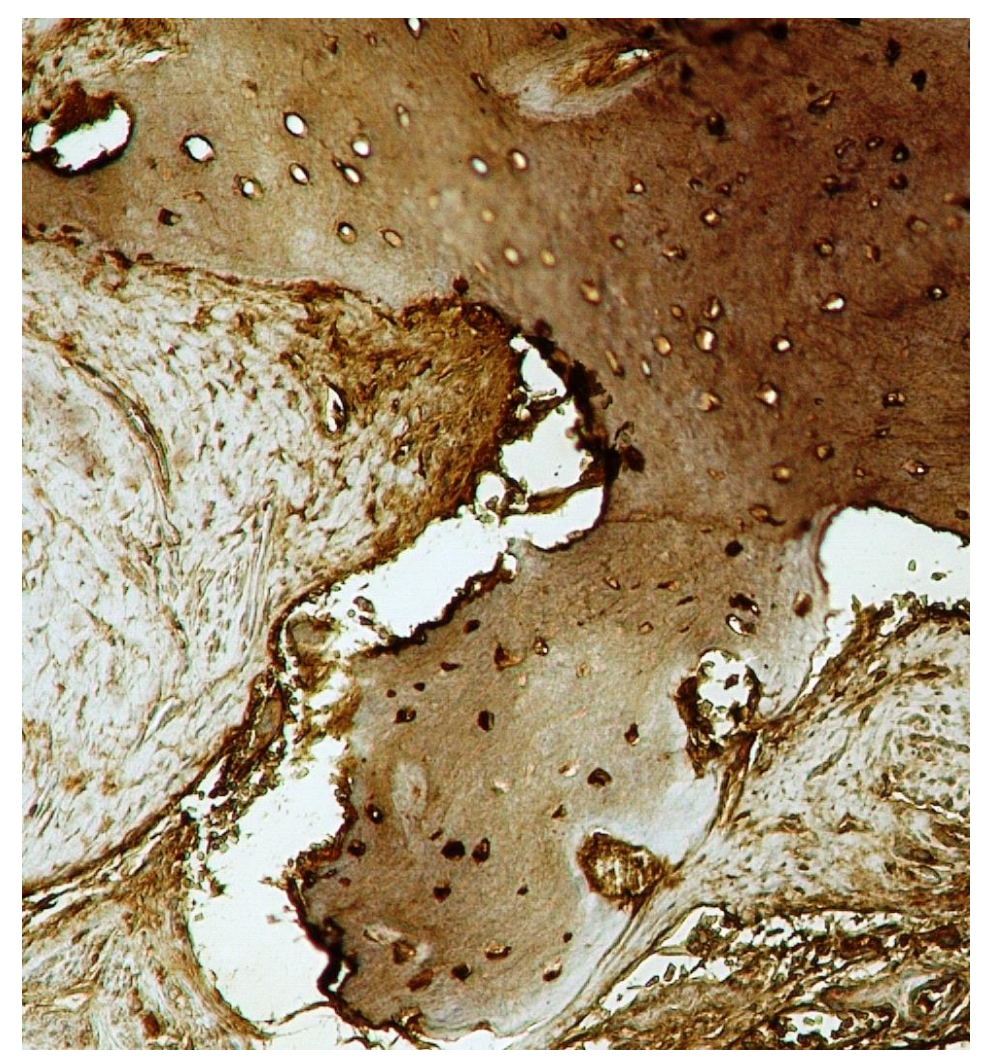

3.25. mikrofotogrāfija. Vidēji daudz (++) $O C$ pozitīvu osteocītu 10 gadus un 5 mēnešus veca kontroles pacienta kaulaudos. $O C$ IMH, $\times 100$

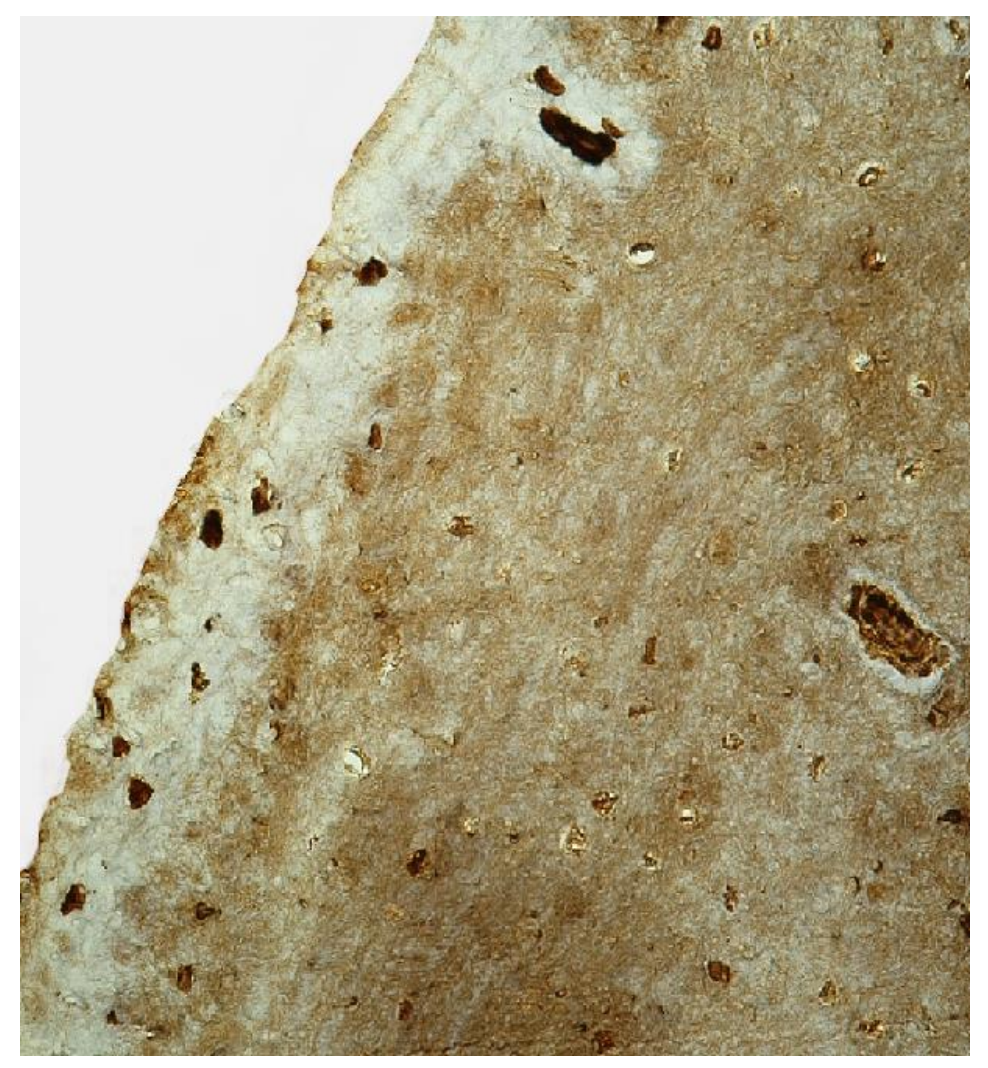

3.26. mikrofotogrāfija. Vidēji daudz (++) $O P N$ pozitīvu osteocītu 10 gadus un 2 mēnešus veca kontroles pacienta kaulaudos. OPN IMH, × 200 


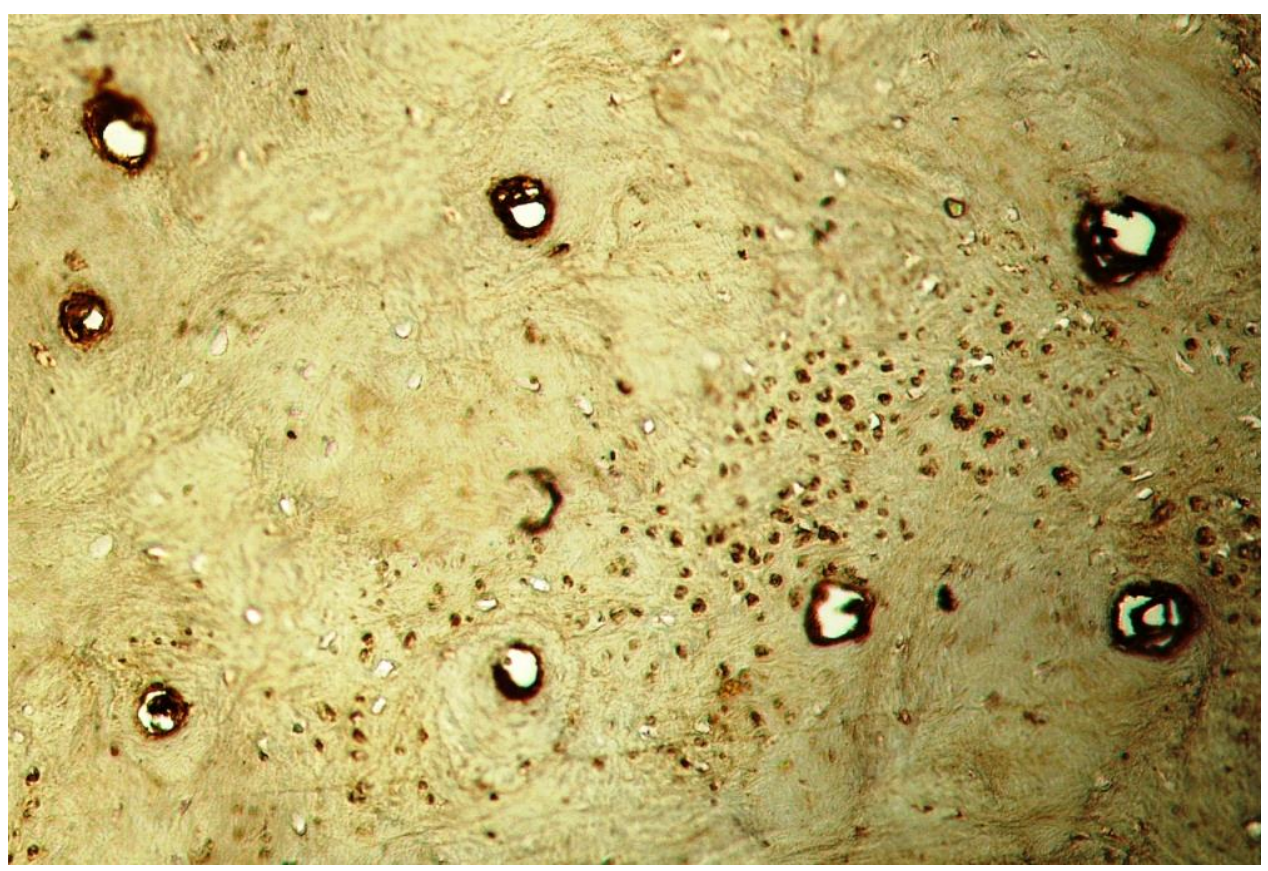

3.27. mikrofotogrāfija. Vidēji daudz (++) $O P G$ pozitīvu osteocītu 6 gadus un 9 mēnešus veca kontroles pacienta kaulaudos. $O P N I M H, \times 100$

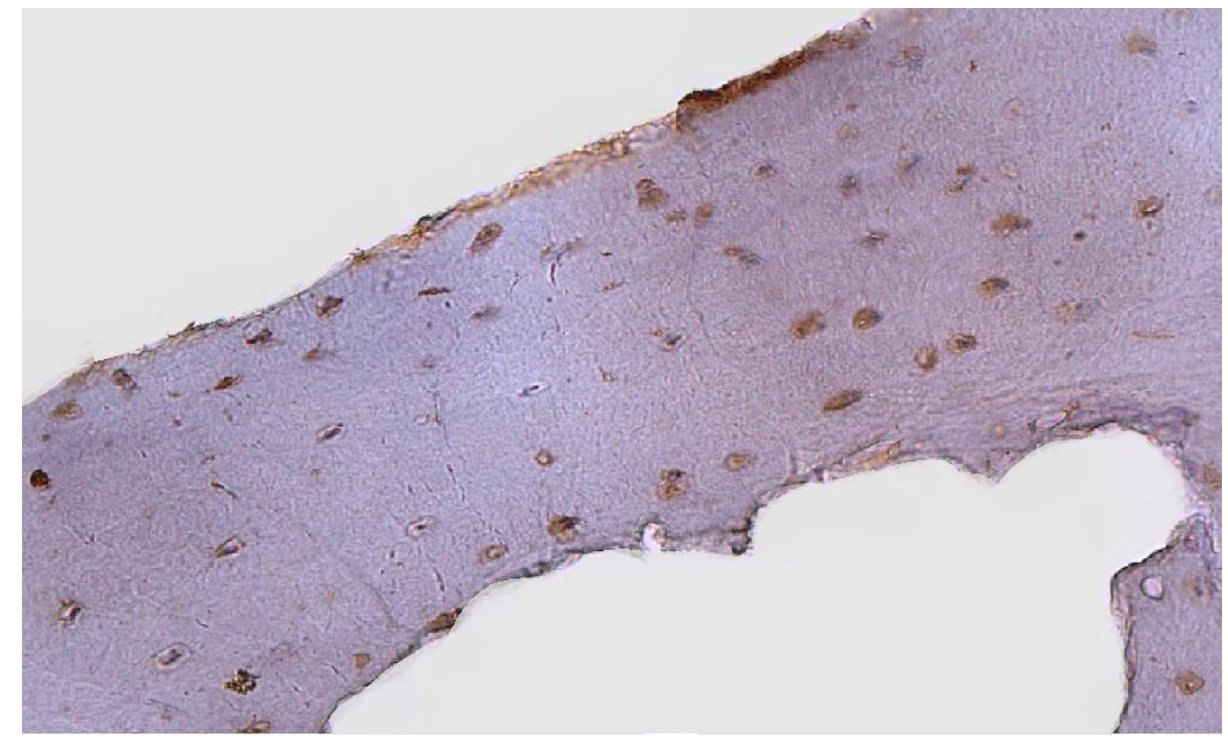

3.28. mikrofotogrāfija. Daudz (+++) BMP2/4 pozitīvu osteocītu 11 gadus un 7 mēnešus veca kontroles pacienta audos. BMP2/4 IMH, × 200 


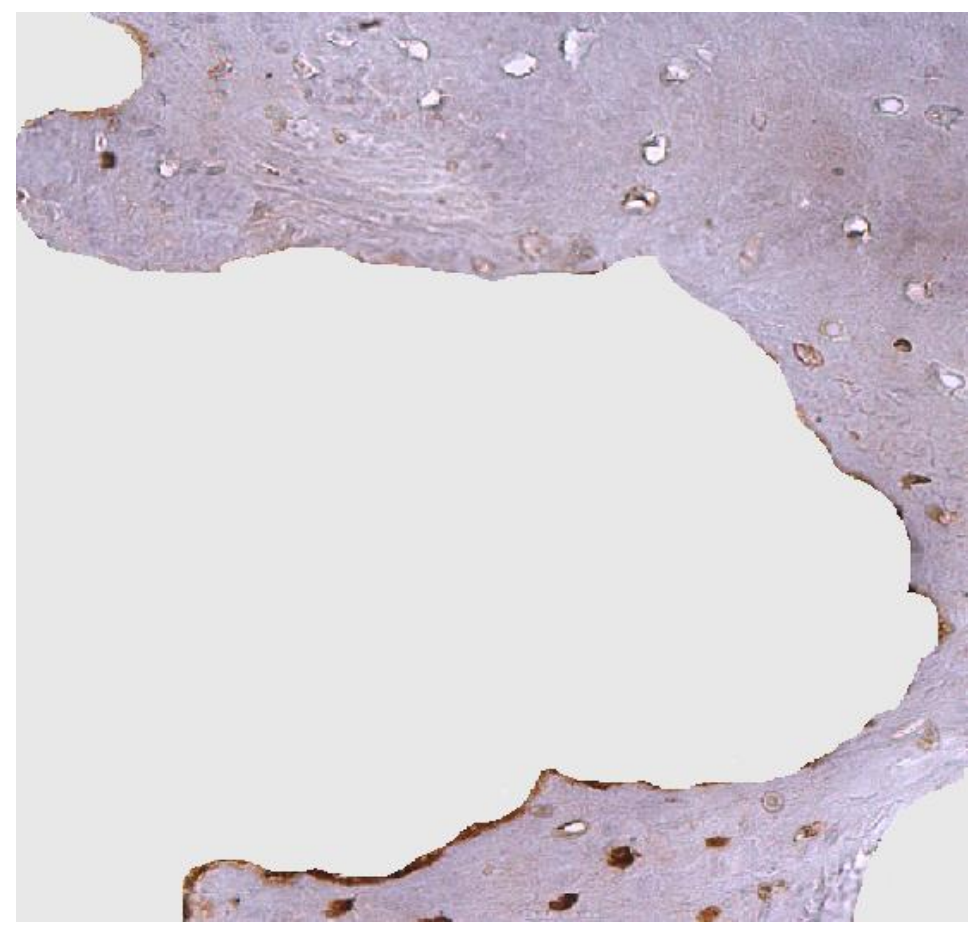

3.29. mikrofotogrāfija. Maz (+) MMP-2 pozitīvu osteocītu 10 gadus un 2 mēnešus veca kontroles pacienta kaulaudos. MMP-2 IMH, $\times 200$

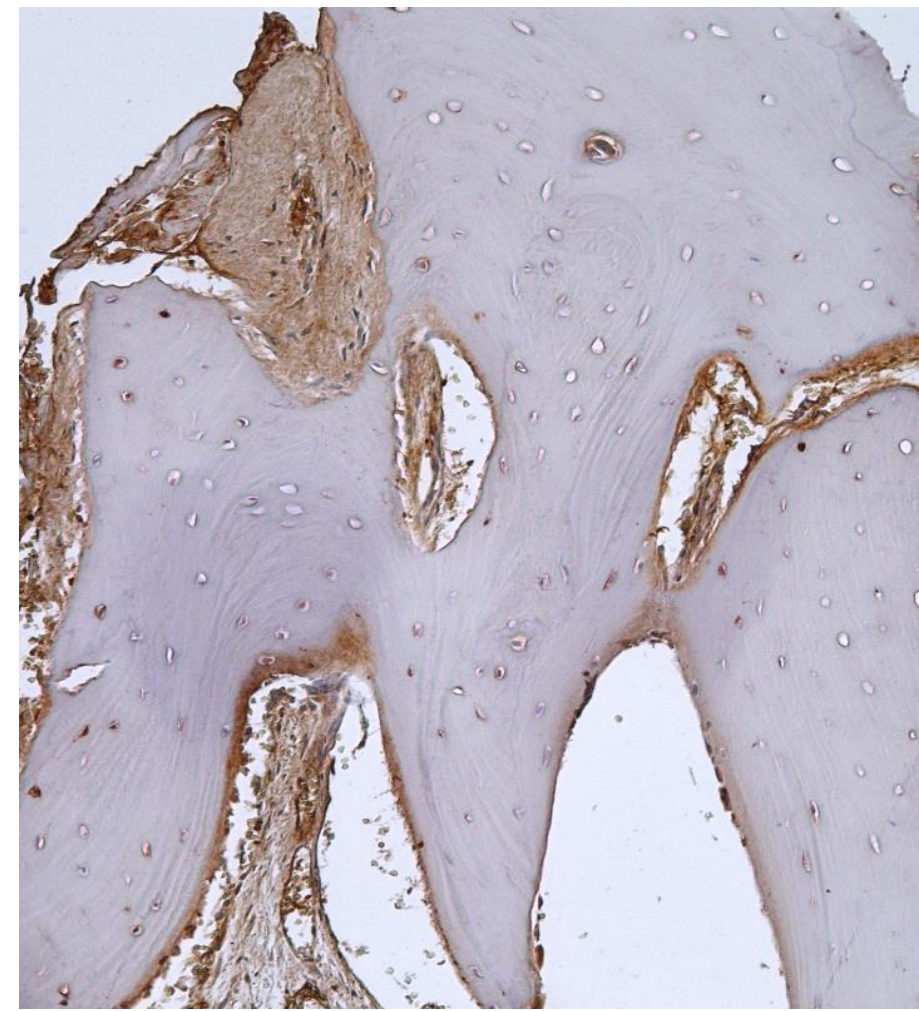

3.30. mikrofotogrāfija. Maz (+) TIMP-2 pozitīvu osteocītu 10 gadus un 2 mēnešus veca kontroles pacienta kaulaudos. MMP-2 IMH, × 200 


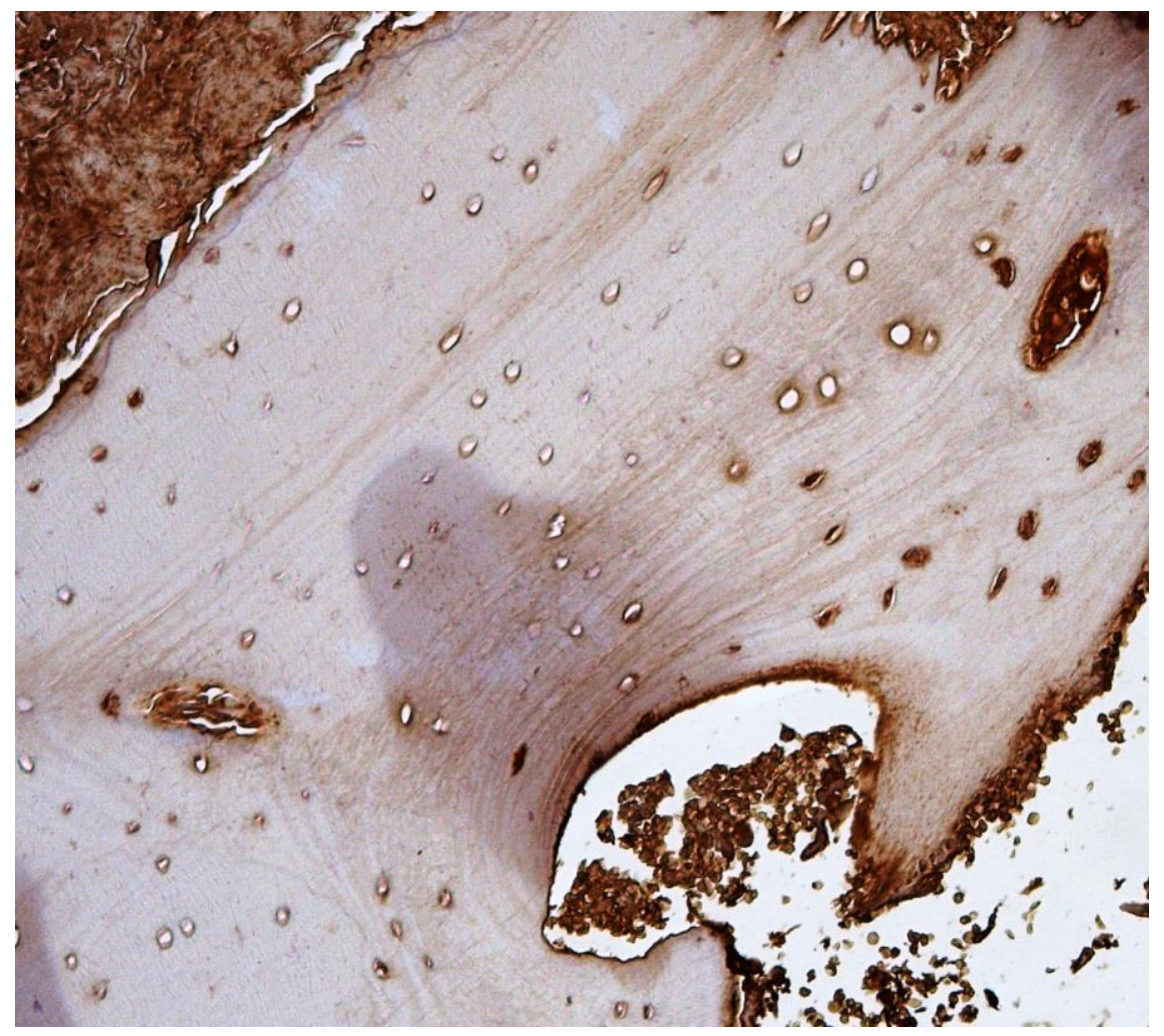

3.31. mikrofotogrāfija. Vidēji daudz (++) TGFß3 pozitīvu osteocītu 10 gadus un 2 mēnešus veca kontroles pacienta kaulaudos. TGFß3 IMH, × 100

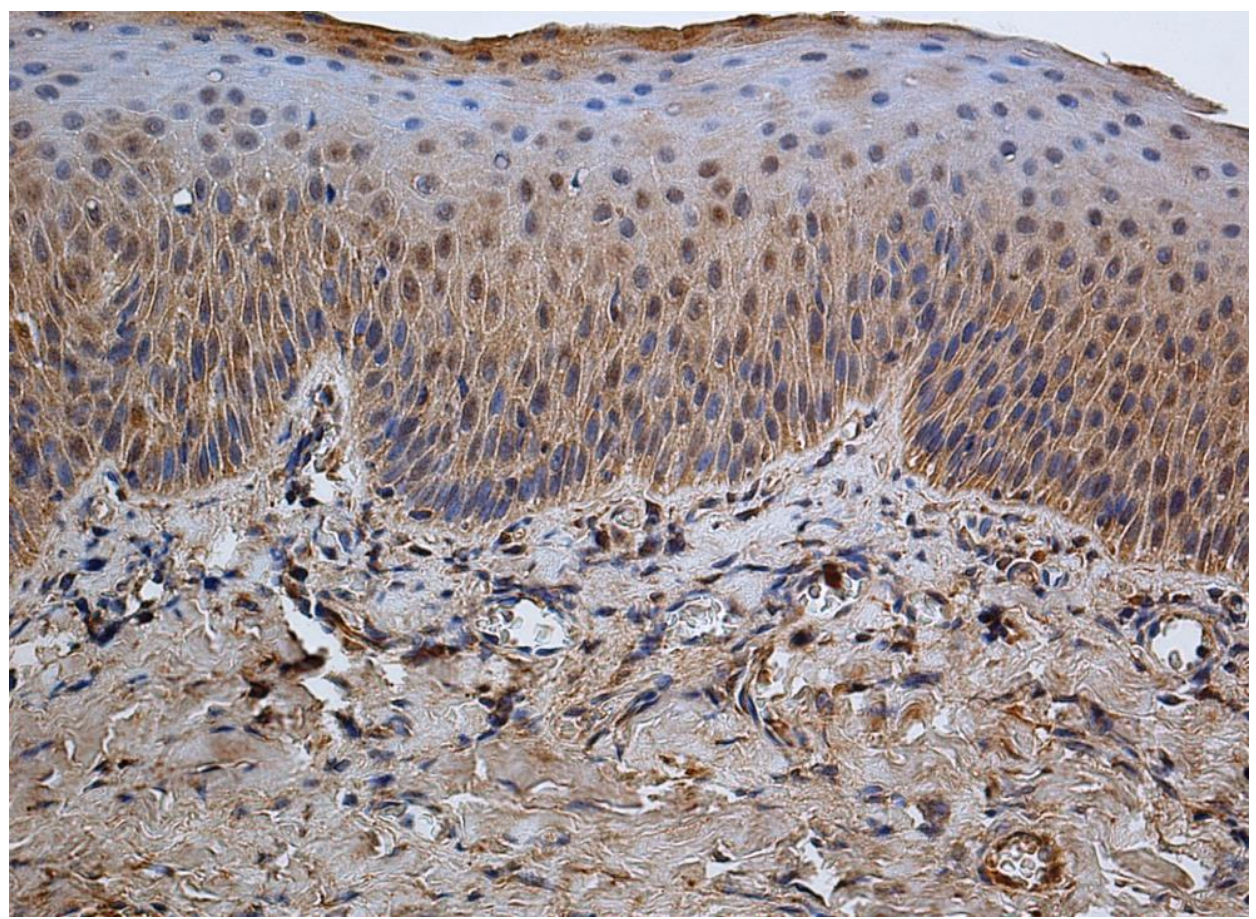

3.32. mikrofotogrāfija. Vidēji daudz (++) $M M P$-2 pozitīvu epitēlijšūnu un saistaudu šūnu mutes dobuma subepitēlijā 3 mēnešus vecam zīdainim ar abpusēju caurejošu lūpas, alveolārā izauguma un aukslēju šķeltni pēc lūpas plastikas. MMP-2 IMH, × 200 


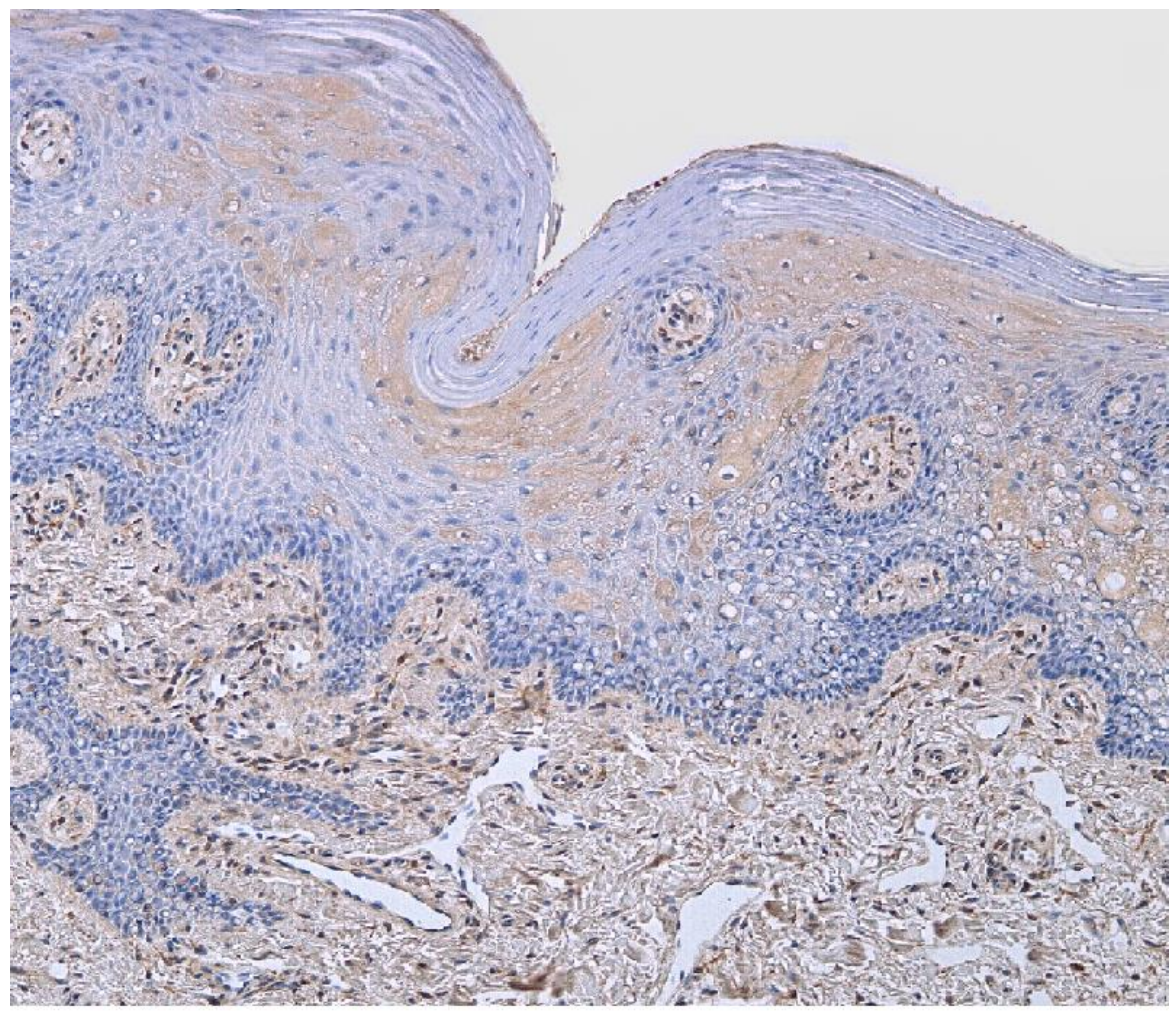

3.33. mikrofotogrāfija. Vidēji daudz (++) $M M P$-2 pozitīvu šūnu mutes dobuma saistaudos 3 mēnešus vecam zīdainim ar vienpusēju caurejošu lūpas, alveolārā izauguma un aukslēju škseltni pēc lūpas plastikas. MMP-2 IMH, × 100

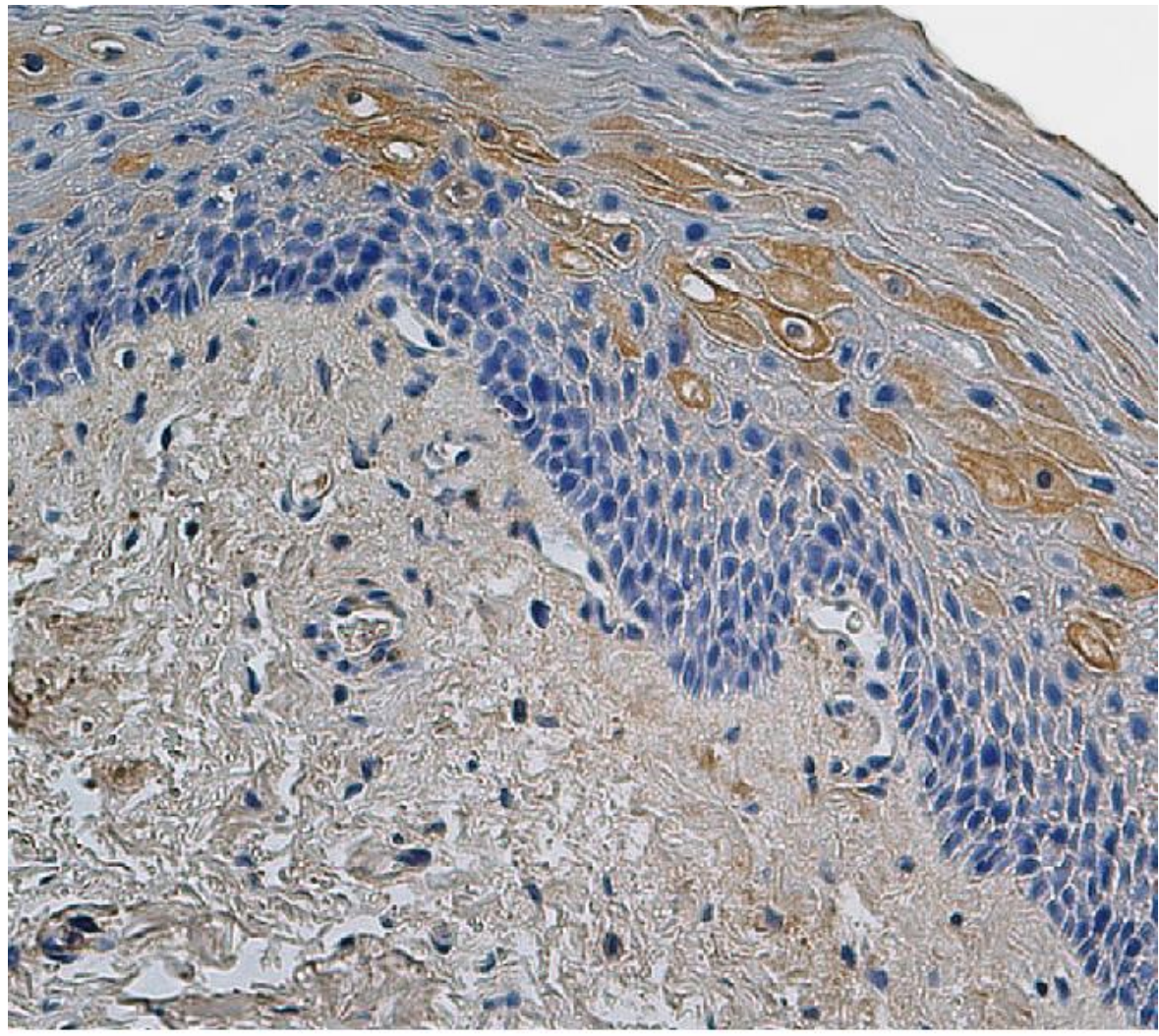

3.34. mikrofotogrāfija. Vidēji daudz (++) MMP-2 pozitīvu epitēlijšūnu mīksto aukslēju gḷotādā 9 mēnešus vecam bērnam ar abpusēju caurejošu lūpas, alveolārā izauguma un aukslēju škseltni. $M M P-2 I M H, \times 200$ 


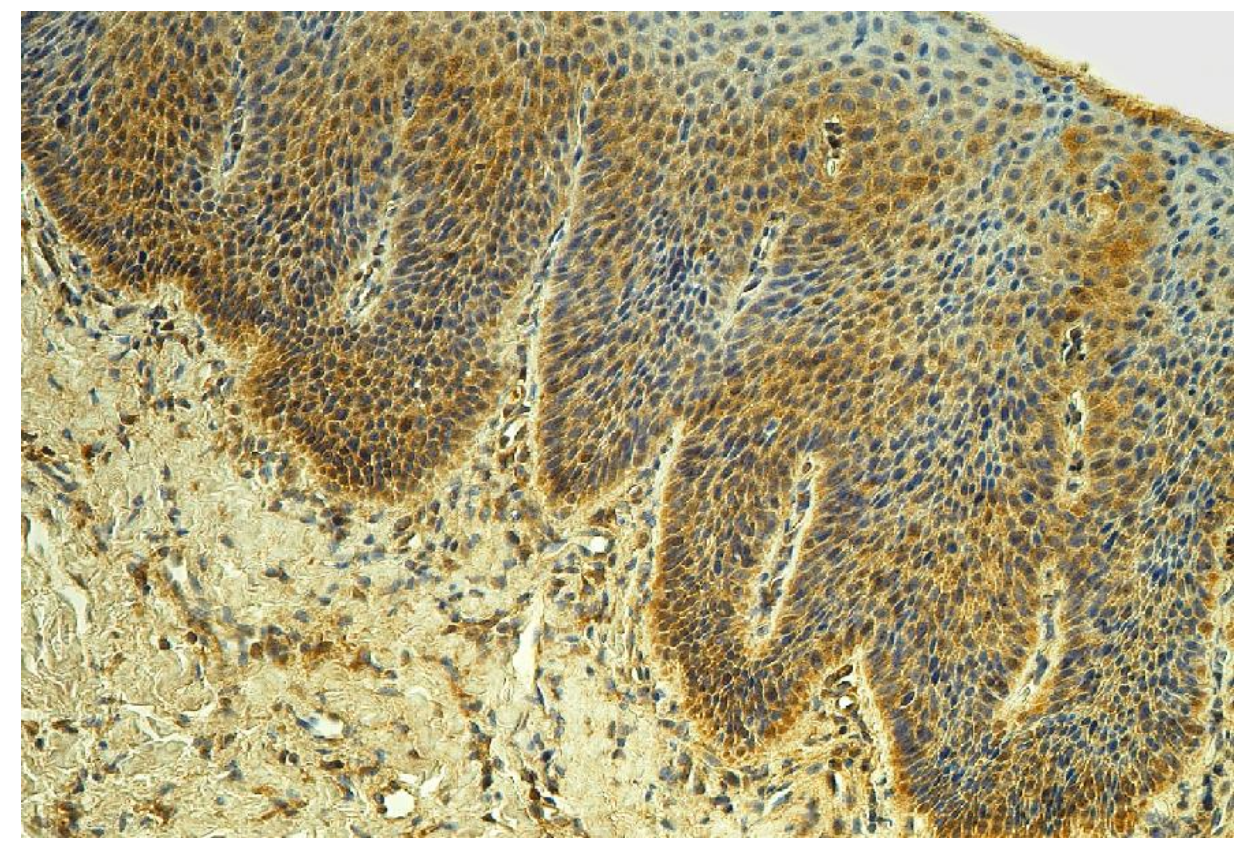

3.35. mikrofotogrāfija. Daudz (+++) $M M P$-2 pozitīvu šūnu cieto aukslēju glotādā 3 gadus un 3 mēnešus vecam bērnam ar abpusēju caurejošu lūpas, alveolārā izauguma un aukslēju škseltni. $M M P-2 I M H, \times 200$

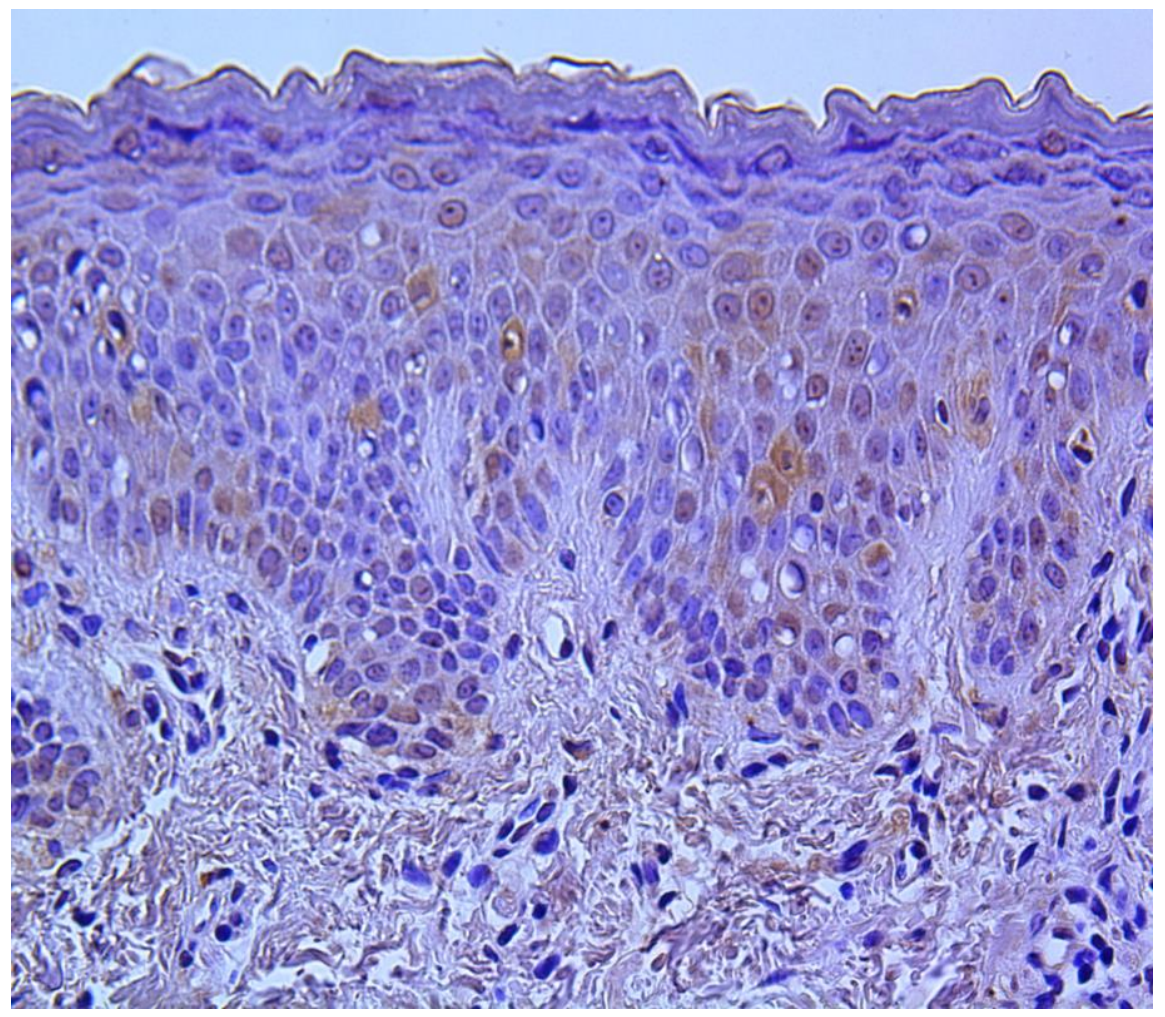

3.36. mikrofotogrāfija. Maz līdz vidēji daudz (+/++) MMP-8 pozitīvu mutes dobuma gọotādas epitēlijšūnu 3 mēnešus vecam zīdainim ar abpusēju caurejošu lūpas, alveolārā izauguma un aukslēju šķeltni pēc lūpas plastikas. $M M P-8 I M H, \times 200$ 


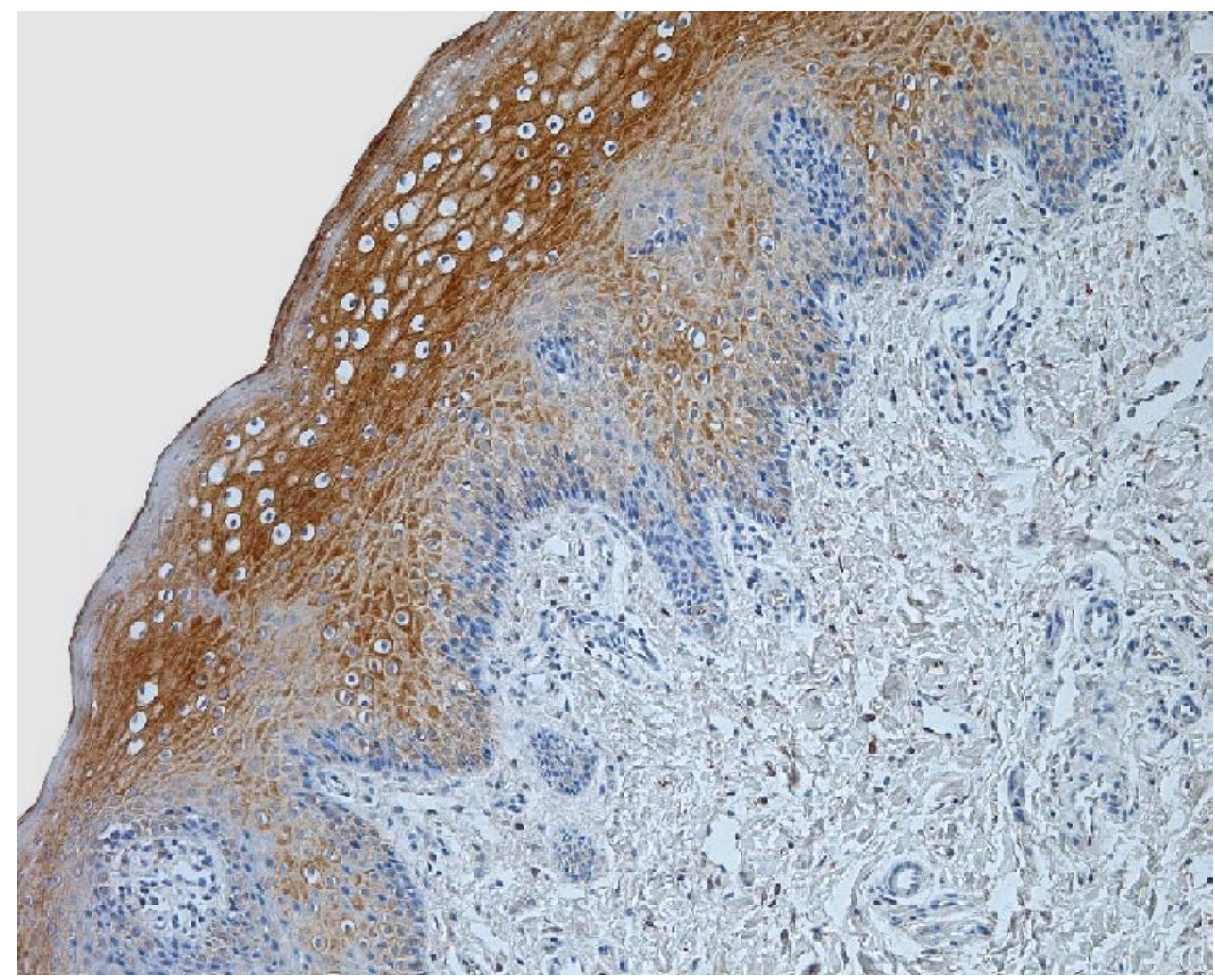

3.37. mikrofotogrāfija. Daudz (+++) MMP-8 pozitīvu epitēlijšūnu un maz (+) MMP-8 saturošu saistaudu šūnu 4 mēnešus vecam zīdainim ar vienpusēju caurejošu lūpas, alveolārā izauguma un aukslēju šķeltni pēc lūpas plastikas. MMP-8IMH, × 100

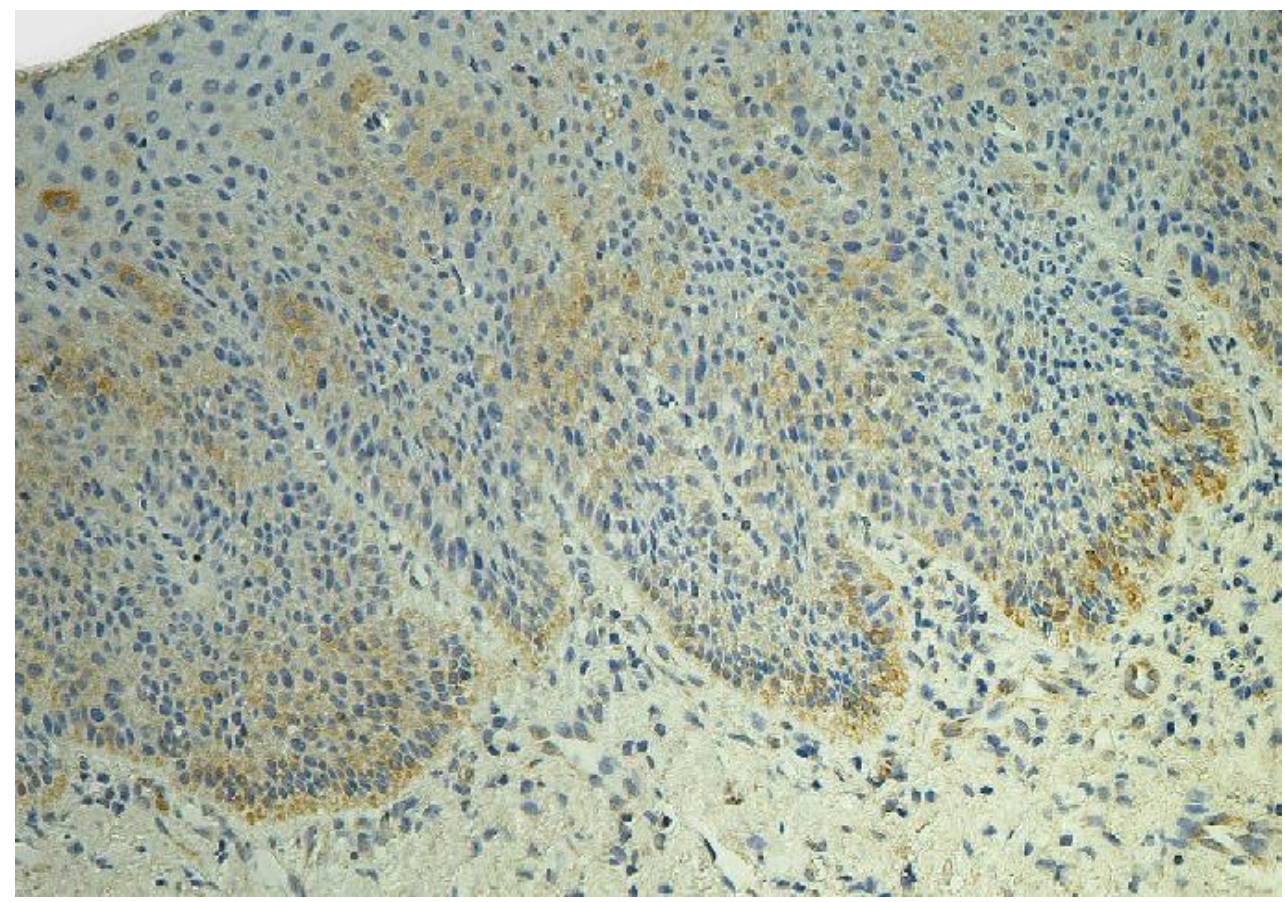

3.38. mikrofotogrāfija. Vidēji daudz (++) $M M P-8$ pozitīvu šūnu mīksto aukslēju glototādā 9 mēnešus vecam zīdainim ar abpusēju caurejošu lūpas, alveolārā izauguma un aukslēju šķeltni. MMP-8 IMH, × 200 


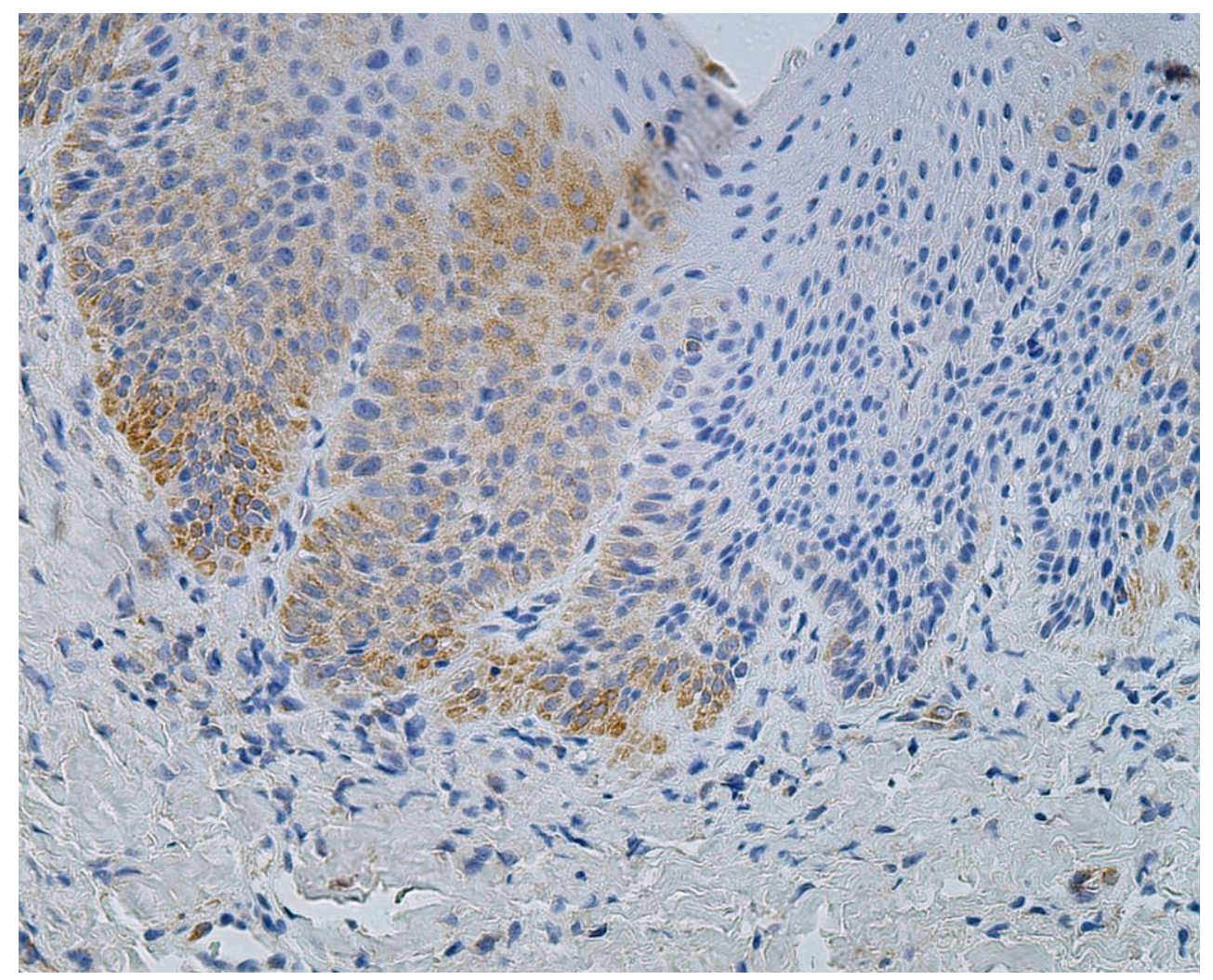

3.39. mikrofotogrāfija. Maz līdz vidēji daudz (+/++) MMP-8 pozitīvu šūnu cieto aukslēju gḷotādā 3 gadus un 4 mēnešus vecam bērnam ar abpusēju caurejošu lūpas, alveolārā izauguma un aukslēju šķeltni. $M M P-8 I M H, \times 200$

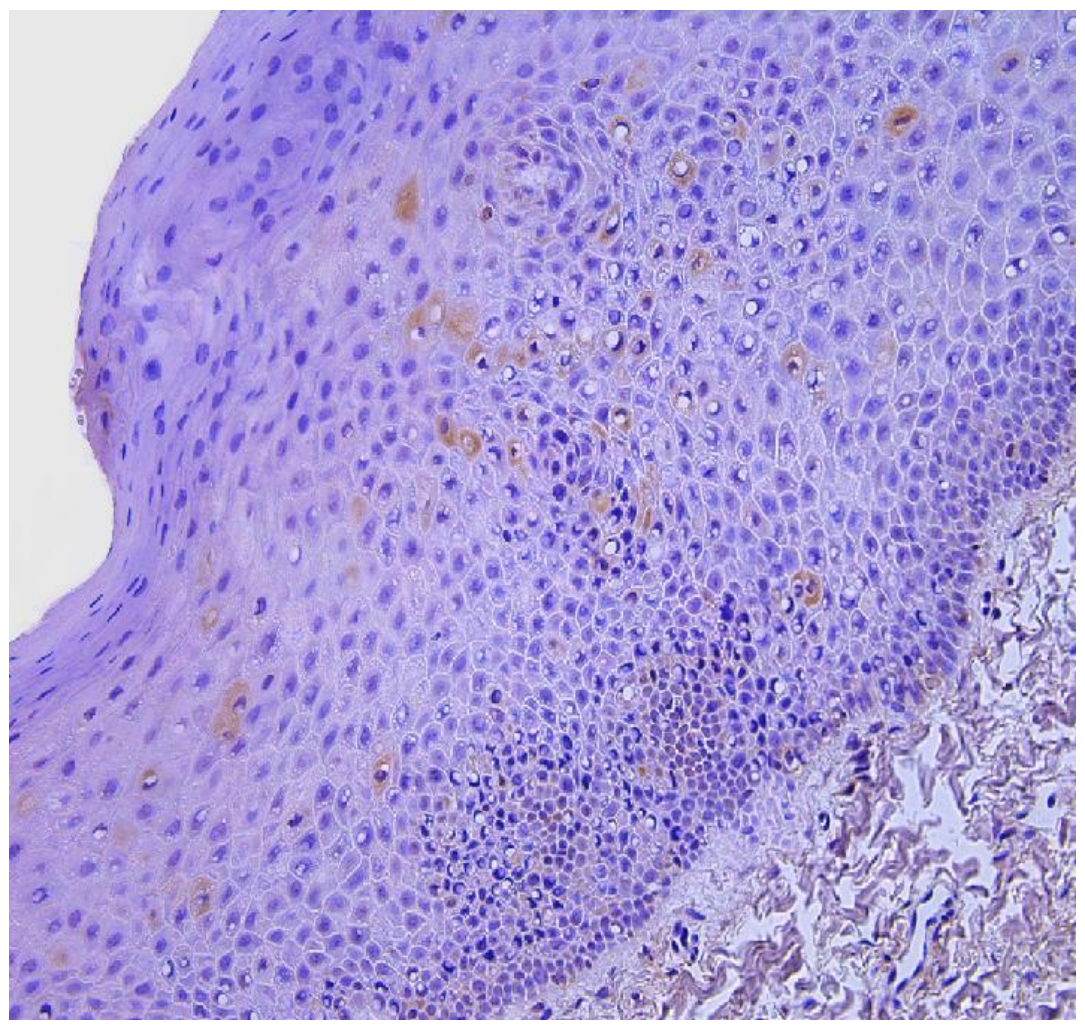

3.40. mikrofotogrāfija. Retas (0/+) MMP-9 pozitīvas epitēlijǔs̄nas 4 mēnešus vecam zīdainim ar abpusēju caurejošu lūpas, alveolārā izauguma un aukslēju šķeltni pēc lūpas plastikas. MMP-9 IMH, × 200 


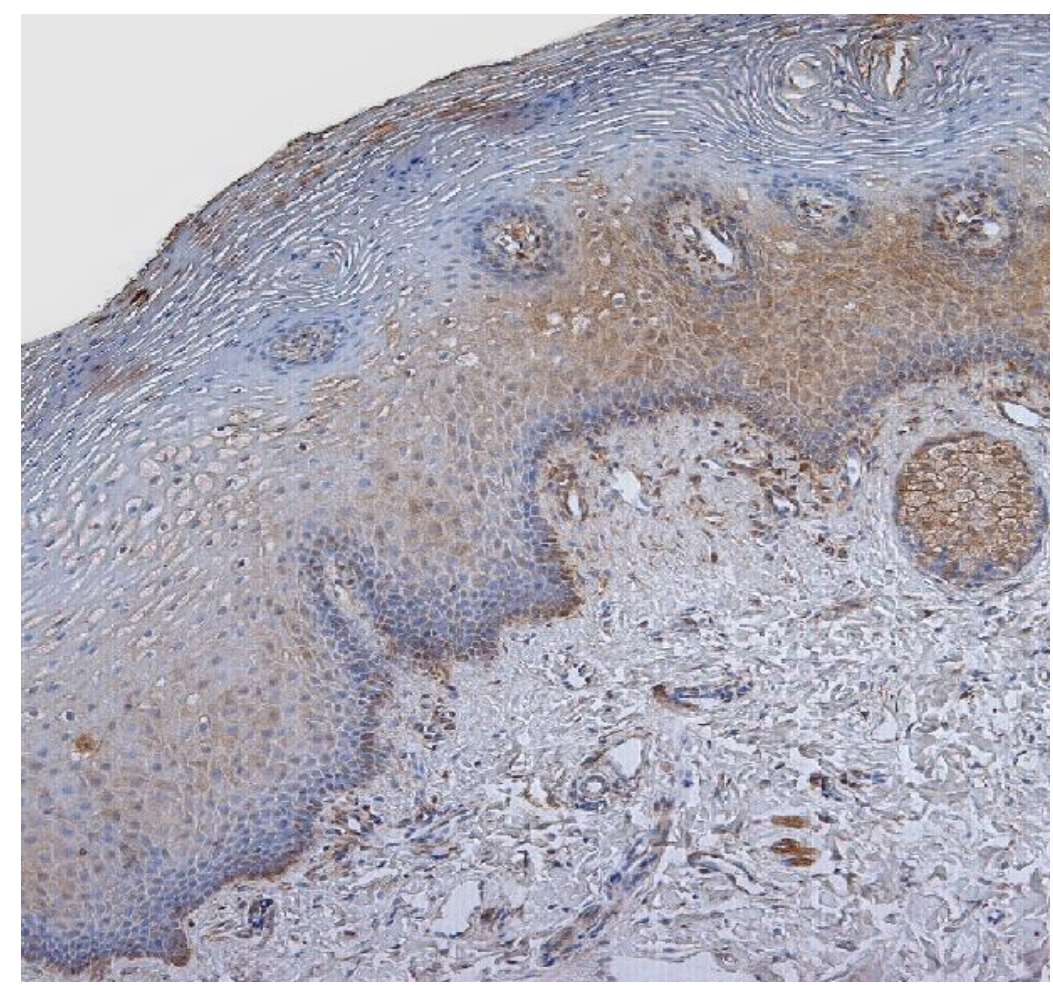

3.41. mikrofotogrāfija. Vidēji daudz (++) MMP-9 pozitīvu epitēlijšūnu un daudz (+++) MMP-9 saturošu saistaudu šūnu 3 mēnešus vecam zīdainim ar vienpusēju šķeltni pēc lūpas plastikas. $M M P-9 I M H, \times 100$

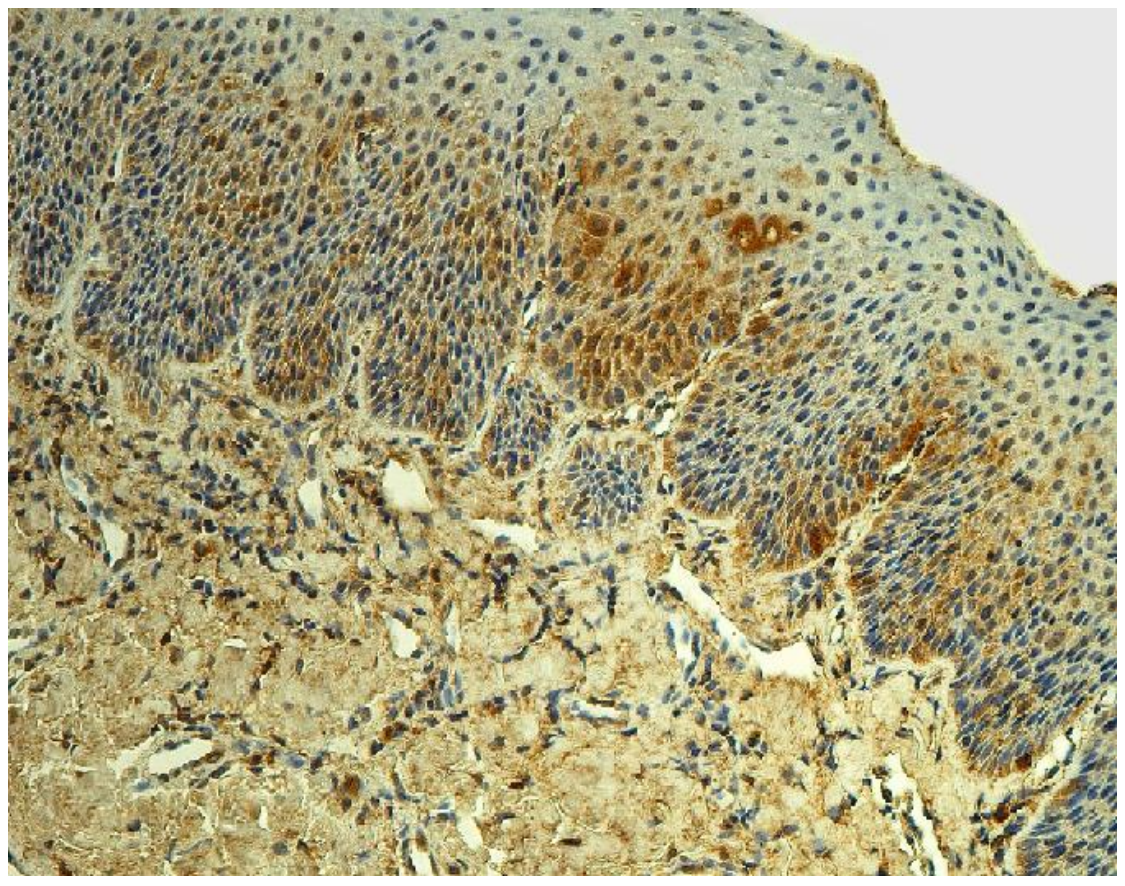

3.42. mikrofotogrāfija. Vidēji daudz (++) MMP-9 pozitīvu epitēlijšūnu un daudz (+++) MMP-9 saturošu saistaudu šūnu mīksto aukslēju gḷotādā 9 mēnešus vecam zīdainim ar abpusēju caurejošu lūpas, alveolārā izauguma un aukslēju škseltni. $M M P-9 I M H, \times 200$ 


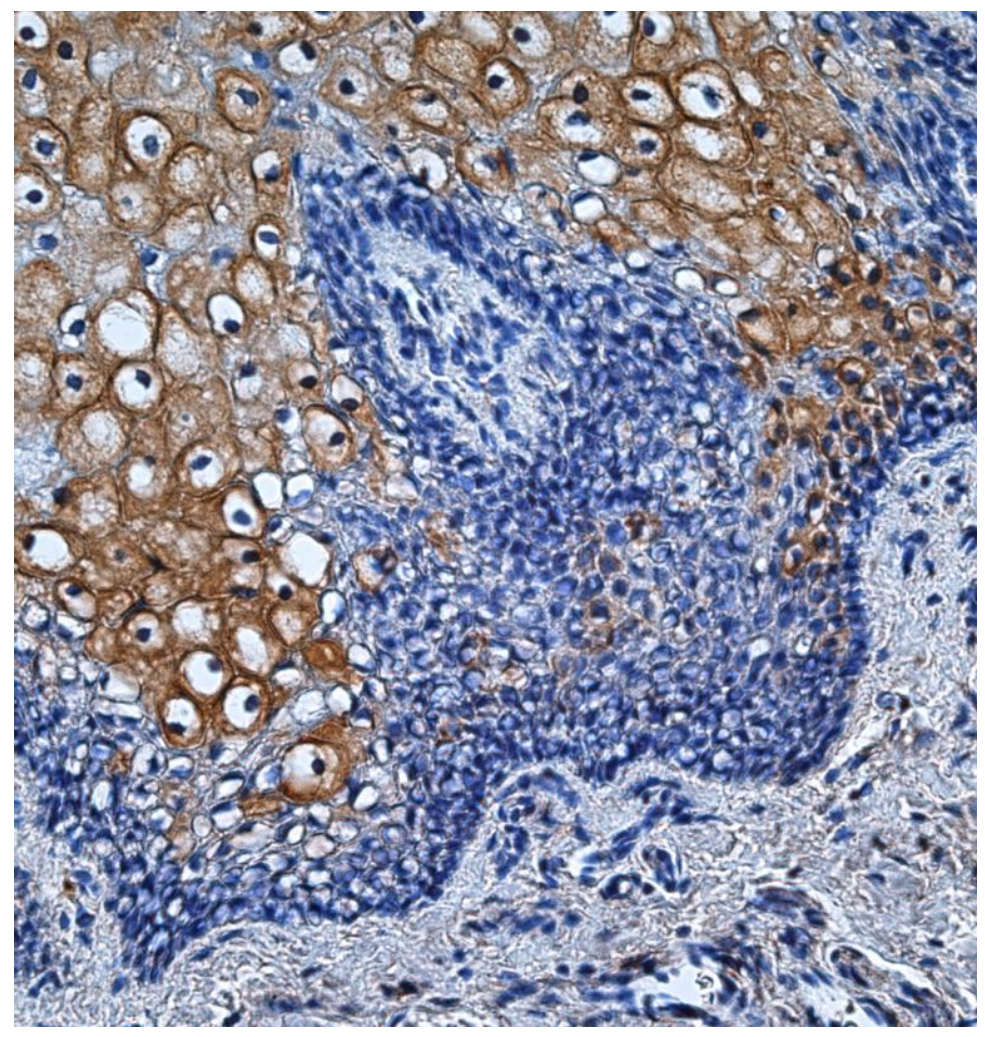

3.43. mikrofotogrāfija. Vidēji daudz līdz daudz (++/+++) TIMP-2 pozitīvu polimorfā slāṇa epitēlijšūnu lūpas plastikas laikā iegūtajā glototādā 3 mēnešus vecam zīdainim ar abpusēju caurejošu lūpas, alveolārā izauguma un aukslēju škseltni. TIMP-2 IMH, × 250

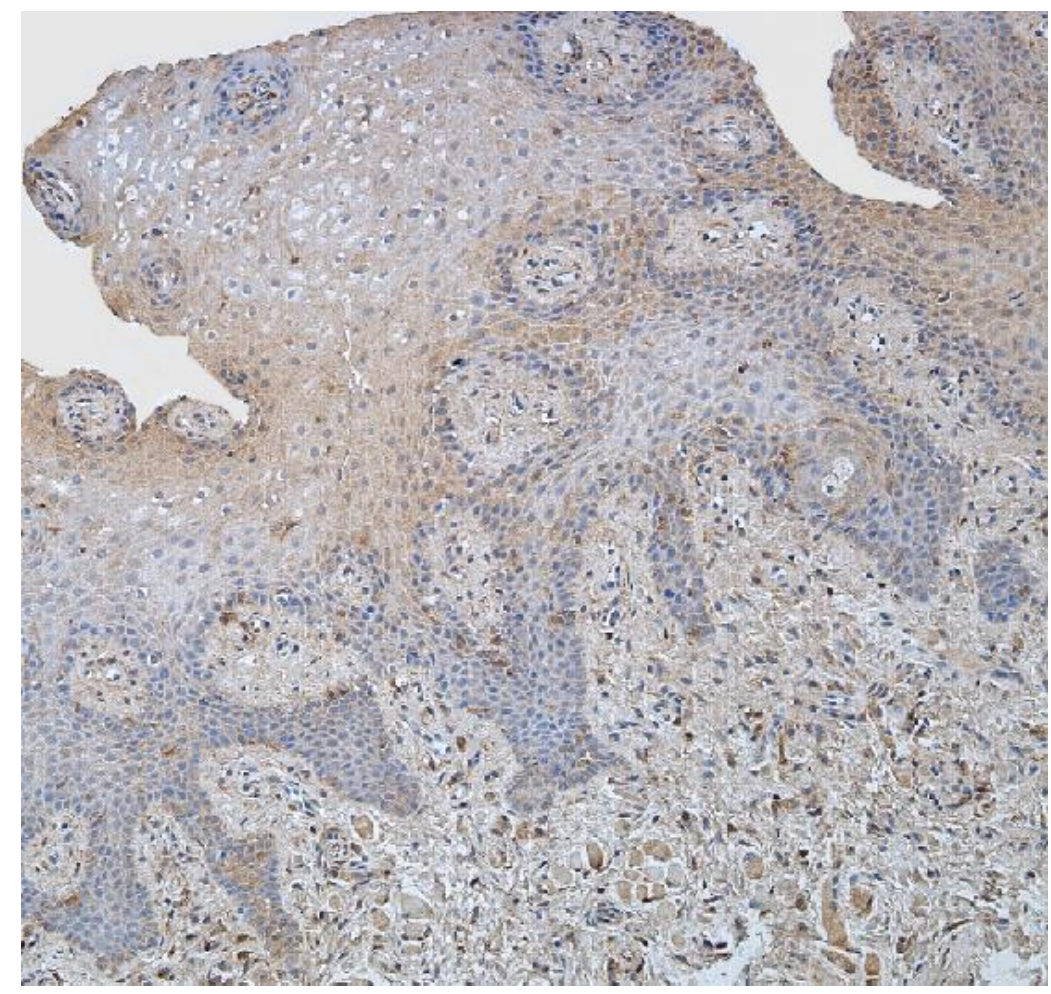

3.44. mikrofotogrāfija. Vidēji daudz (++) TIMP-2 vāji pozitīvas bazālā un polimorfā slāṇa epitēlijjšūnas un vidēji daudz līdz daudz (++/+++) TIMP-2 saturošas saistaudu šūnas lūpas plastikas laikā iegūtajā gḷotādā 3 mēnešus vecam zīdainim ar vienpusēju caurejošu lūpas, alveolārā izauguma un aukslēju šķeltni. TIMP-2 IMH, × 200 


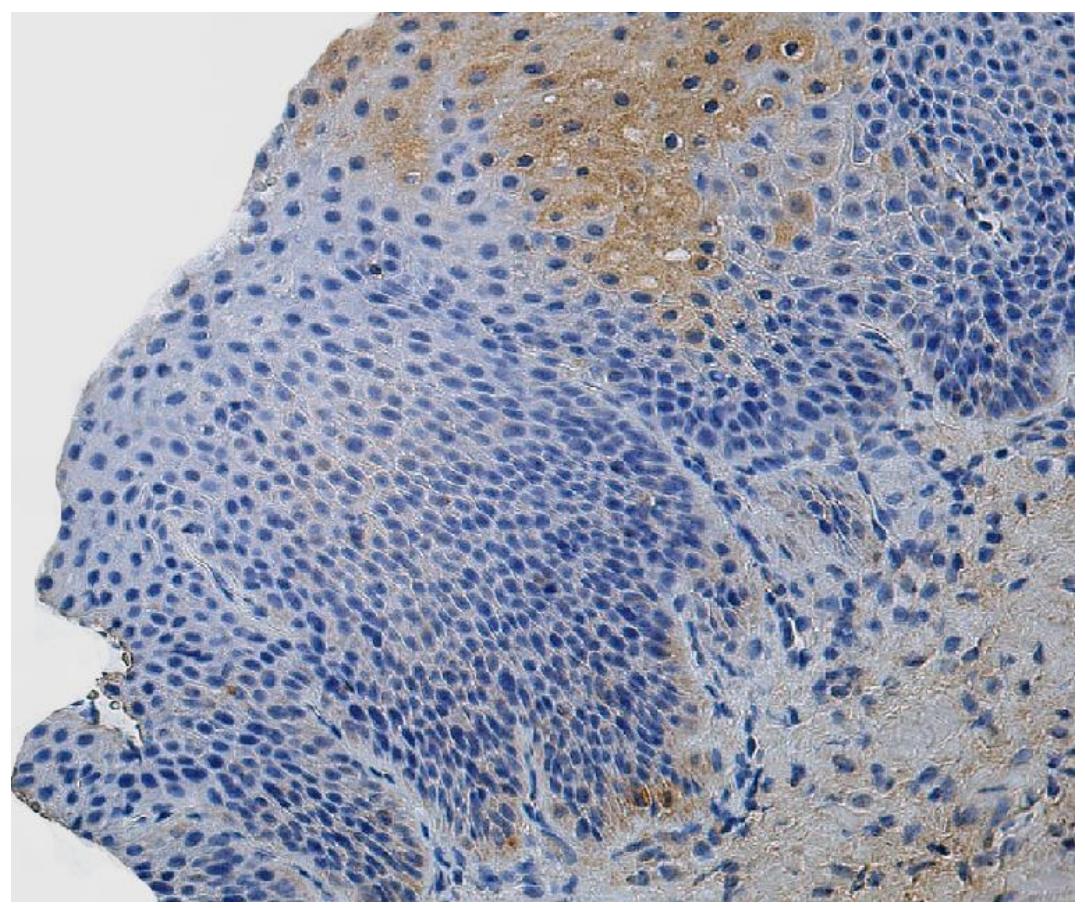

3.45. mikrofotogrāfija. Maz (+) TIMP-2 pozitīvu epitēlijšūnu un retas (0/+) TIMP-2 saturošas saistaudu šūnas mīksto aukslēju glototādā 9 mēnešus vecam zīdainim ar abpusēju caurejošu lūpas, alveolārā izauguma un aukslēju škseltni. TIMP-2 IMH, × 200

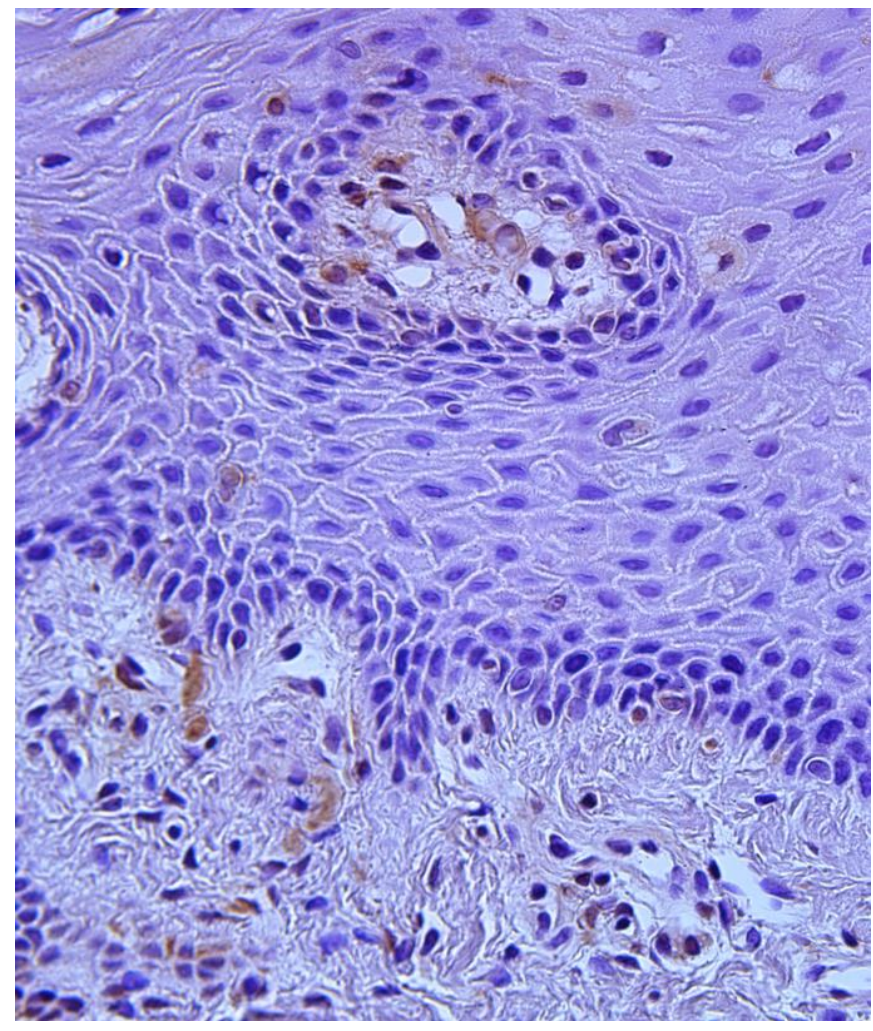

3.46. mikrofotogrāfija. Retas (0/+) TIMP-4 pozitīvas epitēlijšūnas un maz (+) TIMP-4 saturošu saistaudu šūnu 4 mēnešus vecam zīdainim ar abpusēju caurejošu lūpas, alveolārā izauguma un aukslēju škeltni pēc lūpas plastikas. TIMP-4 IMH, × 400 


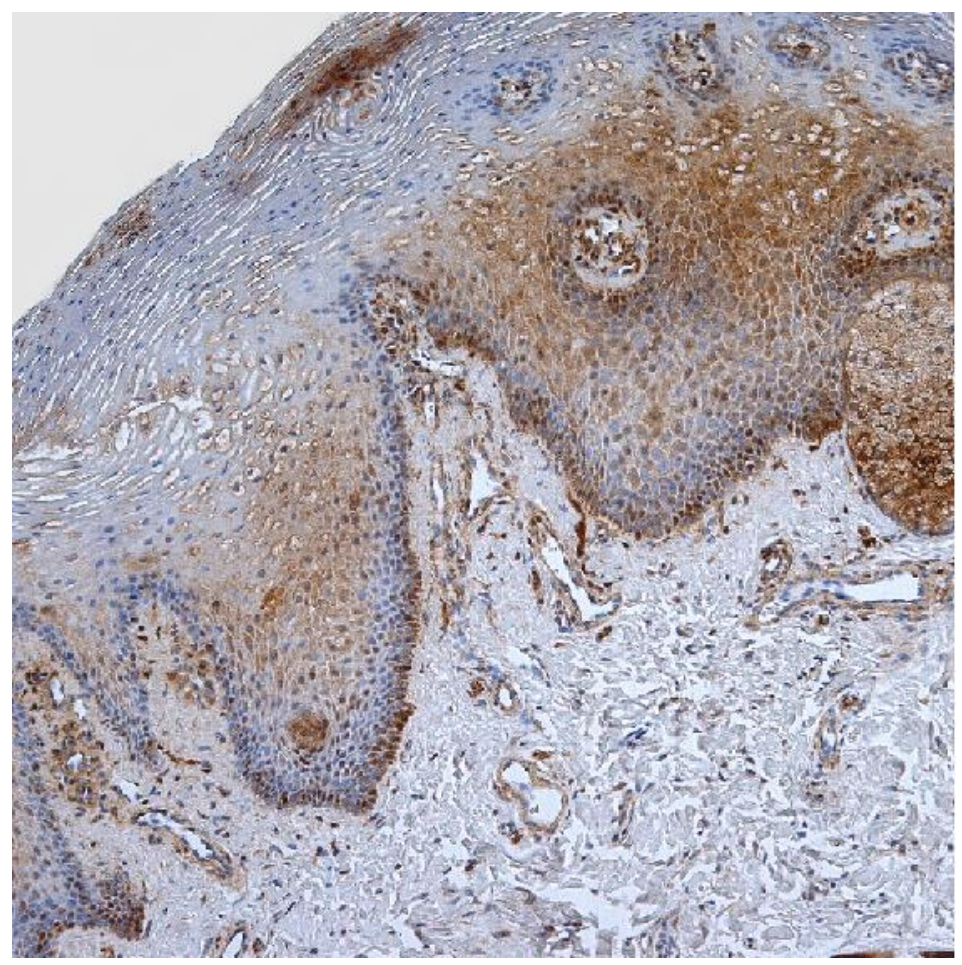

3.47. mikrofotogrāfija. Vidēji daudz (++) TIMP-4 pozitīvu poligonālā slāṇa epitēlijšūnu, bagātīga TIMP-4 ekspresija bazālās šūnās un daudz (+++) faktoru saturošu saistaudu šūnu 3 mēnešus vecam zīdainim ar vienpusēju šķeltni pēc lūpas plastikas.

$$
\text { TIMP-4 IMH, × } 100
$$

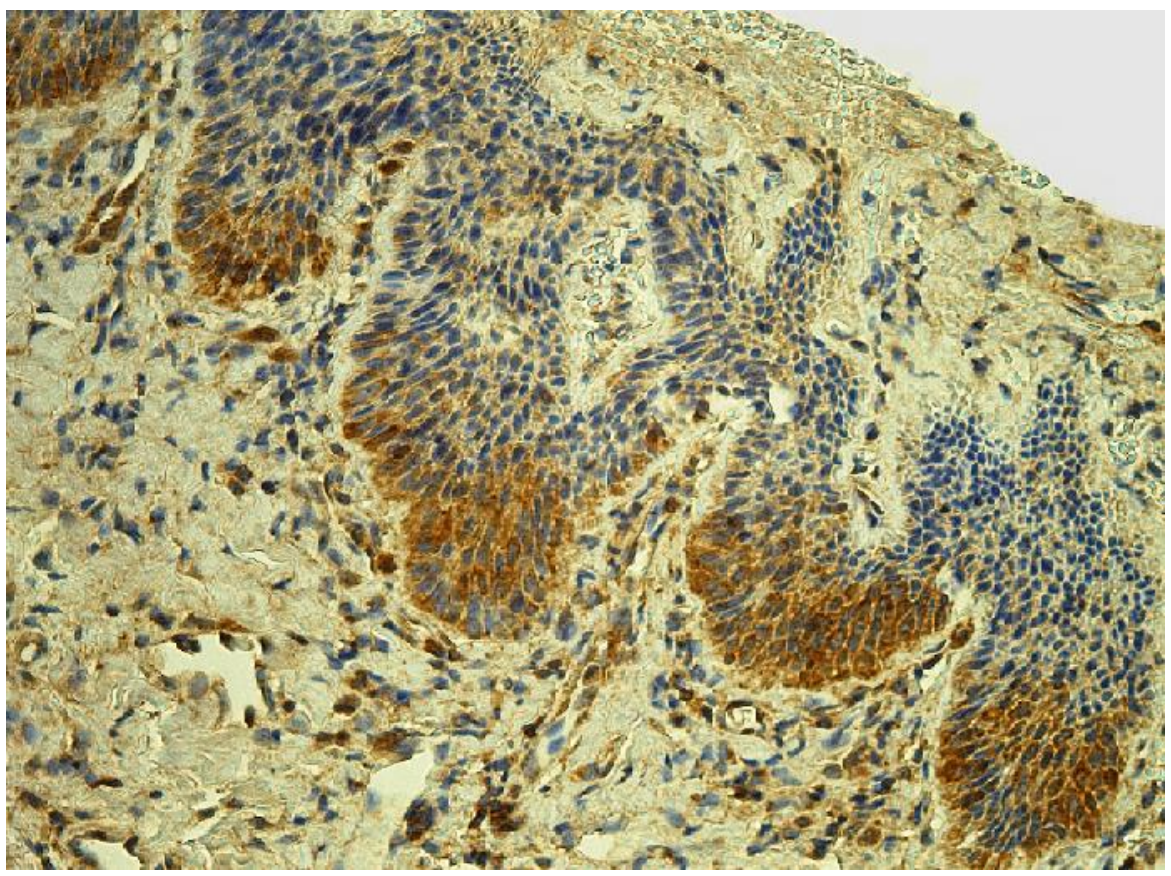

3.48. mikrofotogrāfija. Vidēji daudz (++) TIMP-4 pozitīvu epitēlijšūnu un vidēji daudz (++) TIMP-4 saturošu saistaudu šūnu 3 gadus, 3 mēnešus vecam zīdainim ar abpusēju škseltņi pēc mīksto aukslēju plastikas. TIMP-4 IMH, × 250 


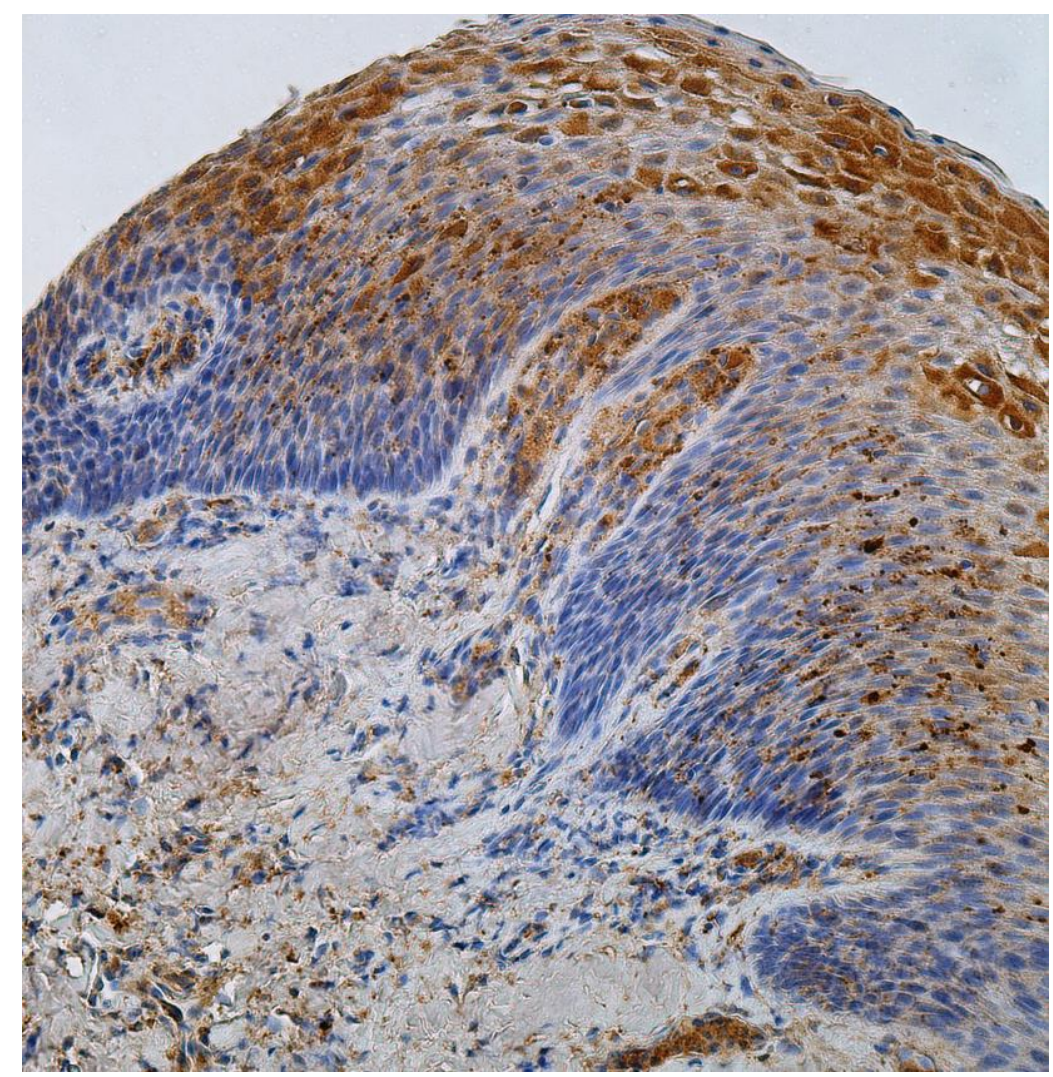

3.49. mikrofotogrāfija. Vidēji daudz līdz daudz (++/+++) TIMP-4 pozitīvu epitēlijšūnu un saistaudu šūnu 3 gadus, 3 mēnešus vecam zīdainim ar abpusēju šķeltni pēc cieto aukslēju plastikas. TIMP-4 IMH, × 200

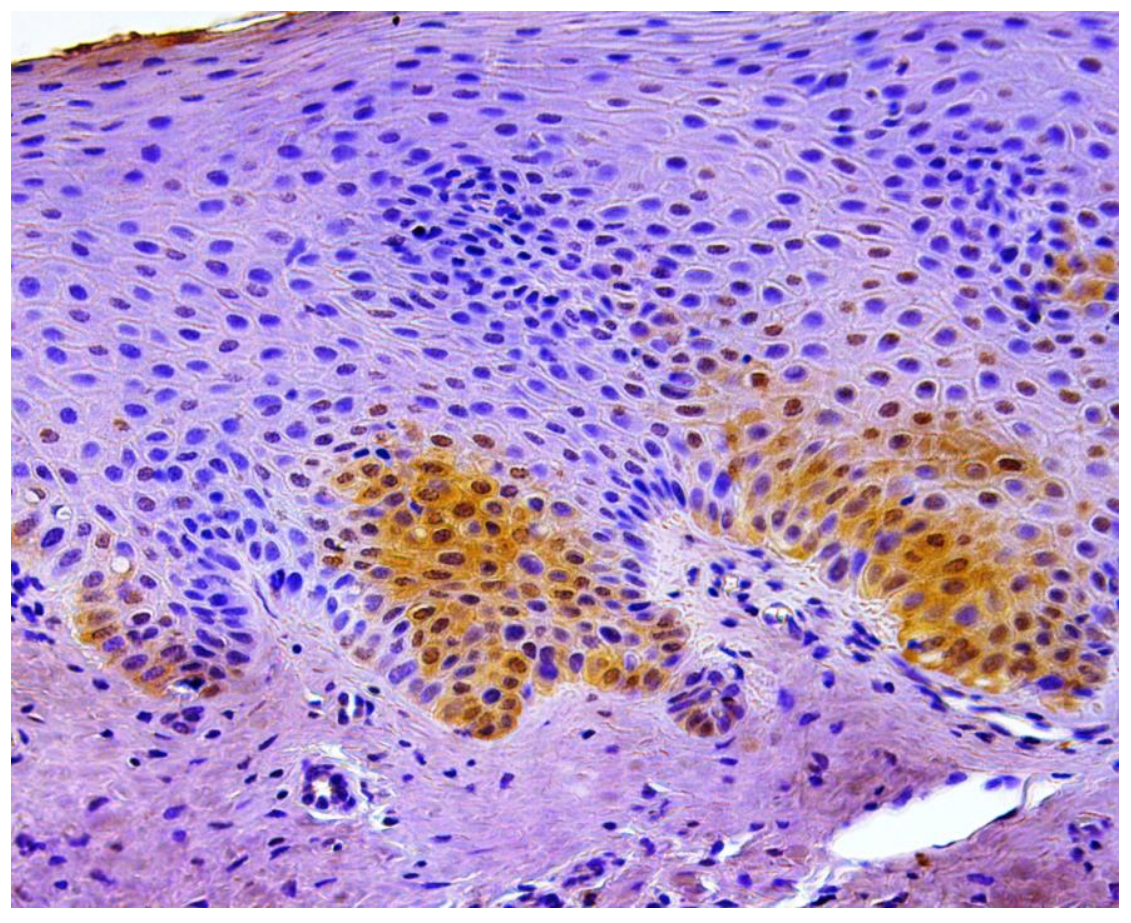

3.50. mikrofotogrāfija. Maz (+) MSX1 saturošu epitēlijšūnu lūpas plastikas laikā iegūtajā materiālā 3 mēnešus vecam pacientam ar abpusēju caurejošu lūpas, alveolārā izauguma un aukslēju šķeltni. MSX1 IMH, × 200 


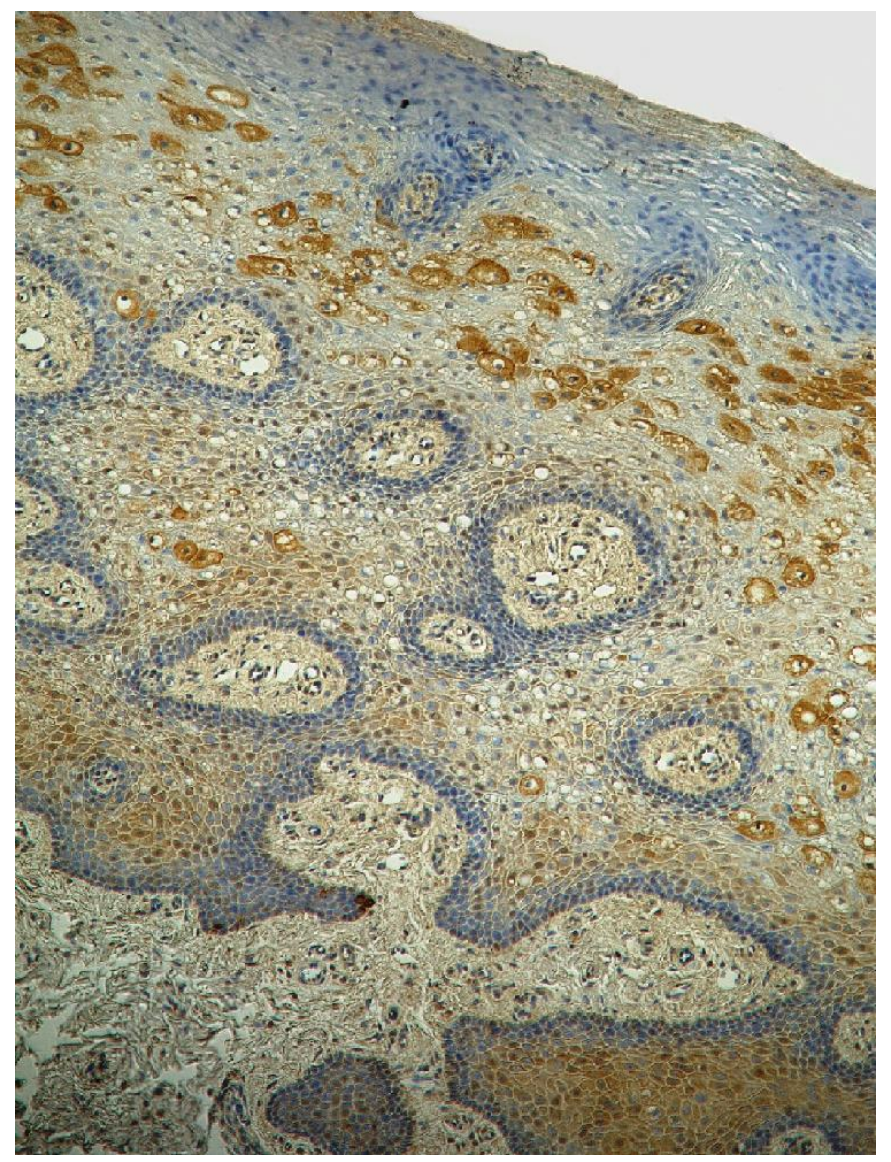

3.51. mikrofotogrāfija. Vidēji daudz līdz daudz (++/+++) perēkḷveidīgu izvietotu MSX1 saturošu epitēlijšūnu un saistaudu šūnu lūpas plastikas laikā iegūtajā materiālā 4 mēnešus vecam pacientam ar vienpusēju caurejošu lūpas, alveolārā izauguma un aukslēju škseltni. MSX1 IMH, × 100

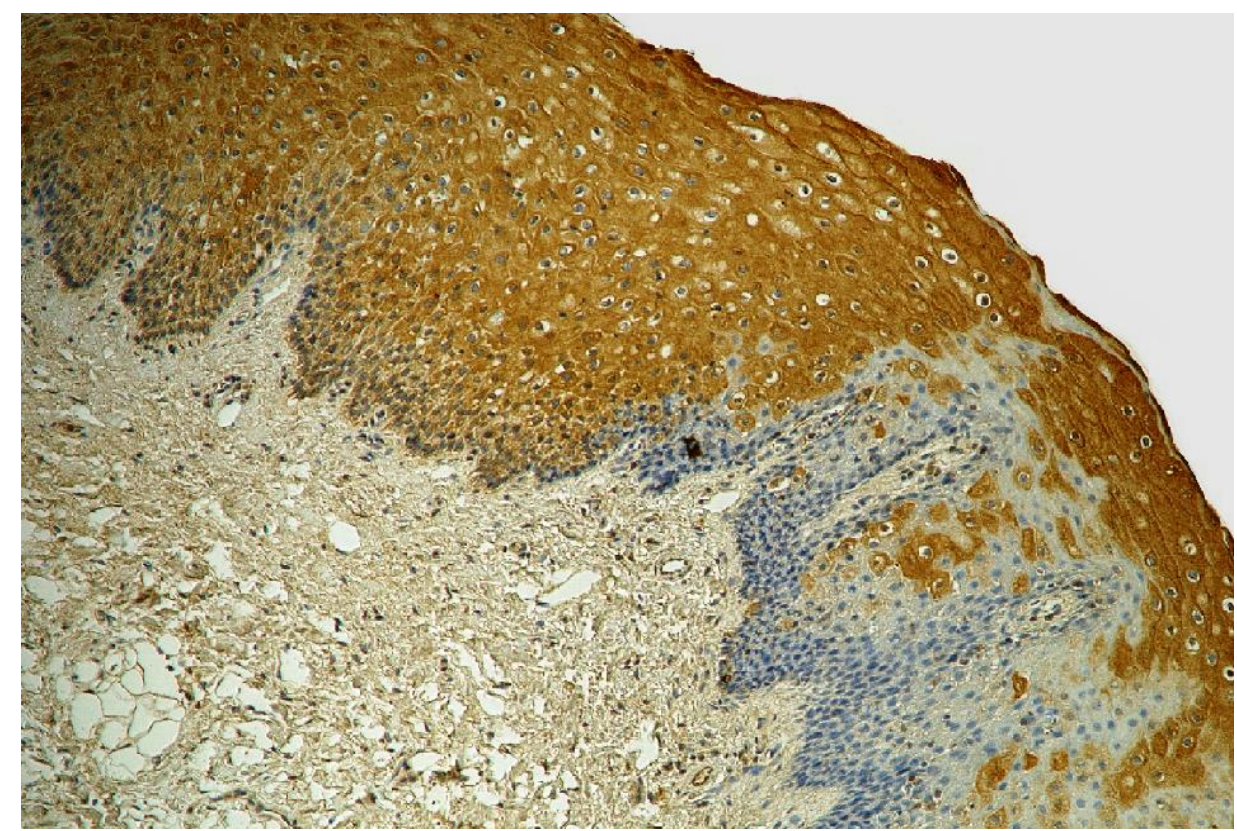

3.52. mikrofotogrāfija. Daudz līdz ḷoti daudz (+++/++++) MSX1 saturošu epitēlijšūnu un vidēji daudz (++) saistaudu šūnu cieto aukslēju plastikas laikā iegūtajā materiālā 3 gadus vecam pacientam ar abpusēju caurejošu lūpas, alveolārā izauguma un aukslēju škseltni. MSX1 IMH, × 100 


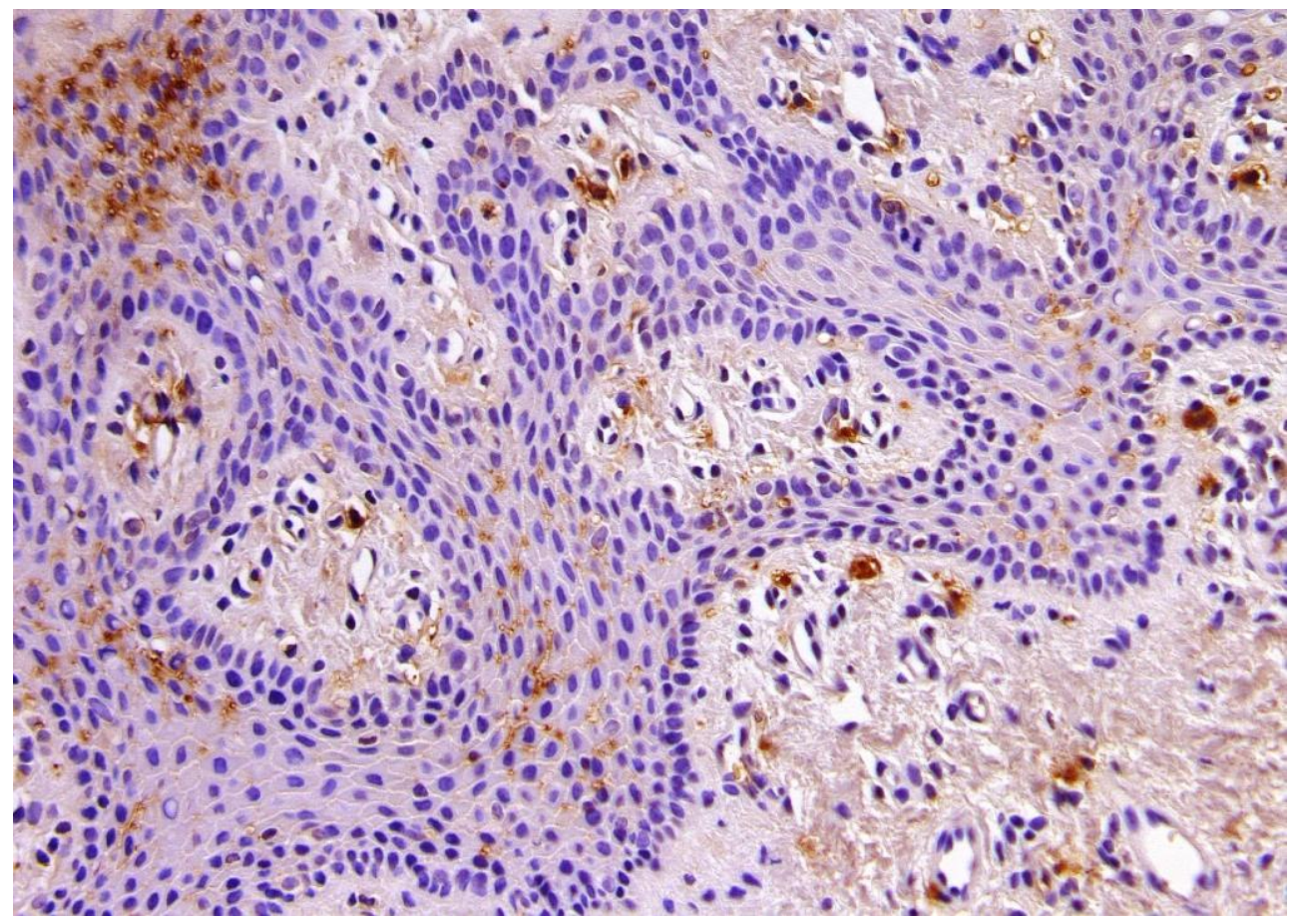

3.53. mikrofotogrāfija. Maz (+) IRF6 pozitīvu epitēlijšūnu un vidēji daudz (++) saistaudu šūnu 4 mēnešus vecam zīdainim ar abpusēju škseltni - lūpas plastika. IRF6 IMH, $\times 200$

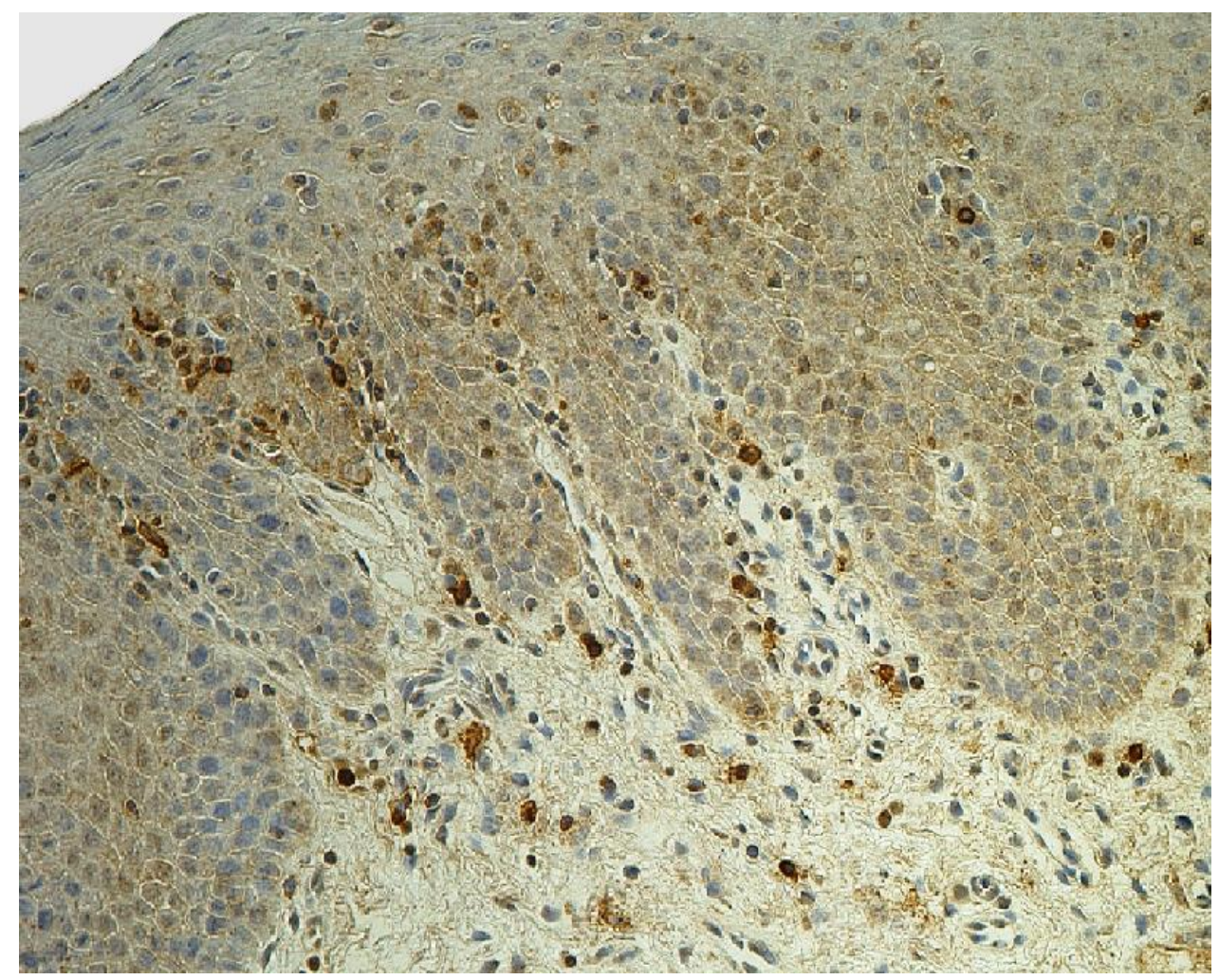

3.54. mikrofotogrāfija. Vidēji daudz (++) IRF6 pozitīvu saistaudu šūnu subepitēlijā 3 mēnešus vecam zīdainim ar vienpusēju šķeltni - lūpas plastika. IRF6 IMH, × 200 


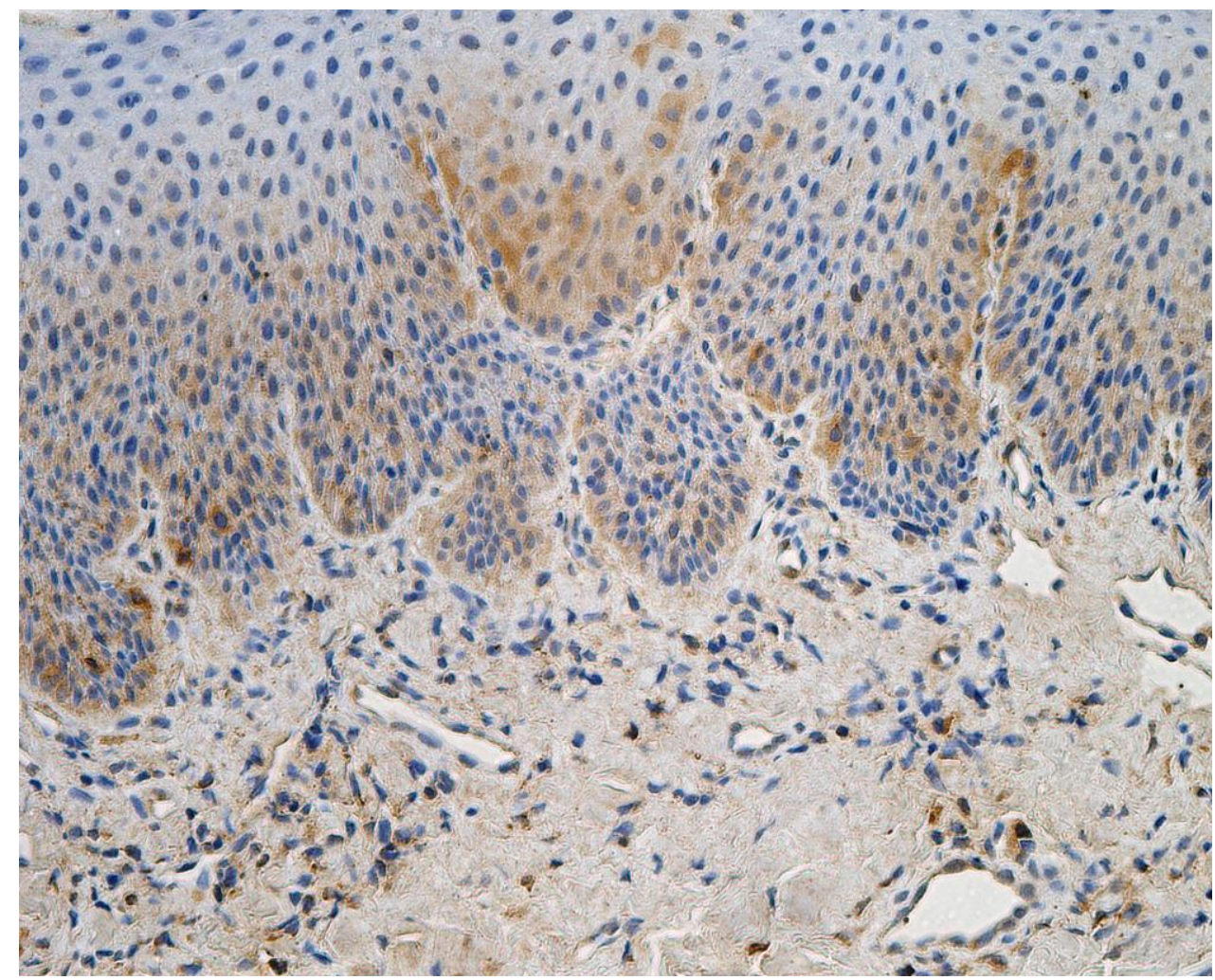

3.55. mikrofotogrāfija. Vidēji daudz (++) IRF6 pozitīvu epitēlijšūnu un saistaudu šūnu 10 mēnešus vecam bērnam ar abpusēju škşeltni - mīksto aukslēju plastika.

IRF6 IMH, × 200

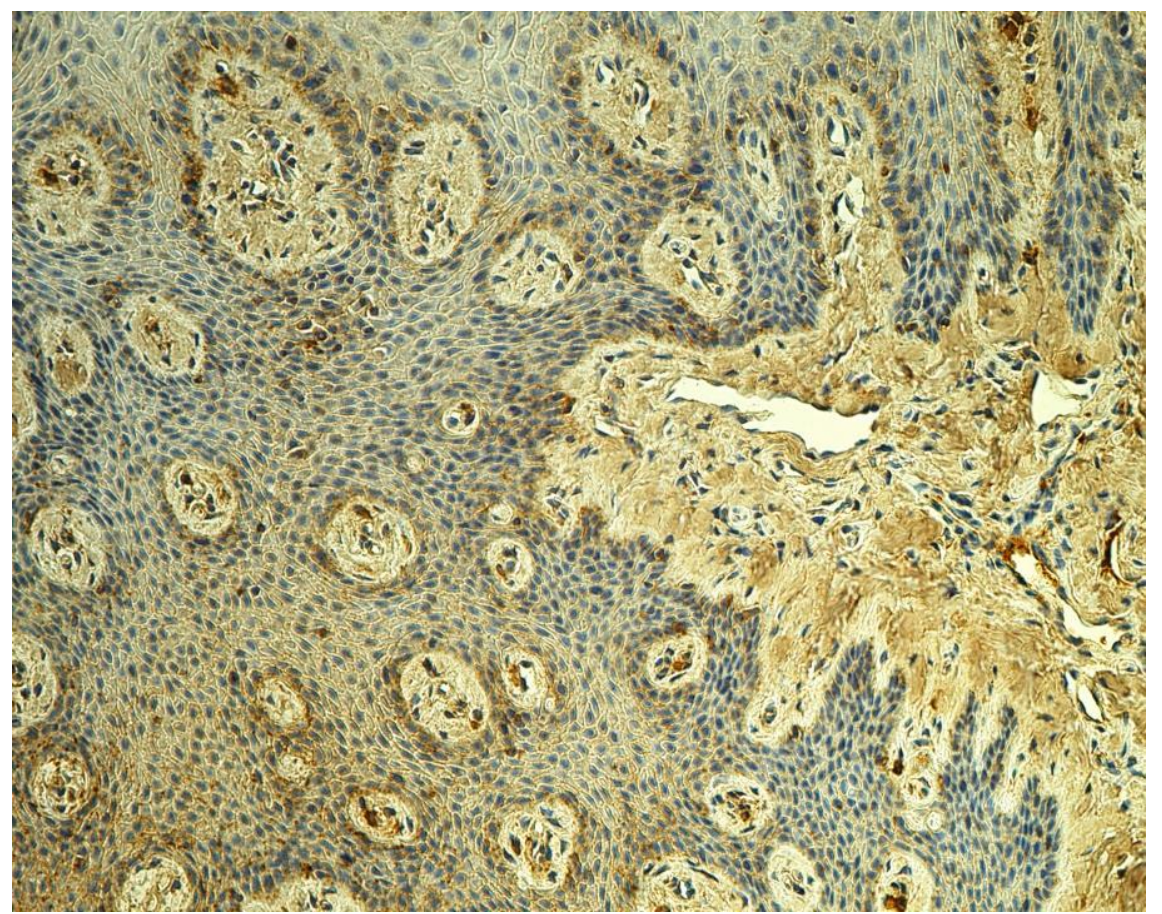

3.56. mikrofotogrāfija. Daudz (+++) vāju un intensīvi krāsotu IRF6 pozitīvu epitēlijšūnu un saistaudu šūnu 3 gadus un 6 mēnešus vecam bērnam ar abpusēju škseltni - cieto aukslēju plastika. IRF6 IMH, × 200 


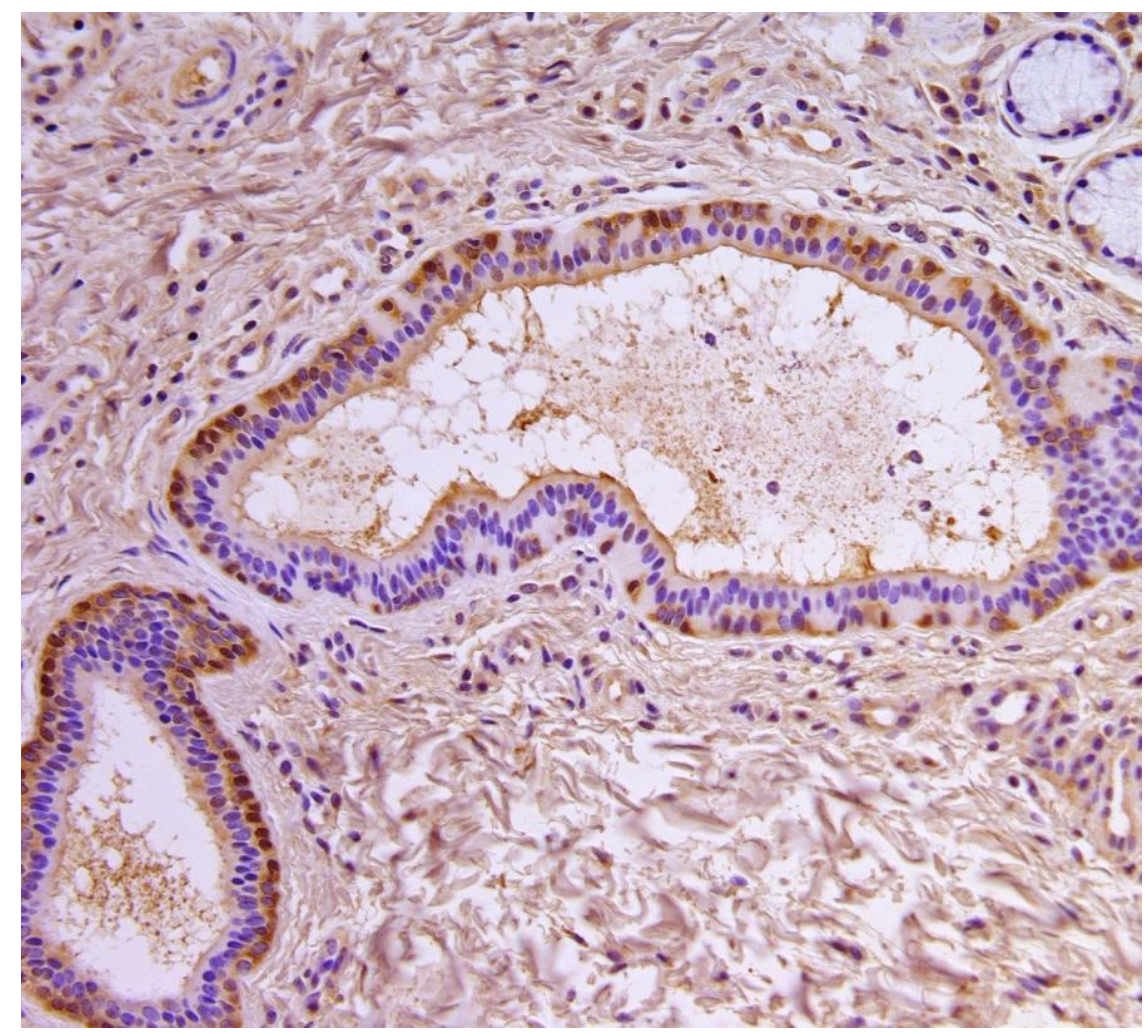

3.57. mikrofotogrāfija. Daudz (+++) PAX9 pozitīvu šūnu siekalu dziedzeru izvados 3 mēnešus vecam zīdainim ar abpusēju škseltni - lūpas plastika. PAX9 IMH, × 200

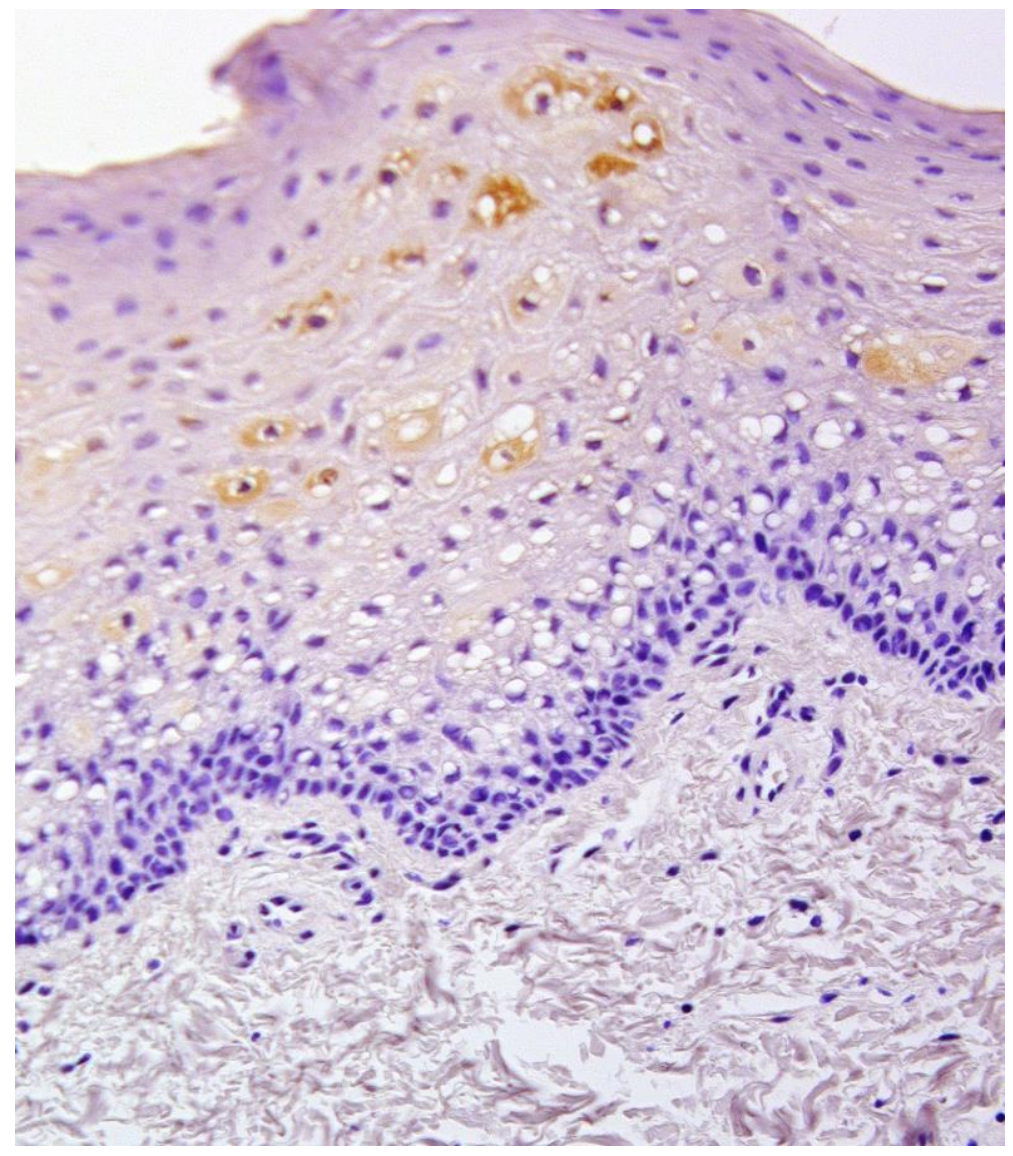

3.58. mikrofotogrāfija. Maz (+) PAX9 pozitīvu epitēlijššnu 4 mēnešus vecam zīdainim ar abpusēju šķeltni - lūpas plastika. PAX9 IMH, × 200 


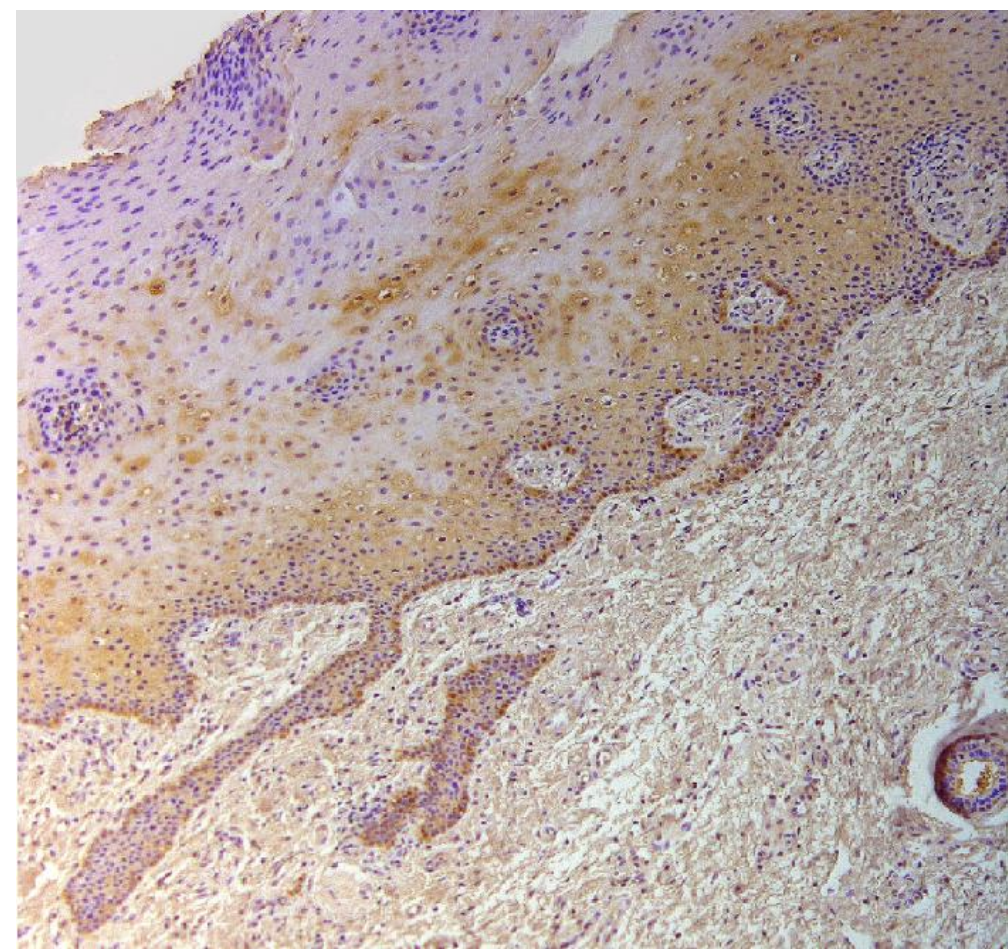

3.59. mikrofotogrāfija. Vidēji daudz līdz daudz (++/+++) PAX9 pozitīvu epitēlijšūnu un maz (+) saistaudu šūnu 4 mēnešus vecam zīdainim ar vienpusēju šķeltni - lūpas plastika.

PAX9 IMH, $\times 200$

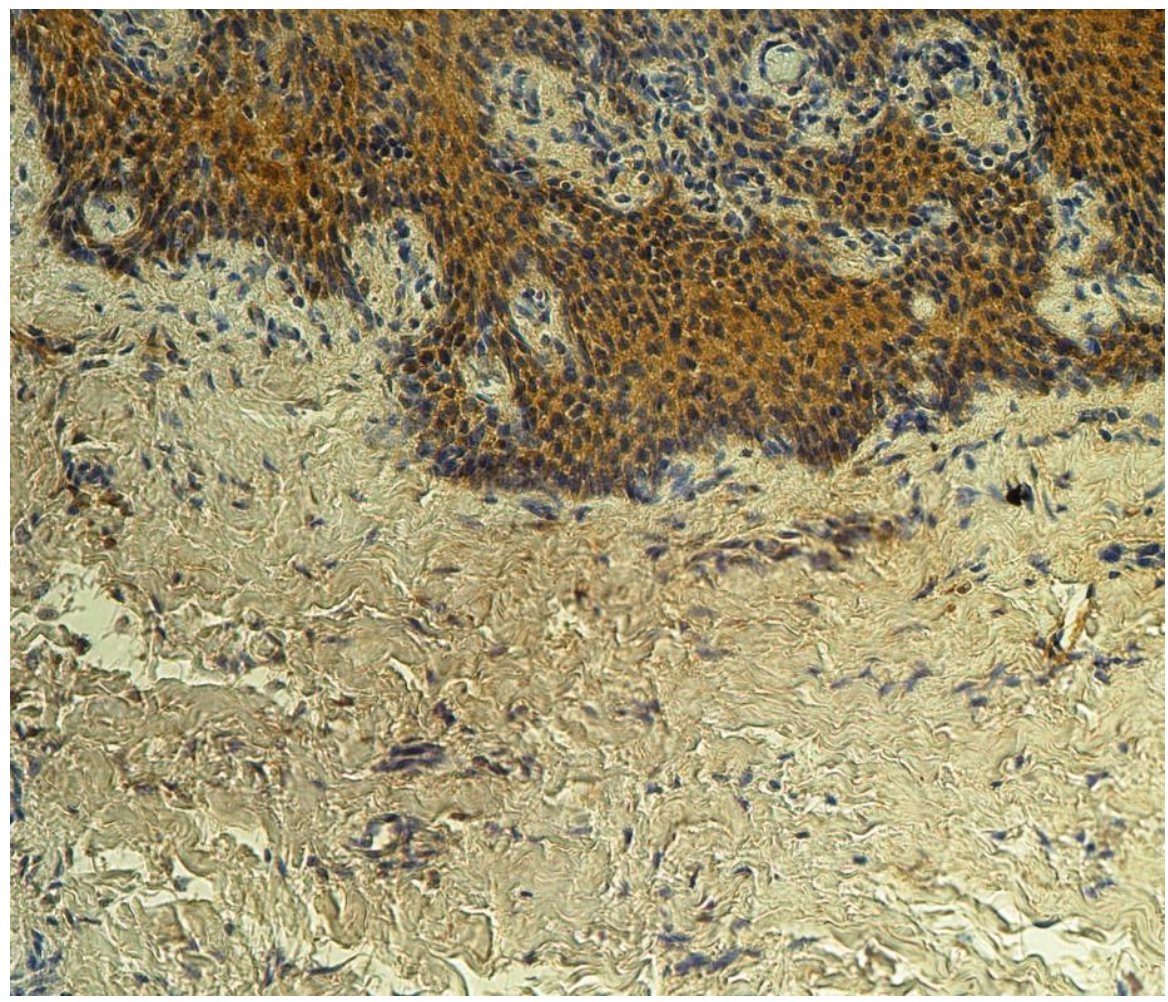

3.60. mikrofotogrāfija. L Loti daudz (++++) PAX9 pozitīvu epitēlijšūnu 3 gadus un 2 mēnešus vecam bērnam ar abpusēju škşeltni - cieto aukslēju plastika. PAX9 IMH, × 200 


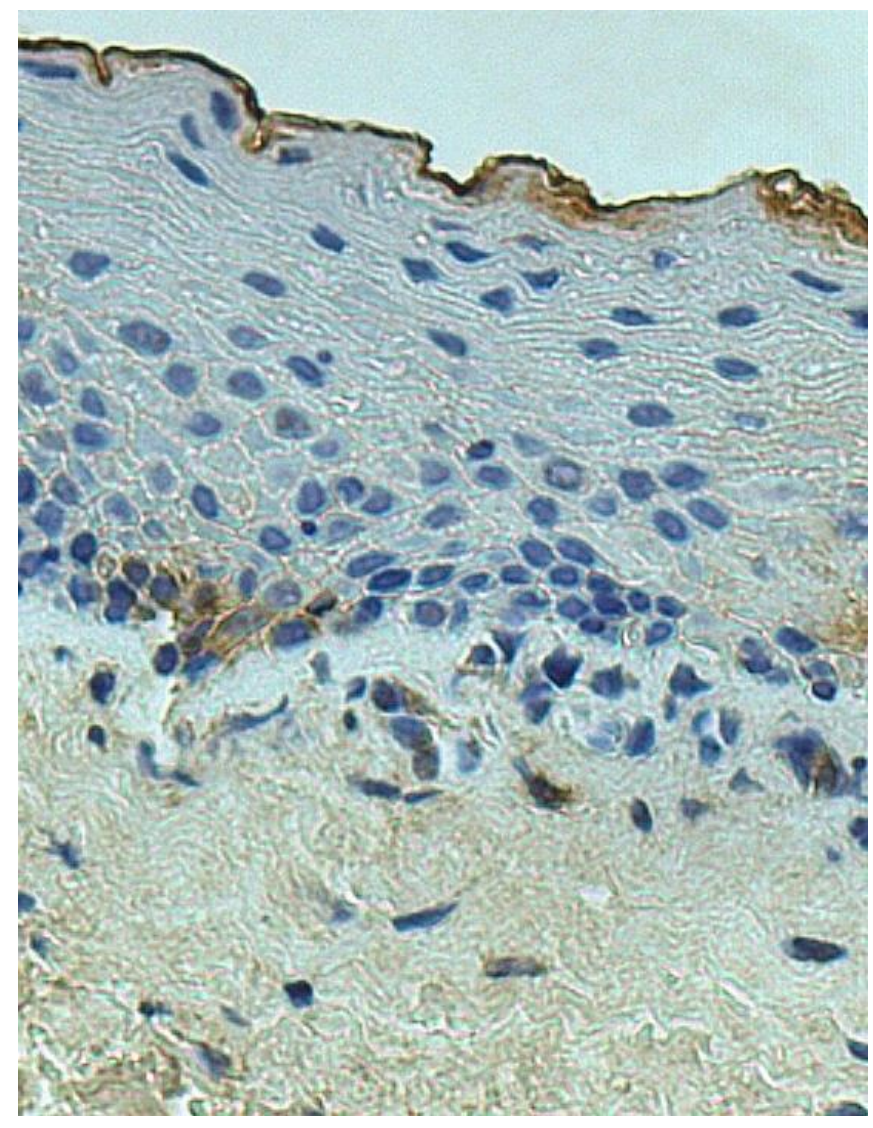

3.61. mikrofotogrāfija. Retas (0/+) RYK pozitīvas epitēlijšūnas 3 mēnešus vecam zīdainim ar abpusēju caurejošu lūpas, alveolārā izauguma un aukslēju šķeltni - lūpas plastika.

RYK IMH, $\times 200$

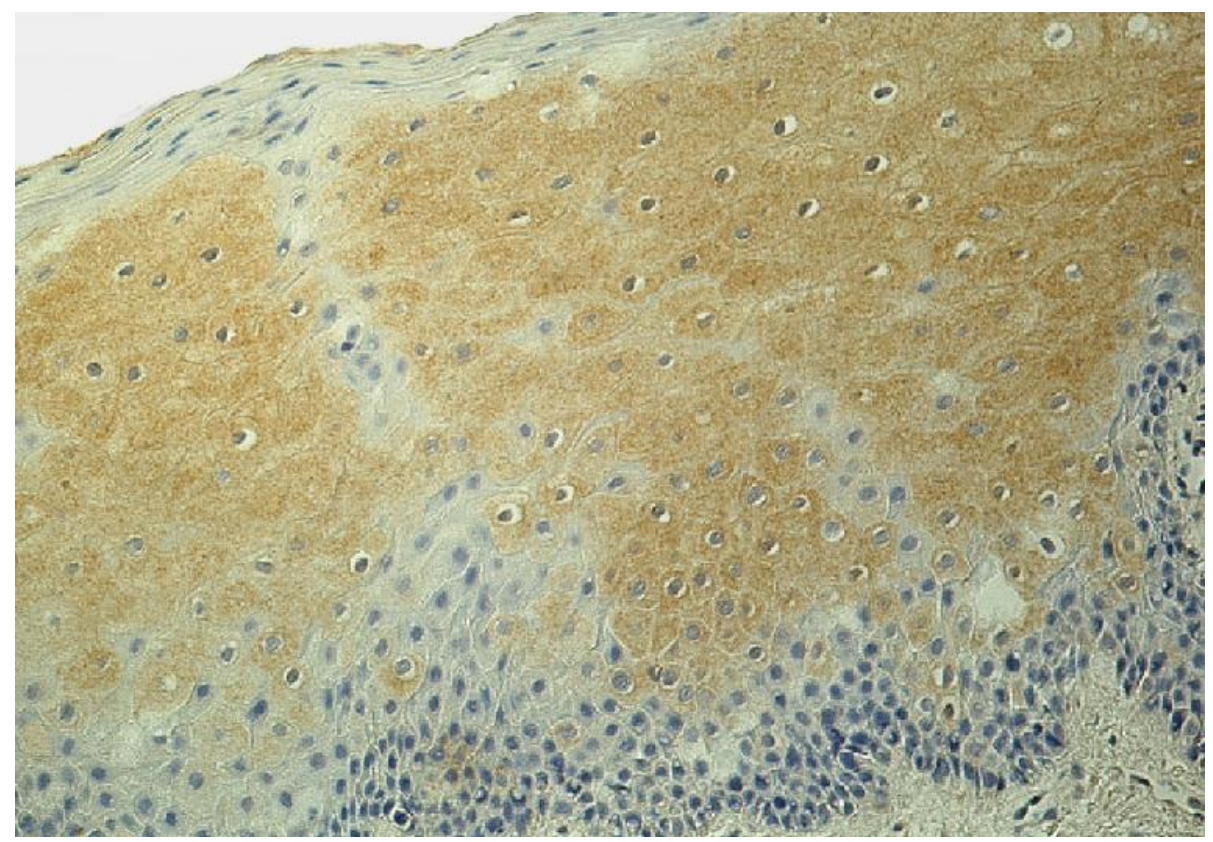

3.62. mikrofotogrāfija. Vidēji daudz (++) RYK pozitīvu epitēlijšūnu 3 mēnešus vecam zīdainim ar vienpusēju caurejošu lūpas, alveolārā izauguma un aukslēju šķ̣eltni - lūpas plastika. RYK IMH, × 100 


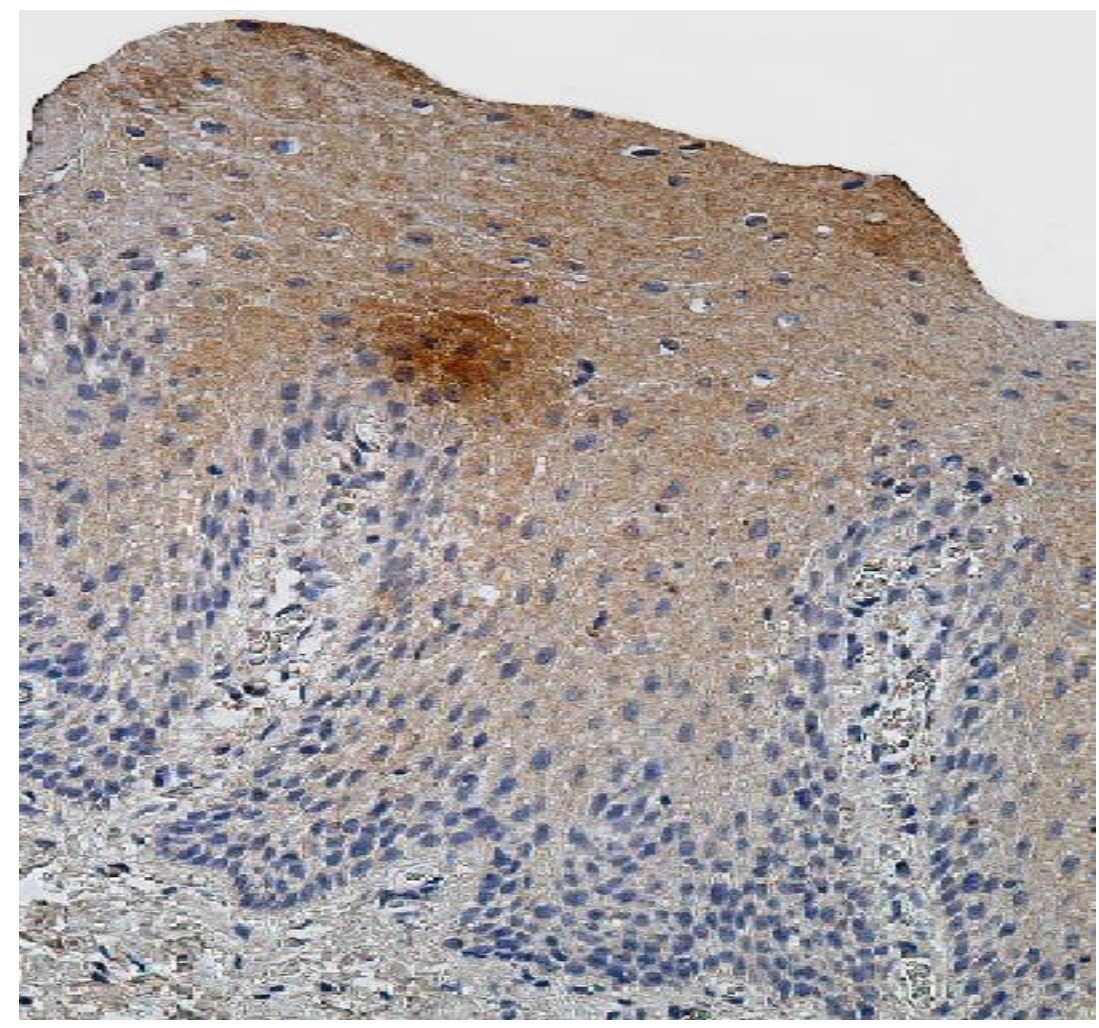

3.63. mikrofotogrāfija. Vidēji daudz līdz daudz (++/+++) RYK pozitīvu epitēlijšūnu 3 gadus un 4 mēnešus vecam bērnam ar abpusēju caurejošu lūpas, alveolārā izauguma un aukslēju škseltni - cieto aukslēju plastika. RYK IMH, × 200

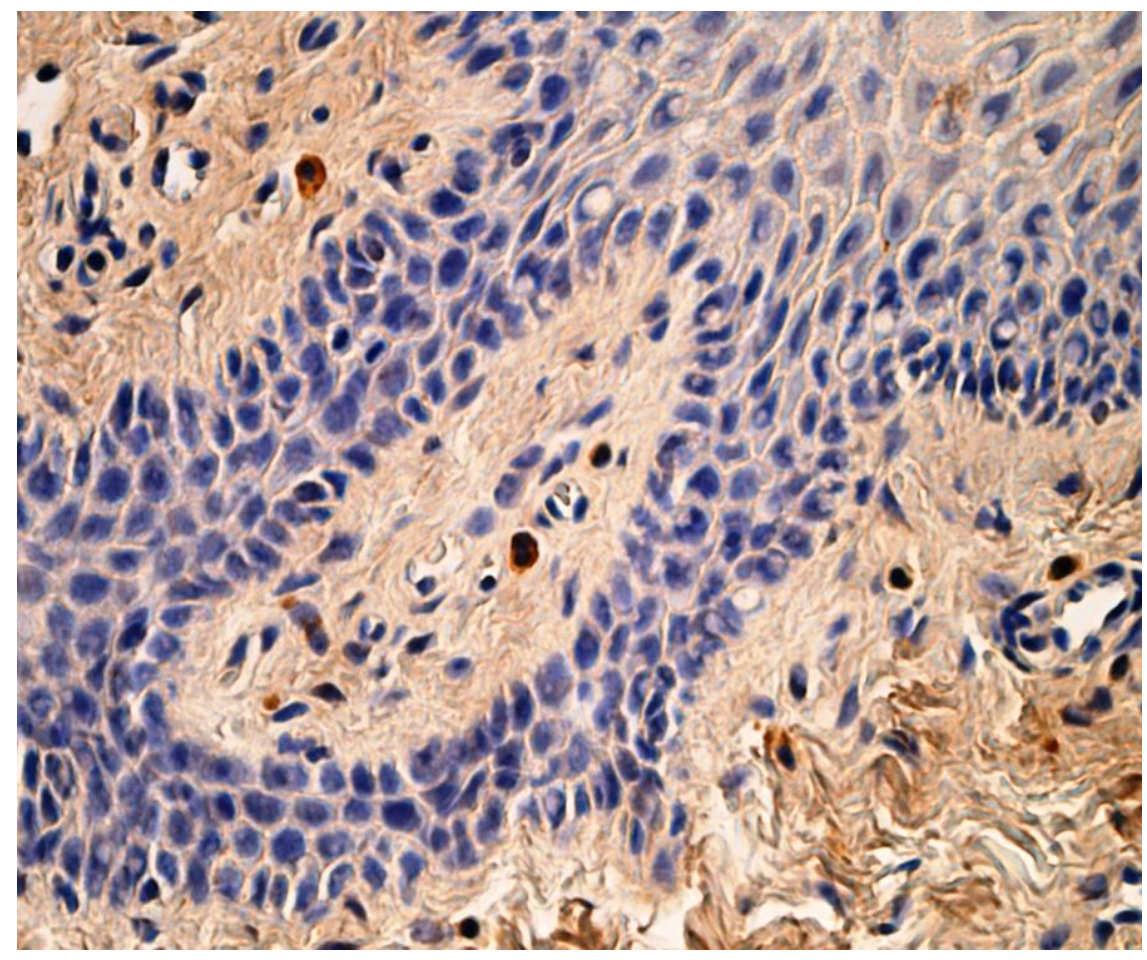

3.64. mikrofotogrāfija. Retas (0/+) TGFß3 pozitīvas saistaudu šūnas 5 mēnešus vecam bērnam ar abpusēju caurejošu lūpas, alveolārā izauguma un aukslēju škseltni - lūpas plastika. TGFB3 IMH, × 400 


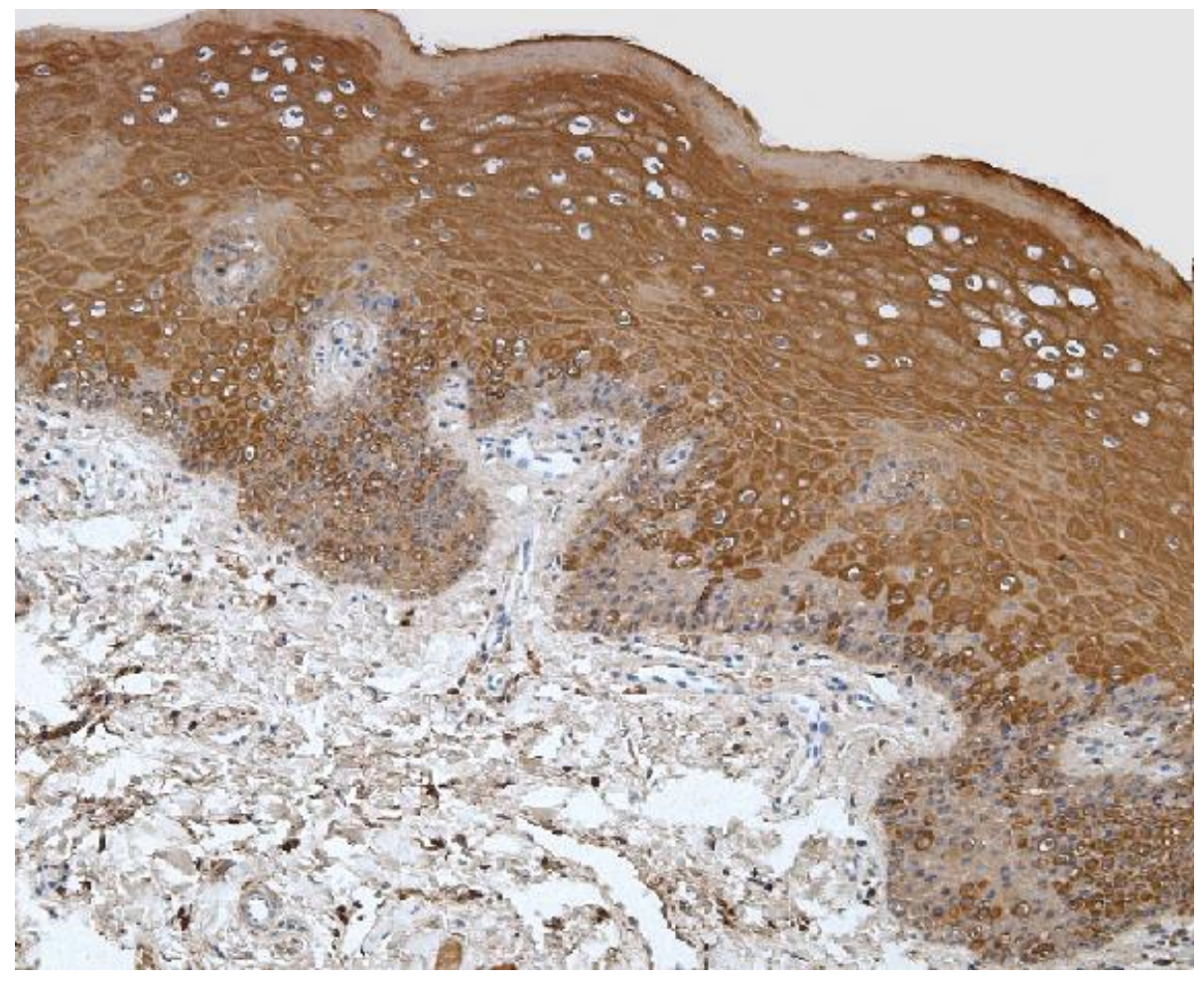

3.65. mikrofotogrāfija. Daudz (+++) TGFß3 pozitīvu šūnu epitēlijā 4 mēnešus vecam zīdainim ar vienpusēju caurejošu lūpas, alveolārā izauguma un aukslēju škseltni - lūpas plastika. TGFB3 IMH, × 100

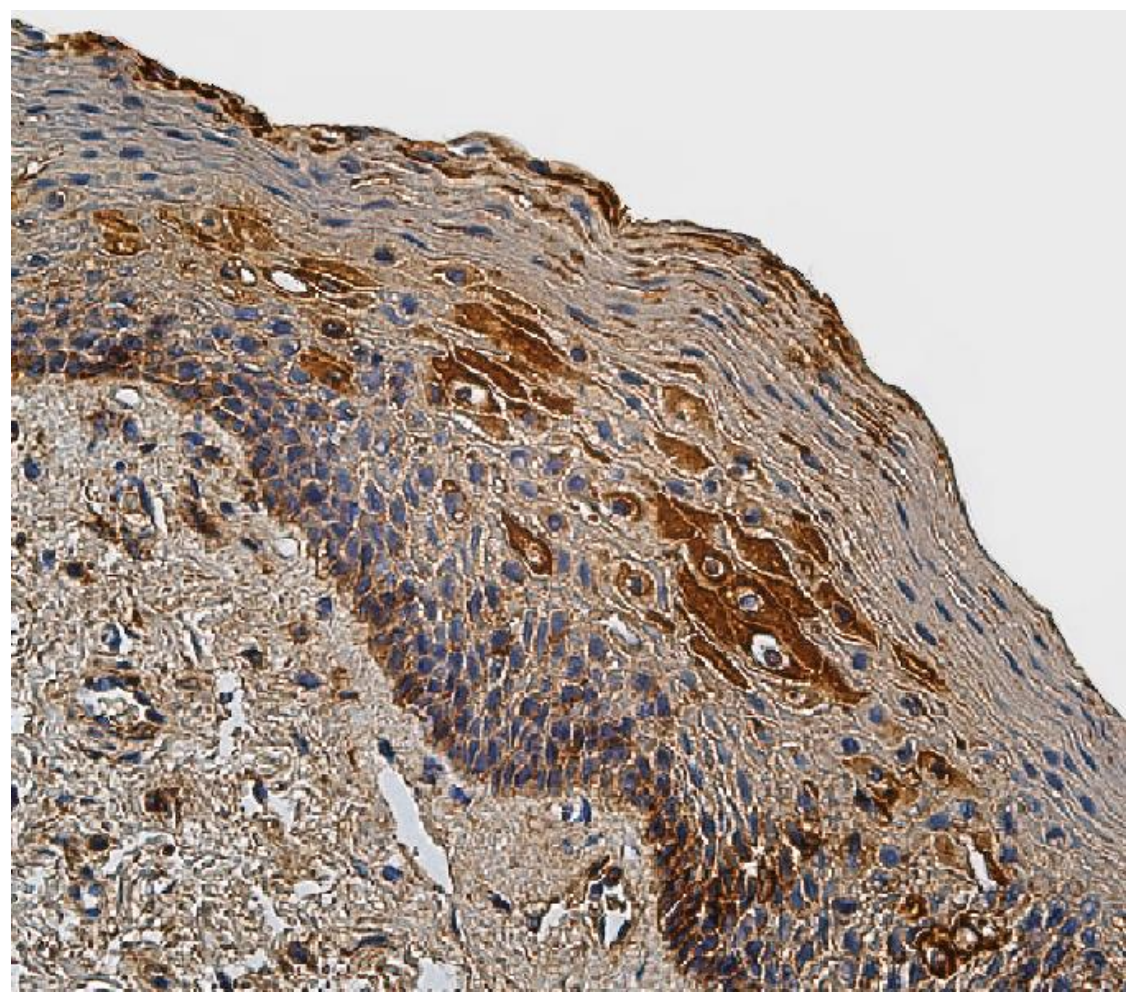

3.66. mikrofotogrāfija. Vidēji daudz (++) TGFß3 pozitīvu šūnu epitēlijā 9 mēnešus vecam bērnam ar abpusēju caurejošu lūpas, alveolārā izauguma un aukslēju škseltni - mīksto aukslēju plastika. TGFß3 IMH, × 250 


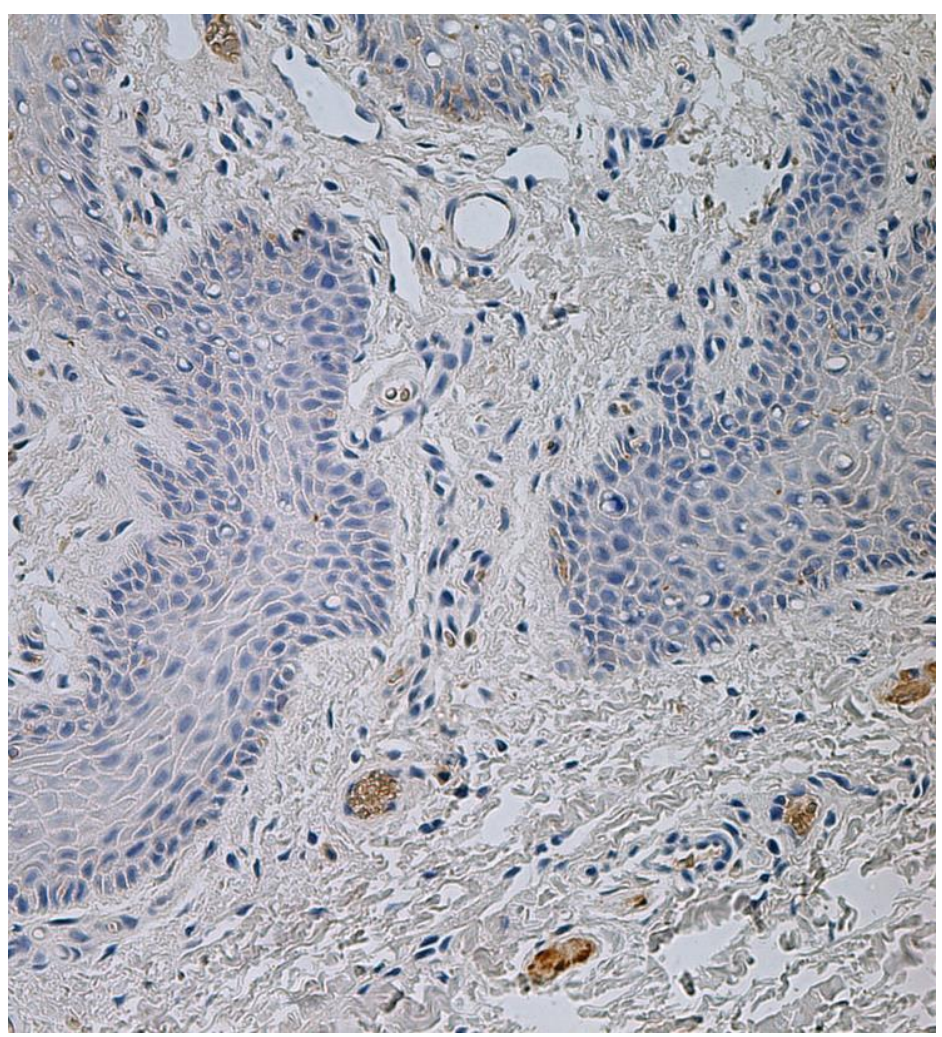

3.67. mikrofotogrāfija. Maz (+) VEGF pozitīvu endotēlijšūnu 3 mēnešus vecam zīdainim ar abpusēju caurejošu lūpas, alveolārā izauguma un aukslēju šķ̣eltni - lūpas plastika.

VEGF IMH, × 200

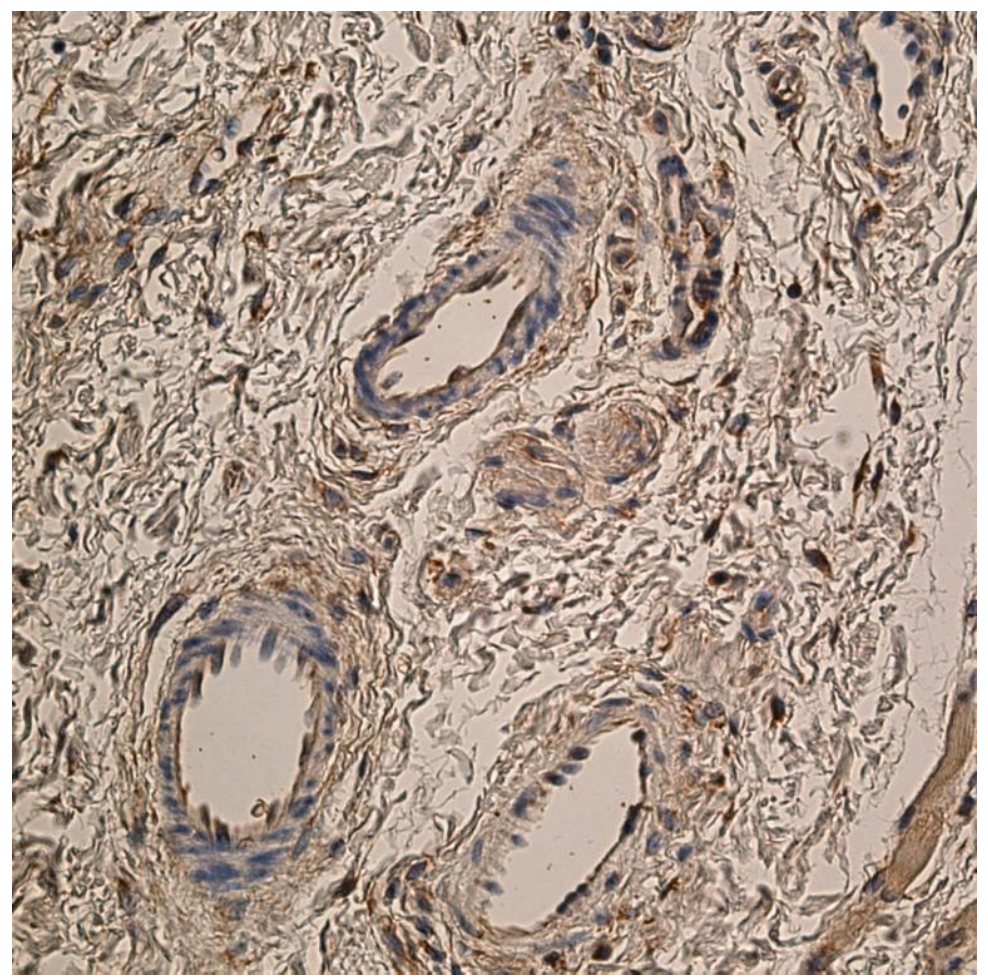

3.68. mikrofotogrāfija. Retas (0/+) VEGF saturošas šūnas asinsvadu sieniṇās 6 mēnešus vecam zīdainim ar vienpusēju caurejošu lūpas, alveolārā izauguma un aukslēju škeltni lūpas plastika. VEGF IMH, × 250 


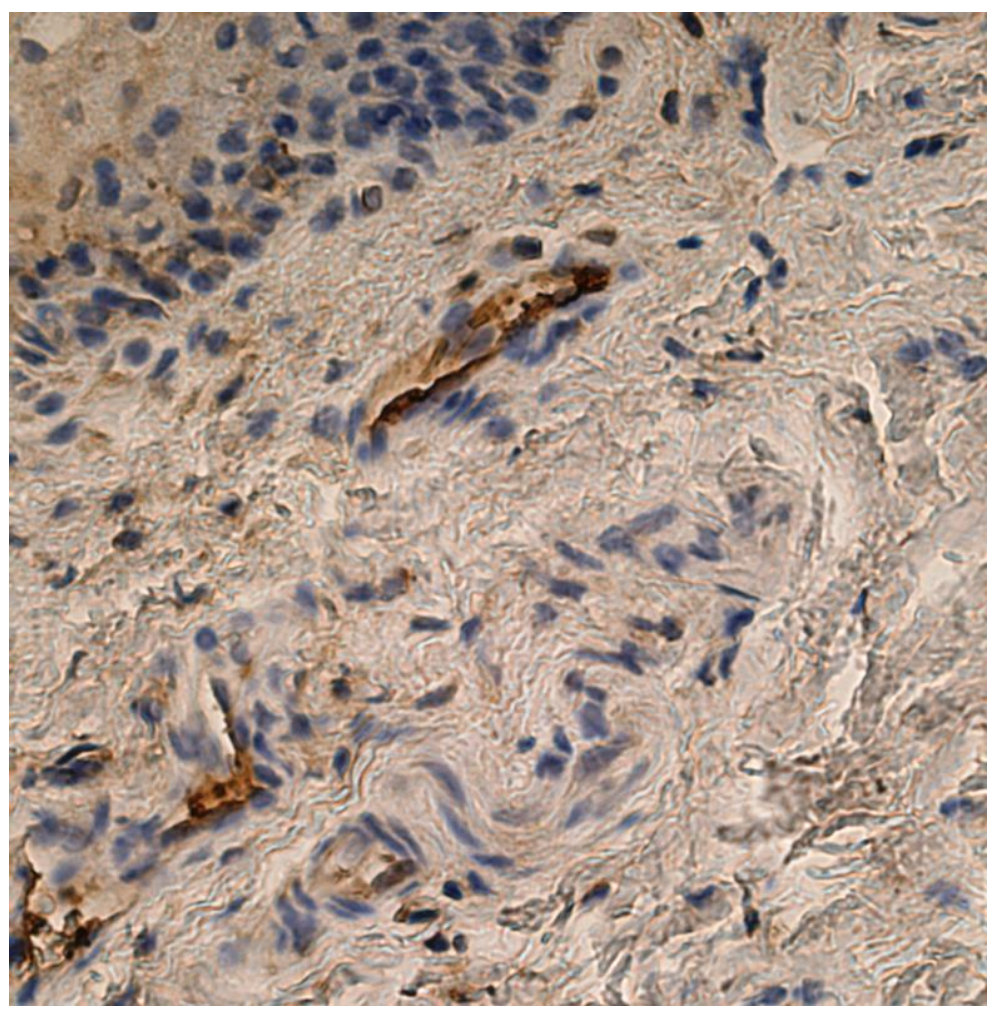

3.69. mikrofotogrāfija. Maz (+) VEGF pozitīvu endotēlijšūnu 10 mēnešus vecam zīdainim ar abpusēju caurejošu lūpas, alveolārā izauguma un aukslēju šķeltni - mīksto aukslēju plastika. VEGF IMH, × 400

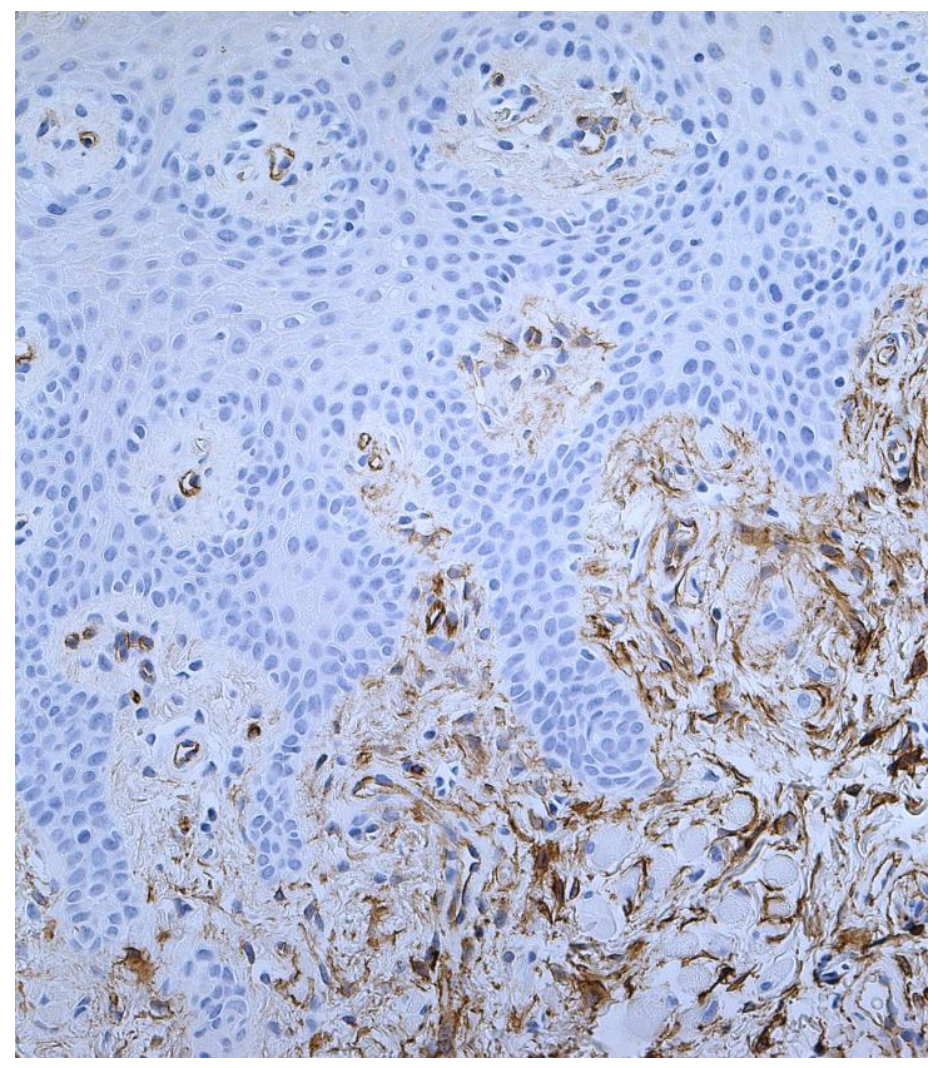

3.70. mikrofotogrāfija. L̦oti daudz (++++) CD34 pozitīvu endotēlijšūnu 3 mēnešus vecam bērnam ar vienpusēju lūpas, alveolārā izauguma un aukslēju šķeltni lūpas plastikas laikā paņemtajā mutes dobuma gḷotādā. CD34 IMH, × 200 


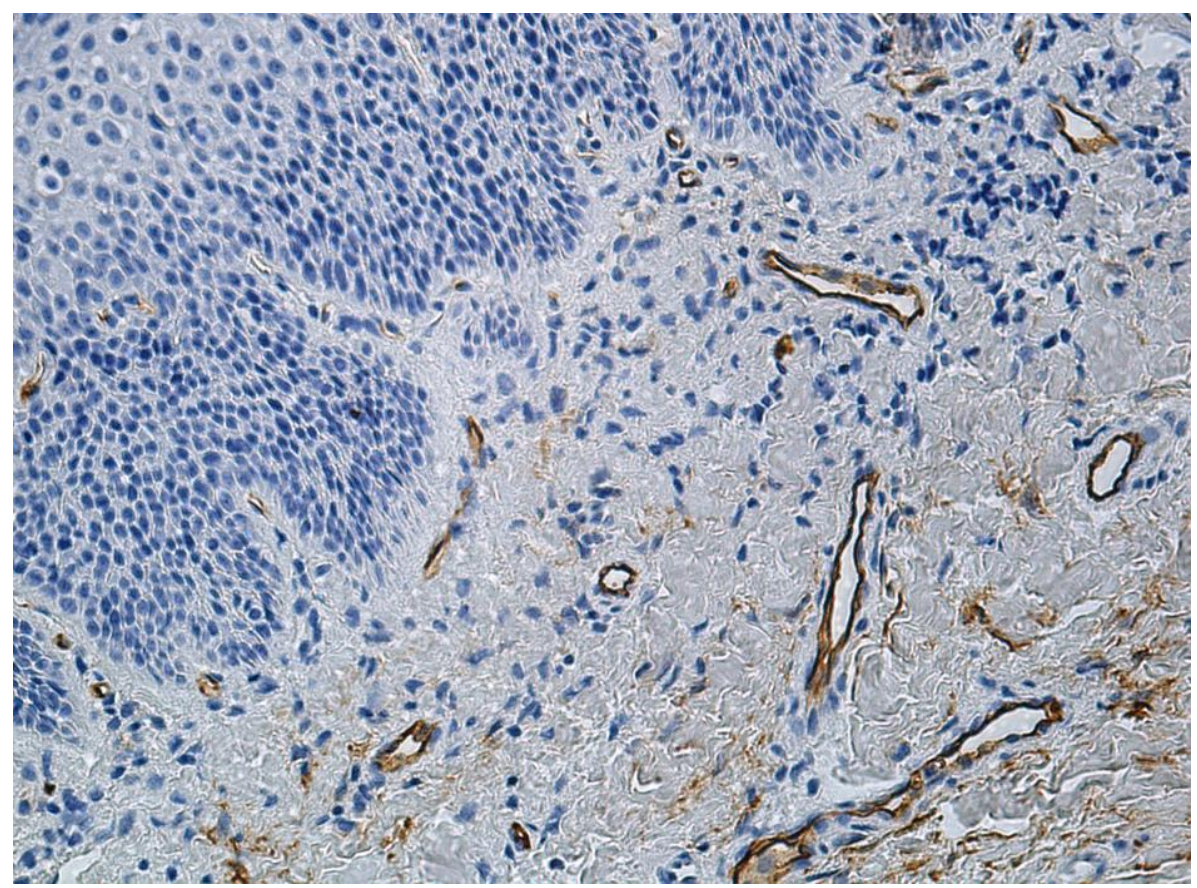

3.71. mikrofotogrāfija. Ļoti daudz (++++) CD34 pozitīvu endotēlijšūnu 3 gadus 2 mēnešus vecam bērnam ar abpusēju lūpas, alveolārā izauguma un aukslēju šķeltni cieto aukslēju plastikas laikā paṇemtajā mutes dobuma gḷotādā. CD34 IMH, $\times 200$

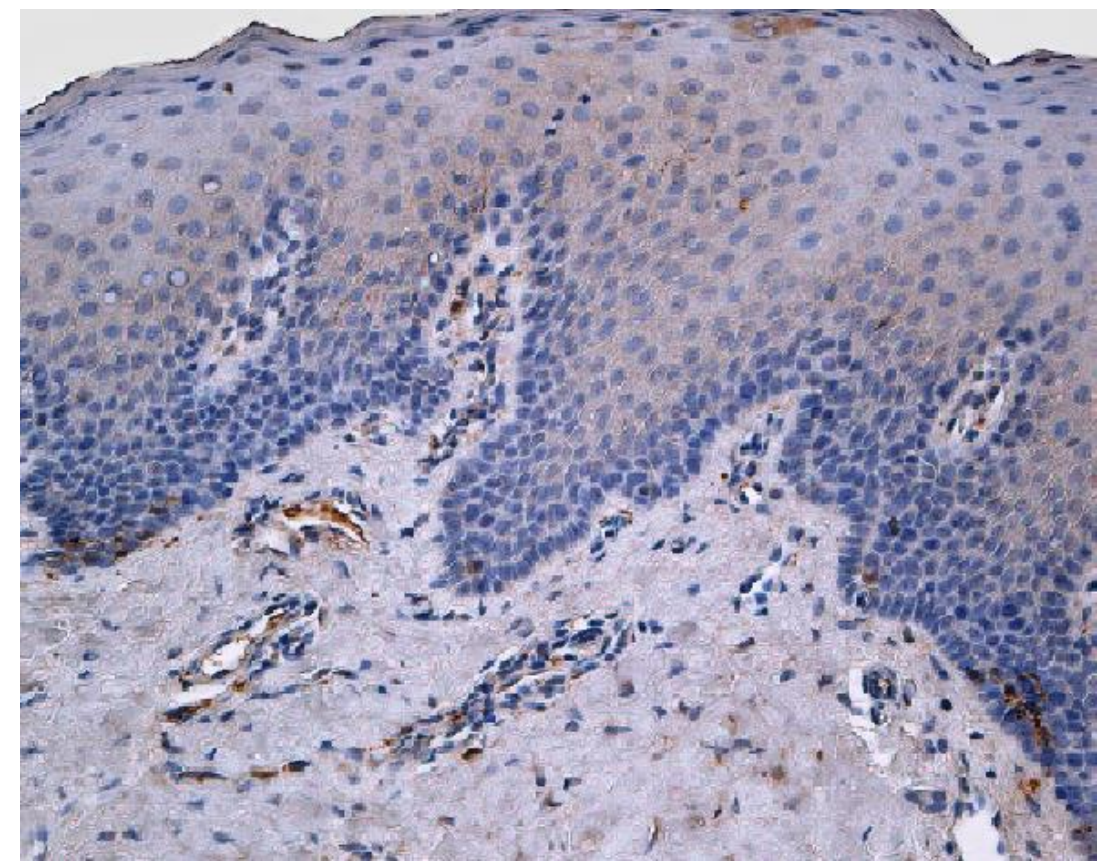

3.72. mikrofotogrāfija. Retas (0/+) PGP 9.5 saturošas nervšķkiedras epitēlijā un subepitēlijā, kā arī asinsvadu sieniṇā 3 mēnešus vecam bērnam ar abpusēju šķeltni lūpas plastika. $P G P 9.5 \mathrm{IMH}, \times 100$ 


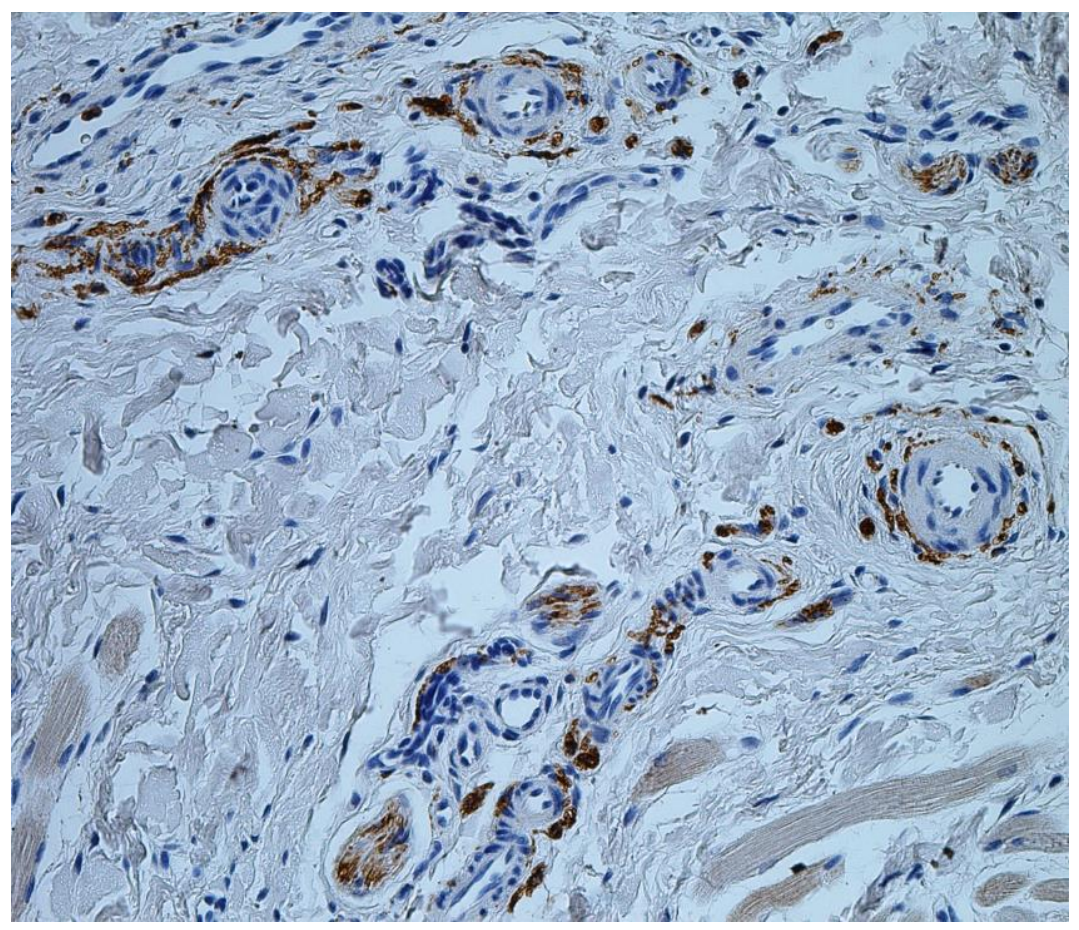

3.73. mikrofotogrāfija. Daudz (+++) PGP 9.5 saturošu nervšķiedru ap un asinsvadu sieniṇā 3 mēnešus vecam bērnam ar vienpusēju šķeltni - lūpas plastika. PGP 9.5 IMH, × 200

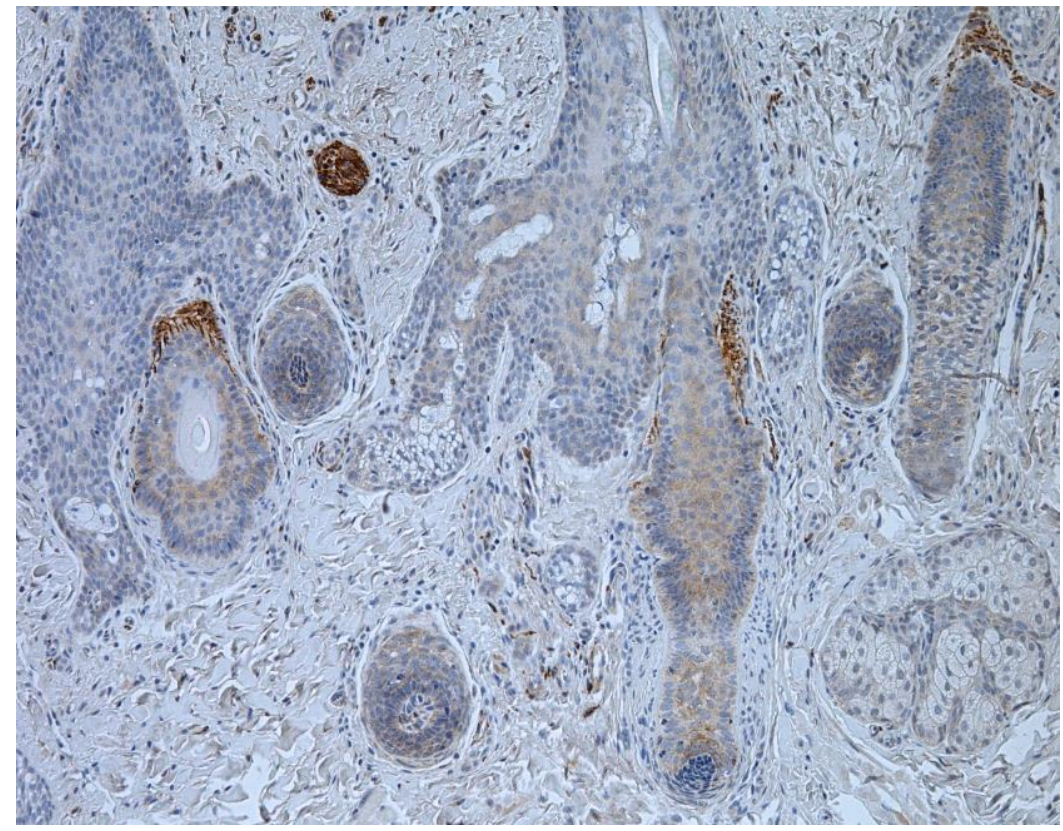

3.74. mikrofotogrāfija. Vidēji daudz (++) PGP 9.5 saturošu nervšķiedru ap mata folikuliem 4 mēnešus vecam bērnam ar vienpusēju šķeltni - lūpas plastika. PGP 9.5 IMH, $\times 100$ 


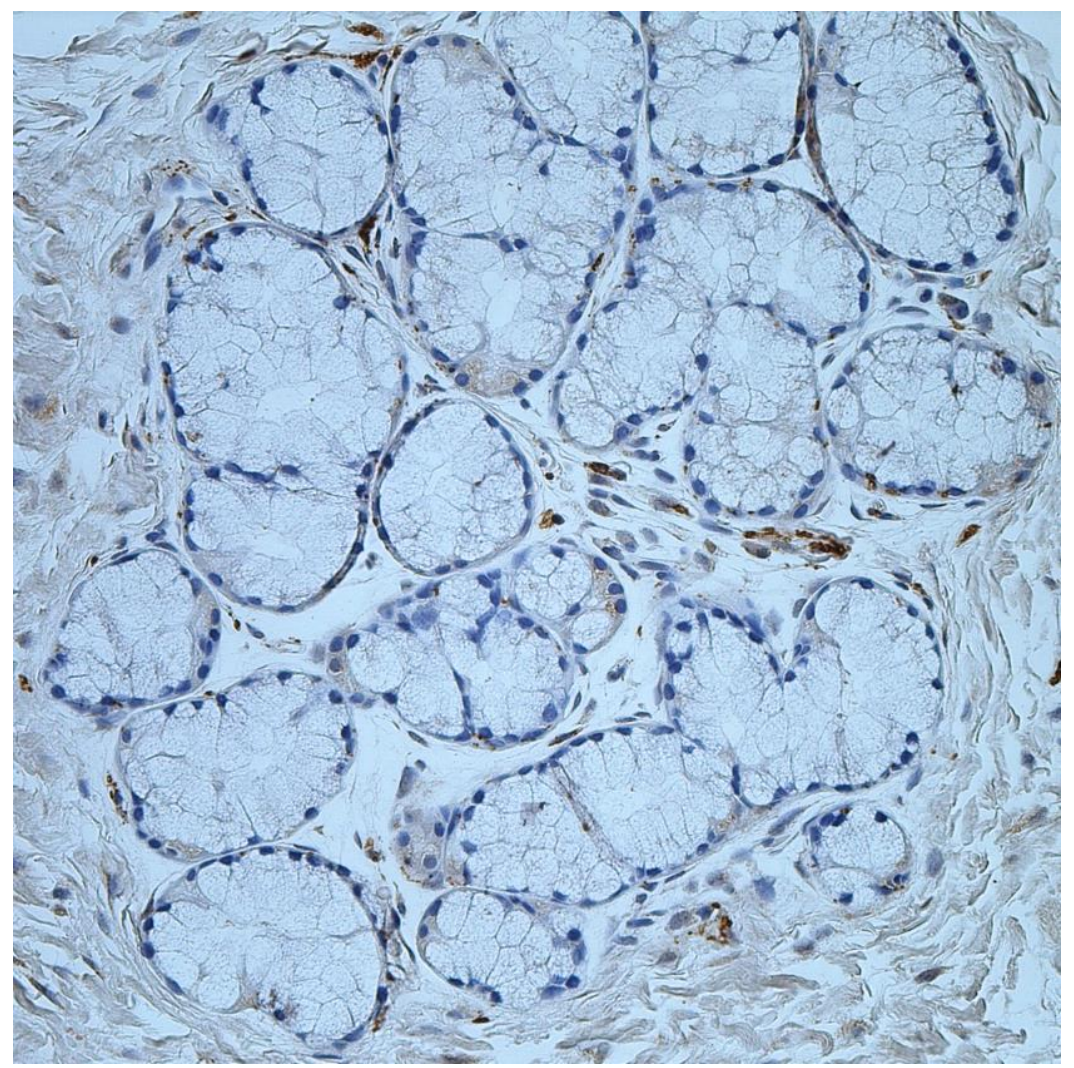

3.75. mikrofotogrāfija. Maz (+) PGP 9.5 saturošu nervšķkiedru ap siekalu dziedzeriem 3 mēnešus vecam bērnam ar vienpusēju šķeltni - lūpas plastika. PGP 9.5 IMH, × 200

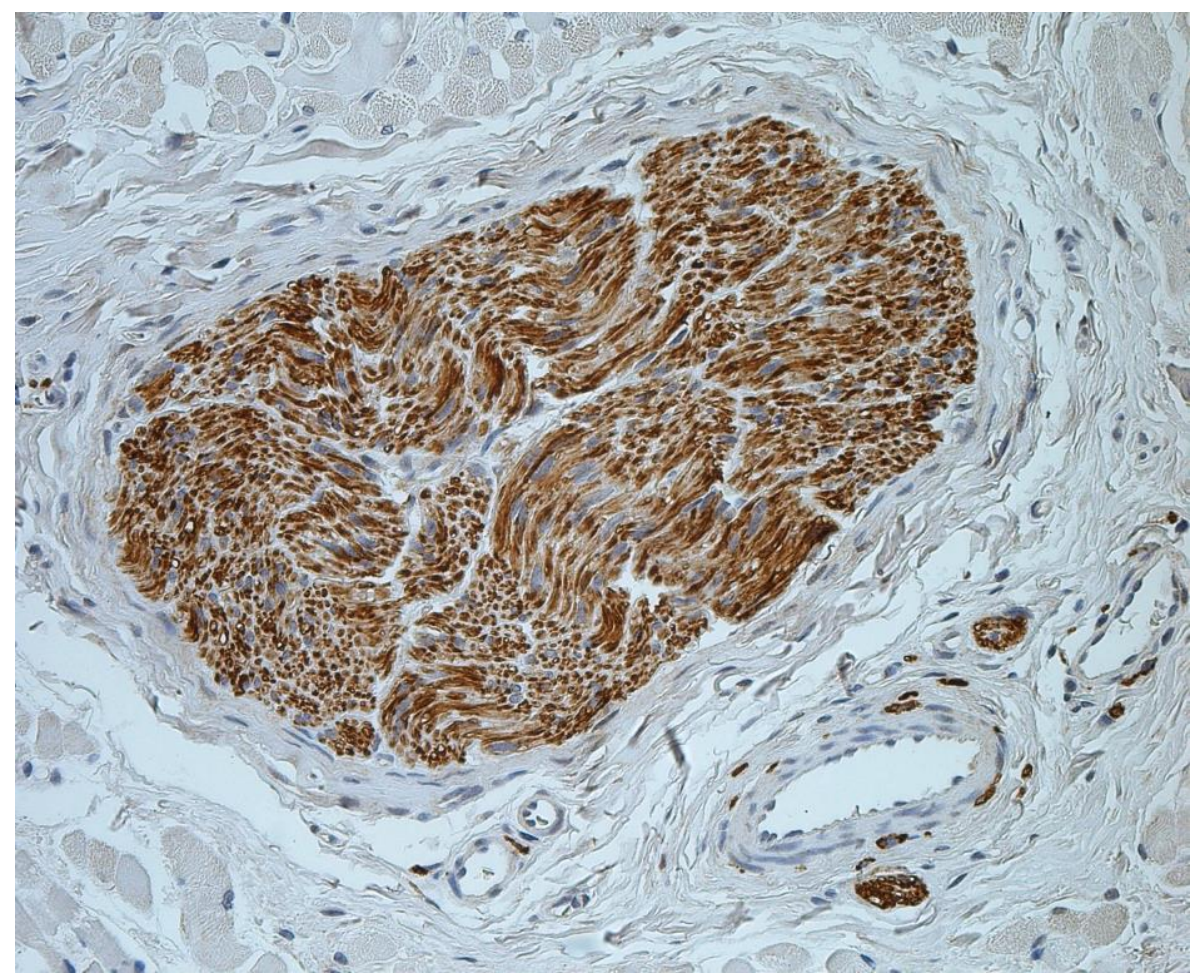

3.76. mikrofotogrāfija. PGP 9.5 saturošs nervu šķiedru kūlītis 3 mēnešus vecam bērnam ar vienpusēju šķeltni - lūpas plastika. PGP 9.5 IMH, × 200 


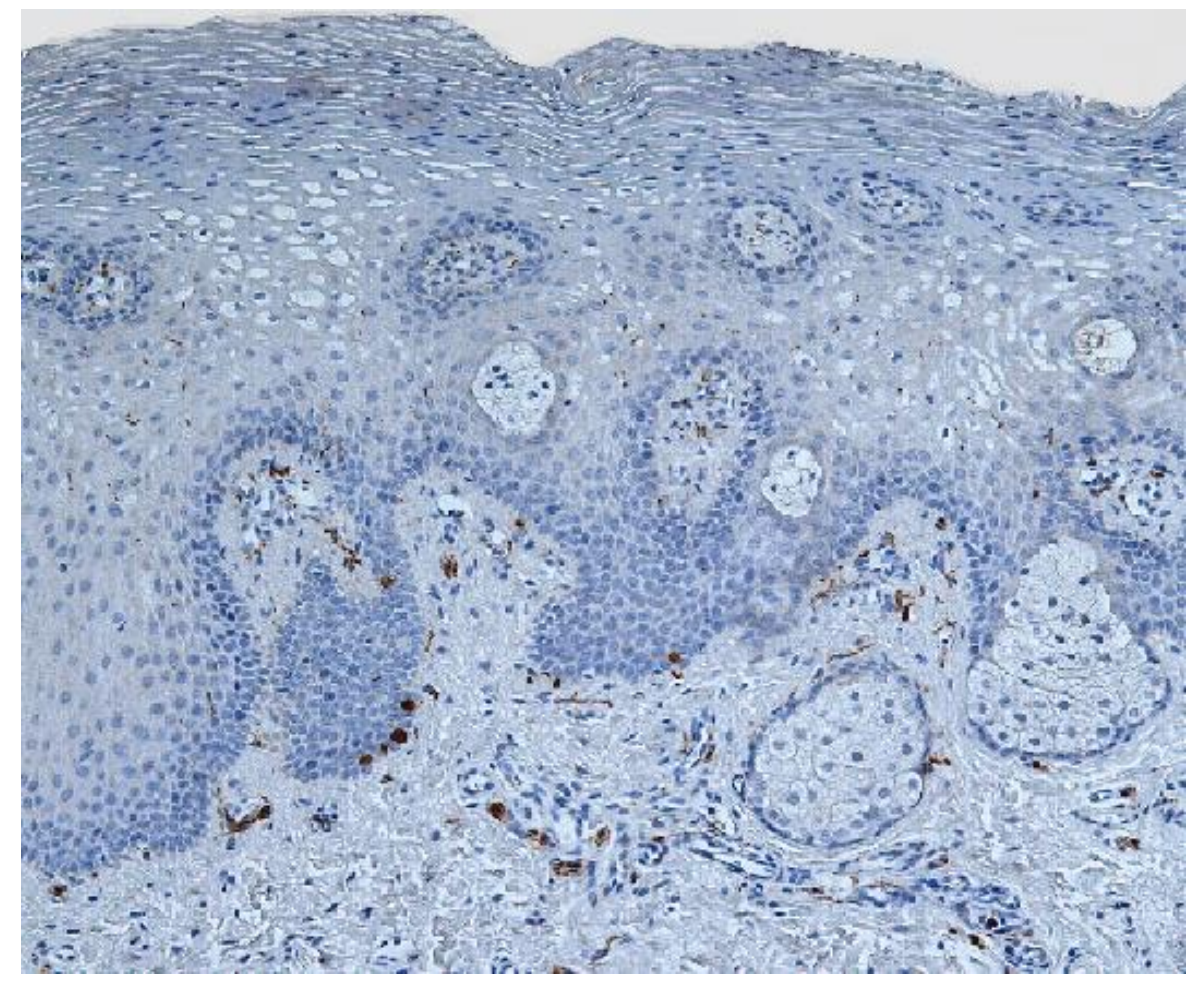

3.77. mikrofotogrāfija. Reti (0/+) PGP 9.5 saturoši neiroendokrīni epiteliocīti 3 mēnešus vecam bērnam ar vienpusēju caurejošu lūpas, alveolārā izauguma un aukslēju šḳeltni lūpas plastika. PGP $9.5 \mathrm{IMH}, \times 100$

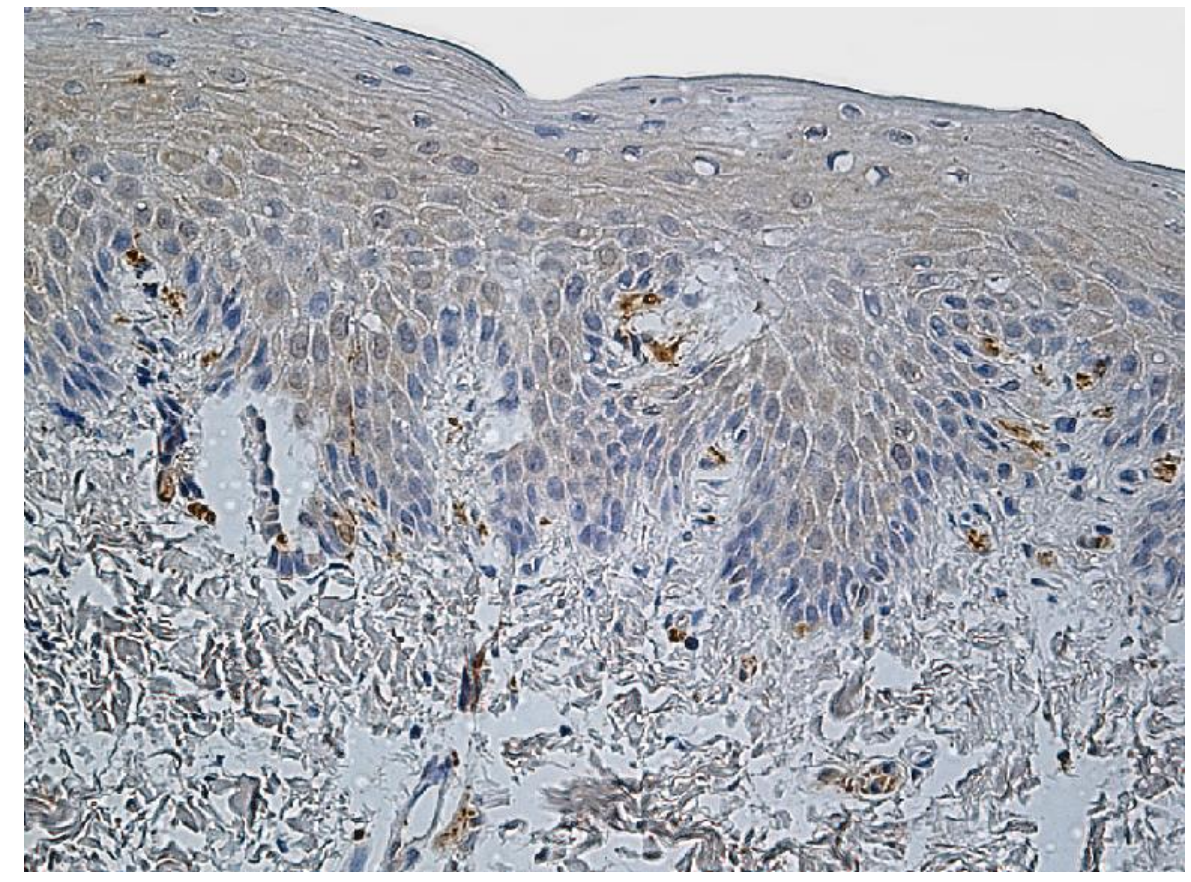

3.78. mikrofotogrāfija. Maz (+) līdz vidēji daudz (++) PGP 9.5 saturošu nervu škiedru stratum basale 9 mēnešus vecam bērnam ar abpusēju caurejošu lūpas, alveolārā izauguma un aukslēju škeltni - mīksto aukslēju plastika. PGP 9.5 IMH, × 250 


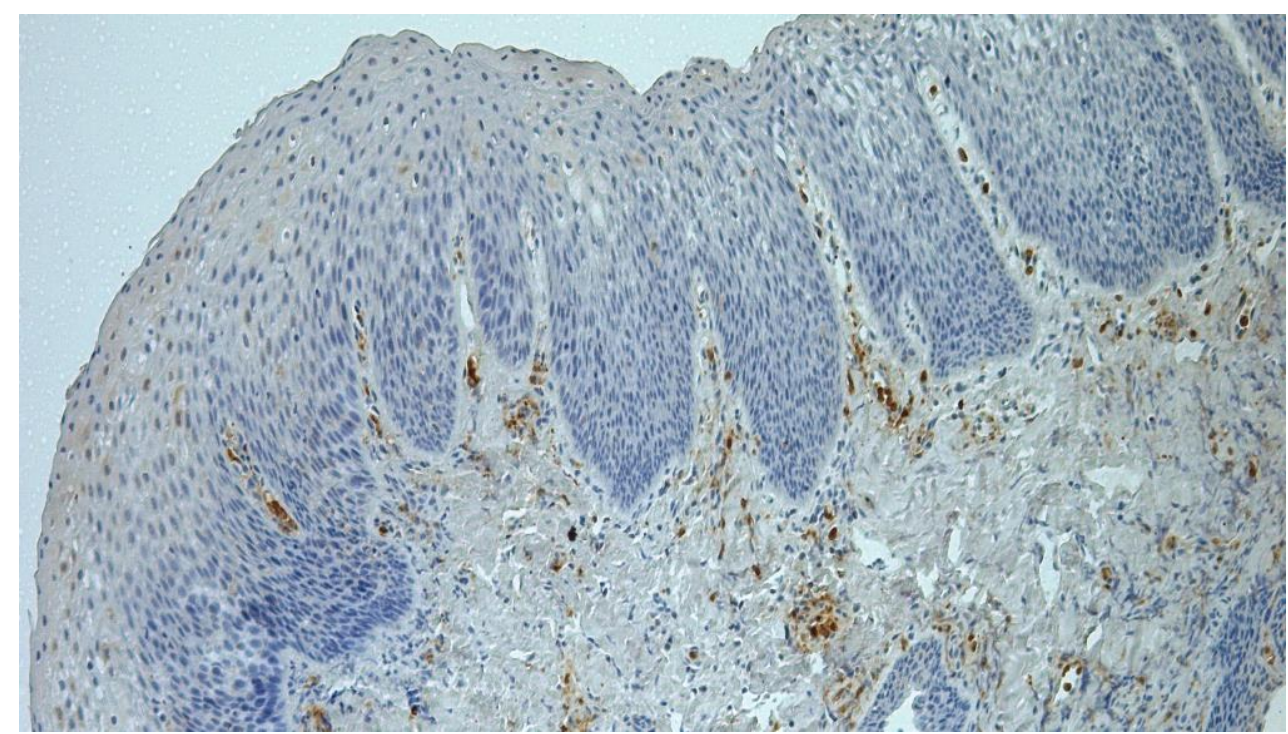

3.79. mikrofotogrāfija. Daudz (+++) sīku PGP 9.5 saturošu nervšķiedru epitēlijā un subepitēlijā 3 gadus un 5 mēnešus vecam bērnam ar abpusēju šķeltni - cieto aukslēju plastika. PGP $9.5 \mathrm{IMH}, \times 100$

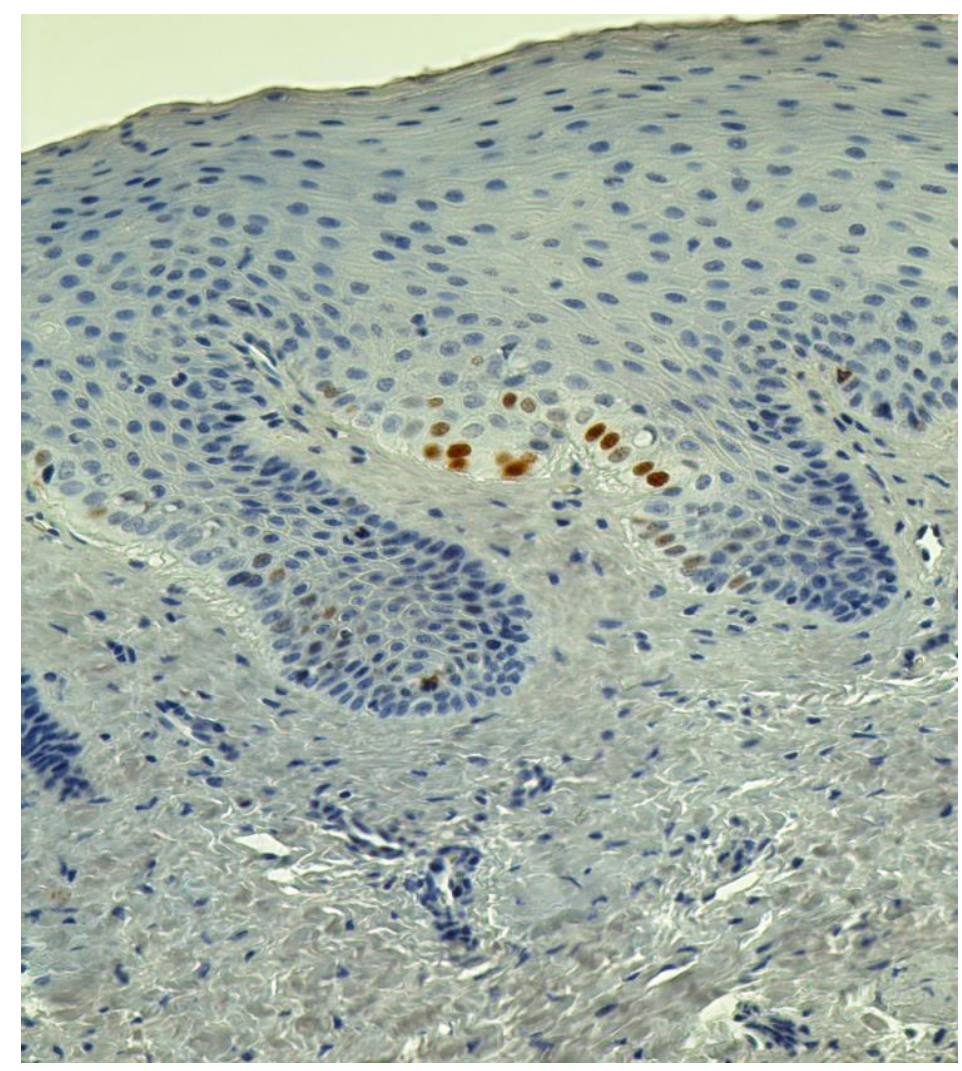

3.80. mikrofotogrāfija. Reti (0/+) Ki-67 pozitīvi epiteliocīti 3 mēnešus vecam bērnam ar abpusēju caurejošu lūpas, alveolarā izauguma un aukslēju škseltni - lūpas plastika. Ki-67 IMH, $\times 200$ 


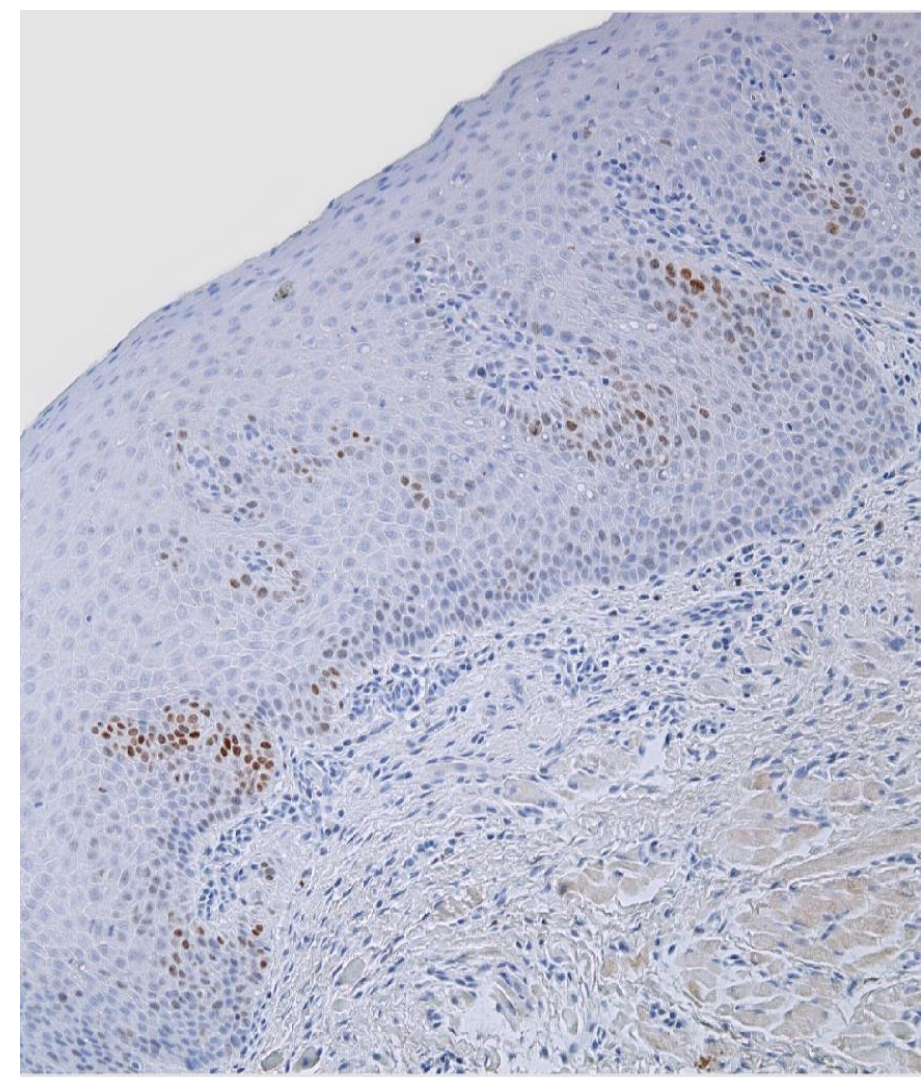

3.81. mikrofotogrāfija. Maz (+) perēkḷveidā lokalizētu Ki-67 pozitīvu epiteliocītu 4 mēnešus vecam bērnam ar vienpusēju caurejošu lūpas, alveolārā izauguma un aukslēju šķeltni - lūpas plastika. Ki-67 IMH, × 100

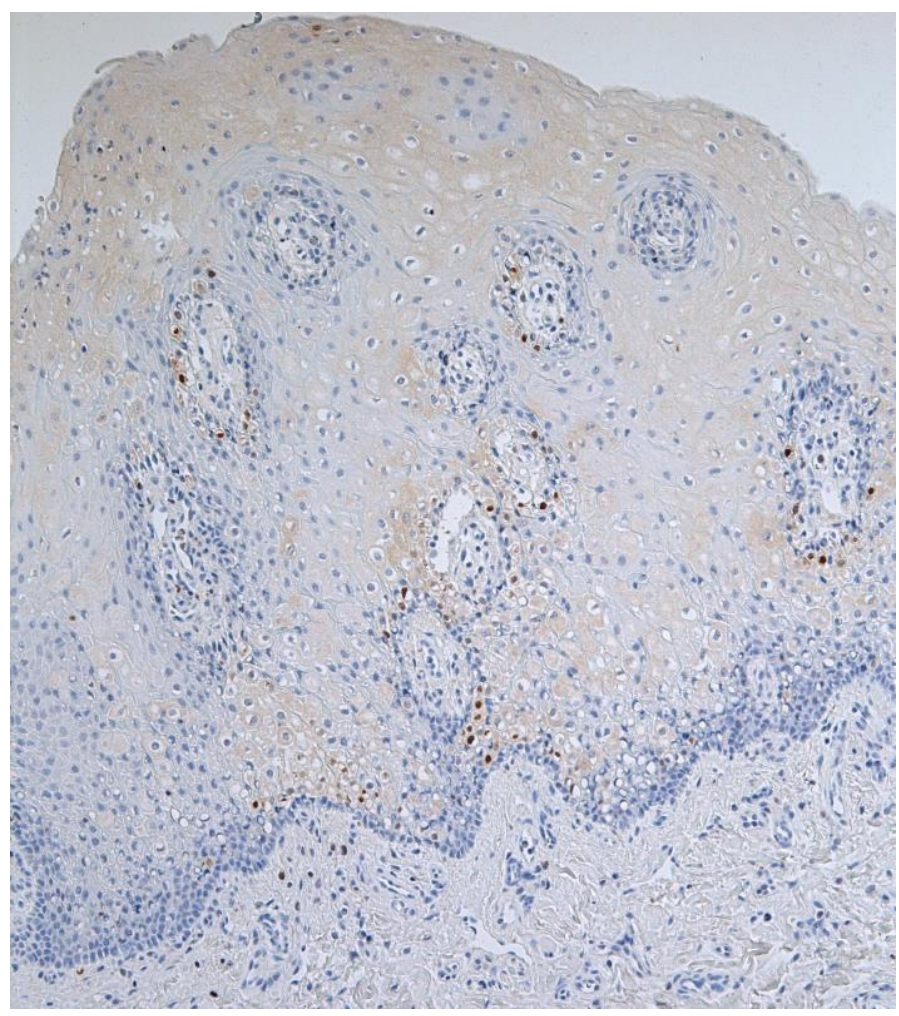

3.82. mikrofotogrāfija. Maz (+) vāju krāsotu Ki-67 pozitīvu epiteliocītu 9 mēnešus vecam zīdainim ar abpusēju caurejošu lūpas, alveolārā izauguma un aukslēju šķ̧eltni - mīksto aukslēju plastika. Ki-67 IMH, × 100 


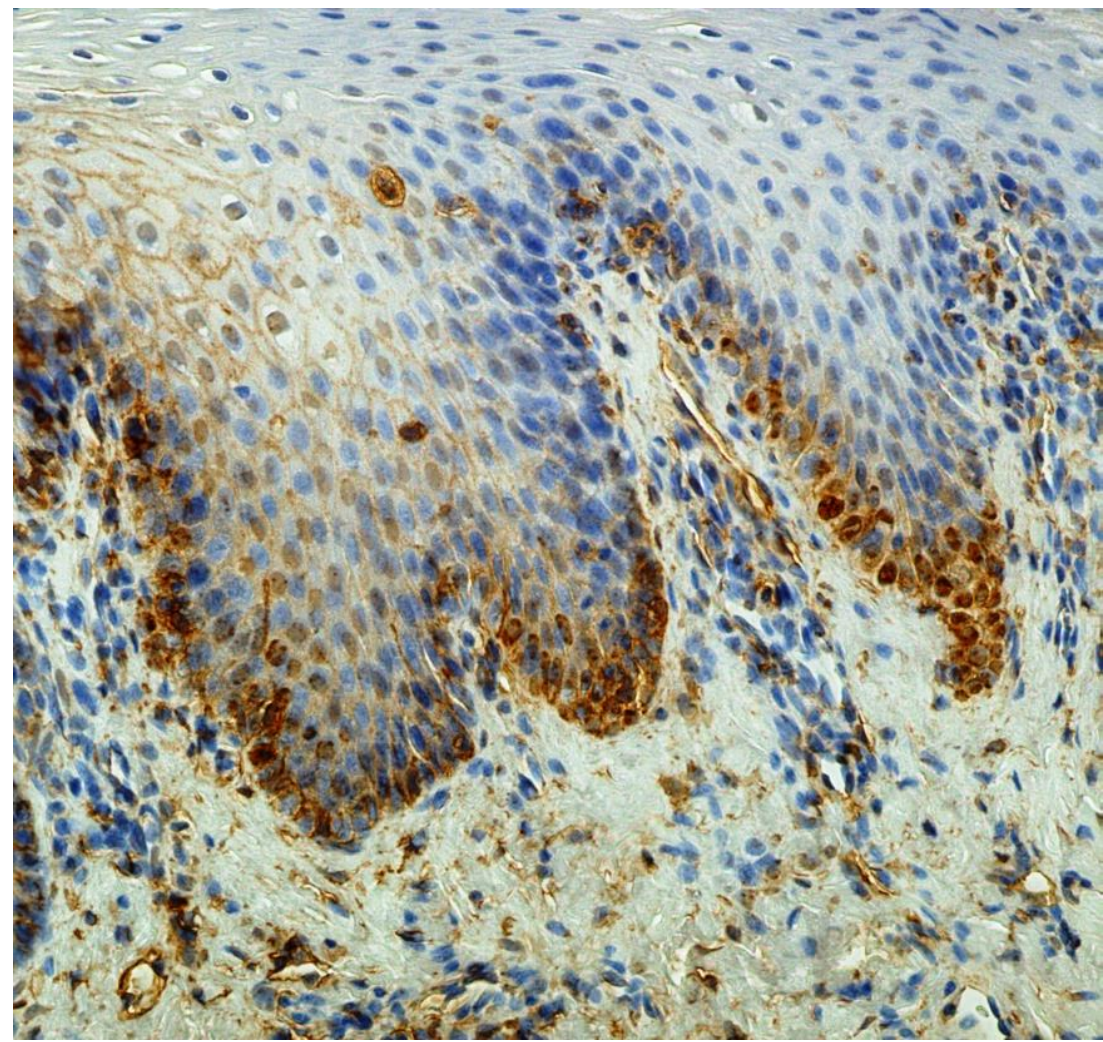

3.83. mikrofotogrāfija. Daudz (+++) nestīnu pozitīvu bazālā slāṇa šūnu 6 mēnešus vecam bērnam ar abpusēju caurejošu lūpas, alveolārā izauguma un aukslēju šķeltni - lūpas plastika. Nestīna $I M H, \times 200$

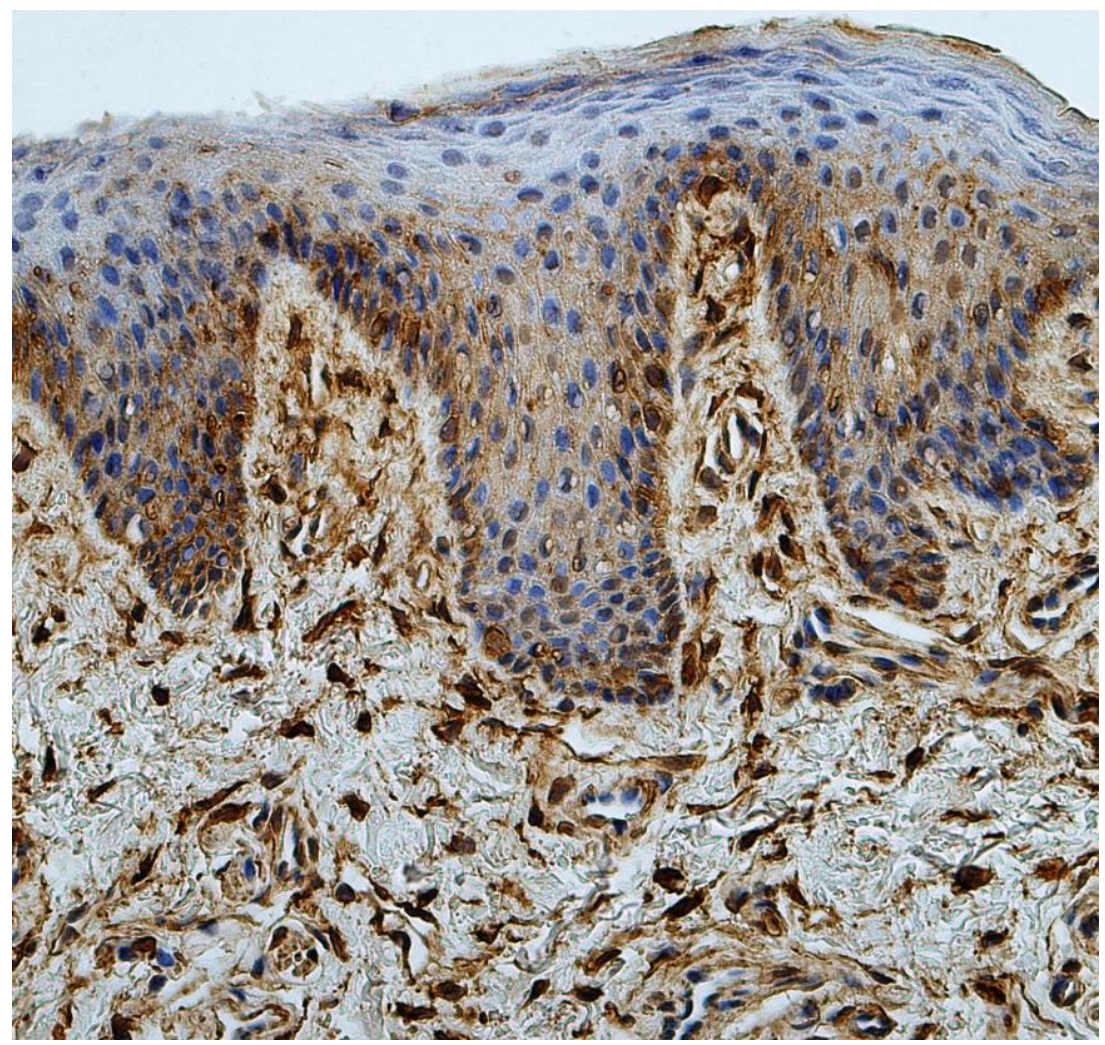

3.84. mikrofotogrāfija. L̦oti daudz (++++) nestīnu saturošu epitēlijšūnu stratum basale 3 mēnešus vecam bērnam ar vienpusēju caurejošu lūpas, alveolārā izauguma un aukslēju šḳeltni - lūpas plastika. Nestīna $I M H, \times 200$ 


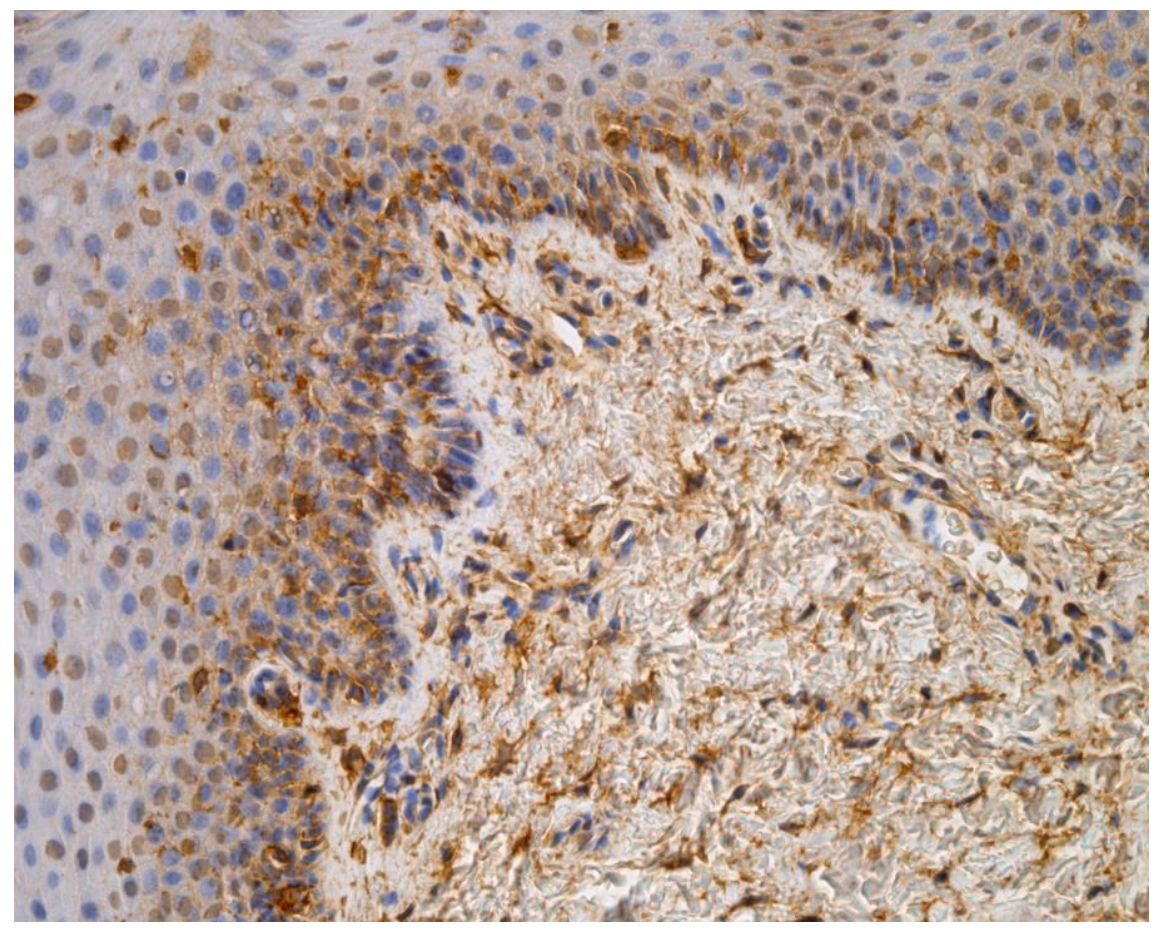

3.85. mikrofotogrāfija. Vidēji daudz (++) nestīnu saturošu šūnu 3 gadus un 4 mēnešus vecam bērnam ar abpusēju caurejošu lūpas, alveolārā izauguma un aukslēju šķeltni cieto aukslēju plastika. Nestīna $I M H, \times 250$

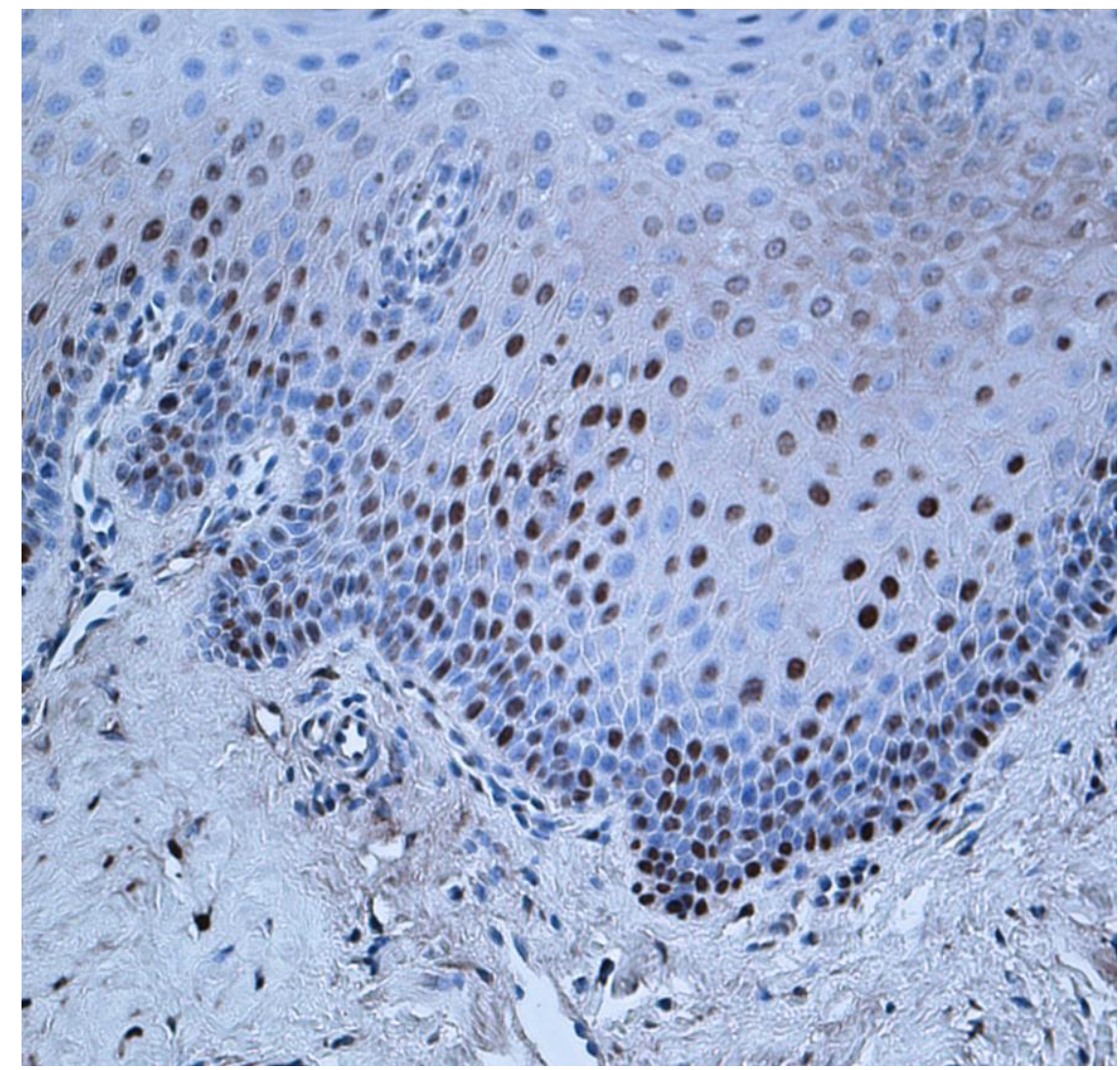

3.86. mikrofotogrāfija. Vidēji daudz (++) apoptotisku šūnu 4 mēnešus vecam bērnam ar abpusēju caurejošu lūpas, alveolārā izauguma un aukslēju šķeltni - lūpas plastika. 


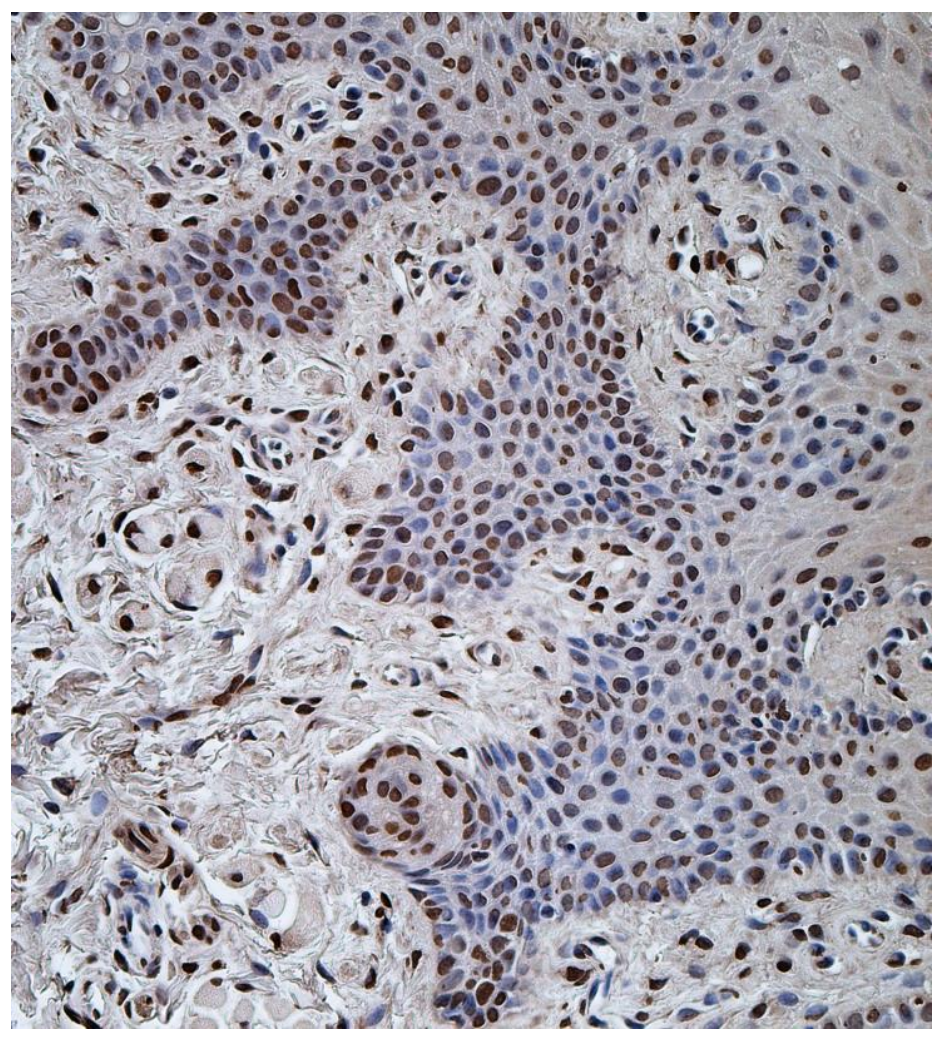

3.87. mikrofotogrāfija. Daudz (+++) apoptotisku šūnu 3 mēnešus vecam bērnam ar vienpusēju caurejošu lūpas, alveolārā izauguma un aukslēju šķeltni - lūpas plastika. TUNEL, $\times 200$

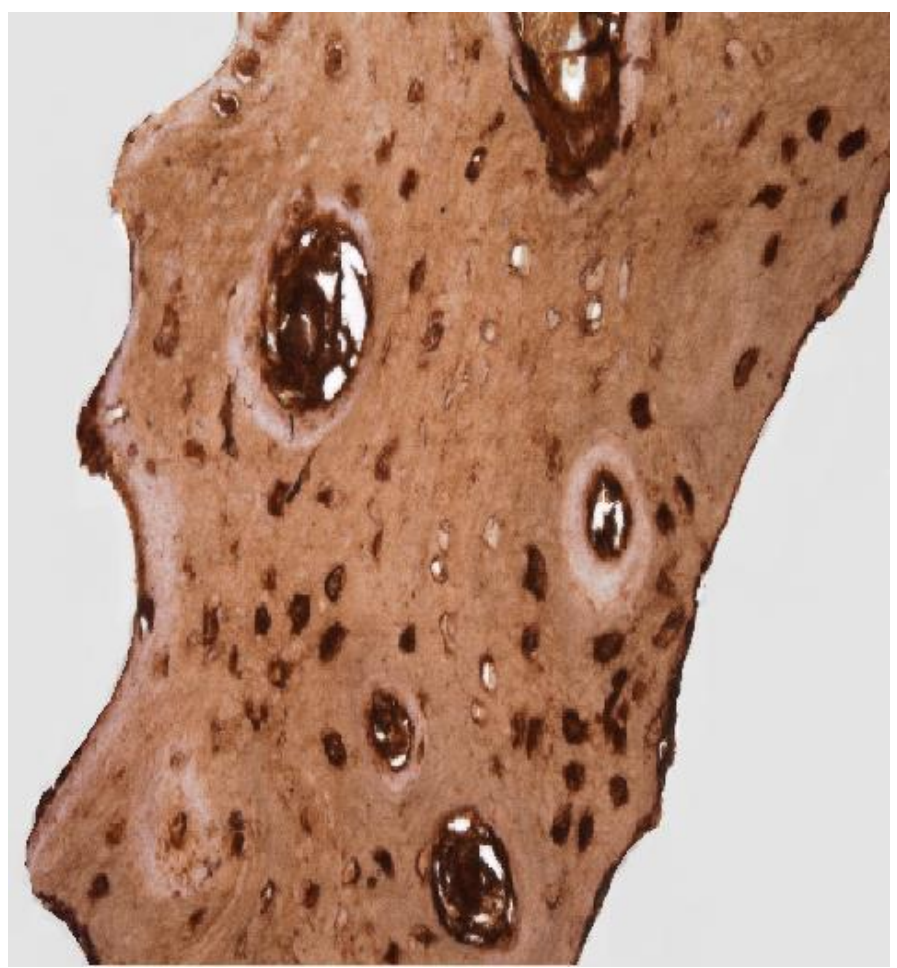

3.88. mikrofotogrāfija. Daudz (+++) $O C$ saturošu osteocītu 9 gadus un 2 mēnešus vecam bērnam ar abpusēju caurejošu lūpas, alveolārā izauguma un aukslēju škeltni osteoplastika. OC IMH, × 250 


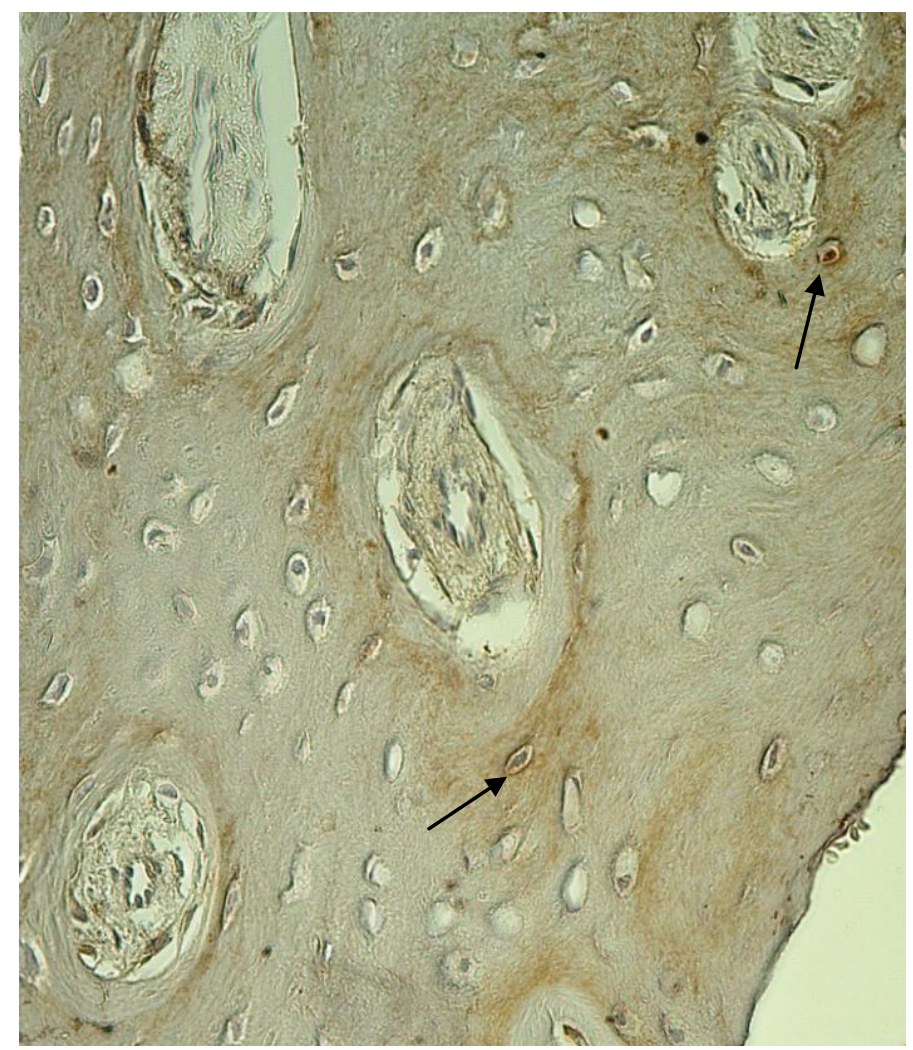

3.89. mikrofotogrāfija. Reti (0/+) $O P N$ saturoši osteocīti 8 gadus un 11 mēnešus vecam bērnam ar abpusēju caurejošu lūpas, alveolārā izauguma un aukslēju škseltni osteoplastika (bultiņas). OPN IMH, × 200

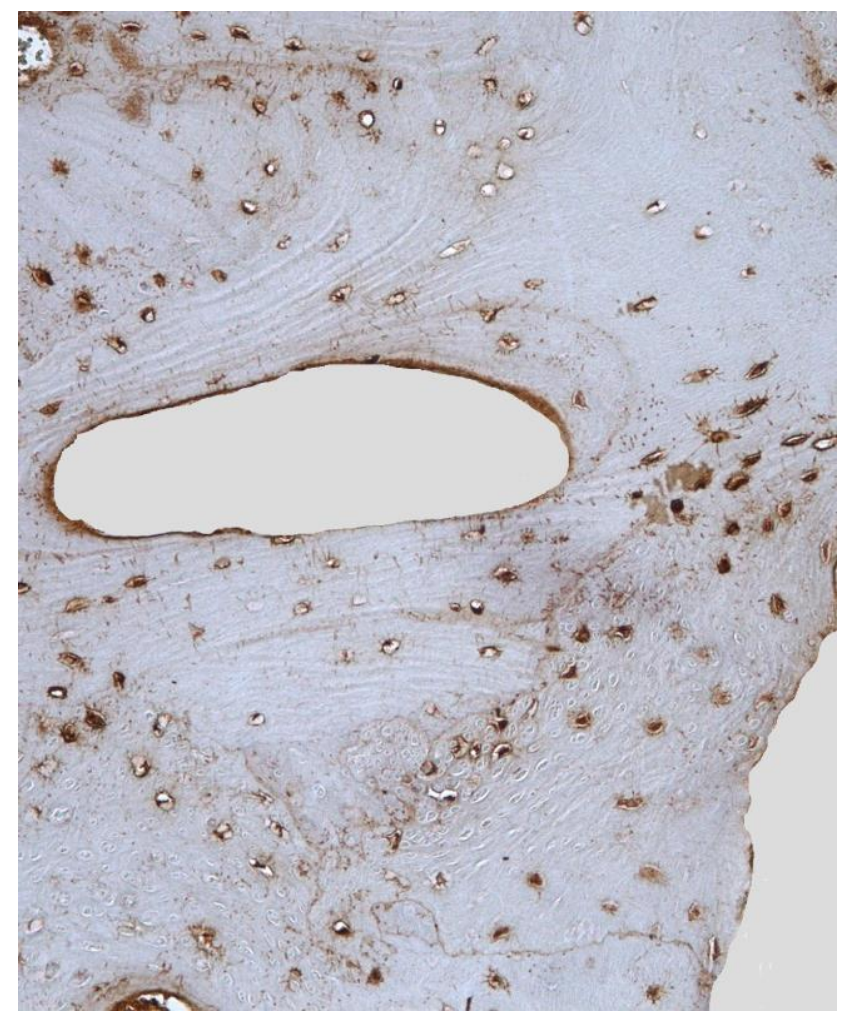

3.90. mikrofotogrāfija. Daudz (+++) $O P N$ pozitīvu osteocītu 7 gadus un 2 mēnešus vecam bērnam ar vienpusēju caurejošu lūpas, alveolārā izauguma un aukslēju šķ̧eltni osteoplastika. OPN IMH, × 100 


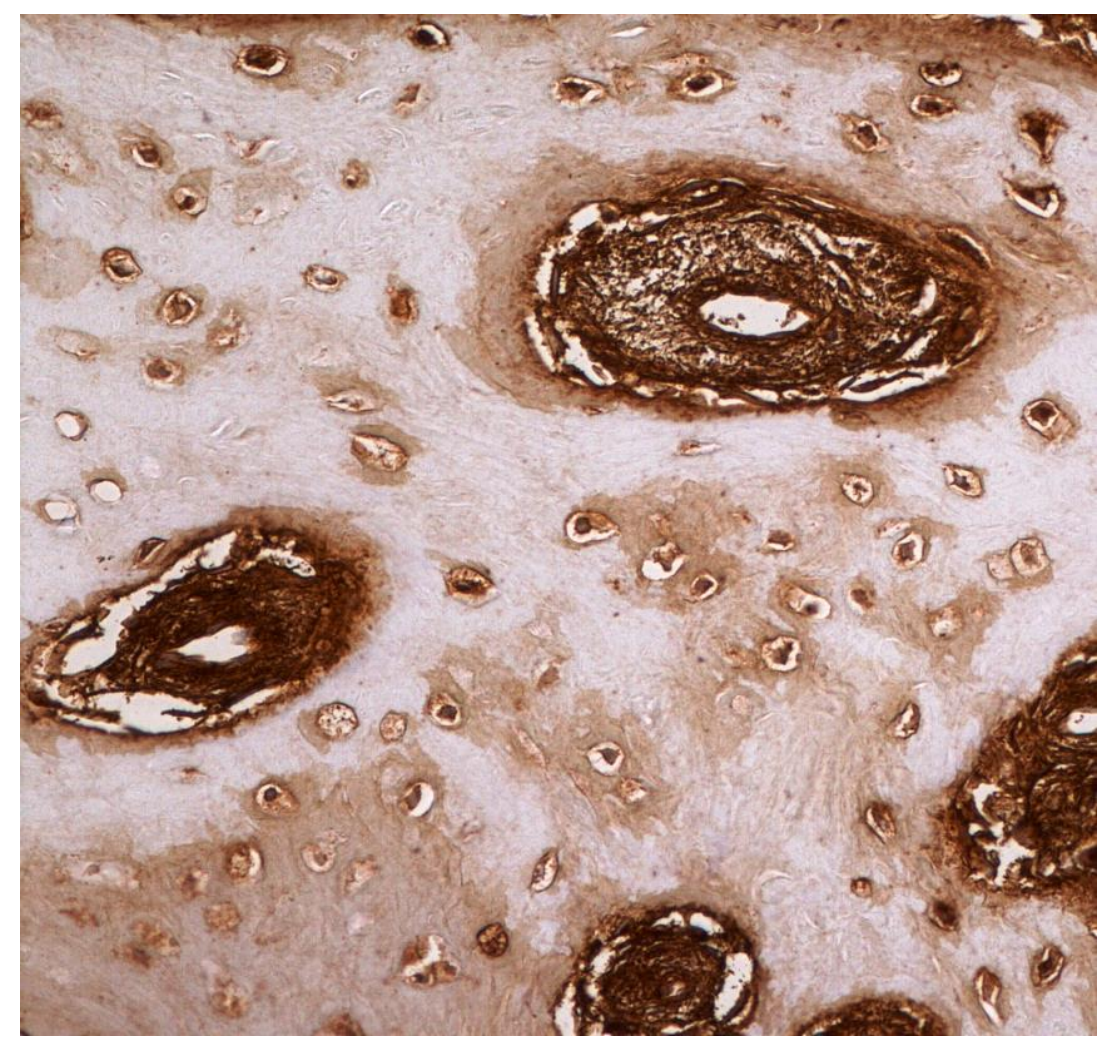

3.91. mikrofotogrāfija. Daudz (+++) $O P G$ saturošu osteocītu 9 gadus un 6 mēnešus vecam bērnam ar abpusēju caurejošu lūpas, alveolārā izauguma un aukslēju šķeltni osteoplastika. $O P G I M H, \times 250$

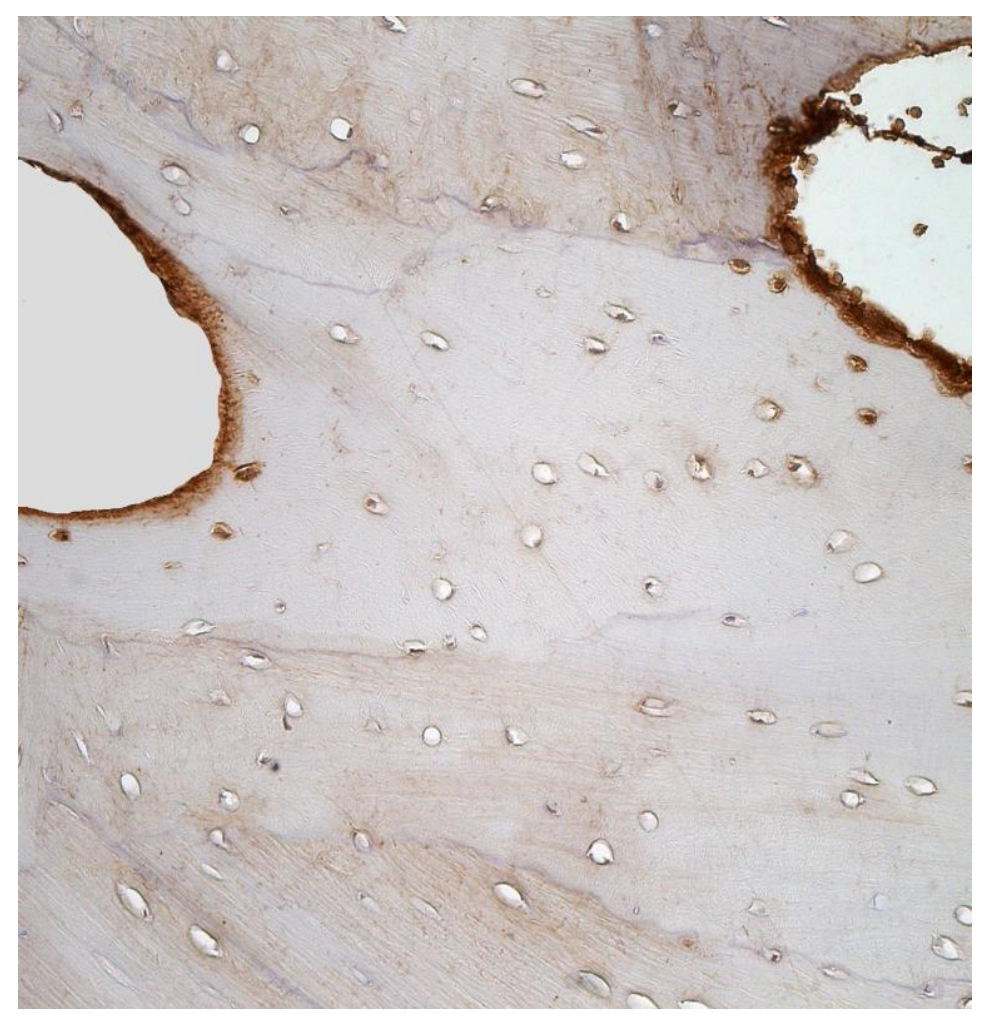

3.92. mikrofotogrāfija. Maz (+) MMP-2 saturošu osteocītu 9 gadus un 6 mēnešus vecam bērnam ar abpusēju caurejošu lūpas, alveolārā izauguma un aukslēju škseltni osteoplastika. MMP-2 IMH, × 200 


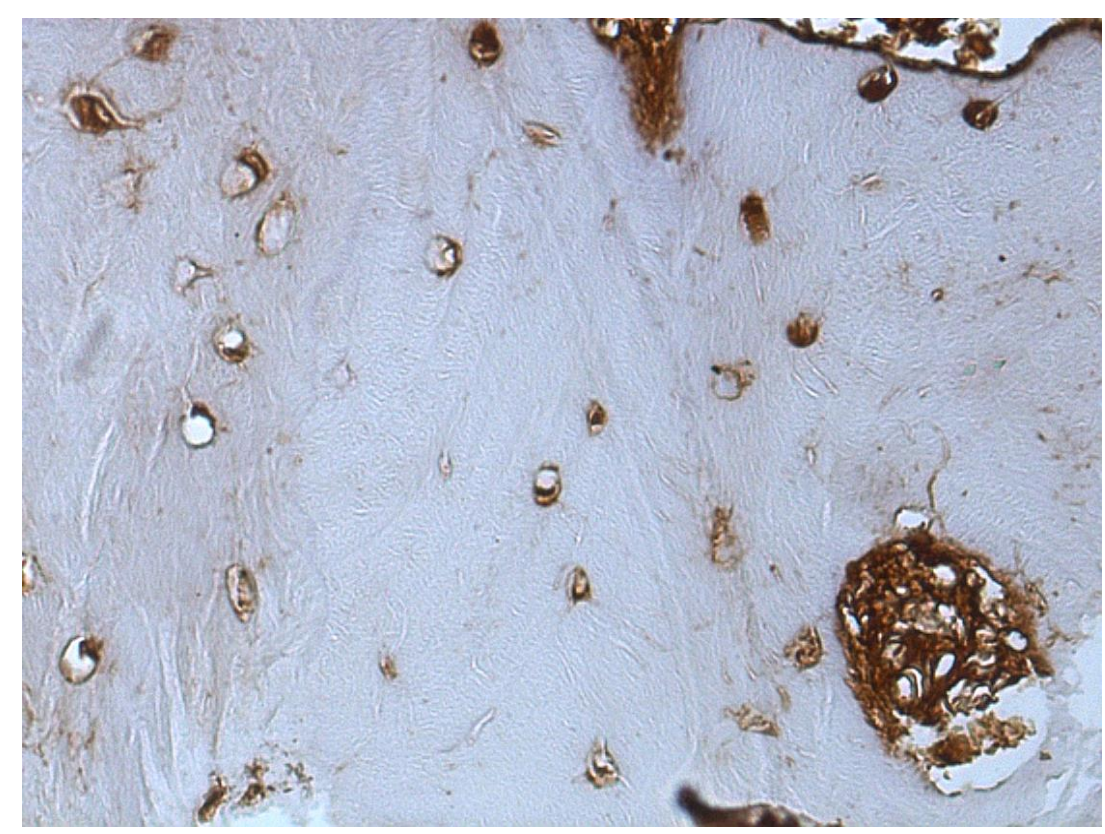

3.93. mikrofotogrāfija. Vidēji daudz (++) $M M P$-2 saturošu osteocītu 7 gadus un 1 mēnesi vecam bērnam ar vienpusēju caurejošu lūpas, alveolārā izauguma un aukslēju škseltni osteoplastika. MMP-2 IMH, × 200

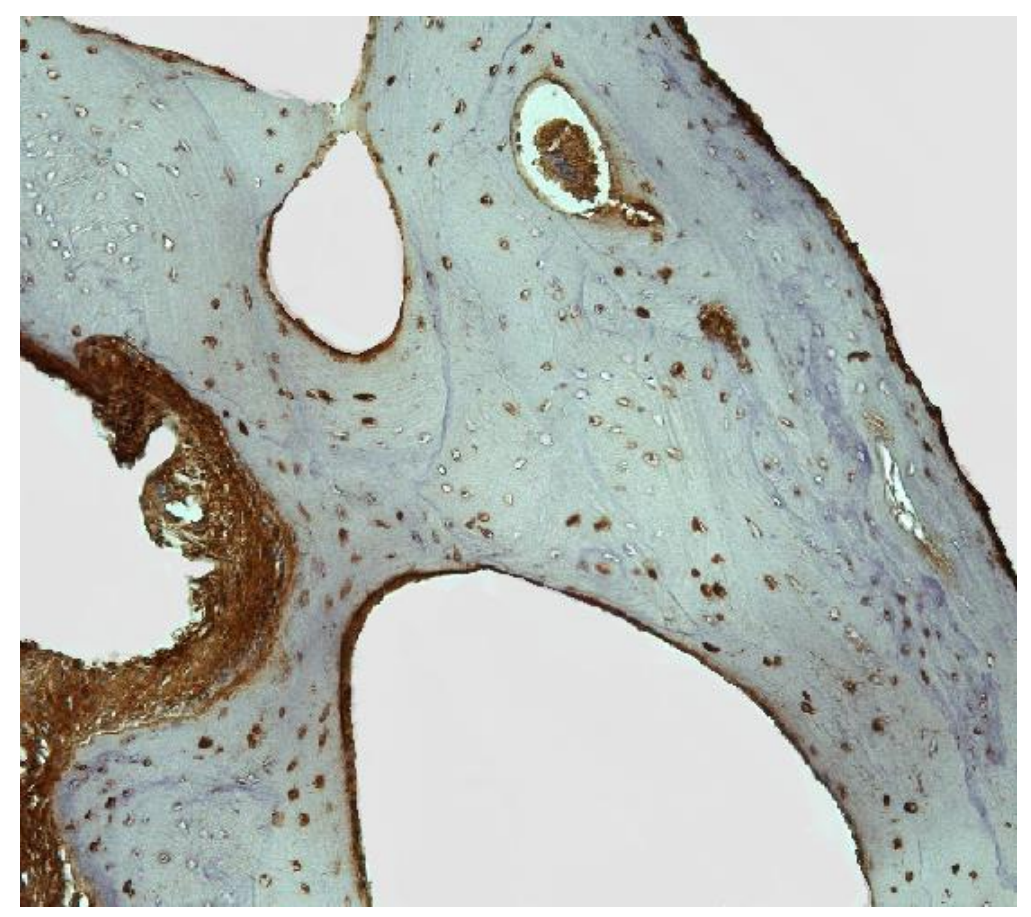

3.94. mikrofotogrāfija. Daudz (+++) TIMP-2 saturošu osteocītu 7 gadus un 8 mēnešus vecam bērnam ar abpusēju caurejošu lūpas, alveolārā izauguma un aukslēju škseltni - osteoplastika. TIMP-2 IMH, × 100 


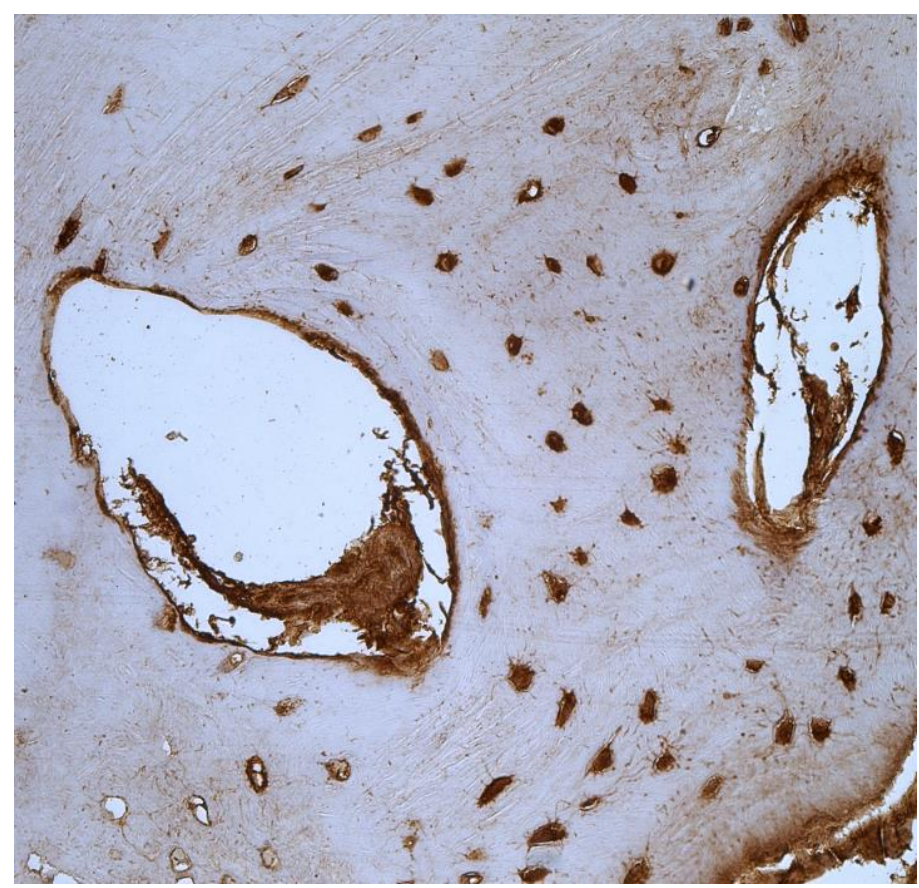

3.95. mikrofotogrāfija. Daudz (+++) BMP2/4 saturošu osteocītu 8 gadus un 6 mēnešus vecam bērnam ar abpusēju caurejošu lūpas, alveolārā izauguma un aukslēju šķeltni osteoplastika. BMP2/4 IMH, × 200

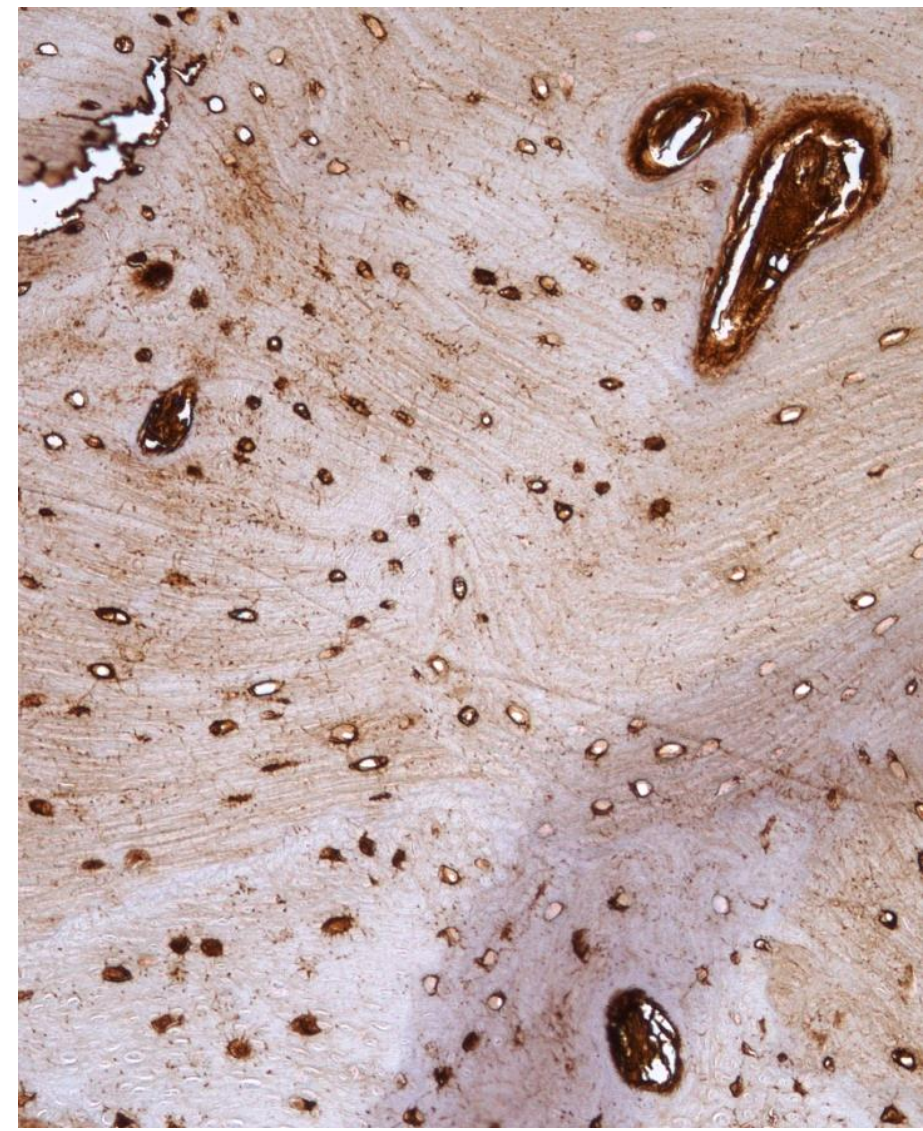

3.96. mikrofotogrāfija. Daudz (+++) BMP2/4 saturošu osteocītu 6 gadus un 8 mēnešus vecam bērnam ar vienpusēju caurejošu lūpas, alveolārā izauguma un aukslēju škseltni osteoplastika. BMP2/4 IMH, × 100 


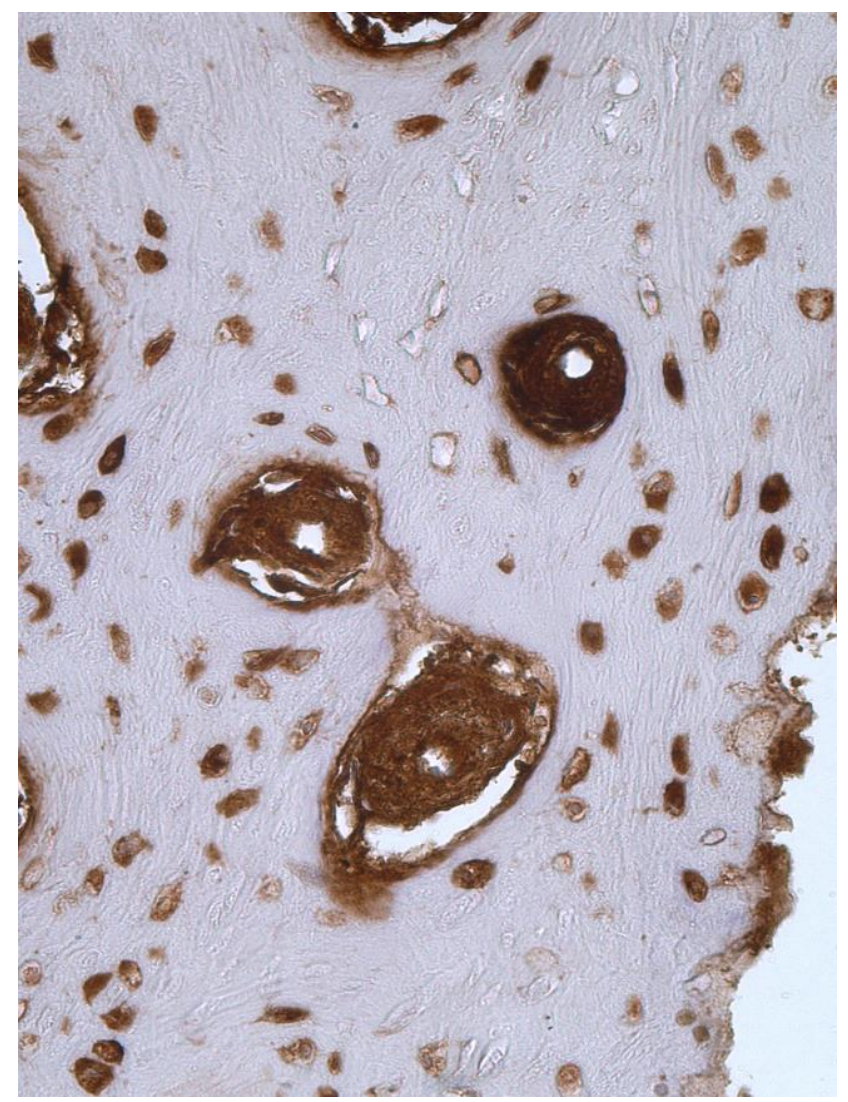

3.97. mikrofotogrāfija. Daudz (+++) TGFß3 saturošu osteocītu 8 gadus un 5 mēnešus vecam bērnam ar vienpusēju caurejošu lūpas, alveolārā izauguma un aukslēju šķeltni - osteoplastika. TGFß3 IMH, × 100

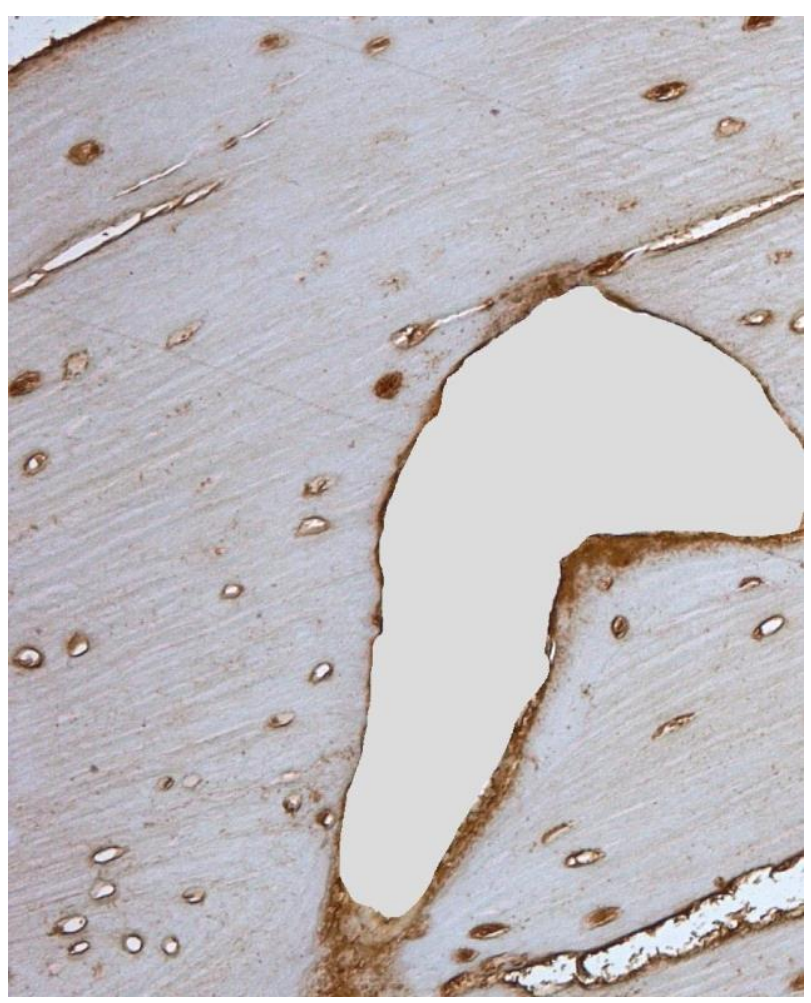

3.98. mikrofotogrāfija. Vidēji daudz (++) TGFß3 saturošu osteocìtu 8 gadus un 6 mēnešus vecam bērnam ar abpusēju caurejošu lūpas, alveolārā izauguma un aukslēju škşeltni osteoplastika. TGFB3 IMH, × 100 


\section{2. pielikums}

RSU Ẽtikas komitejas lēmumi

\section{RSU ĒTIKAS KOMITEJAS LĒMUMS}

Rīga, Dzirciema iela 16, LV-1007

Tel.409173

\begin{tabular}{lll}
\hline Komitejas sastāvs & Kvalifikācija & Nodarbošanās \\
\hline 1. Prof. L. Feldmane & Dr. habil. med. & patologs \\
2. Prof. J. Baltkājs & Dr.habil.med. & farmakologs \\
3. Prof. L.AberbergaAugškalne & Dr. habil.med. & fiziologs \\
4. Doc. E.Daugulis & Dr. med. & anesteziologs \\
5. Doc. I Bārene & Dr.pharm. & farmaceits \\
6. Asoc.prof. U.Teibe & Dr. biol. & fizikis \\
7. Doc. M.Pūce & Dr.med. & ķirurgs \\
\hline
\end{tabular}

Pieteikuma iesniedzējs: M.Pilmane

RSU Anatomijas un antropologijas institūts

Pētijuma nosaukums: Augšanas reǵenerācijas un kvalitātes marķieri iedzimto škeltṇu patpǵenēzē, diagnostikā un terapijas prognozē.

Iesniegšanas datums: 7.05.2003.

Izskatīie dokumenti :

(X) Pētijuma protokols:

(X) Pētijuma veids: operativā materiāla fiksēto audu morfologiska izpēte

(X) Pētijuma populācija: Lūpu, aukslēju un iedzimtu sejas ł̧łautņu centra pacienti

(X) Informācija par pētijumu

(X) Piekrišana piedalîties pētijumā:

Citi dokumenti: SIA RSU Stomatologijijas institūta direktores, Lūpu, aukslēju un iedzimtu sejas škautnu centra vadītajjas piekrišana

Lēmums: pozitîvs - piekrist biomedicīniskajam pētijumam.

Vārds, uzvārds: Līga AberbergaAugškalne priekšsēèètājs

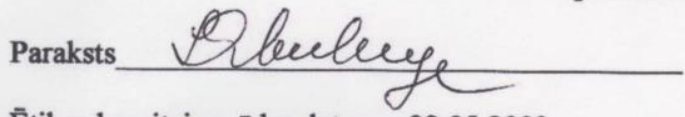

Ētikas komitejas sēdes datums: 22.05.2003.

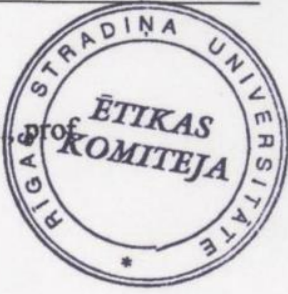


Veidlapa Nr. E-9 (2)

\section{RSU ĒTIKAS KOMITEJAS LĒMUMS}

Rīga, Dzirciema iela 16, LV-1007

Tel. 67409089

Komitejas sastāvs

1. Asoc. prof. Olafs Brūvers

2. Profesore Vija Sīle

3. Docente Santa Purvina

4. Asoc. prof. Voldemārs Arnis

5. Profesore Regīna Kleina

6. Asoc. prof. Guntars Pupelis

7. Asoc. prof. Viesturs Liguts
Kvalifikācija

Dr.theo.

Dr.phil.

Dr.med.

Dr.biol.

Dr.med.

Dr.med.

Dr.med.
Nodarbošanās

teologs

filozofs

farmakologs

rehabilitologs

patalogs

kirurgs

toksikologs

\section{Pieteikuma iesniedzēis:}

Liene Smane

AAI Morfologijas katedra

Pētīiuma nosaukums:

„Audu funkcionālā morfologija bērniem ar abpusējām caurejošām lūpas, alveolārā izauguma un aukslēju škeltnēm"

Iesniegšanas datums:

17.01.2013

Pētrijuma protokols:

Minētā pētījuma mērķis tiek sasniegts izmantojot RSU

Anatomijas un antropologijas institūta arhīva kontroles materiālu, kā arī RSU Stomatologijas institūta operācijas materiālu izpēti, iegūto datu apstrādi un analīzi, kā arī izsakot secinājumus un priekšlikumus. Minētais pētījums nerada nekādas ētiska rakstura problēmas Personas datu aizsardzība un konfidencialitāte nodrošināta.

\section{Pētījuma populācija: $\quad$ nav norādīta}

Komitejas lēmums:

piekrist pētijumam

Komitejas priekšsēdētājs Olafs Brūvers

Tituls: Dr. miss., asoc. prof.

Paraksts

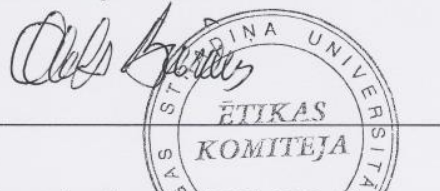

Ẽtikas komitejas sēdes datuns: 17.01.2013 